\title{
Good Guys: \\ A Cultural Semiotic Study of the Print Advertising of the Oil Industry (1900-2000)
}

\author{
Pamela Vang
}

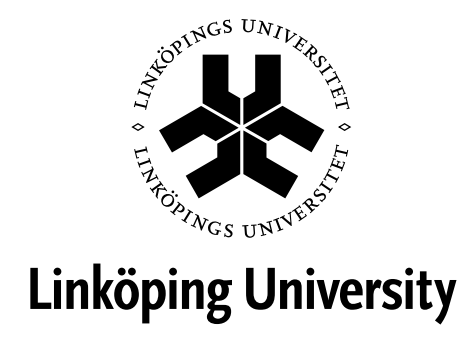

Linköping Studies in Arts and Science No. 621

Studies in Language and Culture No. 25

Linköping University

Department of Culture and Communication

Linköping 2014 


\section{Linköping Studies in Arts and Science • No 621}

At the Faculty of Arts and Science at Linköping University, research and doctoral studies are carried out within broad problem areas. Research is organized in interdisciplinary research environments and doctoral studies mainly in graduate schools. Jointly, they publish the series Linköping Studies in Arts and Science. This thesis comes from the Graduate School in Language and Culture in Europe at the Department of Culture and Communication, Division of Language and Culture.

Distributed by:

Department of Culture and Communication

Linköping University

SE-581 83 Linköping, Sweden

Pamela Vang

Good Guys:

A Cultural Semiotic Study of the Print Advertising of the Oil Industry (1900 - 2000)

Edition 1:1

Pamela Vang

Department of Culture and Communication 2014

ISBN: 978-91-7519-318-2

ISSN 0282-9800

Cover image: Original water colour by Ida van Der Woude

Printed by LiU-Tryck, Linköping 2014

\section{Images removed due to copyright.} For a complete copy contact ep@ep.liu.se or pamela.vang@liu.se 
To Christopher 



\section{Acknowledgements}

No project can be accomplished solo and as this project is nearing its completion, it is time to thank the people who have helped me along the way.

First of all, I would like to thank Per-Olof Brehmer and Johan Holtström for making it possible by giving me the time that I needed to reach the goal.

Then special thanks to my supervisors Jan Anward and Angelika Linke. Angelika's detailed reading, pertinent questions and honest, constructive comments have helped me to think more critically and objectively. Her enthusiasm for my project has been inspiring. I would also like to thank her for opening my eyes to the centrality of culture in our lives. Janne's belief in me and especially his optimism and ability to make mountains into molehills have given me the confidence to continue. Even when he cast me down the last, precipitous slope without any better safety net than the promise of a plaster!

Particular thanks are due to Susanne Tienken, whose perspicacious comments on my work in its earlier stages were extremely useful. I am deeply indebted to her for reminding me that some fifty per cent of the world's population is male; an observation that opened up a whole new world and changed the direction of my study, adding a new and extremely valuable dimension. I must also thank Per Linell who has also contributed in a number of ways, firstly, by introducing me to dialogism and later through his comments at my final seminar. I am also grateful to Lars-Håkan Svensson who introduced me to "the reader", a concept that has been invaluable to my work.

I would also like to thank colleagues at the Department of Management and Engineering for their moral support and interest in my study. In particular, I would like to thank Jörgen Dahlgren, not only for his interest but also for his helpful comments.

Thanks are also due to the helpful and friendly staff at the B.P. Archives at Warwick University and especially to Bethan Thomas.

I would also like to thank Tomas Hägg at UniTryck for his help and for rescuing the footnotes in Chapter 8 and for giving his professional touch to the contents pages. I would also like to thank the different people who have aided me with my all too frequent computer problems, particularly Mats Lindberg from the IT group at IEI, the Department of Management and Engineering and Bo Hagström at IKK, the Department of Culture and Communication who rid me of the computer virus that threatened my work and bugged Chapter 3. Gunilla Christiansen has also helped me quickly and efficiently with some of the computer-related problems that I have encountered along the way. Thank you.

Thanks are also due to my fellow doctoral students and especially those who have gone before both for practical information and advice and for showing me the living proof that it is possible to survive and that there is a life after "D. Day". I am also grateful to Gwenäelle Clairet and Mechtild Tronnier who have sometimes dragged me away from my oil companies to see and experience other things and places. Special thanks go to Gwen for checking all my references! A thankless job which she did brilliantly and any mistakes that are still there are mine and mine only. 
My very special thanks must go to Ida van Der Woude, one of those who have gone before, both for the beautiful water colour which adorns the cover of this book and for the word clouds that feature in Chapter 11. Not only was she their inspiration, but it was also her practical help and technical expertise in creating them made them possible. "We are family!"

Finally, I would like to thank the family and friends that I have neglected and hope that this book will now throw some light onto what I have been busy with for these past five years. Ole, I hope that you enjoy reading it. Christopher, this is for you!

Linköping April 2014 


\section{Contents}

Chapter 1 Introduction

Setting the scene

The Conceptual Basis of the Study

Bourdieu and the Forms of Capital

Goffman and the Presentation of Self

The function of advertising

Purpose of the Study

Analytical Approaches

Structure of the Study

Chapter 2 Five thousand years with oil

"The magic liquid flows"

The Birth of "Big Business"

The Rise of the Oligarchs

$\begin{array}{ll}\text { The Dissolution of an Empire } & 21\end{array}$

In the Nation's Interest $\quad 26$

The Cast of Players Grows $\quad 32$

$\begin{array}{ll}\text { Turbulence and Turmoil } & 36\end{array}$

Winds of Change 43

The Twilight of the Oil Gods? 46

Chapter 3 Advertising as a Communicative Genre $\quad \mathbf{5 5}$

How do we recognise an advertisement? $\quad 56$

$\begin{array}{ll}\text { What is a genre? } & 57\end{array}$

$\begin{array}{ll}\text { Prototypical advertisements } & 62\end{array}$

$\begin{array}{ll}\text { The dialogism of advertising } & 68\end{array}$

$\begin{array}{ll}\text { The new rhetoric } & 70\end{array}$

$\begin{array}{ll}\text { The role of the reader } & 74\end{array}$

$\begin{array}{ll}\text { Bakhtin, Bourdieu and Beyond } & 76\end{array}$

$\begin{array}{lll}\text { Chapter } 4 & \text { Oil Companies in the History of Oil } & 81\end{array}$

What is advertising?

$\begin{array}{ll}\text { The Beginnings } & 83\end{array}$

The Early Years in America $\quad 85$

The Early Years in Britain $\quad 87$

The Contributions of the Oil Industry to the Development of Advertising 88

The Advertising of the Oil Companies in the United States

The Advertising of the Oil Industry in Britain 91

Trends and Developments in Advertising 93

The Decade of Experimentation

Consumption Engineering $\quad 94$

$\begin{array}{ll}\text { Recent Trends in Advertising } & 97\end{array}$

Advertorials $\quad 98$

Story Telling $\quad 99$

Some Closing Words 102 
Chapter 5 Research into Advertising: the State of the Art

Research Trends

Early Research Trends $\quad 104$

$\begin{array}{ll}\text { Endorsement } & 105\end{array}$

$\begin{array}{lr}\text { The communicative turn } & 106 \\ \text { Semiotics in advertising } & 105\end{array}$

$\begin{array}{lr}\text { Rhetoric } & 108\end{array}$

$\begin{array}{ll}\text { Poetics } & 111\end{array}$

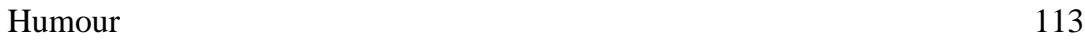

Internationalisation 114

Language

Culture

Context 115

Gender

The Narrative Turn $\quad 117$

Genre revisited 118

Myth and Corporate Identity $\quad 121$

Research into the Advertising of the Oil Industry 122

General studies of the advertising and discourse of the oil companies

Mobil's advertorials

The Op-eds page

"Observations"

The Perspectives of this Study 127

$\begin{array}{llr}\text { Chapter } 6 & \text { Corpus } & 129\end{array}$

$\begin{array}{lll}\text { Chapter } 7 & \text { The Semiotic Landscape } & 133\end{array}$

A World of Signs and Symbols

Shifting Sands of Meaning 134

Roland Barthes and the Semiotics of Advertising

The relationship between text and image

Typography 142

$\begin{array}{lr}\text { Colour } & 145\end{array}$

$\begin{array}{ll}\text { Summary } & 146\end{array}$ 
$\begin{array}{lll}\text { Chapter } 8 & \text { A Century of Rhetorical re-Presentations } & 147\end{array}$

$\begin{array}{ll}\text { Shell and the first decades } & 148\end{array}$

The Pre-War years: Art and Humour 154

You can be Sure of Shell

British Petroleum 162

The Golden Age of Oil 167

Caltex, partners in progress 168

The World of BP 169

"I'll tell you something about Shell ..." 170

$\begin{array}{ll}\text { Shell and the dragon } & 174\end{array}$

Shell in America 176

Mobil $\quad 178$

Shell Valentines $\quad 179$

The years of turmoil 180

Advertising in America 184

Shell in America

The American Companies 187

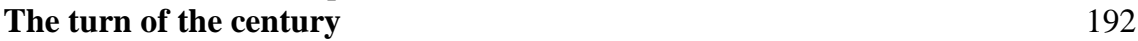

"For all our Tomorrows" 192

Profits or Principles 195

$\begin{array}{ll}\text { Towards a new beginning } & 200\end{array}$

British Petroleum

Beyond Petroleum 201

ExxonMobil: Taking on the world's toughest challenges 205

The world of Chevron $\quad 207$

Total: Our energy is your energy 214

Shell in the twenty first century $\quad 216$

$\begin{array}{ll}\text { Presentations and re-Presentations } & 222\end{array}$

$\begin{array}{lll}\text { Chapter } 9 & \text { The Myth of Oil } & 223\end{array}$

A World of Myth and Adventure

The Bringer of Life

The Magic Liquid

The Sun and the Stars 225

Horse Power 226

Modern Myths 230

Superman 231

Einstein's Brain

$\begin{array}{ll}\text { The Myth of the Hero } & 233 \\ \end{array}$

$\begin{array}{ll}\text { The Adventurer } & 234 \\ \text { The Alchemist } & 240\end{array}$

The Cast of Participants Expands $\quad 242$

The Entrepreneur

The Expert 243

The Educator $\quad 245$

The Myth of the Lady 246

$\begin{array}{ll}\text { Summary } & 251\end{array}$ 
Chapter 10 Doing Being the Good Guys 253

Shell, the Crusader 254

BP, the Missionary 256

Total, the Visionary 257

Chevron, the Partner 258

ExxonMobil, the Expert 259

The Damsel in Distress

$\begin{array}{ll}\text { Summary } & 261\end{array}$

Chapter 11 Advertising: a Mirror of Society? 265

A Mirror of Innovation and Technical Progress

Oil Company Advertising as Social Comment 267

Cultural Knowledge and the Lifeworld 268

Socio-Political Conditions $\quad 269$

$\begin{array}{ll}\text { Language } & 273\end{array}$

The Changing Face of Oil 276

Changing Participant Roles 277

From Paternalism to Partnership

From Product to Presence

Changing Participant Roles and Shared Responsibility 283

From Oil to Energy 284

$\begin{array}{ll}\text { Summary } & 287\end{array}$

Chapter 12 Conclusions $\quad 289$

The Diachronic Analysis 290

$\begin{array}{ll}\text { The Semiotic Analysis } & \\ \text { The Intended Reader } & 291\end{array}$

Research Questions Answered 292

A Mirror of Society? 294

$\begin{array}{ll}\text { References } & 295\end{array}$ 


\section{Chapter 1}

\section{Introduction}

\section{Setting the scene}

Oil! Black gold! The stuff of adventures, a fountain of health and beauty, a source of wealth but also of strife, a seemingly bottomless well spewing out death and destruction!

The life-enhancing possibilities that this residue of a time when dinosaurs walked the earth some 180,000,000 years ago ${ }^{1}$ first beguiled and then entrapped us in a dependency which has had a devastating impact upon the planet. The political consequences of the will to own and control oil supplies can be illustrated by a memo written by Sir Maurice Hankey, the secretary to the British War Cabinet as long ago as July 1918, which stated that control over the oil supplies in Persia and Mesopotamia was "a first-class British war aim". ${ }^{2}$ Andrew Simms and David Boyle (2010:220) have gone as far as to suggest that World War I is what made the British oil giant, BP, and that it was World War II that saved it. ${ }^{3}$ Indeed, the centrality of oil, either for its use or its ownership, has been a recurring factor in most of the wars of the $20^{\text {th }}$ and $21^{\text {st }}$ centuries, and Greg Muttitt (2011:28) confirms that "[n]o one shied away from saying that the 1991 Gulf War was about oil". More recently, celebrations over the fall of Qaddafi were marked not only by rejoicing about the liberation of the Libyan people from the dictator's oppression, but also about the liberation of the country's vast oil supplies. In 2012, the strategic importance of controlling the flow of oil supplies was demonstrated by Iran's threat to close the Strait of Hormuz through which up to 16 million barrels of oil a day are transported, in retaliation against Western sanctions over the country's nuclear programme. By January $5^{\text {th }}$, the sanctions and threats had resulted in a price increase of $\$ 6$ to $\$ 7$ for a barrel of oil; an increase which had severe economic consequences. The global economy is "drunk on oil".

It was oil that made John D. Rockefeller the richest man in the United States ${ }^{5}$ and of the top ten companies in the Fortune 500 global ranking for 2008, six were oil companies (Daniel Yergin, 2008: xv). By 2012, that number had risen to seven. The list was headed by Royal Dutch Shell, followed by ExxonMobil ${ }^{6}$, with BP in fourth place, Chevron in eighth ${ }^{7}$ and in places five and six, two Chinese companies. Total featured as number 11 in the 2012 rankings. Oil is a massive generator of wealth, and also a force for economic instability as its price fluctuations, like the ripples caused by a pebble thrown into a calm pool, spread far beyond the centre of the disturbance. Oil is in some way instrumental in the production and distribution of almost everything that we buy and its cost impacts upon the price that we have to pay. The potential to achieve vast wealth increases the potential to corruption, as the Elf Aquitaine scandal which came to light in 1994 aptly demonstrated. Company executives had spent billions of francs ostensibly to gain access to the oil riches of Africa. "Elf's dirty money

\footnotetext{
${ }^{1}$ Oil is made up of plankton, tiny one-celled life forms that after death, fell to the bottom of the oceans where heat and pressure eventually turned them into oil and gas.

${ }^{2}$ Cited in Greg Muttitt (2011:5).

${ }^{3}$ According to Simms and Boyle (2010:2018), prior to World War I two petrol distributors dominated the UK market; the British subsidiary of American Standard Oil and another owned by the German Europäische Petroleum-Union.

${ }^{4}$ Simms \& Boyle (2010:210) link this metaphor to the fact that we measure oil by the barrel, and point out that it was originally collected in whisky barrels. They also use the metaphor to discuss the "withdrawal" symptoms that climate change for example, is having on our lifestyles.

${ }^{5}$ As long ago as 1919, Standard Oil was registering foreign ships in U.S. influenced "tax havens" to escape U.S. tax regulations (Nicholas Shaxon, 2011:20).

${ }^{6}$ This ranking is by revenue. If instead profits are the main factor, then ExxonMobil is the clear leader.

${ }^{7}$ Conoco Phillips is an American company that falls outside the scope of this study.
} 
greased the wheels of French political and commercial diplomacy around the globe" (Nicholas Shaxon, 2011:4). ${ }^{8}$ Oil and the African continent once again hit the headlines in 2012, when the Nigerian government announced that it was removing the fuel subsidy which was the only benefit that the people of Nigeria, one of the world's major oil producing countries, reaped from the enormous wealth beneath their feet. The implications of the cut for the people were enormous, as it would lead to increased prices, and they were not slow to react with violent protests. For Shell, this was bad news and the fact that in August it was leaked that the company had spent almost $\$ 383$ million on a "private army" to protect its staff and installations in the country where it is a major operator, did nothing to improve the situation. ${ }^{9}$ This was not the first time that the situation in Nigeria had been in focus as the country has been plagued by a succession of environmental disasters linked to the oil industry and to a combination of greed, incompetence and lack of respect for human life. Yet another story in the international news that showed the oil industry in a very negative light, was the hearing in Strasbourg of a group of seven Norwegian divers who are "fighting against a state and an industry" for compensation and recognition for the problems and injuries that they and their colleagues had experienced as a result of their pioneering work during the exploration for oil in the North Sea. ${ }^{10}$

The negative impact of oil extraction on the environment has been extreme and accidents of different kinds have plagued the industry since its incipience. In 2010, BP hit the headlines with the catastrophic spill from the rig, 'Deepwater Horizon' in the Gulf of Mexico. This disaster serves to demonstrate the complexity of our relationship with oil and the oil industry. Although the environmental consequences of this accident were devastating, some of the local people interviewed said that they were happy with the drilling in the Gulf of Mexico as it brought employment and prosperity to the region. Oil and economics are closely connected. The "trial of the century" negligence resulting in the oil spill in April $2010^{12}$, had cost them over $\$ 40$ billion. This included restoration costs of over $\$ 24$ billion for the damage caused to the environment. A similar ambivalence can be seen with regard to the building of the Trans-Alaska Pipeline. Despite an increasing awareness of the potential dangers to the environment, Americans are divided on this issue. While a number of citizens, in particular those whose property will be negatively affected by its vicinity to the pipeline express deep concern, others see only the economic advantages of the project.

Oil is ubiquitous and has become not only a constant refrain in the news headlines but is also part of the weft of our daily lives. It "is the world's biggest and most pervasive business" (Yergin, 2008: xv) and has powered the rise and development of modern business and modern society. Oil is "intimately intertwined with national strategies and global politics and power" (ibid) and has made our world a "Hydrocarbon Society". We all consume and buy products that are derived from oil; for example, the petrol that we put into our cars, the different forms of public transport that we use and the vehicles that carry the commodities that we purchase

\footnotetext{
${ }^{8}$ See the prologue to Shaxon 2011 for more detailed information about the Elf scandal and its political and financial implications. For example, the company "paid" over 6,000,000 dollars to Christine Deviers-Joncour, a former model who was sentenced to prison in 1977 for "persuading" Roland Dumas, Mitterand's foreign minister and her lover, to reverse his public opposition to the sale of missile boats to Taiwan.

${ }^{9}$ For more details see for example Afua Hirsch and John Vidal "Shell spending millions of dollars on security in Nigeria, leaked data shows" in The Guardian, Sunday, $19^{\text {th }}$ August 2012 .

${ }^{10}$ Reported by Rolv Christian Topdahl "Strasbourg hearing heartens North Sea divers" $19^{\text {th }}$ September 2012 http://www.aftenbladet.no/energi/aenergy/Strasbourg-hearing-heartens-North-Sea-divers

${ }^{11}$ Harry Wallop, "BP trial: in numbers" The Telegraph, 26th February 2012.

${ }^{12}$ Richard Blackden, "Gulf of Mexico oil spill: BP wins victory over US government as trial is postponed until 2013” The Telegraph $3^{\text {rd }}$ May 2012. http://www.telegraph.co.uk/finance/newsbysector/energy/oilandgas/
} 
as well as the plastic bags that we carry them in and the energy used to produce all this, all come to us through the direct or indirect intervention of the companies that constitute the oil industry, and our need seems to acknowledge no boundaries. As Simms \& Boyle (2010:234) have pointed out, "[t]hings we never knew we needed suddenly became the necessities of life: the plastic bags, disposable pens, disposable cups, disposable razors, disposable everything" have become the natural accessories of our lives.

Yergin (2008:xvii) states that total world oil consumption rose by almost 30 percent from 1990 to reach a total of 86 million barrels a day in 2008, and in the 2010 Summary of their Annual Report, ExxonMobil alone, for example, reported a 13 per cent increase on 2009. Their net liquid production was 2,422,000 barrels and they had a total net production of liquids and natural gas available for sale of 4.4 million oil-equivalent barrels per day in their upstream business and 6.4 million barrels in petroleum product sales in their downstream business ${ }^{13}$ which gave them earnings totaling $\$ 30.5$ billion. Moreover, the company forecasts that global energy demand is likely to increase by $35 \%$ by 2030 . Our world and our life-styles are fuelled by the oil companies who have become not only an intrinsic part of modern culture but also a fundamental force in our lives.

Unfortunately, as history clearly indicates, oil is not only a fountain of wealth and well-being, but is also a source of conflict and of many of the environmental problems that are facing us today. It is our contemporary Sword of Damocles.

\section{The Conceptual Basis of the Study}

Our relationship with oil and the oil industry are very complex. We tend to love the material advantages that it brings ${ }^{14}$ but increasingly fear and dislike the negative impacts that follow in the wake of the activities of the oil companies and our dependency upon oil and its derivatives. How then, do the oil companies, sometimes heroes, other times villains, protect the "capital" that they have built up over time and in which they have heavily invested and in which they must continue to invest? The oil industry is indeed extremely capital intensive. In their budget for 2011, for example, Chevron projected a spending of \$22.6 billion for exploitation and production activities. ${ }^{15}$

Various crises within the industry have demonstrated the fickleness of customers. One example is the boycotting of Shell products by customers in Germany and Sweden as a reaction to the Brent Spar incident during the mid-1990s when Greenpeace brought to public awareness Shell's intended disposal of the North Sea oil platform and loading buoy. Moreover, as one fuel seems very like another, oil is nothing that the average consumer selects with care and in addition, oil and many of its derivatives have become something that we cannot choose to do without and of whose presence in our daily lives we are moreover often unaware. Further, for historical reasons, the oil industry has some of the qualities of perfect competition, which means that the companies cannot compete on price. Thus, it is probable that the average consumers of oil and its derivatives would not be particularly perturbed if one company disappeared and they were obliged to satisfy their needs elsewhere.

\footnotetext{
${ }^{13}$ Upstream refers to the exploration and production of oil and oil products while downstream refers to sales and distribution of the various products derived from oil.

${ }^{14}$ Simms \& Boyle (2010:210) state that oil provides the modern world with the equivalent of the work that could be performed by 22 billion slaves!

15 "Chevron announced a \$26.0 Billion Capital and Exploratory Budget for 2011" http://www.chevron.com/chevron/pressreleases/article/12092010_chevronannounces2...
} 
Because of this, branding, the various often symbolic means by which a company or product is publically recognized, has become extremely important within the oil industry.

For these reasons, oil companies spend vast sums on advertising to ensure that their brand is brought to the public eye and is projected in a positive light. Chevron, for example, is reported to have an annual budget of some $\$ 90$ million for advertising ${ }^{16}$. One modern trend is that the companies increase their advertising budgets in times of adversity. In 1998, in the aftermath of a period of bad publicity, Shell, for example, spent $\$ 30$ million on advertising contracts with one single public relations company, the equivalent of 30 per cent of its actual annual investment in renewable energy ${ }^{17}$ and $\mathrm{BP}$ is reported to have spent over $\$ 93$ million on corporate advertising in the period between April and July 2010. This figure is approximately 65 per cent more than BP's usual spending and can be seen as a direct result of the negative publicity and imminent threat to its social capital that resulted from the Gulf oil spill. ${ }^{18}$ Moreover, this increased spending was largely targeted at national and local newspapers, magazines and television stations in the USA. ${ }^{19}$

Two main concepts therefore provide the conceptual basis for this study. The first is the concept of "capital" expounded by Bourdieu, and the second is the presentation of self which derived from the writings of Erving Goffman.

\section{Bourdieu and the Forms of Capital}

Oil and economics are closely intertwined: national economies, private economies, and not least the economy of the companies and of their owners and shareholders are dependent on oil. Moreover, as the figures I have quoted illustrate, the oil industry requires enormous sums of money to extract and refine the oil and massive investment to locate and develop new sources and methods of extraction and production. Therefore one of the most interesting questions that arise in connection with any investigation into the workings of the oil industry is how it manages and protects its capital investments. In order to better understand this, the work of Pierre Bourdieu and his concepts of field, habitus and capital, can provide a useful frame within which to study the companies' discourses.

Bourdieu's conviction that social life is "a mutually constituting interaction of structures, dispositions, and actions" (Postone et al; 1993:2) that are both structuring and structured, suggests that his theories can provide a useful concept from which to develop this study. Bourdieu describes a field as a space in which "agents and institutions constantly struggle, according to the regularities and the rules constitutive of this space of play" (Bourdieu and Wacquant, 1992: 102). Moreover, "[ $t$ ] he field is a critical mediation between the practices of those who partake of it and the surrounding social and economic conditions" (ibid: 107). Although the companies that are involved in the oil industry are powerful, they must follow

\footnotetext{
${ }^{16}$ Nick Magel, “Chevron's New Ad Campaign Hijacked by Truth .... and the Yes Men” $18^{\text {th }}$ October 2010, http://itsgettinghotin here.org/2010/10/18/chevron

17 "Greenhouse Market Mania” Corporate Europe Observatory Briefing, 21 September 2012. http://archive.corporateeurope.org/greenhouse/greenwash.html 21 September 2012.

${ }^{18}$ M.E.Kabay, Network World August $15^{\text {th }} 2011$, "The BP case: Online reputation management" http://www.networkworld.com/newsletters/sec/2011/081511secl.html 21st September 2012

${ }^{19}$ Shelley DuBois “Update: BP's advertising budget during the spill neared \$100 million” September 2010 http://money.cnn.com/2010/09/01/news/companies/BP spill advertising costs.fortun
} 
and constantly adapt to the changing rules of play that are imposed upon them from both external conditions and the dispositions that are currently prevalent among their different stakeholders, from national governments, to shareholders, to Mr. Smith filling his car with fuel.

Further, Bourdieu (1998:66) insists upon the influence of history in shaping society. Here, his concept of habitus as a "mental structure that has been inculcated into all minds socialized in a particular way" is useful and confirms the situadedness of social life. Moreover, Bourdieu's interest in language and in the symbolic power with which it is endowed $(1982)^{20}$, how "words make things, because they make the consensus, on the existence and meaning of things, the common sense, the doxa accepted by all as self-evident" (1998:67) is particularly interesting to a study of advertising and how it impacts society. When the focus of the study is an industry that is as debated and contested as the oil industry, this concept acquires even more relevance.

In The Forms of Capital (1986:54) Pierre Bourdieu identifies three types of capital: economic, cultural and social, and claims that although "economic capital is at the root of the other types", its health is intimately connected to the other two. Economic capital is the form that is recognized by economic theory and is the one which most immediately springs to mind, but is often dependent upon the other forms. My interest is not in economic capital as such, but lies in the cultural and social capital that the companies involved in the oil industry have come to possess and must strive to protect and increase.

Bourdieu has suggested that cultural capital exists in three states: embodied, objectified and institutionalized. In the objectified state, cultural capital incorporates material objects such as works of art, that can be bought and sold and as such, is directly connected to economic capital. In its institutionalised state, cultural capital confers recognition. In this form, cultural capital "is predisposed to function as symbolic capital" (ibid: 49) and provides legitimacy; it represents the honour, in the sense of reputation and prestige (1987:33) which is essential for a business to succeed. He considers symbolic capital to be a "fourth species"21, and discussing different forms of capital in relation to business firms, (1998:85) has described symbolic capital as one with "a cognitive base which rests on cognition and recognition" and which "resides in the mastery of symbolic resources" and can provide a company with a competitive advantage (2005: 195). As this form of capital is related to the notion of honour and "good faith" it has a great impact on a brand and its perception. Thus, social capital acts as a type of "credential" for a company and what it represents. It is based on social relationships and implies obligations and its reproduction presupposes effort and the constant affirming and reaffirming of recognition.

\section{Goffman and the Presentation of Self}

Bourdieu's concept of social capital, or social credentials echoes the notion of impression management, of working to create a good image, to present a preferred "face", ${ }^{22}$ propounded by Erving Goffman $(1959,1967)$.

\footnotetext{
${ }^{20}$ Bourdieu recognises the importance of both Saussure's affirmation of the social nature of language (1982:9) and of Austin's insistence on the power of language to "do" things and given an authorized speaker, to "define" the world.

${ }^{21}$ Bourdieu develops this more fully in his work La Distinction from 1979, translated into English in 1984.

${ }^{22}$ Postone et al (1993:2) point out that Bourdieu was associated with Erving Goffman as a visiting scholar at the Institute of Advanced Study and the University of Pennsylvania.
} 
"Face", image, identity and identification are concepts that are central to this study. However, these are no easy terms to define and identity is a notion that is quite unclear in the world of business.

Helena Kantanen (2012) provides an overview of the different ways in which corporate identities have been considered and the relationship of corporate identity with branding, while John Balmer (2001) has identified fifteen reasons for the confusion that abounds. These include the terminology that is used and a failure to make a distinction between the actual, communicated, conceived idea and the desired identities in what he terms the "triumvirate" of corporate identity, organizational identity and visual identity that are the subject of much of the literature on "business identity" (2001:251). He also insists on the importance of tradition and environment and also on communication for identity and identity building.

Corporate identity is generally considered to incorporate all aspects of the work that a company undertakes to rally support among all its stakeholders, including employees, to create and project a preferred face, while the term "image" can be considered to be the equivalent of "perceived identity" (Kantanen 2012:59). Thus, the notion of identity and identity building refers to the active work in which companies engage to create recognition and to project and protect a preferred image, the "work" which they perform to create a suitable "face" in terms of approved attributes (Goffman 1967), while image reflects the result of this work and the way in which it is perceived by the public.

\section{The function of advertising}

It is my contention that the aim of advertising is to protect and nurture capital. When the cultural, social and symbolic capital of a company, those disparate elements that together constitute its brand are under threat, this heavily impacts upon the economic capital, that is to say, the profitability and eventual survival of that company. Bourdieu (1991) has stressed the power of language as a form of symbolic power or "linguistic capital" and stated that the "value of the utterance" is related to the perceived trustworthiness and competence of the agents involved in the exchange. ${ }^{23}$ Companies employ a variety of techniques to validate the truth of their utterances, and I claim that advertising in its various forms constitutes the most common of the "defensive and protective practices" (Goffman, 1959: 24) employed by a company to safeguard the impression it has fostered.

Over the past half century, the "credentials" and "face" of the companies involved in the oil industry have been increasingly questioned and challenged. This in turn has impacted upon their brands and thus on their different forms of capital. To defend their positions, the companies have taken recourse in the power of language to help them create, re-create and to project a positive image that will be understood and accepted. It is these endeavours, their different advertisements and the discourses in which these engage ${ }^{24}$ that this study addresses.

\section{Purpose of the study}

Ryszard Kapuscinski has stated that "Oil expresses perfectly the eternal human dream of wealth achieved through lucky accident, through a kiss of fortune and not by sweat, anguish,

\footnotetext{
${ }^{23}$ One of the ways in which this is expressed in advertising is through the use of endorsers.

${ }^{24}$ Although there are many definitions of "discourse" I favour that of Benveniste who limits its use to instances of enunciation where "the engagement of the locutor is heavily marked" (Johansson \& Suomela-Salmi 2011:84) as this is a feature of advertising. Eco (1972:237) identifies six functions of advertising discourse which engage to produce meaning: the emotional, referential, phatic, metalinguistic, aesthetic and the imperative.
} 
hard work. In this sense oil is a fairy tale, like every fairy tale, it is a bit of a lie" (cited in Shaxon, 2011:209).

The aim of this study is to account for this fairy tale and to reveal and untangle the lies from the dream. In order to do this, I will study the print advertisements of the Majors, five companies that dominate the oil industry today, Royal Dutch Shell, BP, ExxonMobil, Chevron and Total, in order to reveal the work in which each engages to protect its face and to nurture the various forms of capital that constitute the brand. Print advertisements have a long history and are therefore very well suited to studying developments over a longer period of time. Moreover, even today when other forms of advertising are increasingly popular, it is still common for still pictures from television commercials or the internet to appear as print advertisements. Through an analysis of the advertising discourse of the companies, it is my intention to uncover how the fairy tales that they tell respond and correspond to the prevailing circumstances and how their communication strategies have changed in order to accommodate contemporary views and also to differentiate themselves and their brands.

John F.Sherry Jr. ${ }^{25}$ (1987:445), posits that advertising is "a system of symbols synthesized from among the range of culturally determined ways of knowing that seeks to establish powerful, pervasive, and long lasting moods and motivations in people by formulating conceptions of a general order of existence and clothing these conceptions with such an aura of factuality that the moods and motivations seem uniquely realistic." It is this system that companies use to communicate and implant their ideas, principles and even concepts of their experienced or desired reality into the minds of the public and impose this upon the lifeworld. ${ }^{26}$ As technological advances, partly driven by the oil industry, have impacted on every aspect of our lives, not least with regard to the ways with which we communicate with each other nationally and internationally, it might be possible to discern a sociocultural adaptation of the mediated actions of the different oil companies to respond to the new contexts and to their wider and less homogenous publics. ${ }^{27}$ My first research question is therefore:

1. What do these oil companies communicate in their advertisements, how do they do this and to whom do they communicate?

However, to the average consumer, one petrol or petroleum product is very much like another; in the words of Bruce Barton, the advertising guru of the 1920s, it is a "bad smelling liquid" and "hated expense" 28 . Although there have been developments in the production and composition of petroleum fuels and lubricants, the differences among the actual brands was and remains marginal. Thus, on a product level, the goods provided by the different oil companies are largely interchangeable. What then are the identities that the companies strive to build to persuade consumers to buy just their specific products?

\footnotetext{
${ }^{25}$ Sherry acknowledges his debt to Geertz (1973) upon whose conception of religion he bases this definition of advertising (in Umiker-Sebeok1987: 446).

${ }^{26}$ Habermas considers that the lifeworld, which provides the participants in a communication with the shared meanings that are indispensable to understanding functions as a background of intelligibility. See for example Barbara Fultner's (2011) overview of Habermas' linguistic turn.

${ }^{27}$ In line with Kenneth Burke and Chaïm Perelman, Allan Bell (1984) for example, has observed that speech styles are designed to suit the audience addressed, and it seems probable that the communication styles chosen by advertisers should be consistent with this observation.

${ }^{28}$ Quoted in Yergin (2008:194)
} 
My second research question is thus:

2. How do the companies differentiate and profile themselves?

A number of scholars have referred to advertising as society's mirror ${ }^{29}$ and Sherry (1987: 450) has also pointed out that advertising serves "as an artifactual record, an archival document of sorts, which captures material cultural elements as well as mentalistic states [and] a performance." He has also claimed that "[a]dvertising can be seen to display and reinforce versions of social life that are normative and ideal and in this way, can be considered to provide documentation and some sort of reflection of the society with which it is contemporaneous" (449). It is therefore my intention to examine the advertising of the oil industry diachronically in order to uncover the changes in attitude, or "mentalistic states" that it reflects and documents. Such a thread of enquiry finds support in a pragmatic understanding of the situatedness of communication ${ }^{30}$ which I will develop later.

My next research question is therefore:

3. How have the messages that they communicate changed over time, and in what way do they relate to or reflect prevailing socio-political conditions and public opinion?

In other words, I am interested not only in extrapolating the identity work in which the companies engage to tell about themselves and about their realities in order to protect and nurture their different forms of capital, and in Goffman's terms, to present a preferred face to the world, but also to examine how the stories that they tell to this end change to fit the situation. In order to answer the questions that I have listed above, I have taken a historical perspective and have examined and made a close reading of print advertisements for the oil industry over a period of some hundred years. Although I am fully aware of the impact of other media on advertising, limiting my study to printed advertisements facilitates comparison over a longer time period and makes it easier to follow the stories that the companies tell about themselves and about the society in which they are acting.

However, as Guy Cook (2008:115) has pointed out, advertising is one constituent of a much larger activity which includes Public Relations, and the different concepts involved have become increasingly fuzzy and hard to delimit and define. I am therefore subscribing to the very broad definition of advertising as "a branch of propaganda which includes any means of implanting ideas or principles on people's minds and is paid for directly by the advertiser" proposed by George Plante. ${ }^{31}$ Advertising in this broad sense is the way in which a company mobilises all of its activities to convey the impression to others that it is in its interests to convey. It closely related to Goffman's (1959) notion of the presentation of self or the "art of impression management." Thus, I understand advertising to be a form of "mediated action", (James Wertsch 1991:12) and as such, it involves an actor, (the advertiser) a situation (a product that needs publicity or a crisis that needs to be dealt with) and the mediational means

\footnotetext{
${ }^{29}$ These include Roland Marchand (1985) and Richard Pollay (1986).

${ }^{30}$ This is discussed at length by Teun A. van Dijk (2008) who uses the term "context" to refer to mental models and subjective interpretations and situation for the spatiotemporally demarcated fragment of possible social worlds (24). My understanding of situatedness is the here and now of the communicative event within the wider socio-historical context.

${ }^{31}$ Plante, the President of the Advertising Creative Circle, used this definition which he attributed to "the late Harold Stansbury" in the foreword to the brochure that accompanied A National Exhibition presented by The Advertising Circle and sponsored by The Times November $22^{\text {nd }}-$ December $7^{\text {th }} 1955$ at The RBA Galleries, Suffolk Street London S.W.1. Shell-Mex was a major contributor to this exhibition. The brochure is available at BP Archives, Warwick University.
} 
employed. $^{32}$ As mediated action, advertising is performative ${ }^{33}$ in the widest sense, and is mediated by different semiotic devices. It is situated in a specific social, historical and political context, and has as its purpose to influence the behavior and beliefs of those to whom it is directed in a way which is advantageous to the advertiser.

Although my perspective is predominantly diachronic it incorporates a synchronic analysis of the advertisements of the different companies for comparative purposes.

\section{Analytical Approaches}

As the oil industry is strongly associated with national, political and economic interests, no study of it can completely avoid treading on the sociopolitical minefield upon which it is grounded. However, it is not my intention to conduct an investigation into the ideological battles that pervade any discourse that is connected to the oil industry, but instead, my ambition is to describe, analyse and try to contribute to an understanding of the different companies' reactions and responses to the prevailing circumstances and to investigate these through the advertisements produced by the different companies. My preferred approach for accomplishing this ambition is to perform a close reading of the many and very different advertisements that the different oil companies have produced since they first entered our lives at the beginning of the twentieth century.

I do not subscribe to the approach of Critical Discourse Analysis (CDA) which might seem to be the most expected in a study of such a charged topic as I am not interested in uncovering the "ideologically potent categories and classifications" that might be "implicit, absent or suppressed" in the advertisements (Norman Fairclough, 1995: 24). Neither am I interested in addressing "social wrongs in their discursive aspects" and in trying to find "possible ways of righting or mitigating them" (Fairclough, 2010:11) ( $^{34}$ My ambition is neither to engage in political discussion nor to change the world and the advertising of the oil companies, but instead, to describe the advertisements produced by these companies and to uncover the communicative strategies and goals that these encapsulate in the context in which they were produced. However, I do subscribe to the idea that social phenomena and our understanding of the world are socially constructed in and through discourse (e.g. Michel de Certeau, 1984, Michel Foucault 1969, Fairclough 2005) and that advertising discourse is by no means innocent.

Rolf Kloepfer (1987:123) has pointed out that advertising is an act that incorporates a number and variety of academic disciplines, including economics and semiotics ${ }^{35}$, and it draws upon all the arts (ibid:136). My study of the advertising of the oil industry will therefore necessarily encompass a wide range of theories and perspectives. However, like Varda Langholz-

\footnotetext{
${ }^{32}$ This a concept which Wertsch founds upon the work of Habermas' theory of Communicative Action from 1984. Habermas distinguishes between communicative action and instrumental or strategic action, which he claims are parasitic upon the former. I claim that the mediated action in which advertisers engage is in fact a form of instrumental and strategic action, as it is designed to bring about a desired end by persuading others to act in a way that will realise the advertiser's ends.

${ }^{33}$ Here I am following Goffman (1959) who summarises the concept of performance as "all the activity of a given participant on a given occasion which serves to influence in any way any of the other participants."

34 Among other scholars, Ruth Wodak and Michael Meyer (2009:3) have characterized CDA as a method for "de-mystifying ideologies and power" to produce "enlightenment and emancipation" (ibid :7) while Gunther Kress (1990:85) has pointed out that "CDA is an openly political and therefore potentially contentious activity" which stresses power-differences inherent in communicative situations.

${ }^{35}$ Kloepfer suggests that Roland Barthes' 1957 work, Mythologies was the first "faltering encounter" between these fields.
} 
Leymore (1987:319), I consider advertising to be "the communication system par excellence, where the discourse of signs is designed to bring about an exchange of values ${ }^{\text {"36 }}$.

My approach is therefore necessarily eclectic but relies heavily on semiotics, dialogism and the New Rhetoric. Aspects of French Discourse Analysis (FDA) are also useful to my study. FDA draws upon a brand of linguistics referred to as "enonciative linguistics" and is often linked with the work of Wittgenstein and with the Bakhtinian Circle and is therefore compatible with the notion of dialogism.

FDA takes as its "objects of relevance [...] texts or énoncés ${ }^{37}$ which are produced within an institutionalized frame that constrains enunciation" (Glyn Williams, 1999:6) and is much less ideologically charged. It builds on the work of authors such as Bakhtin, who refutes the notion that the meaning of words can exist outside their usage, and of Benveniste's (1966) understanding of discourse as "the life of language in action". This analytical approach also makes use of lexicology, and as the investigation of the use and distribution of lexical items through a corpus reveals the process of change, it is an excellent method for studying developments that occur over time in the social world. In his discussion of the contributions made by Michel Pêcheux, who is a central figure of FDA and is generally considered to be its founder, Norman Fairclough (1992:29) takes up the concept of "relexicalization" (29). This notion in fact was put forward in 1929 by Volosinov, who stated that the "word is not only the purest, most indicatory sign" but is also "the most sensitive index of social changes" (Volosinov 1986:19). One of Benveniste's (1966) interests was the use of pronouns, and what Alistair Cook (1994a) has referred to as "the politics of pronouns," and particularly "the problematic we" (175), is highly relevant to the discourse of advertising. Thus, a study of the lexis that is used by the oil companies is a useful tool for investigating new phenomena and changing attitudes.

As the object of my study is the print advertisements of the oil companies and how these have changed over time, not only are the linguistic and semiotic features of the advertisements important, but the sociocultural features ${ }^{38}$ also have great relevance. Another concept that derives from Pêcheux (Fairclough 1992:31) is that of "preconstructeds," ready-formed elements that circulate in discourses. Thus, FDA is an approach which facilitates an investigation into how the participants in a communicative event, in this case, the creation and reception of an advertisement, evolve and adapt to operate in a social reality. As Alistair Pennycook (1994b: 127) has pointed out, it is an approach which stresses the "situatedness" of the object of the communication and which theorizes discourses as systems of knowledge and thought that are socio-historically specific. FDA is therefore particularly suited to a study of what Foucault (1970) has referred to as the "archive" of our socially and culturally constructed world. Pêcheux himself (1981:5) has described discourse analysis as the uncertain space where language and history are trapped and grapple. However, it is important to follow the advice of Paul Ricoeur and to apply a "hermeneutics of suspicion" and instead of taking things at face value take into account the "world in front of the text," the reality in which the advertisements were engendered (G.D. Robinson, 1995).

\footnotetext{
${ }^{36}$ Basing his arguments on the dictionary compiled by the Grimm Brothers who give the original meaning of the German verb "werben", as "to communicate efficiently", Kloepfer (1987:127) also points out that advertising is a "complex communicative event" and posits that in this sense, advertising is "the attempt at maximally efficient human communication".

${ }^{37}$ Williams consistently spells this "enonce" rather than using the English equivalent.

${ }^{38}$ Following the example of Wertsch (1991: 15) I use the expression "sociocultural" for the sake of simplicity to express how the action mediated by advertising is situated in cultural, social and institutional settings.
} 
Although the New Rhetoric is generally associated with Chaïm Perelman and particularly his work with Lucie Olbrechts-Tyteca, ${ }^{39}$ it is firmly rooted in the later writings of Kenneth Burke. The central idea of the New Rhetoric is that it is necessary to understand the particular audience that is addressed and incorporates the notion of identifying with the intended audience that is fundamental to Burke's rhetoric of persuasion. It concerns the interplay between text, context and audience identification; concepts that are implicit in dialogism and that are particularly important for successful advertising. Thus, following the ideas put forward by Kenneth Burke (1945), in order to project a positive image that will be understood and accepted, the companies must be able to identify themselves not only to their different stakeholders, but also identify with them through the messages that they communicate.

\section{Structure of the study}

As advertising is a form of communication which is firmly grounded in a specific sociocultural context, Chapter 2 provides a historical overview of the oil industry from its incipience to the present day, a period of some 5,000 years. This socio-political background facilitates an understanding of the companies' discourse and the advertisements that the companies produced, and it provides the framing context that allows for a "thicker description" (Swales \& Rogers 1995:236). Meaning is "saturated by context [...] and constantly adjusting to the world beyond [its] own limits" and is moreover always imbued with an ideological dimension (William Hanks 1996:7). Thus, in order to fully understand the messages communicated by the oil companies and appreciate the rationale that drives them, it is necessary to understand and be aware of the different historical and ideological contexts in which they were operating and advertising. Moreover, the chapter shows how many of problems that the industry faces today are not new, but have been a recurring theme for well over a century and a half.

After the historical overview of the oil industry and the socio-political contexts in which it is situated, Chapter 3 introduces the concept of advertising as a communicative, dialogical genre. Here, the concepts of genre and dialogism as well as the new rhetoric and the role of the reader are developed, and examples of prototypical advertisements as "dramatistic" (Burke 1945) performances are presented to illustrate the concepts that are discussed.

Chapters 4 and 5 take up the matter of the genre of advertising. Although scholars disagree on a definition of the term "genre", there is a consensus that a genre is anchored and develops historically. Thus, Chapter 4 introduces some of the basic concepts that are encountered in the literature on advertising and marketing and provides an overview of the historical development of the genre with a specific focus on print advertisements. The development of advertising in the United States is juxtaposed with its development in Britain to show the ways in which it developed on the different sides of the Atlantic. The significant contributions of the oil industry to this development are also presented and more recent trends introduced. Chapter 5 continues the discussion of advertising and describes the trends in the research that is being conducted in the field. A survey of the literature that is being produced in this field shows the significance of the communicative turn and the interest in semiotics, rhetoric and poetics that has blossomed among researchers. The purpose is to show how the concepts introduced in Chapter 3 are being put into practical use and also to position my own study.

Chapter 6 introduces the corpus that I have used and provides an overview of the advertisements used in this study as well as the sources from which they have been taken. My

\footnotetext{
${ }^{39}$ Their Traité de l'argumentation: la nouvelle rhétorique appeared in 1958.
} 
corpus of print advertisements stretches from the 1890s until 2012, and it is not of course possible to present in detail all the advertising campaign or series in which the companies have engaged. It includes postcards which were a common means of advertising during the first decades of the twentieth century and posters, as well as advertisements that appeared in different newspapers and periodicals. A number of more unusual forms of print advertisements, Shell's Valentine cards also form part of this material. For a number of practical reasons, advertisements from Shell and BP dominate my corpus. One reason for this is the access that I had to material, particularly prior to the $1950 \mathrm{~s}$. A second reason is the relative instability of company constellations in the United States. The names Shell and BP are the only ones to have survived the turbulence of mergers and acquisitions.

As communication is achieved by means of different sign systems, semiotics is central to advertisements, and Chapter 7 addresses this. In an advertisement, the relationship between text and image is particularly important and the focus of this chapter is on the visual elements of the advertising text and on their rhetorical functions. McQuarrie \& Mick (2003:218) have claimed that a semiotic, rhetorical approach provides the analytical tools that make it possible to identify and explain the impact of stylistic variation in advertising. This approach makes it possible to "return to the text" (ibid: 193) which is what I propose to do in the two chapters that follow.

Chapters 8 and 9 are comprised of the analyses of the advertisements that I have chosen to represent my corpus. My analyses are based on a close reading which relies largely on a semiotic and rhetorical approach. Chapter 8 is diachronic and traces the development of these from the first years of the $20^{\text {th }}$ century until 2012. The advertisements are analysed with reference to the sociocultural context in which they appeared to situate the messages that are communicated in a frame which increases the reader's understanding and appreciation of "what is going on". The analyses also demonstrate the different types of identity work in which the companies have engaged. Chapter 9 discusses the themes that recur throughout the discourse of the advertisements over the decades and the stories and myths that the companies recount are presented. Chapter 10 shows the ways in which the companies have adapted these shared themes to create individual personalities and create some form of differentiation through the story-lines.

Chapter 11 presents the findings of the study and shows how the companies have worked to protect and nurture their different forms of capital over time and how they have adapted their face work to the prevailing context.

Finally, Chapter 12 answers the research questions:

1. What do the oil companies communicate in their advertisements, how do they do this and to whom do they communicate?

2. How do the companies differentiate and profile themselves?

3. How have the messages that they communicate changed over time, and in what way do they relate to or reflect prevailing socio-political conditions and public opinion? 


\section{Chapter 2}

Five thousand years with oil

Of the top ten companies in the Fortune 500 global ranking in 2008, six were oil companies. As long ago as the 1870 s, less than twenty years after the first well was drilled at Titusville, Pennsylvania, in what was to become the United States of America, the chief foreign executive of Standard Oil, the major oil company, proclaimed that petroleum had "forced its way into more nooks and corners of civilized and uncivilized countries than any other product in business history emanating from a single source" (Yergin, 2008:41).

\section{"The magic liquid flows" 1}

When "Colonel" Edwin L. Drake and his driller, a local blacksmith, "Uncle Billy" Smith, struck oil during the last weekend in August, 1859, little did they know that their discovery was to "bequeath mobility and power to the world's population, play a central role in the rise and fall of nations and empires, and become a major element in the transformation of human society" (Yergin, 2008:13). However, what they had found was nothing new; a semisolid, oozy substance had been seeping through cracks and fissures in the earth's surface since antiquity, and has been dated back to $3000 \mathrm{BC}$ in Mesopotamia. The most famous source of this substance, known as bitumen, was at Hit, near Babylon and the city known today as Baghdad $^{2}$. In fact, the first century BC historian, Diodorus of Sicily, claimed it as one of the greatest miracles of the area (ibid:7) ${ }^{3}$. Bitumen had many uses, from straightening eyelashes to making building mortar, from surfacing roads and waterproofing boats and baskets, to medicine. Pliny the Elder, who died in the year 79 AD, some hundred years after Diodorus, describes the many uses of this oil ${ }^{4}$. It had pharmaceutical applications and was an essential ingredient in a wide variety of salves and unguents whose properties included helping flesh grow back onto naked bones, curing fistulas and removing hard growths. Bitumen, mixed with wax and malachite created a salve that could be used to clean wounds (Plinius Caius Secundus, 1997:45) and mixed with oxide from Cyprus, it could heal mouth ulcers, and sores on the lips and gums (ibid:121). Pliny also enumerates the use of oil for non-medical purposes. These included extinguishing certain types of fire, protecting and restoring paint that has been attacked by minium, or red lead, and treating soft Sifnos stone, which is carved out into bowls and dishes, so that it becomes hard (ibid:289). It was also used successfully in warfare and is probably the "unwearied fire" that Homer describes in the Iliad. The Byzantines also used oleum incendarium as a weapon, on the tips of arrows, for example. This so-called Greek fire was seepage oil mixed with lime, which when touched with moisture would catch fire. Thirteenth century Marco Polo too, was aware that there was a spring near Baku on the Caspian Sea that produced an oil and reported that although the oil was not good in food it was "good to burn" and useful for cleaning camels (Yergin, 2008:41). One thing that Bitumen was not particularly good for, however, was lighting, where it was

\footnotetext{
These words are taken from an advertisement for the patent medicine "Seneca Oil" in Yergin, (2008: 4).

The Healthful balm, from Nature's secret spring,

The bloom of health, and life, to man will bring;

As from her depths the magic liquid flows,

To calm our sufferings, and assuage our woes.

${ }^{2}$ Bitumen had many uses and was commonly traded. It is probable that the walls of Jericho and Babylon were bound with bitumen and that both Noah's Ark and Moses' basket were caulked with this substance. (ibid:8)

${ }^{3}$ It is thought that the escaping petroleum gases which burned constantly provided the basis for fire worship in the region.

${ }^{4}$ Although Yergin $(2008$, p.8) provides a colourful list of the medicinal uses of oil, more detail can be found in Pliny's Naturalis Historia, Book 33, which deals with the characteristics of metals, 34, which discusses copper and 36 whose themes include the characteristics of rock.
} 
generally found to be unsatisfactory. Although seepages were most common in the Middle East where bitumen was a frequently traded commodity, they also occurred and were commented upon in various parts of Europe, although knowledge of its uses had largely disappeared.

In Europe, the nascent oil industry was founded on oil shale, a fine-grained sedimentary rock, rich in organic matter. It was thanks to the refining techniques that were already in place and the commercial success of the hydrocarbon trade that Drake's backers had sponsored him, and it was for this reason that the impact of the Titusville oil find was so immediate (Beaton, 1955:28). During the 1740s, for example, Michael and Thomas Betton had been granted a patent for "An Oyl extracted from a Flinty Rock for the Cure of Rheumatick and Scorbutick and other Cases." They claimed that this oil came from rock lying just above the coal in mines. It was then pulverized and heated in a furnace to extract all the precious healing oil. It was sold under the name of British Oil (Griffenhagen \& Young, 1959:8). The distillation process resulted in three fractions: naptha, which could be used to make gasoline, coal oil, from which kerosene was produced and finally, after the kerosene fraction had been removed, a residue which gave tar, lubricant stock and paraffin wax (Hidy \& Hidy, 1955:8). By 1850, James 'Paraffin' Young was running a full-scale commercial process for retorting and refining oil products manufactured from shale and in 1851, he opened Britain's first commercial mineral oil refinery in Bathgate, patenting his retorting process in both Britain and America (B. A. Harvie, 2011). Until 1856, Young's paraffin was used as a lubricant, replacing the animal oils that had been employed and it was not until 1859 that it became popular for burning.

In America, in what is now the Borough of Queens, the New York Kerosene Oil Works began operations in 1854. The Kerosene works was the brainchild of Dr. Abraham Gesner, a Nova Scotian by birth, and a man whose professional life included working as a physician, a surgeon, a geologist, a chemist and an author. Gesner was also an inventor and developed a process for extracting oil and refining it so that it could replace the illuminants which had previously proved either so expensive, as in the case of whale oil, where sperm whale oil fetched $\$ .2 .00$ to $\$ 2.50$ a gallon and the cheaper whale oil $\$ 0.75$ to $\$ 1.00$ (Kendall Beaton, 1955:29) or was unsatisfactory. Gesner called his new, quality illuminating oil 'kerosene' from the Greek words Keros and elaion, meaning wax and oil, respectively, and changing elaion to bear a closer resemblance to camphene, which was familiar at the time (Yergin, 2008:7 and Beaton, 1955:40) and which tended to smoke. The Austen brothers, who were the general sales agents for the Kerosene Works, furthered the popularity of kerosene as an illuminant by importing a cheap, flat-wicked lamp from Vienna. In this lamp, Kerosene burned cleanly and without either smoke or smell. A descriptive article in the New York Commercial Advertiser, 24 August 1859, just three days before Drake's first oil well was completed, explained not only the set-up of the Works, but also enumerated the commercial products that were then being manufactured. These included paraffin, a naptha called Kerosoline which could be used for "extracting grease from silk, woollen or other fabrics" and as a superior lubricating oil (Beaton, 1955: 50).

Drake had really struck oil at the right time for a successful commercial venture. Refining, experience with kerosene, a lamp, and demand were already in place when he provided the final requirement for this burgeoning industry; the availability of supply (Yeltsin, 2008, p.13). George Bissel, the man who had financed promoted Drake's work, wrote to his wife that "prospects are most brilliant that's certain...We ought to make an immense fortune" (Yergin, 2008:12). Among Bissel's many professions, he had taught Latin and Greek. In addition, he 
had learned to read and write Hebrew and Sanskrit and was so versed in ancient writings. Passing through western Pennsylvania, he noticed seepages and the primitive methods of oil gathering by skimming and oil-soaked rags. He knew that rock oil was used in patent medicines for curing everything from deafness to rheumatism and wounds on the backs of horses and mules. He also knew that the liquid was flammable. He approached Benjamin Silliman, a distinguished scholar at Yale and author of textbooks on physics and chemistry with a sample and to discuss his ideas. Both men were interested in the money that they envisaged the project would earn, but Silliman's fee for his analysis and report almost jeopardised the whole project. However, one of Bissell's backers raised the money needed to satisfy Silliman and the report, dated April 16, 1855, was released. Of the many fractions into which Silliman had distilled the oil and in which he recognised potential valuable products, one was a very high-quality illuminating oil. After the release of the report, there was no shortage of investors and the Pennsylvanian Rock Oil Company was born. The next problem was to find a better way to extract the oil than gathering the seepages. Bissell and the Pennsylvanian Rock Oil Company decided to adapt the method used for salt-boring to oil, and the technique of drilling for oil was born. Drake was the man they chose to implement this "lunatic project" for the first time. (Yergin, 2008: 4-10)

\section{The Birth of "Big Business"}

After Drake's success at Titusville, there was no shortage of speculators who all wanted to buy land in areas where there were seepages. Common Law $^{5}$ meant that the owner of the land also had the rights for any minerals discovered there, and soon there was cut-throat competition among the would-be oil men who were always prepared to cut the price to make a sale (Hidy \& Hidy, 1955:8). The young business was generally peopled by young men who were Civil War veterans looking for a future, and by former forty-niners "prospecting" for black gold. The prevalent attitude was "my business is my own" and the perspectives were short-term. The business was risky and failure was common, wastage due to fires and to leakages was endemic and supplies and subsequently prices, fluctuated wildly, but these disadvantages were outweighed by the lure of excitement and the potential rewards..

It was into this chaos of feast or famine that what was to become the Standard Oil Company emerged. Despite all the problems, oil production had increased rapidly from 2,000 barrels in 1859 to $4,800,000$ ten years later. There was a strong market, but there was no infrastructure to support the burgeoning industry. Everything that was necessary for it to develop, from railroads to barrels, pipelines and storage facilities, was individually owned by individuals who were looking for immediate profit. Then, one February day in 1865 in Cleveland, Ohio, Maurice Clark and John D. Rockefeller shook hands on what signalled the beginning of the modern oil industry (Yergin, 2008:19). Unable to agree about the expansion of the refinery they had started together in 1863 , the two men had decided to hold an impromptu auction in their office, with the highest bidder getting the company. Rockefeller won the company for $\$ 72,500$. In a number of areas, organisations were trying to shut down wells in an attempt to stabilize the situation in 1866 , and in early 1869 , the first organisation to represent oil producers in all the regions, the Petroleum Producers' Association of Pennsylvania, was founded. The aim of this organisation was to prevent abuses in the oil business and also to oppose and lobby against state proposals that were unfavourable to the business (Hidy \& Hidy 1955:10).

\footnotetext{
${ }^{5}$ Common Law is an important concept in the judicial system of England and Wales upon which American law is largely based.
} 
Rockefeller's idea was to introduce the notion of a vertical and horizontal organization into the oil business. In order to lower unit costs and seize a larger share of the market, he started to cooperate with other specialist companies involved in all the different aspects of delivering oil products to the market, including auxiliary enterprises like owning lumber and warehouses. Eventually the name Standard Oil came into being and on January $10^{\text {th }} 1870$, the Standard Oil Company, the name referring to the concept of a "standard quality of product" (Hidy \& Hidy, 1955: 24) was fully introduced and had become an important actor on the American oil scene. Other business men joined the Standard Oil Alliance during the early 1870 s, a period of uncertainty for those involved in the business. Oil production had reached $5,205,000$ in 1871 , a year of turbulence and which saw excessive production and reduced profit margins. Rockefeller and his group believed that the solution to the problem was common ownership, which would ensure that every aspect of the business was managed efficiently and with a long-term perspective. ${ }^{6}$ In fact, although the name most commonly associated with Standard Oil is that of John D. Rockefeller, he himself considered that he was the captain of a team, and it was by allowing his associates, "a body of men who from beginning to end worked in single-minded co-operation, who all believed in each other and had perfect confidence in the integrity of each other, who reached their decisions after fair consideration with magnanimity toward each other" (ibid) to develop and specialise in those areas in which they were most talented and capable, that the Alliance flourished. William Rockefeller, for example, was a good organiser, financier and marketer. His field of speciality was sales for export and by 1872, the United States had entered all the major markets for oil and its by-products, including Japan. Charles Pratt built up a substantial market for a highquality kerosene that was widely advertised as Astra Oil - "It will not explode", while William Gray Warden patented an apparatus and process for distilling petroleum in 1871 and improved the cylindrical tank car by adding a dome to it. Henry Huttleston Rogers, who joined Pratt's firm, improved and patented an apparatus for separating naptha fractions from kerosene and for dividing naptha into its component parts.

By 1881, Standard Oil had embraced a large segment of the American oil industry and simultaneously won the enmity of those that remained outside its protecting wings.

At the very end of the 1870 s, some of the Pennsylvanian oil producers had tried to break out of this embrace by constructing a long-distance pipeline, the Tidewater Pipeline, a daring and unprecedented feat of engineering. The venture succeeded, and in May 1879 oil was flowing down the pipeline. This first long-distance pipeline would carry the oil 110 miles eastwards to connect with the Pennsylvanian and Reading Railroad and would offer producers an alternative to the transport offered to them by Standard Oil. In response to this, Standard Oil built four long-distance pipelines of their own and also became a minority shareholder in Tidewater.

Producers and other people with a vested interest in the oil industry and who were not protected by the embrace of the Standard Oil "gang of thieves" (Yergin, 2008:27), began to use the legal and political system to question the methods and power that the Alliance wielded. Accusations that the Alliance was in fact a monopoly began to appear, and the courts became involved in the internal affairs of the company. The stockholders, and not the Alliance, Standard Oil itself, owned shares in other firms, and thus, in a legal sense, Rockefeller's team was not a monopoly but held the shares "in trust". One of the results of the investigations into the workings of Standard Oil was that the legal concept of "trust" was

\footnotetext{
${ }^{6}$ For more detailed information about the Alliance and the men who constituted it, see Hidy \& Hidy, (1955) Pioneering in Big Business 1882-1911 pp. 13-32.
} 
refined and in January 1882 resulted in the Standard Oil Trust Agreement. ${ }^{7}$ Another consequence of the revelations about the way in which Standard Oil did business was that the Alliance, and the concept of big business in the form of its "overweening control of the oil business" (Yergin, 2008:27) was denounced and called into question, and their dealings became a matter of not always benevolent interest to the public.

Whatever the moral issues that were raised about the methods employed by Standard Oil in those early years, Rockefeller's Alliance was a major driving force towards the life-style which we expect today and provided the foundations upon which big business rests. The Alliance set what was to become a business norm of firms coming together in different formations to minimize risk and maximize profit, a practice which is particularly common in the oil industry. Standard Oil also integrated scientific research and market research into the very core of the business. The company's marketing policy did not only encompass advertising products, both old and new, but Standard Oil salesmen actively enquired into and investigated customer needs and preferences and reported their findings back to the company. Kerosene was still the most important product, and in the words of a New York chemist in 1864 and reported by Yergin (2008:34), had "in one sense, increased the length of life in the agricultural population. Those who, on account of the dearness or inefficiency of whale oil, were accustomed to going to bed soon after sunset and spent almost half their time in sleep, now occupy a portion of the night in reading and other amusements; and this is more particularly true of the winter seasons". However, other implementations of oil and its derivatives were also changing society. It was not only an illuminant, but was used to lubricate the mechanical parts found in an ever increasing number of machines, from train engines to cotton spindles and bicycles, was used in pharmaceutical products, including the petroleum jelly with the trademark "Vaseline" in food preservation and even in the chewing gum which was "highly recommended for use in ladies in sewing circles" (ibid:35). Rockefeller, a devout Baptist, remained convinced that Standard Oil was an instrument for good, for delivering the "new light" to the world of darkness (ibid: 38).

The mixed blessings brought by Standard Oil were clearly expressed in Mineral Resources, 1882, a paper produced by the United States government. The paper declared that " $[\mathrm{t}] \mathrm{here}$ seems to be little doubt that the company has done a great work, and that through its instrumentality oil refining has been reduced to a business, and transportation has been greatly simplified; but how much evil has been mixed with this good, it is not practicable to make a definite statement" (cited in Yergin, 2008:38). The new and ever increasing needs that the oil industry had created had come to stay, and the fear that the source for satisfying these needs was very real, not just in America, but throughout the world.

\section{The Rise of the Oligarchs}

The power wielded by Standard Oil began to decline with the new century. Although the dissolution of the Standard Oil "octopus" by the U.S. Supreme Court in 1911 is often cited as the turning point in the development of the oil industry (Pratt, 1980: 816), the monopolistic position of the Trust in America had become increasingly eroded and a flourishing oil industry had grown up in Russia and in Europe.

\footnotetext{
${ }^{7}$ See Yergin (2008: 24-31) for more information about the events of this period and their impact on Standard Oil and the industry.
} 
In the first decades of the nineteenth century, Baku, in Azerbaijan, "the land of fire", had a small and primitive oil industry which by 1829 comprised eighty-two hand-dug pits (Yergin, 2008: 42-45). The situation in Baku, the historical centre of the Russian oil industry owed its slow development to the ever-changing, short-term systems for allocating land rights in the area. This situation changed in the 1870 s when the Tsarist government began to auction off lands on a long-term basis (Kelly \& Kano: 1977, 309-310), ${ }^{8}$ and the first wells were drilled. In March 1873, Robert Nobel, the oldest and least successful of the Nobel brothers, arrived in Baku with twenty-five thousand roubles that had been entrusted to him by his brother Ludwig, an armaments manufacturer, to buy wood for the rifles that were to be supplied to the Russian army. Instead of buying wood, Robert bought a small refinery and the Nobel family were in the oil business.

With Ludwig at the helm, the Nobel Brothers Petroleum Producing Company soon dominated the Russian Empire, and like Rockefeller, whose developments he keenly followed, Ludwig believed in vertical and horizontal integration and made further innovations in the industry. It was the Nobels who introduced the idea of having a professional geologist as a permanent member of staff and who first moved oil in "bulk", in other words in large tanks, by ship. Transportation of the oil from Baku to its markets was difficult and expensive. Wood was not readily available in the area and this meant that even barrels were costly. Even in Pennsylvania barrels had proved problematic, as a standard empty barrel not only leaked, but was heavy and at 64 pounds, $(29 \mathrm{~kg})$ represented about twenty per cent of the total weight if a full barrel of oil. In Baku, where wood was scarce, the cost of the barrel accounted for half the cost of the petroleum. (Tolf 1976:54) The first attempts at sea transport were unsuccessful due to problems with ballast and ships were wrecked in bad weather. According to one ship's captain, this was because "the oil seemed to move quicker than water, and in rough weather, when the vessel was pitched forward, the oil would rush down and force the vessel into the waves" (Yergin, 2008:43). Ludwig Nobel conceived of a means to solve this problem with the ballast, and in 1878, the Zoroaster, the first successful bulk tanker, was commissioned and in use on the Caspian Sea.Nobel designed this vessel, which measured 184 feet in length and 27 in beam, with the help of Sven Almqvist, the director of Lindholmen-Motala in Sweden, as he had been unable to find support for his ideas in Russia. The Zoroaster made its way to the Caspian during the spring thaws, and although this first ship was small enough to sail from Sweden to the Caspian over the Baltic, Lakes Ladoga and Onega, the Rybinsk and the Mariinsk Canals and the Volga River, it could carry 242 long tons 9 of kerosene in two iron tanks joined by pipes. The ship was the first to be made of Bessemer steel and the design incorporated 21 watertight compartments which gave the vessel extra buoyancy (Tolf 1976:54). Nobel increased his fleet of bulk tankers and the Zoroaster's two sister ships were named Buddha and Nordensköld, three names which honoured ancient fire worshippers. Ludwig Nobel revolutionised oil transport. Indeed this transportation concept was hailed as "the most important fact in the entire history of the petroleum industry" (ibid). Moreover, as oil could now be shipped across the Atlantic to the American market, the grip of Standard Oil began to loosen.

\footnotetext{
${ }^{8}$ After the area ceded to Russia in 1813, the Tsarist government took charge of all but two of the naptha pits. Between 1813 and 1872 no fewer than six different systems of land-ownership operated. The system in operation between 1821 and 34 involved bidding out land rights for extraction and trade in oil on four-year terms. (Kelly \& Kano, 1977:309)

${ }^{9}$ A long ton is an imperial measure which has today been commonly replaced by the term "tonne". A long ton is equal to 2, $240 \mathrm{lbs}$ or $1,016 \mathrm{~kg}$. It is still used in the United States to measure the displacement of ships and was the unit prescribed for warships.
} 
Crude oil production rose from less than six thousand barrels in 1874 to 10.8 million in 1894 . This figure was almost one third of the total American production and American kerosene had been forced out of the Russian market. However, despite the fact that Ludwig Nobel's oil empire has been described as "one of the greatest triumphs of business enterprise in the entire nineteenth century" (Yergin, 2008: 43), due to the geographical position of the oil fields, its market was largely limited to Russia, where demand for illumination was not nearly as high as among the American population. In addition, it was often cheaper and more practical to import from America than to buy oil from Baku. Transport costs were extremely high and coal was a much cheaper source of heating and energy (Kelly \& Kato, 1977: 329).

Two other producers, Bunge and Palashkovsky, looked to find an alternative to the northern route dominated by the Nobels, and won approval from the Russian government to build a railroad west from Baku to Batum, on the Black Sea. Unfortunately, oil prices fell and their project was in danger until the Paris branch of the Rothschild family entered the scene. The Rothchilds already owned a refinery on the Adriatic and had financed railway building throughout Europe. A loan from the Rothchilds allowed the railroad from Baku to be completed in 1883 and Batum became one of the most important oil ports in the world. In 1886, they created "Bnito", the Caspian and Black Sea Petroleum Company with its centre in Batun. The Nobels were obliged to follow suit and the Baku-Batun railroad made it possible for Russian oil to reach the West. Another consequence was that it led to a struggle for the oil markets of the world which lasted for some thirty years and which challenged Standard Oil's domination.

In 1888 the Rothschilds established import and distribution companies in Britain and the Nobel Brothers quickly followed suit. In fact, between 1888 and 1891, the quantity of Russian oil products on the global market rose from $21 \%$ to $29 \%$ while the American market share fell from $78 \%$ to $71 \%{ }^{10}$. Standard Oil were forced to react and they set up their first foreign "affiliate" the Anglo-American Oil Company, less than a month after the Rothschilds. Standard Oil did not restrict this new wave of affiliations to Britain, but also established them in Continental Europe as joint ventures with leading national distributors. In this way, Standard Oil became a truly multinational enterprise (Yergin, 2008:46).

The Nobels had a firm footing in the Russian kerosene market and the Rothschilds needed a market for their own products and distribution channels for their illuminant. Through a London shipping broker, Fred Lane, the Rothschilds, probably the best known Jewish family in the world, were put in touch with Marcus Samuel, a professing Jew, and a descendant of immigrants who had come to England from Holland and Bavaria in 1750. Samuel, who had risen to some prominence in the City of London, was born in 1853 and had been schooled in Brussels and Paris. His father, Marcus Samuel the elder, listed in the 1851 census as a "shell merchant" had been a trader and his most successful product was a little knickknack box covered in shells and was very popular among Victorian girls and ladies as holiday souvenirs. In 1869 when Marcus Samuel went to work for his father the world was changing. Not only had American oil production begun to change lifestyles, but the opening of the Suez Canal had reduced the journey to the Far East by 4,000 miles, steam ships were replacing sailing ships and in 1870, the direct telegraph cable from England to Bombay, and shortly after to Japan, China and Singapore facilitated communications. After the death of their father, Marcus and his brother Samuel Samuel went into a trading partnership, with Marcus

\footnotetext{
${ }^{10}$ Figures have been taken from L'histoire du Pétrole caucasien au siècle passé- Projet 22 at http://www.projet22.com/histoire-29/les-multintionales/article/1-histoire-du-petrole-caucasien (accessed 17-112011).
} 
operating from London and Samuel from Japan, where the brothers' enterprises played an important role in the industrialisation of the country. Marcus Samuel was ambitious and wanted to be socially accepted. He operated with very low overheads and had a flair for instilling trust and obtaining credit. He was also a shrewd business man and recognised the opportunity that the Rothschilds were presenting as well as the risks.

Marcus Samuel realised that the major problem was the Standard Oil Trust Alliance and that this was an enemy that had to be defeated. He was aware that the Trust would slash prices which were already unstable and falling if they became aware that he was breaking into the market and that he must move quickly and discreetly. He would need better tankers to save on shipping costs per gallon, guaranteed kerosene supplies from Batum, access to the Suez Canal to cut the voyage and thereby costs, and a network of inland depots. Samuel's first move was to commission a fleet of tankers built to his new specifications. These tankers were technologically superior to any in existence and were the result of observations made when he travelled to the Caucasus in 1890 with Fred Lane. On gaining the Rothschild contract for nine years, from 1891 to 1900 , to sell kerosene east of the Suez he had to gain access to the Canal; access which Standard had been denied. However, his attempts were met by a clamour of opposing voices arose, warning against a "powerful group of financiers and merchants" under "Hebrew influence" (Yergin, 2008:50). For example, The Times of December $28^{\text {th }} 1891$ carried a copy of the "Petition to the Suez Canal Company (about) Petrol Steamer Tankers" that had been presented to the president and directors of the Suez Canal Company. The petitioning ship-owners claimed that the syndicate in question wanted to carry "abnormally large quantities of petroleum in bulk ... in excessively large tanks".

A number of serious accidents related to loading the oil onto ships had in fact occurred, and the best known had connections with Russian oil. In 1881, one of the first oil tanker disasters had occurred when the Nordensköld, one of Nobel's vessels had exploded during loading. A gust of wind had caused the vessel to list and the kerosene that was being loaded onto it spilled onto the deck and then into the engine room, where engineers were working by the light of kerosene lanterns. Half the crew were killed. A similar accident had also happened on one of the Volga tank barges (Tolf, 1976:58). Among the issues that the petition raised were "the high temperature of the Canal", the "disastrous consequences" of a fire or explosion in "the confined space of the waters of the Canal" and that "any regulation arbitrarily denying the right of passage to steamers built before a certain year [was] highly objectionable"11.

In addition, a well-known firm of London solicitors that refused to reveal the identity of their client, but who were generally assumed to be representing Standard Oil, acted to try to prevent the very dangerous transportation of oil through the Suez Canal. When the Foreign Secretary asked what British interest they were representing, the firm still refused to answer, but instead turned the issue to the newly perceived dangers of Russian seamen let loose in the Canal (Yergin, 2008: 21-52).

However, the English branch of the Rothschilds had financed Benjamin Disraeli's purchase of Suez Canal shares some fifteen years earlier, the French Bank Worms supported Samuel's plans and finally, the Foreign Secretary soon realised that the project was very much in Britain's interests. Lloyds of London, the insurance company, decided that Samuel's new tankers were safe and gave them the green light. These new tankers were a floating bottle, much like modern-day tankers and could be steam-cleaned and filled for the return trip with

\footnotetext{
${ }^{11}$ The full petition can be obtained from the Acorn Archive, Hearts of Oak which is available on-line.
} 
other goods including food. The steam-cleaning ensured that these goods would not be tainted by the taste or smell of the oil carried on the outward journey, and the concept reduced costs and made the round-trip much more profitable. On January $5^{\text {th }} 1892$, approval was granted by the Suez Canal for the passage of tankers built to Marcus Samuel's design ${ }^{12}$ and was reported in the Straits Timer of Singapore, February 18. The newspaper reported the conditions for passage, which included showing a certain signal, that in port, the vessel would be isolated by floating booms, that the refined petroleum allowed had a flashing point below $73^{\circ}$ Fahrenheit, as well as lighting and capacity restrictions. ${ }^{13}$

The first of these tankers, the Murex, named after a type of mussel seashell in memory of his father, the shell merchant, sailed from West Hartlepool to Batum where it filled its tanks with Bnito's kerosene in 1892, passing through the Suez Canal on August $23^{\text {rd }}$. It went on to Bankok where the Samuel had set up his nephew Mark Abrahams. Marcus Samuels and the Rothschilds had beaten Standard Oil. However, there was one problem with the plan. The assumption had been that they would deliver kerosene in bulk to different localities and that the customers would come there with their own receptacles for filling. In reality, the blue Standard Oil cans which the customers had been expected to bring for re-filling had found a new function in the Far East and were used for everything from roofing to opium cups and tea strainers and as a result, there were no customers. Marcus Samuel once again displayed his entrepreneurial genius and chartered a ship loaded with tin plate, instructing his agents to manufacture tin receptacles on the spot. The agent is Shanghai cabled to ask what colour the tin cans should be and Mark Abrahams answered "Red". By the end of 1893, ten more tankers had been launched, each named after a seashell and by 1895 sixty-nine tankers had passed through the Suez Canal, of which all but four were for Marcus Samuel. By 1902, 90 per cent of the oil to pass through the Suez belonged to Samuel and his group. Not only was Marcus Samuel's fortune amassing, but his social status was also on the rise, and he managed to win an election for the post of alderman of the City of London. However, a cloud appeared on his horizon in 1893 in the form of illness. It is said that every cloud has a silver lining, and this particular silver lining was that Marcus Samuel to begin to organise his business better, and together with his brother, Fred Lane and the trading houses of the Far East form a new entity, the Tank Syndicate, to fight Standard Oil (Yergin, 2008:52-54).

The oil wars, involving Standard, the Rothschilds, the Nobels, and the other Russian producers, had begun.

\section{The Dissolution of an Empire}

The Standard Trust Alliance spread to Europe during the nineties, where through affiliates it pushed the adaptation of bulk transportation and distribution with varying levels of success, and in 1898, it made its most important acquisition in Canada, the Imperial Oil Company,

\footnotetext{
${ }^{12}$ The Economist of January 9th 1892 wrote that the "new scheme is one of singular boldness and great magnitude. Whether it is true, as its opponents insinuate, that it is purely of Hebrew inspiration, we are not concerned to inquire; nor does it appear why such a circumstance should count against it....If simplicity is an element of success, the scheme certainly seems full of promise. For instead of sending out cargoes of oil in cases costly to make, expensive to handle, easy to be damaged, and always prone to leak, the promoters intend to ship the commodity in tank-steamers via the Suez Canal, and to discharge it wherever the demand is greatest into reservoirs, from which it can be supplied to customers." (Yergin, 2008:51)

${ }^{13}$ The full article, Bulk Petroleum in the Suez Canal can be accessed at Straits Times Weekly Issue, 24 February 1892, page 106 at http://newspapers.nl.sg/Digitalised/Article/stweekly18920224.2.39.aspx. (accessed 17-112011)
} 
Limited, which had unsuccessfully negotiated with interests in England some years earlier (Hidy \& Hidy,1955:256-257). However, in the United States, it was facing increasing hostility.

Patillo Higgins, a self-educated, one-armed mechanic and lumber merchant of the little township Beaumont, was convinced that there was oil beneath Spindletop, the hill that rose above the flat Texan coastal plain near the Gulf of Mexico. He bought books about geology and tried desperately to involve others in his dreams, but in vain. In 1892 he started a company whose letterhead was "a sketch of two dozen oil tanks, the smoking chimneys of a dozen plants, and several brick buildings" (Yergin, 2008:67) but his efforts were of no avail. Although small scale oil production had accidently started in Texas ${ }^{14}$, the Texas Geological Society went so far as to publish an article in 1898 warning people against Higgins' project. In a last attempt, he advertised for a driller in a magazine to which Captain Anthony F. Lucas, an Austrian immigrant, was the only person to reply. The newly forged partnership of Lucas and Higgins began drilling in 1899 but ran out of money and could find no support. Lucas approached Standard Oil who also turned him down. In desperation, Lucas went to Pittsburgh to meet two well-known wild-catters, James Guffrey and John Galey, who agreed to drill but who imposed extremely hard conditions. They managed to secure financial backing from a banking family, the Mellons, but Lucas would get only one eighth of the deal and Higgins nothing. Galey went to the Beaumont area and chose a drilling spot just where Patillo Higgins had predicted that there would be oil. The drilling started in the autumn and after the drillers had fought their way through the hundreds of feet of sand that had frustrated all previous efforts and at 880 feet, signs of oil appeared. On January $10^{\text {th }} 1901$, they hit oil in a way that nobody had ever before experienced (Yergin, 2008: 66-69) ${ }^{15}$. Oil was flowing from Spindletop, Lucas 1, at an unheard of seventy-five thousand barrels a day. The phenomenon was something that had only previously been seen in the "oil fountains of Baku" and became known as a "gusher". Indeed, a "new language was born on the hill" (ibid:71) with words like driller, roughneck, roustabout, shoe-stringer and poor-boy being introduced to the vocabulary. The Texas oil boom had begun and a pointed to a major shift in industrial society.

Although Standard had refused to back Higgins and Lucas, they were not slow to jump on the bandwagon. In 1902, George Burt, a mysterious stranger got off the train in Beaumont and bought a large piece of land near Spindletop (Pratt, 1980: 823). Burt constructed high fences around this land and built one of the best and most modern refineries in the district. His enterprise, Security Oil ${ }^{16}$ was a "blind tiger" ${ }^{17}$ financed by Standard Oil one of the few

\footnotetext{
${ }^{14}$ The civic leaders of the small town of Corsicana had decided that they needed better access to water if they were to develop commerce in the area. In order to do this, they started a water company which began drilling in 1893 and which to the initial chagrin of the company, hit oil instead of water. They then adapted the method of rotary drilling from the water-well contractors and applied to extend their search for oil.

${ }^{15}$ Yergin (2008:68) describes the drama of the scene in the following words. "Mud began to bubble with great force from the well. In a matter of seconds, six tons of drill pipe catapulted out of the ground and up through the derrick, knocking off the top, and breaking at the joints as the pipe shot further upward. Then the world was silent again. The drillers, who had scattered for their lives and were not sure what they had seen, or even if they had actually seen it, sneaked back to the derrick to find a terrible mess, with debris and mud, six inches deep, all over the derrick floor. As they started to clear the mess away, mud began to erupt again from the well, first with the sound of a cannon shot and then with a continuing and deafening roar. Gas started to flow out; and then oil, green and heavy, shot up with ever-increasing force, sending rocks hundreds of feet into the air. It pushed up in an ever-more-powerful stream, twice the height of the derrick itself, before cresting and falling back to earth.

${ }^{16}$ Security Oil later became Magnolia Oil and in 1925, was legally purchased by Standard New York and eventually became Mobil.

17 "Blind tigers" were ostensibly independent companies that had secret affiliations with Standard Oil (Pratt, 1980:832)
} 
organisations with the financial and technical strengths to do this. Standard became a major purchaser of Gulf oil and although antitrust laws in place which banned its open entry onto the Texan market ${ }^{18}$, Standard still managed to control the pace and shape of the development of the area. In reality, Standard's actions were much more restrained than was generally believed, but its size and tendency towards secrecy made it the popular symbol of all evil, although Rockefeller would claim until the very end that he was an honest but astute businessman. However, the series of vituperative articles about the "Great Anaconda" (Ida Tarbell, 1904:73) or "Unholy Alliance" (ibid:104) led by the "Mephistopheles", John Rockefeller (ibid:97), which Ida Tarbel1 ${ }^{19}$ began to publish in McClure's in 1902 before they came out in book form, History of Standard Oil Company in 1904, as well as unfounded rumours, such as the one that the Standard was planning to build a pipeline from the Gulf to Spindletop to pump saltwater into the field in order to sabotage the production of its competitors, created ambivalent feelings among the public. The good work that in some quarters the company was recognised to be doing could and did in part, off-set the wildest of the allegations (Pratt, 1980:821-822) but Ida Tarbell's accusations caused a great deal of damage to the Trust's image.

Although many oil companies were born at Spindletop, including Humber Oil which later became Exxon, two of the most important companies to emerge in Texas were Texaco and Gulf Oil. These two companies played an important part in shaping the development of the oil industry. Shell, at the time primarily a transport company, also developed ties with the Texan oil fields, and particularly with Gulf Oil, the company that had been built around Captain Lucas' discovery.

The Mellons entered the oil business as a result of the visit of William Mellon, one of the younger members of the family, to the site at Spindletop where their money had been invested. (Yergin, 2008:73- 79). He realised that they would never recoup their investment as long as Guffey was in charge, and so offered to sell the enterprise to Standard Oil, who once again refused due to the adverse legal and political conditions facing them in the State of Texas. At this time, the Trust was investing in the mid-Continental oil fields where the political climate showed less hostility to their activities. As a consequence of Standard's rejection of his proposal, William Mellon decided that he needed to take over the business, "to translate crude oil into money" (ibid:73) and among other things, renegotiate the very disadvantageous contract that Guffey had made with Marcus Samuel, whereby half of the company's production was to be sold to Shell for twenty-five cents a barrel for twenty years. Times, production and prices had changed considerably since the contract had been drawn up. William Mellon began to pursue a strategy that was essentially different to that of Standard Oil and which shaped the oil industry throughout the century. Whereas Standard Oil built upon buying crude oil and controlling its transportation, the Mellon's strategy was to incorporate the production of oil and to integrate all the aspects of the oil industry. This, he concluded, was the only way to break the stranglehold of the "octopus" and become independent. Understanding that the oil produced in the region was badly managed and of

\footnotetext{
${ }^{18}$ See Pratt (1980:819-820) for more details.

19 Ida Minerva Tarbell was America's first great woman journalist and biographer. Ida Tarbell's father, Frank, had been one of the many to be infected by what William C. Mellon, the youngest son of the banking family who had provided the financing for Guffey and Lucas, and who later became the owners of the Gulf Oil Corporation, called a fever, and had sold a prospering business to move nearer to Titusville to take advantage of the oil boom. Frank Tarbell was a victim of this fever. Yergin (2008:72) quotes Mellon's recollection of the oil business which "[f]or a great many ... was more like an epic card game, in which the excitement was worth more the great stacks of chips ..." and Ida had spent her adolescence near Titusville where she had seen her father struggle against the success and advance of Standard Oil. (See Yergin, 2008 for more details).
} 
poor quality, suitable only for gasoline, the Mellons looked to oil from different fields, and when better-quality oil was discovered at Glenn Pool, Oklahoma, moved in quickly and won the race against Standard Oil to build a pipeline to transport the oil from the field to Port Arthur. The Gulf Oil Corporation had become a major actor in the oil industry.

The second company to "be born out of the maelstrom at Spindletop," (Yergin, 2008:77) was Texaco, the work of Joseph "Buckskin Joe" Cullinan, a former Standard Oil pipeline man who had immediately understood the possibilities offered by Spindletop. Cullinan and Gulf Oil tried to merge but were stopped by Texan legislature which feared that it would result in a new oil trust. Texaco, like Gulf Oil, understood the benefits of vertical integration and although it benefited considerably from the political constraints upon Standard, lobbied hard for new laws that would make it possible to vertically integrate operations in a single company. They were of the opinion that neither politicians, elected for periods of only two years and whose time horizon was necessarily short term, nor the government, understood or could be expected to understand the industry, and showed great disdain for "the cheap newspapers and the cheaper politicians, and the still cheaper unions and ignorant public sentiment upon which both the former feed and which both encourage" (quoted in Pratt, 1980: 837). Texaco remained independent, but worked a lot towards filling Standard Oil's needs and drew heavily on their expertise and support (ibid: 824-831). In fact, Joseph S. Cullinan, Texaco's first president, wrote that Standard was "running a kind of incubator" (ibid:825). Cullinan registered the Texaco trademark in 1906 and used a green "T" superimposed upon a red star as the company symbol. It began to manufacture gasoline and at the 1907 Dallas State Fair could exhibit forty different products. By 1913, gasoline was the most important product in the Texaco product range.

Another company that grew from Spindletop was Sun Oil, which by 1904 was a force to be reckoned with in the Gulf Coast oil trade. The Pew family who owned Sun Oil were no newcomers to the hydrocarbon business, and before becoming involved in the Texan oil industry, had been manufacturers of natural gas for a quarter of a century. This gas, which had first been regarded just as a waste product could be used instead of manufactured gas, and by 1883, the Pews were supplying the entire city of Pittsburgh.

Thus, the discovery and development of new oil fields in other parts of the Gulf Coast as well as in the midcontinent, together with the political hostility it experienced in Texas, allowed other actors onto the stage and undermined the position of Standard Oil. On the eve of Spindletop, Standard were responsible for $85 \%$ of crude oil supplies, controlled $80 \%$ of the country's refining capacity and had $85 \%$ of the kerosene market. When the Wright Brothers made their first flight in 1903, their plane was fueled by gasoline manufactured by Standard Oil and its mechanical parts were lubricated by Standard Oil lubricants brought to the Kitty Hawk venue by Standard Oil salesmen. By 1911, Standard Oil's control of the refining process had fallen to between sixty and sixty-five. The death blow was dealt by the United States Supreme Court in the early summer of 1911, when they gave the Trade Alliance six months to dissolve itself.

Theodore Roosevelt had become President of the United States in 1901 and was the embodiment of the progressive movement, embracing reform in every field and at every opportunity. Described as "steamroller in trousers" and "the meteor of the age" (Yergin, 2008:90), Roosevelt, who was awarded the Nobel Peace Prize in 1906 for negotiating peace with the belligerents of the Russian-Japanese war in October 1905, tried unsuccessfully to reform the spelling system and waged war on excessive corporate power. Although his 
feelings about so-called progressive journalists were mixed, ${ }^{20}$ he adopted their agenda and Standard Oil became "the favorite dragon of this irrepressible knight" (Yergin: 2008:90). In 1904 he instigated investigations into the Alliance and the petroleum industry. Finally, after hearing 444 witnesses, examining 1,371 exhibits and 14,495 pages of records and two appeals, Chief Justice White introduced a new principle of "restraint" and declared that the intent of Standard Oil had been to exclude others in order to "accomplish the mastery that was the end in view" (ibid: 93).

Standard Oil was divided in a number of separate entities: Standard Oil of New Jersey, by far the largest and the company that eventually became Exxon; Standard Oil of New York, which became Mobil; Standard Oil (California) which eventually became Chevron; Standard Oil of Ohio, which became first Sohio and then the American arm of BP; Standard Oil of Indiana, which became Amoco; Continental Oil, which became Conoco; and Atlantic, which eventually became part of Sun.

However, it was not only on the home front that Standard Oil had problems, but it had also been losing ground in Europe and the rest of the world.

The situation in Europe was quite different to the one in the United States. Europe had no oil fields of its own and was dependent upon importing oil from other sources. Standard Oil had set up a number of affiliations of which the chief were Anglo-American in the UK, the American Petroleum Company in Holland, Belgium and the west of Germany, Danske Petroleums-Aktieselskab which comprised Denmark, Sweden, Greenland, Iceland and the Faroes, Società Italo-Americana with Italy, Sicily, Malta and parts of North Africa and Deutsch-Amerikanische in Germany where consumption was growing rapidly. However, the European market was more demanding than the American and wanted "the sweetest product possible" (Hidy \& Hidy, 1955:503). Standard Oil had been unsuccessful in France where refiners relied on other sources and where the Rothschilds and Desmarais frères were investing in refineries in Galicia and Rumania, and had not managed to obtain concessions in the Dutch East Indies, where Royal Dutch blocked their every move.

Royal Dutch was the result of a fortuitous storm in 1880. Aeilko Jans Zijlker, who worked for the East Sumatra Tobacco Company was visiting a plantation when he got caught in a storm with a mandur, a native overseer (Yergin, 2008:57-61). In the darkness that fell, the mandur lit a bright torch and explained that it had been dipped in the mineral wax-like substance that rose to the surface of small ponds in the area. Zijlker had the substance analysed and discovered that it yielded about 60 percent kerosene. By 1885, the first well had been drilled in the difficult terrain, and to gain sponsorship, Zijlker called his company Royal Dutch. It was launched in 1890. Zijlker died before he could enjoy the fruits of his enterprise which was taken over by Jean Baptiste August Kessler, who found that the working conditions there were terrible and that the organisation was deficient. However, on February 28 1892, oil poured into the first sill of the refinery, the Dutch flag was raised and Royal Dutch was in business and began to grow rapidly.

Relations between Kessler and the Samuels were friendly but they could not come to a business agreement. However, in December 1900, Kessler died of a heart attack and Henri Wilhelm August Deterding, a banker by profession, was sent out as an interim replacement. The competition between Royal Dutch and Shell had become potentially ruinous and the need

\footnotetext{
${ }^{20}$ The term "muckraker" to refer to such journalists whose attacks on politicians and corporations he feared would lead to revolution is attributed to Roosevelt.
} 
for some sort of amalgamation had become acute. Marcus Samuel had been concentrating less on his business and more on his social position and in 1902, "Sir Marcus"21 became Lord Mayor of London. Shell, however, was failing. In 1901, Standard Oil put in an enormous and very tempting bid the company, but finally, Shell and Royal Dutch reached an agreement to join forces against Standard Oil by first in 1903 building a joint sales organisation, the Asiatic Petroleum Company and eventually, in 1907, the Royal Dutch/Shell Company merged as two separate holding companies with Royal Dutch taking $60 \%$ of the earnings and Shell Transport taking 40\%. The Shell logo, which had been changed in 1904 from a mussel to a scallop, became the symbol of the group. ${ }^{22}$

In the early years of the century, Shell had been facing a number of problems. One of these was the reduced supply of crude from Spindletop. In fact, Captain Lucas, seeing the devastation at Spindletop on a visit some three years after he had discovered oil there, was forced to comment "The cow was milked too hard ... (and) Moreover, she was not milked intelligently" (Yergin, 2008:75).

A second problem was Samuel's repeated failure to manage to involve the government in his oil company. In 1902, for example, Samuel had offered in vain to give the government a controlling voice in the Shell Transport and Trading Company (Gareth Jones, 1977:647). Unlike the situation in the United States where the oil companies had domestic resources, British and European companies had to find their supplies abroad. However, while the American politicians sought to gain insight into the companies and to exert control, the British government pursued a laissez-faire policy. Potentially, the British Government, and especially the British navy, was a huge consumer of oil fuel and Shell, and particularly Anglo-Persian, another company now on the market, were keen to get diplomatic support and military protection for their operations.

A third problem was the growing unrest in Russia and its impact on Baku, Shell's main source of supply which had become the "revolutionary hotbed of the Caspian" (Yergin, 2008:115). In the autumn of 1905, oil wells and derricks were in flames in the region and heavy smoke "hung over the inferno" (ibid). Then, an earthquake shook the whole region. The flow of oil was interrupted and the world began to understand just how dependent it had become upon oil. Standard Oil took advantage of the situation and regained markets that had been lost to Russian oil where two-thirds of the wells had been destroyed. The oil workers of Baku elected Bolshevik deputies to the Duma and although the revolution was over, strikes swept through the region, in part the work of Stalin, who was sent there in 1907 to direct, organise and in his words, foment "unlimited distrust of the oil industrialists" (ibid).

\section{In the Nation's Interest}

It was in fact the Anglo-Persian Company, later to become BP, that finally succeeded in drawing the British government into the oil industry. Oil seepages had been known not only in Azerbaijan but also in Persia, and Baron Julius de Reuter had twice obtained concessions there. Both occasions, 1872 and 1889, had led to protests in Persia and opposition in Russia. However, in 1890, the work of a French geologist in Persia came to the notice of Antoine Kitabgi, who then, in the words of Sir Arthur Harding, the British minister to Persia, had "secured in a very thorough manner the support of all the Shah's principal Ministers and

\footnotetext{
${ }^{21}$ Marcus Samuel was knighted for his services to the business community in 1898 .

${ }^{22}$ Taken from http://www.shell.com/home/content/aboutshell/who we are/our history/the beginning (17-112011)
} 
courtiers, not even forgetting the personal servant who brings His Majesty his pipe and morning coffee" (Yergin, 2008:119). In 1901, Kitabgi, who held several positions in the Persian government was interested in finding a means to supply the government coffers with a desperately needed cash flow, and approached the extremely wealthy self-made speculator, William Knox D'Arcy to offer him the opportunity of investing in the Persian oil industry.

Persia had become one of "the pieces on a chessboard upon which is being played out a game for the domination of the world" 23 and one of the great issues in the rivalry between Russia and Britain, who saw Russian expansion as a direct threat to India. The British government saw the advantages of a British oil concession in Persia and lent D'Arcy their support. After infected negotiations in which the Russians tried to block the venture, D'Arcy was given his concession for a period of sixty years and for an area which covered some seventy-five percent of the country ${ }^{24}$. The task before him, however, politically, geographically, geologically, logistically and technically, was daunting, and even D'Arcy's purse had a bottom. ${ }^{25}$ He was forced to look for other investors, including the Rothschilds, and in 1904, applied to the British government for a loan. The Treasury rejected his application.

The Foreign Office, however, were better aware of the nation's interests and were keen to ensure that Britain maintained its concessions in Persia and not allow them to fall into the hands of the French. For the navy too, the idea of any other power establishing a naval base in the Persian Gulf was one which they would resist with all the means at their disposal. The Admiralty not only feared that the Persian concession could fall into Russian hands, but had also begun to use oil to propel smaller ships and was keen to secure sources of fuel oil. It was the Admiralty that found the solution to D'Arcy's acute economic problem. Their Fuel Committee charged Boverton Redwood, a respected oil consultant, with the task of acting as intermediary between D'Arcy and Burmah Oil, a Scottish company that had been providing them with fuel oil, in forming what they termed "a syndicate of patriots" (ibid:125) to ensure that the Persian concession "should remain in British hands and especially from the point of view of supplies for the navy of the future" (ibid). George Reynolds was put in charge of the operations $^{26}$.

The war with Japan and the Revolution had both weakened Russia, and in the Anglo-Russian Convention of 1907, Britain and Russia agreed to the partitioning of Persia. Russia would get the northern part of the country and Britain the southeast. The middle of the country, which happened to be the site of the new drilling operations, was to be a neutral zone. This partition of the country fired Persian opposition to foreigners and to foreign intervention.

\footnotetext{
${ }^{23}$ Lord Curzon, Viceroy of India, quoted in Yergin, (2008:120).

${ }^{24}$ Extract from a letter dated $6^{\text {th }}$ March, 1922 to the U.S. investment bank, Messrs. J.P.Morgan \&Company. “ The Anglo-Persian Oil Company was formed in 1909, with the object of working the concession obtained from the PersianGovernment in 1901 by Mr. William Knox D' Arcy. The Anglo-Persian Company's activities cover all phases of the petroleum enterprise including producing, refining, marketing and transporting.

On $28^{\text {th }}$ May 1901 Mr. D' Arcy obtained from the Persian Government a concession which runs for a period of 60 years. This concession has the exclusive rights to drill for, produce, pipe and carry away oil and petroleum products throughout the Persian Empire, except in the five provinces Azerbaijan, Gilan, Mazandaran, Astrabad, and Khorassan.” (The B.P. Archives, Warwick University.)

${ }^{25}$ For more detailed information see for example Yergin, (2008: 119-133)

${ }^{26}$ The actual work of the oil syndicate was complicated by the political conditions as well as by local opposition. At D'Arcy's request, and because the Foreign Office understood the “importance attached by His Majesty's Government to the maintenance of British enterprise in South West Persia" a guard force comprising two British officers and twenty Indian cavalry was sent to protect the Concession Syndicate. (Yergin, 2008:129)
} 
However, oil had still not been discovered in any large amounts and in May 1908, Burmah sent a letter to Reynolds instructing him to abandon operations if oil had not been discovered in the two wells he was drilling at Masjid-i-Suleiman, "the last throw of the concessional dice" (Yergin, 2008:130) at a depth of sixteen hundred feet. Luckily, the mail service was slow, because in the early hours of the morning of May 26, at a depth of 1180 feet, (Ronald Ferrier, 1982:88) oil was struck and a gusher of petroleum rose some fifty feet above the ground. ${ }^{27}$ The first message to reach Scotland was a coded telegram sent by Lieutenant Wilson, part of the guard force (ibid) ${ }^{28}$ On April 19, 1909, the newly incorporated AngloPersian Oil Company, APOC, went public and Britain and the Royal Navy had a new potential source of oil and D'Arcy came out of the new situation rather badly. It was agreed by all involved that a new corporate structure was needed and in the ensuing negotiations, D'Arcy lost all control in the enterprise that he had started and funded. He was an entrepreneur, not a manager or an oil man, and the Company was in desperate need of firm management and leadership. Kitabgi thanked him for all that he had done, and received in return, 11,900 Burmah Oil shares taken from D'Arcy's allocation of 170,000 for his part in the affair (Ferrier, 1982:103). Although in part relieved that his worries were over, D'Arcy himself is reported to have said that he felt as if he was signing away a child. The man put in charge of the new organisation and who replaced the "faint-hearted merchants masquerading in top hats as pioneers of Empire" (ibid:91) was Charles Greenway, who was to become "the architect of the Company's early development" Bamberg, 1994:4).

The Royal Navy, under Admiral John Fisher, was one of the forces that led the development of the oil industry. To Marcus Samuel, Fisher was "the God-father of oil" (Yergin, 2008:135) and it was thanks to Fisher that D'Arcy had received some assistance from the British government. Fisher was certain that in the on-going battle with Germany over the size and technical superiority of their respective fleets ${ }^{29}$, the key to success lay in oil. Samuel had persuaded Fisher to test oil propulsion on one of the nation's battleships and in the summer of 1903, HMS Hannibal had steamed out of Portsmouth leaving a trail of white smoke from the Welsh coal on which it was running. Moments later, on a given signal, it converted to fuel oil and was completely enveloped in a heavy black cloud (ibid:134). The disaster had been caused by a faulty burner and Fisher retired to the Marienbad spa in Bohemia to recover from his disappointment. It was there that he made the acquaintance of D'Arcy whose cause he promoted at the Admiralty. Fisher also insisted on modernising the navy, despite bitter protests from the public who wanted to invest in welfare rather than warfare.

The second champion of the oil companies was Winston Churchill (ibid:137- 148) In the first years in Parliament, Churchill had supported the "economists" in the guns-or-butter debate with the "navalists", but when the German gunboat Panther sailed into Agadir in July 1911, he concluded that Germany was indeed on the offensive and intended to challenge Britain's supremacy. At the end of September, Asquith, the Prime Minister at the time, offered Churchill the position of First Lord of the Admiralty, the highest civilian post in the Royal $\mathrm{Navy}^{30}$. Churchill and Fisher then worked to modernise the fleet under the assumption that

\footnotetext{
${ }^{27}$ History really seemed to have repeated itself as fifty years earlier, Colonel Drake had received the instructions to stop drilling just as he struck oil.

${ }^{28}$ The message read; "See Psalm 104 verse 15 third sentence and Psalm 114 verse 8 second sentence "That he may bring out of the earth oil to make cheerful countenance" and "the flint stone into a springing well".

${ }^{29}$ Fisher was convinced that Germany, and only Germany, was Britain's future enemy (Yergin, 2008:136)

${ }^{30}$ Churchill's view was that the "whole fortunes of our race and Empire, the whole treasure accumulated during so many centuries of sacrifice and achievement, would perish and be swept utterly away if our naval supremacy were to be impaired" (Yergin, 2008: 138) ]
} 
petroleum would prove an essential element in this development. ${ }^{31}$ Marcus Samuel was consulted to help Fisher make Churchill understand the importance of oil. Among its other advantages, oil propulsion would give battleships up to four knots more speed, the "first of all necessities" in sea fighting (Fisher, quoted in Yergin, 2008:139). In 1912, Britain committed to oil and began to refurbish her battleships, and sufficient supplies had to be secured. ${ }^{32}$

Churchill asked Fisher to head the Royal Commission on Fuel and Engines, and to ensure that he could not be accused of any conflict of interests, Fisher sold his shares in Shell.

Greenway was quick to realise that the Admiralty was offering a unique business opportunity whereby the Company could become a prominent and indispensable element in national policy. ${ }^{33}$ One advantage of a contract to supply oil to the Admiralty was that delivering a single product in bulk to one customer obviated the need for little affordable distribution and marketing installations (J. H. Bamberg, 1994:5). During negotiations, Greenway had three main leitmotifs (Ferrier, 1982:167), namely, the importance for the Admiralty of the new concessions in Mesopotamia, the growing significance of reliable fuel oil supplies for naval purposes and the danger of foreign domination over oil supplies, "which might not only threaten the existence of the Company but might well imperil British naval supremacy in time of war" (ibid). Greenway's objective was to make Anglo-Persian a major force in the oil industry and he launched an attack against the "Shell menace", suggesting that it was a monopoly, was in the hands of foreigners (the Dutchman Deterding and Marcus Samuel, a Dutch Jew), and that in case of war, the Dutch would be heavily pressured by Germany. Although APOC had a marketing agreement with Asiatic, the trading arm of Royal Dutch/Shell to mitigate potential competitive threats and challenges from the United States, Greenway's analysis was that the nation needed a truly British company, APOC (G. Gareth Jones, 1977$)^{34}$.

The First World War changed the attitude of the British government to the oil companies and to the idea of laissez-faire, ${ }^{35}$ and as a result of a "Veto Force Majeure ....agreement of $20^{\text {th }}$ May 1914 between the Treasury and the Admiralty and APOC, the Government acquired a controlling interest in the Company, as well as a contract for the fuel supply to the

\footnotetext{
${ }^{31}$ A cargo steamer could reduce fuel consumption by $78 \%$ and free $30 \%$ cargo space by adopting internal combustion. In addition, there was no need for stokers and fewer engineers were necessary thus releasing space for fighting men. (Yergin, 2008:139)

${ }^{32}$ In a statement to Parliament on July $17^{\text {th }} 1913$, Churchill warned: "If we cannot get oil, we cannot get corn, we cannot get cotton and we cannot get a thousand and one commodities necessary for the preservation of the economic energies of Great Britain." He went on to warn against the risks of the open market and to suggest that the Admiralty became involved in the oil industry as it was there that "safety and certainty" lay. Independency and variety were crucial to this. (ibid:144)

${ }^{33}$ One of Greenway's reasons was that prior to the general introduction of "cracking" in the 1920s, the composition ratio of the oil drilled was stable and the Persian oil was best for fuel oil. (Ferrier,1982). Although the first patent was taken out in 1891, by a Russian, Shukhov, and later developed and patented in 1908 by Burton, in the USA and taken on by Rockefeller, it was not until the1920 that it became common in Europe.

${ }^{34}$ The following notice that appeared in newspapers August 121914 illustrates this insistence that APOC was a British company working for the good of the nation.

"Shell" Motor Spirit Important Notice

Arrangements have been completed for reserving adequate supplies of "Shell" Spirit for national purposes, the British Petroleum Co. Ltd., are now in a position to supply not only "Shell ii." and "Crown", but also "Shell" Spirit to the motoring public whenever and wherever it may be required. As a matter of course, we have made

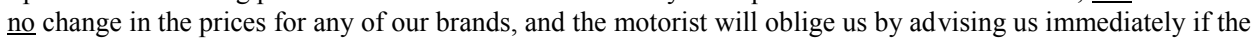
prices charged are in excess of the normal. It is imperative that cans should be returned immediately they are empty. British Petroleum, 22, Fenchurch Street, London, E.C.

${ }^{35}$ See Gareth Jones, 1977 for further details and an analysis of the political attitudes of the time.
} 
Admiralty." 36 Two months later, July $17^{\text {th }} 1914$, exactly one year after he had warned Parliament of the dangers of oil dependency, and despite the protests from Samuel Samuel, who was now an MP, Churchill introduced a historic measure; a bill which would allow the Government to purchase a controlling share in Anglo-Persian and which would allow them the right of veto in affairs of national but not commercial interest and which would put two ex officio directors on the company's board. This step was justified by Churchill as an attempt to maintain and promote competition in the oil industry and a means of averting the alleged dangers of the Shell "octopus" (Gareth Jones, 1977:653). To this end, APOC also received a very favourable twenty-year fuel-oil contract (Yergin, 2008:145) ${ }^{37}$.

Admiral Fisher was not completely happy with this new arrangement as Royal Dutch/Shell had a much better record than Anglo-Persian and as he considered Deterding to be "Napoleon and Cromwell rolled into one" (ibid:147). He strongly encouraged Churchill to placate Deterding and finally, Anglo-Persian did not become the sole suppliers to the Admiralty.

As the war progressed, the need for petroleum products became increasingly evident and the battlefield was "dominated by the use of energy" (Jensen, 1968:538) "[I]t was not manpower but the power of the fuel-consuming engines which was the decisive weapon of war"(ibid: 554) and it was the western allies who, in the words of Lord Curzon, the Viceroy of India, were eventually to "float to victory on a sea of oil". The navy consumed vast amounts of oil fuel and lubricants, the increased mechanisation of the armed forces required fuel and lubrication, aviation fuel was needed, and trench warfare and explosives like T.N.T were also dependent on oil derivatives. In addition, the fact that huge numbers of men were engaged in the war meant that agriculture and factories became increasingly mechanised; a development which also required oil. Until 1916, the British government relied solely on the "patriotism" of the oil companies, but eventually, rationing became unavoidable (Gareth Jones, 1977:654658). Oil supplies had to be safely and efficiently transported from the Middle and Far East and as German submarines were constantly attacking and destroying both British and French tankers, the situation became so acute that the British and the French Governments had to go to the United States for help.

The First World War showed clearly that a secure, sufficient source of oil was a matter of national interest and of the nation's security. The importance of oil was stressed by Tariq Shafiq, one of Iraq's oil pioneers, in a 2009 interview when he claimed that "[ $t$ ]he First World War was not about oil. But ... the loot from the war ... was Middle East oil concessions" (Greg Muttitt 2011:6)

More and more oil was being used in Europe and in the United States in particular, where Henry Ford had introduced the moving production line in 1913 and car ownership had become relatively common, so the price of gasoline affected the lives of large numbers of people. In 1916, Deterding had predicted that the world had entered "a century of travel" (Yergin, 2008:191). Car ownership in the United States was 3.4 million, a figure that rose rapidly in peace time to 23.1 million registered vehicles. From an average of 4,500 miles per car per year in 1919, the corresponding figure for 1929 was 7,500. Moreover, 78 per cent of the world's motor cars were to be found in the States, the leaders of the gasoline age (ibid). The way of life, as well as the countryside where drive-in gasoline stations were mushrooming, was changing rapidly and as the competition for customers increased, so did

\footnotetext{
${ }^{36}$ Taken from the Records of the BP Archive, Warwick University, England.

${ }^{37}$ One of Churchill's arguments was the fear of monopoly and the power of the "two gigantic corporations" Standard and Royal Dutch/Shell.
} 
"the signs and symbols of the new age" (Yergin 2008:193) as the different companies were forced to develop trademarks to assure brand identification. Road maps, first introduced by Gulf in 1914, became increasingly popular and led in turn, to increased motoring and consequently, increased oil consumption.

Although the United States had its own supplies of oil, the fear that these might run out were still real. The Teapot Dome Scandal of 1924 illustrated this only too clearly. American consumption had increased by 90 per cent between the years 1911 and 1918 and the wartime introduction of "Gasolineless Sundays" had made the fear tangible in a country rapidly falling in love with the automobile. Moreover, it was considered important to maintain a supply of oil for the American Navy, which like the British, had been converted from coal to oil. Potential sources of domestic oil were being investigated, including shale in the mountains of Colorada, Utah and Nevada, and the country swung between despair and hope. ${ }^{38}$ The Republican President, Warren G. Harding proclaimed the "harmony of relationship between conservation and development" (cited in Yergin, 2008:195) but chose Senator Albert B. Fall as Secretary of the Interior, which placed him firmly with the "exploitation gang" (ibid). The Teapot Dome scandal revolved around the leasing of two naval oil reserves, Teapot Dome in Wyoming and Elks Hill in California. It was discovered that in 1923, Fall had illegally assumed control over these two sites and had secretly granted them to two powerful oilmen who had paid him a considerable sum of money for the leases (Leonard Bates, 1955:304). The outcome of this discovery had important consequences for the elections of 1924 and for public opinion about "gasoline plutocrats" (ibid: 313) and "oil millionaires corrupting the system" (ibid:310).

In Europe, the situation was somewhat different. Anglo-Persian was facing problems with growing unrest in Persia, and because of its government ownership it was assumed by some countries that the Company's every action was government inspired and as a result, government-owned companies were banned. Problems in Persia and with Turkey as well as oil finds in Venezuela, Bahrain and Kuwait and Saudi Arabia contributed to the chaos on the oil markets and the wild fluctuations in both price and supply. In response to the situation, the French created a completely French company, the Compagnie Française des Pétroles, CFP, to "curtail the Anglo-Saxon oil trusts" and be the "industrial arm of government action" (Yergin, 2008: 174), while in Britain, the plan was to bring the $60 / 40$ arrangement of Royal Dutch/Shell under British, rather than Dutch control. Deterding was willing to amalgamate, as his view was that the way in which the industry was functioning resulted in waste and duplication. In a letter to the president of Standard Oil, he claimed that "[ $t$ ]he world [was] suffering from over-production, over-refining, over-transporting, and - last but not least over-retailing" (ibid: 175). It was in this spirit that in the late summer of 1928, Deterding orchestrated the Achnacarry, or "As-Is" Agreement, through which the major oil companies decided to collaborate to drive down costs. There had been largely unsuccessful, individual attempts to collaborate earlier, such as the one between the Texas Company and AngloPersian under Greenway's successor, John Cadman (J.H.Bamberg, 1994:117), but the motivation behind "As-Is" was much greater. The ambition of the companies was in part, to contest their extremely negative press image but was also to curtail the "destructive rather than constructive competition" (ibid:109) in which they were engaged, with its resulting waste and unnecessarily high operating costs. This state of affairs had resulted in the industry not having "earned a return on its investment sufficient to enable it to continue to carry in the future the burden and responsibilities placed upon it in the public's interest" (Bamberg, 1994:

\footnotetext{
${ }^{38}$ In1919, The National Geographic wrote that "no man who owns a motor-car will fail to rejoice ... The horseless vehicle's threatened dethronement has definitely been averted" (Yergin, 2008: 178).
} 
529). Their belief in the future was strong, as was their faith that improved methods and technologies would contribute to reducing consumption. Among other things, the companies agreed on a percentage share of the market based on their 1928 positions, to establish a uniform selling price, and in addition to supply markets from the nearest source. In this way, they could avoid price wars. The domestic U.S. market was excluded in order to avoid violating the antitrust laws in place there ${ }^{39}$.

\section{The Cast of Players Grows}

It was not only in the United States that motoring had increased after 1918, and in combination with the ever-growing numbers of products made from petroleum derivatives, ranging from textiles to cleaning agents and cosmetics, the oil industry had become increasingly central to everyday life in the interim period between the two world wars. The instability of supply had led the Americans to fear an oil shortage and they were keen to be a part of the search for new sources. They invoked an "Open Door" principle in the quest for new sources, particularly in the Middle East and in Mesopotamia, which was under the British and the French. ${ }^{40}$ This accord between the British and the French was particularly disliked by the Americans who feared that such an alliance would exclude them from markets and production around the world. Indeed, John Cadman was forced to defend the British Government at a dinner given by the National Petroleum War Service Committee in New York and strongly deny that it was in the oil business or was "trying to secure a monopoly of the petroleum resources of the world" 41 .

Competition to secure oil supplies became tougher and prospecting in Africa increased. Oil had been discovered in the mountain area of Jesel Tselfat, Morocco, in 1914, ${ }^{42}$ and some years later, also in Mazaria, where the French were also active in searching for independence from the "grocer" that supplied a commodity that Clemenceau had referred to as "the blood of the earth" 43 . The search for oil extended to Egypt where an Amalgamation between the Anglo-Persian Oil Co. and the Asiatic Co. Egypt as well as East Africa, took place in great confidentiality and a "fraternal spirit" in March1928. ${ }^{44}$ As Gareth Jones (1977: 658) has pointed out, World War 1 led to a "castration complex" among government policy makers who became haunted by the fear that oil supplies would be cut off. The situation in Mesopotamia, or Iraq as it was called from 1920, was very unstable due to political unrest and the oil concession was under threat. One way that the British Government tried to cope with this untenable situation was to amalgamate the oil companies and to increase their control over them. The philosophy behind this was that competition was good and that it was

\footnotetext{
${ }^{39}$ For further details of the agreement and its implications, see for example Bamberg (1994: 528-534) and Yergin (2008: 243-252).

${ }^{40}$ According to an agreement reached at the San Remo Conference in April 1920 to decide the future of the defeated territories of the Ottoman Empire, France was given a 25\% share in the Mesopotamian oil fields and favourable transport terms in return for stipulating Mosul in the British mandate of the area. (Encyclopaedia Britannica)

41 "Denies that Britain seeks oil control: Sir John Cadman Says Empire Does Not Direct Anglo-Persian and Royal Dutch" in New York Times, January 8 1922. ,

${ }^{42}$ The way in which the sample was taken was described as follows: "The oil trickles out from a declivity mixed with water. Sample got by the following method: A quantity of the mixed liquid was absorbed by means of a cloth; and the cloth was squeezed into a large jar. The liquid was then allowed to settle $\&$ the water sunk to the bottom. The sample bottle was then filled from the upper contents of the jar." From the private notes to Mr. Wellesley of the Foreign Office, in May 1922 in the BP Archives, Warwick University.

${ }^{43}$ Cited in Yergin, (2008:507)

44 The BP Archives, Warwick University. Strictly confidential memo of $14^{\text {th }}$ March 1928 to J. Jameson, Esq.
} 
necessary to counteract and balance Shell's power in Africa. At the same time, Britain's relationship with the United States was sensitive and it was considered unadvisable to antagonise them. ${ }^{45}$ It was finally Shell, supported by Calouste Gulbenkian, the Armenian millionaire behind the Turkish Petroleum Company and known by some as the "Talleyrand of oil diplomacy", who persuaded the British government that it would be better to have the Americans "inside" rather than "outside" as competitors and challengers of the Mesopotamian concession (Yergin, 2008:180). In 1925, a group of geologists representing the British and the American companies arrived in Iraq and on October $15^{\text {th }} 1927$, oil was found in vast quantities at Baba Gurgur, Kirkuk, in what was primarily a Kurdish region of the country ${ }^{46}$. The full political implications of this can be understood from the memo sent by the High Commissioner of Iraq warning against the withdrawal of British troops from the country (Muttitt: 2011:7) ${ }^{47}$ On the last day of July, 1928, a contract was finally signed giving Royal Dutch/Shell, Anglo-Persian, the French and the Near Eastern Development Company, specially created to serve American interests, 23.75 percent of the oil each. Gulbenkian was to receive the remaining 5 percent (Yergin, 2008: 187-188). ${ }^{48}$ The contract included a "selfdenying clause" by which the participants agree to work jointly in the region. At one of the last meetings, Gulbenkian took a large map of the Middle East and drew a thick red line along what had been the boundaries of the Turkish Empire. ${ }^{49}$

Thanks are due to the determination of a New Zealand farm boy, Frank Holmes, for the next major development of Middle Eastern oil. Holmes was convinced that there was oil in Bahrain where he had heard of seepages. Ironically, the Sheik was not interested in oil but wanted water, and Holmes agreed to drill for this and in return, receive an oil concession.

\footnotetext{
${ }^{45}$ The philosophy of the British Government is illustrated by the following taken from the BP Archives at Warwick University. Secret document from the Committee of Imperial Defence. Feb $16^{\text {th }} 1928$. Present in Chair, Stanley Baldwin (PM), Churchill. Shell interests in Africa. Amalgamation could not affect or jeopardise Admiralty supplies of naval oil fuel.

The possibility might be dismissed that through the arrangement the Anglo-Persian Oil Company might become a subordinate partner to the Shell Company in a big combine, or in some way lose their independent status. So far from being the case, the arrangement gave the Anglo-Persian an equal position with the Shell in the markets in question, and this precedent might be valuable in other areas. Thirdly, as regards the suggestion that American susceptibility might be aroused by the proposed agreement, it must be remembered that whether with or without the agreement the Anglo-Persian Oil Company were bound to seek fresh markets for their oil in these territories and would consequently in any case be competing with Standard Oil interests. No British Government could, in order to conciliate American opinion, prohibit a British Oil Company from trading in British Colonies, and of course the Standard Oil had themselves taken an aggressive policy in the past, and could hardly object to the competition by the British companies whether separately or in combination. (Sir George Barston)

${ }^{46}$ For thousands of years holes in the ground there had been venting natural gas which was always alight. These holes were thought to be the "burning fiery furnace" into which Nebuchadnezzar had thrown the Jews. This was also the place where Plutarch described how the inhabitants had set the street on fire to impress Alexander the Great (Yergin, 2008:187-188).

${ }^{47}$ The High Commissioner, Sir Henry Dobbs wrote that "the discoveries of immense quantities of oil .... make it now impossible to abandon control of Iraq without damaging important British and foreign interests"

(Muttitt,2011:7)

${ }^{48}$ This was the greatest find yet. When the drill bit had just passed 1,500 feet, "a great roar was heard, reverberating across the desert. It was followed by a powerful gusher that reached fifty feet above the derrick, carrying in it rocks from the bottom of the hole. The countryside was drenched with oil, the hollows filled with poisonous gas. Whole villages in the area were threatened, and the town of Kirkuk itself was in danger. Some seven hundred tribesmen were quickly recruited to build dikes and walls to try to contain the flood of oil. Finally, after eight and a half days, the well was brought under control. It had flowed, until capped, at ninety-five thousand barrels per day" (Yergin 2008:188).

${ }^{49}$ With the exception of those in Persia and Kuwait, all the major oil-producing fields in the Middle East were within this boundary. This so-called "Red Line Agreement" set the framework for future development in the Middle East and was also the focus of many decades of bitter conflict (Yergin, 2008).
} 
Geological reports on the area were not promising but eventually, Holmes succeeded in interesting Gulf Oil in Bahrain. However, Gulf Oil were part of the Red Line Agreement and thereby precluded from operating individually in the area of Bahrain and Saudi Arabia, although they could participate in exploration in Kuwait. Standard of California, Socol, were not bound by the Agreement and took up Gulf's interests. However, the British government strongly opposed their entry. ${ }^{50}$ After a great deal of diplomatic discussions, Britain agreed to a deal with Socol and in 1932, the Bahrain Petroleum Company hit modest amounts of oil.

The neighbouring kingdom of Saudi Arabia was rapidly running out of money, and when during an automobile ride in the desert, King Ibn Saud's English companion suggested that perhaps he should look for money under the ground, the idea received a positive reception. ${ }^{51}$ In Kuwait too, interest in oil was increasing, and the Amir, Sheik Ahmad, an enthusiast of the British navy, was courted by both Gulf and Anglo-Persian (Yergin 2008: 276). The Middle East was becoming centre stage for the oil industry and the locus of increased British and American cooperation. ${ }^{52}$

The Depression and the Second World War left economic chaos in their wake. ${ }^{53}$ Shell and BP merged their United Kingdom marketing operations in a joint venture, Shell-Mex and B. P. Ltd., partly in response to the difficulties of the times. The Bretton Woods International Monetary System to help and protect sterling after the Depression was one example of attempts to bolster and protect sterling and the British economy ${ }^{54}$. Interest in securing oil supplies led to national political disputes such as the one in the United States over the ownership of Arabian oil ${ }^{55}$ and more seriously, to international friction and conflict. In the case of Mexico, for example, this concerned the ownership and extraction rights for oil, while in the case of Japan, the dispute about supplies led to the devastating attack on Pearl Harbour. ${ }^{56}$ Indeed, oil played a central role in the Second World War just as it had done in the First some thirty years earlier.

As a result of the War, patterns of European trade were disrupted and the world of international finance was divided into two, with the United States and the dollar, or "hard currencies" in one corner and the "soft currencies" headed by sterling, in the other. Oil was the key to rebuilding Britain, and the discriminating policy which Britain adopted in 1950 to protect "sterling" oil from "dollar" oil led to problems in Anglo-American relations and to

\footnotetext{
${ }^{50}$ The British government had insisted on a "British nationality clause" in any concession agreement to protect "British interests" (Yergin 2008: 266).

${ }^{51}$ The companion was Harry St. John Bridger Philby, an eccentric former member of the Indian Civil Service who had settled as a merchant in Jidda and converted to Islam. He was also the father of the notorious doubleagent, Kim Philby and the man he proposed to investigate the possibilities was Charles Crane (Yergin 2008:26971).

${ }^{52}$ See for example Bamberg (1994:303-307)

${ }^{53}$ In the words of General George Catlett Marshall, on June $5^{\text {th }} 1947$, "the physical loss of life, the visible destruction of cities, factories, mines and railroads was correctly estimated but it has become obvious during recent months that this visible destruction was probably less serious than the dislocation of the entire fabric of European economy. ... Machinery has fallen into disrepair or is entirely obsolete. ... The breakdown of the business structure of Europe during the war was complete. .... The truth of the matter is that Europe's requirements for the next three or four years of foreign food and other essential products - principally from America - are so much greater than her present ability to pay that she must have substantial additional help or face economic, social, and political deterioration of a very grave character." Taken from http://www.oecd.org/document/ 29.11.2011

54 The system was in use from 1932 to 1944 and was intended to protect trade among the Dominions.

${ }^{55}$ For more details, see Yergin (2008:375-384) and Galpern, (2009).

${ }^{56}$ Yergin $2008: 248-310$
} 
protests from the Anglo-Iranian Oil Company, who saw the policy as government interference in their commercial ventures and also led to the U.S. majors lobbying their government. (Stephen Galpern, 2009:23-24). As the supplies needed for the "rehabilitation of Europe"57 had to be obtained from the U.S.A. and paid for in dollars, this exacerbated the problem. ${ }^{58}$ In June 1947, the Marshall Plan, the European Recovery Programme, was presented and initiated to help reconstruct Britain and Europe and combat the growing power of Communism. Oil, which in a multiplicity of forms and derivatives had become increasingly central to the comfort and convenience of individual citizens and to national economic growth, was one of the key commodities in this Programme, both to provide Europe with the energy necessary for recovery and also to fuel the American economy. Dollars were central to its implementation and success, but trading in dollars was generally detrimental to the economies of Europe. One way for the Europeans to save dollars was to expand their refining capacity, as this would allow the participating countries to buy less expensive crude oil (David Painter, 1984: 372). ${ }^{59}$

The end of the Second World War saw the demand for oil and oil-based products exploding, particularly in the United States where rationing was lifted within twenty-four hours of Japan's capitulation. Oil and the control of this resource became even more important in the face of the growing threat of communism and the Cold War, ${ }^{60}$ and although in theory, both the Truman and Eisenhower administrations advocated the stringent enforcement of antitrust laws, the position of the oil companies was ambivalent. The oil industry was considered essential to American interests and was "widely regarded as an essential public unity requiring government support, [and] diplomatic assistance in developing foreign sources of oil" (Burton Kaufman, 1977:38). Antitrust indictments against the five major American companies, Standard Oil of New Jersey, Socony Mobil, Standard Oil of California (Socal), Texaco and Gulf Oil, who, together with their non-American "sisters", Dutch Shell and British Petroleum $^{61}$, were accused of engaging in a world-wide combination to restrain and monopolize commerce in the industry were diminished or dropped between 1952, when the Truman administration began proceedings and 1968, when the Justice Department decided to drop the last charges. The reason given for this was that "the distribution of oil both foreign and domestic is in fact a quasi-public utility business ... and is [sic] by nature of a monopolistic character." ${ }^{62}$ As Frank Church (1977:32) ${ }^{63}$ has pointed out, "[t]he underlying premise of U.S. policy-makers at the time was that the companies could be used as effective instruments to accomplish U.S. foreign policy objectives, and that the interests of the companies were basically identical with the U.S. national interest", and indeed, between 1947 and 1954, U.S. policy-makers could safely assume that this was in fact the case (ibid:41). The oil cartel case had a number of implications for the American oil industry and its international

\footnotetext{
${ }^{57}$ General Marshall .http://www.oecd.org/document/ 29.11.2011

${ }^{58}$ The idea behind the system was that it protected trade with the Dominions and in this way, sterling. (see Galpern, (2009).

${ }^{59}$ For more details about the Marshall Plan, the dollar shortage and its impact on the oil industry, see for example Painter (1984) and Yergin, (2008: 404-407)

${ }^{60}$ The U.S. "vision of a worldwide multilateral trade regime in the face of communist expansion" (Galpern, 2009:26) was threatened by the British protectionist attitude.

${ }^{61}$ The name adopted by Anglo-Iranian in 1954

${ }^{62}$ Robert Nitschke, quoted in Kaufman (1977: 38-39)

${ }^{63}$ Due to the uncertainty and confusion reigning at the time about the objectives of U.S. international energy policy and the role of the multinationals in achieving them, Senator Frank Church, who had conducted a fouryear investigation of multinationals, including the history of oil companies and U.S. Policy in the Middle East, and Geoffrey Chandler, a Director of Shell International Petroleum Company, were asked to contribute to Foreign Policy, Summer, 1977. As the editors of the periodical point out(p.26), the analyses and conclusions of the two authors substantially diverge.
} 
business in general. ${ }^{64}$ The perceived threat of the Soviet Union in the third world resulted in an increase in "government-sanctioned cartelization" (Church, 1977: 56) whereby national interest benefitted the oil industry.

\section{Turbulence and Turmoil}

The postwar years saw a great many changes in every aspect of life, many of which were a direct consequence of the continued development of the oil industry. Not only did people travel more extensively, more quickly and more comfortably, but domestic life became simpler thanks to the new materials such as plastics and fibers developed from petrochemicals, houses became less dependent on coal and gas for heating, and as a result of the decrease in the use of coal, cities became cleaner and smog began to disappear. In addition, the use of pesticides developed by the chemists working for the oil companies enabled farmers to increase their yields and played a great part in combatting insect-borne disease. Consumption increased and Western economies flourished, largely thanks to the efforts of the oil industry.

However, it was not merely on the social and domestic level that changes occurred. The construction of Tapline, a pipeline for Saudi oil began in 1947, and Standard of New Jersey and Socony-Vacuum ${ }^{65}$, joined Texaco and Standard of California in the Arabian-American Oil Company, Aramco, that later made a fifty-fifty deal with Saudi Arabia.

In 1951 the already tense situation in Iran became more problematic. The fact that the British government were major shareholders in the Company contributed to the Iranian impression that it was a "state within a state in Iran" (Bamberg,1994: 519) and as the part of the country in which the oilfields were situated had had little in the way of amenities or infrastructure before oil had been discovered, it had been necessary to build townships and utilities under Company auspices. This resulted in an enclave community that was seen by some Iranians as a form of private government. The government support which the founders of the company had struggled to obtain was proving to be a double-edged sword. Mohammed Musaddiq ${ }^{66}$, twice Prime Minister of Iran and elderly firebrand chairman of the oil committee, fearing that proposals made by Anglo-Iranian would enable them to gain even more power and a monopoly on sales of Iranian oil, nationalised Iranian oil, an action that led to the first postwar oil crisis. ${ }^{67}$ Although Anglo-Iranian ${ }^{68}$, with considerable help from its fellow

\footnotetext{
${ }^{64}$ One example of this is the entry of the American majors into an Iranian Consortium. The Chairman of the Texaco board, J.S. Leach wrote "I note that 'the National Security Council has determined that it in the security interests of the United States that United States petroleum companies participate in an international consortium to contract with the Government of Iran'" and insisted that the Attorney General guaranteed that they would not be in violation of any anti-trust laws. The consortium received immunity for their work in connection with Iranian oil. (Kaufman, 1977: 46).

${ }^{65}$ Socony-Vacuum became Mobil soon after.

${ }^{66}$ His name is also written Mossadegh, for example by Yergin (2008) and Muttitt(2011).

${ }^{67}$ In a speech from 1951 he explained that as long years of negotiations had yielded no results, it would be better for the people of Iran to take over production of petroleum. Oil revenues could be used to combat poverty and disease and the elimination of the power of the British company would help to eliminate corruption and intrigue.

${ }^{68}$ In December 1954, the company changed its name to British Petroleum and put up at new plaque at the entrance to its headquarters, Britannic House, in London. On trial for treason by the Shah's military court in 1953, he said: "Yes, my sin - my greater sin and even my greatest sin is that I nationalized Iran's oil industry and discarded the system of political and economic exploitation by the world's greatest empire." Mussadiq claimed that his fate would serve as an example of the consequences of trying to break "the chains of slavery and colonial interests".
} 
members of the Seven Sisters ${ }^{69}$ and the British and American governments succeeded in discrediting Musaddiq and building a consortium with Iran and the Shah in 1954, this oil crisis had a noticeable effect on the world oil markets and increased the already deep conviction that supplies had to be secured.

Scarcely had the first postwar oil crisis been resolved, when in 1956, the Suez Crisis led to the second and to the enforced resignation of the British Prime Minister Sir Anthony Eden. ${ }^{70}$ Matters were further complicated by the Iraqi revolution in $1958,{ }^{71}$ the year in which Nasser's Aswan dam was finally funded by the USSR. Syria had joined Egypt to form the United Arab Republic, which brought together the two countries that dominated the transit routes for Saudi and Iraqi oil. Oil was central to the rising wave of Arab nationalism, and "the strongest of weapons the Arabs wield" (Abdullah Tariki of Saudi Arabia, cited in Yergin, 2008:491). In an attempt to sharpen this weapon, OPEC, the Organization of Petroleum Exporting Countries was founded in Bagdad in 1960 with representatives of the major exporting nations, Saudi Arabia, Venezuela, Kuwait, Iraq and Iran, who together produced more than 80 per cent of world oil. Qatar participated as an observer. The aim of the organisation was to defend the price of oil and prevent the oil companies from arbitrarily lowering prices or production levels and to shift the balance of power between the producers and the importers. However, they made very little progress in their common economic goal of increasing their share of oil revenues for a number of reasons, the most serious of which was the political rivalries among the member countries. The next severe blow to the oil industry was in 1967, when the Six Day War closed the Suez Canal once again and led to the third postwar oil crisis.

For Britain, in particular, the events of the sixties had far-reaching repercussions on the balance-of-payments and led to the devaluation of the pound sterling in late 1967. Moreover, another consequence of the economic circumstances was that Britain began to withdraw its troops from the Gulf earlier than planned, and actually left the stronghold of Aden, which had become the main base for the British after the loss of the Suez Canal, at gunpoint. ${ }^{72}$ The situation in the area was deteriorating and the British withdrawal displeased the United States

\footnotetext{
${ }^{69}$ The name "Sette Sorelle", Seven Sisters was given by Enrico Mattei of the Italian international petroleum company, ENI, to the four Aramco (Arabian-American Oil Company) partners (Jersey, later known as Exxon, Mobil, Socal, later known as Chevron, and Texaco), together with Gulf, Royal Dutch/Shell and British Petroleum because of their close association and multiple ventures. The French company, CFP was actually an eighth sister but was excluded from the rubric as it was not Anglo-Saxon (Yergin, 2008:485) and possibly because "Otto Sorelle" or "Eight Sisters" would lack the poetic and rhetorical impact.

${ }^{70}$ The Suez Crisis constitutes one of the most controversial events in British postwar history and has come to be regarded as the beginning of the end of the British Empire. It was the result of the decision announced on July $26^{\text {th }}$ by Nasser, the Egyptian President, to nationalize the canal in retaliation to the British and American governments reneging on their agreement to finance the construction of the Aswan Dam. As the Suez Canal had been extremely important for both Britain and France in the transportation of their oil supplies, this presented an economic threat that was difficult to ignore. A number of countries became involved in negotiations including Australia and the USSR but in October, Eden held secret discussions with the French which resulted in the formation of a plan by which Israel, which had declared its independence in 1948, invading Egypt, thus allowing the British and French to seize the Canal as an act of intervention between warring nations. Despite lack of consensus among the Cabinet, British and French troops invaded Port Said on the night of November 5-6 and took control of the waterway. (Matthew Neely October 2006, (matthew.neely@bodleian.ox.ac.uk, January 16, 2012)

${ }^{71}$ On July 14th 1958, now celebrated as the national day, the Free Officers' Movement in the Iraqi Army overthrew the king, Faisal II and installed its leader, Brigadier General Abd al-Qasim, as prime minister. The front page of the New York Times announced that 'Intervention will not be extended to Iraq as long as the revolutionary government in Iraq respects Western oil interests.' (Muttitt, 2011: 10-11).

${ }^{72}$ Two rival factions, the communist, National Liberation Front (NLF) and the Front for the Liberation of South Yemen (FLOSY) began fighting and the British troops were caught in the middle.
} 
who felt that they should not be expected to fill the vacuums left by Britain and France in the area. $^{73}$

However, the situation of the oil industry during this period was not simply one of gloom and doom. As the world became increasing oil-dependent, "the dizzying growth in demand" was matched by "the even more dizzying growth in available supply" (Yergin, 2008: 507). France discovered oil in Gabon in West Africa and in the Algerian Sahara. Although Shell became a partner in the venture, it was very important to the French to secure their "own" supplies and not be dependent on the Anglo-Saxons. In order to strengthen their position, the French merged their state companies to form what became known as Elf-ERAP, or Elf. ${ }^{74}$ An almost twenty year joint venture between Shell and Anglo-Persian hit oil in the delta of the River Niger in 1956, while three years later, the Groningen natural gas field was discovered in 1959 off the Netherlands, ${ }^{75}$ and as exploration moved Northwards, vast quantities of extremely high quality oil were also discovered in the North Sea when in November,1969, in one final, desperate attempt, Phillips rig, Ocean Viking struck oil on the Norwegian side of the median line. In 1968, oil was discovered in Alaska and entered the market some ten years later ${ }^{76}$ and oil from the politically more stable North Sea began to come ashore in the mid-seventies. ${ }^{77}$

The most exciting find at the time was however in Libya, a poor, inhospitable country plagued by droughts and locusts, where Standard Oil of New Jersey made a big strike in April 1959. Libyan oil was not only plentiful but it was also low in sulphur, which increased its attraction for the then increasingly environmentally conscious Western Europe and United States ( Church, 1977: 37) ${ }^{78}$ By 1965, Libya was the world's sixth largest producer and by the end of the decade was out-producing Saudi Arabia.

The discovery of all these "Elephants" ${ }^{, 79}$ was another problem for OPEC, and during the sixties, the market price for oil dropped heavily. ${ }^{80}$

\footnotetext{
${ }^{73}$ See Galpern, (2009) for more details.

${ }^{74}$ The French companies in question were Régie Autonome des Pétroles (RAP) which had discovered oil in Algeria and Bureau de Recherches Pétroliers (BRP) who had found oil in Gabon. Elf later became Elf Aquitaine and eventually, Total.

${ }^{75}$ Test flows began in August 1968 from the Esso-Shell British pipeline on the Leman Bank. Philips, Mobile and $\mathrm{BP}$ also had rigs and after some discussion and objections on the part of Shell, the companies agreed on the price of $2.87 \mathrm{~d}$ a therm. (The Economist, August 3 1968:56) Prices were a central issue in negotiations with the British Government, where for example, Shell/Esso wanted to charge a higher price from gas found farther from the shore. In 1968, Britain consumed 1,100 million cubic feet of gas a day, a figure that was expected to double by $1971 / 72$ and to quadruple by 1975 . Contracts with the oil companies were drawn up such that when demand was lowest, for example during the summer, they would be compensated by a higher unit price. (The Economist, March 9, 1968:57-58).

${ }^{76}$ As oil taxes and royalties were much cheaper than in the other American States, this field was extremely profitable. Moreover, production increased rapidly, rising almost threefold to 180,000 barrels a day, almost the output that had been predicted for 1971. (The Economist, July 27 1968:70)

${ }^{77}$ Phillips, Amoco, Shell and BP all have fields in the North Sea as well as Norwegian companies. Production started in the Argyll field in June 1975. The exploration and exploitation of the North Sea has pushed the edges of technology and many lives have been lost due to the volatile weather conditions. North Sea oil revenues are also one of the issues most often raised by Scottish Nationalists.

${ }^{78}$ See 60

79 "Elephant" is the name given by the industry to a large oil field.

${ }^{80}$ Adjusting for inflation, the price fell by $40 \%$ leading to cutthroat competition. "Oil was available for anybody, anytime, any place and always at a price as low as you were charging for it. ... The market was just falling on its face." Howard Page of Jersey is quoted in Yergin (2008:511).
} 
Despite the massive new finds, all was far from plain sailing for the oil industry. The oil flow out of Nigeria which was at the rate of 25 million tons a year prior to the Biafran War which began in July 1967, dropped and reinvestment in a new pipeline was needed. ${ }^{81}$ Libyan oil, the source of rejoicing soon became a source of problems. In September 1969, a group of young army officers under the leadership of the charismatic Muammar al-Qadaffi and deeply inspired by Nasser brought off a coup. After closing down British and American military bases, expelling Italian citizens and closing and auctioning off all the Catholic churches in the country, Gaddafi turned his attention to the oil industry. He informed the heads of the twentyone oil companies operating in the country that he was prepared to shut down production if they did not succumb to his demands. As Libya was supplying 30 per cent of European oil and the Suez Canal was closed as a result of the Arab-Israeli war ${ }^{82}$, he was in a very strong bargaining position. Gaddafi's argument was that "[p]eople who have lived without oil for five thousand years can live without it again for a few years in order to attain their legitimate rights" (quoted in Yergin, 2008:560). The Libyan revolution inspired other oil producing nations to increase their demands and put pressure on the oil companies. The Shah of Iran managed to break the 50-50 profit-sharing barrier and gained 55 per cent for his country, Venezuela demanded 60 per cent and prices began to rise uncontrollably. The more moderate countries could not restrain Libya and the other more radical producer, Venezuela. Shell was of the opinion that the companies had to present a united front, but Washington's acquiescence to the Shah in 1971destroyed their proposed "Front Uni" 83 .

In 1973, as a result of the Arab embargo ${ }^{84}$ the world faced the fourth postwar oil crisis in which prices rose from $\$ 2.90$ per barrel in September to $\$ 11.65$ at the end of the same year. However, it also had a number of other, far-reaching consequences which stretched far beyond closed filling stations, for both the oil companies worldwide ${ }^{85}$ and for the general

\footnotetext{
${ }^{81}$ Some two thirds of the oil was found in the Biafran region and the east bank and had to flow through the 140mile Trans-Niger oil pipeline to Port Harcourt and Bonny. In response to the civil war and the problems that this casued, the Although Nigerian oil, split 50/50 between Shell and BP amounted to less than 10 per cent of their total output, it was low in sulphur and therefore highly valued at refineries. Further, the Nigerian fields were 7,000 miles closer to northern Europe than those of the Middle East. (The Economist, September 7, 1968) Some two thirds of the oil was found in the Biafran region and the east bank and had to flow through the 140-mile Trans-Niger oil pipeline to Port Harcourt and Bonny. In response to the civil war and the problems that this caused, companies slashed their way through the 50 miles of mangrove swamp to Forcados and the sea, building a pipeline capable of transporting vast quantities of oil to 200,000 ton tankers anchored in deep water. (The Economist, May 25 1967:88)

${ }^{82}$ The canal was choked with the debris of war including sunken ships loaded with live ammunition its slowing sides were suspected to be covered in mines. It had become a giant cesspool. It was finally reopened on June $5^{\text {th }}$ 1975 through the concerted efforts of the Egyptian, American, British and French navies and a number of other groups including a German salvaging company. Arndt http://www.saudiaramcoworld.com/issue/197505/suezthe.reopeneing.htm (January 18 2012)

${ }^{83}$ This referred back to the union the oil companies had formed against the Soviet Union in the 1920s. (Yergin, 2008:563)

${ }^{84}$ The embargo was initiated by Sadat of Egypt in response to what he considered to be American Zionism. He eventually persuaded the reluctant King Faisal of Saudi Arabia to put pressure on the Americans. Nixon's proposal to send an extensive military aid package to Israel did nothing to alleviate the situation and in the words of Kissinger (Yergin, 2008:590) the oil weapon, "of political blackmail" had been brought into battle. For further details about the embargo and the Yom Kippur War, see for example Yergin (2008) and Church (1977:39)

${ }^{85}$ Britain, for example, was on the Arab list of "friendly nations" and was supposed to receive its full supplies. The government also owned half of the shares in BP but were not supposed to interfere in commercial matters. Edward Heath called the chairmen of BP and Shell to insist that they ensured that Britain received preferential treatment and did not suffer any loss of supply. Neither man could agree to the Prime Minister's demands, McFadzean of Shell partly because the company was $60 \%$ Dutch-owned and that the Dutch largely controlled the natural gas supplies, and Drake of BP because he was convinced it would lead to disaster and to nationalisations. The situation was worsened by the coal-miners' strike (Yergin, 2008:605-611).
} 
climate of opinion ${ }^{86}$. In the United States, the Nixon Presidency was in serious difficulties as a result of the Watergate scandal, and this, the embargo, the so-called Saturday Night Massacre $^{87}$ and the October War led people to suspect that Nixon had deliberately started the war to distract attention from his own problems. The oil companies were inculpated through the discovery of a number of illegal contributions to campaigns that had been uncovered, and in the public mind, were suspected of having managered the whole situation to satiate their greed. ${ }^{88}$

Although the embargo ended in 1974 and President Nixon resigned, relief was short-lived. The United States tried to calm the free-for-all of independent barter deals for national supplies by convening an energy conference in Washington. The Japanese, for example, were keen to find a framework in which to mute the "tendency of the U.S. policy to become very confrontational" (Yergin 2008: 612) and the Germans were also eager to discuss multilateral solutions. ${ }^{89}$ That oil, international relations and politics were inalienably intertwined was becoming increasingly evident. By the end of the year, the IEA (International Energy Agency) was established in Paris, although one major industrial country, France, had refused to join..$^{90}$

The OPEC representatives settled in what had earlier been known as the "Texaco Building" in Vienna, were suddenly extremely powerful, as the importance of oil prices to world commerce had become very clear. However, the oil exporters, unused to wealth and power, managed to convert their $1974 \$ 67$ billion surplus into a $\$ 2$ billion deficit by 1978 . The money had been spent on industrialisation and infrastructure in their respective countries, but also on weapons, waste and corruption, and to turn this deficit into a surplus again, they hiked up their prices, leading to a prices shock that was particularly devastating for those countries that did not have their own supplies of oil, and a new concept, the "fourth world" was born. Disagreement between the moderate Saudi position on oil prices and that of some of the other

\footnotetext{
${ }^{86}$ Sir Frank McFadzean, the chairman of Shell Transport and Trading, pointed out to Edward Heath, the Prime Minister, who had summoned him to Chequers along with Sir Eric Drake, the chairman of BP, that the oil companies had been sucked into a vacuum "from the failure of governments to plan on how to handle an oil shortage" (Yergin, 2008:605), a position explained and analysed by Church (1977) who points out that the "power" of the oil companies was derived from the "vacuum left by importing governments" (p.57).

${ }^{87}$ This was the name given to Nixon's executive dismissal of the independent special prosecutor, Archibald Cox and the subsequent resignation of two Attorney Generals October $20^{\text {th }}$.

${ }^{88}$ The oil companies were put in a position in which they were required to make "potentially volatile political decisions during the embargo ... [that were] beyond the realm of normal corporate concerns" (cited in Yergin, 2008:606).

${ }^{89}$ There were problems in general with regard to the relationship of the United States and some of the oil producers, especially Iran. In some interesting correspondence from 1975, BP discusses the problematic nature of balancing their relationship with Iran and interests there with their position in the U.S. In a letter dated $3^{\text {rd }}$ June 1975 for example, Sir Eric Drake at Britannic House writing to Sir Jack Rampton, KCB, Permanent Under-Secretary of State, Department of Energy, suggests that there are risks in allowing Iran, or Germany or the U.S to acquire blocks of BP's total shareholding from the Bank of England and states that the purchaser of such a block should not have the right to representation on the BP Board. He points out the risks to BP's position overseas, and that "an Iranian purchase would present special risks for our position in the U.S. which would need to be carefully weighed against any advantage to our relationship in Iran. However, there would be no objection, and might be advantages in a purchase by German interests. The conclusion was that "[s]ubject to a clear understanding that such acquisition would not carry any right to a seat on the Board or overt commercial advantages, it is the Company's view that the balance of advantage to the Company lies in permitting the Iranian Government with its attendant U.S. risks, or a German company/institution, to acquire up to \% of BP's shares (i.e. a quarter of the Bank of England's shareholding.) (BP Archives, Warwick University)

${ }^{90}$ The French Foreign Minister, Michel Joubert, considered that the IEA was an instrument of war, and indeed, the Americans had hinted that discord on energy issues could jeopardize their security and maintenance of troops in Europe. (Yergin 2008: 611-612).
} 
nations, particularly Iran, was a matter of concern. The Saudis were also very unhappy with the attitude that the United States was displaying to the Shah ${ }^{91}$, who they considered to be a mentally unstable megalomaniac. However, as Yamani, the man who became the symbol of the new age of oil pointed out, "If the Shah departs from the stage, we could also have a violent, anti-American regime in Teheran"(Yergin, 2008: 621).

Political tension in the Middle East was increasing, and in March 1975, one of the nephews of King Faisal of Saudi Arabia shot him in the head during an audience with the Kuwaiti oil minister. In December of the same year, "Carlos" a Venezuelan terrorist of Marxist persuasion led an attack on the OPEC building, killing three people and taking the remaining oil ministers, including Yamani, ${ }^{92}$ and their aides as hostages. Then, in 1977, when the Shah came to visit President Carter at the White House, a battle between pro and anti-Shah demonstrators broke out. The police replied with tear gas and footage of the Shah wiping tears from his eyes in a very undignified manner was shown on Iranian television. The American system which had allowed this to happen compounded antipathy to the United States and helped the Iranian populous to realise that the Shah was only a man.

The next series of violent actions to result from the political instability in the area had a great direct impact on the oil industry. Demonstrations in Iran, hailed by Carter on New Year's Eve 1978 as "an island of stability in one of the more troubled areas of the world" thanks to the great leadership of the Shah (ibid:654), led to strikes by oil workers in 1979. The main producing area was known as "The Fields" and included Anglo-Persian's original wells. It was in the hands of the Oil Service Company of Iran, Osco, the descendant of the consortium that had been established in 1954 after the fall of Musaddiq. However, the rise of Ayatollah Khomeini, led to changes. ${ }^{93}$ Americans in particular were extremely unpopular, and on November $4^{\text {th }}$, more than sixty were taken hostages by young militant Islamists at the embassy in Teheran.

Iraq's declaration of war against Iran in $1980^{94}$ exacerbated the situation for the oil companies, and the panic which ensued sent prices soaring from $\$ 13$ to $\$ 34$ a barrel and led to the fifth postwar crisis. It also resulted in the centrality to the U.S. government of oil from the area becoming an open issue. In the words of Paul Wolfowitz ${ }^{95}$, cited in Muttitt (2011:22) "We and our major industrialized allies have a vital and growing stake in the Persia Gulf region because of our need for Persian Gulf oil and because events in the Persian Gulf affect the Arab-Israeli conflict." The war between Iraq and Iran, which ended in a cease-fire in 1988 , destroyed much of the infrastructure in place to support the oil industry, and recovery was halted by Saddam Hussein's invasion of Kuwait two years later, on August 2 1990, in his miscalculated attempt to secure more oil resources and domination of the world's oil supply.

\footnotetext{
${ }^{91}$ Nixon and Kissinger had established a "blank cheque" policy with the Shah who was free to buy as many American weapon systems as he wanted as long as they were not nuclear. This was part of their "two pillar strategy" for security in the wake of British withdrawal from the Middle East (Yergin 2008:626).

${ }^{92}$ Yamani was considered by the Iranian media to be a devil, a "stooge of capitalist circles, and a traitor", who was acting "in the service of imperialism and Zionism" (Yergin 2008: 623-624).

${ }^{93}$ Evacuation of the twelve hundred expatriate oilmen and their families began. One afternoon, for example, when one of the Osco managers, Exxon's, George Link was waiting in his car for a gate to be opened, someone tossed something into the vehicle. Link instinctively jumped out only to see his car explode seconds later. See Yergin, 2008: 658-666 for more details about the crisis in Iran after Khomeini's rise to power.

${ }^{94}$ According to Muttitt (2011:23) Saddam Hussein started the war in part to prevent the spread of the revolution to Iraq and to annex Khuzestan, the province next to Basra where most of the oil was found.

${ }^{95}$ Wolfowitz became one of the loudest voices in the call for U.S. intervention. See Muttitt (2011:22-23) for more details.
} 
As Wolfowitz argued in Berlin in 2003, the United States and its Allies waged war against Iraq for reasons very similar to those of Saddam Hussein when he invaded Kuwait; it was in reality "a war for oil" and for control over "the planet's most lucrative natural resource deposits". ${ }^{96}$ When coalition forces entered Baghdad, for example, they protected the Oil Ministry and left all other institutions unguarded. Saddam's threat to destroy the Saudi petroleum supply system had earlier led to great uncertainty, and as companies built up inventories, prices rocketed and the sixth postwar oil crisis had become a reality. As a result, when he threatened Kuwait, international response was immediate and massive. When Saddam Hussein did not respond to international moves towards compliance, in the early hours of January $17^{\text {th }}, 700$ coalition aircraft launched their attack against Iraq and oil prices first spiked from $\$ 30$ to $\$ 40$ a barrel to only collapse to $\$ 20$ a few hours later. The state of the oil market, and as a consequence, of many of the world's major economies, became one of turbulence and crisis.

Instead of achieving world domination, by 2003, under the disastrous leadership of Saddam Hussein, Iraq, the world's largest purchaser of arms in 1985 and a country which spent some 30 per cent of its total gross national product as well as the lives of half a million of its inhabitants on Saddam's "War Machine," was in crippling debt to the foreign lenders who had financed his wars. ${ }^{97}$ The war against Saddam Hussein completely disrupted the flow of Iraqi oil. ${ }^{98}$

However, instability and fluctuating oil prices were not just a feature of the Middle East where "Britain's informal empire" (Galpern, 2009:283) had provided easy access to the oil that was so salutary to the balance of payments. ${ }^{99}$ In 1983, the British National Oil Company

\footnotetext{
${ }^{96}$ Paul presents some interesting facts about the Seven Oil wars in Iraq and relationships between different governments and oil companies. For example, the relationship between Tony Blair and BP CEO John Browne was such that the press referred to Blair as the BP Prime Minister.

${ }^{97}$ Indirectly, Elf Aquitaine (later to become Total) helped Saddam to finance his wars as, together with Chevron, they had provided technical advice to the Oil Ministry during the 1990s in return for the billion-barrel Majoon field near Basra. The company (then Total) lost this field to Shell in the 2009 auction as due to international restrictions against the régime, no contract had been signed.

${ }^{98}$ For further details of the impact of the wars and their effect on both the country, its people, its oil industry and the companies working there, see Muttitt (2011).

${ }^{99}$ The benefits of having the Government as shareholders which BP had so keenly sought in the first decades of the century were now a disadvantage and the question of Government ownership was raised in Parliament on several occasions. For example Hansard vol.320 no.115 (Wed 16 June 1971) records the "Motion International Companies: Relations with States" which includes a reference to BP by Lord Kennet. On another occasion, Parliament were reminded; "The British Government are pledged not to interfere in the commercial affairs of the company..." $31^{\text {st }}$ October 1973.

In an Aide memoire of $11^{\text {th }}$ Feb.1975 on the effect of a changing the relationship between HMG and BP on their international position, the company state; "BP's U.K. operations, important though they are, are only a part of the Group's activities. Even if there was need for a further injection of Governments funds, in terms of financial requirements, or efficiency of operation (which there is not), it would be necessary first to give serious consideration to the effect on the Company's international position of any change in the relationship between $\mathrm{HMG}$ and $\mathrm{BP}$.

$90 \%$ of our trade and the preponderant part of our assets are outside the U.K. Our most valuable asset (and future source of earnings of foreign currency) is Alaska where BP will have, through Sohio, a 54\% share-holding in half the reserves so far discovered in Alaska, (which in turn, represents $12 \%$ of the reserves of the United States) ... Our position in the United States is only one instance, although the most recent, of the way in which BP has been able to establish important operations in foreign countries. ... Our present international position rests therefore not on much on the legal situation .....as on precedent and history ... BP under the control of the government would compromise its business dealings abroad. This is particularly important in an era of greater national concern about energy and oil." They go on to point out that in France, S.F.BP had 11\% share of the
} 
cut the price of North Sea oil with devastating results for Nigeria, now a member of OPEC and a country that had become over-dependent upon its oil production. Nigeria declared that they were ready for a price war and found backing among the now twelve OPEC nations. The more moderate Saudi Arabia was forced to play a pivotal role in the balancing of supply and demand. The global situation was changing and the oil industry was meeting nationalisation. The oil companies needed to find a new identity and new resources as their assumed ownership of the oil found in the countries in which they operated was questioned. Because of the turbulence and upheaval in Iran where it had been a major player and the nationalisation of Nigerian oil, BP was forced into leading the way. The emergence of new, short-term "spot markets" meant that traditional integration was no longer so attractive and the corporate culture had to change from that of a quasigovernmental bureaucracy to one that a BP company executive described as a "nimble trading-oriented approach" (Yergin, 2008:704). ${ }^{100}$ Libya was the source of a major headache and there were problems in Venezuela and Mexico.

\section{Winds of Change}

The problems facing the oil industry were not, however, limited to political disputes ${ }^{101}$ and wars. The flow of oil affected and changed everything in its path. The rise of motor transportation led to a rapid change across the face of the western world, and nowhere was this more evident than in the United States where consumption increased rapidly and the new concept of suburban living, ${ }^{102}$ motels, ${ }^{103}$ shopping malls, turnpikes, drive-in movies, drive-in restaurants and fast-food came to characterise the affluent life-style. Roads and highways were the arteries and veins that supplied this life with its needs, and oil and its derivatives the blood that pumped through them.

However, these changes were not only for the good, and increasingly, voices were raised to query the impact that the oil industry was having on the environment in general and on the health and lives of the Earth's inhabitants.

market and to say that "[i]n Germany, where our second largest overseas Associate is situated, the government reaffirmed that they will not permit foreign governments to control important sectors of their energy industry. The same attitude is likely to develop in Scandinavia, Benelux and South Africa." With regard to new markets and producing countries the company write; "A change in status of BP to one in which we were seen to be an arm of the Government could not fail to add a whole new dimension of political risk." (BP Archives, Warwick University) Margaret Thatcher's Government progressively divested its interests in BP throughout the seventies and first part of the eighties as part of the move away from nationalisation.

${ }^{100}$ Yergin,(2008:704-706) describes how BP chairman, P.I. Walters had been campaigning for the de-integration of BP's operations since a1967 telephone call from Aristotle Onassis, the Greek tanker tycoon. Walters is famed to have claimed that "there are no sacred cows in BP". Yergin describes how the four Aramco partners were forced to follow suit.

${ }^{101}$ Geoffrey Chandler (1977:52) suggests that the power the companies had commanded was a direct consequence of their bargaining capacity, derived from the balance of supply and demand and points out that they are "responders to an economic and political framework, not creators of it".

102 The beginning of this phenomenon may be in 1946, when the Levitts, a family of builders, acquired some 4,000 acres of potato farming land on Long Island, twenty-five miles east of New York City and turned it into 17,400 houses costing between $\$ 7,990$ and $\$ 9,500$. Levittown became the prototype of the postwar suburb, an affirmation of the American Dream and an arm in the war against communism. "No man who owns his own house and lot can be a Communist. He has too much to do" (William Levitt quoted in Yergin, 2008:532). By 1976, the majority of the American population lived in the suburbs.

${ }^{103}$ The term is thought to have been coined in 1926 in San Luis Obispo, California and referred to a cluster of cabins that grew up around a gasoline station along the highway. The director of the FBI, J. Edward Hoover considered them "camps of crime" and "dens of vice and corruption", but in 1952, after the American family took to the roads, the first Holiday Inn opened in Memphis and the real era of the motel was born. (Yergin, 2008:533) 
One of the first challenges to the oil industry came in the form of a book written by Rachel Carson, an American marine biologist and conservationist, published in 1962 and entitled Silent Spring. The first chapter, "A Fable for Tomorrow", described the "grim specter [that] has crept upon us almost unnoticed" (Rachel Carson, 1962: 3) and called into question the effect of pesticides, particularly DDT, upon the environment and upon people's health, as the chemicals entered the food chain and accumulated in the fatty tissue of animals with devastating results. The impact of this book, which convincingly illustrated the interconnectedness of life, was enormous, and after it had come to the attention of President J.F. Kennedy, federal and state investigations were instigated to assess the validity of Carson's claims ${ }^{104}$. The chemical industry, which was an important arm of the oil industry, spent a quarter of a million dollars to discredit her research, and in the words of Linda Lear, her biographer, ${ }^{105}$ she was portrayed as a "bird and bunny lover", a cat-loving, hysterical spinster. $^{106}$

Then followed a number of serious oil spills. Although oil was known to be a risk-filled business, accidents and spills had been associated with far-away places and with people working in the industry and for whom it was one of the risks of the job. ${ }^{107}$ This changed on the morning of Saturday, 18 March 1967 when the Torrey Canyon, a 300m long, Liberianregistered supertanker, chartered to British Petroleum ran aground on Pollard's Rock between Land's End and the Isles of Scilly off England's Cornish coast. Although it was not the first accident with an oil transport to have occurred in this area, ${ }^{108}$ the Torrey Canyon received a great deal of media coverage and had a strong impact on public consciousness and opinion.

\footnotetext{
${ }^{104}$ James Lovelock, originator of the Gaia Theory and the inventor of the electron capture detector (ECD) that can detect infinitesimal traces of pesticides and who worked as science advisor to Lord Rothschild, a biologist and then coordinator of science for Shell who produced DDT, Dieldrin and a number of other pesticides, describes the pain and rage experienced by Rothschild as a result of the media storm raised by Carson's book. Rothschild was agonized to discover that his company had inadvertently caused harm and was very unhappy with the politicizing of the situation. The insecticidal properties of DDT had been discovered by Professor Paul Herman in 1939 who had received a Nobel Prize for this work. His discovery saved many lives as DDT was effective against the mosquitoes that killed millions of people in the malaria regions and also curbed the typhus epidemic in Naples in the aftermath of WWII. Lovelock claims that the problem lay not with the pesticides and insecticides in themselves, but in their indiscriminate use when agribusiness started using them large-scale to improve yields. (Lovelock: 2006: 137-139)

${ }^{105}$ In the introduction to the Fortieth Anniversary Edition of Silent Spring(2002)

${ }^{106}$ Rachel Carson is often regarded as the founder of the ecological movement and was posthumously awarded the Presidential Medal of Freedom by President Carter. In order to fully understand the impact of her work it needs to be put into the perspective of her times. Firstly, the cold war was at its zenith and there was a general climate of suspicion. "The chemical industry, one of the chief beneficiaries of postwar technology, was also one of the chief authors of the nation's prosperity. DDT enabled the conquest of insect pests in agriculture and of ancient insect-borne disease just as surely as the atomic bomb destroyed America's military enemies and dramatically altered the balance of power between humans and nature. The public endowed chemists, at work in their starched white coats in remote laboratories, with almost divine wisdom. The results of their labors were gilded with the presumption of beneficence. In postwar America, science was god, and science was male" (Linda Lear's introduction to the Fortieth Anniversary Edition of The Silent Spring (x-xi). Although Rachel Carson's research was based on large quantities of data and sources, her poetic style was not in line with this masculine view of science.

${ }^{107}$ In September 1965, the danger to life was brought closer to home when part of BP's Sea Gem rig collapsed as it was moved away from the discovery well shortly after gas had been struck in the West Sole field at the cost of 13 lives.

${ }^{108}$ The Thomas W. Lawson, a seven-masted schooner built in 1902 was destroyed in a storm off Annet, an uninhabited island in the Scilly group in December 1907 and is this accident is generally considered to be the first major oil spill from a ship in modern history. All but two members of her crew of 18 were killed and her cargo of 58,000 barrels of light paraffin oil was spilled into the sea. The vessel was under charter to the AngloAmerican Oil Company, part of Standard Oil.
} 
The 119,328 tonnes of crude oil that it was carrying seeped out into the Atlantic Ocean. By the following day, a twenty-mile slick, a "greeny, browny gunge" (Dennis Barker, Guardian reporter at the scene, cited in Patrick Barkham, 2010) had escaped from the vessel's punctured tanks and nobody knew how to tackle the problem. Previously, coastal spills had been cleaned up using solvents and emulsifiers, and BP, who manufactured these so-called "detergents", provided the navy with this means to combat the oil, and inadvertently, exacerbated the environmental disaster ${ }^{109}$.

The second major oil spill of the sixties took place in January 1969 in Santa Barbara, California. The Santa Barbara spill was caused by a "blowout" on a Union Oil Rig six miles off the coast and 3 million gallons of oil spilled into the sea, spoiling the coastline and killing wildlife. An oil spill on the doorstep raised the awareness of many Americans to environmental issues and to the negative impact of the oil industry. ${ }^{110}$

Other shifts in public attitude towards the environment and man's relationship to it were taking place, and environmental issues began to compete for a place in political processes. These shifts both increased the demand for oil and also called for the regulation of its use. Air pollution was prompting utilities to change from coal to oil and in 1965, the Mayor of New York pledged to banish coal from the city. On Thanksgiving Day 1966, smog gripped the city and by 1967, the Senate passed a clean air bill by a vote of eighty-eight to three. In 1970, Federal legislation was enacted to establish what are now known as environmental impact statements and one hundred thousand people paraded down Fifth Avenue to mark Earth Day, a direct consequence of the Santa Barbara spill.

It was not only in the United States that environmental awareness was on the agenda, however, and the publication of the study, Limits to Growth, presented by the Club of Rome, was received with great interest and enthusiasm. Presented in 1972, at a time of worldwide economic boom, high inflation and an even higher growth in the use of resources, while at the same time, American oil reserves were declining and worldwide energy use was rising dramatically, the study warned that "the limits to growth on this planet will be reached sometime within the next hundred years" (cited in Yergin, 2008:550) if resource depletion continued unabated. The price of oil had fallen during the $1950 \mathrm{~s}$ and $60 \mathrm{~s}$ as each producing country had tried secure higher volumes for its products by decreasing prices and increasing volumes, and this had greatly contributed to consumption. New technologies had also helped refineries to increase the yield and the belief that "more is good" was complemented, at least in the United States, by the creed that "Bigger is Better". Between 1960 and 1970, demand for oil had risen in the free world by 21 million barrels per day. However, another issue that the

\footnotetext{
${ }^{109}$ On Easter Monday, the tanker broke into two pieces and the government began to bomb the tanker to sink it. To burn off the oil, they first tried using aviation fluid and then Napalm. The slick contaminated 120 miles of Cornish coast with disastrous consequences for wildlife. However, thanks to the prevailing winds, Cornwall escaped relatively lightly and the oil that washed up on Britain's coast represented only 15 per cent of the total. Nineteen days after the disaster, a huge slick hit Guernsey where it was pumped into a quarry where authorities were still trying to remove the last of the oil in an environmentally friendly way in 2010 and on the coast of Brittany. The international laws that are in place for such events today did not exist in 1967, and if it is possible to consider that anything positive resulted from this first major ecological disaster, it is that International Maritime laws were created and that public awareness increased (Barkham, 2010).

${ }^{110}$ According to Karen Stevens writing in the Santa Barbara Pet Examiner January 28, 2009, many believe that this oil spill prompted the modern environment movement. A number of activists started the Community Environmental Council (CEC) which launched the first-ever Earth Day in April 1970. Get Out Oil (GOO) was also founded in Santa Barbara as a direct consequence of the spill.
} 
study raised and which was to become increasingly important, was the consequences of hydrocarbon burning and the resulting threat of global warming.

The findings of the Club of Rome were emphasized one year later by E.F. Schumacher, a German-born, Buddhist economist based in England, in a collection of essays entitled Small is Beautiful a study of economics as if people mattered. ${ }^{111}$ Schumacher expressed great concern about the way in which "[t]he illusion of unlimited powers, nourished by scientific and technological achievements, has produced the concurrent illusion of having solved the problem of production" whereas in reality, the travellers on "Spaceship Earth" were wasting "irreplaceable capital which man has not made, but simply found, and without which he can do nothing" (Schumacher, 1973:15). The Yom Kippur War and the oil embargo which the producing nations of the Middle East imposed upon the United States and the Netherlands, when the latter did not reverse its attitude towards Israel, (Church, 1977:39) encouraged the burgeoning conservation movement and led to discussions about reducing energy consumption and the development of alternative energy sources (Chandler, 1977:58). ${ }^{112}$

\section{The Twilight of the Oil Gods? ${ }^{113}$}

As mentioned earlier, the Arab oil embargo had a number of far-reaching consequences. It not only confirmed that something must be done to diversify sources of oil but also consolidated the need to conserve reserves. In Japan, the mood was that the country needed to move from energy-intensive to knowledge-intensive industries, while in France, Jean Blancard, the General Delegate for Energy in the Ministry of Industry argued that the world was facing a transformation, not a crisis, and that dependency upon the Arab nations was unthinkable in the long term. In response, President Pompidou convened a meeting of his most senior advisers and decided that French energy policy should be grounded in nuclear power, a return to coal and on energy conservation. A further French initiative was the ban on any advertising that could encourage consumption. For example, a manufacturer could advertise that a heater was more efficient than others, but not that it was the best form of heating as this could encourage the use of energy. This situation was problematic for the oil companies who were accustomed to waging aggressive advertising campaigns to win just one per cent of the gasoline market from their competitors (Yergin, 2008:637-638).

In America too, the role that the oil companies were playing and had played in the crisis was under question, ${ }^{114}$ and hearings were held about the energy crisis and the role that the oil

\footnotetext{
${ }^{111}$ Schumacher was the economic adviser to the National Coal Board but also wrote for both the Times and the Economist. While he acknowledged that " [t] here is no substitute for energy" and that the "whole edifice of modern life is built upon it", (cited in Yergin, 2008:541) he insisted that we must use natural resources with care. In the essays, he posited that "Modern man does not experience himself as a part of nature but as an outside force destined to dominate and conquer it" (p.14) but that in the "battle with nature" man must inevitably lose. Small is Beautiful was awarded the prestigious Prix Européen de l' Essai Charles Veillon in 1976.

${ }^{112} \mathrm{BP}$, for example, considered developing solar panels, but had problems finding sponsors. In a note of November $15^{\text {th }} 1974$, Dr.R. Poulter of Bristol University advised Dr.M.G.Billett of BP that the "sponsoring company in Birmingham have decided not to proceed any further with the project, at this time, until the economic climate improved a little. In my opinion, they have changed their minds altogether about solar panels, and no more funds will be forthcoming". A research project into wave calming was also discussed the following year. (BP Archives, Warwick University).

${ }^{113}$ Adapted from E.F. Schumacher, quoted in Yergin, (2008:541)

${ }^{114}$ Louis Turner (1976) recounts the changing relationships of the oil companies and their "parent governments" from a historical perspective. He describes how even in the United States, popular ill-feeling towards the majors grew during the 1970 s and concludes that the majors were "no longer the allies of the leading consumer
} 
companies had played. ${ }^{115}$ Unfortunately for the companies, the hearings coincided with a new production of Eugene O'Neill's play A Moon for the Misbegotten, where one of the characters bellows the line "Down with all tyrants! Goddam Standard Oil!" ${ }^{116}$ a line which was greeted with great enthusiasm and appreciation by the audiences. The picture of the oil industry was one of greed, manipulation and "obscene profits". ${ }^{117}$ The role of oil and energy in national politics became a burning issue and was further complicated by the demand that change and conservation should not impact on the "American way of life", a seemingly impossible equation. $^{118}$

In 1969, the Mobil management had anticipated the problems of energy shortages and rising prices and was prepared for the criticism that they expected would ensue. Their response was to initiate a preemptive campaign to counter-act what they considered to be "anti-business and oil-industry news media, politicians, and consumer and environmental interest organizations" (Brown \&Waltzer, 2005:200). This campaign took the form of an advertorial campaign in The New York Times to defend itself and the industry and to advocate policy positions. Their first advertorial was on October 19, 1970, just one month after the newspaper had started its socalled op-ed page advertorial initiative and to the dismay of the other oil companies, advocated an increased use of public transportation. ${ }^{119}$

Many Americans found it hard to understand that one of their fundamental beliefs, namely that resources were cheap and endlessly abundant was a myth. To improve the fuel efficiency of motor vehicles was one of the answers to the problem, as one in seven barrels of oil produced in the world was burned on America's roads, and to find alternative sources of energy was another.

governments ... [and] not pure agents of the producers either. Rather, they [had become] actors with economic interests at both ends of the oil operation, and hence vulnerable to the displeasure of either set of governments. "(p.380).

${ }^{115}$ Chandler (1977:70) argues that the oil companies were essentially "innocent" and that the power that they were claimed to yield was a myth. He posits that companies consist of people with "abilities and skills whose use can be maximized or minimized according to the framework created by governments".

${ }^{116}$ The hearings were led by "Scoop" Jackson and were televised. Senior executives of the seven largest oil companies were questioned about their company operations and profits and asked whether "this so-called energy crisis [was] only a pretext; a cover to eliminate the major source of price competition - the independents, to raise prices, to repeal laws, and to force adoption of new tax subsidies." In the specific case of what became Exxon, (the corporate name which replaced Standard Oil Company of New Jersey and which formally replaced the Esso, Enco and Humble brands January 1, 1973) one of the chief officials claimed that he could not remember the amount of his company's 1973 dividend. Unfortunately, the 1973 earnings which were up 59 per cent over those of the previous year, were accidentally released three days into the hearing. The oil companies became one of the most unpopular institutions in the entire country. See Yergin, (2008: 638-641) for more details including a comparison between absolute profits and real rates of return which were significantly lower.

${ }^{117}$ See for example Prasad and Mir (2002) who analyse U.S. oil companies' response to their decreasing popularity and questioned legitimacy through a series of CEO letters to shareholders written in the 1970s and 80s. Their critical hermeneutic analysis shows how "the oil companies represented themselves as honest intermediaries", that there was an "organic harmony of interests between the industry and the country at large" (p.104) and how the "interests of the U.S. oil industry are identical with American national interests" (p.106). ${ }^{118}$ In an attempt to solve the problem, in January 1975, President Ford proposed a huge expansion of nuclear power stations and coal mines among other measures, and shortly afterwards, Nelson Rockefeller, the Vice President, and grandson of " the man who personified the monolith of oil" (Yergin, 2008:642) championed a massive programme to subsidize synthetic fuels with other high-cost energy projects. However, Congress approved the Alaskan oil pipeline.

${ }^{119}$ The issue of advertorials and the Mobil campaign will be taken up in much greater detail in the next chapter, on advertising. 
The seventies, which had started badly for the oil companies, ended in even greater confusion than they had begun. Increasing political crises and disruption abroad put more and more pressure on the oil industry which was already facing criticism and mistrust at home and added to the problems it was facing. ${ }^{120}$

Oil spills were not a thing of the past, and among the most reported disasters of the 1970s was the Amoco Cadiz. In March 1978, on route from the Middle East to Le Havre in France for Shell, the tanker lost its entire cargo of 1,604,500 barrels, or 216, 000 tons of light crude oil and 4,000 tons of bunker fuel into the Atlantic Ocean near the Brittany coast when it ran aground in stormy weather on Portsall Rocks, and eventually split into three parts. The environmental impact of the spill was enormous and about 200 miles of coastline were affected by the oil which penetrated the sand on some beaches to a level of 20 inches. Diving birds, oysters, molluscs and sea urchins died and fish caught in the area tasted of petroleum and had skin ulcerations and tumors. Indeed, of the 26 species of Amphipoda known to live in the eelgrass beds of the area, 21 were not found after the spill. ${ }^{121}$ Attempts to clear up the damage were complicated by indecision as to who should take responsibility and also had a negative impact on the environment. ${ }^{122}$

The next decade was no safer for the environment, and among the larger "incidents" that took place was the accident with the Castillo de Bellver, a vessel trading under the Spanish flag and carrying 250,000 tonnes of light crude oil when it exploded and sank some $80 \mathrm{~km}$ off Table Bay, South Africa in August 1983. The weather conditions were luckily such that a serious ecological disaster was averted. ${ }^{123}$ An "incident" that occurred at the end of the eighties had a much greater environmental impact and received much more media coverage, however. In March, 1989, the Exxon Valdez, ${ }^{124}$ a single-hull supertanker, ${ }^{125}$ ran aground

\footnotetext{
${ }^{120}$ General mistrust in the oil companies perhaps reached a peak with the Elf Aquitaine scandal that opened in 1994 and cumulated on November 12 2003. During the trial, it came to light that, sanctioned by successive French governments, the state-owned oil company, France's largest enterprise, had been robbed of over 305 million euros by its top executives. Much of this money had gone into setting up "a Franco-African foundation" to secure France's oil independence, but great amounts had also gone into the personal enrichment of the people in power. For more information see for example the reports by Hugh Schofield (2003) Antoine Lerougetel (2003) or David Ignatius (2002). Ignatius (2000:4) even reports how one of the accused, Alfred Sirven, swallowed the computer chip to his cell phone to destroy all records of his telephone contacts.

${ }^{121}$ For a scientific investigation into the effects of the spill see, for example, the paper by den Hartog \& Jacobs (1980) who had begun a study of fauna in the area in 1977 and were therefore able to compare results before and after the spill. In fact, the environmental effects of the Amoco Cadiz spill can still be seen and are among the most widely studied to date.

${ }^{122}$ Although the Torrey Canyon disaster had resulted in the development of an international framework with a strict liability regime for the compensation of damages for pollution from oil spills the legal wranglings in the case of the Amoco Cadiz were extensive. See for example Thébaud et al. (2004) and Grigalunas et al. (1986) for more details about the ways in which the economic consequences of oil spills and other environmental disasters can be calculated. A decision about who was responsible and how costs should be calculated was taken in January 1992 in the United States Court of Appeals for the Seventh Circuit. See West Forest University School of Law at for the transcript and more information . www.wfu.edu

${ }^{123}$ Although the area is ecologically and economically important (some 50per cent of South Africa's lobsters and fish are caught in the area) the prevailing winds pushed the slick off shore with little resulting coastal pollution.

${ }^{124}$ The vessel was repaired and re-named later and after a number of name changes, Exxon Valdez was sold to a Hong Kong-based shipping company in 2008 and re-named Dong Fang Ocean.

${ }^{125}$ As a result, single-hull vessels were banned by law in the United States. A single hulled Maltese tanker, Erika broke up and sank off the French coast in December 1999, spilling a 15 kilometre long slick of heavy fuel oil This prompted the EU to pass the first two measures addressing maritime safety, the Erika packages. Three years later, another single-hulled tanker, the Prestige flying a Bahamas flag, sank off the coast of Spain spurring Erika III, which addressed the issues of civil liability and flag states. The European Parliament and Council Regulation against vessels of this sort entering member state harbours or anchoring in their territorial waters was
} 
spilling vast quantities of oil ${ }^{126}$ into Alaska's Prince William Sound and thereby causing what was the worst environmental disaster in U.S. history. ${ }^{127}$ If the physical clean-up after the disaster was complicated and long-drawn, the legal clean-up was even more so. Victor Goldberg (1994:34) suggests that "Exxon created more than a huge oil spill; it also created a new line of business - cleaning up the oil spill". Disasters like the Exxon Valdez spill impact upon so many lives in so many different ways. ${ }^{128}$

The 1990s was a decade when environmental awareness became deeper, particularly in Europe where the devastating effects of spills from Erika off Brittany and the Sea Empress off Milford Haven, ${ }^{129}$ followed in 2002 by the Prestige off the Galician coast in Spain, were felt, and the actions and perceived irresponsibility of the oil industry and the oil companies were becoming increasingly questioned. Moreover, oil damage was not limited to transportation spills and horrendous pictures from Kuwait, where over 600 oil fields had been set afire by Saddam's forces in 1991 during the Gulf War leading to what Yergin, (2008:759) calls "by far the largest oil spill in history" were broadcast worldwide. More oil was going up in flames each day than Japan's daily oil imports; over a billion barrels during the seven months of fighting. The country and much of the Gulf was engulfed in a thick, poisonous smoke, creating a huge-scale environmental disaster. In the words of Ryan Chilcote, describing the situation for $\mathrm{CNN}$ in 2003, "[B]lack rain fell from the sky, and a vast network of lakes was born ... lakes of oil as deep as six feet". ${ }^{130}$

If the oil companies themselves could perhaps be exculpated and cast in the role of innocent by-standers in these situations, that was certainly not always the case. In September 1978, a United States Coastguard helicopter on a routine patrol accidentally discovered a spill at

signed into law on April 2007 Environment News Service, "Double Hulled Tankers for Heavy Oil Now Law in Europe" http://www.ens-newswire.com/ens/apr2007/2007-04-28-02.html (January 27, 2012). The leaking Prestige drifted at sea for eight days contaminating six countries with spilled oil. Experts predicted that marine life would be affected for at least ten years because the oil contained polyaromatic hydrocarbons which are highly toxic and can have carcinogenic effects (Tanker World, May 2007). A study of over 800 sailors who helped to clean up the oil detected an increase in problems associated with respiratory organs in this population (Antonio Ojea, 2007). The legal consequences of this disaster led to the Kingdom of Spain bringing a civil suit against the American Bureau of Shipping on the issue of classification. More information, including a health update on the people involved in the clean-up operations can be found on

http://en.wikipedia.org/wiki/Prestige oil spill

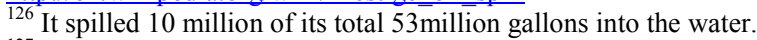

${ }^{127}$ It was not only the size of the disaster, with some 500,000 birds, including 150 bald eagles, 4,5000 otters, 14 killer whales and an immense loss of other marine life that was the cause for the immense media attention that the accident received, however. It was established that the third mate, who was not certified to take the tanker into those waters was at the helm because the captain and many of the crew were drunk at the time. The slow response to the accident exacerbated the situation. Moreover, the poor communication on the part of the company with the media has led to the Exxon Valdez becoming a classic study in Public Relations for how not to respond to a crisis. It can be usefully compared with the 2010 Deepwater Horizon disaster.

${ }^{128}$ The Exxon Valdez spill generated more than 30,000 different claims for litigation and involved over 100 law firms. One problem is that many victims are affected indirectly. At the same time, during the clean-up operations, fishermen were for example paid more than they would normally earn and hotels which lost the tourist trade gained from the people involved in the clean-up. See Goldberg,(1994) for an interesting discussion of the legal problems and implications.

${ }^{129}$ Alison Anderson (2002) argues that it was the media impact of these accidents that forced sections of the oil industry to take a more proactive approach to environmental communications. This will be discussed at more length in the next chapter.

${ }^{130}$ Jonathan Lash, president of the World Resources Institute is quoted by Ryan Chilcote (2003) as stating: "The oil that did not burn in the fires travelled on the wind in the form of nearly invisible droplets resulting in an oil mist or fog that poisoned trees and grazing sheep, contaminated fresh water supplies, and found refuge in the lungs of people and animals throughout the Gulf". 
Greenpoint, in the Brooklyn area. The area was the home to the early oil industry and had boasted more than 50 petroleum processing plants by the $1870 \mathrm{~s}$. The spill was the result of a tank explosion that had taken place in 1950, but it was not until late 1979 that the first pumps were installed at the site to try to recover the oil. ${ }^{131}$

Another environmental disaster of incomprehensible magnitude that came to public knowledge and which has had far-reaching consequences has been occurring in the Niger Delta since the 1970s. Here, Shell are generally considered to be the main, though by no means sole, culprits. It has been calculated that as many as 546 million gallons of oil have spilled into the Delta over the last half century. According to the Nigerian federal government, quoted by John Vidal in The Observer Sunday, May 2010, there were more than 7,000 spills between 1970 and 2,000, with 2,000 major spillage sites dating back decades. ${ }^{132}$ However, these spills in Africa received relatively very little attention at the time. ${ }^{133}$ There are a number of reasons for the spillage, such as old and corroded pipelines and tankers, sabotage $^{134}$ and actual operations as well as corruption and lack of accountability. ${ }^{135}$

However, this was not the only reason for Shell receiving bad publicity in the 1990s. Shell operated in Nigeria as a joint venture with the government through its local company, Shell Petroleum Develoment Company of Nigeria (SPDC). The oil industry, and Shell in particular, was extremely important for the Nigerian economy, ${ }^{136}$ but the local ethnic minority communities, such as the Ogoni, who lived in the Niger Delta, saw almost no benefits from the operations. Moreover, due to the environmental impact of the company's activities in the area, the indigenous people lost their source of livelihood and suffered from bad health (Sharon Livesey, 2001:72). In 1993, a massive non-violent protest against Shell and other oil companies was organised by the Movement for the Survival of the Ogoni People (MOSOP). The Ogoni claimed that their wealth had become a nightmare and that "black gold" had "despoiled" their rich environment and become "a curse for them while feeding others fat" (ibid:74). As a result, Shell closed its operations in the area. The Nigerian government blamed

\footnotetext{
${ }^{131}$ According to Nicholas Confessore, writing in The New York Times, the 17 million gallons of oil and gasoline had leaked out into the ground and were probably the cause of stains on patio furniture and a strange, metallic taste to locally grown tomatoes. With the help of the now well-known lawyer, Elin Brockovich, many of the residents who were born and raised near the spill filed a lawsuit on October 212005 against the companies involved: primarily ExxonMobil, but also BP, which had merged with Amoco, earlier Standard Oil of Indiana in 1998, and ChevronTexaco, which had absorbed Gulf and which had refineries in the area. On November 18, 2010, CNN reported that ExxonMobil had agreed to "accelerate its cleanup" of the underground spill and would pay $\$ 25$ million in penalties and improvement schemes in the area.

${ }^{132}$ For more details, see the article by John Vidal (2010) in The Observer or the one written by Adam Nossiter for the New York Times the same year. These articles were inspired by the public reaction to the Deepwater Horizon disaster. The Amnesty International Report for 2011 also discusses the Niger Delta oil spills.

${ }^{133}$ Postnote 75, (a parliamentary publication for British MPs, from the Parliamentary Office of Science and Technology intended to provide an overview of issues arising from science and technology) February 1996, lists the "Ten Largest Spills and some Recent Spills" and the amounts lost from both the Exxon Valdez $(37,000)$ and the Sea Empress $(70,000+)$ are insignificant in comparison with figures from for example the Atlantic Empress (280,000 tonnes) in 1979 or $A B T$ (260,000 tonnes) in 1991. However, the latter "incidents" occurred of the coasts of Tobago and Angola respectively.

${ }^{134}$ This is usually performed by siphoning oil from the pipe to be bunkered and sold elsewhere. Estimates vary but Jay Pryor of Chevron is quoted in Peel (2005:11) as saying that he has "run companies that have had less production than is being bunkered in this country." Apart from the enormous financial consequences, bunkering causes the pipes, which are already in need of repair, to become further damaged, and oil leaks out into the environment. Explosions are common as a result of these activities. For example, in 2006, over 200 people were killed in an oil line explosion.

${ }^{135}$ See for example Michael Peel's (2005) account of the crisis in the Niger Delta.

${ }^{136}$ Livesey (2001) states that in 1995, SPDC accounted for about $14 \%$ of Shell's total oil production and that the Nigerian government derived $80 \%$ of its federal reserves and $90 \%$ of its foreign exchange from oil companies.
} 
the MOSOP leaders, who were tried by a kangaroo court of the military tribunal. Nine of them were executed on November 10, 1995. Shell's critics saw the trial and executions "as the deadly effect of Shell's presence in Nigeria" (Livesey, 2001:74) and international boycotts and protests followed. ${ }^{137}$

Another reason for Shell receiving extremely negative publicity in 1995 concerned its proposal to dispose of the Brent Spa, an enormous superannuated oil storage and loading platform situated in the deep waters of the Atlantic Ocean (ibid:58). Greenpeace strongly opposed this and rallied opinion throughout the world, threatening to chain themselves to the "toxic timebomb" (Philip Mirvis, 2000:63) unless Shell, which at the time was the biggest of the major oil companies, changed its plans. Public response was enormous; for example, sympathizers fire-bombed two petrol stations in Germany ${ }^{138}$. The British government too was in public conflict over what Shell should do as the proposal had received government approval. ${ }^{139}$ Public outcry resulted in the rig being dismantled and recycled and not dumped in the ocean ${ }^{140}$ and Shell was forced to present financial accounts to explain their decision to sink the rig rather than haul it back to shore (ibid). ${ }^{141}$ Despite the fact that Greenpeace later admitted that the facts that it had presented had been precipitate and inaccurate, the damage to shell and the oil industry was extensive. ${ }^{142}$

Problems with supplies and a dawning awareness of the environmental consequences of oil encouraged a move towards nuclear power during the late forties and the fifties. However, Hiroshima and Nagasaki indelibly marked nuclear power as a potential weapon of mass destruction. As Gamson and Modigliani (1989:1) have pointed out, "Nuclear power, like every policy issue, has a culture" and there is always "a symbolic contest over which interpretation will prevail" (ibid:.2) and the image of the mushroom cloud over Hiroshima was indelibly etched into public opinion. The move towards nuclear power as an alternative to oil as a source of energy for industry and heating was also threatened by a number of environmental scares. Although the 1957 fire at Windscales in the North West of England which had released radioactive material into the surrounding environment and the 1966 accident at the Fermi reactor outside Detroit, ${ }^{143}$ for example, did not receive a great deal of press, the accident that caused the core to melt in the second reactor at the plant on Three Mile Island near Harrisburg in Pennsylvania, 1979 received immense media coverage. The plant

\footnotetext{
${ }^{137}$ Unfortunately, this was not the last time that the Nigerian Government attacked its own people through the oil companies, and in 1998, over a hundred activists with grievances against Chevron saw company helicopters in the sky above them and assumed that the company had fulfilled their promise to get back to them. Instead, the helicopters contained members of the Nigerian navy and police, who fired and the people below, wounding many and killing two. In 2008, Chevron was cleared of all charges after the plaintiffs' lawyers withdrew many of the claims.

${ }^{138}$ Some German Shell stations reported 50\% lower sales as a result of this controversy.

139 At the company's annual meeting of shareholders in October, 1995, protestors gathered under a banner proclaiming that Shell were "murderers" and held them responsible for the situation in Nigeria and the executions of the Ogoni tribal leaders. Editorials throughout Europe and the US condemned the Nigerian government and the oil company Shell for its complicity (Mirvis:2000).

${ }_{140}$ Greenpeace were adamant that the oceans were not a dumping ground and the Brent Spa was eventually taken to Stavanger in Norway for dismantling.

${ }^{141}$ The events of 1995 caused Shell to rethink its policies and raised issues of transparency and were to have major consequences for how the company began to communicate with its stakeholders. The trend was quickly followed by the other majors. This will be discussed in more detail.

${ }^{142}$ See for example, Dickson \& McCulloch (1996) and Vian Bakir (2006).

${ }^{143}$ Gamson and Modigliani (1989) discuss this lack of media reaction, and comment that it has been suggested that the American public, at any rate, was encouraged to see the atom as "a benevolent servant" which would provide humankind with "more comforts, more leisure, better health, more real freedom [and] a much happier life"(13).
} 
had been in operation for only five years. This led to a questioning of the safety of nuclear power. ${ }^{144}$ When seven years later, in 1986, there was a serious nuclear accident in Chernobyl in the USSR, which had far-reaching consequences throughout Europe the search for safe, alternative, non-polluting sources of energy became serious. As Martin Langford (2005:365) points out, "environmental crises do not respect borders - major environmental incidents become global almost instantly..."

The Intergovernmental Panel on Climate Change, which was created in 1988 to provide governments with a better, scientifically-based understanding of what was happening with the world's climate, added a new dimension to public awareness of the detrimental effects of our modern hydrocarbon-supported lifestyle on the environment. The IPCC's first Assessment Report revealed that climate change was a topic that deserved much more attention and a political platform and the second report, which was published in 1995, provided the basis for the 1997 Kyoto Protocol on Climate Change. This further increased the pressure on the oil industry. In Europe, people were becoming increasingly aware of the impact of $\mathrm{CO} 2$ emissions upon the climate and the concept of global warming was taking root. The different environmental movements had begun to be heard and listened to. Initially, 84 countries signed the Protocol but the United States Senate rejected the treaty by a vote of 95 votes to 0 (Yergin, 2008:771).

The oil companies, who were the main source of $\mathrm{CO} 2$ emissions and the driving force behind the Hydrocarbon Age were forced to react. One of the ways in which they did this was by cooperating $^{145}$ and consolidating; strategies that the industry had been using to respond to difficulties since the early years of Standard Oil, and the late 90s and early years of the new millenium saw a number of important mergers. ${ }^{146}$ Another way in which they reacted was to move increasingly into alternative energies such as wind, solar energy and different forms of biofuels. The newly merged company, BP Amoco, claimed that it had merged to rise to the "challenge to ensure that hydrocarbons can be found, produced, refined, distributed and used without damaging the natural environment" and was described to shareholders as a "groundbreaking deal for the oil industry. (...) a new 'super major' with significantly greater competitive strengths than either partner could achieve on its own - a global corporation for a global economy" (Letter to shareholders, February 1999, BP Archives, Warwick University). ${ }^{147}$ It also enthused about solar energy, involving Tony Blair, Hilary Clinton and Al Gore ${ }^{148}$ in launching the enterprise, and proclaimed proudly; "Solar energy is a real energy option for business in a low emissions era and BP Amoco's investment will now help to cut costs for

\footnotetext{
${ }^{144}$ The World Nuclear Association admitted that some radioactive gas was emitted some days after the accident but claimed that it was not enough to cause a dose over background levels to local residents and that nobody was adversely affected by the "incident" at the plant. http://www.worldnuclear.org/info/inf36.html (January 23, 2012)

${ }^{145}$ Muttitt (2011) describes how the oil companies effectively divided post Saddam Iraq among themselves at bargain prices by not competing and bidding against each other for new contracts.

${ }^{146}$ British Petroleum merged with Amoco, formally Standard Oil of Indiana, on December 31, 1998, Mobil and Exxon merged in 1999, Belgian Petrofina merged with Total in 1999 and then with Elf Aquitaine in 2000, to become Total, Texaco and Chevron merged in 2001 and became Chevron, and Phillips Petroleum merged with Conoco in 2002. Only Shell did not consolidate by merging with another company.

${ }^{147}$ The company wrote that they were "aware that big companies are commonly regarded with suspicion" and insisted that the alliance was driven not by size, but by "a belief that, by combining our market presence, the talent of our people, our technological expertise and our access to investment opportunities, we could achieve continuing improvements in our performance. Simply, we can do more together than separately." (Letter to the Shareholders, February 1999).

${ }^{148}$ Hilary Clinton, for example, was photographed at the BP G8 showcase display in 1998 and Al Gore was called upon to open the California plant.
} 


\section{business and individual users in the future. Solar's time has now come. This will be one of the great business enterprises of the $21^{\text {st }}$ century."149}

In this way, they believed ${ }^{150}$ that they could target emissions reductions of almost twice that required by the Kyoto agreement. ${ }^{151}$

However, despite growing awareness, our need for the black gold seems to be insatiable, and as Simms \& Boyle (2010:248) admit, without this, “[t]he extraordinary growth in humanity's material production, consumption and its sheer size over the last century would not have happened" the sources from which it can be extracted are becoming increasingly physically and technologically difficult to work and are thus more expensive. ${ }^{152}$ Spills and accidents still occur, and the growing complexity of the operations would not seem propitious to their decreasing either in number or magnitude. The explosion of the BP offshore rig, Deepwater Horizon on April 20 2010, in the Gulf of Mexico, drilled to a depth of 18,360 feet $(5,600 \mathrm{~m})$ below sea level, clearly illustrates this point. Although this was by no means the only spill of the year ${ }^{153}$ it was the largest by far and resulted in the loss of lives. Media interest was enormous, partly due to the location of the accident, the loss of life and the fact that BP, who had assured stakeholders that the likelihood of a spill was negligible and that the consequences of such an eventuality would be minor, was accused of having cut corners by ignoring warnings that the use of cement for the casing was against best practice. As Anabela Carvalho has pointed out, (2007) the media has an important gatekeeping role (p.225) as they decide what should be reported ${ }^{154}$ and how. ${ }^{155}$ The mismanagement of the situation by the

\footnotetext{
149 This is particularly interesting for two reasons: one, which will be discussed later, is the new BP logo, and the second relates to the fact that BP announced their decision to abandon solar energy and solar panels in December 2011. One reason for this is that China has taken over the market and has dumped prices.

${ }^{150}$ Taken from a solar energy brochure available at BP Archives, Warwick University.

${ }^{151}$ However, according to Simms \& Boyle, (2010:239) BP was responsible for 6 per cent of global greenhouse emissions from fossil fuels in 2004 and if if the rule of thumb used by the UK Treasury was used to estimate the environmental consequences of burning fossil fuels was applied to their figures for 2006, the environmental cost would be just over $£ 229$ billion, which is almost the same as the total government revenue from fossil fuels. Taken from a solar energy brochure available at BP Archives, Warwick University.

${ }^{152}$ At The Offshore Europe Conference in Aberdeen, September 7th 1993, John Browne delivered the keynote speech "BP Exploration, Maturity and Beyond" in which he expressed the need to continue finding new, secure sources of oil and made the analogy of North Sea exploration and the early drilling activity in the Gulf of Mexico. "Oil activity in the Gulf of Mexico dates back to 1923 when the first wooden drilling platforms were constructed in the coastal waters of Louisiana. The in 1930 they started to drill from barges. (...) In 1976 the first oil discovery in water depths greater than $100 \mathrm{ft}$. But still people kept breaching the previous limits.

${ }^{153}$ Wikipedia http://en.wikipedia.org/wiki/List_of_oil_spills (January 31, 2012) lists 14 spills for 2010 alone, ranging from a minimum of three tonnes (Great Barrier Reef oil spill, MV Shen Neng1 to the Deepwater Horizon, estimated to a minimum of 492,000 tonnes. These include yet another spill accounted to ExxonMobil in the Niger Delta(between 3,246 and 95,000 tonnes) and a spill from the Trans-Alaska Pipeline (400 to 1,200).In 2011, Shell were responsible for what was described as the worst North Sea oil spill for a decade. (Fiona Harvey, in The Guardian August 15, 2011).

${ }^{154}$ As Michael Keating of The Guardian pointed out (January 12, 2012), "[i]n 2010 the world watched in horror as the Gulf of Mexico filled with $5 \mathrm{~m}$ barrels of oil from an undersea leak caused by the careless handling of equipment on the part of BP and its partner Halliburton. Shocking images of uncontrolled spillage erupting from the ocean floor travelled around the world for weeks, sparking a media frenzy, a range of stern governmental responses and a huge amount of public outrage. .... Last month, on the other side of the Atlantic, the oil giant Royal Dutch Shell's operation caused from $1 \mathrm{~m}$ to $2 \mathrm{~m}$ gallons of oil to spill into the ocean off the coast of Nigeria, also the result of an industrial accident. It was the worst spill in the country in 13 years in a part of the country where the gas and oil industry has been despoiling the environment for more than 50 years, on a scale that dwarfs the Deepwater Horizon spill in the Gulf of Mexico by a wide margin. Shells claims it has cleaned up the mess but the villages counterclaim the oil has been washing up on their coastline. The world's media seem to be uninterested in checking the facts." Keating goes on to say that lack of public interest is simply because the victims "unfortunately lack the political and media clout" to do anything about it.
} 
company unleashed the full fury of the media and exacerbated an already critical situation and aroused an angry response from President Obama who decided that there should be a moratorium on drilling. ${ }^{156}$

Interestingly, local people who were interviewed after the accident showed great ambivalence towards BP and the oil industry. On the one hand, they were unhappy about the immediate effects of the oil spill on their environment and on their livelihoods, but on the other, considered the oil company and the oil industry in general, as a source of employment and of economic advantage.

The response of the people of the Mississippi Basin to the oil spill is illustrative of general public opinion. The oil industry is a two-edged sword; it is a dirty, dangerous business, but the economic rewards that it brings are seen to outweigh its disadvantages. Moreover, the everyday comforts that the industry brings are now seemingly indispensable parts of our lives and we have grown accustomed to the advantages in terms of travel, easy-care fabrics and plastics that oil and its many derivatives bring. The oil companies are both heroes and the villains and their role is constantly in flux, depending on the current circumstances and on who describes them.

In addition, the fact remains, that despite the problems inherent in the oil business of which the BP disaster was a sharp reminder, as the companies themselves predict, demand is not declining. Moreover, emerging economies are driving both production and consumption to new heights and the impact that the "Majors" have on our lives and environment is at least as great as it has been since our apparent need for oil and energy erupted into our lives a century ago.

\footnotetext{
155 "Operations of the codification of [an]issue into media discourse are directed by the perceived interest and social impact of a topic, as well as other "news values", economic considerations and editorial lines" Anabela Carvalho, (2007:223)

${ }^{156}$ Martin Langford (2005) points out that environmental issues now have such a high public profile that they put regulators and governments under increasing pressure to be seen to act to protect the environment.
} 


\section{Chapter 3}

Advertising as a Communicative Genre

In the previous chapter, I described the development of the oil industry and gave an overview of some of the mile stones in its history to provide the background which is necessary to understand the rationale behind companies' advertising. This chapter introduces the main concepts that underlie my study of the advertising of the "Majors" as communication. The communication code is not a simple, single linguistic whole, but as Roman Jakobson (1960) has shown, involves six entities: the sender; the destination; the context; the contact or physical channel and psychological connection between the addresser and the addressee; the code; and the message. The communication code is an abstraction ${ }^{1}$ that encompasses the communicators' lifeworlds, attitudes and history and incorporates the concept of dialogism. Thus, although my approach is eclectic, the concepts which inspire my approach can be classed under the general headings of discourse analysis, genre theory, the new rhetoric and encompassing these, dialogism. Moreover, in line with Jakobson (1960:353) I strongly hold that the "secondary factors" of language, poetics, the emotive elements of speech, are essential in communication. Underpinning all of these is semiotics which will be discussed in more detail in Chapter 7.

My understanding of discourse analysis is based on French Discourse Analysis (FDA) ${ }^{2}$ which is an approach based on a project undertaken by Michel Pêcheux ${ }^{3}$ in the 1960s. FDA centres on the notion that language is a situated, social action which is dependent upon temporal and physical conditions of production and as such, offers a broad range of methodological techniques. In his comprehensive study of FDA, Glyn Williams (1995:313) states that this approach "collapses the distinction between disciplinary boundaries which divide linguistics and the social science" thereby "obliging the linguist to confront the social and the social scientist to confront the linguistic". Although FDA is indebted to the writings of Michel Foucault, Jacques Lacan and Wittgenstein, Pêcheux's orientation became increasingly linguistic and the work of Saussure, Zelling Harris, ${ }^{4}$ Noam Chomsky, Roman Jakobson, ${ }^{5}$ Emile Benveniste and Antoine Culioli shaped and developed the project. It is from

\footnotetext{
${ }^{1}$ Per Linell (2009:7) asserts that dialogism is an epistemological or even ontological framework which covers human action, cognition and communication. It is the epistemological framework that takes dialogicality (a property of the subject matter of the human and cultural sciences) systematically into consideration.

${ }^{2}$ The term French Discourse Analysis is attributable to Pierre Achard (1986), but is most strongly connected with Michel Pêcheux. In a paper reviewing and discussing the development of work on discourse and enunciation in France over the past twenty years and relating these to the importance of taking language into account in the field of sociology, Achard, refers to the French way of doing things. Achard links Foucault's conception of discourse with that of Benveniste, and it is to the Foucaultian position that he ascribes the label French Discourse Analysis. Achard recognises the importance of Pêcheux as the originator of this field.

${ }^{3}$ Achard (1995:82) points out that Pêcheux had envisaged discourse analysis as an analysis (which supposed a point of view) of the way in which sense comes to words (semantic processes) in a relationship to be established between the forms (linguistics) and practices (historical materialism) of which the definition (theory of social formations and their transformations) is applied to sociology. In other words, that meaning only exists in a practice that includes language (discourse).

${ }^{4}$ Harris' interest in lexicometry inspired Pêcheux's development of Automatic Discourse Analysis (ADA) and this technique, which involves collecting and analysing large corpuses of vocabulary over time has been useful in my analysis of the evolution of the advertising messages of the oil industry.

${ }^{5}$ Roman Jakobson was the link between the Prague Circle and the work of the French linguists, especially Benveniste whose role in the development of FDA was central. Jakobson was the link to structuralism and influenced, for example, Claude Lévi-Strauss who was important in the early development of FDA. Like LéviStrauss, Vladimir Propp is also a figure that is referred to in conjunction with the early structuralist aspects of FDA. Another influence of Jakobson was his rejection of the langue/parole division which led to his development of synchrony and diachrony into metaphor and metonymy, and thereby shifting the focus to include
} 
Benveniste's interest in the link between the ' $\mathrm{I}$ ' and the 'you' or 'him/her', that enunciative linguistics developed through the work of Antoine Culioli, and became integrated into FDA. ${ }^{6}$ Influenced by the work of M.M. Bakhtin, the interest of Pêcheux and the group around him became language in use rather than in an abstract form. ${ }^{7}$

In his account of the problems of "enunciation", Tzvetan Todorov (1970) states that the object of linguistics is not actually language in itself. He suggests that by accepting the notion that enunciation is an individual act of language use which results in an énoncé, the object of linguistic study is this énoncé, and not enunciation in itself. Speaking, or any other form of enunciation, is not a purely individual, chaotic activity, as this would be unrecognisable and incomprehensible, but involves repetition, play and conventions. In other words, advertising can be considered as an act of enunciation, while a physical advertisement is an énoncé, and this is the object of my study.

Following Linell (2009: 28), I am using the concept of dialogism as both "meaning-making” and "sense-making". However, whereas Linell does not really make a distinction between the two, I consider that it is the sender of the message, in this case the advertiser, who makes, or tries to make meaning, while the receiver, the public to which the advertisement is addressed works to make sense of the message. Moreover, it is very much in the interests of the advertiser that the public interprets and "makes sense of" the message in the way that he intended. I consider a single advertisement to be a communicative event when, through a knowledge and understanding of the reality of the recipient or audience, the advertiser sets into motion a series of semiotic triggers to elicit desired responses.

\section{How do we recognise an advertisement?}

We pick up the morning newspaper and open it. The news headlines share the front page with an advertisement for an airline. When we open the paper and begin to flick through it we are informed that we can get three pairs of shoes for the price of two in a certain shop, that in a certain chain of stores a particular brand of cosmetics is on special offer, that we should buy the latest and safest new car and that we can buy tickets for a concert if we ring a given number. We drink our morning coffee out of mugs decorated with company logos, and on the back of the cereal packet we can read that if we buy three more packets and send away the bar codes we will be able to get a new set of breakfast bowls at a reduced rate. As we eat breakfast, we listen with one ear to the radio and between the popular songs that are played hear that a local furniture shop is having a sale and that a local garage is now providing customers with a free car while their own vehicle is being serviced. The children are watching television while they eat and when we drag them away to get ready for school, they tell us that there is a new film out that we really must see and that they need new smart phones. The post

the socio-cultural framework of language and history and to the distinction between ordinary language and poetic language.

${ }^{6}$ The focus of enunciative linguistics as it is understood by the group that was built up around Pêcheux is language in use rather than in an abstract form. See Johansson \& Suomela-Salmi (2011) for example for more discussion and information about this.

${ }^{7}$ This view was not uncontested and while Pêcheux and his group insisted on the importance of the social and relationships, Oswald Ducrot's pragmatic approach to discourse was concerned with the frame in which the dialogue unwinds. Here, the énoncé is not studied with regard to its indexical functions in relation to "I" and to contextual reality, his pragmatic approach views the human subject as split by the discourse it produces (Jan Zienkowski, 2011:3).

${ }^{8}$ I use "he" partly as the generic form but also because it is my contention the intended reader is male. 
arrives, and among the bills are several unsolicited letters suggesting that we join a book club, invest in a new insurance scheme and get a new credit card. There is also a glossy catalogue showing children's toys now that Christmas is coming this year too, and a flyer from a newlyopened pizzeria showing their menu and advising us that they make home deliveries. At the bus stop on the way to work we shelter from the rain between a poster showing a new type of telephone and one showing balmy beaches with white sand and palm trees. At the bottom of the picture we are given details about how it is easiest to get there. As we travel to work, giant hoardings flash their messages along the roadside. To be a successful and accepted member of society you must have this! Buy, buy, buy! Once at work, we start the computer and are immediately confronted with pop-ups encouraging us to follow a specific course of action.

Advertising is ubiquitous and exists in a multitude of forms. What is common to every advertisement, however, is that is the means by which the advertiser tries to persuade us to act in such a way that the consequences will in some way be to his or her advantage. In other words, advertisements are examples of what John Austin (1962) calls “perlocutionary acts”, or speech acts performed with the intention that they will lead to specific, pre-determined consequences. Advertising is a communicative act or activity which is extremely well represented in what Angelika Linke, (2007:474) using a term borrowed from Luckmann, refers to as our "genre spectrum".

\section{What is a genre?}

The word "genre" comes to us via French from the Latin to mean a kind, or class and is a concept found in the fields of art, music and literature, for example, and genre analysis has now become a tool of applied linguistics. Genres construct our social reality and play a major role in our communicative budget. "[G]enres are socially ascribed classifications of semiotic form ${ }^{9}$ [and] exist only in so far as a social group declares and enforces the rules that constitute them" (Hodge \& Kress, 1988:7). Foucault (1966) has stated that we are predisposed to sort and categorise the different elements of our world, and while agreeing that "the urge to classify is fundamental" Carolyn Miller (1984:151) has insisted that genre goes beyond the substance and form of the discourse which it classifies and is instead "social action".

Despite the numerous forms in which advertisements reach us and despite the variety of media that advertisers use to channel their messages, we generally have "a very clear and definite conception" (Winfried Nöth 1987:279) ${ }^{10}$ about what advertising is and recognize an advertisement when confronted with one. I argue that this is because advertising is a "communicative genre"11 and as such, is part of our cultural knowledge and social memory. Arthur Asa Berger (1997:37) has pointed out that as we are socialized from childhood to adulthood we absorb the conventions of the different genres which we inevitably encounter.

Genre is omnipresent and as Jacques Derrida (1980:65) teaches us, "there is no genreless text”. However, there is no consensus on the meaning of the term. ${ }^{12}$

\footnotetext{
${ }^{9}$ Thus paintings, music, and texts of all kinds are categorised by genre and divided further into sub-genres.

${ }^{10}$ Richards \& Curran (2002) have investigated definitions of advertising from a number of sources including text books and dictionaries in an attempt to find consensus as to whether an activity is advertising or not.

${ }^{11}$ For a discussion and overview of the term and concept "communicative genre” see Linke (2007).

${ }^{12}$ See for example Alistair Fowler (1982), Daniel Chandler (1997) who provides an overview of definitions and discusses the construction of the audience and their need for "cultural capital", William Hanks (1987), John Swales (1990) whose interest is primarily in the field of Applied Linguistics and who studies genre as a means to help students to learn to recognize and reproduce constituent parts of academic and texts, provides an overview and also refers to the definitions provided by other writers. Vijay Bhatia (e.g. 1993, 2002) has also written
} 
Anna Trosborg, (1997) reports that one of the prevailing questions is whether the criteria for identifying and defining a genre are internal or external to the text, or a combination of both. ${ }^{13}$ This is a question that is very relevant in the case of an advertisement. Do we recognize an advertisement because of what it says or because of its form or because of where it is, for example?

Writing in 1924, Yury Tynyanov (1977, in David Duff 2000) stressed the importance of studying genres in relation to one another and as a constructive principle rather than as a repertoire of devices. He claimed that there can never be any static definition of a genre which covers all its manifestations as the development of a genre does not follow a straight line but is a process of evolution and even of revolution. In his analysis of the fairy tale as a specific genre, his contemporary, Vladimir Propp $(1968,1971)$ insists that to understand the evolution of the fairy tale, we must consider its environmental circumstances as a tale is born out of life, even if it reflects this only weakly He discovered (1971) that certain features or functions are constant and are transformed ${ }^{14}$ from one tale to another.

The stances of these two scholars are by no means incompatible and both are relevant to a study of the genre of advertising which is a genre that is both embedded in the prevailing social climate and in a constant state of evolution. Discussing literary forms, Tynyanov suggested that even when a form undergoes a great change, if sufficient, often secondary features that have been taken for granted and do not seem to characterise the genre at all are preserved, it is still recognisable. This observation seems also to hold for advertisements. ${ }^{15}$

However, another aspect of the development of genres was observed by Tzvetan Todorov some fifty years later; ${ }^{16}$ genres originate in other genres, and "a new genre is always a transformation of an earlier one, or of several: by inversion, by displacement, by combination" and can be described as "a system in constant transformation" (in David Duff, 2000:197). In short, as Briggs \& Bauman (1992:149) have commented; "genres leak”. Alistair Fowler (1979) ${ }^{17}$ provides a rather unusual approach and makes an interesting comparison between genre changes with changing fashions and taste, explaining that different times have different tastes and what makes a strong impression on the public in one age is not interesting in another. It is my contention that Fowler's observation is extremely pertinent in the case of advertisements. $^{18}$

extensively about genre in academic and professional contexts while Briggs \& Bauman (1992) take a more socio-cultural approach. Bauman (1996) discusses the role that genre plays in illocutionary force and Cook, (1992, 2001) whose main focus is the genre of advertising and its interface with literary studies.

${ }^{12}$ See for example Linke (2007:476). Cook (2001:7) posits that advertising is a "particularly slippery case" of an already fuzzy category.

${ }^{13}$ This is in line with Foucault's musings on the criteria by which one is to isolate any of the "unities" with which one deals in order to be able to define them (1969:6).

${ }^{14}$ The concept of transformation in modern genre theory is used in two related but distinct senses. One is diachronic and denotes a significant modification of a genre in the course of its historical development while the other is synchronic. Propp's approach uses the term in both senses. His enumeration of the different forms in which motifs appear across a range of texts is synchronic, while defining the types of mutations or transformations that give rise to the differences is diachronic. My approach to my corpus involves both senses.

${ }^{15}$ Guy Cook (1992:xv), compares advertising with literature and points out that there is as little consensus as to what constitutes literature as there is about the status and morality of advertising.

16 Todorov wrote in 1976 but I will refer to the English translation from 1990 that is found in Duff (2000).

${ }^{17}$ Fowler (1979:103) produces a paradigm of the main genres over time beginning with Cicero. This shows not only how their numbers increased but also how the "fashions" changed.

${ }^{18}$ Gérard Genette (1992) has demonstrated the confusion that underlies the notion of genre, tracing this back to a misrepresentation of Plato and Aristotle. He shows how the "all-too-seductive" triad of lyric, epic and dramatic which has been the foundation of many genre theories, conflates the two categories, "mode," which he suggests 
A genre is a social accomplishment defined by the communicative purpose that it is intended to fulfill, and therefore communicative goal and cognitive structure are linked (Trosborg 1997) and Bhatia (2002:6) has referred to examples of genre as "conventionalized or institutionalized artefacts". This is in line with Todorov who insists that genres "exist as an institution" and that is for this reason that they function as 'horizons of expectations' for readers and as 'models of writing' for authors” (in Duff 2000:199). Todorov's contention is that genres "communicate indirectly with the society where they are operative through their institutionalization" and that just as any other institution, "genres bring to light the constitutive features of the society to which they belong” (ibid: 200). Ireneusz Opacki (1987) has contended that socio-historical factors shape a specific attitude towards the world and bring about the rise of a new trend that better fits the genre to the internal tasks and problems that it has been developed to address (in Duff, 2000, 118-119). He has used the term "hybridization" to refer to the process of evolution through cross-fertilization that occurs when, in the course of their historical development, other genres enter the sphere of influence of the dominant genre, or "royal genre". This view is compatible with what Clifford Geertz has referred to as the "blurring of genres".

Some Marxist theorists and commentators have considered genre to be an instrument of social control and a means of reproducing a dominant or desired ideology, (David Chandler, 1997:4), and an advertisement is certainly an institutionalized genre which in some ways can be considered to fulfill this role. However, due to the genre memory that we have acquired over the course of our socialization, we can usually recognize it as such and have acquired the cognitive skills to interpret and respond to the message accordingly. Intuitively, we recognize enough of the constituent parts of the text before us to understand that it is an advertisement. The physical advertisement itself is a "frame" into which the "concrete contents" (ibid:.xxi) or typical constituent parts that go to make up the advertisement are arranged. Just as genres in general do not have unchanging, fixed constitutive features (Opacki, 1987, cited in Duff 2000:123), neither are the prototypical elements that constitute an advertisement immutable. I consider that a print advertisement is a very clear example of the category "gestalt" that Angelika Linke (2007:478) introduces to the concept of genre, and that despite the multiplicity of styles and even media which advertisers use, an advertisement has a prototypical structure which makes it recognisable as an instance of the genre "advertisement". ${ }^{19}$ This structure can be adhered to more or less faithfully, or can be ruptured and made to jar with the reader's expectations and thereby create interest. A successful "rupture" can eventually become embedded into the genre and lead to a new sub-genre or to the development of the primary genre.

Fairclough (1995:85) has identified three different “conceptions of genre” which he discusses in terms of their value for analyzing media discourses. It is my contention that Fairclough's first type of media genre, the schematic view, in which he identifies four elements, the headline, the lead, the satellites and the wrap-up, is particularly pertinent to a study of the prototypical structure of advertisements, and that is the presence of one or more of constituent parts that suggests to us that what we are seeing is an advertisement.

Two scholars who have contributed to genre theory are particularly important to my study. The first of these is the Canadian critic, Northrop Frye, whose Anatomy of Criticism (1957)

is essentially linguistic and specifies the means of enunciation, and "genre", which is literary and defined by thematic as well as formal criteria. However, as he points out, trying to define these `archigenres' as ideal or natural types is not possible as their relationship is complex and often one of inclusion. This is a stance with which Jacques Derrida (1980;59) generally acquiesces.

19 This seems to hold for all advertisements irrespective of the medium in which they are displayed. 
has been hailed as one of the most original contributions to poetics since Aristotle (Duff, 2000: 98). Frye conceived four fundamental categories in literary forms: comedy, tragedy, irony/satire and romance. From these, he built a theory of "myths" and linked each of these mythoi ${ }^{20}$ with a season. It is his Mythos of Summer, or Romance, that is central to my interpretation of the advertising of the companies involved in the oil industry.

The Romance, as Frye himself expresses it, "is nearest of all literary forms to the wishfulfilment dream". According to Frye, a general feature of society in every age is that "the ruling social or intellectual tends to project its ideals in some form of romance” (1957:48) and virtuous heroes and beautiful heroines represent the ideals that they wish to portray and to promote. Romance is marked by its search for some kind of golden age and inevitably, the plot is adventure and involves a "quest". The quest of the Romance is for some form of treasure or wealth, which according to Frye, "means in its ideal forms, power and wisdom" (ibid: 51). This observation corresponds to those made and developed by Propp (1968) and discussed and substantiated by Christopher Booker (2004). Arthur Asa Berger (1996:43) has modified Propp's basic functions and I will show how these are recurrent themes in the advertisements that make up my corpus. ${ }^{21}$ Frye (1957:47) postulates that in the Romance, "all the reader's values are bound up with the hero". Hence the "hero of romance is analogous to the mythical Messiah or deliverer”, (in Duff, 2000:100). Frye also points out that a common theme of quest-romance is that of dragon-killing and I propose to show that both the quest and dragon killing are recurring themes in the advertisements that make up my corpus. ${ }^{22}$ As Bakhtin has observed in his discussion of the characteristics of genre and plot $(1984: 104)$ "[t]he adventure plot (...) is precisely clothing draped over the hero, clothing which he can change as often as he pleases”. This heroic positioning becomes evident from a close reading of the advertisements of the oil majors. ${ }^{23}$

Any discussion of genre and genre theory must include the work of Mikhail Bakhtin and his Circle, and Bakhtin is the second scholar whose work is central to my study. No serious investigation into the world of advertising can ignore the insights that his contributions to our understanding of the underlying processes of communication afford. For Bakhtin, ${ }^{24}$ genres are a social concept and constitute a fundamental feature and requirement of human co-existence. They also bring meaning to the "shared, abstract, linguistic markers" (1981:282) of (literary) language. The "specific organisms called genres" knit together the lexicological, semantic and syntactic features of language "with the intentional aim, and the overall accentuated system inherent in one or another genre”. Developing and extending Saussure's concept of parole, he takes the stance that individuals do not have the freedom that parole assumes they have as there is no total freedom in the way that we can combine words and the forms of language.

\footnotetext{
${ }^{20}$ Frye uses the term mythoi to denote "four narrative pregeneric elements of literature [or] generic plots" (1957:27)

${ }^{21}$ Among Berger's list of basic actions, those most relevant for my corpus are: cooperate, help, initiate, pursue, search for, tell truth, question, protect and suffer, while among the heroic goals, to succeed in a quest or task and make up for a lack dominate.

${ }^{22}$ Although Frye's notion of Romance is central to my findings, we must not ignore comedy. Some of the advertisements in my corpus, for example some of the early Shell series, depict and make use of the comic, or in Bakhtinian terms, the carnivalesque aspects of life, particularly in their use and representation of characters. As Frye points out, (1957:29) the tendency of the comic society is to include rather than to exclude, and I will demonstrate that through comedy, the advertisements embrace all levels of society.

${ }^{23}$ However, Roland Barthes sees a danger in myth in that it "allows layers of meaning to accumulate within its representations of culture, and encourages unreflective practices." He claims that the truth of myth characterises 'what-goes without-saying' and in this way, leads to ideological abuse. (Peter Pericles Trifonas 2001: 10).

${ }^{24}$ Briggs \& Bauman (1992:145) make the interesting observation that although Bakhtin's comments about genre provide new and often revolutionary insights, his own definitions are strikingly similar to those of Aristotle.
} 
Instead he contends, "We learn to cast our speech in generic forms and, when hearing other's speech, we guess its genre from the very first words" (1986:79).

In his introduction to Vern McGee’s 1986 translation of Bakhtin's Speech Genres and Other Late Essays, Michael Holquist has pointed out that Bakhtin shows us how "genres are not constructed with words as they exist in the system [he] calls mere language, but rather as they are present in communication" (ibid:xvi). The effect of this is that the concept of genre is transported into the here and now of the participants in the communicative event. ${ }^{25}$ As Volosinov (1986:20) has stated, “[a]ll [... ] forms of speech exchange operate in extremely close connection with the conditions of the social situation in which they occur and exhibit an extraordinary sensitivity to all fluctuations in the social atmosphere”. This is in line with Goffman's notion of self-presentation (1959) and Weinstein \& Deutschberger's concept of alter-casting (1963), for example. That this observation clearly holds in the case of the advertisements produced by the oil companies is something that I intend to demonstrate.

Bakhtin's reading of the novel as a genre raised questions about traditional literary categories which are equally applicable to the advertisement as a genre. Like the novel, the advertisement "parodies other genres [and] squeezes out some genres and incorporates others into its own peculiar structure, reformulating and re-accentuating them" (1981:5). ${ }^{26}$ Bakhtin says of what he terms "high genres" that they are "woven by various intermediate links and connective tissue into the unified fabric of the heroic past and tradition" (ibid: 18), and I propose to demonstrate how this can also be said of the creation and development of advertisements and are connected with the mythoi of Frye. However, not only echoes of the epic, but also of the serio-comical or carnivalesque can be found among the print advertisements of the oil companies. According to Bakhtin, the characteristics of the seriocomical $^{27}$ are that it is situated in "a zone of familiar contact with the open-ended present" (1984:108), relies on experience and free invention and that it often involves parody and retold dialogues. Typically, the characters of the carnivalistic advertisements are lower class $^{28}$, and in this way, act to include different social groupings as participants in the communicative event created by the advertisement.

The deep structure of an advertisement parallels the different levels of communication that Bakhtin uncovered within the novel. He showed how the different characters were in constant dialogue with themselves ${ }^{29}$, with each other, with the reader and with society and in doing this, he devised a new terminology with which to express his ideas. Among Bakhtin's terms, some of the most central to my study are polyphony ${ }^{30}$ and polyglossia, which refer to the

\footnotetext{
${ }^{25}$ As Sheila Vieira de Camargo Grillo (2007) explains in her exposition of epistemology and discursive genres as postulated by the Bakhtinian Circle, the constitutive aspects of the énoncé are dialogical in their nature and excite a response in the other. Thus, the style and form of the composition of the énoncé are conditioned by the anticipated or desired response of the addressee, which in turn, is dependent upon the knowledge and opinions that he or she holds (22).

${ }^{26}$ Again, this notion is echoed by Fairclough (1995) in his discussion of media discourses, a communicative genre to which advertisements belong.

${ }^{27}$ This term is used by Bakhtin in Epic and Novel (1981) and also appears in a number of dictionaries.

28 The use of lower class characters to bring comic relief or to provide other, less heroic voices has been typical of English dramatic genres since Shakespeare.

${ }^{29}$ Hubert Hermans (2001) has referred to the "dialogical self” as a "theatre of voices” and Viveka Adelswärd (2000) has also developed this notion.

${ }^{30}$ Polyphony is a concept that derives from music and refers to the existence of a diversity of voices and points of view in a text. Jean-Claude Anscombre (2009: 12), who disagrees with Bakhtin's view of polyphony, suggests that the constant references to Bakhtin attributing to him the term and concept are a founding myth rather than a scientific fact. Oswald Ducrot, another central figure in the pragmatically oriented group to discourse analysis also refutes Bakhtin's views and proposes a triadic view of polyphony. Ducrot (1980) focuses on understanding
} 
hybrid nature of language and of the different voices that can be heard in a text or utterance ${ }^{31}$ and heteroglossia, ${ }^{32}$ which Bakhtin explains as the generation of meaning by the "primacy of context over text" (1981:xx) or a means of communicating "specific points of view on the world" (ibid:292). ${ }^{33}$ Another term attributed to Bakhtin which is extremely important here is the concept of alterity. Indeed, Bakhtin (1986: 97) asserts that if one does not "account for the speaker's attitude toward the other and his utterances (existing or anticipated), one can understand neither the genre nor the style of speech".

Advertising involves "authoring”. An advertisement is very much a form of communication and its reception is a communicative event. As such, advertising is a social practice anchored in a specific socio-cultural and historical context. If it is to succeed in its purpose, an advertisement must satisfy all the requirements of shared meaning making, including the phatic. As Michael Holquist has affirmed in his translation of The Dialogical Imagination, (1981) Bakhtin extended the concept of authorship to encompass speech and effectively abolished, or at least blurred, "the cardinal distinctions between written and spoken texts and aesthetic versus nonaesthetic use of language." This is something that is very clear in advertisements.

\section{Prototypical advertisements}

Before introducing the other aspects that I consider to be central to advertising as a communicative genre, I will illustrate and discuss the four prototypical structures that characterise print advertisements and introduce some of the basic communicative techniques that they employ.

Winfried Nöth (1987:280) accounts for an advertisement as "a complex of semantic frames" rather than as a genre. Using the concept of "frame" as "an organisational principle, relating a number of concepts which by convention and experience somehow form a "unit" which may

an utterance from a specific semantic perspective situated at a specific point in time and introduces the notion of the split subject, the speaking subject, the locator or speaker and the enunciator or utterer. This can be compared with Goffman's (1981) participant roles and with Ädelswärd’s(2000) inflated speaking subjects. Ducrot also proposes a split hearer, the listener, the hearer and the addressee or receiver. Both impose their attitudes on the utterance. An overview of Ducrot's idea of polyphony is provided by Johansson \& Suomela-Salmi (2011:89) and is elaborated by (Eddy Routlet, 2011:212). While Bakhtin works within a frame of the sociology of interaction, Ducrot focuses on what he calls 'ideal discourse structuralism' and distinguishes the following entities: the speaking subject (an empirical being who is the physical agent of the utterance), the speaker (who can say ' $\mathrm{I}$ ') and the enunciator, a discourse being corresponding to a certain point of view which has not necessarily been expressed by the speaker. The ScaPoLine group, (Scandinavian Polyphonic Linguistics) represented by Henning Nølke, Kjertin Fløttum and Coco Norén (2004:152) develop this further to propose four distinct polyphonic relationships: authentic polyphony which implies equality among the voices and sources of the various points of view, and they state is that defined by Bakhtin, mixed polyphony, which displays neither equality nor hierarchy, and two forms of hierarchical polyphony. Although the voices and sources of the points of view that are displayed in any form of advertisement are scarcely egalitarian and the voice of the advertiser dominates, I use the term polyphony in the sense that is traditionally imputed to Bakhtin.

${ }^{31}$ My understanding of the terms polyphony and polyglossia, which refers to the intermingling of languages, cultures and perspectives, is that polyphony is the dynamic, creative act and that polyglossia is the result.

${ }^{32}$ David Danow (1991:51) has discussed heteroglossia, or different styles as Bakhtin's "master trope" for elucidating a theory of the novel. Danow summarises the way in which heteroglossia first conveys a sense of creative tension that has its origins in the centripetal and centrifugal forces of literary and extraliterary languages in the novel and secondly, the presence of socio-ideological languages, such as those of specific professions and genres. It is my contention that heteroglossia is a common feature of advertisements.

${ }^{33}$ Bakhtin is not consistent in his definitions and has also described heteroglossia (1981:278) as element that is always present in the poetic image, in the image-as-word, when acts of verbal recognition of a word in context occur. 
be actualized in various cognitive tasks" developed by van Dijk in1977, he contends that the "ADVERTISEMENT-frame will represent the main elements of our knowledge about the text genre and our expectations about a typical advertisement" and identifies a number of subframes, consecutive frames and parallel frames. Nöth's (1987) primary distinction is between the pragmatic frame, which describes the process of advertising and the acts that this involve, and the textual frame which is the one that interests me. This frame comprises an outer frame and incorporates those "formal indicators that distinguish the advertisement from the surrounding messages" (281) such as location, graphic framing, typography and the particular section of the paper in which it appears, and the inner textual message. The inner frame contains those elements or "content units which constitute the textual core message of a typical advertisement” (284) and this is my main focus of interest.

In simple terms, "[a]ll advertising is a message: it involves a source of utterance, which is the firm owning the product being launched (and praised), a point of reception, which is the public, and a channel of transmission, which is precisely what is called the support of advertising” (Roland Barthes 1994: 173). An advertisement is, of course, produced by a team of specialists including copywriters and artists, and it is they who create the advertisement and who actualise the vision and desire of the company. Erving Goffman's participant framework (1981) can provide a point of departure which can explain and categorise these roles. Following Goffman, source of utterance, the company or party whose ideas are communicated in the advertisement, is the principal, the "party to whose position the words attest" (Goffman1981: 226), the copywriter with the other members of the creative team is the author, and the character who utters the words in the advertisement is the sounding box. In addition to Goffman, a number of scholars have addressed the matter of participant roles in speech acts, (Jan Anward, 2002, Ann Banfield, 1982, Stephen Levinson, 1988) and have suggested a variety of terms to deal with the different actors that may be involved. James McCawley (1999:595) insists that terms are not absolute but are dependent upon the frames and temporalities in which they occur, and provides interesting examples of how both "speaker" and "hearer" conflate into different roles. This is a position which is endorsed by Adelswärd (2000) who illustrates how absent or virtual speakers commonly participate in communicative events and shows how unpacking the participants analytically leads to numbers much larger than those on the surface. However, as my interest centres on the finished advertisement, my focus is on the sounding box and the different ways in which this role is made manifest and also on the role into which the public is cast. For the sake of simplicity, I will refer to the public as the reader even when the advertisement consists predominantly of a visual and the textual elements are subordinate to this.

Fairclough (1995:5) has asserted that in media texts, a group to which advertisements belong, three questions are central. These are how the world is represented; what identities are set up for those involved; and what relationships are set up between the different participants. These three questions are also central to the concept of dialogism.

Print advertisements tend to belong to one of four types. The first form of advertisement (figures 3:1) is not so usual today, but was the most common when advertising was in its infancy. It comprises a text which typically names the product or service and explains why it is beneficial. The participants in the communicative event are the sounding box, the author of the text that represents the company voice and the reader. While this type of advertisement requires might not require a great deal of cultural processing on the part of the reader, it always requires a cognitive effort as it must be read. 
However, if we look more carefully at the example in figure 3:1a, it becomes clear that although the reader is not directly addressed, the company voice is engaging with the reader who is required to make an effort to understand and appreciate the message being communicated. This is done both through the lay-out of the information presented and the attention-grabbing size of "Performance is proof" which is repeated in the company name "Shell" and thus frames the message. The language of the advertisement is poetic (Jakobson 1960) in the sense that it makes use of alliteration "Performance is proof but claims prove nothing," and the repetition and recycling of not only of vocabulary (proof /prove, performance is proof/ performance never achieved, across the Atlantic/ across Africa), but also of structures is recurrent. Moreover, while the advertisement makes use of the fact that "Shell" flew all the way to Australia, apparently without any human intervention, the illustration shows a ship, the traditional way of travelling to Australia as well as the new means of transport, the aeroplane. This apparently simple advertisement also incorporates references to earlier advertisements that show Shell providing the motor spirit for sea journeys, as well as for record-breaking flights; something about which that the reader is expected to be aware.

\section{Image removed due to copyright.}

\section{Figure 3:1a: simple Shell text} advertisement 1924

\section{OilO is the best company. OilO products are the best. People who use OilO are intelligent and discerning.}

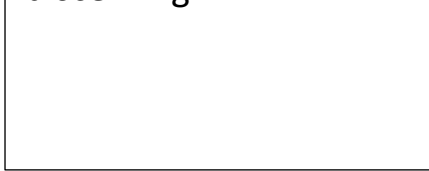

Figure 3:1b: simple generic text advertisement

The advertisement in figure 3:1b includes a number of different voices as the company logo ${ }^{34}$ is shown in a corner of the page, adding yet another layer of company participation to the communication. In this generic example, the company voice is represented iconically through the logo within the advertisement itself. This very simple example begins to illustrate the complexity of participant roles and relations in an advertisement.

The second type comprises an image and a simple text, often just a name. This type of advertisement (figures 3: 2) display a number of communicative functions.

\footnotetext{
${ }^{34}$ A distinction should be made between a logotype, a name, and a logomark, which is a symbol or icon. For example, Shell commonly use just a logomark although some versions of their logo (those from 1948, 1958 and 1961) included the company name in the middle of the Shell mark, a so-called combination mark. They reverted to a logomark in 1972.
} 
In the example provided by figure 3:2b and framed within a simple figure, is a single word and it is this that holds the message. ${ }^{35}$ In the example shown in figure 3:2a however, the company name is accompanied by a slogan. First, the reader is expected to recognise the text as a member of the genre "advertisement" and understand that this is, in fact, an advertisement for the product. The product might already be known to them, and the advertisement acts to remind the reader of its existence and to trigger a repurchase. Alternatively, the reader is made aware of this product and becomes interested to know more and to purchase it. The participants in the communicative event are again the company voice and the readers. Readers fall into two main categories; first, those who might simply see the message and second, vehicle owners, who are potential customers and therefore are the intended recipients or intended readers whose response is invited. The most basic context involves understanding that this is an example of the genre advertisement, and responding accordingly.

\section{Image removed due to copyright.}

Figure 3:2a simple Shell advert UK 1930s

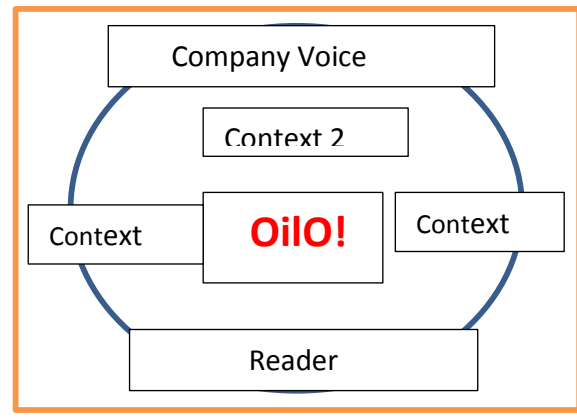

Figure 3:2 b simple generic advert

It must again be stressed that advertisements and advertising campaigns appear within a specific social and historical context. The circumstances or contexts in which the Shell advertisement in figure 3:2a first appeared are not those of today, and thus it is composed of intertextualities and connotations that the British reader of 1930, the intended reader, might recognise and react to, but which are by no means obvious to today's readership. In this apparently simple Shell advertisement there are a number of these. First of all, the colours used in the advertisement resemble those of the Union Jack. The connotation is that Shell is a British company and that patriotism stands high among its virtues. Secondly, the two figures in the centre of the advertisement are positioned and portrayed in such a way that they remind the reader of the "Quick Starting Pair" series which dates from the mid-twenties, and the reader would be expected to bring associations from that series to the new, transformed advertisement. Familiarity is blended with novelty to attract the reader's attention and to facilitate a speedy recognition and understanding of the message. The position adopted by voice of the company $I$ is therefore in alignment with the cultural knowledge and preferences expected to be typical of the intended readers.

However, the advertisements that are most common are those that involve participants who are positioned inside the inner textual frame as illustrated in figures 3 and 4 . Such participants act or perform in some way, either alone or engaged in communication with other participants within the frame. Inspired by Kenneth Burke's (1945) “dramatistic” perspective, Goffman (1959) adopted the term dramaturgy to describe the way in which individuals

\footnotetext{
35 This is an example of what Nöth (1987:284) refers to as the "minimal advertising message", the brand name or the company's name either as a verbal or visual sign.
} 
"perform" the role of their social selves in public, and named the study of social interaction in terms of theatrical performance dramaturgical analysis. Advertisements such as those shown in figures 3 and 4 often take the form of a tableau mini-drama, and Burke's Pentad (1945: xv) is a useful analytical tool for the dramaturgical analysis of an advertisement. The Pentad simply shows "what is going on". The five elements of the Pentad are Act, (what took place in thought or deed) Scene, (the background situation) Agent, (who) Agency (how) ${ }^{36}$ and Purpose, and together, they enable an onlooker to describe what is happening in a social situation or drama that is being played out. Rather than using Burke's term "agent”, however, I prefer to refer to participants within an inner textual frame as actants.

Advertising dramas can involve a single, framed actant or a number of them. Even in the case of a drama involving a single, framed actant, there are a number of potential participant formats that the advertisement can follow. For example, the actant can address the reader directly with an utterance and thus, adapting Burke's terminology, be cast as a speaking agent, or instead, be portrayed needing and receiving advice from a voice that is outside the frame and function more as a type of representant, a participant whose role is to illustrate the benefits of the product being advertised.

The examples in figures 3:3 illustrate the more common variant where an actant addresses the reader.

\section{Image removed due to copyright.}

Figure 3:3a Single participant Shell advertisement USA 1946

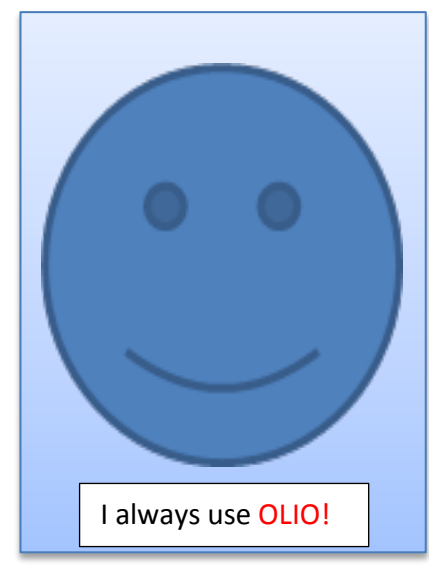

Figure 3:3b Single participant generic advertisement

In the very simple example in figure 3:3a, the Act is the re-fuelling of a motor car, the Scene is assumedly that someone has pulled up at a Shell pump for petrol, the Act is the filling of the car and the words uttered by the Agent, the petrol pump assistant, the Agency is the attendant using the pump to fill up the car with Shell and the Purpose is to inform the reader of the superiority of the product. As we are disposed to take people at their word, the reader can be assumed to interpret this statement from the pump attendant, "Share the Road and Super Shell Both Save on Stop-and-Go" as a recommmedation. The actant participant is

\footnotetext{
${ }^{36}$ Laura Ahearn (2001:112) broadly defines agency as "the socioculturally mediated capacity to act" and it is to this understanding of the term that I lean.
} 
directly addressing the reader and actively endorsing the product by naming it and recommending it. This assumption is strengthened by the smiling breast pocket portrait. ${ }^{37}$

Figures 3:4 show how although the actant participants are ostensibly engaged in private dialogue, the reader is also cast into a participating role in the small drama being played out, in this case as a member of the class, an casual overhearer, and as the audience. First, figure 3:4b provides a very simple example of this prototype but the example from Shell, although ostensibly of the same type, is much more complicated. Based on Burke (1945), I refer here to such actant participants specifically as the speaking agent, or speaker and the addressed agent, or addressee. Bakhtin has talked about the "the word with a sideward glance" (1984:237) and this form of advertisement provides a very clear example of such a phenomenon. Although the actants are ostensible engaged in communicating with each other, in the performance that is played out, speaker simultaneously addresses the other actant and the reader who is the intended recipient of the utterance.

\section{Image removed due to copyright.}

Figure 3:4a: Shell, multi-participant mini-drama from the 1930s

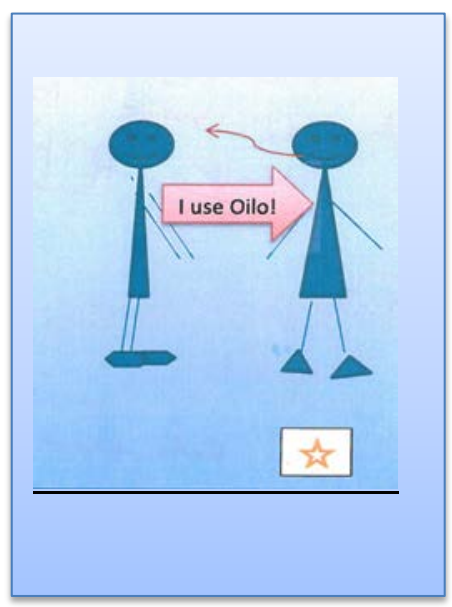

Figure 3:4b: generic multi-participant mini-drama

The postcard advertisement shown in figure 3:4a is postmarked 1912, and is an interesting example of Shell searching for a voice and one where Burke's "pentad" is a tool which can help to uncover the different forms of agency that make up this tableau, or "strip" of daily reality. This is an early example of what I will call a "dramatistic advertisement" or tableau from life and can be considered a precursor of the animated scenes that are commonly enacted in tv commercials to impel us to purchase services and commodities today.

In this example, the Act consists of the master giving a lesson on Shells and the Scene or context is a classroom. The participant Agents are the Master and the Scholar and their Agency is determined by these participant roles.

What is particularly interesting is that the utterances attributed to the actants, or agents are clearly scripted and the different elements of Burke's Pentad are clearly indicated in the textual element of the advertisement like stage directions. On the wall at the back of the classroom, we are provided with the words of the Master: "Please draw on the blackboard what you consider the finest shell” and are told that he is giving a lesson on shells. We are also told the Scholar's response, which is to draw a can of Shell Motor Spirit. "We" the readers, are informed by the voice of the drama's director or script writer, that the Scholar's

\footnotetext{
${ }^{37}$ The significance of distance and the way in which the participants are portrayed is taken up in Chapter 7.
} 
"father is an enthusiastic motorist" and that the boy "draws the 'Shell' that he has heard praised so much". This written utterance, presumably the voice of the company through the mediation of the script writer, takes us beyond what we can observe and into the mind of the Scholar. Thus, archeologically, the identity of the speaking "I" , or perhaps more accurately, the "drawing I" is on one level the boy, echoing what he has heard his father say, at a level below, it is the boy's father, and below this, the artist depicting the product and finally, the "I" of the company. The Purpose of this drama is to bring Shell to our attention and to praise its products. The actant participants, the agents, are the Master, who is the catalyst and the Scholar whose response is a drawing, which is the focal point of the advertisement. Two other Scholars represent actant witnesses to the action and the artistic perspective used in the drawing positions "us", the readers, in the classroom, standing close to the Master's desk, turned towards the board. "We" are not directly addressed but are in the room, cast in the role of audience participants watching the drama. The slightly oblique angle encodes detachment and relational equality with the Master (Kress \& van Leeuwen 1996: 140-148) ${ }^{38}$.

The Shell is in the centre of the advertisement and is the subject of the communicative event, the "it" that is being talked about. Both the Master and the Scholar are turned towards the blackboard and the "finest Shell", with their hands creating vectors which draw the eye towards the blackboard. The gaze of the other boys is also turned towards the blackboard. The Master is smiling and is obviously pleased and impressed by the Scholar's answer and does not consider that he has been facetious or insolent. The Englishness of the product is implied by the map on the wall behind the Master showing the south east of the country.

\section{The dialogism of advertising}

So far, my focus has been on the actant participants that appear in the advertisements, but despite this, it has not been possible to ignore the addressee. The purpose of advertising is to elicit a reaction, and ideally a positive response on the part of the individual or individuals addressed and therefore it is necessary to consider not only who is doing the talking, but also who is doing the listening. The distinction between information and communication is that the latter implies a relationship with "the Alter," and the building of a relationship that will achieve a preferred response, is central to advertising.

Through the examples of prototypical advertisements, I have shown that advertising is an inherently dialogical and dynamic communicative genre and as such, incorporates the "interactivity, responsivity, addressivity, contextuality, interdependencies and heterogeneities, and the dialogical appropriation of the world through semiotic means" that Per Linell (2009:267) insists are central to dialogism. Thus, it is necessary to investigate the roles played by all the different participants involved and to untangle the ways in which interactivity, responsivity, and addressivity are approached by advertisers in order to identify the voices that are heard and uncover how the interpersonal relationships among the dialogical participants are constructed?

Emile Benveniste, the founding father of enunciation theory, (Johansson \& Suomela-Salmi 2011:84) has problematized these questions. ${ }^{39}$ Benveniste (1974: 80) has taught us that an enunciation, an utterance, is the act of a speaker who mobilizes a language for his own use. In every enunciation, the speaker is designated by the first person pronoun, and thus, the Ego, or

\footnotetext{
${ }^{38}$ The notion of perspective and what this means will be discussed in more detail in Chapter 7.

39 Johansson \& Suomela-Salmi (2011) provide a useful summary of Benveniste's main arguments from the essays on pronouns (1966) and enunciation (1974).
} 
the "I" designates the speaker, the "locutor" in the specific individual speech act ${ }^{40}$ wherein it occurs (Benveniste, 1966:232). The enunciation is then appropriated by the recipient, the Alter, or "you," for whom it is explicitly or implicitly intended (Benveniste, 1974:82). This accentuation, or discursive relationship towards the partner or target recipient, (ibid: 85) whether this be real, imaginary, individual or collective, provides the figurative frame of the utterance and is dialogical in its nature. Thus, in most normal situations, the "I" and "you" are characterized by their specific uniqueness and their inherent inversibility. The " $I$ of an utterance is not the particular individual situated in a particular place at a particular time but rather the person who at this particular moment confronts, in his consciousness as subject, another individual, who for this "I" at this moment in time becomes "you". However, "you" can also be used to designate a group that is not "I" or the non-subjective person as opposed to the subjective person designated by "I". In other words, "you" can refer not only to an individual or group of individuals addressed by the "I" but can also be an expression of differentiation and of distancing the self from the other (Alistair Pennycook 1994a). Moreover, these pronouns do not only exist in the singular form. In the case of the first person "I" and "we", the plural pronoun does not necessarily refer to the nominal plural but can refer to a generalisation, a form of inclusive "mankind" as well as an exclusive "we" as opposed to "you", the others. However, for Benveniste, the very uniqueness of the subjective "I" contradicts the possibility of a true pluralisation. It creates a junction between the "I" and the "non-I" to denote "I and you" or "I and them" (ibid: 233). "We" annexes an indistinctness to "I" and becomes "prudently generalized" (ibid: 235), vague, amplified and diffuse. This elasticity in the referential potential of pronouns is a common feature of advertisements.

However, the question that I have just raised about the identities of the dialogical partners is even more complex than it might at first sight appear from Benveniste's problematisation of pronominal use, because as Hermans (2001) points out, the dialogical self is a "multiplicity of positions" 41 among which dialogical relationships can be constructed. He conceptualizes "the self in terms of a dynamic multiplicity of relatively autonomous $I$-positions" which can move from one position to another and fluctuate among different and even opposed positions (2001: 248). Building on the work of Markus \& Nurius (1986) who have argued that we have a number of "possible selves", Hermans (1996:34) lists the domains of the actual self, the ideal self and the ought self among the "theatre of voices" which constitutes the dialogical self and which moves through an "imaginary landscape of the self, ${ }^{42}$ expressing itself in the voice issued from the position assumed at that moment, the "Me" (Meira \& Ferreira, 2008:294). Peter Raggatt (2007) also shows that the dialogical self is not fixed and the positions that it adapts to and adopts tend to be situation-specific and ephemeral (359). Ellis \& Stam (2010:423) have pointed out that the positions and identities that we take "are always oriented toward some version of the good". Using the work of Ricoeur as a starting point, they state that we are interdependent and cannot envision or realize our aims without others, and uncover "an accountability in the very gap between self and other" (ibid: 433), an ethical trajectory which they map onto the dialogical self.

Uncovering and then analysing these positions or roles will make it possible to discover the identities that the companies strive to create, and facilitate an analysis of the ways in which

\footnotetext{
${ }^{40}$ Benveniste himself refers to "grandes fonctions syntaxiques” (1974:84) the great syntactical functions which he lists as interrogation, intimation, (these include imperatives, vocatives and other forms that imply a living, immediate relation between the speaker and the addressee) and assertion. Johansson \& Suomela-Salmi (2011:84) suggest that we would now refer to these as speech acts.

${ }^{41}$ Hermans (1996:33) states that this is a term which he finds more dynamic and flexible than the more traditional term "roles".

${ }^{42}$ Italics in the original.
} 
they portray themselves in order to safeguard their different forms of capital. This will be one of the tools for an archeological expedition into the polyvocal and multi-semiotic world of oilcompany advertising.

An advertisement is an act of communication whose purpose is to elicit some form of desired response. In other words, it is not merely what Austin refers to as a "constative", although this is very often an element of the advertising message, but an illocutionary act whose ambition is to persuade. Thus, a successful advertiser must have a strong audience orientation, or in other words, a clear sense of "recipient design" (Sacks et al., 1974). Kenneth Burke (1945) has insisted that the persuasive aspect of rhetoric is actually the ability to identify your cause with the interests of your audience and in the case of advertisers, has suggested that they simply want us to respond to their messages immediately and without any pause for reflection. People "adapt their practice to their addressee" as Hanks (1996:244) has pointed out, and indeed, may even try to "altercast," that is to say to project an identity "which is congruent with one's own goals", upon the addressee (Weinstein \& Deutschberger 1963:454). This is in line with Frank Cioffi's (1988) observation that by means of borrowings, the use of genre and reflexivity, advertisers can project and even create an audience. For advertisers, this is particularly important as dialogue is not simply a communication between different forms of "I" and "you", but as the attributes which Linell affords it imply, is a "living tripartite unity" Bakhtin (1986: 122) between these and the world (e.g. Dell Hymes 1972, Linell, 2009, Ivana Marková 2003). As Bakhtin (1986:122) said: “The word is a drama in which three characters participate”

This leads to the concept of the semiotic triad, the semantic whole and semantic positions that in the simplest form are constituted by "I", "thou /you" the addressee ${ }^{43}$ and "it", the Object that is the topic of discussion. Thus, just like any other communicative event, for advertising to fulfill its purpose, the participants must change and adapt in response to evolving social contexts. "...a message signifies only insofar as it is interpreted from the point of view of a given situation - a psychological as well as a historical, social and anthropological one” (Umberto Eco 1990: 131). Culture as well as context, are central to dialogical relationships. "There is no such thing as a message without a context, [and neither] can any understanding occur without a situation” (Linell 2009:17). The self is socially embedded, and individuals and their actions are constrained by culture just as much as they are enhanced by it (Ellis \& Stam 2010, 423). ${ }^{44}$

\section{The new rhetoric}

The centrality of dialogism and its insistence on "Alterity" and responsivity to advertising leads to an interest in the addressee and to the ways in which the companies muster their rhetorical resources to persuade and influence the public.

\footnotetext{
${ }^{43}$ Ivana Marková prefers to use the terms “Ego” and “Alter” and expands their meaning to include groups and even abstractions like ideologies. This widening of the concepts of "I" and "thou/you" occurs frequently in the advertisements that make up my corpus.

${ }^{44}$ For more comments on the importance of culture see for example Hermans 2001, Hermans \& Dimaggio, 2007, Peter Raggatt, 2007,Göran Sonesson, 1998).

${ }^{46}$ According to Mikael Holmgren Caicedo (2009:14) the term "rhetoric” first appeared in 385 B.C. in Plato's Gorgias and referred to the art of public speaking. However, it is perhaps Aristotle's (384-322 B.C.) concept and elaboration of the art that is most strongly associated with rhetoric today and Aristotle's idea that rhetoric is the art of persuasion "the faculty of observing in any given case the available means of persuasion" (Rhetoric, 2004:v) that is frequently cited in literature associated with advertising.
} 
Rhetoric $^{45}$ is a term that has experienced very bad publicity, and Barthes' comprehensive overview of Classical Rhetoric as a "machine" that produces "a complete, structured discourse, fully armed for persuasion" (1994:50) is perhaps typical of the rather negative view of rhetoric that predominated at least during the first half of the twentieth century. The two dominant attitudes towards rhetoric have either associated it with something "superficial, unsubstantial and superfluous" or with manipulation and the exercise of power and control (Flory \& Iglesias, 2010:113). From traditionally being a self-evident aspect of a good education, rhetoric became increasingly associated with the self-interested manipulation of public opinion and was considered rather suspect. Bakhtin (1986:150), for example, expresses an extreme view of rhetoric, contending that while dialogue is about mutual understanding, rhetoric is about victory. He claims that in rhetoric, there is the unconditionally innocent and the unconditionally guilty, victory or destruction. His contention is that "[r]hetoric is often limited to verbal victories over the word, [and] when this happens, rhetoric degenerates into a formalistic verbal play” (1981:353).

From the middle of the $20^{\text {th }}$ century, however, a new view of rhetoric and argumentation began to emerge, a phenomenon that Wayne Booth (2004:77) has considered to be a major revolution. I. A. Richards was among the theorists who objected to the traditional view of rhetoric and instead, proposed that the scope of rhetoric should be extended from a study of rules for how to speak or write effectively and should incorporate the study of language as communication (Foss et al 2002). Much of his perspective concerned how words come to mean what they do and how they serve their users. "Words mediate or serve as a screen for individuals in their thinking, feeling, and willing [...] and constitute the common world for people because they serve as common representatives of reality” (ibid, 2002:24). This is reflected in the more pragmatic stance taken by Geoffrey Leech (1983:15) who considers rhetoric ${ }^{46}$ to be "the effective use of language in its most general sense" with the goal of producing "a particular effect in the mind" of the hearer." 47 Indeed, Aristotle, defined rhetoric as "the faculty of observing in any given case the available means of persuasion" (2004:6) and identified three ways of doing this. The first of depends on "the personal character of the speaker", the second "on putting the audience into a certain frame of mind; [and] "the third on the proof, or apparent proof, provided by the words of the speech itself" (ibid:7). These three types of persuasion, or effective language use, are referred to as ethos, pathos and logos.

The concept of the New Rhetoric dates from 1958 when Chaïm Perelman and Lucie Olbrechts-Tyteca published The new rhetoric and Stephen Toulmin's The uses of argument appeared (Booth, 2004:58). The ambition of Perelman and Olbrechts-Tyteca was to create a new form of rhetoric which incorporated the written as well as the spoken word and which centred on argumentation and the listener or reader. ${ }^{48}$ Audiences are seen by Perelman and Lucie Olbrechts-Tyteca as agents of reason and reasoning who possess freedom and agency when encountering arguments (David Frank, 2010:257). They recognised three types of

\footnotetext{
${ }^{46}$ Interestingly, in his discussion of rhetoric, Teun van Dijk (2008:191) separates the concepts rhetoric and argumentation.

${ }^{47}$ Compare this, or the similarly pragmatic stance taken by Lloyd Bitzer (in Lucaites et al, 1999: 234), with the position taken by John O. Ward (2007) who posits that it is important for the survival of democracy to understand the techniques of persuasion in order to be able to counter propaganda.

${ }^{48}$ However, while Leech (1983:57) asserts that there are two "rhetorics", the interpersonal and the textual which can be characterized respectively by input constraints and output constraints the proponents of the New Rhetoric do not specifically make this distinction. Although Leech borrows his terminology from Halliday he considers that Halliday's insistence on grammar is rather misleading and also points out that the constraints are reversed for the hearer for whom Textual Rhetoric constrains input and the Interpersonal Rhetoric constrains the output of the decoding process.
} 
audience. The first is identified as the universal, ${ }^{49}$ consisting of all rational beings and the second is the particular audience which is made up of a specific segment of humanity while the third audience is "I". The "rhetorical audience is always composite as real audiences must consist of disparate individuals with differing convictions of differing intensity" (Alan Gross 1999:204) and the task of the speaker is to achieve a "synthetic unity" (ibid). The aim of rhetorical discourse is thus to gradually bring the "rhetorical audience to the desired adherence" (ibid: 203) while bringing the actual audience to the same point. Thus, the speaker must identify and construct the rhetorical audience. If audiences are constructed, then it is necessary for the speaker to understand their views of both what is real and what is preferable and form some sort of initial common ground from which his argumentation can develop. Associative relationships can be drawn into argumentation and the concept of presence allows the speaker to identify what the audience should foreground.

The focus of the New Rhetoric on the audience implies that the writings of Wolfgang Iser and Hans Robert Jauss are important for my study. Iser's concept of the implied reader and the role that he plays in the actualisation of a text ${ }^{50}$ is central to the way in which advertisers create their advertisements and sometimes alter-cast the reader (Weinstein \& Deutschberger 1963). Jauss' reception theory includes the historical element which is necessary to understand the horizons of expectations of the audiences addressed by the advertisements that make up my corpus. Umberto Eco (1984:7) has also taken up the question of the addressee, or "Model Reader" whose task is "to deal interpretively with the expressions [used in the text] in the same way as the author deals generatively with them". Using the terminology of Austin (1962), Eco further defines the Model Reader as "a textually established set of felicity conditions to be met in order to have a macro-speech act (such as text) fully actualized" (11). Nan Johnson (1988:152) conflates the reader response theory with rhetoric, pointing out that its affective orientation is "aligned quite closely with the traditional paradigm of rhetorical theory".

The new rhetoric stresses the importance of knowing and understanding the target audience ${ }^{51}$ and its valorization. These are issues that are central to most modern marketing manuals and fundamental to market research where identifying the market and segmentation is vital. ${ }^{52}$ As potential customers have unique needs and wants, each is potentially a separate market and must be identified and understood. To apply Bourdieu's terminology, (2001) rhetors, or advertisers, evaluate the conditions of the market to produce the linguistic expressions that are most appropriate to achieving their ends. The action of an orator is always aggressive in the sense that it seeks to change or transform the listener. It is an action that is intended to cause

\footnotetext{
${ }^{49}$ Perelman's concept of the universal audience is one of the most complicated or "vexed" in the words of James Crosswhite (2010, 305), who suggests that universality is a dynamic process which works in concepts as well as in audiences and that argumentation both depends on this dynamism and promotes it. He describes this universal audience, or "auditoire universel" as "a paragon of receptivity that possesses all the capabilities and knowledge necessary for making the most reasonable judgements about the strengths of an argument” (302).

${ }^{50}$ Linda Scott (1994b) has developed the work of Iser (1974) to propose that reader-response interpretation is also applicable to the domain of advertising. She shows how an advertising text interacts with the knowledge, expectations, emotions and motives of the reader who may then make an individual interpretation of the image. Although Scott includes the writings of Stanley Fish in her paper and refers to the expectations of the reader, she makes no reference to the work of Jauss.

${ }^{51}$ Although Bakthin insists addressivity and on identifying with the audience, he understands it as a social process that involves both the speaker and the addressee in partnership. Just like Burke, he claims that a word is not a neutral object but a "two-sided act" whose meaning is determined by negotiation between the one who speaks it and the one for whom it is meant.

52 See for example Hansen \& Riis Christensen (2007) or Magnus Söderlund (2003). See also the chapter 10, on market segmentation in Kotler et al (2005)
} 
another action. To this end, communication occurs on the audience's terms. Thus, the concept of temporality is central to argumentation, as every argument must be integrated into a perpetually changing context (Bolduc \& Frank, 2010) ${ }^{53}$. Although the work of Toulmin had a much lesser impact than that of Perelman and Olbrechts-Tyteca, he also insisted on the importance of the addressee, something that is central to my study.

The other proponent of rhetoric and the one that is most useful to my study is Kenneth Burke, whose name is firmly associated with the reintroduction and development of the art of rhetoric. Burke not only valorizes the audience, but also considers rhetoric to be a symbolic action and a dialogical process. He insists that rhetoric is "addressed" (1950:38) since its purpose is to persuade and persuasion implies an audience. For Burke, "the basic function of rhetoric, the use of words by human agents [is] to induce actions in other human agents..." (41) and the best way to do this is for the rhetor (whether a speaker or a writer) to identify him or herself favourably with the audience. Identification ${ }^{54}$ is the route to cooperation (xiv). Burke maintains that identification is necessary to compensate for the "mystery" or estrangement that exists in the domains of human experience and arises as a communicative, cooperative response. For Burke, "[i]dentification is compensatory to division" and the rhetorical situation is one of segregation and congregation (George Cheney, 1983:145). Motive and situation are also central concepts in Burke's view of rhetoric which has been described as a "response" to the situational demands perceived by the rhetor (Carolyn Miller, 1984:152). She points out that Burke noted that because of this, the matter of motivation is "liquid" (ibid: 158).

The action performed by rhetoric is to form and change attitudes and this is often best done through appealing to the addressee's emotions and thus, poetics is also an important element of rhetoric. For Burke, language is symbolic action and human action is rhetorical. Pivotal to his theory of language is the notion that the human-being is a "symbol-using/symbolmisusing” and “symbol-used” animal (Herbert Simons, in Simons \& Melia 1989:15). ${ }^{55}$ Words are not neutral tools with which we can describe reality and language is much more than a means of pointing to referents but is what shapes us all. Burke (1966:6) asks who does the talking and where the words that we hear come from and wonders whether we use words or if they use us. He likens an ideology to a god, to a "spirit taking up its abode in a body" and making it "hop around in a certain way" and suggests that in "an advertising world that is so

\footnotetext{
53 This work by Bolduc and Frank is the first translation of Perelman and Olbrechts-Tyteca's 1958 article "De la temporalité comme caractère de l' argumentation” and also provides a commentary on the essay. It is the opening article in volume 43 of Philosophy and Rhetoric, devoted to The New Rhetoric Project and incorporates their complex task of describing different forms of receptivity to arguments. In his introduction to the volume, James Crosswhite (2010:302), points out that it was Perelman and Olbrechts-Tyteca who crossed philosophy and rhetoric to open up a new field of research.

${ }^{54}$ Identify and identification are terms that reappear throughout the works of Burke and in the literature of marketing and corporate rhetoric. See for example George Cheney (1983) who uses Burke's rhetoric of identification to study organizational communication. I understand identity and identification to mean both recognising and understanding the addressee and displaying, or appearing to display empathy.

${ }^{55}$ Burke's full definition of man (1966:16) is: "Man is the symbol-using (symbol-making, symbol-misusing) animal Inventor of the negative (or moralized by the negative) separated from his natural condition by instruments of his own making goaded by the spirit of hierarchy (or moved by the sense of order) and rotten with perfection."
} 
strong on the glorification of the positive (as a way of selling either goods or bads)” (ibid:12) the negative has sometimes to be made enticing and sanctions can be built upon. ${ }^{56}$

Two other concepts developed by Burke are particularly useful to my study. The first of these is the "terministic screen", which unlike a window pane screens our realities by prefiguring and typifying them and directs our attention to a certain perspective. The second is the Dramatistic Perspective (1966: 36-39) which I have already introduced. For Burke, as we use and respond to symbols in creating meaning, human action is inherently dramatic, involving conflict, purpose and choice rather than merely motion. While Erving Goffman's view of human action is dramaturgical in the sense that it is concerned with an actor and the performance that he or she gives to influence others and on how he or she can create credibility, for Burke, the emphasis is on the play itself and on language and interpretation.

Motivation is another word which recurs throughout Burke's writings, and dramatism attempts to account for the motivational (or explanatory) vocabulary of ordinary discourse and its influence on human action as well as for particular sociological vocabularies when these are used to explain such action (Michael Overington, 1977:133). Burke enquires into the tripartite nature of motives and discusses the "language of motives, motives in language and language as motive”. He insists that there is a cultural importance of words and that the connotations which hold clusters of terms together can become justifications in themselves for action. This is notion is also encountered in the work of C. Wright Willis (1940:905) who posits that idea that "Motives are words [and the] names for consequential situations, and surrogates for actions leading to them". By naming consequences, an individual elicits behaviour and thus, by verbalising or imputing motives, an agent is influencing others (obod: 907). Further, he claims that "motives are circumscribed by the vocabulary of the actor" (ibid:910) and that "[o]ne of the components of the "generalized other," as a mechanism of societal control, is vocabularies of acceptable motives” (ibid:908).

\section{The role of the reader}

In the preceding pages I have discussed the matters of addressivity, responsivity and context. These can be illustrated and their complexity investigated by the advertisement in figure 3: 5 from 1932. The issue that we must now address is the role of the reader who is actually the most important member of the cast of participants.

First, the company voice calls out or "hails" the reader with the words "Heartiest Congratulations to Mrs. Mollison." "Hailing” is a term usually associated with Louis Althusser, and I use it here to refer to what is more traditionally referred to as the headline. Althusser took the position that if we are hailed, or believe that we have been hailed, (for example by a policeman), we naturally react and respond in some way to the call. As Renée Jarré (2007:1) has pointed out, in the case of advertising, a hailing heralds the individual who receives this message "to join in on the proposition at hand" and in this way, the advertisement "works to recruit subjects".

In this example, the identity of the addressee of the hailing is ambiguous, but the preposition "to," implies that it is the reader, rather than the subject of the congratulations. In small print underneath this hailing are the words "who again used Shell Aviation Petrol.”

\footnotetext{
${ }^{56}$ Burke (1966: 12-13) describes how the new positive powers developed by new technologies have resulted in a new era of negativity and that new "thou-shalt-not" controls have to be put in place to avoid these powers from getting the upper hand.
} 


\section{Image removed due to copyright.}

In order to fully appreciate this message, the reader should know that Mrs. Mollison is an aviator who has set and broken a number of records. The implication is that she has done this yet again and that as usual, she has used Shell. The visual is not merely amusing but has underlying meaning. On the simplest level, the giraffe suggests that she has just flown over Africa again ${ }^{57}$ and as the heads are looking up, this has happened moments ago, but on a deeper level, a culturally competent reader is expected to recognise that this is another advertisement from the popular "twoheaded series ${ }^{58}$ that had accidentally come into being some three years earlier, as the development of an earlier series. Thus, the reader does not need large print to understand that the words coming from the giraffe's mouth are "That's Mrs. Mollison ...that was!" but can probably guess what the giraffe is saying as it is yet another recycling of the original “That's Shell ... that was!” from 1930.

\section{Figure 3:5 Heartiest Congratulations}

The company voice has stepped into the advertisement to become a full participant in the event and speaks both as the company, Shell and inclusively, as a member and representative of the public to congratulate the aviator on her achievement.

Another issue that needs to be raised concerns the role played by Mrs Mollison. She is not actually present and is not directly addressed. However, in Burke's terminology, it is her "agency" that has provided Shell with an advertising opportunity and it is this that is the topic or "act" of the "scene." From this perspective, Mrs Mollison is cast in the role of topical participant. The intertextual clues provided by the advertisement enable the reader to understand that it is for Shell even without access to the overly clear explication about the product that Mrs Mollison used. Intertextuality, a term that was coined by Julia Kristeva (1969) is defined by Stef Slembrouck (2011:174) as being "about how history is inscribed into situated practice" and by Kristeva herself ${ }^{59}$ as the sum of knowledge that makes it possible for texts to have meaning. ${ }^{60}$

\footnotetext{
${ }^{57}$ Mrs Mollison, or Amy Johnson as she was better known, was an economics graduate and the first woman to gain an aeroplane mechanic's licence. In 1930, in her Gipsy Moth, she was the first woman to fly solo to Australia and one year later, with Jack Humphreys as her co-pilot, she was the first pilot to fly from London to Moscow in one day and from there, went on to cross Siberia to Tokyo, setting the time record. She married Scotsman, Jim Mollison in 1932, and although she broke some records together with her husband, she also broke his time record for a flight from London to Cape Town. To the best of my knowledge, however, after her marriage she is always referred to in the Shell advertisements as Mrs Mollison. She divorced Jim Mollison in 1938 and reverted to her maiden name. During the war, she worked as an Air Transport Auxiliary and 1941, died when the 'plane she was flying crashed into the waters of the Thames Estuary in circumstances which are still disputed.

${ }^{58}$ This series will be discussed further in Chapter 8 .

${ }^{59}$ Kristeva, who coined the term, has described a text as something that "is constructed of a mosaic of quotations" (1986: 37) and includes the way that a reader draws references to other texts as well as to the writers borrowings and recyclings.

${ }^{60}$ Based on the work of Norman Fairclough, Slembrouck (2011: 158-9) describes how an intertextual analysis shows among other things how texts draw upon orders of discourse and the configuration of conventionalized
} 
If we re-examine the example that was provided there, we can see that the advertiser "hails" the reader and draws him directly into the drama played out in the tableau or scene. Rather than Burke's choice of "Scene" I prefer the term setting to refer to the actual physical surroundings. The reason for this is that in theatrical terms, a scene is an action or part of a larger piece of action, that is played out while the set refers to the scenery and props in which this action is set. In the case of our example, the setting is a desert and the agent is the twoheaded giraffe. Thus, we are hailed by the company voice to take notice of the scene or small drama that has its setting in a desert and in which the actant participants are both speaking agents and to add our congratulations to Mrs Mollison to those expressed by this voice.

Julia Kristeva (1969:11) also favours the concept of the theatre and has conceptualised a text as constructing the mobile theatre of its movement by transforming language filling it with the social and historical. This example demonstrates how a text, in this case in advertisement, is tied to and is read in a social context, a society ${ }^{61}$.

Moreover, the advertisement provides a good example of the polyphony that is common in advertisements. Besides the company voice, which is cast in two different "I" roles, there is the voice of the giraffe, the actant.

The culturally competent reader not only recognises the reference to other advertisements in the series ${ }^{62}$ but is also required to understand who specifically the advertisement refers to. Thus, to fully understand the message communicated by this advertisement, the reader is faced with at least a double intertextuality; the factual and historical, and the internal references of the advertisement itself, both with regard to the words and to the visual. It is an example of Barthes' "déjà-lu” the already read, a play on the common expression "déjà vu;" what has already been seen, and what Jonathan Culler (1981:108) has described as "the family archive", which advertisers use as a technique to draw the reader into a sense of being part of the situation and of belonging. In short, this technique of rousing the reader's recollection of earlier advertisements and of demanding interpretation is a way of creating empathy and a sense of "we-ness." This is something that is firmly anchored in the text, which must lean on the social and political practices of the day (Kristeva 1969:17). ${ }^{63}$

An advertisement is a multi-layered communicative project ${ }^{64}$. On one level, the communication is between the advertiser and the reader, while on another level, even a print advertisement resembles one of the theatrical tableaux so popular at the royal courts of

practices that are available to both text producers and consumers, and to the dependence of texts upon society and history. These features are very obvious in the advertisement above (figure 3: 5).

${ }^{61}$ Unfortunately, Kristeva’s wordplay $(1969$ :12) « Le texte se lie - se lit doublement par rapport au réel » does not translate.

${ }^{62}$ Fairclough introduced a distinction between what he called 'manifest intertextuality' when specific other texts are drawn upon and 'constitutive intertextuality` which a type of discourse that is constituted through a combination of elements of other orders of discourse. He later renamed this latter 'inter-discursivity' (Slembrouck 2011:159). The Mrs Mollison advertisement is a clear example of the former type.

${ }^{63}$ Kristeva adds a third element of support; the ideology of the progressive class.

${ }^{64}$ The term communicative project has been attributed to Emanuel Schegloff (2007) who uses it rather loosely. Following Linell (2009), I use it as a technical term which implies dialogicality, an orientation to and concern with an addressee's response. 
England and France during the Renaissance, for example or miniature theatrical performance. W. B. Worthern (2010:24) has posited that the reality of a dramatic performance might be captured as a "double pentad" ${ }^{65}$ and I argue that the same holds true for the interpretation of an advertisement, in particular, one in which actant participants are represented. Such instances demand another type of reading and understanding of the participants in the communicative event and in the roles that they are required to play.

\section{Bakhtin, Bourdieu and Beyond}

In From Notes Made in 1970-71, Bakhtin writes that "[h][uman life is always shaped and this shaping is always ritualistic" (1986: 154). I maintain that genre is a shaping device. Indeed, in his Response to a Question from Novy Mir, Bakhtin (1986:5) asserts that genres "throughout the centuries of their life accumulate forms of seeing and interpreting different aspects of the world.” It is my contention that in this way, Bakhtin's concept of speech genre finds resonance in Bourdieu's idea of the symbolic power of language and the ways in which this is linked to habitus and field, ${ }^{66}$ and that the two scholars form a "continuous complementarity" (Robert Barsky 1995:88).

Slembrouck (2011:166) introduces his discussion of the relationship between the writings of Bakhtin with those of Bourdieu with the following quotation from Bakhtin: "A single, concrete utterance is always given in a value-and-meaning context, whether it is scientific, artistic, poetical, etc. or in the context of a situation from everyday personal life.”

This definition of language as a linguistic market displays similarities with Bourdieu's theory of linguistic practice based on the concepts of capital, habitus and market which, according to Slembrouck, "is arguably a project of linking an analysis of participant-oriented eventmeaning with an analysis of objective conditions and relations between social groups as indexed by constituents of heteroglossia" (ibid). For Bakhtin, heteroglossic relationships are sociological, and heteroglossia is the co-occurrence of "social class dialects, languages of special groups, professional jargons, [...], genre languages, the languages of generations and age groups, of the authorities, of literary and political movements, historical epochs, etc. (1981:262-3). This definition has a striking similarity with Bourdieu's view of language and of the power that it can sway. The discourse situation is related to habitus. Habitus is also transsituational capital and brings about a speaker who is a strategic player; it refers to a set of internalized dispositions acquired over time, and is the schematic knowledge which generates practices. Slembrouck (168-69) also suggests that Bourdieu's insistence on the bodily disposition of the linguistic habitus evokes a comparison with Bakhtin's concept of the carnivalesque, and of the necessity of incorporating the relations between body-image and collective identities into the concept of heteroglossia.

Among other scholars whose work combines the approaches to language taken by Bakhtin with those of Bourdieu are Ian Burkitt (1998) who insists that combining the approaches to language taken by Bakhtin with those of Bourdieu, makes it possible to develop a more practical and embodied understanding of language. ${ }^{67}$ John Myles (2013) successfully fuses Bakhtin's concept of speech genres and is belief that all "words have a "taste" of a profession" (Bakhtin 1981:293) with Bourdieu's view that any utterance is "impregnated with

\footnotetext{
65 This can be likened to Goffman's (1974) "Frame within a frame”.

${ }^{66}$ Broadly speaking, the term field is used to refer to a professional setting while habitus implies a more socioculturally bound setting or attitude.

${ }^{67}$ Burkitt (1998:165) compares “Bakhtin's notion of the fluid structure of certain speech genres and Bourdieu’s idea of generative schemes and structures found in social practices”.
} 
ideological accents," to ground a sociology of voice. ${ }^{68}$ Robert Holton, (2000) too, shows how both authors relate the use of language to common sense, "not as a system of abstract grammatical categories but rather as language conceived as ideologically saturated, language as world view” (Bakhtin, 1981:271). Holton parallels this Bakhtinian stance with Bourdieu's concept of the social significance of taste, and also suggests that the concept of heteroglossia formulated by the former is similar to the idea of heterodoxy posited by the latter. The world must be understood within a context that is culturally, physically and temporally specific, in short, within the bounds of a particular habitus. ${ }^{69}$

In his discussion of what he refers to as "auto-presentation", Barsky (1995:85) extends the partnership of Bakhtin and Bourdieu to include Goffman's insights into "face" as "the positive social value a person claims for himself by the line others assume during a particular contact.” Discussing the concept of “authoring” Barsky relates Bakhtin's insistence on how we experience and respond to outer appearance in the other to Bourdieu's linguistic law of the market place, and his view of discourse as a commodity (ibid). This can be equated with Goffman's insistence that we endeavor to present ourselves to others in a way that is strategically adapted to our definition of the situation and that will best suit our personal interests.

It is my contention that the ideas of these three very different scholars are complementary and that they combine to inform and underpin the genre and the craft of advertising.

Bakhtin has stated ${ }^{70}$ that "[f]or the writer-craftsman the genre serves as an external template" (1986:5), and a final example will illustrate this template and the prototypical "constellations of co-occurrent formal elements and structures” (Briggs \& Bauman 1992:141) of printed advertisements as well as the way in which an advertiser, in my example Shell, has mustered its rhetorical skills to elicit a positive response from the reader.

Typically, a print advertisement comprises both verbal elements and images.

The verbal elements consist of the headline, the body copy, the baseline, the pay-off and the slogan. ${ }^{71}$ Christine Wikman (2005:13) proposes a useful definition of a headline as the recurring theme of a publicity campaign and which acts as a sort of title for the advertisement. This is very clear in the Shell advertisement and it leads the reader into the body copy which provides more information. Typically, it is written in a smaller font size than the headline. The baseline is usually at the bottom of the advertisement and provides practical information such as contact details. Today, however, the traditional physical address and telephone number of the company have been increasingly replaced by an e-mail address. The pay-off anchors the claim made in the headline and often has the form of a slogan. Some advertisements also include a sub-headline to complement the headline.

\footnotetext{
${ }^{68}$ Burkitt made this observation as a result of his study into Interactive Voice Response (IVR) Services

${ }^{69}$ A number of Brazilian scholars, such as Sheila Vieira Camargo Grillo (2007), Angela Francisca Mendez de Oliveira Neil Armstrong Franco de Oliveira (2012), also draw analogies between the work of the Bakhtin and Bourdieu. See also Anthony Wall's (2001) review of Bakhtin's impact on the social sciences in Brazil.

${ }^{70}$ This statement is from Reponse to a Question from Novy Mir, a text which revolves around the concept of genre.

${ }^{71}$ The word slogan comes from the early 1500s and the Gaelic expression sluagh-ghairm . This was the battle cry used by Scottish Highland or Irish clans and is made up of the elements sluagh "army, host, slew" and gairm "a cry." Its use in the sense of "distinctive word or phrase used by a political or other group" is from 1704.

Today, slogans are commonly used by businesses to promote their goods and even by political parties to promote their ideas. Typically a slogan is between three and seven words in length. Examples are the Nike "Just do it" and McDonald's “I’m loving it”.
} 
Advertisements commonly include an image or series or images called the visual. These can take a number of forms but photographs and drawings are the most common. Finally, there is a logotype ${ }^{72}$ which is a combination of the visual and the verbal as it comprises the product or company trademark expressed graphically. Jean-Marie Flosch (2001:66) describes the logotype as the "living manifestation of a brand's identity".

These are the elements of the advertisement-frame (Nöth 1987) that help the reader to recognize that the text ${ }^{73}$ in question is a member of the genre "print advertisement".

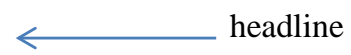

\section{Image removed due to copyright.}

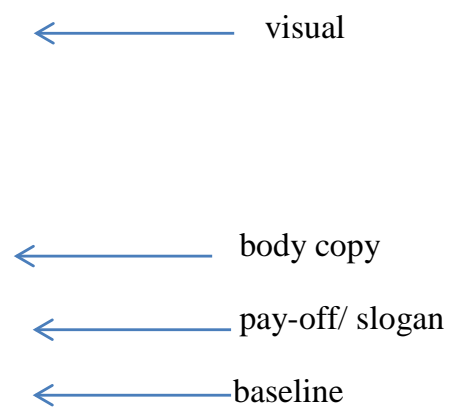

Figure 3:6 Prototypical advertisement with multiple participants

The participant roles in the example in figure 3:6 are especially complicated as besides the two who are engaged in conversation within the inner textual frame, there is a third participant, the husbandman with the bull. Following Goffman’s (1981) terminology, within this frame there is an addressed recipient, the participant who has the visual attention of the speaker and who could take the next conversational turn, and also an unaddressed recipient, the husbandman who is cast as an over-hearer, an inadvertent or "non-official" listener. However, the reader is an official hearer, or in Levinson's (1988:170) terminology, the goal of the address and is hailed in the opening, the headline, "I'll tell you something else about Shell ...”. The speaking voice is both that of the company or principal and the animator, the gentleman to the left with the pipe, who is turned towards the gentleman dressed for riding. The reader is brought into their on-going discussion as an eavesdropper, an "engineered" follower of the talk (Goffman 1981:132), a position which is reinforced by the bird's-eye angle from which he follows this conversation.

The body copy, the words spoken by the actant, speaking participant, read:

\footnotetext{
72 Flosch (2001:66) describes the logotype as "the living manifestation of a brand's identity".

${ }^{73}$ I use the term "text" in a very wide sense as a complete advertisement and include the visual elements.
} 
"Shell chemicals make the grass grow. Grass is one of the farmer's most important crops the basic feed for dairy and fatstock herds. The growing of good grass needs skilful husbandry, with nitrogen in plenty and effective weed control. Shell materials meet both these needs - with the most concentrated granular nitrogen fertiliser on the home market, and with selective weed-killers. Well-nourished and with the weeds out, the grass improves quickly in both yield and quality. This is just one aspect of Shell's overall contribution to agricultural progress. With fertilisers and weed-killers, with insecticides, fungicides and seed dressings, Shell agricultural chemicals are in the forefront of the drive to increase still further our home food production. Farming may be à way of life', but today it is also one of the nation's biggest industries - and in farming Shell chemicals are helping to cut costs, and raise yields.”

The words spoken are those of an educated man who knows and understands the needs of farmers and of grass, and the habitus is that of the gentleman farmer, a habitus commonly associated with social esteem and admiration. The speaker is attributed with the characteristics of authority, not merely through the vocabulary he uses and the confident emphatic nature of his speech brought about by the frontal positioning of the sentence topics, but also by his outer appearance, his clothing and his confident stance. He might be a representative for Shell's fertilizers or he might be a neighbouring farmer, but he understands and is confident in the milieu in which he is acting. The elegant riding dress of the other man is a marker of a wealthy gentleman farmer and the success of his enterprise is shown by his skilled, professional helpers, illustrated by the white-coated husbandman.

However, half way through the speech, the voice of the speaker changes and becomes that of the company itself rather than that of the ventriloquist actant. "This is just one aspect of Shell's overall contribution to agricultural progress." To the heteroglossic nature of the speech is then added yet another voice which moves away from the professional voices of the grass specialist and Shell with a more familiar, homely, everyday quality; "Farming maybe a way of life" and introduces a new aspect of the role played by Shell in society, emphasizing its importance. Farming is now an important national industry, and Shell thus cast themselves in the role of a true patriot working towards bettering "our" home food production. Shell has moved its position from the third person topic with the implications of distance and objectivity that this affords to being one with the reader in an inclusive "we-ness".

This raises another aspect of the reader's role and of the importance of understanding the social and historical context in which the drama of an advertisement is played out. The advertisement dates from 1958 and the contemporary reader would be very aware that rationing had only recently come to an end after WWII and also of the importance of national self-sufficiency, in food production as well as in other areas. Finally, the advertisement ends with a baseline that provides contact details. This offers the reader an opportunity to go enter into a deeper relationship with the company. Another point of interest is that it was published in The Economist, a weekly periodical whose readership would be expected to be welleducated and relatively wealthy and influential, and this advertisement and the others that make up the series also imply that Shell might be a good investment opportunity.

This chapter has outlined the approaches that underpin my study of the print advertisements of the companies in the oil industry.

One of the central concepts is that an advertisement is a genre and as Tynyanov pointed out in 1924, genre is in a constant state of evolution that is driven by both historical and cultural events and fashions. Therefore the following chapter provides an overview of the historical development of the genre of advertising and looks in particular at the ways in which the oil industry has been implemental in the ways in which it has evolved. 


\section{Chapter 4}

Oil Companies in the History of Advertising

As the purpose of this study is to analyse and discuss the advertising discourse of the oil industry in order to uncover the different and changing messages that the major companies communicate and the means by which they accomplish this task, I begin this chapter with a historical overview of advertising ${ }^{1}$ before going on to describe the contributions that the industry has made to the development of advertising. My intention here is to anchor the phenomenon of advertising as a communicative genre with a long and colourful history, and to describe the social and historical contexts which have shaped its development. The previous chapter showed that although there is no single, clear definition of the term, the general agreement is that despite the "fuzziness" of the concept, ${ }^{2}$ a genre is always anchored in a socio-cultural reality, is shaped by history and evolves throughout its history. Thus, a historical overview of the development of advertising is a useful and appropriate point of departure.

\section{What is advertising?}

The Concise Oxford English Dictionary defines advertising in its earliest sense as "to make generally or publicly known" or "to seek (for) by public notice". According to Raymond Williams, however, (1980:170) the earliest advertisement is often considered to be a three thousand year-old papyrus from Thebes, offering a reward for a runaway slave. The paintings urging people to go to watch the contests between gladiators in the ruins of Pompeii and flybills on the pillars of the Roman Forum are also examples of early advertisements, while Guy Cook (1992:4) puts forward the sugggestion that the earliest known advertisement is for a brothel in Ephesus. From these examples, we can see that even in these early cases, the information that is made known offers some sort of reward or satisfaction to those members of the public who respond. In other words, the information communicated in an advertisement differs from that communicated for example, by a notice to the effect that the train has been cancelled or that road works will delay traffic.

Common definitions of advertising involve the idea of "drawing attention to" something, often to promote sales. Richards \& Curran (2002), who have investigated definitions of advertising from a number of sources, including text books and dictionaries in an attempt to find consensus as to whether an activity is advertising or not, cite for example, Daniel Starch, (ibid: 63) who in 1923, suggested that the "simplest definition of advertising, and one that will probably meet the test of critical examination, is that advertising is selling in print." 3 A more up-to-date definition, which includes the ambition on the part of the advertiser to elicit some kind of response and which also incorporates technical advances and encompasses a broader range of media can be found in the American Heritage Dictionary (2000):" The activity of attracting public attention to a product or business, as by paid announcements in the print, broadcast or electronic media". Thus, as advertising evolves in accordance with the

\footnotetext{
${ }^{1}$ Ronald Savitt (1980:52) has emphasized the importance of historical study for gaining an understanding of the origins and patterns of change that can be discerned both in a discipline and in society at large.

${ }^{2}$ See for example Angelika Linke (2007:476). Guy Cook (2001:7) posits that advertising is a "particularly slippery case" of an already fuzzy category.

${ }^{3}$ However, as Starch was writing in 1923, this definition is not really appropriate for today when printed advertisements are found not only on paper, the only medium which he considered, but also for example on teeshirts, bags and mugs. As Qvarsell \& Torell (2005:11) insist, in a historical context, a definition of the term must be rather general and open, as over time, major changes have taken place, which affect both the economic and communicative conditions of advertising as well as those that concern the actual marketing of a product or concept.
} 
framework which is imposed upon it by the society in which it operates, any narrow definition of the word risks omitting or excluding some relevant aspect of the phenomenon. ${ }^{4}$

Among the more traditional definitions of the various phenomena and activities that constitute the world of advertising, and which I incorporate into my own use of the term, Philip Kotler et al. (2005:905) provide the following: advertising is "[a]ny paid form of non-personal presentation and promotion of ideas, goods or services by an identified sponsor", marketing (ibid: 914) is "[a] social and managerial process by which individuals and groups obtain what they need and want through creating and exchanging products and value with others" 5 and a brand (ibid: 906) is a" name, term, sign, symbol or design, or a combination of these, intended to identify the goods of services of one seller or group of sellers and to differentiate them from those of competitors". ${ }^{6}$ As Naomi Klein (2000: 5) has pointed out, although the terms advertising and branding are often used interchangeably, they are not the same process. Branding can be considered as the "core meaning of the modern corporation" while advertising is "one vehicle used to convey that meaning to the world".

Branding can be closely related to the concept of corporate identity which Göran Rossling (2001:14) defines as "the interface between the company and the surrounding world" or "the sum of everything that a company says or does ... the soul of the organization" and which is projected through people, products, design and advertising. Today, this is often achieved at least in part by corporate narrative or storytelling and by relationship marketing, defined by Kotler et al (2005:920) as the "process of creating, maintaining and enhancing strong, value-laden relationships with customers and other stakeholders". One branch of this is the concept of corporate philanthropy. Merriam Webster defines philanthropy as "goodwill to fellow members of the human race; especially: active effort to promote human welfare." Thus, corporate philanthropy is philanthropy carried out on the part of a company in theory without any expectation of direct corporate gain such as increases in revenue, but which usually involves indirect gains. Such gains include brand enhancement, good will, engaging employees in company visions, and achieving recognition. ${ }^{7}$

As I indicated in the introduction, my use of the term advertising is rather broad and encompasses the all of the aspects above which might typically be considered to fall outside Kotler's more classic definition. I extend the term to include branding ${ }^{8}$ as well as issues

\footnotetext{
${ }^{4}$ Qvarsell \& Torell point out that the Swedish word "reklam" which was first used in 1868, like the English "advertise" has its etymology in the idea of crying aloud. In the Swedish case, this is the Latin reclamo, to cry out loud, to protest. The Oxford Dictionary of English Etymology points out that the verb "to advertise" not only incorporates the idea of giving or calling notice to something, but has its roots in the Latin advertere, to warn.

${ }^{5}$ However, as Leslie Dawson (1971) has pointed out, despite the important and ubiquitous nature of marketing as "a social process intended to achieve social goals [and which due to its inherently social character] impinges upon virtually every major social problem confronting society...” (p.71) practitioners experience problems in defining the field.

${ }^{6}$ Branding is particularly important when one product is very much like another, such as oil and its derivatives. Branding can be done by some form of differentiation in the form of a "brand personality", as while it is easy to imitate ingredients and claims of quality, "a vivid personality is much more difficult to imitate and so can be a more trustful sales factor." Jennifer Aaker (1997) has suggested that there are five different dimensions of brand personality: sincerity, excitement, competence, sophistication, and ruggedness" (cited in Ang \& Lim (2006).

${ }^{7}$ Opposing views on this topic have been expressed by Milton Friedman on the one hand, who claims that the purpose of a business is to maximize profits (1970) and on the other, Peter Drucker (1984) who posits that the advancement of society is in the interests of the company. Among the oil companies, Shell, for example, have explicitly stated their adherence to Druckner.

${ }^{8}$ Kotler et al. (2005:906) define a brand as a "name, term, sign, symbol or design, or a combination of these, intended to identify the goods of services of one seller or group of sellers and to differentiate them from those of competitors."
} 
related to corporate philanthropy. In short, I am using the term advertising to represent not only information and encouragement to buy products and services, but also any means of presenting and maintaining a positive corporate face or image to the world at large and to different stakeholders in particular. In other words, I consider that for a company or organisation, advertising is a way to protect and accumulate different forms of capital and, following Foucault, a way of exerting power through discourse to form and transform society.

The examples with which I propose to illustrate the historical development of advertising will derive predominantly from the world of Big Oil, which I contend has been a leading driver in the development of advertising as a genre and even as an art form. In the words of art historian and critic, Frank Rutter, advertising, or more specifically the creation of posters and advertising designs is "as healthy and invigorating a proceeding as the practice of any other genuine branch of pictorial or plastic art" 9 .

\section{The Beginnings}

Because of their different circumstances, advertising in Europe and in the United States did not develop in parallel. Advertising in Europe began with tavern signs and objects over shop doors which symbolized and identified the tradesman. Handbills and posted bills at inns and taverns made an appearance in England, and during the Elisabethan era were commonly used to advertise theatre performances, while pamphlets appeared in the early seventeenth century. In London, St. Pauls's was a recognized centre for the posting of certain bills (Raymond Williams, 1980:170) and originally, the United States borrowed most of its advertising methods and media from Britain, and circuses, theatrical shows, fairs and carnivals, as well as medicine shows, were publicized in this way.

In the American context, Jackson Lears (1994) traces the development of advertising through the life and work of a certain James Whitcomb Riley, a "clever rhymester and sign painter". 10 Riley developed the art of advertising from merely setting up posters announcing a show, to a form of entertainment that is a precursor of the product demonstrations sometimes encountered in shopping centres and also television commercials, for example. In the complex, carnivalesque tradition of American advertising in the nineteenth century, it became common to hire entertainers as bait, and there were no sharp boundaries between salesmanship and performance (ibid). ${ }^{11}$ Riley commonly made burlesque of Shakespeare in his performances, assuming a cultural elite among his audiences. Advertising had become a "many-voiced cultural conversation" (ibid: 3 ).

\footnotetext{
${ }^{9}$ Rutter wrote these words in the catalogue for the second advertising Exhibition in 1934, and extended particular praise to Shell-Mex and B.P. Ltd for their "great courage and good judgement [for] discovering new talent of genuine promise as well as employing artists with established reputations." This is a tradition which the companies, and especially BP, continue today.

${ }^{10}$ Lears (1994) describes how in 1872, Riley was employed by Dr. S.B. McCrillus, whose "marvelous brews and decoctions relieved every form of distress, from the pinch of tight shoes to a dose of the blues" (10). Riley remained in McCrillus' employ for some two years, entertaining prospective customers and designing trademarks which he painted (often without permission) on barn doors. After trying unsuccessfully to adapt to a more sedentary lifestyle, Riley joined a "band of itinerant musicians and comedians with the Wizard Oil Company", another patent medicine purveyed by a "Dr." C.M. Townsend. Riley's job was to illustrate the blackboard during Townsend's lectures but he soon began to start telling stories himself and to paint "fantastic illuminations on glass, which set afloat the virtues of Magic Oil" (41).

${ }^{11}$ Jackson Lears (1994) points out that the term "mountebank", which today is almost synonymous with charlatan, originates from "bench mounter", the jugglers and entertainers who climbed up on benches in order to be seen while they performed.
} 
The major impetus to the American development of advertising came from the circuses which traversed the country, and even though bill-sticking was generally considered to be a "promiscuous part-time employment of unorganized men" (Lears, 1994:10), ${ }^{12}$ by 1830, this had become a business. Another man who had a great impact of the development of advertising and on how advertisers expressed themselves, was Phineas Taylor Barnum ${ }^{13}$, who not only owned a museum in New York which he advertised using handbills and posters but also a circus which he advertised as the "Greatest Show on Earth." Barnum went against the tradition of moderation and respectability that other circus owners tried to follow, and introduced the use of superlatives on his handbills and posters. ${ }^{14}$ It was also at this time that what could be considered to be the first embryonic advertising companies appeared (ibid). Although the role of status of billposters was still lowly, an increasing number of contracting companies began to own and have exclusive rights over locations such a fences and walls grew up and developed. These companies began to paint their names on the locations to indicate their exclusive rights to them and eventually, due to a shortage of space, built special structures to be used for advertising. As Roland Marchand (1985:39) has pointed out, these early advertising agencies were little more than "brokers of space" but the spaces, which became known as billboards ${ }^{15}$ soon came to dominate the American landscape and also had an impact on Europe.

However, during this period, although outdoor advertising was not unusual in the United States, it did not develop as extensively or in the same way that it did in Britain, and instead, newspapers became an increasingly popular medium for advertising. There were a number of reasons for this. The first of these was that Benjamin Franklin, a man of innumerable talents and known as one of the Founding Fathers of America, together with some other entrepreneurs had built a number of paper mills, thereby lowering the need for earlier restrictions on paper. Consequently, newspapers began to increase in number and newspaper advertisements became increasingly common. While in Britain there was a so-called "knowledge tax" on newspapers, this was not the case in the United States and there were no $\operatorname{taxes}^{16}$ on advertisements (Hendon \& Muhs 1986:8). Thus, although at first, rates were arbitrary and unpredictable, ${ }^{17}$ advertising in newspapers was some thirty times cheaper in New York than in London. ${ }^{18}$ However, by the middle of the 1880 s, rates had begun to stabilize and became fixed. Franklin, who became a successful newspaper and editor in Philadelphia, had originally accepted illustrated advertisements in his newspapers, but soon, the British practice, which lasted well into the twentieth century, of only allowing small font sizes and advertisements in the format of today's small-ads became more common. ${ }^{19}$ In 1851 , however,

\footnotetext{
${ }^{12}$ Hendon and Muhs (1986:16) claim that as circus owners were keen to preserve their "respectability" they used no "over-blown" adjectives in their advertisements.

${ }^{13}$ Jackson Lears (1994:39) describes Barnum as the "impresario" of the "magical charge of the early modern market".

${ }^{14}$ As newspapers did not allow display advertising, Barnum's posters were particularly effective.

${ }^{15}$ The earliest quotation including this term seems to be from 1891 and can be found in Northall's Before and Behind the Curtain.It reads "With excusable vanity, the billboards of the Park, standing side by side with those off the National, still continue to style the Park 'The Theatre'” (Hendon \& Muhs (1986:13). The British equivalent of billboard is "hoarding".

${ }^{16}$ See Raymond Williams (1980) for more details of taxes such as the Advertisement Tax first imposed in 1712.

${ }^{17}$ As M. H. Mallory, publisher of the New York Churchman cited in Lears (1994:92) put it, the rates were like a "lady's favors."

${ }^{18}$ Hendon \& Muhs (1986) list five major reasons for the rapid development of newspaper circulation and newspaper advertising in the American colonies.

${ }^{19}$ In Britain, it was believed that a large number of small advertisements had a better circulation value than a smaller number of larger ones. The cost for breaking a column rule was therefore very high. In the spirit of Plato and the Guilds, who had preached that honorable competition was dependent upon equality of size and
} 
Robert Bonner revolutionized advertising. His New York Ledger permitted display advertising and became very popular. Moreover, Bonner also advertised his Ledger in other newspapers by purchasing a column or a whole page and repeating the same phrase over and over throughout the space. He also made use of white space, which he believed attracted the eye, and his idea that larger type and variety in typefaces were more effective became prevalent. These techniques had a profound effect and are commonly found in advertising as well as in lay-out in general, today.

Another contribution to the development of advertising was the entry of magazines onto the market. Originally, magazines had not shown any interest in advertising, but in the 1890s, Harper's magazine changed this and started a new trend.

\section{The Early Years in America}

As the subject of this investigation is the advertising discourse of the oil industry and the major players were based in the United States and Britain, this chapter centres on the development of advertising in these countries. Moreover, as the United States ${ }^{20}$ became the leaders in this field, the developments there are of particular interest.

Hendon \& Muhs (1986) suggest that 1870 marks the dividing line between what they term ancient and modern outdoor advertising, and one reason that they give for this is the innovative use that the United States Government made of the medium during the Civil War. Despite the popularity of outdoor advertising, newspaper and magazine advertising also continued to increase in popularity in America. A further development was that in 1872, the people working in the field of advertising began to organize themselves, and by 1891, the first permanent national association of advertisers was formed and its members began to fight for recognition and respectability.

During the twentieth century, the spread and impact of advertising in the United States was enormous, and branding became increasingly important. Mass-marketing campaigns can be dated back to the second half of the nineteenth century, but their original purpose was to help people to change their lives through the adoption of new products as well as inventions such as the car or electric light. Advertisements informed potential consumers about the existence of such new inventions and tried to convince them of their benefits. Some of these products bore brand names, but the brand name was not central to the product. However, if early branding existed to bestow names on new consumer goods, or on generic products such as flour or sugar which were now bought ready-packaged instead of scooped out of a bin by the local shopkeeper, ${ }^{21}$ the introduction of more and more products of a similar kind, often massproduced in factories, made competitive branding and image-building essential. Corporate logos began to appear in the 1880 s and the "corporate "personality", uniquely named, packaged and advertised, had arrived" (Klein 2000:6).

Marchand (1985:10) traces the development of advertising in the early years of the twentieth century from "brand-name publicity through advertising jingles and poster-style displays" to what he rather dramatically claims is "the Archimedean lever that is moving the world"

opportunity, (see William Kelley 1956) for more information about early ideas about marketing and promotion, including the notions propounded by Plato) it was also believed that larger advertisements overshadowed the smaller ones and were therefore unfair. (ibid:9)

${ }^{20}$ The trade consolidated in New York which became its centre and the home of the major agencies. By 1923, New York's Madison Avenue had become synonymous with advertising agencies in 1923.

${ }^{21}$ Klein (2000:6) cites Lupton \& Abbott who in1996 posited that "a nationwide vocabulary of brand names replaced the small local shopkeeper as the interface between the consumer and the product". 
(ibid:5). The advertising campaigns conducted for WW1 had shown that "it is possible to sway the minds of whole populations, change their habits of life, create belief, practically universal, in any policy or idea"22 Advertising began to function as a general means of mass communication and was becoming big business. This business began to consolidate in New York, which by 1923, had become the home of the major agencies and synonymous with the term "advertising".

Another important factor that contributed to the development of advertising was the work of Samuel Sparling, who, inspired by a visit to Germany, where he had studied economics, had described in his Introduction to Business Organization, published in 1906 how business could be developed as a science. In the second part of the book he discusses the "organization of distribution" (1906: vii) and lists all the means available at the time, including direct selling and advertising. In the chapter devoted to advertising, Sparling describes advertising as a "creative force" (ibid: 295) and discusses advertising campaigns and trademarks, among other things. ${ }^{23}$ One consequence of Sparling's work was that in 1908, Harvard University founded its Graduate School of Business on the premise that business was a profession, an art and a science (Jones \& Monieson, 1990:106) ${ }^{24}$ and began to develop the field of advertising as a serious field of study.

The Harvard Awards were instituted in 1924 to further develop the business of advertising and to reward advertising excellence. Another intention behind the Awards was to raise the status of copywriters, who belonged to a profession tarred with the brush of the early years of billposting and who were often likened to mendacious charlatans. In the words of Professor Neil Borden who was in charge of administering the Awards, these would encourage advertising to rise "to a higher level of intelligence, decency, and appreciation" (Marchand 1985:26). This is in line with what DiMaggio \& Powell (1983:152), discussing the development of institutions and organizational fields, ${ }^{25}$ refer to as a "normative" process. In other words, advertising was becoming a profession that was recognized in its own right as something that had generally accepted standards and regulations. Another significant development was that in 1926, the Saturday Evening Post began to carry an Index of Advertisers in addition to one over its editorial content, and this too contributed to promoting advertising as a professional occupation. ${ }^{26}$

In another attempt to further advance their image and raise their status as a respectable profession, American advertisers also began to insist on the importance of a high level of education and culture for those engaged in the business. Earnest Calkins (1868-1964), a wellknown advertising agency president, went so far as to contend that "advertising had brought beauty into the machine age and raised the level of public taste" (Marchand, 1985:27). ${ }^{27}$ By

\footnotetext{
${ }^{22}$ Marchand (1985:4), citing the popular advertisers' magazine, Printers' Ink, which ran from 1888 to 1967.

${ }^{23}$ Jones \& Monieson, (1990) summarise his work which has been credited as one of the earliest contributions to marketing literature

${ }^{24}$ Farmer (1967:3) describes marketing at the time as "a trivial activity indulged in by trivial people". This contrasts with the proud claim of Stanley Resor, President of the J. Walter Thompson agency in the midtwenties, that his staff included 105 college graduates, including five PhDs. (Marchand,1985:26)

${ }^{25}$ DiMaggio \& Powell (1983:148) define an organizational field as "those organizations that, in the aggregate, constitute a recognized entity of institutional life" [something that incorporates) "the totality of relevant actors".

${ }^{26}$ This tradition continued, for example in Scientific American, well into the 1970s.

${ }^{27}$ In fact, in 1930, Calkins had noted that literary experts such as Kipling had "expressed admiration for the literary quality" of much recent advertising and that the "stigma once attached to advertising art" had disappeared. Commercial artists were no longer considered failed artists and the N.W. Ayer and Son agency sought to confirm the status of their artists by establishing their own gallery where exhibitions of advertising artists were regularly staged. (Marchand,1986:48).
} 
1928, Bruce Barton, a well-known advertising man, had raised the concept of advertising to new heights.$^{28} \mathrm{He}$ urged oilmen, for example, to consider that they were no longer selling an "evil smelling" expense, but the commodification of mobility in "the magic of gasoline" (Marchand, 1985:194). ${ }^{29}$ In fact, Barton proclaimed that advertising was "the voice of business' better self" (ibid). One of the reasons for this was the way in which advertisers introduced the general public to different forms ${ }^{30}$ of the visual arts through their advertisements. It was particularly in magazines that American audiences were exposed to art and to new art forms.

\section{The Early Years in Britain}

In Britain, outdoor advertising continued to dominate and evolve. However, in contrast to the situation in the United States, where billboards came to dominate the landscape, in Britain, there was some resistance to billboards, or hoardings as they were known, covering the countryside. One of the driving forces for this movement was SCAPA, the Society for Checking the Abuses of Public Advertising, ${ }^{31}$ an organisation that had been founded in 1893 with the object of drawing the public's attention to the "disfigurement caused by outdoor advertising".

This was not the first negative British reaction to outdoor advertising. Raymond Williams (1980:173), for example, describes the problems of so-call fly-posting that had resulted in a London act prohibiting it without the owner's consent as early as 1837 . One reason for this was that the idea of boards or spaces on which to stick posters had not developed in Britain as it had in America and as a result, many were stuck onto private property, and this had led to protest. $^{32}$

\footnotetext{
${ }^{28}$ Barton is the man who succeeded in turning General Motors into a metaphor for the American family, "something personal, warm and human" and the faceless General Electric Company into GE, "the initials of a friend". His claim was that the role of advertising was that it should "help corporations find their soul" (Klein, 2000:7)

${ }^{29}$ Barton had risen to fame with a book called The Man Nobody Knows, which proved that Jesus was not only the most popular dinner guest in Jerusalem but also "the founder of modern business" and "the greatest advertiser of his day." Barton's message to the oilmen was that petrol was "the juice of eternal youth (...) It is comfort. It is success. And you have sold merely a bad smelling liquid at so many cents per gallon." $\mathrm{He}$ instructed them to change it from a hated expense to something that works miracles; the miracle of mobility.

${ }^{30}$ As Marchand (1985:140) points out, as trends moved from oil painting, which had previously been associated with "prestigious 'high art' connotations" to photography and modern art, Americans, and particularly the uppermiddle classes, gained familiarity with the whole gamut of avant-garde, from cubism, futurism, vortism, impressionism, Art Deco and expressionism, not from visiting galleries, but from the "visual adventures" they could find in the pages of Ladies' Home Journal and the Saturday Evening Post. Advertisers experienced "surge of enthusiasm for color and style" in the mid- twenties, and colour began to play an increasing important role in magazine advertising in the United States, a development which took place there much earlier than it did in Britain.

${ }^{31}$ The inspiration to SCAPA had come from two articles that had appeared in 1890, one discussing questions of taste in advertising and the second complaining about the spread of outdoor advertising and the annoyance that it caused. The first article, which appeared in the New Review, was written by Alfred Waterhouse, an architect and was entitled "Street Improvements in London" and the second, appearing in the National Review, was by Richardson Evans and was entitled "The Age of Disfigurement". For more information, see Terry Nevett (1981). ${ }^{32}$ Perhaps ironically, according to John Walker, (1994) by the 1980s, opinion had changed and there were 126,000 poster sites in Britain alone.
} 
Although in Britain too, "wartime crusades [had] proved that advertising was no mere commercial tool but a great moral and educative force, capable of serving 'unselfish social purposes'" (Marchand, 1985:4) it was the technological advances in printing and lithography and the work and influence of Jules Chéret, the "father of the modern poster" 33 that were driving forces for the development of outdoor advertising and Shell, and later BP were among the companies that made good use of these developments.

\section{The Contributions of the Oil Industry to the Development of Advertising}

I claim that possibly the most important single contributor to the development of modern advertising during the first decades of the twentieth century, the period that Pollay (1985) refers to as the "Emergent Era" of advertising, ${ }^{34}$ was the oil industry.

The first contributions of the oil industry to the development of advertising stem from the market surveys conducted by Standard Oil group to discover new potential uses for oil and its derivatives. Once these uses had been found and the resulting products had been produced, the public had to be made aware of the existence of these previously unknown commodities which would become essential to their lives. In other words, the companies had to find means to communicate the news to the public in a manner that would persuade them of the need to purchase the newly developed necessity. The concept of market surveys and the promotion of unknown products were direct results of the business ideas of Rockefeller and his team.

Another major contribution of the oil industry to the development of advertising was rooted in the need for the oil companies to find some way of differentiating their products and by the 1920s, advertising had become a very important activity for them. As Pierre Martineau, director of research at the Chicago Times (quoted in Vance Packard 1957:25) wondered, what direction could advertising could take when differences among brands of gasoline or tyres, for example, had become trivial or non-existent? In other words, the oil companies were among the pioneers of branding.

\section{The Advertising of the Oil Companies in the United States}

In the United States, one of the ways in which the companies advertised was a direct result of the fact that the increasing popularity of the motor car had led to a network of new highways which "visibly symbolized a world now moving at a pace set by the automobile" (Marchand: 1985:4) and to the growth of suburbs. This rapid increase of cars on the roads resulted in the advent of service stations which began to spread over the face of the country. ${ }^{35}$ According to Tim Russell, (2007:8), Gulf, Texaco and Shell played "pivotal roles" in this development. "The key issue for standing out in the flow of information is recognition" (Göran Rossling 2001:13 citing the Eriksson Corporation), and the stations were not only a site where a product could be purchased, but were also a way for the companies to achieve brand

\footnotetext{
${ }^{33}$ Jules Chéret (1836-1932) was a master of Belle Epoque art. After studies in London where he became inspired by the British approach to poster design and printing, he returned to Paris where he created posters for cabarets and theatres such as the Folies Bergères and Moulin Rouge. His liberated, joyous female characters, "Cherettes" were an inspiration to many women. His posters came to include advertisements for perfumes, soaps and even railways. Chéret's work and success in this field inspired among others, Toulouse-Lautrec.

${ }^{34}$ Richard Pollay (1985) refers to the 1930s as "A Decade of Experimentation", the 1940s as "A Decade of Emergency" and the 1950s as "The Subsiding Sizzle".

${ }^{35}$ This development in the United States far outpaced that in Britain and is attributed by Russell (2007:7) to the launch of Ford's Model T and to the breakup of the Standard Oil Company. In fact petrol stations did not begin to appear in Europe until the early 1920s (ibid: 10).
} 
recognition as they hoisted "aloft the symbols ${ }^{36}$ of the new age" (Yergin, 2008:193). In other words, the different companies made visible their trademarks or $\log _{0}{ }^{37}$ along the highways.

Increasing competition had forced companies in all fields to develop such trademarks and to place them all over the countryside in order to assure brand identification, ${ }^{38}$ but for the oil companies this was particularly important, due to the nature of their products. A brand became much more than a trademark; ${ }^{39}$ it became an identity which incorporated much more than the product ${ }^{40}$ and when the world's first purpose-built drive-in service station was built by Gulf Refining, and opened in Pittsburgh on December 1, 1913 (Russell, 2007:8) it had a number of major repercussions. Although this was the first station of its kind, it was by no means the last, and soon numbers of service stations under the banner of the different oil companies were spread across the country. To mark the opening of the first station, a local advertising man suggested handing out free maps of the region, an early form of customer repeat-purchase incentive. ${ }^{41}$ This technique has survived ${ }^{42}$ and been developed in a wide variety of ways and the idea of the corporate gift has spread from oil company dealers to many other businesses, particularly those involved in franchising. ${ }^{43}$ The concept of doing business under the trademark of another company and whose brand you represent, is another business development that can be attributed to the oil industry and which has had an impact on the development of advertising.

Trademarks however, were not enough, and new more holistic ways of approaching the notion of "brand" became necessary. In the case of the oil companies, this often involved special company uniforms for the service station personnel, special ways for the personnel to

\footnotetext{
${ }^{36}$ Matthew Rampley (2005: 15-16) discusses the way in which Western society has become a predominantly visual culture with a "plethora of advertising imagery selling every imaginable product and service". The logo, the visual marker of the product being sold, makes a major contribution to what Walter Benjamin termed a 'dream landscape' to promote consumption. As man is a visual animal, (of the 11 million bits per second reaching the brain, 10 million are visual cues) symbols are very important. Leonardo da Vinci (cited in Waern et al (2004:15) also pointed out how incredibly rapidly we see things and are able to sort out visual impressions. ${ }^{37}$ These included Texaco's star, Shell's scallop, Gulf's orange disc and Jersey Standard's patriotic colours of red, white and blue (Russell, 2007:162). Standard Oil in general had problems with using logotypes due to legal issues.

${ }^{38}$ For further information, see for example, Tim Russell (2007) and Olle Wilson (2012).

${ }^{39}$ The definition of a trademark in U.S. law is "any word, name, symbol, or device, or combination thereof, used to identify and distinguish goods from those manufactured or sold by others" (Klein, 2000:176).

${ }^{40}$ Wendy Gordon, (2006:20) has stated that "[w]e learn about a brand through the multiple experiences we have with it in different ways and conditions overtime. Each exposure or experience is integrated with those that are already embedded to create a totality of meaning." Chris Barnham (2008) has also discussed the way in which brands "communicate" through a narrative model based on semiotics.

${ }^{41}$ The tremendous goodwill that these generated quickly led to maps becoming a staple product of the different service stations. Shell has been a leader in this field and Wilson (2012) provides examples such as Caltex's maps of Sweden where their service stations were marked with red stars ${ }^{41}$ or BP's road map of Sweden.

${ }^{42}$ For example, to coincide with the European Football Championship which took place during the early summer of 2012, Statoil offered a card which could be stamped every time a customer bought petrol. When the card was full, the customer could choose one of a variety of different balls.

${ }^{43}$ The oil companies provided their company dealers not only with road maps to give their customers but also with other types of free gifts to attract customers and to encourage their loyalty. Shell, for example, sent out Valentines during the middle years of the twentieth century, a ploy that proved very popular. As John F. Sherry Jr. (1983:157-158) has pointed out, the giving of gifts has important social dimensions and is a vehicle for enforcing social obligation. Quoting van Baal (1975), he shows how gift giving has been "interpreted as an invitation to a partnership, and as a confirmation of the donor's "sincere participation" in a recipient's tribulations and joys, despite the presence of an ulterior motive." On the receipt of a gift, an individual tends to feel a need to reciprocate; in the case of gifts bestowed by companies on their customers, this reciprocation is affected by the recipient of the gift showing loyalty to the donor, by buying more of his products.
} 
deal with customers, and providing better facilities than the competitors. ${ }^{44}$ Rossling (2001: 14) has pointed out that strong corporate identities involve not only products, but also the company's employees as well as its symbols and trademarks. ${ }^{45}$ During this early period, the concept of "selfimage," became increasingly important, both for a company to differentiate itself from its competitors and also for the consumer to feel that he knew what he was buying. The oil companies led this development. ${ }^{46}$

In other words, the oil companies were leading exponents of the early practice of branding. John F. Sherry Jr. (2005:40) discusses the phenomenon of branding, which he considers to be "a principal repository of meaning in consumer culture [and] both a storehouse and a powerhouse of meaning", terming it "brandthropology" (ibid). ${ }^{47}$ From an analysis of the tripartite etymology of the word "brand", Sherry posits that the "brand embodies the transformative heat of passion, properly tended. It is bestowed, and it is earned. The brand bespeaks the forging of family" (ibid: 41). He concludes that "brands are an experiment in memetic engineering [which] encode and engender the meanings that sustain our culture of consumption" (ibid: 61). The brand is the projection of corporate image and according to Gregory\& Wiechmann (1991) is an essential element the positioning a company for maximum growth. Branding is particularly important when one product is much like another, which is the case of oil and its derivatives. As Klein (2000: 5) has pointed out, although the terms advertising and branding are often used interchangeably, they are not the same process. Branding can be considered as the "core meaning of the modern corporation", in other words, following Goffman's terminology, it can be considered to be the face which a company chooses to present to the world, while advertising is "one vehicle used to convey that meaning to the world". Branding can be done by some form of differentiation in the form of a "brand personality", as while it is easy to imitate ingredients and claims of quality, "a vivid personality is much more difficult to imitate and so can be a more trustful sales factor.'

I will argue that the major oil companies have all attempted to create and communicate a unique "brand personality" through their advertising. Jennifer Aaker (1997) has suggested that there are five different dimensions of brand personality: sincerity, excitement, competence, sophistication, and ruggedness" ${ }^{\prime 8}$ and I propose to identify and compare the dimensions chosen by the five Majors.

\section{The Advertising of the Oil Industry in Britain}

If the American oil companies helped to develop advertising as a brand and spread their corporate logos and symbols on billboards and on service stations all over the countryside, in

\footnotetext{
${ }^{44}$ For more information about this see Marchand (1985) and for information about how oil companies acted, see for example Russell (2007) and Wilson (2012)

${ }^{45}$ Rossling (2001:14) defines corporate identity as "the interface between the company and the surrounding world" or "the sum of everything that a company says or does ... the soul of the organization" and which is projected through people, products, design and advertising.

${ }^{46}$ Packard (1957) describes for example how the chief researcher for a major advertising agency claimed that it was possible to predict what petrol a person would choose from the way in which he drew a car. The explanation given was that [i]n buying a gasoline you get paid back to you who you are. Each gasoline has built up an image or personality. Each helps a buyer answer the question 'Who am I? ' Your aim is to find the people who have an affinity for your gasoline" (p.48).

${ }^{47}$ This interpretation contrasts with the more traditional view of branding as "a cognitive or structural enterprise in models of strategic management [which slights] the cultural complexity that animates brands in so many distinctive ways" (Sherry 2005:61).

${ }^{48}$ Cited in Ang \& Lim (2006).
} 
Britain, it was as patrons of the arts and of national security that the oil companies profiled themselves. One reason for this was that the number of indigenous oil companies was extremely limited and therefore unlike their American counterparts, Shell, and later BP, did not need to advertise competitively. Further, because these companies had close government connections, their advertising was expected to maintain certain standards. As art was considered to be a sign of education and of respectability, ${ }^{49}$ and due to the influence of Chéret and the development of graphic techniques, the artistic poster had become a staple of companies such as the London Passenger Transport Board (LPTB) ${ }^{50}$. Following in their footsteps, various railway companies also used fine and commercial artists ${ }^{51}$ to produce their advertisements.

This was the tradition to which Shell adhered at a very early stage and which it helped to develop. It was also usual for such companies to have regular exhibitions of their posters as in this way they were able not only to promote their name but also to achieve a reputation for good taste and for public service (John Hewitt, 1992:123). This practice can be considered to be an early form of the corporate social responsibility which has become so important among major companies today.

Another difference between the way that the oil industry advertised in Britain and America was that Shell, for example, advertised largely on posters ${ }^{52}$ displayed on the side of the delivery lorries that were used to transport cans of fuel to customers across the country. This was in part a response SCAPA and in part, was a means to display the advertisements all over the country and arouse interest when the lorries drove past. The earliest posters, or "Lorry Bills" ${ }^{25}$ as they came to be called, were typical of those that had been common since the 1890 s, simple and functional in their message, illustrating the product, displaying the commodity, identifying the user and defining the use to which the product could be put ${ }^{54}$.

\footnotetext{
${ }^{49}$ Therefore it can be considered as part of the companies' social and cultural capital.

${ }^{50}$ Perhaps the most famous such poster in Britain was produced by Pears Soap in 1887. Painted by Millais, one of the Pre- Raphaelite Brotherhood in 1886, "Bubbles" was a portrait of his little grandson and based on a Dutch $17^{\text {th }}$ century tradition. The poster led to widespread debate about the relationship between art and advertising. Millais was later accused of having both exploited his grandson and sold his soul to commercialism. His main critic was Mary Corelli, the author of a best-selling Faustian novel called The Sorrows of Satan; the tale of a penniless young writer who unwittingly sells his soul to the devil. Corelli accused Millais of prostituting his talent to sell soap. Pears made another important contribution to advertising as they were one of the first companies to introduce a catch-phrase on a large scale: "Good morning! Have you used Pears' Soap?" (cited in Williams, 1980:173).

${ }^{51}$ David Freedberg (1989:xix) doubts the possibility of "talking Adequately about high art without considering less privileged images as well", and this is most certainly the case with advertising art.

${ }^{52}$ The poster can be traced to two main sources. One is the handbill with woodcut illustration and the other a new sense of effectiveness in simplified design and colour. This dates from the late nineteenth century and it is largely thanks to lithography, an economical mode of large-scale printing, that it became so popular. The Woman in White poster from 1871 and the chromo-lithograph from Millais' Bubbles (1886), used for Pears Soap are often taken to be the starting point. BP Archives, Warwick University

${ }^{53}$ One reason for the development of lorry bills was SCAPA, the Society for Checking the Abuses of Public Advertising. The inspiration to SCAPA had come from two articles that had appeared in 1890, one discussing questions of taste in advertising and the second complaining about the spread of outdoor advertising and the annoyance that it caused. The first article, which appeared in the New Review, was written by Alfred Waterhouse, an architect and was entitled "Street Improvements in London" and the second, appearing in the National Review, was by Richardson Evans and was entitled "The Age of Disfigurement". For more information, see Terry Nevett (1981)

${ }^{54}$ Taken from "The Shell Advertising Poster" in "The Shell Art Collection" The National Motor Museum Trust at Beaulieu, Hampshire.
} 
Unlike the United States ${ }^{55}$, in Britain, there was some resistance to billboards or hoardings covering the countryside. ${ }^{56}$ One reason was that there the development of boards or spaces to stick posters had not developed in Britain as it had in America and as a result, many were stuck onto private property. ${ }^{57}$

The posters used by public companies and by those with government connections, such as Shell and BP, were often created by talented artists and had a high aesthetic appeal and in this way, the lorry bills brought served an educational purpose, bringing "art" to people all over the country. The bills were also an opportunity for many artists ${ }^{58}$ to receive exposure and to make a name. ${ }^{59}$ In fact, when the second advertising Exhibition was held in 1934, it was opened by a person of no less weight in the art world than Kenneth Clark, the Director of the National Gallery. The art historian and critic Frank Rutter, who wrote the "Note" or introduction to the catalogue, described the creation of posters and advertising designs "as healthy and invigorating a proceeding as the practice of any other genuine branch of pictorial or plastic art" and praised Shell-Mex and B.P. Ltd for "great courage and good judgment, [for] discovering new talent of genuine promise as well as employing artists with established reputations." He also commented on the "exceptional consideration that Shell-Mex and B.P. Ltd. has shown in the matter of placing its posters." 60

Another early development in the use of art in advertising and which was pioneered by Shell, was the postcard. Postcards were created to celebrate special events of national and historic interest such as the 1910 flight by L.I.Paulhan (figure 8: 2) from London to Manchester, which, of course, was done using a Shell product. In the same vein, Shell produced a set of playing cards which were issued to the British forces during the First World War. ${ }^{61}$

Although the oil companies helped to introduce "art" to the general public who lived far from art galleries and museums, perhaps the major contribution that the companies involved in this industry in Britain brought to advertising in its emergent years was to develop it in accordance with the concepts of social responsibility and social involvement which later became common in corporate advertising in general, and in their own advertising in particular.

\footnotetext{
${ }^{55}$ In a very interesting passage in his autobiography, Confessions of an Advertising Man (1963) David Ogilvy, founder of the American advertising agency, Ogilvy \& Mather writes: "As a private person, I have a passion for landscape, and I have never seen one improved by a billboard. Where every prospect pleases, man is at his vilest when he erects a billboard. When I retire from Madison Avenue, I am going to start a secret society of masked vigilantes who will travel around the world on silent motor bicycles, chopping down posters at the dark of the moon. How many juries will convict us when we are caught in these acts of beneficent citizenship?" (in Klein, 2000:3)

${ }^{56}$ SCAPA had been founded in 1893 with the object of drawing the public's attention to the "disfigurement caused by outdoor advertising". Williams (1980:173) describes the problems of so-call fly-posting that had resulted in a London act prohibiting it without the owner's consent as early as 1837 .

${ }^{57}$ Perhaps ironically, according to John Walker, (1994) by the 1980s, opinion had changed and there were 126,000 poster sites in Britain alone.

${ }^{58}$ Artists whose names are associated with Shell include D.C. Fouqueray, Paul Nash, John Reynolds. Rex Whistler, and the American artist McKnight Kauffer.

${ }^{59}$ To provide artists with a chance to become known is still a feature of the advertising of British oil companies today, particularly BP.

${ }^{60}$ He went on to write: "There is a place for everything; and even the finest possible poster-design, which is a sheer joy when exhibited on a suitable hoarding or a lorry, would inevitably become an offence and an eyesore if shown, say, in the foreground of the view from Richmond Hill.

Indeed it may be said that Shell-Mex and B.P.Ltd. now goes to an extreme in its desire to woo the human eye with kindness and never to offend, for even its most effective and artistic posters are rarely seen on hoardings." In fact, only four were reproduced in this way.

${ }^{61}$ The cards were for Shell aviation fuel and carried the slogan "Always in front" (David Bernstein, 1983:7).
} 


\section{Trends and Developments in Advertising}

Of course despite the fact that the oil companies played a major role in the development of the advertising industry, they did not lead this development alone. However, the oil companies were among the first to adapt to new trends and techniques.

\section{The Decade of Experimentation}

Richard Pollay (1985) has nominated the 1930s as the decade of experimentation, and this can certainly be seen from the development of the advertisements of Shell and B.P. ${ }^{62}$ Indeed, most of the most famous advertisements that they produced stem from this period and the slogans and advertisements from this time still live on in cultural memory almost a century later. $^{63}$

One of the major developments that occurred during this period was that the visual aspects of the advertisement became increasingly important elements of the communication. As Marchand (1985:153) pointed out, advertisements were no longer read, (for example figure $3: 1$ ) but became increasingly "seen" (for example, figures 3:3, 3:5). Copywriters ${ }^{64}$ who had a few years earlier had proudly compared "the purposes and challenges of their craft to the labors of Shakespeare, Stevens and Dickens" (ibid: 26) ${ }^{65}$ and who were fond of quoting Aldous Huxley on this point, ${ }^{66}$ found that they had become a mere "adjunct to a $\$ 1,500$ illustration and a million-dollar idea" (ibid:154). Matthew Rampley (2005:16) confirms the shift from the written word to image in advertising, and claims how "in its current form, consumerism would be unthinkable without the plethora of advertising imagery selling every imaginable product and service." ${ }^{67}$ In America, photographers too, enjoyed the urge "to teach men to gaze unconventionally" (ibid: 149) and were courted by the advertising agencies. One characteristic that was attributed to the photograph was that of authenticity, "the pure and simple denotation of reality" (Barthes 1977:28). As David Freedberg (1989:439) points out, the image in a photograph "does not lie, as we might like to think, in the associations it calls forth; it lies in something more authentic, more real, and infinitely more graspable and verifiable than association." This gave photographs a quality which advertisers perceived to have great value.

\footnotetext{
${ }^{62}$ Shell-Mex and B.P. Ltd.

${ }^{63}$ These include "You can be sure of Shell" and "See Britain first on Shell". This will be discussed in the analysis.

${ }^{64}$ Just as well-known artists were used for the visual aspects of advertising were a number of well-known writers employed in copywriting. One of the best known is Dorothy Sayers, the well-known author and translator, who was employed by S.H. Benson's agency from 1922-1931. Her collaboration with artist John Gillroy resulted in the Coleman Mustard advertisements and the famous Guinness "Zoo" advertisements, some of which, such as the Toucan, are still used today. Sayers is credited with coining the phrase "It pays to advertise" and used the advertising industry as the setting for one of her detective stories, Murder Must Advertise.

${ }^{65}$ This perception of their craft was not shared by many. In his novel about a young man who makes a living as a copywriter, Keep the Aspidistras Flying, (1936) George Orwell, for example, wrote that "most copywriters are novelists manqués" (60) "[w]riting to tickle money out of fools' pockets" (59).

${ }^{66}$ Huxley had said that "the advertisement is one of the most difficult of modern literary forms ... The problem presented by the sonnet is child's play compared with the problem of the advertisement." Moreover, Calkins had claimed that expert writers like Rudyard Kipling, Brander Matthews and H.L. Mencken had "expressed admiration for the literary quality "of a great deal of recent advertising (Marchand,1985:26).

${ }^{67}$ Rampley (2005:16) also insists on the importance of the logo, a "distinctive visual marker ...that has become) more important than the commodity it denotes." This is in line with van Leeuwen (2008: 130) who posits that the "image is becoming less central, and other, formerly more marginal modes of communication such as typography and colour are becoming more important. See also Ries \& Ries (2002:245), Sherry (1987:443) and Williams (1980) for further comments about the importance of the visual aspects of advertising.
} 
Another example of how advertising developed can be attributed to the work of George Gallup, who early in 1931 publicized the findings of his first research study, an analysis of newspaper readership. His findings were that not only children but even adults of all classes and walks of life enjoyed reading comic strips, and had major implications for advertisers (Marchand, 1985:110-112) who discovered that the best techniques from other sources could also be successfully applied for example to comic-strip advertising. Shell-Mex and BP Ltd were among the companies that made use of the technique of combining art, humour and the written word, and expanded this to encompass some form of corporate narrative and public relations work. ${ }^{68}$

In Britain, the onset World War Two curtailed any major developments in advertising, and in fact, the oil companies were prohibited from advertising their products during these years and during the years of rationing and hardship which followed, but in the United States, advertising continued to evolve.

\section{Consumption Engineering}

However, the increasing use of art and humour were not the only new directions that advertising took, and when the Advertising Circle presented its National Exhibition sponsored by The Times at the RBA Galleries in London, November $22^{\text {nd }}-$ December $7^{\text {th }} 1955$, George Plante, President of the Advertising Creative Circle raised some interesting issues in his Foreword to the Exhibition catalogue. Taking up the question of art and advertising, two terms which he considered to be imprecise, he pointed out that "[t]o-day the business of advertising embraces far more than the writing and drawing of advertisements. It includes the study of all phases of marketing and general practice and in so doing it contributes to the general policy decisions of the advertiser. The physical presentation of the advertising idea is only a part of this business and the illustration is only a part of the physical presentation." ${ }^{\circ}$ The Introduction to the Catalogue also took issue with the question of art and advertising and made the claim; "Painting and drawing, of course, are instruments only as far as advertising is concerned, contributing to the practical end for which it exists, but far from being the whole story. The art OF advertising is something besides. It may be compared to the direction of an orchestra, in which there are a number of performers. The instruments in the 'orchestra' are many." 70

Robert Byron, who penned the introduction to the 1981 "Exhibition of Modern Pictorial Advertising by Shell" catalogue, developed the idea that art was only one "instrument" of advertising, by writing: "The principles of successful advertising are as numerous, precisely, as those of psychology, and as difficult to formulate. Each advertisement must caress some

\footnotetext{
${ }^{68}$ Mobil made use of the cartoon form in their Observations which will be discussed in the following chapter, and Shell and BP Ltd offered a strip-cartoon book produced for children, Tony Strikes Oil, from 1953, showing how BP produced oil from the Anglo-Iranian oil fields (BP Archives, Warwick University). In this way, the company not only brought their name to public view in a sympathetic light, but also raised awareness of their products and production methods and through this attempt, which is a kind of relationship marketing could hope to improve their standing with the public and attract young, potential customers. Cartoons featured in ShellMex \& B.P.Ltd advertisements from the 1960s and one of the most successful oil company campaigns, Esso's "Put a tiger in your tank" starred a cartoon tiger.

${ }^{72}$ As Qvarsell \& Torell (2005:22) point out, advertisers must also incorporate decisions about what is a legitimate argument in favour of a product and what constitutes pure manipulation.

${ }^{73}$ BP Archives, Warwick University
} 
instinct, sentimental, logical, or otherwise, which is shared by a body of persons. (...) The fundamental principle is to please the ordinary man's aesthetic sense or sense of humour, in the belief that he will come to associate this pleasure with the accompanying name, and ultimately to regard the commodity or institution denoted with something like affection. ${ }^{, 71}$ In other words, advertisers had begun to understand the importance of human psychology as a factor for successful communication and it had begun to take an increasingly central position in the advertisers' arsenal.

According to Marchand, (1985: 25) advertisers were already "consumption engineers" in the early decades of the twentieth century, and as the century progressed, they had become increasingly aware of "the power of word triggers and picture triggers ${ }^{72}$ to evoke desired responses" ${ }^{73}$ (Packard, 1957:27). ${ }^{74}$ Consequently, advertisers, or as Packard terms them, "professional persuaders" (ibid: 13$)^{75}$ began to expand the players in their orchestras to include psychologists and social scientists, in the performance of what they called "motivation analysis". ${ }^{76}$ Pollay, (1986:18) confirms this and citing a passage from Advertising Age 1957 points out that "[i]t is worth recognizing that the advertising man in some respects is as much a brain alterer as is the brain surgeon, but his tools and instruments are different".

The study of the mental processes involved in advertising was nothing new. Indeed, as early as 1896 , experimental psychologists, such as Harlow Gale ${ }^{77}$ had begun this work ${ }^{78}$ and had reached the conclusion that the consumer was irrational, a "suggestible creature under the hypnotic influence of the advertising copywriter" (David Kuna, 1976:347). The major proponent of this theory was Walter Dill Scott, ${ }^{79}$ and the interest that the advertising

\footnotetext{
${ }^{71}$ An Exhibition of Modern Pictorial Advertising by Shell (1981) Curwen Press, BP Archives, Warwick University

${ }^{72}$ Bo Bergström (2003:134) points out that images are an important tool that can be used to influence people and that their power is in fact frightening. Images open our eyes in ways that words cannot do. Freedberg (1989) also insists on "emotion as part of cognition" (430) in his discussion of understanding response to images.

${ }^{73}$ Kotler (1972:50) describes the "core concern of marketing [to be] that of producing desired responses in free individuals by the judicious creation and offering of values." Kotler's view of advertising can be contrasted with that of Packard and of Bergström, for example.

${ }^{74}$ As early as in 1948, Maurice Merleau-Ponty had described how " $[\mathrm{t}]$ he things of the world are not simply neutral objects which stand before us for our contemplation. Each one of them symbolizes or recalls a particular way of behaving, provoking in us reactions which are either favourable or unfavourable" (63).

${ }^{75}$ Discussing the ethical problems facing the advertising industry, Williams (1980:176) goes as far as to say that after WW2, advertising "turned from the simple proclamation and reiteration, with simple associations, of the earlier respectable trade, and prepared to develop, for all kinds of product, the old methods of the quack and the new methods of psychological warfare."

76 "Motivation research is the type of research that seeks to learn what motivates people in making choices. It employs techniques designed to reach the unconscious or subconscious mind because use preferences generally are determined by factors of which the individual is not conscious ... Actually in the buying situation the consumer generally acts emotionally and compulsively, unconsciously reacting to the images and designs which in the subconscious are associated with the product." (Louis Cheskin, the head of a research team at the Color Research Institute, which worked with psycho-analytically oriented studies for merchandisers, cited in Packard, 1957:14)

${ }^{77}$ Gale tested among other things, the attention value of different colours and the different parts of a magazine page (Kuna, 1976:347)

${ }^{78}$ The now classical AIDA advertising model (Attention $\rightarrow$ Interest $\rightarrow$ Desire $\rightarrow$ Action, ) attributed to St. Elmo Lewis in 1898, was based on a psychological approach. It was designed for personal selling, but later used for advertising. It became part of what Kotler, (discussed in Vakratsas \& Ambler 1999), has called "Response Hierarchy Models". It is also mentioned briefly in Chapter 5.

${ }^{79}$ Scott was commissioned by Thomas Balmer, a prominent advertising agent, to begin a series of studies on the psychological aspects of advertising and his book The Theory of Advertising from 1903 had as a central tenet the importance of suggestion. His insistence on the importance of persuasion and suggestion, influenced by the idea
} 
profession showed in the psychology of suggestion has been largely attributed to his work (Kuna 1976). Inspired by such ideas, Louis Cheskin ${ }^{80}$ and his team also investigated the impact of colour ${ }^{81}$. In fact, by 1951, advertising agencies were being exhorted to "recognize themselves for what they were - 'one of the most advanced laboratories in psychology"" (Packard, 1957: 29). As the Wall Street Journal reported, during the fifties, "[m]ore and more advertising and marketing strategists are adopting their sales campaigns to the psychologists' findings and advice" (ibid:43) and billions of dollars were spent on advertising of this nature. Particularly when one product is very like another, as is the case with petroleum and its derivatives, it was discovered that it was important to create brand loyalty. ${ }^{82}$ This could be done by some form of differentiation in the form of a brand personality, as Shell discuss in their 1963 Corporate Advertising catalogue, ${ }^{83}$ because while it is easy to imitate ingredients and claims of quality, "a vivid personality is much more difficult to imitate and so can be a more trustful sales factor" (ibid:46). Thus, to create a "vivid personality" was a necessary ploy for all the oil companies, and after conducting an in-depth study into what motivates consumers, the McCann-Erikson agency, for example, "found that there is considerable magic in the word power" and "perfected an ad strategy that hammered at two words, with all letters capitalized: TOTAL POWER" (ibid:72). These two words, along with the image of Tony the Tiger, the kindly, powerful feline, came to define the personality of the Esso brand.

These words, like so many other slogans and images produced by advertisers, became what André Breton called "catalysts of desire" ${ }^{84}$ Advertising has facilitated and fuelled our move to go beyond buying commodities in order to meet our basic needs, ${ }^{85}$ and now instead, "commodities address a wide range of desires, wishes and anxieties on the part of the consumer. Commodities play a crucial part in the formation of individual identities..." (Rampley, 2005:146). Following Marx'(1867) concept of commodity fetishism, Rampley describes how "a commodity, which is a mass produced artifact, a result of human labour and exchangeable for any other of its type, becomes endowed with its own properties, as if it were

\footnotetext{
of hypnosis, led to the "impressionistic school" of advertising and was in stark contrast to the tenets of the "reason why" school, whose proponents included the advertising agent and copywriter John E. Powers (Kuna, 1976).

${ }^{80}$ See for example Cheskin \& Ward (1948) where he explains how the intangibility of market reactions and the seeming importance that "forgotten" experiences exert over our behaviour (p.572).

${ }^{81}$ Merleau-Ponty (1948/2004) has pointed out that "a particular mood emanates from each colour" (60) while van Leeuwen (2011:6) quotes Barthes, who has proclaimed that colour is "a kind of bliss" and to whose power which Derrida paid "homage".

${ }^{82}$ Wendy Gordon (2011:11-12) insists on the importance of emotions in the seemingly most rational decisions and stresses the fact that memories are not static. Thus, brand associations are likely to change depending on the context in which they are recalled.

${ }^{83}$ Discussing their corporate advertising in a 1963 catalogue, (BP Archives, Warwick University), Shell-Mex and BP Ltd. describe the rationale behind a prize-winning 1961 campaign conducted by their advertising agents Mather \& Crowther. They write: "In our competitive field the way products are marketed has become as important to their success as their own qualities. The services we can provide for our customers have become vital incentives to buy. So these advertisements show the services we offer to nuclear power station contractors and house-wives, road-builders and farmers, to take just a few examples. They also show how we are continually streamlining these services to effect many economies. The campaign has translated the personality of the company into print." (italics and spelling mistake (effect) in the original, bold font mine). ${ }^{84}$ Cited by Merleau-Ponty (1948/2004:66).

${ }^{85}$ Packard (1963:20-32) discusses the concept of "Say's Law" and relates this to Mazur's "consumerism" and what J. Walter Thompson asserted was "activation by advertising" (21). The motor industry was a leader in the field of activating consumption and advocating "more car per car" (30). The extra size and weight of new models increased petrol consumption enormously, from twenty to fifteen miles per gallon in the first eight years of the fifties and new petroleum types were developed for the more powerful motors. These high octane motors also ravaged various components of the car, such as the mufflers. Not only were these trends beneficial to the oil companies, but new industries were born to supply the newly created needs of the motorist.
} 
more than a product." Again, I must insist that the oil companies have played upon this notion to encourage us to consume their products in ever increasing quantities in order to support the life-style which they have persuaded us to believe is a necessity and a right, and to encourage us to identify with just their specific version of what is basically the same product.

One method in which advertisers have been supported in this seemingly impossible task is consumer research, a field which Standard Oil can be considered to have invented. Morris Holbrook (1987a) has claimed that consumer research and marketing need to be distinguished, and states that the former looks at the phenomenon of consumption in all its forms. While Holbrook recognizes the role of other disciplines, including sociology, anthropology and what he broadly terms the "humanities" in consumer research, in my view, his suggestion that everything that we do involves consumption and that "[w] hat remains in the human condition is an imperfect and tainted world in which consumers can only strive to surmount their constant barriers to fulfillment" (131) espouses consumer research with marketing. Therefore I consider consumer research as a prescription for how best to advertise and include it in this overview.

The question is how, what Kotler \& Levy have termed "customer satisfaction engineering" (1969:10) is applied today, especially to every day commodities such as oil. What then are the techniques that advertisers or marketers are employing to sell their products or promote their brands? ${ }^{86}$ As Lannon \& Cooper (1983) point out, although brands have rational and practical values, it is their symbolic values that make them unique. ${ }^{87}$ Therefore they posit that successful advertising is dependent upon the advertiser being able to tap into the intuitive level of their publics, which involves a holistic, cultural perspective of the phenomenon. ${ }^{88}$ Advertisers have thus been searching for new ways not only to "persuade" but also to uncover what factors actually lead their publics ${ }^{89}$ to noticing, recalling and responding positively to an advertisement and to a perceived brand personality.

\section{Recent Trends in Advertising}

As the general public become increasingly aware that companies are trying to persuade them to buy their products and commodities, particularly in the wake of the "scientific approach", pursued for example by Cheskin and which is often thought to have led to increased skepticism among consumers, advertisers have been obliged to develop new techniques and methods to encourage brand loyalty and consumption. Although advertising in the form of television commercials started in the 1950s and the internet has become a self-evident stronghold for advertisers, these forums and the developments that have taken place there are

\footnotetext{
${ }^{86}$ In his editorial on the occasion of the diamond jubilee of the Journal of Marketing, Roger A. Kerin (1996:4) tries to categorise the trends of the six decades. He posits that the major themes of 1956-65 concerned assessing the impact of the marketing mix while those of the next decade were uncovering buyer and organizational processes, that marketing was seen more as a behavioural science. Kotler (1972) has also tried to trace the history of marketing through its different phases from a branch of applied economics to the social focus which he posits it has achieved. Kotler here defines marketing as "the disciplined task of creating and offering values to others for the purpose of achieving a desired response (46).

${ }^{87}$ In the words of Pollay $(1985: 25)$, the emphasis moved from the product to consumer appeal and motivation, or from selling the steak to selling the sizzle.

${ }^{88}$ Firat \& Venkatesh (1993:237) have pointed out that "many consumers know that the objective of advertisements is to persuade, and think that while other people are persuaded by advertisements, they, themselves, are not." This implies that advertisers must know their customers and potential customers in order to by-pass this built-in resistance and suspicion in order to achieve their goals.

${ }^{89}$ Moffitt (1994: 160) defines a public as "a group of individuals who share knowledge, attitudes, or behaviors toward an organization and who also hold a similar image of the corporation which has been projected to the environment by the corporation".
} 
outside the scope of this study. Instead, I will discuss those developments which I consider have most relevance to the print advertising of the five oil Majors below.

\section{Advertorials}

One very interesting direction that advertising took in the 1970s and that was raised to a fine art in the capable hands of Mobil, ${ }^{90}$ was the advertorial. This form of "masked advertising" (Nöth, 1987:279), became popular when The New York Times newspaper launched the page on September 26, 1970, opening the space to noncommercial advertising", "a window in the world" (Brown et al. 2001:26). The op-ed space was sold on an editorial page opposite the standard one, and was designed to cover diverse opinions and commentaries and to allow corporations to polish their identities and to comment on "policy issues" (Smith and Heath 1990:48-49) ${ }^{92}$. The "advertorial" ${ }^{93}$ is an instrument that owed its early success in part to the fact that it did not have the appearance of an advertisement, and therefore was attributed a more authentic voice and a detachment from the more sordid aims of persuasion for commercial gain than an advertisement. ${ }^{94}$ In fact, the newspaper claimed that this was the "page that policy makers look to first, and "where views would be "heard by the people who make decisions" (Brown \& Waltzer, 2005:197). This reflects the ambitions of The Economist, a periodical in which the major oil companies have tended to advertise. As Porter \& Kramer (2006) have pointed out, every company exists and operates in a social context as well as in a competitive context, and "must integrate a social perspective into the core frameworks it already uses to understand competition and guide its business strategy" (p.7). The advertorial is one form of incursion into the social sphere through which a company tries to transform and construct social phenomena, or "people's concepts of the world they live and act within" (Fairclough, 2005:915).

Brown \& Waltzer (2005:197) define advertorials, as a form of outside lobbying, as "paid messages in the media sponsored by organized interests to create and sustain a favorable political environment to pursue their respective goals" ${ }^{95}$ and identify two types of advertorials; image ${ }^{96}$ advertorials and advocacy advertorials. ${ }^{97}$ The former are "designed to create a positive impression of the sponsor and a favorable climate of opinion" while the latter are intended "to win support for an interest's viewpoints on controversial issues" (ibid). They provide a company with a means to "prime" and "frame" its stance on a number of issues.

\footnotetext{
${ }^{90}$ The Mobil advertorials will be discussed in more detail in the next chapter.

${ }^{91}$ The newspaper claimed that this was the "page that policy makers look to first" where views would be "heard by the people who make decisions" (cited in Brown \& Waltzer, 2005:197).

${ }_{92}$ The newspaper claimed that opening the op-ed page was "in furtherance of the objectives of the First Amendment of the Constitution" (cited in Brown et al. 2001:27).

${ }^{93}$ A combination of the words advertisement and editorial, Webster's define the advertorial as "a report in the form of a paid advertisement intended to provide information to the public" They go on to point out that it is usually a company or other organization that makes use of this means of communication.

${ }^{94}$ Brown et al. (2001) provide a brief history of advertorials from their incipience in 1908, through the Depression and up until 1998. They state that in the 1970s, when the phenomenon grew with the op-ed page of the Times, it was the "industries that felt the most beleaguered - petroleum, energy, and chemical industries [that] led the pack" p. 28). They also provide an overview of the literature on advertorials (p.26).

${ }^{95}$ Kotler \& Levy (1971:3) discuss the possibilities of "social marketing" as a "promising framework for planning and implementing social change" which is to some extent what the advertorials attempt to do.

${ }^{96}$ Gregory \& Wiechmann (1991:1) insist that image is "the very leading edge of corporate strategy".

${ }^{97}$ For more information about these different types, see Brown et.al. 2001.

98 Alex Wang (2007:126-127) claims that "priming and framing essentially involve salience and selection of representations." He concludes that "priming plays an integral part in the process of agenda-building as advocates attempt to communicate with publics, whereas framing plays an integral part in defining social issues and actions in dealing with them"
} 
"Advertorials are crafted to catch the reader's eye, and can run up to 650 words which is longer than the 400 word maximum for 'letters-to-the-editor.' The style is crisp, assertive and frequently witty" (Brown \& Waltzer, 2005 :199). ${ }^{99}$ Although Mobil has dominated the advertorial genre, its use of this communication strategy is by no means unique and Shell, for example, has taken advantage of the advertorial concept in a number of situations when energy policy has been on the public agenda.

\section{Story Telling}

An area that is receiving increasing attention is story-telling and has emerged from the work of Vladimir Propp. A number of scholars, such as David Glen Mick, have studied "story grammars" as advertising models. Mick has shown how the stories or "consumer myths" that are narrated in an advertisement typically follow the canonical sequences ${ }^{100}$ of story elements identified by Propp, and work to "preserve the ethos of consumerhood" (1987:250).

The concept of myth is central to my study and story-telling, or the narrative turn, is a term that I am using as an umbrella to incorporate the many different ways in which organisations describe the work that they are doing using different forums and addressing different publics. Under this umbrella, I include company reports and strategy documents as well as different aspect of public relations (PR) a domain that is one of conflicting philosophical assumptions. Not only do scholars and practitioners differ in how they define and describe public relations and organizational communication, but also in what they hold to be the purpose and effect of this branch of marketing. Is the purpose of public relations to manipulate different stakeholders or is it to disseminate information and promote understanding? (Grunig, ed. 1992:6) Whatever stance scholars and practitioners might take, and wherever the somewhat ambivalent conceptual distinction between PR and marketing is drawn, is it is a matter of fact that public relations has become increasingly important and is one of the means by which companies narrate their identity and promote their social ambitions. For this reason, increasing attention has been paid to its study. Pracejus et al (2006:84) suggest that since the 1950 s, companies have made use of corporate art to legitimize and reify their corporate face, while the growth and development of the Advertorial can be considered to be another instantiation of the increasing use of public relations (PR). The enormous growth in advertising with its "biased message paid for by a company with a selfish interest in that the consumer consumes" (Ries \& Ries, 2002:5) ${ }^{101}$ leads to the risk of a "wallpaper effect" (ibid: 8). In their discussion of PR, they note that an advertisement can no longer be an argument, but only serve as a reminder (ibid: 95) and that as marketing no longer deals with products, but instead, with perceptions, public relations are a much more efficient way to deal with these circumstances (ibid: 51). They posit the idea that advertising is brand maintenance while PR is brand building (ibid: 125) and positioning. PR seeks influence and legitimacy and advertorials are one means to achieve this end and is a form of PR by which a company reaches the people who count (247). That the oil companies, for example, are interested in

\footnotetext{
${ }^{99}$ Mobil used two different forums for their advertorials: One was the Op-ed page of The New York Times which they rented every other Thursday from the inauguration of the space in 1970 until 2000, and which aimed more at decision makers and Observations, half-page olios in the Sunday magazine section for the general public. For more information and analyses of these advertorials, see for example Crable \& Vibbert (1983) who have anaysed the Op-ed pages over the period 1976-1980, or Sharon Livesey (2002) and Smith \& Heath (1990). ${ }^{100}$ Zelling Harris developed his seminal idea of "transformation" which was later taken over by Chomsky, partly from his examination of advertising messages (Mick 1987:252).

${ }^{101}$ In 1975 , the annual expenditure per capita was $\$ 110$ and by 2002 had reached $\$ 865$, which even adjusting for inflation represents a doubling. Annual advertising expenditure has outpaced U.S. GDP of which it represented $2.5 \%$ in 2002, and was just below that of the defense budget. In 2002, the US accounted for $44 \%$ of the world's annual advertising expenditure (Ries \& Ries, 2002: 9).
} 
reaching such people is also reflected in the publications in which they choose to communicate today.

One of the most common ways in which companies reach out to the public and try to influence their judgment is through corporate sponsorship. Sponsorship in itself is nothing new, and the oil companies, for example, have a long history of sponsoring aviators and record breaking speed events. Neither has the sponsorship been limited to events that have a direct connection with the demonstration of their products. BP sponsored the London 2012 Olympic Games contributing perhaps naturally to transportation systems, but also to sponsoring the preparation of individual athletes. As I have already remarked, Shell for example, not only sponsored record attempts but even provided unknown artists with the opportunity to make their name (John Hewitt, 1992). However, as Julian Stallabrass (2004) has remarked, businesses have moved from sporadic sponsorship, including that of artists and the arts, to building partnerships which link both brands in an attempt to inflate them both. Companies now commission works of art ${ }^{102}$, exhibit them and even curate exhibitions that are held in public venues and this is a means of exploiting and cultivating cultural capital. Stallabrass (2004:92) suggests that companies reap a number of benefits from such activities. One is that art audiences tend to be relatively better off and better educated and by companies are thus highly valued as potential customers, while another is that the sponsorship makes them seem charitable. ${ }^{103}$ The companies reap the success and acclaim generated by the exhibitions ${ }^{104}$ while it is often the State that anonymously pays the mundane bills and ensures that the drains are maintained. Further, sponsorship of the arts and of museums is seen to legitimize the creativity of the company and to show them in the light of a social benefactor and patron. This is a traditional way of expressing prestige, wealth and cultural capital. ${ }^{105}$

Kotler (1986:117) too, stresses the importance of public relations in marketing today, positing that the practice has gone beyond "the task of arranging need-satisfying and profitable offers to target buyers", something that can often be satisfied by an assiduous application of the classical four Ps of marketing strategy, ${ }^{106}$ to the need to satisfy the requirements of an increasingly important group of "gatekeepers"; third parties such as governments and interest groups. To this end, he introduces two further Ps, power and public relations, and introduces the concept of "megamarketing" which he defines as "the strategically coordinated application of economic, psychological, political, and public relations skills to gain the cooperation of a number of parties in order to enter and/or operate in a given market" (ibid).

Again, this can be recognized in the different forms of communication employed by the oil companies. $^{107}$

\footnotetext{
${ }^{102}$ This is in itself not new and the London Transport Company did this in the first decades of the $20^{\text {th }}$ century, and Shell has a long history of involvement in such exhibitions.

${ }^{103}$ Stallabrass (2004:92) claims that companies that sponsor arts often have image problems and "seek to burnish their reputations with cultural munificence" and cites BP's relationship with the Tate as an example.

${ }^{104}$ BP sponsored a highly acclaimed exhibition Houghton Revisited during the summer of 2013. The exhibition showed the art collection of Britain's first Prime Minister, Sir Robert Walpole, which he sold to Catherine the Great to adorn the Hermitage. Among the other sponsors was Christie's, the famous auction house that specialises in Fine Arts.

${ }^{105}$ The term is reported to have been was first used by Bourdieu in "Cultural Reproduction and Social Reproduction" (1973) written with Jean-Claude Passeron but has been associated with Bourdieu since 1986.

${ }_{106}$ The four Ps are Product, Price, Place and Promotion.

${ }^{107}$ This, of course, was the reason behind Mobil's aggressive advertorial campaigns. However, other companies in the oil industry have also made use of PR in different forms from the early days of Caltex with its film buses in Sweden (Wilson 2012) to BP's summer Big Screen Showings and the various different competitions that Shell, for example sponsor.
} 
Advertorials are not the only manifestation of public relations, however, and in direct opposition with the tenets of Milton Friedman, ${ }^{108}$ various types of corporate philanthropy or corporate social responsibility (CSR) are also increasingly common nowadays. Sen \& Bhattacharya (2001) discuss the impact of CSR in an American context and ascribe it with six broad domains: community support, diversity, employee support, environment, non-U.S. operations and product (ibid:226). ${ }^{109}$ Shell, in fact, wrote about a number of these domains in the report which was commissioned from Peter Knight in 1998 and an interest and insistence on these domains can be increasingly noticed in the communication of the Majors through their advertising. As Waeraas and Ihlen (2009) have pointed out, it is not enough for organisations to do good, but they must be seen to be doing good and in order to acquire legitimation, need to adapt or manipulate social environments to this end and to their advantage in a kind of corporate "evangelism". One area in which it has become increasingly important to show social responsibility is that of the environment and climate change, in other words, corporate "greening" 110 This is especially for companies involved in the oil industry,

Another strategy is corporate narrative, whereby companies not only try to justify their actions to the general public but also work to make their personnel feel that they are a part of a greater and often mythical whole. ${ }^{111}$ As McWhinney and Batista (1988:46) point out, "[t]he myth is the foundation of life" and "each organization might embody a core myth." This core myth often centres on or around the founder of the company but can also be based on the notion that the business in which they are engaged is and the products that they are selling are not merely for profit but for the common good. This is the underlying theme of the oil companies and is in line with what Maarten Hajer (1995:63) refers to as "story-lines". Storylines are a means to position actors in roles such as victims, problem solvers and top scientists, and allows an organization to create coalitions. In fact, "many stories incorporate a problem-solving motif wherein a protagonist faces a dilemma requiring goal setting, strategy development, strategy implementation, and evaluation" (Rumelhart, cited in Mick, 1987:253) and I intend to demonstrate how these story elements are implemented by the companies involved in the oil industry.

\footnotetext{
${ }^{108}$ In 1970, Friedman wrote that to remain consistent with the fundamental capitalistic principles of a free market built upon the concepts of Adam Smith, the only responsibility of a business is to its shareholders and that the only social responsibility that it has is "to use its resources to engage in activities designed to increase its profits so long as it stays within the rules of the game, which is to say, engages in open and free competition without deception or fraud" (in Prasad and Holzinger 2008:3).

${ }^{109}$ More discussion about the impacts of CSR can be found for example Du et al. (2007), Alex Wang (2007) who discusses the effects of priming and framing on enhancing public response to different aspects of CSR, Saiia et al (2003), Porter \& Kramer (1999) and Porter \& Kramer (2006). Sherry (1983) discusses corporate gift giving, including the donation of scholarships and research funding and Javalgi et (1994) provide an empirical investigation of the impact of corporate sponsorship in the marketing mix. The oil companies are particularly active in these areas.

${ }^{110}$ See for example Newton \& Harte (1997), for a review of the green business literature or Peter Newell (2008) who explores the notion of accountability through corporate reactions to climate change and Renato Orsato (2006) on the economics of being green.

${ }^{111}$ See in particular the extensive work of David Boje on what he terms "Storytelling Organizations" for example (2005). Mary Boyce (1996) provides a critical review of organizational storytelling, and Stutts and Barker (1999 discuss audience assessment in situations like the Exxon Valdez catastrophe and while Taylor et al. (2002) examine Management Storytelling in cases including the Exxon Valdez disaster.
} 


\section{Some Closing Words}

This chapter has followed the history of the genre of advertising and also described the contributions which the companies involved in the oil industry have brought to the development of advertising and marketing ${ }^{112}$.

The next chapter investigates research trends in the world of advertising in general and also presents the work and findings of scholars who have made a special study of companies involved in the oil industry. Particular attention is given to research into semiotics and rhetoric, which are not only the focus of a rapidly growing number of researchers today, but are also central to my study. The vexed issue of genre is again addressed and the ways in which the oil companies have developed and used new, hybridized forms described. The different means which companies have at their disposal to influence and respond to public opinion are introduced and discussed in the context of the oil industry.

Just as the historical overview of the oil industry in Chapter 2 provides a description of the social, cultural and political context in which the advertising of the oil companies can be understood, my ambition with Chapters 4 and 5 is to provide the reader with a frame of reference that facilitates and enriches their understanding of the individual advertisements in my study and which allows these to be put into a greater perspective as examples of a genre. An advertisement is the product of its time and of the trends and fashions that are in sway when it comes into being and as such, to be understood and appreciated cannot not be viewed in a vacuum.

${ }^{112}$ The concept of consumer research has been attributed to Standard Oil who interviewed people to find out what they would like, then developed this and found ways of bringing the new development to public attention. 


\section{Chapter 5}

Research into Advertising: the State of the Art

Samuel Sparling recognised the "creative force" of advertising as long ago as $1908 .{ }^{1}$ Since then, much of the scholarly examination of advertising has had a prescriptive purpose and its end has been to teach practitioners to improve the force of the message that they wish to communicate. My interest lies not in how to advertise but rather in examining and describing the skilful and creative ways in which the tapestry of an advertisement has been woven. To this end, it is necessary to examine the different wefts and warps and weaving techniques that are used. Therefore this chapter provides an overview of some of the most common ways in which scholars are examining the different materials that are used to create an advertisement and describes some of the more specific tools which the weavers of advertising communication use in their trade. My main focus is on those threads of research into advertising that are most central to my study; rhetoric and semiotics.

Therefore this chapter introduces some of the trends in research into advertising and focuses especially on those trends that are related to the relatively new interest in advertising as a form of communication. The interest in how semiotics, rhetoric and poetics can be used to attract the public's attention to the advertiser's message and to aid their retention of it has exploded, and it is these threads that are particularly interesting from my perspective. The chapter first provides a general overview of research in the field of advertising and then the research that has focused on the advertising of the oil industry is presented.

\section{Research Trends}

Packard (1957:206), citing a 1954 study published in Business Week wrote: “Today's emphasis on people's motives, the search for a science of behaviour, is more than just a fad. Far from blowing over, you can expect it to keep getting more important." Judging from the number of publications in the field of advertising and marketing today that instruct practitioners just how to motivate people in general and potential consumers in particular, Packard's prophecy has shown to be correct and there are numerous books and manuals that describe how an advertiser or marketer can achieve success. ${ }^{2}$ Morris Holbrook (1987a) for example, points out that in his own specific field, consumer research, other disciplines "have begun to sneak [in]" to help deepen our understanding of consumer behaviour. In this way, marketers can better understand what drives consumer behaviour and use this to inform advertising theory and practice. Indeed, it is on the basis of disciplines such as sociology and psychology, and in particular on the "linguistic turn" that organizational research has taken, that much of the more recent research into company discourse in general and advertising in particular, is founded. Holbrook \& Batra (1987) for example, discuss the role of emotion as a mediator of consumer response to an advertisement, while Catrin Johansson (2007) has shown how Goffman's ideas about impression management, framing, footing and face are useful concepts for public relations. Goffman's insights into the way that individuals, and by extension companies and institutions, choose to present themselves to the public are central to

\footnotetext{
${ }^{1}$ See Jones \& Monieson (1990).

${ }^{2}$ Examples include Holbrook \& Batra (1987), Magnus Söderlund, (2003) and Hansen \& Riis Christensen (2007) who discuss the importance of tapping into emotions for successful advertising. Hansen \& Riis Christensen define emotions as "inner guiding unconscious processing" (p. 100) and include an overview of what they call "neuroeconomics" in their volume. James Grunig ed (1992), provides advice for successful public relations management, and the numerous publications by Phillip Kotler and his various co-writers provide extensive information on different aspects of marketing. Vakratsas \& Ambler (1999) provide an interesting overview of different types of models and empirical results of how advertising works.
} 
my understanding of advertising and to the wide scope of activities that my umbrella definition of the concept covers.

\section{Early Research Trends}

One of the early forms of research into how to affect people by means of advertising was the use of laboratory experiments into various aspects of consumer and marketing response, such as those conducted by Cheskin. One of Cheskin's interests was the impact of colour and the effect that it plays in the everyday lives of the majority of people. This led him to analyse what he termed "strikingness" and to investigate gender preferences in both colour and form (Cheskin \& Ward 1948:578). In a more recent experiment, Hansen \& Riis Christensen( 2007) have demonstrated the importance of neurology in emotional response tendencies, and shown how these can be measured and applied in the planning of advertising strategies. Another example of how advertisers have joined forces with researchers to study and improve the impact of their advertisements is memorability research. The purpose is to investigate how well a consumer recognizes pictorial stimuli compared to verbal, and what form of stimulus has better recall effects. ${ }^{3}$

As I stated in Chapter 4, pictures in advertisements have become increasingly important. Pollay (1985:28) has reported that in general, magazine advertisements have increased in size. While 87 per cent of the advertisements in the first two decades of the twentieth century were partial pages, by the $1920 \mathrm{~s}$, some 43 per cent were a full page or more and by the $1970 \mathrm{~s}$, multi-page spreads constituted 16 per cent of the sample he used in his study. ${ }^{4}$ Moreover, over 75 per cent of print advertisements had pictures covering at least half of the available space by the 1950 s, something which my investigation of oil-company advertising during this period confirms. Here too, the dominance of pictures has been increasing.

Advertising is a costly business ${ }^{5}$ and advertisers choose the media in which they place their advertising message with care. An advertisement placed in a newspaper or magazine demands that the reader makes a "sacrifice of the best of his possible alternative time uses" (Philip Nelson, 1974:745) to give it attention. ${ }^{6}$ Therefore in order for the reader or potential consumer to "sacrifice" time to the advertisement, it is necessary to make it eye-catching and interesting. It is also important that the advertisement is received and understood positively and is remembered. McQuarrie \& Phillips (2005) are among the scholars who argue that pictures are extremely important in advertising communication and suggest that these can also be used to make indirect claims which can confer some advantage to direct claims (7).

Thus, advertising researchers have traditionally devoted a great deal of attention to discovering how readers are attracted to advertisements and what processes seem to enhance and facilitate both recall and a positive response. An interesting example is the work by Ogilvie \& Mizerski (2011) who use the different semiotic approaches of Saussure's communication model together with Peirce's triadic semiotic philosophy. Their purpose is "to gain greater insights into the consumption behaviours of individuals from a communication as

\footnotetext{
${ }^{3}$ See for example Edell \& Staelin (1983) for more information about this.

${ }^{4}$ It must be stressed that Pollay's work is based on an American corpus and that the situation in the U.K. was quite different as Kelley (1956) and Hendon \& Muhs (1986) and have described.

${ }^{5}$ Shelley Du Bois, September 12010 , reported for CNN that in the three months following the 2010 disaster, BP spent $\$ 93$ million in advertising. This figure is three times that of the same period the previous year and provides some indication of the vast amounts that the industry spends on advertising.

${ }^{6}$ Nelson suggests that the printed media has the advantage that the reader can look at the advertisement as many times as he or she wishes.
} 
well as an experiential perspective" in order to provide useful information ${ }^{7}$ which helps marketers to strategically focus communication with their target audience and for public relations where the establishment of mutual trust and confidence is essential.

\section{Endorsement}

In the world of advertising, endorsement is the act of publically supporting a product or a brand and this is an area that is particularly interesting to my study.

The first formal advertising model is attributed to E. St. Elmo Lewis in 1898 (Vakratsas \& Amber, 1999:26) and is known as AIDA. (Attention $\rightarrow$ Interest $\rightarrow$ Desire $\rightarrow$ Action). According to Zafer Erdogan (1999:291) celebrity endorsers ${ }^{8}$ both attract and maintain the attention of potential consumers and improve recall rates for the messages advertised. Additionally, such endorsers can be effective as they trigger interest in the product endorsed and awaken aspirations to be like the endorser. His literature review shows that not only attractiveness but also expertise and trustworthiness are considered to be important qualities in an endorser as these help establish trust and engender confidence. However, as Walker et al (1992:70) point out, celebrity endorsers also "bring their symbolic meanings to the endorsement process", the cultural meanings that "reside" in the products and these meanings are then "passed on" to the products. This means that it is extremely important to get a "proper fit between the celebrity and the product" (Till \& Shimp 1998:67) and the associations that the endorser generates must be the right ones. Thus, when the endorser is subject to negative publicity, this can impact on the brand. ${ }^{9}$

\section{The communicative turn}

Creating and responding to an advertisement is a form of communicative event, and the study of different communication systems has become the focus of much of the research into advertising that is taking place today. Marketing scholars are therefore turning to different areas of semiotics and linguistics in their search to optimize the persuasive qualities of their communication with different audiences. However, marketing specialists are no longer the only scholars with an interest in advertising, and linguists and semioticians have increasingly begun to study advertising and bring a number of different perspectives to the task of analyzing what is actually "going on" in an advertisement and how this is achieved. It is among this rapidly expanding group that I position myself.

Geoffrey Leech is generally acknowledged to be the first British scholar to consider advertising as a linguistic act and to address the question of language in advertising. ${ }^{10}$ Since Leech's pioneering work, a number of scholars have joined the ranks of those who are interested in advertising in its various forms as an act of communication. Guy Cook (1992,

\footnotetext{
${ }^{7}$ The object of their study is the use of make-up in everyday life and how this is experienced by women.

${ }^{8}$ Zafer Erdogan (1999:293) identifies four types of endorsing activities: Spokesperson, actor, endorsement and testimonial. These will be discussed later.

${ }^{9}$ Till \& Shimp contend that cartoon "celebrities" are generally immune to negative publicity (68) and that the creation fictitious endorsers can also be successful advertising tactic.

${ }^{9}$ Leech's master's thesis (1963) Disjunctive Grammar in British Television Advertising builds on the notion of "block language" coined in 1935 by Heinrich Straumann for a type of language that is grammatically simple and which is designed for the speed and efficiency of communication. This was followed in 1966 by English in Advertising: A Linguistic Study of Advertising in Great Britain which was the first in the field.
} 
2001) for example, has analysed advertising as a form of literature and more recently (2008:117), has examined the interest that scholars in the field of Applied Linguistics (AL) have given to advertising and Public Relations (PR). This interest is largely due to the ubiquitous nature of PR and to the increasing blurring of the boundary of PR with news and politics and consequently, with the issue of power. Advertisements and PR both rely heavily (although not exclusively) upon language in order to persuade and obtain affiliation with the ideas that they propound. Roger Fowler (1996:54) defines linguistic activities as practices of "person-management through language." He comments that the tendency in such practices is towards stability, the consolidation of social legitimacy and modes of control which "habitualize perception". Fowler posits that any form of institutional utterance, including advertising and company reports, is a linguistic act and it is my contention that the purpose of all forms of advertising is to bestow legitimacy and a positive face upon the product or company that is advertised. Moreover, constant exposure eventually leads to the public accepting the message communicated without greater reflection, and in this way it becomes part of our reality. ${ }^{11}$

As I have stated, the focus of my interest is not on how to be a successful advertiser but rather on uncovering the techniques that the oil companies have used to habitualize our perception of their products and their work through their print advertisements. Researchers have been able to show that most persuasive and successful advertisements are crafted around the principles of rhetoric and the shifting landscape of semiotics, and it is in these that I will anchor my own analyses.

\section{Semiotics in advertising}

David Glen Mick (1986:197) cites Sebeok who stated in 1976 that the scope of semiotics includes "the exchange of any messages whatever and the system of signs which underlie them". Semiotics is central to my study and is something which is developed further in Chapter 7 where the particular focus is on the visual elements of an advertisement. The present chapter, however, provides an overview of the ways in which scholars from different fields have adopted a semiotic approach to their research into advertising.

The First International Conference on Marketing and Semiotics took place in 1986, and in his review of research in this area that year, Mick suggests that semiotics provides a useful tool for consumer research. Although he attributes the interest and development of this scientific field $^{12}$ to the work of Sidney Levy in the $1950 \mathrm{~s}^{13}$, it began to gain momentum ${ }^{14}$ in the late 1970s and since then, an increasing and varied body of studies that consider various semiotic aspects of advertising has appeared. The volume edited by Jean Umiker- Sebeok (1987) just one year after that first conference, gave proof of the interest among marketing scholars in

\footnotetext{
${ }^{11}$ According to Michel de Certeau (1984), we live in a "recited society" which is made up of récits, (the stories and fables created by the advertising and informational media) citations of stories and of the interminable recitation of stories. "Hidden experts" produce the "consumable fictions" which we accept and live by (summarised by Graham Ward 2000). Certeau (1984:7-8) discusses how Experts are becoming increasingly common and imbued with authority that they often do not merit.

${ }^{12}$ Deirdrie McCloskey (2009: 25) insists that semiotics is a science and distinguishes between practice and science, pointing out that the original meaning of the word "science" refers to a "highly systematic study". ${ }^{13}$ In "Symbols for Sale" (1959: 118) Levy claims among other things that "[p] eople buy things not only for what they can do, but also for what they mean" and suggests that "the interactions among symbols which direct consumers' choices are liable to the difficulties of all communications, and consequently warrant study" (124).

${ }^{14}$ It is also possible that the impact of Roland Barthes' seminal study of the Panzani advertisement which appeared in 1964 had begun to spread throughout the English-speaking world, contributing to this interest.
} 
this area. Jean-Marie Flosch, ${ }^{15}$ has insisted that semiotics provides a means to investigate the 'nebulae of meaning' that are or that become advertising concepts. Flosch points out that a "word is a condensed utterance" which often incorporates a number of meanings ${ }^{16}$ that are attributable to history and to context and goes on to say that: "Semiotics uses this double lesson of the dictionary as its point of departure" [and like the word], an advertising concept under the analytical gaze of the semiotician - constitutes only the small, visible tip of an iceberg of meaning, while its plot, roles, décor and stage setting are not always apparent, or at least not all at the same time" (2001:6).

There is a tendency for scholars to privilege either the discourse of the text or that of the image. For example Cook $(1992,2001)$ who compares advertising with literature, states that "there is as little consensus about what constitutes literature as there is about the status and morality of advertising" (ibid: 1992: xv). However, while other scholars, such as Barthes, whose seminal analysis of the Panzani advertisement ${ }^{17}$ dates from 1964, and later Flosch $(1985,2001)$ tend to privilege the image in their semiotic analyses ${ }^{18}$, it is understood and acknowledged that the different elements and semiotic systems that together comprise and compose the "finalization" of a work of advertising are inextricably interlinked and that it is only together that they produce meaning. Günther Kress (2010:1) has posited that "[w] riting and image and colour lend themselves to doing different kinds of semiotic work; each has its distinct potentials for meaning" (italics in the original) and advertising and marketing researchers have turned to semiotics in order to investigate advertisements as what Flosch (2001) referred to as "objects of meaning." Scott \& Vargas (2007) study and discuss the parallel streams of response to advertising images, one of which considers visuals as sensory data while the other presumes that images are communicative artifacts. The authors argue that images can communicate brand information more predictably and sometimes more effectively than can writing. They suggest that a logo seems to be "the whole of a brand distilled into a single sign - a shorthand jot for a very long and complex text" (355). The importance of the logo is evidenced by Flosch (2001) who describes and analyses the work that preceded the changing of the logo of Crédit du Nord after its merger with Banque de $1^{\prime}$ Union Parisienne. ${ }^{19}$

Discussing the impact of visuals in general and how through their fluency in the visual language "advertising creatives" can transfer relevant cultural knowledge to brands, Olsen et al (2012:856) state that "industry experts have argued that visuals have become the lingua franca of advertising". The importance of art is advertising has also been discussed by John Berger (1972) who points out that advertising makes use of the techniques and symbols of the history of painting. This aspect of advertising is also taken up by Marchand (1985) who suggests that artistic references suggest a cultural superiority. This is in line with the ideas expressed by Bourdieu (1984) to the effect that fine art provides a taste-making vehicle. Thus, art in an advertisement lends a patina of culture and superiority to a product and contribute to its culturally symbolic value. ${ }^{20}$ Taking a different angle on the role of visual art and culture,

\footnotetext{
${ }^{15}$ In his introduction to the 2001 publication of Flosch's book from 1995, John Sherry (2001:ix) has referred to him as "France's foremost semiotician of marketing." For the sake of simplicity, I will refer to this edition.

${ }^{16}$ Flosch (2001) for example, discusses the word and concept "clarity" to try to unravel the knot of its numerous synonyms and antonyms.

${ }^{17}$ This is discussed in more detail in chapter 7.

${ }^{18}$ Göran Sonesson has also written extensively about semiotics privileging the image (e.g. 1992 and 2005), and claims that the battles about iconicity have been fought on the field of the image. He points out that according to Peirce, an icon does not have to be visual and argues for different levels of iconicity.

${ }^{19} \mathrm{BP}$ provide evidence of the importance of a logo as they describe the motivations and reasoning behind the helios as their logo for the $21^{\text {st }}$ century.

${ }^{20}$ See for example Schroeder \& Zwick (2004) who analyse and discuss the associations between the traditions and conventions of art history and production and advertising images.
} 
Borghini et al (2010) present what they find to be a symbiotic relationship between commercial art and street art, and discuss the "potential contributions of the creative rhetoric employed by the stakeholders of street art to the advertising practice" (113).

McQuarrie \& Mick (1999) discuss the way in which an approach that combines the image and the verbal elements of an advertisement can be used to inform the ways in which readers draw meaning from the "bricolage" of both these elements. They posit that using a text-interpretive perspective which draws on semiotic, rhetorical, and literary theories can "provide a systematic and nuanced analysis of the individual elements that make up the ad [as it] treats visual and verbal elements as equally capable of conveying crucial meanings" (38).

As semiotics "seeks to identify the conventions and operations by which any signifying practice [...] produces its observable effects of meaning" (Culler 1981:48), its interest for advertisers, whose task is to persuade, cannot be ignored.

\section{Rhetoric}

"The goal of rhetorical theory is always to organize the possibilities for persuasion within a domain and to relate each possible stratagem to specific desired outcomes", (Phillips \& McQuarrie 2004:113), and this is the central purpose of advertising. This central purpose explains the increasing interest that researchers are showing in the uses of rhetoric and rhetorical strategies in advertising.

The concept of a desired outcome or response is closely linked to the ideas propounded by Perelman and Olbrechts-Tyteca, Kenneth Burke and later to the concepts of readership put forward by Wolfang Iser $(1974,1978)$ which I discussed in Chapter 3, and has been enthusiastically adopted by researchers interested in the impact of an advertisement. ${ }^{21}$ Perhaps the most commonly cited author in much of the research into advertising discourse is Aristotle who insisted that rhetoric was the art of persuasion and identified three modes for doing this: ethos, "furnished by the spoken word" (2004:7) and dependent upon the character of the speaker; pathos, the more emotional aspect of persuasion that rouses sympathy; and logos, the "apparent proof" (ibid) provided by the speaker's words. ${ }^{22}$ Wayne Booth (2004:xi) has summarized the art of rhetoric as "the entire range of resources that human beings share for producing effects on one another" (italics in the original). This is indeed a toolbox for an advertiser.

Among those scholars who have investigated this toolbox are McQuarrie \& Mick (1996) who trace the history of rhetoric from Aristotle to the advent of modern social psychology and discuss why it is an important aspect of consumer research. Their purpose is to contribute a "richer and more systematic conceptual understanding of rhetorical structure in advertising language" (424).

However, as Philippe Breton (2003:17) points out in his treatise on argumentation, the third of Aristotle's modes of persuasion, proof provided by the speaker's words, is pure argumentation, an act of communication, and as such can never be universal. Chaïm Perelman (1977), for example, has addressed the situated, dialogical nature of rhetoric by insisting that an argumentation can never take place in a void but requires the speaker to create some form

\footnotetext{
${ }^{21}$ Iser, (1978:26) for example, points out that if a text is classified as represented meaning and potential effects, then it is identified with a specific intention. The intention of an advertisement is to trigger a potential (desired) effect.

${ }^{22}$ Perhaps it is the words "apparent proof" that led at least in part to the moral questioning of rhetoric, or what Wayne Booth (2004) refers to as "Rhetrickery".
} 
of mental contact with the auditorium. As he points out, any form of communication is a two way process and a speech must be heard, and book must be read if they are to have any effect. I would like to add that in the case of an advertisement, it must be noticed. Perelman, like Burke, insists on the importance of the speaker recognizing the audience ${ }^{23}$ and strengthening a sense of community or communality around those values that he or she is trying to impose. This is a lesson which advertisers have taken to heart and whose impact scholars have begun to investigate. While rhetoric has always been recognized as an important aspect of persuasion, ${ }^{24}$ and as such, a central element of advertising, the interest shown in different aspects of literary theory by those involved in advertising in its widest sense, particularly by consumer researchers, is relatively new. D. McCloskey (1996:231) for example, points out that both sophistry ${ }^{25}$ and rhetoric "have experienced rehabilitation".

A general consensus is that an experience that is in some way pleasurable to the reader facilitates both recall and a positive response. To this end, a number of researchers such as Linda Scott (1994) have turned their attention to techniques based on literary theory and criticism, particularly to rhetoric and Reader Response Theory. Scott (1994a:461) has pointed out that "[a]dvertising often takes a highly fictive form" which makes use of dramatic settings, provocative narratives, imaginary characters, exaggerated pictures, and figurative language". ${ }^{26}$ Mick \& Buhl (1992) adapted the concepts of Reader Response Theory to consumer response to advertisements. They stress the importance of the reader's horizons of expectations and conclude that the meanings construed from the advertisements were individual and dependent on the readers' "life themes", which are relatively stable, and "life projects" which are in constant flux. Frank Cioffi (1988:278) has labelled the process through which an advertiser provides implicit or explicit directions which map out for the reader the way in which the text should be read and interpreted "audience-projection" and identifies four techniques for this. ${ }^{27}$ This is in line with Gry Høngsmark Knudsen (2012), who also insists that consumers negotiate meaning and that interpretations are both polysemic and dialogic in nature. Elliott \& Elliott (2005) have built on the work of Mick \& Buhl (1992) to develop the concepts of Iser (1974) and Stanley Fish (1980) and Linda Scott (1994b) ${ }^{28}$ too has investigated reader response.

Phillips \& McQuarrie (2002) take a historical perspective on advertising to investigate how rhetorical style, and specifically figures such as the metaphor and rhyme have changed over time $^{29}$, while McQuarrie and Mick (2003a) have investigated the impact of rhetorical figures such as rhyme and metaphor on recall and attitude. Their earlier work (1992:181) includes a study into the idea of "resonance", which is defined as "a play or twist within an ad's

\footnotetext{
${ }^{23}$ Perelman (1977) points out that the audience does not necessarily consist of those that the speaker explicitly addresses. This is in line with the general participant framework of advertisements and was illustrated by the prototypical advertisements in Chapter 3.

${ }^{24}$ Researchers into consumer behaviou $r$ also frequently cite the works of today.

${ }^{25}$ McCloskey rejects Plato's notion that sophistry was "mere verbal trickery" and recognizes it as an understanding of the world based on the social and on conversation (1996:323).

${ }^{26}$ The approaches mentioned here that are based on different literary theories will be discussed in much greater detail in the theoretical framework.

${ }^{27}$ The four processes that Cioffi identifies are projecting an audience through context, the use of genre as an audience-projecting device, artistic borrowings, reflexivity or mirroring.

${ }^{28} \mathrm{Scott}$ 's focus is male response to idealized images of masculinity.

${ }^{29}$ The period in question is from 1954 to 1999. Phillips \& McQuarrie motivate this choice because the years from the early $1950 \mathrm{~s}$, through the end of the century, have been identified as a period when product discourse centred in mass media texts and because a span of almost 50 years is long enough to ensure that stylistic trends have the opportunity to emerge. Their motive is prescriptive, to find possible "new avenues for research into persuasive strategies" (1).
} 
structure that serves to produce an echo or multiplication of meaning". They claim that this is something that an advertisement exhibits when it "combines wordplay with a relevant picture to create ambiguity and incongruity" (McQuarrie and Mick 1992:183) and point out that this is just one of the family of literary devices termed "rhetorical figure". Their reader response approach (1996) draws on semiotic, rhetorical and literary theories and they conclude that "rhetorical figures, in whatever form, can be expected to have two primary effects on consumer response. The first is increased elaboration and the second is a greater degree of pleasure" (ibid: 39). They insist that "the experience of advertising is a function of a complex process facilitated by tacit, culturally situated knowledge structures that predate and, to a notable degree, pattern the kinds of meaning" (ibid: 42). Guy Cook (2001:3) shows that among other things, advertisements "use fictions, word play, compressed story-telling, photography, puns and rhythms in ways which are often memorable, enjoyable and amusing". Considering the fact the many of the early copywriters had a background anchored in literature $^{30}$ and many aspired to become writers, ${ }^{31}$ it is perhaps surprising that interest in advertising as literature developed so late.

However, as I have already indicated, the importance of the pictorial elements of an advertisement has increased, and this is reflected in the number of publications that examine the rhetorical aspects of the image. Scott (1994a:252) theorizes advertising images as rhetoric and points out that "[r]hetoric is an interpretive theory that frames a message as an interested party's attempt to influence an audience". She insists that "pictures are not merely analogues to visual perception but symbolic artifacts constructed from the conventions of a particular culture" and therefore must have a specific intended audience. Visual images are not automatically available and comprehensible to everyone but require the same cultural competences as any other text. Thus, it is important to understand visual symbolism and the concept of artistic style. Scott also insists on the importance of understanding foregrounding, backgrounding and colour contrasts (ibid: 256). Olsen et al (2006) are among the scholars who study advertising as rhetoric and in particular, visual rhetoric, as a social product. Their ambition is to develop a socio-historical theory of commercial and visual art and to do this they study the development of the trope of white space to demonstrate how rhetorical convention is a result of history.

Scott \& Vargas (2007:341) have extended "the rhetorical stream" by suggesting that in contemporary advertising, pictures are beginning to function in a way which resembles that of a writing system, while Borghini et al (2010:114), who "approach the craft of advertising as rhetoric", insist that the symbols that used to persuade in this form rhetoric are both verbal and visual. McQuarrie \& Mick (1999), Phillips \& McQuarrie (2004), and Scott (1994a) have also approached advertising rhetoric in this way. Phillips \& McQuarrie (2002:5) have noticed however, that what Barthes (1977) referred to as "verbal anchoring" has decreased over time and note that by avoiding anchoring, advertisers can state "the Unspeakable" (6). Pracejus et al (2006) have examined how the objects and symbols used in commercial art, or advertising, derive meaning from their histories, and discuss the rhetorical connotations of white space as a visual trope, positing that among the attributes that it is typically used to convey are elegance, power and modernity. Their findings show that white space has a significant positive impact on consumer brand perception. Gail Tom \& Annmarie Eyes (1999) have

\footnotetext{
${ }^{30}$ In chapter 4 I mentioned the work of Dorothy Sayers for example, and John Betjeman the Poet Laureate, wrote a variety of texts for Shell including guide books and poems for their White May and Pink Aladdin paraffin oils and also lent his voice to television commercials.

${ }^{31}$ Consider, for example, Orwell's failed poet but highly successful copywriter Comshack with his "vivid phrase that sticks and rankles" (1936:59).
} 
shown that advertisements that include visual rhetorical figures are better remembered than those that do not, a finding corroborated by McQuarrie \& Mick (2003b:217).

\section{Poetics}

The importance of poetics in advertising is underlined by Sherry \& Schrouten (2002:219) who observe that the Academy of Management now includes an "Art and Poetry" track at its annual conference. They discuss how poetry can convey pan-human emotion and how privileging the emotional can result in a deeper sympathy between the writer and the reader. Barbara Stern (1998:10) has pointed out that the writings of scholars such as Wayne Booth and Kenneth Burke have begun to erase the distinction that Aristotle made between rhetoric on the one hand, and on the other poetics, as the intention of both is to persuade and influence. Poetics, in fact, is a frequent element of pathos as it stirs emotions. Writing together with Zinkhan and Sherry, (1998) she argues that poetic representations are a valid modality of consumer experience ${ }^{32}$ and cites S. I.Hayakawa (p. 292) who in $1964^{33}$ called advertising "the poeticizing of consumer goods" and pointed out that advertising can be considered "sponsored poetry". Stern also refers to the Russian poet Mayakovsky, who as early as 1923 claimed that "great ad lines were poetry". This notion has more recently been echoed by Roger Fowler (1996:56) who has pointed out that "[c]reativity in language is not limited to 'literary 'texts'". As research into advertising discourse demonstrates, it is also central to advertisements and the concept of poetics, a traditional area of literature, has now entered advertising theory and constitutes an important element of my study.

Paul Ricoeur (1975:266) suggested that the essence of poetic language is not the fusion of sense and sound but the fusion of sense with a fleet of images that it evokes or excites. George Zinkhan, the whose interest in creativity in advertising led him to becoming particularly active in this area of advertising research, considered that poetry can function as a means to deeper understanding. Zinkhan (1994) suggested that poetry, of which metaphor and image and sound and rhythm are important elements, can encourage both scholars and practitioners to think more about the "creative spark which drives much of advertising" (3).

Tropes have attracted the attention of researchers, and the best known of the rhetorical figures is the metaphor (McQuarrie and Mick 1999).

Paul Ricoeur (1978: 144) attributes "[t]he first articulate account of the metaphor" to Aristotle who states that "it makes discourse (logos) appear as such and such" (italics in the original). Good metaphors require the capacity to contemplate similarities and to "set before the eye" the idea that they wish to communicate. Likening this to Wittgenstein's concept of "seeing as"34 (150), Ricoeur calls this the "picturing function" of metaphorical meaning. However, metaphor has not always received good publicity ${ }^{35}$ and has been considered a means of deception. Among the qualities that Wayne Booth (1978) attributes to metaphor are that it

\footnotetext{
${ }^{32}$ Representating Consumers: Voices, views and visions (2004)

${ }^{33}$ From semantics to the U.S. Senate

${ }^{34}$ Ricoeur (1975:268-270) compares what he means by "seeing as" in comparison to Wittgenstein's use of the term in detail. For Ricoeur, it is a factor revealed by the act of reading, the way in which the imaginary is realised. He describes it as the intuitive relationship that holds together the sense and the image. For Wittgenstein, Ricoeur claims that "seeing as" is not a question of metaphor nor of imagination, but is instead a question of hypothesis.

${ }^{35}$ While Hobbes acknowledged that one of the four purposes of speech was to "please and delight ourselves and others, by playing with our words, for pleasure or ornament, innocently" in Leviathan, he states that the "general use of speech is to transfer our mental discourse into verbal; or the train of our thoughts, into a train of words. $[\ldots]$ to show others that knowledge that we have attained [and] to make known our wills and purposes" (in Ted Cohen, 1978:4-5).
} 
communicates more than the words literally say and that it is active, lending energy to whatever is more abstract. He also insists that a metaphor is context-dependent. Like Booth, Carl Hausman (1989:5) also insists on the active qualities of the metaphor. Moreover, he suggests that "creative metaphors are performative" as they have the "force of acts of generating or bringing". In this he echoes Ricoeur's reference to the "metaphorical act" (1978:159).

A fervent believer in the power of metaphor, Gerald Zaltman pioneered and patented the ZMET, the Zaltman Metaphor Elicitation Technique, during the 1990s. Writing with Coulter in 1995, Zaltman advocated that "developing effective copy requires research methods that open windows into the consumer's mind and that access relevant rational and emotional issues and their interplay" (35-36). Basing his insights on the work of Lakoff and Johnson, Zaltman, who believes that metaphors are an invaluable tool for advertisers, has stated ${ }^{36}$ that they "the engines of the imagination".

Among researchers who have studied metaphors in the context of advertising is Carita Lundmark (2006) who uses the theories of conceptual metaphor and conceptual blending to analyse what she terms "the creative exploitation of idiomatic expressions" in British magazine advertising. Barbara Stern (1990) has studied metaphors in advertising from a descriptive standpoint and taking the perspective of Aritstole's Poetics, considers them as an "art" In this, she follows Cohen (1978:7) who "subscribe[s] to the opinion that metaphors are peculiarly crystalized works of art".

Metaphors are not limited to words and visual as well as verbal metaphors can be used in an advertising picture both separately and together, often in the headline. Indeed, it is usual for the picture and the headline to work together to make meaning. To this end, Phillips (1997, 2000, and writing with McQuarrie in 2004) insists on the importance of both visual and textual metaphors and states that verbal copy is thought to act as an anchor for consumer response. Bonhomme \& Lugrin (2008) also reflect upon metaphor and metonymy in advertisements. Their particular interest lies in the impact of visual and verbal tropes and the relationship between them. They conclude that engaging the public in interpretive games and requiring people to "read beyond the image" (ibid: 248) will result in a better retention of the message. ${ }^{37}$ These scholars find that on a communicative level, visual images have a denser information potential than verbal (ibid: 256) and make concepts more concrete. They state that visual tropes offer a "fan" (ibid: 251) of interpretations which activate readers according to their pre-dispositions. The trope then becomes a source of stimulation to the imagination and contributes to the pleasure of the reader. In other words, like Ricoeur, (1978) they attribute metaphor with the arousal of feelings.

Phillips \& McQuarrie (2004) have investigated the persuasive role of pictures and discuss the importance of "marrying textual analysis as found in literacy, semiotic and rhetorical disciplines, with the experimental methodology characteristic of social and cognitive psychology" (p.113) to reach an understanding of the phenomenon. Ang \& Lim (2006) follow another direction to study the influence of metaphors on how customers perceive brands, and reach the interesting conclusion that brands that are non-metaphoric may be perceived to be more honest. They also point out that metaphors can be found in both advertising headlines and pictures, and suggest that they can influence the way in which a brand personality is

\footnotetext{
${ }^{36}$ Cited in Ang \&Lim (2006:40).

${ }^{37}$ One of the examples upon which they draw is the Esso tiger. It is perhaps interesting to note that in line with the findings of Till and Shimp ((1998), this extremely popular and successful product "endorser" is a cartoon character whose reputation and appeal remained untarnished.
} 
perceived. Interestingly, McQuarrie \& Phillips (2005) report that figurative pictures approximately doubled in number between 1954 and 1999 and suggest that by means of such pictures, claims that would be unacceptable in verbal form can be made ${ }^{38}$. Joy et al (2009) discuss the role of conceptual blending using visual elements of advertisements to explore how consumers harness this to construct meanings. They argue that conceptual metaphor and blending are complementary, and examine the occurrence of these phenomena in three types of blending networks in advertisements.

Ted Cohen (1978:8) has observed that there is a transaction between "the maker and the appreciator of a metaphor" which draws them closer together and which constitutes the acknowledgement of a community. In other words, understanding metaphor requires a dialogical process which cultivates a sense of intimacy. This insight is shared by Donald Davidson (1978:31) who has stated that "[m]etaphor is the dreamwork of language" and requires "collaboration between a dreamer and a waker". To better understand this collaboration, another branch of research into metaphors in advertising concerns how well the metaphors are understood by the target audience. This strand includes the work of Morgan \& Reichert (1999) and Ward \& Gaidis (1990) as well as that of Charles Forceville (1994) who investigated pictorial metaphors in advertisements basing his analyses on the concepts of linguistic, denoted and connoted messages posited by Roland Barthes (1964). In 1995, Charles Forceville published the results of an experiment that he had conducted to investigate whether or not participants recognized advertising metaphors as such, and to what extent their interpretations correlated.

Following Aristotle, A.I. Richards has insisted that the metaphor is the "supreme communication device" and proclaimed that "command of metaphor [allows us to] go deeper still into the control of the world that we make for ourselves to live in" (cited in Booth 2004:70). The interest that scholars are showing in this field seems to indicate that Richards is not alone in appreciating the power of this particularly ubiquitous rhetorical device control and make a world for others to live in, that is to say to influence, persuade and even manipulate different publics.

\section{Humour}

Another common characteristic of advertisements is humour ${ }^{39}$ and its impact in advertising was approached by Sternthal \& Craig as long ago as 1973. However, humour seems to be culturally as well as individually programmed. They conclude that while humorous messages do seem to attract attention, there is no clear evidence that humour is more successful and more persuasive than a serious appeal, a question that Zinkhan \& Gelb (1987) also address. Among researchers who have investigated the impact of humour are Madden \& Weinberger (1982), who contend that humour is a fundamental human emotion and tentatively suggest that it has a positive effect on the way in which the advertising message is received.

James Leigh (1994) has examined figures of speech in the headlines of print advertisements and concludes that alliteration, assonance and puns are the most common. Puns, of course, are often humorous and often found in the headlines or slogans. W.D. Redfern (1982) has referred to puns in advertising as "guano of the mind" and suggests that they are highly economical and labour-saving promotional devices. Verbal and visual puns ${ }^{40}$ have received extensive

\footnotetext{
${ }^{38}$ The authors cite Calkins who has stated that "A picture ...can say things that no advertiser could say in words and retain his self-respect".

${ }^{39}$ Humour and different types of visual and verbal jokes were standard ingredients of Shell's early advertising.

${ }^{40}$ Shell can perhaps be considered the masters of the pun.
} 
interest in more recent research, both with regard to their appeal and to their impact on recall. Farough Abel (1994) for example, posits that the interactiveness required to interpret puns is conducive to memory performance while McQuarrie \& Mick (1992:180) define what they call "resonance" as "wordplay in the presence of a relevant pictorial".

More recently, Elmira Djafarova (2008) has explored the role and interpretation of puns in print advertising using a pragmatic approach. She points out that advertising messages are aimed at enormous, heterogeneous audiences and that consequently, the impact of punning cannot always be assured and that the ambiguity carried by puns may cause difficulties if the advertising text does not provide enough explanation. As she points out, advertising is about association, and punning can convey more than one meaning economically. Djafarova builds on the work of Keiko Tanaka (1992), who used the notion of Relevance Theory developed by Sperber \& Wilson, (1981), ${ }^{41}$ to investigate puns in advertising. Although there is a risk that the pun will be missed or not understood, Djafarova's contention is that solving the pun can lead to enjoyment and the additional processing effort required can result in better recall.

The work of Weinberger \& Gulas (1992) and Spotts, Weinberger \& Parsons (1997) seems to indicate that humour should not be the focal point of a magazine advertisement for any product, as context and audience factors are central. These findings are particularly relevant today when advertising has become increasingly international. Few studies have been made into the impact of humour on different nationalities and culture groups, but Lynette Unger's findings (1995) seem to imply that humour can in fact travel, and that the affective model for humour in persuasion suggests that it can be a mediating variable which positively influences the addressee.

\section{Internationalisation}

\section{Language}

As Garrett \& Iyer (2013) state in their literature review of international advertising research, globalization is becoming an increasingly important factor for world markets, and in its wake, cross-cultural issues are occupying an increasingly central position. For Multinational Corporations (MNCs), such as the oil companies, identical advertising strategies result in lower costs, but do not guarantee success in different markets (Subhash Jain, 1989), and this is something which international marketers must wrestle with. Two main issues arise with regard to internationalization and globalization: language and culture. Language choice and use constitute the essence of verbal communication and as language and culture are very often interconnected as Lynette Unger (1995) points out, an increasing body of research is developing in this area. However, as the advertisements in my corpus are all in English and the bulk of the research on language concerns bilingual advertising, I will not specifically address the question of language here.

\section{Culture}

Roland Barthes (1977:36) has insisted that the impact of culture on advertising communication extends beyond language and understanding both the denotational and the connotational aspects of a message "is a matter of an almost anthropological knowledge". As companies advertise internationally, the issue of culture and consequently, even cultural

\footnotetext{
${ }^{41}$ The principle of Relevance Theory is that "Every act of ostensive communication communicates the presumption of its own optimal relevance" in Tanaka (1992:92). In other words, in any communicative situation, the audience will search for a meaning that fits their expectation of what is relevant and upon finding a suitable meaning, will stop processing the message.
} 
values, has become increasingly complex. An interesting illustration of this observation is found in the work of Biswas et al (1992) who compared print advertisements in France with those of the United States and take up the very interesting issue of the purpose of communication. They argue that while "Americans view communication as a process of transmitting messages for the purpose of control" and consider it to be a means of "persuading others, changing attitudes, and influencing or conditioning behavior," Europeans (exemplified in their study by the French) "view communication as a process through which shared culture is created, modified, and transformed" (ibid: 74). Similarly, Hong et al (1987:55) insist that "communication is [...] closely tied to cultural norms", and that as it is a form of social communication, "[c]ultural values tend to be reproduced in idealized form through advertising so that the audience may want to identify closely with the subject of the advertisement." This echoes Levy (1987:24) who cites Lévi-Strauss' view that culture is the rules for the "games of communication."

\section{Context}

Advertisements are anchored in not only in culture but also in context. In Chapter 3, I took up the matter of context and its unobservable centrality to communication (van Dijk 2008) and now return briefly to the concept of context in advertising. Although the majority of the out into the impact of culture on addressee response to advertising tends to be carried out in Asian contexts, a number of scholars are now exploring the impact of cultural differences in European advertising. Christine Wikman (2005), for example, has built on Barthes (1977) to investigate the reactions of native Italians and Swedes to Italian food advertisements. She concludes that "because of their encyclopaedic knowledge, [Italians] make an interpretation which corresponds well to the sender's intended meaning" while Swedish receivers "do not recognize the frames used by the sender". Context can be understood as a kind of framing device which is embedded in culture but which incorporates attitudes and what is taken-forgranted.

I.H. Rowlands (2000) has demonstrated the importance of the nationality and home base of a company in its response to outside pressures, in the specific case in question, to climate change. ${ }^{42}$ Moreover, as Peter Svensson (2009:556) points out, in crisis situations, specific situations framing the crisis require different communicative strategies which must reflect the different cultures and systems of values of those involved. An example of this is that today, in much of Europe, "green is good," and Øyvind Ihlen (2008) provides an overview of the way in which companies use the power of rhetoric to project a green image. Waeraas \& Ihlen (2009) focus on what they call "green legitimation" (p.96) to apply the concept of rhetoric to uncover the means by which successful companies ${ }^{43}$ communicate the impressions and beliefs that legitimize their actions.

\section{Gender}

Mary Douglas (1970:98) asserted that the way in which the body can be used as a medium of expression is restricted by the controls set in place by the social system and that consequently, the human body is "an image of society" and any natural way of considering it must involve a social dimension. One way in which culture is reflected through advertisements and which has received a great deal of attention since Erving Goffman's (1976) seminal article concerns the way in which gender roles are portrayed. Two general approaches to this matter have developed. One of these has its focus on audience reception, while the other, following

\footnotetext{
42 The companies that were investigated were the American oil company Exxon and British BP.

${ }^{43}$ The companies that they study are General Electric, Toyota and Starbucks.
} 
Goffman, centres on the ways in which gender is cast and presented. This includes the ways in which characters are posed. It is this latter approach that I find most interesting.

Erving Goffman (1977:302-304) echoed Mary Douglas to point out that all societies place infants at birth into one of the two sex classes and seem to have developed a conception of what is essential to and characteristic of these two classes and which attributes are desirable. Through socialization into a sex class, individuals build up a gender identity which is a profound source of self-identification. This genderism ${ }^{44}$ becomes linked to behavioural traits and practices. Advertising is a particularly persuasive proponent of a specific value system (Pollay 1983) and it is therefore not surprising that researchers have begun to investigate the way in which the images, and particularly photographs, used in advertising portray the prevailing social and cultural norms. Goffman's ideas have brought about a strong interest in the way in which gender and gender roles are depicted, and the depiction of gender in the advertising of the oil companies is one of the issues which I intend to confront. Perhaps unsurprisingly, the majority of the people that feature in the advertisements in my corpus are male and as my historical overview has shown, it is the masculine that is traditionally the norm in the oil industry.

Since Goffman opened this Pandora's box, a number of scholars have taken issue with the way in which the female is presented in advertisements and the way in which through the representation of bodies, "advertising actively creates and reinforces gendered identities" (Patterson \& Elliot 2002:232). ${ }^{45}$ Scott (1994b), for example, insisted that an understanding of the relevant culture and a "shared vocabulary" (p.255) are essential elements of visual rhetoric, and the way in which women are portrayed in advertisements is heavily embedded in culture. Suzanne Romaine (1999) has provided a comprehensive overview of how advertisements display gender in both images and language, and discusses the stereotyping that is typically found. Like the majority of scholars, her focus is on the portrayal of women. Judith Waters \& George Ellis (1996) and Mee-Eun Kang (1997) for example, confirm Goffman's findings and discuss the negative consequences of such stereotyping and its relationship to what becomes the social ideal while Veronika Koller (2012:20) states that stereotypes are "petrified knowledge structures" or metonymic conceptualisations in which the characteristics of a specific group come to represent the whole category. As Richard Pollay (1986:27) pointed out, advertisements might not mirror reality but they do have the capacity to reinforce stereotypes, as well as to promote specific, often romanticized life-styles.

Writing in 1996, Jean Umiker-Sebeok claimed that the gender system in U.S. print advertising seemed to have remained unchanged and that males still appeared to dominate spatiotemporal resources and have positions of more power and authority (e.g. Courtney \& Wernick Lockeretz 1971, Belkaoui \& Belkaoui 1976, Elliot et al (1992), Mee-Eun Kang 1997, Bell \& Milic 2002). John Mager \& James Helgeson (2010) have looked at changes and consistencies in gender portrayal for a period of fifty years and conclude that although there has been some change, Goffman's observations still tend to hold. In their follow-up to Courtney \& Wernick Lockeretz (1971), Wagner \& Banos (1973) also perceive some slight change and note that the number of women in working roles had doubled, while Venkatesan \& Losco (1975) deduce that although the portrayal of women as sex objects decreased during the period of their study (1959 to 1971), other stereotypes had not. Their study was based on specific periods, 1959 to 1963, when the Equal Pay Act was passed, the period 1964 to 1968 when the Civil Rights Act emphasized the role of women and insisted that they should be in governmental positions, and

\footnotetext{
${ }^{44}$ Goffman himself uses italics for these terms.

${ }^{45}$ Patterson \& Elliot are particularly interested in the recent development of the depiction of male bodies in advertising.
} 
finally the period of the Women's Liberation Movement, 1969 to 1971. These findings are generally supported by Sullivan \& O'Connor (1988) who investigated women's role portrayal in magazines from 1958 to 1983 . Similar observations were made by Demarest \& Garner (1992). Ford et al (1991) have also pointed out how traditional female stereotypes, particularly those relating women and domesticity, continued well into the 1980s. Steven Lysonski's (1985) investigation of gender role portrayals in British magazines between 1976 and 1983 found that shifts had been minor. Lysonski raised the question whether there was a cultural lag between stereotypes and reality. Elliot et al (1992) confirm that women are still portrayed primarily as "homemakers". Investigating advertising over the last three decades of the twentieth century, Lori Wolin too (2003), finds that although there has been a move to a slightly less stereotypical stance, this still exists.

As my brief survey indicates, the gendered nature of advertising has received a great deal of attention, and typically, the research has focused on the portrayal of women (Koller 2012).

More recently, however, some attempts have been made to redress this balance. Noting that semiotically, masculinity is irrevocably connected with and opposed to femininity, Schroeder \& Zwick (2004: 23) investigate the cultural construction of masculinity by looking at the way in which the male body is visually represented in advertising and apply a historical approach to show how a "visual viewpoint illuminates advertising representations infused with visual, historical, and rhetorical presence and power" (ibid). They contend that "advertising plays a strong role in promulgating dualistic gender roles and prescribing sexual identities (ibid:21). William O'Barr (2006) has investigated how gender expectations are instilled through advertisements. According to O'Barr, masculine images typically convey power, strength, virility, athleticism, and competitiveness ${ }^{46}$, while feminine images show beauty, submissiveness, nurturance and cooperation, but gender is neither fixed nor static. ${ }^{47}$ Another area of gender research that has begun to attract attention is concerned with response, and Elliott \& Elliot (2005) for example, study the "negotiated character of male identity" (6) from this perspective.

Klassen et al (1993), attempt to address the issue of gender on the basis of Goffman's gender analysis, and expand the frame to include not only "appropriate behavior" (30) but also the way in which the relationships between men and women are portrayed. On the basis of their own investigations and a literature review, they conclude that there is a slight trend towards a more egalitarian portrayal of the sexes in American magazine advertisements. However, with the exception of the work of García-Muñoz \& Martínez (2009) who observe that women are portrayed as consumers or as victims, the research to which I have referred is exclusively Anglophone and monocultural, and moreover, it is predominantly American.

However, when companies advertise globally, the question of who is portrayed and how this is done becomes particularly interesting and extends far beyond the matter of gender.

\section{The Narrative turn}

Anna De Fina, (2008: 422) has argued that narratives provide a resource for identity construction. However, narratives are not only for individuals, but they also constitute a very important resource that organisations employ to further their purposes.

\footnotetext{
${ }^{46}$ Linda Tuncay Zayer (2010) identifies eight salient themes of ideal masculinity: the Adventurer, the Athlete, the Attractive Man, the Daredevil, the Family Man, the Goal-Driven Man, the Individual and the Strong Man. Her research is based on a segment of American men who fall into the category Generation X and who are predominantly single, well-educated and Caucasian. They are also outwardly heterosexual.
} 


\section{Genre revisited}

For this reason, I will very briefly review those strands of research that are concerned with narrative investigation. These can all be categorized as different forms of the genre "advertisement", a "blurry" concept which was presented in Chapter 3 and whose historical development was traced in Chapter 4.

I take a broad perspective on this field which includes corporate narrative and corporate story-telling. David Boje has written extensively on corporate story-telling ${ }^{48}$ and claims that this is central to their identity building. He suggests that successful story-telling is an important element in the subsequent success or failure of an enterprise. Stories serve a rhetorical function (1995) and are often also an important element of employee satisfaction. It is by narrating a particular identity that companies seek to legitimize and strengthen their positions and protect their different forms of capital. However, the use of story-telling to convince or persuade an audience is by no means new, and in fact, Aristotle (2004:93) considered that stories in the form of fables were a useful rhetorical technique

My perspective on narrative here is perhaps best expressed by the umbrella term institutional advertising, a form of corporate discourse which Marchand (1985) claims dates back to 1908. As Harry Keyishian (1996:49) stated, this form of advertising "is designed to articulate corporate values - or what the corporation wishes the public to believe are its values". Keyishian incorporates both corporate philosophy and corporate worldview in his use of this umbrella term. ${ }^{49}$ Moreover, I suggest that companies often use story telling as a line of defense in their crisis rhetoric when deflecting criticism. Therefore I would like to add the matter of values advocacy to this thread. Values advocacy has been discussed for example by Bostdorff \& Vibbert (1994) who describe it as an appeal to shared cultural values.

Corporate social responsibility ${ }^{\mathbf{5 0}}$ is frequently projected through the stories told in the press as well as in company advertisements. One of the most successful cases of a company creating a positive, socially caring image was in fact The Body Shop, whose policy was not to advertise its products at all. Instead, the company achieved publicity through publicly professing its values and social commitments (Livesey \& Kearins, 2002). ${ }^{51}$ It was by a corporate discourse that worked to create and build upon a caring, transparent image that The Body Shop was so successful. Foucault has stated that power of different types is based on human relationships and is constructed through discourse ${ }^{52}$ and it is upon relationships with different stakeholders that the company has concentrated.

I take the stance that corporative narrative is an element of company public relations. According to Ries and Ries (2002) there has been a dramatic shift from advertising-oriented marketing to public relations-oriented marketing. This, they claim, is because public relations (PR) has more credibility than advertising and if properly directed, can provide the positive perceptions that an advertising campaign can then exploit. They make the claim that advertising should follow PR both in timing and in theme. Their claim is that PR creates a

\footnotetext{
${ }^{48}$ Boje has written about corporate story-telling in general and also about the stories told by specific companies. However, to the best of my knowledge he has not investigated the stories told by the oil companies.

${ }^{49}$ Keyishiam describes and discusses the television advertising of GeneraL Electric (G.E), a company that like those involved in the oil industry has had its share of criticism, to illustrate his thesis. There are, in fact, a number of striking similarities between G.E's advertising campaigns and the approaches of the oil giants.

${ }^{50}$ Ihlen (2008) discusses this concept and its link to public relations.

${ }^{51}$ The authors compare the 1998 Sustainability Reports of The Body Shop and Royal /Dutch Shell.

${ }^{52}$ Foucault's definition of discourse is wide and incorporates practices and structures. Livesey and Kearins (2002) expand this even further to include corporations and the natural environment.
} 
brand while the role of advertising is to defend it. Among the other claims that they make to contrast advertising with PR are the notion that advertising is visual whereas PR is verbal, that PR is less expensive and that it is serious and does not build on humour. While Ries and Ries discuss the matter from a prescriptive point of view, Guy Cook (2008) has investigated advertising and PR from the concept of genre and applied linguistics. Although he generally agrees with the ideas put forward by Ries and Ries that I have listed above, he states that the boundary between the two genres is by no means clear. He concludes that both are promotional activities but that as advertisements have a long history and can be easily identified, PR, which is less regulated and less constrained, has provided organisations with a means to infiltrate the social sphere. Cook claims that while advertisements may have some artistic merit, PR "in many ways reflects the worst aspects of propaganda" (124).

Like Cook, I interpret PR widely, and consider that the boundary between the advertising and PR is extremely blurred. This finds confirmation in the work of Vijay Bhatia. Developing his work from 1993, Bhatia (2002:10) discusses what he calls "colonies of genres". He states that primary forms ${ }^{53}$ of promotional genres have traditionally been regarded as advertisements, and has augmented his earlier list to include sub-genres such as "Cross-cultural Variation", which includes testimonials and consultation documents and "Mixed forms" which serve a mixture of two or more communicative purposes through the same generic form. Mission statements, press communiqués and company brochures are encompassed within this group.

While the primary forms of promotional genres, or to misappropriate a term used by Ireneusz Opacki (1987) "royal genres", have traditionally been advertisements and sales promotion letters, Bhatia has found that annual reports and corporate brochures are also entering this field as "mixed" or "embedded" genres. This demonstrates how the promotional genre has a historical development which is similar to that of literature. Opacki has used the term "hybridization" to refer to the process of evolution through cross-fertilization that occurs when in the course of their historical development, other genres enter the sphere of influence of the dominant genre, or "royal genre". He contends that socio-historical factors shape a specific attitude towards the world and bring about the rise of a new trend that better fits the genre to the internal tasks and problems that it has been developed to address (in Duff :2000, 118-119), something that Bhatia's work demonstrates.

My understanding of PR incorporates the Mission Statement, which is often short and can include a slogan or motto. ${ }^{55}$ Chevron, whose current slogan is "Human Energy" and whose very brief mission statement reads "At the heart of The Chevron Way is our Vision to be the global energy company most admired for its people, partnership and performance," provides a good example of this.

In their study from 1995, Swales \& Rogers identified and described two types of Mission Statements, one built around an empowering historical vision and a second that was a crisis response. Both were rhetorically designed to "ensure maximum employee 'buy-in'" (223). Moreover, these statements could be either very scientific or "more poetry than product" (237). Veronika Koller's study (2008) indicates that there has been a change in this form of

\footnotetext{
${ }^{53}$ I do not use the term primary genre in the Bakhtinian sense as a form of everyday life, of dialogue, but tend towards Bhatia's use of the term. Thus, I use primary genre in the sense of the first of its kind or the "royal genre" from which others have developed. Thus, I consider advertorials and mission statements to be secondary forms of the primary genre of a traditional print advertisement, for example.

${ }^{54}$ Bhatia (1993:68) describes this as a "conformative" in the sense that such genres are "universally conventionalized to such an extent that even in their cross-cultural realizations, they rarely show any variation". Although his main focus here is on research papers, he takes up a discussion of sales promotion letters here.

${ }^{55}$ Ries \& Ries contend that PR of different types often precedes and informs an advertising campaign.
} 
corporate communication. Koller has identified mission statements as one of the forms in which internally and externally oriented corporate discourse cannot be clearly demarcated and points out that these often function as carriers of ideology (158). She proposes that mission statements serve a number of purposes. They serve to promote companies as an employer of choice, the preferred provider of specific products, and construct "the branded company as a socio-cognitive representation" as well as "promoting particular self-schemata for their audience" (162). Koller claims that when we think of corporate discourse in the public sphere it is advertising, with its "ubiquitous, pervasive and even intrusive nature" that first comes to mind but strongly supports the view that different forms of corporate discourse are colonizing the public sphere (169).

Issues management, is a relatively recent branch of research, which according to Crable \& Vibbert (1985:3), is an attempt on the part of a company to "generate and nurture issues until they result in favorable public policy" and is something that they analyse with respect to the Mobil Oil Company. I suggest that among the strategically most important issues for companies today is "greening" and the impact of their activities on the environment. To this end, companies have increasingly begun to produce corporate environmental reports as environmental friendliness is increasingly being considered good business practice and increasingly too, have based advertisements or even whole advertising campaigns on these reports. Discussing the issue of creating a "green" image through environmental reports, Aud Solbjørg Skulstad (2008) was able to investigate 23 corporate environmental reports. Of these reports, four were provided by oil companies and are among the very earliest in his corpus. ${ }^{56}$ Heath (2002) and Heath \& Cousino (1990) have also investigated this communicative phenomenon and found that it is a catalytic strategy which is used to prompt or make things happen (9). However, I would like to posit that image repair strategies and crisis communication as examined for example by Benoit (1997), Stutts \& Barker (1999) and Peter Svensson (2009), are also forms of issues management and can even be subsumed into corporate narrative. Øyvind Ihlen, (1994) who has taken a rhetorical approach ${ }^{57}$ to investigate the ways in which organizations try to influence and indeed create both public opinion and policies on energy and the environment, extended this to what he terms critical rhetoric and uses the technique to study public relations strategies, or "Radical PR".

Another interesting development can be found in the work of Ken Hyland (1998) who has investigated the metadiscourse employed in company communication in the form of the words penned by the CEOs. Hyland suggests that metadiscourse is a manifestation of the writer's linguistic and rhetorical presence in a text and that it is used to realize rational, credible and effective appeals. ${ }^{58}$ Such a form of discourse is found in the advertising of Chevron for example. Another interesting investigation is that conducted by Prasad \& Mir (2002). They studied the letters written by the CEOs of different U.S. oil companies to their shareholders during the troubled times of the 1970s and 1980s to defend their honesty and legitimacy and to argue for the "organic harmony" (104) of the interests of the oil industry and of the nation.

\section{Myth and Corporate Identity}

\footnotetext{
56 These reports are BP's New Horizons from 1991, Esso UK 1992, Shell International's Shell and the Environment from 1992 and Hydro (2005). The only other report to date from 1991 is the RTZ Corporation's RTZ and the Environment.

${ }^{57}$ M Flory and Iglesias (2010) also review attitudes to rhetoric and narrative, and stress the importance of a good understanding of these skills.

${ }^{58}$ See for example The Language of Evaluation, Appraisal in English by Martin and White (2005) for how companies use language to position both themselves and their stakeholders.
} 
While these different forms of narrative occur to greater or lesser extents in the advertisements that comprise my corpus, the most important aspect of narrative for my study is myth. Myths are everywhere and the theories that attempt to account for the phenomenon of myth and for its function are numerous. ${ }^{59}$ Trying to define myth, Robert Segal (2004: 5) has proposed that "myth is simply a story about something significant" while Joseph Campbell (1988) has called mythology "the song of the universe" and claims that it is the music that we dance to.

McWhinney \& Batista (1988) have also discussed myth and the role of what they term "remythologizing", as an element in corporate narrative and Corporate branding, something that has become increasingly important. As Naomi Klein (2000) has argued, the brand has come to float free of the product and has become an allegorical embodiment ${ }^{60}$ of particular combinations of virtues or admirable characteristics. A branding is often entwined in the thread of myth, and Gioia et.al (2000) for example, make interesting contributions to this notion. ${ }^{61}$ John Balmer (2001) is one of the increasing number of researchers who investigates the question of corporate identity, a very wide field which includes products as well as the way in which a company is perceived by its different stakeholders. Further, the business organisation is increasingly becoming considered as a performer that stages both its products and its identity. This is in line with Goffman's notion of performance and with Kenneth Burk's view of life as drama and is a concept to which I adhere.

Tom Sullenberger (1974) discusses the concept of "folklure" and the way in which marketing techniques based on the mythologies of folklore are applied to market "hundreds of different products". He includes fuels and chemicals in his list of mythologized products. I opine that myth is central to the advertising of the oil industry and that Frye's theory of myths, and particularly his account of romance, or the 'mythos of summer', is particularly relevant to the stories that the companies tell. ${ }^{62}$

I claim that the communicative techniques that are often employed in various ways in the advertising of the companies involved in the oil industry incorporate all the forms of narrative which I have described above. These techniques are used in the companies' discourse in general as well as in their advertising to protect the different forms of capital that they possess. Social capital, for example, is intricately bound up in corporate social responsibility. In this context, Foucault's concept of the discourse of power, as well as the ideas put forward by Pierre Bourdieu, are central to institutional advertising. ${ }^{63}$

\section{Research into the Advertising of the Oil Industry}

Maarten Hajer (1995:44) insists that in order to analyse discourse, there is a need to consider the context in which something is said and to whom a statement is directed. He contends that discourse is "an ensemble of ideas, concepts, and categorizations that are produced, reproduced, and transformed in a particular set of practices and through which meaning is given to physical and social realities". It is in these meanings and how they are achieved that

\footnotetext{
${ }^{59}$ See for example Robert Segal's overview (2004).

${ }^{60}$ Consider for the animated Mr. Shell figure of the television commercials of the 1960 s or the Esso tiger.

${ }^{61}$ Mossberg \& Nissen (2006) point out that not only organisations, but also products tell a story.

${ }^{62}$ I will develop the relationship between oil advertising and myth in the analysis sections and return to it briefly in my discussion.

${ }^{63}$ Taking a Foucauldian approach, Aurélie Leclercq-Vandelannoitte (2011:1247) for example, has shown that

"discourses produce and mediate [both] organizational and social phenomena" and do not simply mirror society.
} 
researchers in the advertising of the oil companies have shown particular interest. In any investigation into the companies involved in the oil industry, who are frequently subject to mistrust and accused of greed and environmental destruction, and who are under "particularly intensive green-stakeholder pressure" (Backer, 2009:50), it is especially relevant to consider the social and political context of a statement as well as its content.

\section{General studies of the advertising and discourse of the oil companies}

Research into the discourse of the oil companies has tended to concentrate not so much on their advertising in general, but rather more on their corporate reports and response to specific situations $^{64}$ and in particular, to crises. Brinson \& Benoit (1999), for example, have looked into the Texaco's "tarnished star" and how the company attempted to restore its image while Øyvind Ihlen (2007) has focused on the way in which the Scandinavian companies, Statoil and Norsk Hydro have tried to legitimise their business and minimise its impact on the climate. Ihlen discusses the rhetorical means through which the Norwegian oil industry argues that its production is sustainable (2006).

Using the Appraisal Framework developed by James Martin in 2000 which is expounded in Martin and White (2005) to investigate how writers or speakers construe their identities and position their audiences to do likewise, Matteo Fuoli (2012) made a quantitative analysis of BP's social reports to investigate how the company elicits trust and an acceptance of its authority and viewpoints, while Tarya Ketola (1993) examined and compared the strategies that the Seven Sisters adopted in their environmental policies. Martin Langford (2005) has examined the ways in which companies have reacted to environmental crises and discusses BP's response to the Torrey Canyon spill and how Exxon reacted to the Exxon Valdez disaster, while Alison Anderson (2002) has examined the media's response to oil spills. Lisa Dickson \& Alistair McCulloch (1996) have investigated the way in which the media reported Greenpeace's claims and actions against Shell in connection to the disposal of the Brent Spar and reflected on the outcome of Shell's slow response to the charges levelled against them.

Two companies that have received a great deal of attention are Shell and Exxon. Sharon Livesey has analysed the discourse of Shell $(2001,2002)$ and their attempts to create an ecoidentity and project themselves as a caring corporation. Applying a Foucauldian discourse theory to provide a basis for explaining what Shell understood and acknowledged, (2001: 59) she considers their "green talk" as performance. Lise Backer (2008) has also investigated the ways in which Shell have worked to project a green image and studied Shell's use of "evolutionary tales" to change their identity from that of an oil company to an energy company. Using organisational sense-making as a method, she examined their attempts to develop a proactive position to turn the North Sea into a major green energy producing area in cooperation with Vestas, a major wind turbine company. Backer \& Clark (2008) investigated the "greening" of Shell from a social constructionist perspective, using the company's annual reports to shareholders, their internal newsletter ShellWorld, reports to society and articles in the Financial Times that included the word Shell in the headline. ${ }^{65}$

\footnotetext{
${ }^{64}$ See for example the study by Prasad \& Mir (2002).

${ }^{65}$ Although an investigation into television commercials is beyond the scope of this dissertation, what is perhaps most interesting is their discussion of the "Dreamer" television commercial which focused on renewables and which was run extensively during 1999. Backer \& Clark (2008:238) claim that through this, Shell was trying to prevail in the "myth structure of rationalized societies" in an attempt to nurture and protect their social, and consequently, economic capital. This campaign also ran in France in French, for example.

${ }^{66}$ Livesey and Kearins claim that it was Shell and the Body Shop introduced the concept of sustainability
} 
Other research has focused on Shell's response to direct criticism. Hajer (1995), for example, investigated the company's response to the acid-rain accusations levied against it in the Netherlands and shows how story-lines can become political reality. Livesey \& Kearins (2002) have also applied an approach based on Foucauld and Norman Fairclough, and that is inspired by Hajer's concept of discourse coalitions, to examine the sustainability report ${ }^{66}$ that Shell produced as a reply to the very negative publicity that it had experienced. Mirvis (2000) and Graafland (2002) have also examined the company's response to the bad publicity that it received during the 1990s. This is an area that Vian Bakir (2006) has also approached in an investigation of the way in which Shell responded to Greenpeace's disagreement with the company's risk assessments in conjunction with the disposal of the Brent Spar oil storage and loading buoy. Bakir suggests that for successful policy-oriented risk communication, social trust is imperative. Boele et al (2001) and Wheeler et al (2001) have addressed the thorny issue of Shell's approach to corporate responsibility in Nigeria, while Coupland \& Brown (2004) have examined the approaches that the company has used to attempt to construct a positive identity.

As I previously mentioned, the various discourses of Exxon Mobil have also received quite a lot of attention. Livesey, (2002) for example, has used rhetorical and discourse analytical approaches to study the company's corporate public discourse and to this end, applies both Foucault's focus on discourse as power and on Burke's (1966) concept that language is symbolic action. Pettenger \& Plec (2010) have also studied how the company has "greened" its image and use Goffman's concept of frame together with Bateson's "play frame" from 1972 to help them. Stutts \& Barker (1999) have studied ExxonMobil's use of the narrative paradigm to promote their image and focus their attention on the company's "Human Driver" campaign.

An interesting study is that of Ian Rowlands (2000) who investigated Exxon's stance on climate change and compared this with that of BP. His observations were confirmed by Newell \& Paterson (2010) who showed how the response of not only BP but also of Shell differed from that of Exxon. Similarly, Skaerseth \& Skodvin (2001) have shown how ExxonMobil and Shell, both with headquarters in Houston, Texas, have different views. While ExxonMobil lobbied intensely to prevent a ratification of the Kyoto Protocol in the United States, Shell explicitly supported it. ${ }^{67}$ Kolk \& Levy (2004) for example, found that there seems to be a difference in sensitivity to societal concerns regarding environmental issues between the United States and Europe and extended their investigation to include the oil companies. While both BP and Shell were very aware of the importance of legitimacy and public opinion, Exxon saw little advantage to improving its green image. Also in the context of the oil industry, Newell \& Paterson (2010) confirm this finding and show how the response of not only BP but also of Shell differed from that of Exxon and seemed to be affected by national identity.

\section{Mobil's advertorials}

reporting. In the case of Shell, this was the Knight's 1998 revision of their business principles and the positioning of the company as being in an ongoing "dialogue" with its stakeholders.

${ }^{67}$ This is also discussed in Skaerseth \& Skodvin (2001). See also Lorenz et al (2008) who contrast the discourse of BP, considered to be the first company to publicly acknowledge climate change, with that of Exxon Mobil in the first years of the century. The authors compare the way in which the two companies rhetorically position their stances on climate and the ways in which they act to comply with their beliefs and achieve their stated aims. 
However, the aspect of the advertising of the oil companies that has probably received most attention is the campaign run by Mobil in the American newspapers that I briefly referred to in the previous chapter. Their pioneering use of the advertorial, which I consider to be a form of PR, has attracted the attention of a number of scholars who have investigated various aspects of the company's advertorial-type advertising. One reason for this is the novelty and originality of this form of communication, while another is the length of time that the company engaged in such advertising. A further reason could be the variety of topics that Mobil discussed and their interest from a social and political perspective in order to protect and increase their different forms of capital by advocating different stances and striving to legitimize their position. Mobil used two different forums for their advertorials. The first of these was the op-eds page of the New York Times.

\section{The Op-eds page}

Brown et al (2001) and Brown \& Waltzer (2005) trace the development of the longest running of these campaigns, the Op-Ed advertorials ${ }^{68}$ from the first one, which appeared on October 19,1970 until the last one, which was published at the end of $2000{ }^{69}$ They describe how Mobil was the first company to take advantage of the opportunity presented by the New York Times and how they rented space every Thursday for some three decades. According to Robert Kerr (2005) this editorial-advocacy campaign was an attempt to "legitimize corporate speech $^{70}$ as an activity fully embraced by the First Amendment, utilizing discourse that consistently framed the corporate role in democratic processes as no less than identical to that of the individual citizen" at a time when corporate efforts to affect public opinion were strong but unpopular, especially with the law courts. According to his reviewer, Philip A. Dynia, Kerr identified seven fundamental, recurring themes which constituted this dominant frame and which portrayed "seven aspects of the modern corporation: (1) responsible citizen, (2) voice of reason, (3) societal concern, (4) civic engagement, (5) civilizing force, (6) expert, and (7) vital democratic participation."

Brown \& Waltzer report how the advertorials did not appear only in the New York Times, but were also published on a regular basis in eight other newspapers with a wider or different audience. The authors point out that although the very first advertorials had the identifying logo "Mobil Oil Co." at the bottom, this was quickly replaced by the one-word logo, "Mobil". They suggest that when the campaign began in 1970, the oil industry was facing a number of major problems ${ }^{71}$ and that therefore Mobil's management was keen to preempt criticism and engage in a national dialogue on key economic and political issues. ${ }^{72}$ Brown \& Waltzer

\footnotetext{
${ }^{68}$ Op-ed page advertorials are one quarter of a page, or three page columns wide by 10.5 inches long and are framed to separate them from other material on the page. (Brown et al. 2001:27).

${ }^{69}$ When the company merged with Exxon in 1999 to form ExxonMobil, they reduced their renting of the lower right quadrant of the page to every other Thursday.

${ }^{70}$ Kerr distinguishes between "corporate speech"-media efforts by corporations that seek to affect political outcomes or social climate - and "commercial speech" which promotes products or services.

${ }^{71}$ These included oil spills, the Arab embargo and price increases.

72 This contention finds support in the fact that in January 1970, Standard Oil of New Jersey (Esso) advertised that they, together with their principal U.S. affiliate, Humble Oil \& Refining Company were sponsoring a Sunday edition of CBS Evening News. They stated that the popular and respected television journalist, Roger Mudd would be achor and that the programme would be in colour. They say that they decided to sponsor the half-hour news programme because they felt that there was a need for more weekend news and also because "we believe it will give us an excellent opportunity to tell an intelligent audience some interesting things about our company and the way it does its job around the world. Not to brag. But to inform. We want you to draw your own conclusions." They go on to list the "notable correspondents" whose reporting will be featured and say that they will include have sports. To my knowledge, while the Mobil advocacy has received a lot of attention, no research has been done about this.
} 
(2005)n analyse the advertorials over time for policy content and relate this to the political administration of the time and show how the company used the space "to inform publics about the company and its operations and good deeds, the energy industry, its contributions to the economy, and Mobil's positions on a broad range of public policy issues" They also list seven particular series which were aimed to address particular contemporary issues, such as the 1987 series "Toward a more competitive America" which was a response to growing deficits and Japanese trade ascendancy, and a six-part "Global Climate change" series prior to the Kyoto meeting in 1997 (206).

This confirms the study made by Smith \& Heath (1990) who show that the company tried to engage in a national dialogue on key economic and political issues and to portray itself as "a champion of the public interest"(49) and as a "liberal minded [and]sensitive corporation which enjoy[ed] challenging ideas and public policy issues" (53). They arrive at these results by analysing a selection of 60 Mobil "issue" ads placed in the New York Times between 1982 and 1986, using a system known as Marwell \& Schmitt's Compliance-gaining taxonomy, to ascertain that the company's most common compliance-gaining strategy seems to be moral appeal and expertise.

Perhaps two of the most interesting of Mobil's advertorials, and those which have received most attention, are the very first, from October 1970, and a later one from 1981 in which they explain why they "buy this space". Brown \& Waltzer (2005:200) have discussed the first ${ }^{73}$ and describe how it "extolled the value of public transportation and urged people to use it, much to the dismay of other oil companies". Gregory \& Wiechmann (1991:164) have also examined the first advertorial and point out that its headline seemed to be at odds with the company's business interests: “America has the world's best highways And the world's worst mass transit. We hope this ad moves people..." ${ }^{, 74}$ The advertorial questioned the wisdom of continuing to build expensive highways while public transport lagged so far behind. He cites Hern Schmertz, Mobil Oil's vice president for public affairs who stated that it was "the first time that a major oil company had come out publicly for improved transportation" and that as a consequence, they infuriated a number of former allies. It is interesting to notice that the headline makes use of a pun, an area that is also receiving a great deal of attention in advertising research today. Gregory also discusses the 1981 advertorial which has the headline "Why do we buy this space?" 75 and explains why Mobil believes that it is important that the voice of business is heard.

\footnotetext{
${ }^{73}$ The advertorial opened with the words: "In recent years the United States has developed a really superb highway system. It's been built with tax revenues earmarked specifically for road building. But the highway construction boom has been accompanied by a mass transit bust. Train and bus travel in this country, with few exceptions, is decrepit. The air traveler suffers increasing indignities despite bigger, faster planes." The concluding paragraphs read: "While Mobil sells fuels and lubricants, we don't believe the gasoline consumed by a car idling in a traffic jam (carrying a single passenger, probably) is the best possible use of America's limited petroleum resources. Our products ought to help people get where they want to go. To us, that means a green light for mass transit ... soon".

${ }^{74}$ The advertorial makes use of a play on the word "moves" in the first sense "transports" and in the second, "affects emotionally".

${ }^{75}$ The opening copy reads: "For more than 12 years now, we've been addressing Americans with weekly messages in the principal print media. We've argued, cajoled, thundered, pleaded, reasoned and poked fun. In return, we've been reviled, revered, held up as a model, and put down as a sorry example. Why does Mobil choose to expose itself to these weekly judgments in the court of public opinion? ... Our answer is that business needs voices in the media, the same way labor unions, consumers, and other groups in our society do. Our nation functions best when economic and other concerns of the people are subjected to rigorous debate." The text ends: "We still continue to speak on a wide array of topics, even though there's no immediate energy crisis to kick around anymore. Because we don't want to be like the mother-in-law who comes to visit only when she has
} 
Although the frequency with which Mobil published advertorials decreased ${ }^{76}$ after its merger with Exxon, the concept of addressing themes which were of current, strategic interest remained. One of these is the theme of global warming and Sharon Livesey (2002) for example, makes a very interesting analysis of four global warming advertorials published in March and April 2000, after the company had become ExxonMobil. Lorenz et al (2008) also take issue with these four advertorials, and point out that the company questions the reality of climate change by purposefully confusing the relationship between weather and climate. They claim that ExxonMobil uses scare tactics when they posit "we know with certainty that climate change policies, unless properly formulated, will restrict life itself” (9).

\section{“Observations"}

In their seminal paper, Crable \& Vibbert (1983) studied the second forum that the company used to address a less elite audience than the "policymakers, opinion leaders, and active publics" (Brown et al. 2001:25) ${ }^{77}$ targeted by the op-ed page. This was a campaign that ran in "Observations", half-page Sunday newspaper magazine section ads. Crable and Vibbert analyse Mobil's "Observations" over a four-year period from 1976 to 1980 and focus on their rhetorical situation, their argumentative approach, the cultural foundations of their arguments and then assess the "Observations". ${ }^{78}$ According to the authors, the intention behind this campaign was to make Mobil Oil as much a part of the American Sunday afternoon as the Sunday newspaper. While the op-ed page advertorials were aimed at decision-makers, the "Observations" are half-page olios in the magazine section of the Sunday newspaper. These sections are generally composed of cartoons, chatty news items, letters from readers and a "sprinkling of quotations from such diverse sources as John Locke [and] Robert Frost..." (383). The authors posit that purpose of the epideictic "Observations" was generally "warrant-establishing" and employed "support-seeking strategies" (Crable \& Vibbert 1983 : 381). They quote Mobil's claim that it wanted to engage the "[g]rass-roots movements [which] work faster when they've got the help and coordination of the men and women running the country" (385).

\section{The Perspectives of this Study}

Despite the interest in semiotics and rhetoric in their various forms that this overview of the trends in research into advertising has clearly shown, the investigations that have been carried out to date into the advertising and discourse of the oil companies have not followed this path.

problems and matters to complain about. We think that a continuous presence in this space makes sense for us. And we hope, on your part, you find us informative occasionally, or entertaining, or at least infuriating. But never boring. After all, you did read this far, didn't you?"

${ }^{76}$ Although the number of op-eds decreased, this can be seen in relation to the new trends made possible by the internet which companies, including ExxonMobil, began to make increasing use of. See for example, Pettenger and Plec (2010). Cook (2001:223) also points out that on the Internet, it is particularly difficult to distinguish between advertising and information.

${ }^{77}$ In their discussion of institutional isomorphism, DiMaggio \& Powell (1983:150) point out that organizations "compete not just for resources and customers, but for political power and institutional legitimacy, for social power as well as economic fitness" and cite the argument that "the major actors that organizations must take into account are other organizations".

${ }^{78}$ The rhetorical situation was a result of the oil embargo and the concerns about energy shortages in a context of a burgeoning environmental awareness. In the eyes of the general public, the American oil companies were not trustworthy and there was a concern that the oil crisis might be a ploy to engender greater profits. 
Instead, they have focused on a specific event or set of circumstances in the life of one company (e.g. Stutts \& Barker 1999, Livesey, 2001, 2002, Livesey \& Kearins 2002, Backer, 2008, Pettenger \& Plec, 2010). Moreover, with the exception of the research into Mobil's different regular newspaper contributions, the focus of the studies has generally been on corporate reports of different types. Particular interest has been given to crises such as oil spills and to the increasing importance to be considered "green" and the analytical approaches used have generally been grounded in some form of CDA.

My interest, however, does not lie in power relations or in identifying and righting social injustices. Instead, my intention is to study and analyse the advertisements that the oil companies have produced over time as individual pieces in which different semiotic and rhetorical techniques have been woven together to make up the vast mosaic that constitutes the advertising discourse of the industry. By taking a wide as well as a longitudinal perspective over the communicative strategies employed by the different companies and showing how these draw on and are adapted to the different contexts and knowledge of the world (van Dijk 2008: x) that derive from changing contemporary situations, I hope to be able to untangle and describe the strategies that the companies have employed to tell the stories that their audiences want to hear. In other words, my ambition is to uncover the different means with the companies work to present a "preferred face." 



\section{Chapter 6}

Corpus

The materials that make up my corpus come from sources as disparate as the Musée de Montmatre, a little shop in the same district of Paris, the BP Archives housed at Warwick University and the on-line Advertising Archives as well as the Shell Art Collection on-line at Beaulieu and books and periodicals. This disparity also reflects the variety of advertisements and materials that constitute my corpus.

My corpus extends from the very early posters which were produced in France for oil lamp fuel in the 1890s to the last days of 2012, after BP had ended its sponsorship of the London Olympics. Its backbone has been gleaned from the weekly British periodical, The Economist, which dates from 1843 and which has an increasingly international readership and subsequently, advertising base. My examination of this periodical begins with the year 1918 when World War I had underlined the importance of the oil industry. However, even ten years later, although information about oil outputs appeared regularly, no actual oil company advertisements could be found among the few small notice-like advertisements that were published. I continued to examine The Economist at ten-year intervals until 1958. One reason for this was that a ten-year period can show trends. Another was that in 1938, the year before the outbreak of World War II when the newspapers were filled with stories and information about Hitler and unrest in Europe, the imminent threat of war could be expected to generate activity among the oil companies that had proved so important to the outcome of World War I. After the outbreak of war, petrol rationing resulted in the oil companies not being allowed to advertise their fuels in Britain until 1952. Although Shell did advertise in The Economist in 1948, the quarter-page advertisements are all to "thank Shell Chemicals" for "the sheen in hair" or for "the 'feel' of fabrics".

1958 was an interesting year from the point of view of my corpus. Rationing had only recently ended and cars were on the roads again, while at the same time, the effects of Suez Crisis and of the Marshall Plan were evident. From 1958, I added the American monthly periodical, Scientific American, the oldest continuously published monthly magazine in the United States. This decision was guided by a number of factors. The first of these was that this was a year when both Shell and BP advertised frequently in The Economist with a variety of different series. Moreover, Caltex, an American company also published advertisements regularly in this British periodical that year, and the third and most pragmatic reason was that the earliest complete set of the periodical in a Swedish library, specifically that of Karolinska Institutet in Stockholm dates from that year. Moreover, Scientific American, which in its first number, published on September $23^{\text {rd }} 1845$, proclaimed itself to be "[t]he advocate of industry, and journal of scientific, mechanical and other improvements" is the oldest periodical in the United States ${ }^{1}$ and therefore has a history comparable with that of The Economist. Like The Economist, Scientific America has an international public and is even published in different languages. ${ }^{2}$ Further, I was interested in discovering whether British oil companies had begun to advertise in the United States in the same way as American companies had begun to advertise in Britain.

I examined both of these periodicals at five-year intervals until 1990 when BP introduced its radically innovative "For All Our Tomorrows" series as a first response to the growing

\footnotetext{
${ }^{1}$ The periodical began as a weekly and was in a state of steep decline when it was taken over by three new owners in 1948 and was revitalised as a monthly.

${ }^{2}$ It was published in Spanish for some 15 years at the turn of the last century and then began to appear in a number of different languages, including Spanish, Russian and Chinese during the 1970s. Today, it appears in 18 foreign languages.
} 
pressure from environmentalists, and from this point, have examined the periodicals at much closer intervals, usually in conjunction with some major event, such as a response to a disaster or the period of mergers at the turn of the century. During this period, I also began to examine a third periodical, The New Statesman. The reason for this was that BP stopped advertising in The Economist and shifted its campaigns to this British politics and cultural affairs weekly. ${ }^{3}$

All three periodicals have a long history and address a well-educated readership with a relatively good economy. Moreover, both The Economist and Scientific American have an international audience and their publications are available world-wide, while The New Statesman has a much more national readership. This has made it possible to compare the advertising strategies of the companies and also to determine the extent to which their advertising is global, glocal ${ }^{4}$ or local. These concepts are discussed for example by Jain (1989) for example and taken up briefly in Chapter 5.

However, my corpus is not limited to the advertisements that I have gleaned from these periodicals.

The earliest advertisements in my corpus are the Chéret posters from the late 1890s and which advertised lamp oil. I have also had access to the Shell Art Collection on-line. This collection is housed at Beaulieu. The earliest examples in this collection are the 150 postcards that Shell produced and the majority of these date from about 1908 to just after WWI. These are different series that are connected with motor racing and trails, aviation, heater and oil lamps, and motor spirit. However, a few postcards were produced as late as 1938 and there is even an example from 1953 wishing the public "Many happy returns of Shell Day" which celebrates the end of rationing after the war and which is an example of the popular "two-headed series" from the early 1930s that appeared in newspapers as well as on lorry bills. These postcards can be accessed on-line at AR Postcards on the Shell Art Collection's homepage. Also available on-line are a number of the Shell Valentines that were published from 1938 until the 1970 s and which were sent to lady customers. Some of Shell's many posters are also available on-line and I have found others in books that the company has published including catalogues from different art exhibitions. A number of the Shell Guides to Britain have also furnished me with material as has John Hewitt's (1992) study of the company's advertising in the early 1930s.

My second major source of material is the BP Archives. In addition to the advertisements produced by BP and Shell-Mex and B.P. Ltd. the Archives house letters, the minutes of company board meetings, books, photographs and a plethora of fascinating material including Exhibition catalogues which not only show company posters but also the texts of art experts and company executives. The Archives include material produced for retailers with different kinds of advertising material for their garages, for example. Other advertisements in different forms, include booklets that target farmers, beautiful advertising reviews that include

\footnotetext{
${ }^{3}$ The New Statesman dates from 1913 and was started by members of the "Fabian Society", a political group ideologically to the left of centre and which included well-known writers and thinkers such as George Bernard Shaw, H.G. Wells, Annie Besant, Leonard and Virginia Woolf, Ramsay MacDonald and, the suffragette, Emmeline Pankhurst, and for a short time, Bertrand Russell. After a number of years of serious decline, it recovered during the 1990 s and no longer has a specific political leaning.

${ }^{4}$ Roland Robertson, a sociologist is credited with popularizing the term which was introduced in the 1980s in articles by Japanese economists in the Harvard Business Review http://en.wikipedia.org/wiki/Glocalization April 242013.
} 
paintings for Shell Marine Lubricants by different artists, AD Words, the BP Proverbs series, the BP Ethyl series, and books explaining how oil is produced, including one in cartoon form and another with beautiful sepia paintings that I have called the Magic of Persia series. There are also special advertisements featuring Donald Campbell. Among the wealth of material in the Archives are different advertisements produced for BP in Italian from the early 1960s and a beautiful book of water colours of different shells written in German for a German public. On the left of each double page is the Latin name of the shell and this is then followed by information about the particular type. The book ends with the scallop shell, the Shell logo. Other examples in my corpus are advertisements found in specialist publications as diversified as Motor to the humorous advertisements that were published in the Poultry and Farming Press during the early 1950s. These latter were for White May and Pink Aladdin Paraffin which could be used for example in incubators, and the series of small books with little poems, including some written by John Betjeman. The letter in figure 6:1 is from Tom Palmer at the SMBP Studio (Shell-Mex \& BP) who writes "Here is a copy of what I think is the first edition of WHITE MAY BLOSSOMS, in the writing of which I collaborated with Princess Margaret's favourite poet." He goes on to say that this is John Betjeman, explains who wrote what, and asks to have the booklet returned.

The Archives also house advertisements that appeared in newspapers, including the different competitions, from everything from road safety to "literature" that Shell and BP ran during the 1960s. Advertisements that appeared in The Economist can also be found there.

Although I have also accessed the Advertising Archives online, I have found very little there that has been useful for

\section{Figure 6:1 personal letter} my purposes. Other material has come for example, from the companies' homepages and it has been possible to access specific campaigns directly. One example of this is Esso's "Put a Tiger in Your Tank." I have also found useful material for my corpus in a number of books that have been written about different aspects of the oil industry. Therefore with these few exceptions, the advertisements of the American companies and of Total that make up my corpus have been found in The Economist and Scientific American. ExxonMobil has advertised on occasion in the New Statesman, and all of the companies have at times also placed advertisements in Newsweek, New Scientist and even daily newspapers in parallel with those in that appeared in my major sources.

As the American companies, ExxonMobil and Chevron did not come into being in their current forms until 1999 and 2000 respectively after a series of mergers, and Total was rebranded in its current form in 2003 after its take-over of Belgian Petrofina in 1999 and acquisition of Elf Aquitaine in 2000, when I deem it useful, I have incorporated advertisements from the companies that merged with or were acquired by these three majors to guide my analyses and contribute to my findings. Standard Oil of New Jersey published an extensive series of which I have collected 20 in Scientific American during the 1970s, and Mobil also advertised regularly as did Amoco, which later merged with BP. Phillips Petroleum also advertised quite extensively, even in The Economist when the British companies were silent, but although I have these advertisements in my corpus, as Phillips is not included in the study, I have chosen to ignore these. 
Although the advertisements of Shell and BP can be considered to be over-represented in my corpus and this implies an imbalance, I do not believe that it will have a negative impact upon my general findings. Shell dominates as it has advertised longest and most extensively in Britain and moreover, is the only one of the Majors that has not changed its name.

It is interesting to note that there were two periods when the oil companies produced little or no print advertisements. One of these was during the 1940s as a result of WW2 and the period of rationing that immediately followed this. The other period stretches from the mid-1970s to the beginning of the 1990s. I have only found one small series for Mobil (later to become ExxonMobil) from the late 70s and not one single advertisement for the other companies in The Economist during this period. Significantly, the periodical is filled with articles describing various oil crises, both concerning supplies and environmental issues. Perhaps an article from October $15^{\text {th }} 1988$ entitled "Changing colour" summarizes the situation and mood of the time. This article opens with the words: "Green is the world's new political colour" and describes how pollution has finally become an issue and that "in the rich countries, people increasingly tell opinion pollsters that they are unhappy about the environment: about noise and filth, but also about the possibility that they are doing lasting harm to the fabric of the world that their children will inherit". At the beginning of the 1990s, the companies began to advertise once again.

In addition to the 150 postcards produced by Shell, most of which I accessed on-line, my corpus is made up of two series from Total, four series from ExxonMobil, and four series from Chevron, of which three are inter-related. This makes a total of over 50 advertisements from these companies between 2000 and 2012. Some of the advertisements appeared regularly, either under a relatively short period or perhaps once a month over a longer period of time, while a few, I found only once. In the case of BP, there is a "beyond petroleum" series that is set in Australia and a great number of advertisements for their merger with Amoco at the turn of the century as well as their many different advertisements for their sponsorship of the arts, particularly of museums, and until 2012, their sponsorship of the London Olympics. To these should be added their advertisements from the their early years, their marketing merger with Shell and later, their own series, including the revolutionary "For all our tomorrows" campaign. The total number of BP advertisements that have passed through my hands therefore exceeds 150. Apart from their extensive advertising prior to WWII, Shell dominates my corpus for the year 1958 with three series in The Economist together over 20 advertisements, and one series of six in Scientific American. Of their advertisements at the turn of the century, "Profits and Principles" I have found ten examples and between 2002 and 2010 they advertised frequently with five extensive series and a number of single advertisements and published more advertisements in The Economist in 2008 than the other companies together. Shell's contribution to my corpus exceeds 500 advertisements.

Obviously, such an extensive corpus has meant that it was necessary to make a selection, both of the different series that make up the corpus and of the examples that represent these series. This has not been easy and I have had to make some difficult decisions and reject some very interesting material. The advertisements that I have selected to appear in this study have been chosen either because they are particularly representative of a series or of a period, because they illustrate a turning point, or because they are special in some way. Selection is highly personal and although I have tried to be as objective and analytical as possible, someone else would probably have chosen differently; if not perhaps, on the series level, certainly on the choice of which advertisement is most interesting or most representative. 


\section{Chapter 7}

\section{The Semiotic Landscape}

\section{A World of Signs and Symbols}

As even the most cursory glance at the advertisements which I selected in chapter 3 to illustrate their prototypical examples shows, "[t]he consumer world is a web of meanings among consumers and marketers woven from signs and symbols ensconced in their cultural space and time" (David Glen Mick, 1986:196). This brings us to the subject of semiotics.

According to Umberto Eco (1979:8), semiotics "studies all cultural processes as processes of communication" and is "concerned with everything that can be taken as a sign [while a] sign is everything which can be taken as significantly substituting for something else" (ibid:7). He postulates (3) that semiotics involves both codes and signs and that the production of signs must take into account a large range of phenomena including the common use of language, aesthetic communication and different types of interactional behaviour. Eco posits a distinction between 'signification' and 'communication' suggesting that the former entails codes while the latter is related to sign production, and to this latter, I would like to add, interpretation. As Hodge \& Kress (1988: 4) have remarked, for a message to function as intended, its recipients must have knowledge of a set of conventions that provide the specific information necessary to read and understand the message that the producer wished to communicate.

Communication is firmly embedded in the social world and is anchored in a particular cultural understanding and point of view. Culture, as Clifford Geertz (1973:89) defined it "denotes an historically transmitted pattern of meaning embodied in symbols, a system of inherited conceptions expressed in symbolic forms by means of which men communicate, perpetuate and develop their knowledge about and attitudes toward life". However, the contours and horizon of what Kress \& Van Leeuwen (1996:33) described as the semiotic landscape, are ever shifting. Flosch (2001) reminds us that semiotics is a practical relation to meaning and moreover that it is a process that is concerned with anything has or possible could have meaning. Such "objects of meaning" entail written texts, but also any other "signifying device" including logos, films or behaviour. Further, he insists that central to "the shifting sands of meaning" (5) with which we grapple is the "communication context" which is itself an object of meaning. Therefore it is essential to understand the both conditions of production and the intentionality of the relations between the signifier and the signified.

It is therefore not surprising that a semiotic approach to the phenomenon and genre of advertising, a form of communication which in its print form, the form upon which I have chosen to focus, very much relies upon both linguistic and visual codes as well as aesthetics and social embeddedness, has gained increasing interest among both its practitioners and researchers since the First International Conference on Marketing and Semiotics in 1986.

In Chapter 3, my focus was on written communication and linguistic codes, and I stressed the importance of identifying with the reader and his worldview in order to persuade. Rhetoric and the concept of dialogism, particularly addressivity, were discussed as the corner stones of relationship-building with the audience. However, this can be achieved through pictures as well as through written texts, and it is the rhetoric and dialogism of the visual codes employed in advertisements that is central to this chapter. 


\section{Shifting Sands of the Meaning}

However, it is not merely the landscape of semiotics that shifts but also the vocabulary that is used to define the phenomenon. Although Nöth (1990: 14) points out, like Holbrook (1987b:84) before him, that semiotics is generally used to refer to the philosophical tradition of the theory of signs deriving from Peirce while semiology refers to the linguistic tradition with its roots in Saussure and is the one to which I lean, I prefer to use the term semiotics. There are two reasons for this; the first is that I consider that advertising exemplifies Kress' view of social semiotics, and the second is the predominance of that term in the literature. ${ }^{1}$

\section{Roland Barthes and the Semiotics of Advertising}

A number of scholars have specifically discussed the semiotics of advertising (Cook, Eco, Flosch and Sherry, for example) but it is the work of Roland Barthes that brought this into the spotlight. In the Photographic Message (1961) he discussed connotation, which he defined as "the imposition of second meaning on the photographic message proper" $(1977: 20)^{2}$ in photographic images found in the press, and identified a number of ways in which this was produced. One of the means by which the reader of the image can be prepared for connotation is by "pose". ${ }^{3}$ This is made possible by the "store of stereo-typed attitudes which form ready-made elements of signification" (22) to which we have access. Barthes suggests that there is a 'historical grammar' of iconographic connotation which derives from example from paintings and which are present in 'culture'. Both people and objects can be posed and lead us to make associations, "a veritable lexicon" that are relatively stable and can be constituted into syntax (23). He adds the notion of photogenia, or informational structure and technical effects and takes the matter of syntax as an example. However, Barthes contends that a text is a "parasitic message" (25) and points out that today, an image often no longer illustrates a text but that instead, words are often accessory to the image.

In 1964, Barthes developed the insights gained from his analysis of press images to study a Panzani advertisement. ${ }^{4}$ The advertisement was made up of a photograph showing some packets of pasta, a tin, a sachet, tomatoes onions peppers and a mushroom all emerging from a half-open string bag, in yellows and greens against a red background (1977:33). Despite the fact that the linguistic message is French, the "Italianicity" of the advertisement is connoted by the colour scheme and by the ingredients. The composition of the photograph, or the way in which the objects are posed evokes still life alimentary paintings. Barthes identifies three messages in the advertisement whose interpretation and understanding are dependent upon some general cultural knowledge. There is a linguistic message, an iconic message and a noncoded iconic message (36) or symbolic message. The literal image is denoted and the symbolic one connoted. He concludes that it is likely that metonymy furnishes the image with connotation while among the syntagmatic figures, asyndeton predominates (50).

Barthes suggests that the linguistic message has two functions with regard to the iconic message. These are anchorage, which helps to fix the "floating chains of signifiers" (39) and

\footnotetext{
${ }^{1}$ Following the lead of Jakobson, Lévi-Strauss, Benveniste, Barthes, and Greimas who founded the Paris School of Semiotics in 1967, Jean-Marie Flosch (2001:4) also chooses the term semiotics.

${ }^{2}$ This text originally appeared in French in 1961.

${ }^{3}$ Erving Goffman (1976) also recognised the powerful connotations afforded by pose in the gendered relationships that he observed in the advertisements that he studied and Kress \& van Leeuwen (1996) discuss its implications for the way in which photographs are interpreted.

${ }^{4}$ More recently, Christine Wikman (2005) has developed this study to compare the effects of culture on audience response to olive oil, pasta and coffee. She considers advertisements and response to these in Italy and in Sweden.
} 
relay, which advances the message by setting out meanings that are not immediately found. Barthes also attributes the notion of "having-been-there" or of "being-there" to a photograph, and suggests that this too has connotation. As a photograph is a recording of something real that the photographer has experienced, something that has existed, and is not an imaginary depiction of what might be, it suggests verisimilitude. Thus the denoted image in an advertisement plays a special role in the general structure of the iconic message; it naturalizes the symbolic message and "innocents the semantic artifice of the connotation" (45). Barthes points out that the variations that exist in readings of the coded iconic, or symbolic message, are grounded on underlying pragmatic, cultural, patriotic, historic or aesthetic background knowledge. For Barthes, the advertising photograph (and image) exists in an ideological world, a view which is elaborated in Terry Royce, (1998:42): "Ads as a means of representation and meaning construct ideology within themselves through the intervention of external codes which are located within society. The ad will use images, notions, concepts, myths, etc. already available in the culture. An ad does not simply reflect ideology; it reworks it, thus producing new meanings. It uses objects which are signifieds of ideological systems and thought that already exist and then makes them signifiers of another structure (the ad). Its connotational process depends on our knowledge of the forms of ideology that advertisements employ."

To adapt the words of Günther Kress (2010:62) to my purpose; in a "Social Semiotic theory, advertisements are made (...) by an advertiser who brings meaning into an apt conjunction with a form, a selection/choice shaped by the advertiser's interest. In the process of representation sign-makers remake concepts and 'knowledge' in a constant new shaping of the cultural resources for dealing with the social world". The advertisement achieves meaning through the mediation of the reader who receives and uses the sign and who must therefore know the legacy with which the sign is imbued.

\section{Text and Image}

\section{The relationship between text and image}

As my brief overview of Barthes' work on the semiotics of advertising demonstrated, the advertising message, which is the focus of this study, is multimodal and the codes with which it is made up comprise much more than words. Eco (1972: 13) has defined a code as any system of symbols that by convention, allows information to be shared, and has stressed both the cultural and the structural processes that are involved in the systems that underlie these communicative processes. To this end, it is necessary to consider an advertisement as a gestalt and to examine all the elements of which it is composed. Not only the components of the advertisement but also the structuring of the information has semiotic meaning and is central to the way in which the message is understood and interpreted. Colour too is a semiotic mode. The co-occurrence of and interrelationship between visual and linguistic signs is receiving increasing interest (see for example Royce 1998) ${ }^{5}$

A successful advertisement is very much a happy marriage of text and image. In her discussion of how texts and images function together, Susan Hagan (2007:51) takes her point

\footnotetext{
${ }^{5}$ Royce (1998) demonstrates that the intersemiotic complementarity between the visual and verbal modes is realised through three simultaneously-occurring intersemiotic resources. Firstly, the visual and verbal ideational meanings are lexico-semantically related by means of the intersemiotic sense relations of repetition, synonymy, antonymy, hyponymy, meronymy, and collocation. Secondly, the visual and verbal interpersonal meanings are related through intersemiotic reinforcement of address and intersemiotic attitudinal congruence. Thirdly, the visual-verbal compositional meanings are integrated through the compositional relations of information value, salience, and visual framing, as well as the influence of visual synonymy, and potential reading paths.
} 
of departure in three assumptions. These are that image and text are potentially equal contributors to meaning, that both visual and verbal information contain structural elements that produce complementary differences in what each modality communicates and that these differences affect what the audience imagines as well as what will actually be communicated if only one modality at a time is present. She suggests that while text specializes in concrete statements while inviting imagined images, images produce concrete scenes and invite an imagined text. While perceptual ties that originate in the history and interests of the individual reader allow a connection between the two modalities to be noticed, cohesive ties clarify the nature of that connection (Hagan,2007: 53).

Hodge \& Kress (1988) identify two communicative planes. The message, which is the smallest semiotic form that has a concrete existence has directionality, that is to say that it has a source and a goal, a social context and a purpose. This is the semiotic plane. The message is in some way connected to the world to which it refers and its meaning derives from this representative or mimetic function. The plane in which representation takes place is the mimetic plane (5). They introduce the term logonomic system (8) to refer to "the set of social messages which govern the normal production and reception" of a text. Kress (2010: 26) insists that in the unpredictable world of meaning-making, a rhetorical approach to communication is needed which implies that the rhetor, the source, must make an assessment of the situation, the audience and the semiotic means at his or her disposal to construct and design the message in the way that is the most appropriate for the purpose.

In other words, it is necessary to take into account the six factors identified by Roman Jakobson (1960). Any verbal behaviour is goal-directed, but there is no conformity in the means that are used to achieve the ends. The poetic elements of language cannot be divorced from the purely linguistic, and "the relations between the word and the world concerns not only verbal art but all kinds of discourse" (351). Thus, I claim that to tease out the full meaning that is intended in an advertisement it should be considered in its entirety. This means that the rhetoric of both text and image should be analysed together and in addition, the advertisement should be placed in its socio-historical context and whenever possible, even the place where the advertisement appeared should be taken into account as this too has significance. Whether an advertisement is a poster on the side of a lorry or appears in a newspaper or magazine are important factors in interpreting the message. Moreover, the type of publication as well as the actual position of the advertisement within the publication, are factors that, for example, the research into Mobil's Op-Eds and their Observations, has identified as carrying meaning.

Inspired by Barthes and basing their approach on linguistics and Michael Halliday's three metafunctions of language, ideational, interpersonal and textual, Kress \& van Leeuwen created a "grammar" of visual design (1996:1) or a means to investigate the ways in which the "individual people, places and things" depicted in images can be "combined into a meaningful whole". Reading a visual involves the simultaneous interplay of three elements which correlate with these metafunctions. These are the represented participants, a category that comprises all the elements or entities that are present in the whether animate or inanimate, the interactive participants, a category that includes the social relations between the reader and the visual, and the coherent structural elements of the visual, the compositional features (in Royce \& Bowcher, eds. 2007:66). Kress \& van Leeuwen, (1996:2) use Halliday's own words to explain that grammar is much more than formal correctness: "It is a means of representing patterns of experience .... It enables human beings to build a mental picture of reality, to 
make sense of their experience of what goes on around them and inside them" ${ }^{6}$ and suggest that grammar is "an inventory of elements and rules underlying culture-specific (...) communication (Kress \& van Leeuwen 1996:3). Visual language, like verbal, is "not transparent and universally understood, but culture specific" (ibid). It is a social construct. Thus, the codes that make up the language are not stable but are dependent upon historical and cultural contingencies.

Although a number of scholars have extended their work for approaching multimodal discourse analysis, " the "grammar" developed by Kress \& van Leeuwen remains the point of departure and thus, it seems germane to provide an overview of some of their points that are particularly relevant for a study of advertisements.

The authors (1996:8) define Saussure's langue as "a system of available forms already coupled to available meanings" and define parole as "an individual utterance that is a particular realization of the potential of langue ...." . Communication requires that the sender creates a message that is maximally understandable in the context and representation requires a choice of forms that are apt and plausible. Visual design, like all other semiotic modes, should fulfil both an ideational function that represents the world around us, and an interpersonal function which enacts social relations and interaction (ibid:13). They argue that perspective can be used to distinguish between the 'objective' and the 'subjective' (ibid: 17) while whether an individual that is depicted looks at the camera or not is a way to convey a sense of interaction or of its lack.

The way in which different elements are positioned is also extremely important. Just as we read a text from left to right, ${ }^{8}$ we read images in the same way. This implies that what is new is usually found on the right of the page. "Pictorial structures (...) have a deeply important semantic dimension" (ibid: 45). Transactional relations can be represented by vectors, for example, and vectors, focus, colour saturation and other techniques for foregrounding some objects or individuals and relegating others to the background are also commonly used to guide the reader's eye and consequently, interpretation of the message. The authors also point out that people who are depicted in an image are either interactive or represented, defining the former as those who are involved in the act of communication and include both the creators and the readers or listeners, while the latter are the subject of the communication. Abstractions are included in this latter category. However, the first category is a complex construct and includes "implied" participants, such as the "implied viewer" and the "implied producer" as well as the real producer and those participants explicitly represented in the image (ibid: 46). They use the term 'Actor 'to describe the active participant in an action process from which the vector emerges and 'Goal' for the passive participant at which the vector is directed (ibid: 74). A further participant role that Kress \& van Leeuwen identify is the 'Reacter' (ibid:64). This is a participant who looks at another who is in some way active,

\footnotetext{
${ }^{6}$ They suggest that the changing role of the visual can be traced to the 1920 in the Soviet Union where "the semiotic revolution was allied to the political" (1996:27) and where the visual was the medium that could be used to bring a message to a population that was socially and linguistically heterogenous.

${ }^{7}$ An example is Kay O' Halloran (2008) who investigates how the metafunctional principle can provide an integrating platform for theorizing how semiotic resources interact to create meaning, particularly with regard the meaning potential of semiotic resources distributed across strata including lexicogrammar and typography. Her approach, Systemic functional multimodal discourse analysis (SF-MDA) can also be used for mathematical discourse, for example.

${ }^{8}$ The visual code is culture-specific and Kress \& van Leeuwen specify that they are writing for a West European or Anglophone public that normally reads from left to right across the page.
} 
at some phenomenon. ${ }^{9}$ Reactions can be transactional or non-transactional. A Nontransactional reaction means that the Reacter is looking at something outside the picture. ${ }^{10}$

In the example in figure 7:1, Yoshida, the Japanese housewife who, thanks to Shell, can feed her children the "warming noodles" that they need to provide them with energy, is pictured as a Reacter, kneeling watching her daughter whose skipping is a metaphor for the energy which Shell is providing, "not just for tonight's bowl of warming noodles, but for years to come when the children may have children of their own." The little boy is also looking at his sister and the gazes of the mother and son create vectors which draw the reader's attention to the energetic little girl in the foreground on the right of the page and who represents a future with abundant energy.

\section{Image removed due to copyright. Image removed due to copyright.}

However, it is important here to mention the concepts of 'type' and 'token'. In the case of the people who are depicted in an image, their representation as a type or a token has particular relevance for the deeper interpretation of the overall message. Although the matter of type or token is quite complex, generally it can be said that while a type is a sui generis, or a universal, a token involves spatio-temporal particulars and is an instance of a type; it exemplifies the type (Linda Wetzel, 2011). ${ }^{11}$

This is an issue which van Leeuwen (1996) takes up in his discussion of the ways in which 'social actors' are visually as well as linguistically represented. He identifies two main

\footnotetext{
${ }^{9}$ Goffman (1976) has shown that this role is commonly undertaken by a woman.

${ }^{10}$ Kress \& van Leeuwen (1996:66), point out that male non-transactional reacters are usually shown gazing into the far distance. This can create a powerful sense of empathy or identification on the part of the reader.

${ }^{11}$ However, Katalin Morgan, (2012:88) brings up the notion that types, are "patterns and images that reduce the complexities of a phenomenon to a few significant characteristics. They portray reality as narrow, incomplete, and rudimentary." This notion corresponds more to that of stereotype. As the carrier of stereotypes is language and pictures, with their often ingenious combination of both, advertisements have the capacity to construct reality by directing our thoughts towards particular understandings and indeed often do just this.
} 
categorisations, functionalization, which classes actors by what they 'do' and identification, which classes them by what they 'are'. Identification can be further subdivided into classification, which includes gender, age and ethnicity, physical identification and relational identification (van Leeuwen, 1996:54). His contention is that the location of the actor as well as the dress and grooming (ibid:34-35) all contribute to our interpretation of the person, to their agency, to what he or she represents and to our understanding of social reality.

Figure 7:2 is taken from Shell's 2002 series "People, planet and profits" and shows a fisherman in the typical dress associated with his function as a deep-water fisherman in the northern hemisphere. Thus, he can be considered to represent a type. His age suggests that he is experienced and he is leaning casually against the rail of the boat, a lifeboat behind him to connote safety and a lack of risk-taking and behind him is an oilrig silhouetted against the sunrise. This is one simple example of a "terministic screen" that formulates conceptions of a general order of existence and clothes these with such an aura of factuality that they seem uniquely realistic. Gazing into the camera, relaxed and confident, he symbolises the experience and common sense of the voices that Shell listens to for advice in matters that concern their operations. ${ }^{12}$ The dress and location of the fisherman show him as a type, but his agency, advising Shell, as well as the way in which he looks into the camera at the reader, move him beyond this universality and to individualise him. At the same time, he becomes a symbol for Shell's way of working.

Symbolism is an important aspect of communication and mood and atmosphere are important in visual design and can be realised in a number of ways.

Kress \& van Leeuwen (1996) identify "Symbolic Attributive Processes" which derive from qualities of the 'Carrier', while "Symbolic Suggestive Processes" represent meaning and identity that comes from within (110-112). The authors state that in cases of the former, the human participant usually poses for the viewer rather than being involved in some action. Thus, in their terminology, the fisherman is a carrier of symbolic attributes. ${ }^{13}$ The reader can be manipulated in a number of other ways too. As Kay O' Halloran (2008: 447), points out, “a linguistic text typically unfolds syntagmatically as a chain which is sequentially processed, and meaning culminates progressively as the text unfolds." However, with a visual image, the whole takes precedence over the perception of parts and this means that relations can be created between represented participants, between interactive and represented participants and between interactive participants (119) in a number of ways. Through the design of the whole, the reader can be instructed by the interactive participants who to different degrees regulate what is "said" with the image, to follow a specific direction. One way of doing this is by represented participants looking directly at the reader thereby establishing contact. This acknowledges the reader specifically and constitutes an 'image act' (122) which demands something of the reader. In other cases, the reader becomes an invisible on-looker and the represented participants are 'offered' for perusal (124).

Distance is another cue for interpreting meaning and can suggest the relationship between the reader and the represented participant.

\footnotetext{
${ }^{12}$ I will return briefly to this series in Chapter 8.

${ }^{13}$ An example that they give of symbolic suggestive processes is particularly interesting for my purposes. It is a photograph (p.112) of an oil drilling installation in the Sahara. Detail is de-emphasized, and the extreme lighting, where the setting sun plays the role of a low back light sets the mood. The installation becomes a symbol that suggests the disappearing Bedouin lifestyle.
} 
In the example shown in figure $7: 3$, the woman is gazing into the camera in an 'image act' which is enhanced by her close distance to the camera.

One of the interesting points about this advertisement, and indeed about this series, is that the statement that hails the reader is on the right of the page, the "new" position, while the information and answer is on the left which is very unusual as we naturally read English, and thence view pictures, from left to right. This results in a first interpretation that the woman and child that are

Image removed due to copyright. portrayed are victims of AIDS. However, this is ambiguous. The woman and child that are depicted in the photograph are clean and well-nourished and their faces express calm and contentment. The child's arms, wrapped around the woman's neck invoke a sense of love and trust and their eyes are particularly bright. The woman is turned to the right but gazes at the reader demanding contact, while the child is a non-transactional reacter looking outside the photograph over the reader's left shoulder. This is not a picture of the ravages of AIDS but of two happy, healthy individuals. The

Figure 7:3 We agree connotation is that their contentment is thanks to Chevron's corporate policy.

However, not only relationships but also status can be implied by distance. 
The "expert" is usually framed as a 'breast-pocket' shot. Frequently too, as the examples in here, experts are nominated in that they are named. The expert, Rick Scott, (figure 7:4) who is going to make hydrogen energy a reality, is looking directly at the reader, with an open, friendly smile that demands a positive response.

I have already mentioned that subjective and objective stances are expressed by perspective, and relations too can be created through angle. An oblique angle tends to encode detachment while a frontal view suggests involvement and the reader is obliged to accept this stance. Ian Hazlewood, shown in figure 7:5, has been photographed from an oblique angle suggesting detachment and from below which means that the viewer has to look up to him. The entrepreneur and computer network design expert is standing, offered for our perusal, gazing to the right away from the camera towards a private vision of the future which he does not wish to share with the reader. The rather blurry background shot of Tower Hamlets, where his computer network support expertise assists local businesses and is helping to improve the life of the community, connotes that the area is moving from neglect towards prosperity and a role that is more centre stage.

Modality, which refers to the truth value or credibility of a statement can also be expressed in an image, but is interpersonal rather than ideational and is dependent upon what is considered to be the social or individual norm. As Kress \& van Leeuwen point out; "the eye has had cultural training, and is located in a social setting and a history" (1996: 163). "[M]odality is a system of social deixis which 'addresses' a particular kind of viewer, or a particular social/ cultural group, and provides through its system of modality markers an image of the cultural, conceptual and cognitive position of the addressee" (ibid: 178). Colour, focus and detail are modality markers.

Geometric shapes also have meaning although these can be glossed differently. Generally, however, angularity is associated with the inorganic and with technology while circles denote endlessness, warmth, protection and nature. The atom, for example, has been said to stand for "power and knowledge. Its sure, regular orbits and defined spaces represent[ing] 'law-abiding solar systems of energy' under central direction" (Jim McClennan, cited in Kress \& van Leeuwen, 1996:88).

Just as speech can follow the rules and logic of rhetoric, so too can the image. One of the ways in which this is done is through the use of visual metaphor (figure 7:6) Another is through the composition of the image and in the case of an advertisement, for example, the lay-out. I have stated that the left tends to mean the known or given while the right refers to what is new, but this can be extended to encompass what is at issue. However, a second way of structuring the message is along a vertical axis, from top to bottom.

In an advertisement, the upper section tends to visualize the possible or the ideal and to make an emotive appeal while the bottom represents the real, the more practical, and the informative (ibid:193). Three inter-related systems, information value, salience and framing are important meaning-makers and Kress \& van Leeuwen identify the verbal concepts of intonation in salience and of rhythm which is achieved by successive waves of salience. Framing and rhythm can impact upon each other and the visual flow in the spatial integration of the different elements on the page. Connectedness can be achieved or emphasized by vectors and cohesion can be brought about by colour, for example. Composition codes and determines reading paths, although different readers may follow different paths. 


\section{Image removed due to copyright.}

Figure 7: 6 not invented yet
Terry Royce (1998:28) has formulated what he calls the intersemiotic complementarity of language and visual images, where "visual and verbal modes semantically complement each other to produce a single textual phenomenon" and Daly \& Unsworth (2011) have discussed ways in which image and text can reinforce each other. They show how meanings in images and written language can interact to affect the way in which a text is understood. The notion of complementarity refers to an extension of meaning where a new element or participant is introduced into either the image or the written text, while concurrence is a means whereby one mode reinforces or elaborates the meaning of the other. This can take four forms, exemplification, exposition, equivalence and homospatiality, which refers to two different semiotic resources cooccurring in one spatially bonded homogenous entity (ibid: 63). An example (figure7:6) from Shell's series from about 2008 demonstrates this latter.

The advertisement concerns an environmental fuel made from straw and the concept of the fuel is reinforced by the homospatiality of the straw-like letters that directly address the reader and also by the straw cars in the picture. The greens and yellows of the colour palette elaborate the environmental friendliness of this new fuel.

\section{Typography}

I have already shown how the written mode and the visual mode reinforce each other, but this goes beyond images, colour and lay-out to include the actual typography of the advertisement. Homospatiality, which I have just described, is a common instance of this, and Daly \& Unsworth give an example (ibid), of when "the letters of the word 'seaweed' are created using fluid images of strands of seaweed." Kress \& Van Leeuwen (2001, cited in Nina Nørgaard 2009:142) take the position that multimodality extends even to the simplest examples of printed verbal discourse and contend that all modes need to be treated in the same way as semiotic systems in themselves with potential choices, patterns and grammar which create significance. Therefore the "visual aspect of printed language is meaning-making in its own right and interacts with other modes of meaning in a complex process of semiosis" (ibid:141) and in the world of advertising, this has been given particular attention. Typography is not only "what language looks like" (ibid: 143) but is also a reminiscence of the bodily movements of earlier calligraphers and hewers in stone. However, until fairly recently, typography was not considered a semiotic mode in its own right and most research that was done in the area was only concerned with matters of legibility. In fact, only in 1980, R. McLean wrote that "to a very limited extent, lettering may help to express a feeling or a mood that is in harmony with the meaning of the words," but for the most part, lettering and calligraphy are abstract arts (...) What moves us is something formal, and, in the last resort, inexplicable" (cited in Van Leeuwen, 2006:141). 


\section{Image removed due to copyright. Image removed due to copyright.}

Van Leeuwen argues that typography is a semiotic mode in its own right and can fulfil Halliday's metafunctions. He suggests that ideationally, a rounded font can illustrate indulgence, for example. Typography can even enact interactions and express attitudes, by for example changing a word into a question or a warning, or it can represent the dull and ordinary. It can also realise textual meaning by demarcating the different elements or units of a text or by foregrounding key elements. Further, Van Leeuwen (2005: 138) points out that the printed word has two levels of meaning, the "word image" which refers to the idea represented by the actual word, and the "typographic image", which is the holistic visual impression. He shows how letter forms can display two semiotic principles, connotation and metaphor.

The two examples above (figures 7:7 and 7:8) which are also taken from the Shell Real World series show some of these different attributes of typography. In figure 7:7, the irregular form of the letters that represent the brain connotes the non-standard thinking that will be necessary to solve the world's energy problems. The second example (figure 7:8) shows how words have been written to form the bendy milkshake straw that was the inspiration for the new snake drill that can go round corners and extract oil from pockets that were previously difficult and expensive to reach and which is the focus of the advertiement.

Typefaces can have connotations that are mythical in the sense used by Barthes (1957) and are a resource for meaning making which builds upon cultural knowledge. Typography almost always co-occurs with other modes of communication and it is important not to isolate these Van Leeuwen (2006:144). In many cases, the choice of typeface is connotative, in the specific sense that a sign can be 'imported' from one context into another to signify ideals and values that are associated with the 'export' context (ibid: 146). Nørgaard (2009:155) for example shows how the typeface known as E13B which was designed to be read by machines and consequently allow cheques to be handled by machine, "became a typographic signifier of the emergent human/computer interface and the intersection of money and technology". 
Similarly, Courier, which was created in 1955, is often used in literary texts to signify typewritten (Nørgaard, 2009: 156). Thus, it is indexical in nature. ${ }^{14}$

The specific features of letter forms can also have metaphorical potential (Van Leeuwen, 2005: 140) and a rounded font can lend itself as a metaphor for the organic, the natural or feminine (Van Leeuwen 2006: 143), while angular fonts can suggest technology and hardness. The letters in figure 7:7 have both of these forms implying the different qualities that Shell brings to bear upon the problems that the world is facing. As these examples show, typefaces can now blur the boundaries between image and letterform. However, there is no one-to-one relationship between typographic form and meaning and the meaning potential is dependent upon the context in which the forms occur.

Typography is a "signing mode between language and image" Hartmut Stöckl (2005) and serves to encode language as well as to convey subtle, connotative meanings. It can convey genre and reinforce the thematic structure of a text and facilitate access to the reader. Finally, it can take on pictorial qualities. Pictorality is achieved "when the typographical elements [...] form visual signs that resemble objects, such as the snake drill in figure 7:8. A classic example is Louis Carroll's Mouse's Tale ${ }^{15}$ where the pun on the words tale and tail are pictorialized.

Typography can also illustrate emotions (ibid: 206). Its communicative flexibility is provided by its threefold semiotic nature. Stöckl contends that these three semiotic layers correspond to Peirce's three sign types and suggests that reading is mainly symbolic, an act of deciphering conventional signs which can take on indexical and iconic qualities (208).

Colour, perspective and apparent textural qualities of the surface of the paper or of the print (figure 7:6) are also providers of what Kress \& Van Leeuwen refer to as "experiential meaning potential". Hagan (2007:67) insists that although typography and words interact and that text and typography are always 'marked' "blending in ways that are either culturally meaningful or contextually meaningful or lean towards personal associations," prolonged exposure to the specific typography can reduce its effect over time as what is novel has always most impact.

However, Stöckl (2005: 209) suggests that typography has a "weak grammar", partly due to the fact that one typographic element can have multiple meanings and that one meaning can be realised by different typographic means. He points out that in an advertisement, the typographic standard is that different functional parts or elements are usually clearly marked off from each other and the most essential elements of the message are made salient through the typographical design. Typography is the "body and dress" of the advertising text.

\footnotetext{
${ }^{14}$ One example that she gives is from Dan Brown's The Da Vinci Code where Courier is used to signify "computer text" as it was used in the infancy of computing (157).

${ }^{15}$ This appeared in Alice in Wonderland by Lewis Carol (1865) and the tale is written in the shape of a tail.
} 


\section{Colour}

Van Leeuwen (2008) has posited that the image is becoming less central and that the previously marginal modes of communication are becoming increasingly important. I have already discussed the development of typography, but there is also more awareness of the impact of colour as something that is "subversive, pleasureful, and 'escaping the inky law of the trace' (Derrida, 1987 in van Leeuwen, 2011:ix).

"What makes a mode mode-like is its availability as a resource for making signs in a socialcultural group" (Kress \& van Leeuwen, 2002: 346). However, they also put forward the idea that colour can also fulfil Halliday's three metafunctions. Ideationally, it can denote specific people and things, and it is particularly important in branding. Company logos all make use of a specific colour scheme, for example, and the petrol stations belonging to different oil companies are clearly recognisable because of their specific colour combinations. As I have previously mentioned, the companies introduced staff uniforms in the filling stations in America at an early stage to ensure that customers recognised the brand and to create a sense of brand personality. On an interpersonal level, colours can help us to realize 'colour acts' and 'do' things for or to each other. Painting hazards orange or dressing in specific colours, such as black at a funeral to convey respect and sorrow are examples of this while today, green is the colour associated with the environment. On a textual level, colour can promote cohesion or salience, and in an advertisement, for example, the colour blue on a packet of soap powder can be repeated in a tranquil lake to give symbolic value to the product. Moreover, "[c]olour fulfils these three metafunctions simultaneously" (van Leeuwen, 2011:12).

Colour cannot stand on its own, but it can have metaphoric or connotative potential and is commonly associated with affect. Johan Wolfgang von Goethe (1810) commented that colour "is immediately associated with the emotions of the mind" (cited in van Leeuwen, 2011:22) but also has symbolic meaning. Kress \& van Leeuwen (2002: 355) distinguish two types of affordance, or sources of making meaning with colour. The first is association which can carry significant symbolic value in a given socio-cultural context, while the second relates to a colour's distinctive features. The authors draw parallels between this and the distinctive feature phonology that Jakobson and Hallé introduced in 1956. Colour always has a quality, such as regal dark red or the bright red of danger and the scale of value of colour ${ }^{16}$ is a fundament of the "edifice of symbolic meanings and value systems" (ibid: 356) of every society.

The role of semiotics "is to induce the selection or preservation of qualities of form, colour, volume or typography that are deemed pertinent; [or to facilitate ] the choice or preservation of those qualities that ensure that the packaging, product design or logo signify what they are supposed to signify" (Flosch 2001:8). Colour and typography work together to communicate brand. For example, the BP helios logo with its green, yellow and white colours which represent the sun and the earth is a clear example of the form and colour of a logo symbolically representing the desired face of a company. While the new Total logo preserves the red and blue colours of the previous logos, it has extended the palette to include orange, and following (Van Leeuwen, 2006), the rounded, interlinked form connotes continuity and nature. The ExxonMobil ${ }^{17}$ logo was also designed to preserve the colour scheme of its Enco and Esso brands and moved into the future with the angular, linked " $\mathrm{X}$ " letters that connote technology and also recall the "ss" of Esso.

\footnotetext{
${ }^{16}$ The scale of value is the grey scale from maximally light (white) to maximally dark (black) and light and dark are fundamental human experiences (Kress \& van Leeuwen 2002: 355).

${ }^{17}$ The new logo was designed by Raymond Loewy, a well-known industrial designer.
} 


\section{Summary}

This chapter introduces some of the concepts of semiotics which researchers into advertising and marketing have enthusiastically adopted, and shows how different features of its extensive landscape are central to the communication of the advertising message and also play a part in branding. Although semiotics, as a system of codes is also central to the verbal message and indeed encompasses all forms of communication, my focus here has been on the visual. This is because the textual and the visual elements of an advertisement are intertwined and their rhetoric is complementary. Pictures, as well as words, can move an audience and create relationships with their beholder. Therefore it is important to have some understanding of the complex mechanism that underlies our reception of an advertising image and have some awareness of the rhetorical devices employed to move and manipulate the senses of the beholder.

Rhetorical approaches reveal "how" an utterance or text is constructed to lead to the "desired outcome in the world" (McQuarrie \& Mick, 2003:195) and are thus concerned with their illocutionary force. As Marcia Pointon (1997:7) confirms, "in some cases the pictorial image is more powerful than words to convey to us a complex mass of information and ideas" and this is something of which advertisers have been aware and used to their advantage for decades (Marchand 1985, Freedberg 1989, Rampley 2005). Just like words, images, and particularly photographs, have potential for addressivity and persuasion, while visual rhetorical figures, just like verbal ones can add to the "pleasure of the text" (McQuarrie \& Mick, 2003:198). Advertisers adopt and adapt these potentials to their purpose.

However, as Flosch (2001:8) has observed, successful communication requires "reciprocal presupposition." 18 In other words, communication builds on a shared understanding of the meaning of the codes employed. Intertextuality is common not only in the written elements of an advertisement but also in the visual. An awareness of context and at least a degree of shared cultural knowledge are essential

\footnotetext{
${ }^{18}$ Eco (1990:224-225) identifies semantic presuppositions and pragmatic presuppositions. The former commits to the truth-functional approach while the latter requires felicity conditions and the shared knowledge of the participants in the communicative situation.
} 


\section{Chapter 8}

A Century of Rhetorical re-Presentations

Texts "speak: they participate in society's communicative practices, and are an important means of influencing world-view and social structure" (Fowler, 1996: 130). As such, they are not one-way processes but dialogical performances, a tenet which most certainly holds for advertising texts.

It is now time to revisit the questions raised in Chapter one and begin to investigate the ways in which the oil companies have mustered and organized the different semiotic means at their disposal to project, present and re-present a positive image that will protect and increase their capitals. Having previously established that advertising is an inherently dialogical and dynamic communicative genre that incorporates "interactivity, responsivity, addressivity, contextuality, interdependencies and heterogeneities, and the dialogical appropriation of the world through semiotic means" (Linell, 2009:267), it is now necessary to ascertain the roles played by the different participants in the communication and how these roles are enacted. Communication implies a relationship with "the Other" and some form of response and relationship building to elicit a desired response is central to advertising. An analysis of these relational roles will allow us to uncover the rhetorical identities of the companies and their presumed audiences, and facilitate an analysis of the narratives that they tell about themselves in order to safeguard their capital. This will be my point of departure for an archeological expedition into the polyvocal and multi-semiotic world of oil-company advertising.

As Goffman (1959:16) has stated, an individual, or this case, a company, will generally "mobilize his activity so that it will convey an impression to others which it is in his interest to convey" and it is in an advertiser's interest to convey to others that the product or service is worth purchasing and further, that the nature of the company's business is in some way laudable. In other words, the advertiser must choose an appropriate "footing" to achieve the desired effects.

How then do the oil companies identify and form a relationship with their publics and present and promote the desired face? What are the rhetorical techniques that are used? What are the pronouns that populate the advertisements? In an utterance, an "I" an addresser, presumes a "you" an addressee and this raises a number of questions. Dialogism is not limited to "you and me," but incorporates our shared vision of the world out there, about which we are communicating. This world is not static, and consequently, not only must speakers adapt how they choose to communicate in response to the evolving social context but also what they choose to communicate.

An advertisement is a communicative event, a term which I am using to refer to an instance of communication, whose purpose is to elicit some form of desired response. In other words, an advertisement is not merely what Austin refers to as a "constative", although this is very often an element of the advertising message, but is an illocutionary act (McCloskey 1989) whose ambition is to persuade, and as Maillat \& Oswald (2009) have so rightly pointed out, communication can only take place if the message conveyed is understood by the audience. Thus, a successful advertiser must have a strong audience orientation, or in other words, a clear sense of "recipient design" (Sacks et al., 1974). Indeed, Kenneth Burke (1945:24) has insisted that the persuasive aspect of rhetoric is actually the ability to identify your cause with the interests of your audience. People "adapt their practice to their addressee" as Hanks (1996:244) has pointed out, and indeed, may even try to "altercast" the addressee (Weinstein \& Deutschberger 1963). Thus, for an advertisement to fulfill its purpose, it must be in tune with contemporary attitudes and beliefs. 
In Chapter 2, I described the socio-political context in which the advertisements that make up my corpus are based and in chapter 4 overviewed the trends in advertising. This has allowed me to make what Stuart Hall (in Daniel Chandler, 2002:192) refers to as a dominant or hegemonic reading of the advertisements. This term means that the "reader fully shares the text's codes and accepts and reproduces the preferred reading." In other words, to fully understand the message communicated, in this case the advertisement, the reader should be aware of the socio-cultural circumstances in which the énoncé, was produced and is not deaf to metaphors, whether verbal or visual. I have also described the theories and approaches which inform my study.

In the following, I will make a close "preferred reading" of the advertisements which BP, Chevron, ExxonMobil, Shell and Total have produced to find answers to my research questions. Shell advertisements dominate my analyses just as they dominate my corpus. This is because Shell was an early player, has not changed its name or entered into any mergers and also, because since the beginning of the twentieth century, the company has advertised extensively. As I am taking a dialogical approach, my interest lies in the textual frame of the advertisements (Nöth, 1987:283) and it is the different semiotic and rhetorical means which the companies use to communicate with their audiences that are the foci of my analyses.

\section{Shell and the first decades}

The earliest advertisements in my corpus are for Shell and are in the form of postcards. These postcards are usually colourful and often humorous.

The example below (figure 8:1) dates from 1905 and is a very early Shell postcard. The message is clear, "Shell Motor Spirit, Best on Land and Sea" and the giant, upright Shell ${ }^{2}$ is flanked on the left side by a motor car to illustrate the land and on the right, by the sea and two boats. The message communicated is purely informational. However, a later version of the card uses the surface of the shell like that of a trophy, and the names of the winner of the Tourist Trophy Race for 2006, the Honourable C.S. Rolls, driving a Rolls Royce car is engraved on it with the information that he was using Shell, just like the 1905 winner. Racing was very popular but as the names of the winners on the 1906 postcard suggests, racing, and motoring in general, tended to be the province of the wealthy.

\section{Image removed due to copyright. Image removed due to copyright.}

Figure 8:1 Best on Land and Sea

Figure 8:2 Triumphs of the Air

\footnotetext{
${ }^{1}$ Hall suggests that such a reading "may not have been the result of any conscious intention on the part of the author" (Chandler, 2002:192), but I cannot accept such an assumption in the case of an advertisement where every word and every element is the result of careful thought and planning.

${ }^{2}$ The logotype in this form dates from 1904.
} 
The advertisement described is relatively simple. However, from a participant perspective, even in this relatively simple case, what Goffman (1981:226) refers to as the "principal" or "the party to whose position the words attest" is cloaked by the intermediaries of the artist and the copywriter working in conjunction. The human figures are signs ${ }^{3}$ and are indices of the uses of the Shell product in a modern world.

The second example (figure 8:2) is from1910 and illustrates the third use of "Shell" Motor Spirit. The complicated nature of the participant roles in advertising is illustrated in this postcard which celebrated the successful flight from Manchester to London undertaken by Mr.L.I.Paulhan. One issue raised is the assumption that the recipient has the background knowledge that is required to interpret the message; in this case, an awareness of geography and some knowledge of engines are necessary.

Under the heading "Triumps of the Air" , Mr. L.I.Paulhan writes: "I used "SHELL" on my flight from London to Manchester, and from start to finish the Gnome Engine ran splendidly, which is a tribute to the quality and uniformity of "SHELL" Motor Spirit.

This is a very early example of product endorsement and raises a number of questions about the participants and their roles. Besides the intended reader and the company voice implicit in the heading, there are a number of actant participants whose roles are not self-evident. Is Mr. Paulhan, the real "I" or agent of the utterance writing in his own words and in his own person, or is Shell, what McCawley (1999:600) terms the "primary animator", the body that controls the animation of the utterance? Where is Mr. L.I. Paulhan? Is he calling out from the aeroplane in the distant right hand corner? Who is he addressing? Is his dialogical partner in the drama the lady holding the iconic laurel-wreathed can, or is it the reader? The reader's gaze is drawn to the colourful right - hand side of the postcard, and the heading explicitly points to and hails the can of Shell Motor Spirit, rather than the Mr. Paulhan's achievement, as the "triumph of the air". Both the heading and the rather impractical dress of the lady holding it aloft echo the green of the laurel wreath that encircles the triumphant can rather than the 'plane or its invisible pilot. The statement proclaimed by the heading, the can and Mr. Paulhan's plane are separated from the textual information by the physical structure of the aeroplane in the foreground. The colour balance is achieved by the red text in which the airman's feat is acknowledged. However, following Kress and van

Image removed due to copyright.

Figure 8:3 Suffragettes Leeuwen (1996), the product is "given" as the triumph of the air, and Mr. Paulhan merely represents a new angle and new possibilities. It is the product and its attributes that address the reader and the endorser's voice is an echo and pale elaboration of the voice of this principal actant.

The next examples further illustrate how Shell made use of contemporary events to attract the attention and interest of its audiences. Figure 8:3 is the first of two postcards which Shell produced on the theme of the Suffragettes and dates from 1908 and a third card, which refers to the 1910 elections, specifically includes this group among those depicted.

\footnotetext{
${ }^{3}$ Here, I use the term sign in a Peircian sense, to mean that is stands in relation to an object and its interpretant. The couple in the car are thus an index for motoring and the people on the boat for the product's use for motor boats.
} 
This was the era when women were fighting for emancipation and the right to vote and this is reflected in Shell's advertising of the time which portrays women as independent beings. The postcard shows a group of women calling for votes for women as well as votes for Shell Motor Spirit. It is interesting to note that while the rallying cry of the suffragettes was "votes for women", it is ladies that vote for Shell. This is an indication of the market which Shell was addressing. Another interesting linguistic element of the advertisement is that while the women were fighting for equality with men, they quite happily acknowledge that Shell is "unequalled". Humour is also added to the advertisement by the form of the veils over the hats of a number of the women which echo the shape of the Shell logo that is prominently placed in the middle left centre of the picture, and by the fact that the women's elegantly white-gloved right hands are lifted in a rallying salute more associated with workers.

The reader is positioned behind the women in the crowd, looking down on them and on the same level as the woman leading the rally. This positioning, together with the direct form of address, creates a sense of "being there" and draws the reader into a relationship with the women and with Shell.

The postcard advertisement in figure 8:4 dates from 1909 and uses a direct form of participant address: "Safeguard your interests by using "Shell": "It's perfect purity that's the point." The female figure astride the beautiful white steed is bearing a golden shell as a shield and holding aloft a banner whose device

\section{Image removed due to copyright.}

Figure 8:4 Joan of Arc is the Shell can in a laurel wreath. This advertisement utilises the 'imagic' iconicity ${ }^{4}$ associated with Joan of Arc who was beatified that same year. ${ }^{5}$ Thus the impact of the advertisement is increased by its contemporary relevance. The strong, fearless young woman sitting on the beautiful white horse represents purity, and the rippling muscles of the horse suggest speed and strength. Together, they protect the castle in the background, and by extension, both "every man's home" and the nation.

Symbolically, Joan represents the power and purity of "Shell" motor spirit ${ }^{6}$ and this is underlined by the pure, blue sky with the white writing, the colour of clouds on a perfect summer's day.

The typeface connotes a hand-written message (Stöckl 2005, Hagan 2007) and suggests a personal relationship between the addresser and the addressee. The company logotype used as a protective shield metaphorically shows how Shell can "safeguard your interests," and together with the banner, constitutes the most salient element of the advertisement. Shell and the product name are all in the central section. However, the identity of the speaker is unclear. Are they the words of the company, Goffman's principal, or those of the actant or agent, Joan, in her shining golden armour and mounted on the pure white steed that are written across the heavens? One connotation is that the product protects that which is nearest and dearest to the addressee, his "interests", or in other words, his motor vehicle and his country.

\footnotetext{
${ }^{4}$ Jan Assman (1995: 129) discusses the concept of "figures of memory" which is associated with cultural memory that stores past cultural formations. Much of the theory is based on Aby Warburg's notion that we recognise and reuse images from the past, even unconsciously.

${ }^{5}$ Although Joan of Arc had been a symbol of the Catholic League from the 16th century, interest in her became more intense in the middle of the $19^{\text {th }}$ century, both in France and in England. This culminated in her canonisation on May $16^{\text {th }} 1920$ by Pope Benedict XV.

${ }^{6}$ The metaphor of Joan of Arc for the purity of Shell spirit also echoes the Biblical verse (Matthew 5.8) "Blessed are the pure of heart". The idea of Shell's purity was used in numerous advertisements after this.
} 
The advertisement in figure 8:5 illustrates Shell's patriotism. It is from 1908, a period of political unrest when the Anglo- Persian Company was squabbling with France and Russia over concessions in Persia. Shell was not directly involved in this, and the advertisement clearly and simply makes the statement that the nation, symbolised by the British Lion, stands secure upon Shell. Shell is invincible and together, Shell and Britain are invincible.

In 1912, Britain finally committed its battleships to oil and supplies had to be secured. Despite the fact that Shell had been instrumental in this change and had also proved more reliable than Anglo-Persian, in 1913, Churchill introduced a bill which would make Anglo-Persian the suppliers to the Admiralty. ${ }^{7}$

The postcard from 1913 refers to this situation and assumes an addressee who will understand the symbolism of the advertisement and its reply to the accusations, levelled by Greenway of Anglo-Persian, that Shell was in the hands of untrustworthy foreigners. The postcard shows a rather different Nelson's Column (figure 8:6) with a shell at the base and a red sealed Shell can replacing the national naval hero. The a reader who does not recognise the monument from Trafalgar Square cannot fully appreciate the accolade which Shell is awarding itself by replacing the national hero, Admiral Nelson, with their red can, and by connotation, declaring itself to be the new national hero. The slogan "It's perfect purity that's the point" is also a comment on the purity of their intentions; to strive for Britain's best.

\section{Image removed due to copyright. Image removed due to copyright.}

\section{Figure 8: 5 British Lion}

Figure 8: 6 Nelson's Column

The statement to the right reinforces this message. On one level, it implies that Shell has a greater reputation than Nelson, but on another, it presents a comparison with Anglo-Persian, the company's rival. The superlative "'highest" also involves a play on words as in this case, the can of Shell is physically highest.

These advertisements (figures 8:5 and 8:6) completely lack "the appellative function presupposed by the intention to sell" (Nöth 1987:279) and instead appeal to the reader's sense of patriotism by implying that Shell is good for the nation. Figure 8: 7 shows one of the very few advertisements in my corpus that illustrate the buying or selling of any of the products

\footnotetext{
${ }^{7}$ Admiral Fisher eventually managed to change this and Shell too became suppliers to the navy. See Chapter 2.
} 
that are available from the companies. This dates from the mid-1920s and is particularly interesting because it not only shows a lady purchasing Shell Oil, but also provides a price list for the different qualities of Shell Oil that are on sale. The reader is not directly instructed to make a purchase, but the apparent social status and assurance of the lady motorist as she places her order encourages confidence in the product and the price list down the right hand side of the advertisement provides the potential customer with all the information that is necessary. The price list is a very interesting aspect of the advertisement as it is the only example in my corpus that provides the reader with prices. The advertisement appeared during a period of turmoil with widely fluctuating prices a couple of years prior to the As-Is Agreement of 1928 when the major oil companies agreed to collaborate and establish uniform pricing. When this advertisement appeared, price was still used for competitive advantage.

\section{Image removed due to copyright. Image removed due to copyright.}

\section{Figure 8:7 Postcard with prices}

Figure 8:8 Oil for heating

Although the majority of the advertisements that it produced at this time are for Motor Spirit, Shell, like the other early companies in the industry had come into being because oil had become a popular, cleaner and safer illuminant and it was also used for heating. ${ }^{8}$ The example in figure 8:8 shows an Eskimo sitting on a crate of Shell Motor Spirit ${ }^{9}$ warming himself in the company of a polar bear. This advertisement can be considered as one of the series which showed Shell and cans of Shell appearing in the most unlikely places, including the North Pole and among the pyramids of Egypt. ${ }^{10}$

Before moving on from the first decades of the twentieth century and Shell's postcard advertisements, there are two other examples that I would like to discuss as they can be considered as prototypes for the company's later advertising techniques.

The first of the two (figure 8:9) shows an old man with wings dressed in a red Grecian-type robe flying through a blue sky in pursuit of a be-winged can of Shell Motor Spirit. He is moving from the left (the given) to the right, the new and the possible. Below the old man is the Shell logo. Closer inspection reveals that the old man is Father Time ${ }^{11}$ with his scythe. Below the man the word "Shell" is written in the same red as his gown and the can and the sinuous curves of the " $\mathrm{S}$ " echo the form of the bottom of his robe. This shape is repeated in the "M" and the "S" of the words Motor Spirit which appear against a yellowish background

\footnotetext{
${ }^{8}$ A number of humorous advertisements in Poultry World, as well as a series of small booklets of poems for example, testify to this use as late as the fifties. Among those who penned the poems for Shell-Mex \&B.P. was the future Poet Laureate, John Betjeman.

${ }^{9}$ A similar advertisement shows the Eskimo sitting on a barrel of 'Royal Standard Extra Refined Petroleum'

${ }^{10}$ The places where Shell is found in these advertisements are places of contemporary interest. The Egyptian advertisements, for example appeared during a period of great interest in Egyptology when Howard Carter had just begun to excavate in the Valley of Kings and similarly, after Scott's first journey to the South Pole, Polar expeditions were popular.

${ }^{11}$ This is another example of our "figures of memory".
} 
that echoes the colour of the logo and whose form follows the contours of the flying protagonists. In the bottom right hand corner are the words "Always Ahead of Time" written in blue to balance the blue of the sky. The extended cross bar of the "A"s echo the wings above and as they extend only to the left, suggest a movement towards the right, a flight into the future which cannot be stopped and which is represented and fuelled by Shell.

\section{Image removed due to copyright. Image removed due to copyright.}

The triangular arrangement of these words, together with the word Spirit above them, builds a pyramid whose vectors draw the eye to the flying can. The advertisement is an early example of the "resonance" created by wordplay and a visual that McQuarrie \& Mick (1992) have described and in which Shell came to excel.

The advertisement in figure 8:10 is also an early example of "resonance". The word "key" in the slogan "The key to successful motoring" is reproduced in the elaborate red key which has been created out of the word "Shell" and which repeats the colour of the laurel-wreathed can. This is an early example of typography taking on additional meaning through its pictorial qualities (Stöckl 2005). Again, the colours red and yellow are central, while the new message is produced in blue.

\section{Image removed due to copyright.}

\section{Figure 8:11 Shell lorry bill} obviously stated message or explanatory text and no clear participant actant.
The advertisement shown in figure 8:11 dates from $1920^{12}$ and was the first Shell poster. It was used both as a lorry bill and a garage sign, which implies that the reader would not be expected to spend much time examining and interpreting its content but should register the sign and interpret its message instantaneously.

The sign is colourful and the name Shell stands out clearly against the clear blue background, attracting attention. This advertisement makes no direct address to a reader, there is no

To understand the message, the reader must recognize the red and yellow Shell Motor Spirit cans and know that Shell is an oil company. In other words, the addressee must be aware of the identity and meaning of the "objects" or what Kress and van Leeuwen, (1996:46) have

\footnotetext{
${ }^{12}$ It appeared in two versions, the one shown here (8:11), and one with a darker blue background and with Shell written in yellowish letters. The Joan of Arc postcard (figure 8:4) also appeared in two versions, the one with the light blue sky that I have shown and a second darker version
} 
referred to as "represented participants" that are the subject of the communication. The cans are pouring the liquid into the letters that make up the name Shell and that act as receptacles. The content is being poured cleanly back into the name without spilling suggesting a natural cycle and the rather rounded letter shapes together with the white colour connote a form of natural purity ${ }^{13}$, a quality of its products upon which the company had long insisted, while the red $^{14}$ cans not only symbolize Shell, but also add a third colour, encouraging the viewer to associate Shell with the red, white and blue of the Union Jack, and thereby with the attribute of Britishness. This apparently simple advertisement therefore demonstrates the "inevitably relational dimension of meaning" (Berger, 1985). The tail of the "S" resembles that of a mermaid, to add yet another level of connotation and connecting Shell with the sea and with the beautiful legendary creatures that live there.

\section{The Pre-War years: Art and Humour}

There is a symbiotic relationship between $\operatorname{art}^{15}$ and the British oil industry. During the 1920s and 30s, Shell and later BP advertised extensively through lorry bills, and although the artists were often unknown or better-known individuals whose work was not instinctively associated with commercial art, many of these posters became recognized works of art. ${ }^{16}$ Here, I first present and analyse the advertisements of Shell in some detail and then look at those produced by BP, whose advertising, particularly after their marketing operations were merged with those of Shell in $1932,{ }^{17}$ followed the same pattern. However, BP's advertising was rather less extensive and has generally had a lesser impact on the British cultural memory.

\section{You can be Sure of Shell}

One of the first series of Shell advertisements was the "Quick-Starting Pair", an expression that became a popular slogan. The example in figure 8:12 was created by Jean D' Ylen and dates form 1925. Typically, the posters in this series did not feature the product but instead, highly stylized animals of speed, such as eagles or the mechanical horses driven by god-like creatures in chariots with the Shell logo. The idea of a god-like creature driving a chariot made of a shell and with the shell logo as a shield can be found in the early postcards and I will return to this in the following chapter.

With the exception of the example from 1909 (figure 8:4) Shell advertisements had made no use of direct address to the intended addressee. However, one series of lorry bills began to

\footnotetext{
${ }^{13}$ Theo van Leeuwen (2011) discusses the impact of colour and colour symbolism. In the American flag which has the same colours as both the Union Jack and the flag of the French Republic, white signified purity and innocence, blue vigilance and red hardiness and valour (18). Van Leeuwen also takes up the subjective aspects of colour, first formulated by Johann Wolfgang von Goethe in 1810, and the importance of culture.

${ }^{14}$ The fact that the Shell cans are red is a matter of chance. Standard oil used blue and thus, Shell shoes red to distinguish the two companies' cans (Yergin, 2008: 52).

${ }^{15}$ Marchand (1985) discusses how in an American context, many people became aware of art through advertisements. However, in the U.S.A. this acquaintance was usually made through magazines while in Britain oil company lorry bills played a major role.

${ }^{16}$ It is through their commissioning of often unknown artists for their lorry bills posters that Shell and BP became patrons of the Arts, a role which they still play. Julian Stallabrass (2004:92) has pointed out that sponsorship and longer term deals with art institutions have obvious and quantifiable benefits for corporations as this enables them to reach out to a richer and better educated public as well as appear to be charitable. Stallabrass also comments that many companies that sponsor the arts have image problems and names BP's alliance with the Tate as an example. However, this interest is something that both Shell and BP have shown for many decades and pre-dates any of the image problems that they face today.

${ }^{17}$ The companies merged these operations partly in response to the difficult economic conditions of the time and demerged in 1976.
} 
change this. The series that led to this change was called "See Britain First" (figure 8:13) and dates from 1925.

\section{Image removed due to copyright. Image removed due to copyright.}

A sentence, like a narrative, presumes an addresser as well as an addressee, (Barthes, 1966:18) and in this example, the addresser is the voice of the company that addresses the reader directly without any apparent intermediary. This creates a relationship with the reader who is no longer cast as a mere observer but is called upon to act.

In the first examples, as illustrated by the poster of Sma' Glen Crieff painted by D.C.Fouqueray (figure 8:13), the reader participates as an outsider, contemplating from a distance others with whom he can either identify or envy, "seeing Britain first - on Shell" and is evoked to emulate them. The individuals depicted are members of the wealthy leisured class who have arrived "on Shell" in a beautiful corner of Scotland to picnic and enjoy the scenery. The picture is framed which increases the viewer's sense of exclusion and outsidership.

This series, the "See Britain First" was followed by the "Everywhere you go" campaign which involved a more direct address and more obvious participant roles. This series centred on the famous slogan "You can be sure of Shell" which followed Shell for many decades, in many campaigns and series, and even in songs ${ }^{18}$.

The McKnight Kauffer lorry bill of 1931, (figure 8: 14) however, shows a change not only in the style of the landscape drawing but also in the participant perspective.

\section{Image removed due to copyright. Image removed due to copyright.}

Figure 8: 14 Stonehenge by headlight

Figure 8:15 The Shell Chain

\footnotetext{
${ }^{18}$ In the 1960s, both Bing Crosby and Sammy Davies Junior sang "The Shell Song" which ended with the words of the slogan and was used in television commercials for Shell motoring products.
} 
Here, as in most of the later examples, there are no people, and the perspective with which the reader regards the scene is that of an actant participant. The reader is inscribed into the image as the motorist arriving at the scene. First, the powerful, evocative poster with its mysterious, brooding, night colours attracts the eye. The immense stones are cast in light and not in shadow, as the natural light on the horizon implies that they should be, signaling that we are seeing them by the light of headlamps. The addressee becomes an actant in the narrative described in the advertisement and is given agency through the use of the product. The addressee is also required to participate actively to interpret and understand the message.

With Shell products, "you" can drive to Stonehenge by car and see this magnificent sight, for example by the light of your headlights. Shell, the company, the implicit addresser, or source of the message, identifies an addressee who knows what Stonehenge is and who is able and can be persuaded to purchase what is necessary to make the trip.

Like a narrative, the 1931 lorry bill (figure 8:15), which is also by McKnight Kauffer, also presumes an "I", an addresser, but here, it is unclear whether the implicit "I" of the slogan is the voice of Shell or if it is that of a third party recommending the company. What is clear however, is the visual metaphor. The chain represents the strength of Shell, the company and its products, while the tracks along which the chain is running show how smoothly mechanical parts move with Shell lubricants. ${ }^{19}$ This is repeated in the coil in the top left hand corner preceding the "you" of the address. The simple background allows nothing to detract from the message, while the limited number of colours and their cold, metallic properties connote mechanization and modernity. The technological achievement behind the products is suggested by the straight, angular lettering of the word Shell and by the straight lines of the track and the frontal view of the chain (Kress \& van Leeuwen, 2002, van Leeuwen 2006).

The "You can be Sure of Shell" slogan was first recycled in the famous "Everywhere you go" lorry bill series from the following year. In fact a number of series took this slogan as their form of participant address. The first of these followed the previously established travel theme and aimed to encourage travel and sight-seeing throughout Britain with Shell products as the facilitator. Here, the addressee is doubly hailed. Everywhere YOU go, YOU can be sure of Shell.

The Paul Nash lorry bill from 1932 is a good example of this (figure 8:16). The reader can experience the second person pronoun as both a direct and personal individual address as well as a more general call to a wider group of individuals to which he belongs. In fact, the relational and universal elements of the message frame the advertisement.

This series is a call to travel and adventure and an implicit assumption is that the

\section{Image removed due to copyright.}

Figure 8:16 The Rye Marshes addressee is a person who travels and who is interested in the country and in exploring what it has to offer. The speaking "I", in this case the company through the mediation of Paul Nash, creates a relationship with the individual "thou" of the second person addressee, the potential explorer, and

\footnotetext{
${ }^{19}$ Barthes (1977, in French, 1964) and later Forceville (1995) for example, discuss the denotational and connotational aspects of pictorial metaphors
} 
with the general collective "you" of the public at large. This slogan is example of the ambiguity of participant roles and the way in which voices can conflate (Adelswärd, 2000).

The stylized clouds packed underneath the "you" of the address draw attention to the word, while the angles of the geometric shapes with which the marshes are depicted create vectors which lead the eye to the upper "you". As Kress and van Leeuwen (1996:53) state, a triangle, is a fused structure of a participant and a vector, because it can convey directionality, point at things. This holds especially when the triangle is tilted as in this example. Moreover, geometric patterns, at least at that time, represented modernity and technology, the world of the motor car. Thus, the advertisement communicates a message to its recipient that is inclusive, in that it identifies the addressee with the modern, motor-borne explorer of the countryside and exclusive, as it identifies him as a member of that particular privileged group.

The places to visit in many of the advertisements in this series are depicted in a very modern, stylized manner, as the Nash poster shows, and the name of the place is provided in very small print above the slogan. This implies that either the addressee is expected to recognize the destination or alternatively, that the destination in itself is of minor importance and that the journey is central. A further point of interest is that although it can only be assumed that the invitation or exhortation is to make the journey by car, the destinations are all depicted free from motor vehicles. Like the "See Britain First" series, what is common to the images in this series is that the name of the place to visit is written very discreetly. It is the concept of travel, of seeing the country on Shell that is central, not the details of a specific location. Another interesting feature of the series is that the British countryside is idealized, and industry, like the motor vehicle, is conspicuous by its absence. It can only be inferred that the "going" is by means of car. In many of the bills, the landscapes or famous monuments to be visited are represented rather modernistically.

I have previously suggested, the persuasive effect of an advertisement is largely a result of the addressee's sense of "identification" with the rhetor, or in this case, the image that the company tries to project through its actant representatives and the stances that these are seen to assume, how have the major oil companies tackled this issue? Ellis \& Stam (2010: 428) have postulated that the "narrative self is born into a world of practices from which it must choose projects and life plans that can give its life narrative unity," and I claim that a company must create a corporate, narrative identity which can provide it with a clear and unambiguous image that finds resonance with the narrative selves of its different stakeholders.

Another popular poster series that used the "You can be Sure of Shell" slogan and that built upon this notion of identification was the "Conchophiles" ${ }^{20}$ series. In fact, Brunyé et al (2009) have shown how readers embody an actor's perspective when the pronoun you or I is used in a narrative. The example in figure 8: 17 is a lorry bill also designed by Paul Nash, and dates from 1935. In this example too, the relational aspect of the message frames the advertisement: "You can be sure of Shell, Footballers prefer Shell". The wide-ranging membership categories represented in this series include theatre goers, actors, journalists and gardeners. "You", the intended recipient of the message, is directly addressed and can associate with the group evoked or, in cases where the Shell pokes fun at the members of this category, laugh at himself or alternatively, enjoy the joke at their expense. Opera Goers are one example of a category at which Shell pokes fun.

In the example in figure 8:17, the addressee is brought into some form of membership with the popular and successful group of individuals collectively known as footballers.

\footnotetext{
${ }^{20}$ The term "Conchophiles" is an alternative to conchologist and refers to "Shell" lovers and collectors.
} 


\section{Image removed due to copyright.}

The positioning of the slogan, the first element in the communication, "hails" the reader, "thou" and commands attention. The vertical lines of the stylized image draw the eye down to the pay-off. "Footballers prefer Shell". This is implicit both in the more inclusive reading of "you" as people, "we" the group, which includes footballers and football enthusiasts.

\section{Figure 8:17 Conchophiles: Footballers}

The ball banging from left to right into the empty goal denotes success, power and forward motion, and leads the eye to the word "prefer" with Shell following automatically from the European reader's natural eye-movement towards the right.

These two series position the company in direct communication with the reader, "you" the addressee, and create a sense of group membership and identity. In other words, Shell is playing the role of a trustworthy, hard-working partner who makes life in general, and spare time in particular, easier and more enjoyable for the dialogical partner, the individual motorist, the general public, and the specific membership category that experiences the address.

These lorry bills were complemented with smaller, newspaper publications in "small ad" format. $^{21}$

The example from 1928 for the "Quick-Starting Pair" (figure 8:18) is particularly interesting for a number of reasons. The images are taken from cricket and are therefore heavily culturally laden. Not only is the reader required to understand the allusions made to the game of cricket, but also be aware of the identities of cricketing heroes, Hobbs and Sutcliffe, and of their run of success. The text reads as follows:

"If you want to learn how to steal runs watch Hobbs and Sutcliffe. A perfect partnership - perfect co-ordination of effort. Off from the crease in a flash. Not a moment wasted - movements like lightening. So with Shell Oil and Petrol. They are the ideal pair to enable your car to make the quickest possible start."

The men are invested with double agency. They are playing the part of successful cricketers and are representatives of Shell, acting as endorsers of the company's products and have been attributed the quality of "Quick-Starting Pair". The cricketers are looking towards the reader but at the fielder who has been unable to react quickly enough to catch the ball. Moreover, there is a play on words as the expression "to steal a run on somebody" (derived, of course, from cricket), means to be faster, to catch unawares. Another interesting element of this advertisement is that it speaks directly to the reader, "you". The second person pronoun is often ambiguous, and this is a clear example of its inherent ambiguity. For a cricket enthusiast, this could be "thou" and draw him directly into the role of potential actant, while for other readers it could be interpreted as a more generalized address.

\footnotetext{
${ }^{21}$ See for example Hendon \& Muhs (2007), Kelley (1956) or Williams (1980) for explanations of why this was the case in Britain, while in the U.S.A. companies were advertising in full colour in magazines and periodicals such as Fortune in the first half of the 1930s.
} 


\section{Image removed due to copyright. Image removed due to copyright.}

\section{Figure 8:18 Cricketers}

Figure 8:19 That's Shell -that is!

Stylistically, the text seems to imitate casual spoken language, but the alliteration of the "p" sound of this "perfect partnership" and the stylistic device of omitting the verb in the description of the partnership not only drive the description forward but also imitate the sounds and movements of a cricket match. The " $p$ " represents the sound of the ball against the bat while the short bursts of description are like the runs illustrated at the top of the advertisement.

However, these advertisements and slogan developed into one of the best-known and bestloved Shell series. It began with a number of advertisements by Rex Whistler, such as the one in figure 8:19, where one actant participant comments to the other "That's Shell - that is" as speed lines show that a vehicle running on Shell has just raced by. The address is to both the other actant and to the public. As the different typographical styles indicate, it is the virtual narrator or speaker, the company voice that declaims the slogan and not the incumbent, actant speaker.

Later, John Reynolds changed this to "That's Shell - that was!" and in 1930, drew a poster of a navvy holding a shovel and looking after the disappearing car. A member of the public added another head to the drawing (figure 8:20) and it was this that made the series so popular that it lasted for over twenty years with different two-headed characters, (figures 3:5, 8:21) often in the small newspaper format. This is a very interesting example of a member of the public that comprised the intended addressees actively participating and responding to an advertisement, thereby helping to develop the communication. ${ }^{22}$

Another example from the mid-1930s, for example, shows the working class two-headed character wearing a special sort of hat that had been made popular by the Prince of Wales. This shows how Shell is for everybody. In fact the variety of characters that populate Shell's advertisements and the different social classes to which they belong, as well as their allpervasive humour, shows a carnivalesque view of the world and demonstrates the inclusivity of Shell (see Frye1957:29). Every class and everybody was a target for leg-pulling.

\footnotetext{
${ }^{22}$ The person who added the head was sent a cheque for two guineas as thanks for his contribution.
} 


\section{Image removed due to copyright. Image removed due to copyright.}

Figure 8:20 Two-headed navvy

Figure 8:21 The Knock-less Monster

The example from 1933 which is entitled "Knock-Less Monster" illustrates how the series developed. The reader participates as a witness to Nessie's surprise and is not directly addressed. Instead, the two heads of the Loch Ness Monster seem to be commenting to each other. However, the advertisement is not as simple as it might first appear and the play on words requires an effort of interpretation on the part of the recipient which adds to the pleasure of the message and in better recall (for example Abel, 1994, Bonhomme \& Lugrin 2008, Djafarova 2008). The monster's reaction to what it has just observed, "Crikey" is an exclamation of surprise, and then it explains to itself and by extension, the reader, what caused this surprise. As the speed puffs on the road indicate, a motor vehicle has just sped past and the only possible explanation is that it was running on Shell. Moreover, the play on words, where Loch Ness becomes Knock-Less, reminds the contemporary reader ${ }^{23}$ that Shell products prevent the phenomenon known as knocking. ${ }^{24}$ As McCawley (1999:598) has pointed out, one of the pre-requisites of successful communication is that the participants have "[s]hared knowledge, in its pragmatic presupposition" and in this case, it requires knowledge of both the phenomenon known as "knocking" and cultural knowledge of Loch Ness and its famous monster.

Two other very popular and long-running series came into being in the 1930s. The advertisements in these series appeared in small format in newspapers and periodicals. These series were very humorous, but assumed that the addressee would understand the often difficult allusions. Both made use of the "You can be Sure of Shell" slogan.

Like the "Everywhere you go" posters, the first of these series was built on the concept of travel and of place names and played with place names while the other series was built on common colloquialisms and everyday expressions.

In the example in figure 8: 22 , the addressee is expected to make the association between the name of the town, Stockport, and of keeping port; in other words, to expand the name of the town into the admonition to "Stock port wine in your cellar" but "Stock Shell in your garage". The company speaks directly to the addressee both in the familiar tone of the admonition and in the slogan.

\footnotetext{
${ }^{23}$ However, as Djafarova (2008) points out, the impact of the pun cannot be guaranteed and for example, today's audience might not understand the joke implicit in the pun as the concept of knocking has largely disappeared.

${ }^{24}$ Knocking, also known as pinking, occurs in spark-ignition internal combustion engines when the peak of the combustion process does not occur at the optimum moment for the four-stroke cycle, resulting in a noise.
} 


\section{Image removed due to copyright. Image removed due to copyright.}

In the example in figure 8:23, the company voice also addresses the reader directly. In this case, there is not only a play on words "cum/come" but the advertisement serves two functions. First, it is of course a means of bringing the product name to the public, but on a more particular level, it advises the public that winter is approaching and that the motorist "you" needs to change from Shell's summer products to those adapted to the winter climate. These winter products will be available from Monday.

These are only some of the advertisement series that pre-supposed that the reader shared a lifeworld and a wealth of cultural knowledge with Shell. For example, another cartoon-type series, "Some phrases seldom ring true" requires the reader to be able to see the incongruity between the visual and the written text in order to extract the humour (Steve Oswald, 2013). This series comprises cartoons created around common English sayings, as illustrated in the example in figure 8:24. These were published in different newspapers and some were also published in The Economist, for example during 1938.

The reassuring slogan at the bottom first catches the reader's attention. The voice of the company is in dialogue with the reader of the message and to whom the statement "Some phrases seldom ring true" is addressed. The cartoon in figure 8:24 exemplifies such a statement. The elderly couple who meet in the street greet each other with the words "Good Morning" although the reader can clearly see that it is pouring down and windy. The reader is asked to compare this state of affairs with the reliability of Shell and with the slogan that makes this claim. Another example is a very large charlady telling another, very thin one "You could have knocked me down with a feather" when a tank would have been have been better suited to the task.

An example from another "You can be Sure of Shell" series that illustrates the assumption that the reader shares the encyclopaedic knowledge of the speaker is provided in figure 8:25. This series, the "Times change" series celebrates thirty years of Shell and insists that it is still a company which can be relied upon. The advertisement uses the typical format or "grammar" of left for the old and right for the new. However, the participant roles in this series are interesting as the example illustrates. The text reads: 


\title{
Image removed due to copyright. Image removed due to copyright.
}

\begin{abstract}
"We must move with the times, you know ..." How often said, and how seldom acted upon! For over thirty years Shell has moved with the times, constantly adapting itself to the ever more exacting demands of motor engines. Shell progresses by steady evolution, and can justly claim to be the petrol of the past, the present, and the future."
\end{abstract}

The advertisement ends with the slogan "You can be sure of Shell."

First of all, the reader is enveloped into the embrace of the plural pronoun "we". Although Bakhtin (1981:337-338) has pointed out that what we say is filled with other people's words, reported speech or direct quotation incorporated into a speech is uncommon in advertisements. This form of polyphony, or what Susanne Günthner (1998:18) refers to as a "hybrid construction", brings the reader into the group of individuals who share the experience of hearing this platitude. However, in this context, the statement is not merely a platitude, but has a double resonance. The speaker is both echoing the oft heard words and also, as the voice of the company, expressing their business philosophy. The "we" is both the generalized "one" and the company. Similarly, "you" refers both to the general "one", the unspecified all of us together, and the participant addressee of the communicative event. The speaker then goes on to discuss Shell in the third person. Thus, Shell is both the "I", the real voice that is heard and is also what is being talked about, and the slogan at the bottom of the advertisement anchors it in the past while looking forward into the future. Shell is reliable and modern.

The slogan and the company name make clear to the reader that these examples are advertisements and not merely comic cartoons.

\section{British Petroleum}

Shell, however, were not alone and BP too advertised in a way which was similar if not as extensive. Like Shell, the company produced lorry bills encouraging travel, but I will focus on those advertisements that illustrate the more individual approaches of the company. B.P's advertisements, like those of Shell, assume a shared lifeworld with the reader. 
A recurring dialogical third party in the advertisements of both the companies is patriotism. Earlier in this chapter I shown how Shell tried to demonstrate its patriotism through its advertising, (figures 8:4, 5 and 6), initially as a means to encourage the government to get involved in the oil business and later as a response to BP's greater success in persuading the government how important this was. However, Shell's metaphorical approach to patriotism was not that practiced by BP who displayed a much more explicit and aggressive form of patriotism in their early advertisements as the examples in figures 8: 26 and 8:27 show.

\section{Image removed due to copyright. Image removed due to copyright.}

\section{Figure 8:26 BP as the centre of the Union Jack}

The example shown in figure 8:26 is a "minimal message advertisement" (Nöth, 1987: 284). It is simply comprises a Union Jack with the company name and the product that is advertised in the centre. The initials of the company, British Petroleum, thereby become an integral element of the flag, and the company name and the national flag become linked as one.

\section{Figure 8:27 Every county}

The example in figure 8:27 is one of the early BP postcards that shows how BP, the "British Petrol" is a national enterprise and that BP is "The Can that Serves every County." Lines go from the can even to the remotest parts of England, Scotland and Wales to illustrate this point.

However, other advertisements were less blatantly patriotic, and series such as the BP Proverbs series which appeared in the press, rely heavily on cultural knowledge.

The headline of the advertisements in this series hails the reader with a well-known proverb or saying. An interpretation of the picture is then provided by the proverb, which in one sense, can be said to illustrate the meaning of the drawing. This is then made more explicit by a brief explanation of the drawing and proverb and of how these relate to BP.

The visual in the proverb shown in figure 8:28, "The proof of the pudding is in the eating" dating from 1928 for publication in general newspapers, is a young couple sitting on the running board of their car with a picnic spread on a make-shift table in front of them. The table is constructed from a piece of wood placed on two BP cans This statement is followed up with a recycling of the proverb "The proof of the petrol is in the using" and then the words: "Fill up with BP, the spirit that is always up to proof," and the reader is given a contact address for the company at the bottom of the advertisement. 


\section{Image removed due to copyright.}

\section{Figure 8:28 The proof of the pudding}

Other advertisements from BP are different series for BP Ethyl. In one of these, the "snappy engines" series, the scene presented in each advertisement is a conversation in which the reader participates as an eavesdropper. The agents or actant participants in the scenes that are enacted all feature members of the upper classes discussing issues connected to motoring.

One such example features two gentlemen and a horse (figure 8:29). Only the heads of the two speakers appear in the drawing that accompanies the dialogue. To the left, is a gentleman wearing a top hat, standing by his horse's head looking up at the addressee who is in the top right hand corner of the page, and who is in the process of lighting a cigarette, then an attribute of sophistication. The initiator of the dialogue comments to the addressed participant: "Not late at the meet for once", implying that this is the usual situation. These words are in the top left of the page, in the position associated with what is generally know, or given, thus underlining common nature of the situation. However, the addressee replies, with his gaze fixed on the first speaker, "No - I've found that my sports car does better on 'BP' Ethyl". The casual style of the addressee and the nature of his reply together with his apparent habit of attending hunting meets imply his social wealth and position. The reader participates only as an eavesdropper.

An interesting feature of this series is that the salient aspects of these advertisements are the words "BP Ethyl for Snappy Engines" at the bottom of the page, and the tableaux of a leisurely, upper class lifestyle. The text that accompanies these advertisements is much smaller and is the repeated throughout the series and reads: " $\mathrm{BP}$ ' Ethyl is specially prepared for high compression engines. No livelier petrol can be obtained from any pump. The special dopes used for speed records are both unobtainable and unsuitable for ordinary motoring."

This text is addressed to the reader and represents the voice of the company, and not only provides information, but pre- empts questions. The passive constructions lend distance and authority to this voice. It is also interesting to note how the petrol has been given the qualities of a living creature; it is "lively," an adjective that resonates with the notion of energy and sprightliness and is commonly used to describe children and horses. Moreover, the reader is assumed to understand the concept of a high compression engine and that such engines are 
desirable. However, what is perhaps most interesting today is the third and last sentence. There are no negative associations with the word "dopes" and the implication of this statement is that motorists generally wish to be able to drive quickly and to use the specially engineered products that break speed records, and thus the company finds it necessary to point out that the every-day motorist cannot buy these products and that they are not recommended. This makes an interesting comparison with the situation that I described in the Shell advertisement from 1906 in figure 8:1.

\section{Image removed due to copyright. Image removed due to copyright.}

The British companies made great use of current events as well as of record-breaking pioneers, who explicitly or implicitly lent their names to their products in their pre-war advertisements. The example in figure 8:30 is one of a series which is based on the concept and format of removing the initial letters $\mathrm{B}$ and $\mathrm{P}$ for the reader to add and by so doing, construct meaning. Among the events that were used for advertising purposes was the 1935 Derby. The example shown here (figure 8:30) provides a particularly interesting example that demonstrates how BP used current events to further its marketing and to show its strong connection with things of national interest. "Ahram Erhaps but BP ethyl - a cert" requires the reader to understand that "Barham", is a horse, entered for the Derby by the Aga Khan will "perhaps" win the race. However, you can be certain of BP Ethyl; it is "a cert". Another example read "Banish Pinking" when it was completed. The choice of the verb "banish" is also significant as it is has strong associations, often related to individuals who have been forced into exile. However, not only does "banish" imply that someone, or in this case, "pinking" is forced unwillingly, to leave forever, but it also allows BP to allow the company initials to stand for a quality claimed for one of its products. Yet another advertisement created the expression "Best Possible". These advertisements involve the reader actively engaging in meaning-making, in a dialogical process (Ted Cohen 1978) while Farough Abel (1994) has suggested that the interactiveness required to interpret such types of advertisements is conducive to recall.

However, BP also used lorry bills, as figures 8: 31 and 8:32 for BP Ethyl show. 
Figure 8:31 is interesting because of the horse motif. Firstly, it employs the idea of a "double horse" like Shell. Secondly, the stylized horses and riders, one looking forward and the other backwards, ressemble some sort of ancient pottery design and thirdly, the horse and rider figures are placed in a black saddle-shaped area in the centre of the advertisement.

The textual elements of the advertisement follow the shape of the saddle. Horses are common participants in the advertising of both companies and feature in different ways in a number of $\mathrm{BP}$ advertisements as figures 8:29 and 30 illustrate.

Image removed due to copyright. Image removed due to copyright.

Figure 8:31 stylized horses

Figure 8:32 peacock a little something

The advertisement shown in figure 8:32 "BP Plus a little something others haven't got" makes an interesting comparison to a Shell series. In this lorry bill, a peacock displays his magnificent plumage; something the other birds do not have to illustrate the way in which BP is better than other petrols.

\section{Image removed due to copyright.}

Figure 8: 33 Important little differences from little points of difference from all other
However, a Shell series from 1929, which also aimed to advertise the superiority of a product, took a different approach. Entitled "Important little differences," the series, which was created "for insertion in general newspapers", and was therefore generally available to the public, explains the technical advantages of Shell petrol, such as its anti-knocking chemicals and easy starting, and describe these characteristics as the "important little differences" that make Shell superior. These advertisements illustrate the "little differences" that make Shell superior by comparing petrol with women as figure 8:33 shows.

Two men, Clodpate and Motorist are the scripted, but unrepresented actants discussing petrol. To Clodpate's assertion that petrols are all the same, Motorist answers that petrols "differ as widely as one girl from another" and then goes on to explain that "[b]eauty is no more than little differences of face and figure, just as the supremacy of Shell results petrols." 
The actants portrayed in the advertisement are an elegant, slim, young society woman, a clutch bag clasped under her left arm and waving her handkerchief and a second woman, dressed and posing in exactly the same way, but who is twice as big. The other advertisements in the series also use what Shell considers to be flaws of feminine beauty to symbolise the inferior petrol of other companies. While BP claims that it has "extra", Shell suggests that its competitors have less.

\section{The impact of World War II on the advertising of oil}

\section{Image removed due to copyright.}

The Second World War had a major effect on the advertising of the oil companies. Shell's final campaign before its outbreak, the "Fore" series by Thomas Derrick, which ran in 1939 was short, and in the words of David Bernstein (1983:13), "pregnant with meaning" and filled with foreboding.

The series in question was not very extensive. Although it made use of wordplay, the humour that was evidenced was black and the series seems to acknowledge the inevitability of war. Sitting together on the sofa, the ladies are foretelling what is to come (figure 8: 34 ). The other advertisements in the series depict a soldier and a woman at her mangle. The title of the former is "Forearm" punning on the concept of preparing for war and the lower part of the arm, and "Foreclose", a legal term that means to try to recover what has been lost though an unpaid loan. The mangle of course, is "for clothes" and is a heavy piece of machinery used for sheets and items of clothing and by association, a tank for flattening towns and countries.

\section{Figure 8: 34 Foretelling}

The war brought rationing and in Britain, there was no advertising, a situation that endured until the 1950s. Branded petrol became available again in 1952, and prior to this, Shell in particular, ran a number of advertisements proclaiming that "Shell Day is coming", playing on the notion of D-Day, or "That's rationing ... that was!" based on the two-headed series. In the U.S.A. the situation was quite different and petrol rationing was lifted directly after Japan's capitulation in September 1945.

In Britain, after 1953, when petrol tankers began to transport oil and petroleum, posters and lorry bills became a thing of the past and the companies' advertising experienced a renewal.

\section{The Golden Age of Oil}

If the first fifty years with oil can be considered an age of innocence, where people revelled in the new-found freedom that oil and its derivatives enabled, the end of the war saw an explosion in the demand and desire for oil and oil-based products.

The next examples that are analysed in this chapter appeared as full page, monochrome advertisements in The Economist in 1958. Whereas almost all the earlier advertising on the part of the oil companies had appeared in specialist magazines and in the general press, their advertising in The Economist increased significantly in the 50s when full page advertisements appeared instead of the small ads of the pre-war years. Another interesting development was 
that the companies on either side of the Atlantic began to place advertisements in each other's more prestigious periodicals.

\section{Caltex, partners in progress}

Not only did Shell and BP resume their advertising, but American companies also began to announce their presence and in 1958, Caltex, the California Texas Oil Company, a joint venture between The Texas Company and Standard Oil of California, which became Chevron, also advertised in The Economist in 1958. They placed a total of thirteen advertisements with six different motifs in a series called "International Panorama of Progress" The example in figure 8:35 appeared three times.

The advertisements followed the same format. The upper two thirds of the page comprised a drawing circumscribed by an irregular frame with part of the drawing protruding from this frame to add perspective. In this way, a sense of dynamic is given to the drawings as one element seems to be leaving the restricting frame, progressing from the past into the future. The lower part of each page is divided into three columns and the first of these is filled with two circular shapes; one a globe and next to it, a circle with the CALTEX logo, a five-pointed star with the company name written through it. Below are the words Petroleum Products. The specific heading or title of each advertisement is written across the two columns of text which are written as one paragraph. Another interesting common feature of the advertisements in this series is that a five-pointed star is used as a form of punctuation to replace the full-stop. Further shared features of these six advertisements are that all but one use the expression "Through the power of petroleum", and each advertisement ends by stating that Caltex is the "partner in progress" in "over 70 countries in Europe, Asia, Australia and New Zealand."

The visual in figure 8:35 shows a flat country road running towards the reader but with a slight angle towards the left, and with different types of vegetation growing to the right and in

Image removed due to copyright.

Figure 8: 35 International Panorama of Progress the background, to the left of the drawing, fields with trees running alongside. A camel is walking out of the drawing, his head held high and angled to the left away from the reader. It is pulling a cart piled high with bundles of what seems to be some sort of hay. It is being driven by a white-bearded man in a turban, and high up on top of the load sits a younger man, also wearing a turban, looking backwards towards the right, into the future, at the load that follows drawn by a modern car. In the background going in the opposite direction but towards the right is a vehicle with the Caltex symbol on the back.

The text opens with a direct reference to the visual, anchoring it:

"Ancient and modern transportation, travelling along the same road, present a vivid and, at the same time, curiously appropriate contrast. This meeting of the past and present symbolizes the rapid advance in many parts of the worlds from slow, laborious methods of hauling goods and equipment to swift, up-to-date means of 
transport. Power once supplied by beasts of burden is steadily being supplanted by the more efficient power of petroleum."

Caltex is "bringing to the peoples of many nations a new prosperity, a new era of comfort and convenience" and is "participating in the present and planning for the future in over 70 countries." The company insists on the international nature of its work and the choice of the word "peoples" underlines the global and culture-transcending scope of their operations. The company insists that as a result of their presence and partnership, the future will be one of prosperity for more people.

\section{The World of BP}

BP advertised quite extensively in The Economist during 1958 with both a series entitled "BP maps the Future" and with a number of individual advertisements. These latter generally imitated the form of a popular newspaper lay-out and presented "BP news" and include a long piece about the successful record attempt by Donald Campbell ${ }^{25}$ who had used BP products in his Bluebird. A more typical example is the launching of the new Clydebank tanker, "The British Duchess" the first 42,000-ton tanker ever built by a British firm for a British fleet, by H.R.H. the Duchess of Gloucester and proclaims her as "second only to the Queen Mary". The advertisement goes on to explain that BP "plans far bigger ships than this" and that building is already underway or on order for among others, six sister ships to the British Duchess, 12 50,000-ton vessels and "7 giants of 65,000 tons." This is because "[w]ithin the next 10 years Britain may have to double her oil supplies. The British Petroleum Company is making sure that not only is the oil found and brought to the surface and refined, but that there are ships to carry it. Ships like the British Duchess are even further proof of how confidently BP plans for the future." This advertisement demonstrates not only how the company sees itself as a central actor in the future and prosperity of Britain, but also the conviction that oil is the key to this prosperity and well-being; a conviction that was generally held by most European governments who, as one of the results of the war, were all dependent upon the U.S.A for their supplies.

The importance of oil to the prosperity and well-being of Britain and the Commonwealth permeates all of the company's advertisements and is clearly shown in the "BP maps the Future" series and the ways in which BP is working to provide more oil is explained. Typically, these advertisements show a globe and the geographical position of the phenomenon about which the company is talking is indicated. The globe reinforces the title of the series that appears in a banner in the top right of each visual and supports its double meaning; to map out the future, to show its direction and to draw a map of the different places where oil and BP will lead to a new and better future.

Among these advertisements, is one which explains how thanks to BP and its new Kwinana Refinery, a new township is "springing up" in West Australia with a fine new school for the children of all the staff. The choice of the verb "to spring" is significant as it echoes both the town "Alice Springs" ${ }^{26}$ and also refers to the notion of a fountain or spring bringing wealth

\footnotetext{
${ }^{25}$ Donald Campbell broke a number of speed records on land and on water. He died in 1967 during another water record attempt on Lake Coniston.

${ }^{26}$ Neville Shute's popular novel, A Town Like Alice which had been published in 1950, centres on turning a small, outback community into a prosperous community like Alice Springs. This is what BP claim to be doing in the West Australian bush.
} 
and prosperity to the township, Medina ${ }^{27}$ that has "risen amid the gum trees and casuarinas of the Australian bush".

\section{Image removed due to copyright.}

\section{8:36 BP Maps the Future} the globe, from Canada through Europe to Asia, to New Zealand.

The example shown in figure 8:36, takes issue with the need to double oil supplies over the next ten years that was also raised with the launching of the new tanker. The advertisement shows an underwater drilling barge that will "shortly be at work for BP in the Persian Gulf 80 miles from the Arabian mainland" and the reader is informed that the platform has retractable legs so that it can be towed and that there is also a landing platform for helicopters. The text states:

\begin{abstract}
"TODAY THE WORLD is using twice as much oil as in 1946. So far, production has kept pace with demand. At its expected rate of increase, by 1966 demand may well have doubled again. What is being done to meet this situation? The answer is that exploration in known and suspected oil-bearing areas is proceeding on a colossal scale. In this world-wide operation the BP Group of Companies and its Associates are engaged, in some twenty countries, at an investment cost running into millions of pounds.
\end{abstract}

BP is also increasing the capacity of its fourteen refineries; adding new vessels to its 2,000,000 ton tanker fleet; Figure In 1946 the world used some twenty million tons of BP products; in 1956 fifty-three million.

The ever-increasing demand for oil must be met: no organisation in the world is working harder to meet it than the British Petroleum Company."

The advertisements that BP published during this period typically stress the importance of oil supplies and how oil can be equated with well-being and prosperity everywhere in the Commonwealth. Moreover, they show an unequivocal belief that demand will increase and that they will be there to meet it.

\title{
"I'll tell you something else about Shell"
}

Shell advertised extensively during 1958 and published two series in The Economist that year that concerned Shell chemicals as well as a few single advertisements, most of which used the "You can be Sure of Shell" slogan.

One of these series appeared at approximately two-monthly intervals while the second appeared every month. In both cases, new advertisements were produced on each occasion and five advertisements from the first series were published and thirteen advertisements ${ }^{28}$ were published from the second series.

\footnotetext{
${ }^{27}$ Medina is, of course, an important city in Saudi Arabia, one of the most important suppliers of crude oil. Just as oil brought wealth to the Arabian desert, so will oil bring prosperity to this new township in the Bush.

${ }^{28}$ One advertisement, the only one with Britain and England as its locus, appeared twice and concerned how Shell Chemicals were helping British farmers to ensure food supplies. As food rationing had only gradually been phased out after the war, it is perhaps not surprising that secure food supplies, as well as secure oil supplies, were considered to be a matter of some importance.
} 
The first of these series is the "I'll tell you something else about Shell" the "gossip" series which I introduced in Chapter 3 (figure 3:6) and where I discussed the complexity of the participant roles. Here, I my focus is the textual frame and on the actual content of the advertisement. Typically, the advertisements in the series involve two individuals who are portrayed as being in the middle of a conversation. The characters portrayed in the series are representatives of a number of respected professions or life styles, and therefore their testimony to the work and accomplishments of Shell carry weight and authority, or "the weight to impose reception" (Bourdieu, 1972: 648). Each advertisement in the series opens with the words "I'll tell you something else about Shell ..." and ends with a statement about the importance and ubiquity of Shell Chemicals. The advertisements in the series are all staged in different "worlds" (Schutz) and these multiple realities underline the relevance and the ubiquity of Shell.

In figure 8:37 the characters are two city gentlemen at a bus stop, with furled umbrellas, briefcases, and in one case, a bowler hat. These are iconic representations of good business sense and respectability.

The text of the advertisement reads:

"Forget petrol for a moment and think of plastics ... there's an industry that's really gone places in the past few years. Many plastics products start life as something-from-petroleum in one of Shell's chemical plants - Shell Chemicals supply base ingredients in bulk. They're already making plastic materials in useful quantities. Now they are starting production of this new high-density polyethylene we've been hearing about - and that'll stir up some new ideas in domestic and industrial equipment! The plastics industry is forging ahead and it's people like Shell, with their important in plastics vast knowledge of organic chemistry, who will be producing the "goods to make goods".

I'll tell you something else about Shell ...

\section{Image removed due to copyright.}

The advertisements in this series are particularly interesting from the perspective of audience design and participant roles as they provide a very clear case of "divided illocution" (Alwin Fill, 1986) or citing Wunderlich, "multiple addressed utterances" (ibid: 28).

The semiotic structure of the pages develops the complexity and ambiguity of the split audience of the participation framework. Implicitly, the anaphoric "I'll tell you something else" conveys that the two active participants were discussing different aspects of Shell when we happened upon them, and that what is now to be said is perhaps not common knowledge; that we are about to receive insider information.

The "tellability" (Sacks, 1992, cited in Geert Jacobs: 1998:517) of the information being conveyed is illustrated and underlined for example by the words of the speaker or "informer". In another of the advertisements in the series, the informer declares "I'm told that of all the industries in Britain, the Figure 8:37 I'll tell you something else about Shell... production of petroleum chemicals is 
expanding at the greatest rate...." showing that he himself is repeating information that he has been told by somebody else. In the example illustrated here, we are instructed to forget what we know about Shell, namely petrol, and to think of plastics. The language of the speech is educated but chatty with short forms and colloquialisms, such as "this new high-density polyethylene" and "that'll stir up". Moreover, it is quite disjointed to represent natural language. Unlike the multiple voices of figure 3: 6, this advertisement has only one speaker who explains with the words of a lay-man rather than a professional (David Danow 1991) what Shell is doing.

To use Althusser's terminology, the headline "I'll tell you something else about Shell ...", 'hails' the reader, who is immediately drawn into the action and given the ambiguous dual role both of addressee and also as some sort of "overhearer".

This shifts the perspective of the reader who becomes an actant in the drama that is unfolding before him. Here, I am using the term "overhearer" in the sense given by Clark and Carlson (1982:346) who distinguish participants from overhearers on the basis of their presence in the previous exchange. The parts of the advertisement that stand out consist of the hailing at the top of the page and as a pay-off, a "new" fact about Shell Chemicals at the bottom. In this case, it is the fact that Shell Chemicals are important in plastics. ${ }^{29}$

These two components frame the picture and explanatory text or copy, and are written in a larger, bold font. The words Shell Chemicals are capitalized, and this feature of the typography combined with the verb which follows, endows the name with the status of an independent, active personality. The use of different font sizes for the different elements of the sentence foreground different aspects of the message, and in this series, what is foregrounded is implicitly that Shell is much more than just a petroleum company, and explicitly that Shell is a pioneer in the field of chemicals. The talk, or mini- lectures, of the different informants of the series merely provide an example of this important fact and is therefore presented in a smaller font. This is in line with the observations made for example by Stöckl (2005:211), that in standard advertising typography, the "different parts of the text are usually clearly marked off from one another."

Another interesting feature of the design is here is that the pay-off section is centred on two lines, a little right of centre, starting just under the foot of the listening businessman. He stands cross legged, with his right foot in front of the left, pointing at the words "Shell Chemicals" and drawing attention to them. The bus stop is also angled to create a vector that directs our attention to the pay-off and helps to frame the fact that Shell Chemicals are important in plastics. Another interesting feature of the page design is that the advertisement is not framed, which enables it to extend beyond the confines of the page to encompass and include the reader/actant who experiences the advertisement from a bird's eye perspective. Therefore on one level, the reader is hailed as the addressee of the message and at the same time is cast both as an overhearer and as the on-looker to a mini-drama being staged by the company for his benefit. This open design is common to all the advertisements in the series.

If we analyse the advertisement from a dialogical perspective, we find that three aspects of dialogism are particularly relevant. These are the notions of Relationism, Voice and Bakhtin's "living tripartite unity," or what Linell (2009:89) refers to as Semiotic Triad. What Linell

\footnotetext{
${ }^{29}$ The new facts that are presented in the other advertisements in the series are: Shell Chemicals are helping to build; Shell Chemicals are important to the young generation; Shell Chemicals are everywhere in the home; Shell Chemicals aid agricultural development.
} 
refers to as the Pragmatic Triad (Linell 2009:90) is formed by the I-you-it of Shell the organization, 'I'is the speaker at the bus stop, 'you' is both the reader and the other man at the bus stop while 'it' encompasses Shell the company, Shell Chemicals, Shell plastics and the opportunities that these bring. The opening words are relational. The speaking, "I", the "informant", not only directs his utterance to his companion, the "represented participant" at the bus stop, the addressee, "you", the but also to the "you" of the reader, the invisible "overhearer" or "interactive participant" (Kress \& van Leuween, 1996:179) who at the same time, is the intended recipient of the message to be communicated. The opening words also situate the utterance in relation to a context. The presupposition, which is that the men have been talking about Shell, triggers the notion of the newsworthiness and "tellability" of Shell. The socio-historical context is also present as a third party in the discourse and in the visual. The 'I' and 'you' who have been hearing about Shell's new products merge into a 'we' which incorporates both the participants and the overhearing reader as well as the general public.

The voice speaking, the embodied voice, is ostensibly that of one of the men in the illustration, but is also a generalised voice or perspective (Linell, 2009: 116) and the voice of the company This polytonality, or multiplicity of voices at the same time, is visually represented by the different typographical styles used and is emphasised by the closing statement. This is an example of what Bakhtin referred to as heteroglossia, a different style, foregrounded by the bold font. The "it" of the Pragmatic Triad include the plastics industry and Shell, who are referred to as "they" and "people like Shell" ... with their vast knowledge of organic chemistry".

The Situational Triad, "Now-Here-I", (ibid: 92) includes the two men talking at a bus stop, current general knowledge about plastics and the idea that this is just the beginning of a new era. The deictic references in the discourse further help to anchor and contextualize the situation. This triad provides the coordinates that we need to assign a situated interpretation to the text, and the addressee that complements it comprises both the addressed participant and the overhearing reader.

The more abstract, third triad, the "Word-Concept-Referent" uses language as well as the semiotic representation provided by the picture, to stimulate cognition and interpretation and involves the concept of double dialogicality. As we enter the exchange as overhearers, we are unaware of the content of the previous utterances and thus have to interpret and draw inferences from the information that is available. As the two men are standing by a bus stop and as buses are commonly known to run on petroleum, one inference is that Shell is providing the fuel for the public transport system. The language used by the informant is familiar but authoritative, and consists of what Clark \& Carlson (1982) refer to as "informatives". Beginning with an imperative statement, the informant praises the success and progress of the industry to develop reasons why the addressee should think of plastics. This leads to a factual statement about the origins of plastic products and of Shell's involvement in this process. It is interesting to note how the references to Shell vary, from Shell as "they" to "people like Shell". The implication that "we" the participant addressee, the reader and the general public are all aware of the new development and importance of "this high-density polyethylene" is emphasized by the deictic "this". The lexical choice, "forging ahead," is also significant as it stresses the way in which Shell is pushing on vigorously, fighting any objects in its path in order to reach its goal.

Another aspect of the advertisements in this series is that they implicitly suggest that Shell is a good business opportunity, and that in this way, the reader too can become a part of this successful company that is helping to improve living standards. The reader is offered the 
possibility to communicate easily and directly with the company as the address and telephone number both provided at the bottom of the page. Thus, the reader is addressed on one level through the actant speaker who is also the ventriloquist's dummy of the company, and at the same time is being given the possibility to become an actant in his own right.

\title{
Shell and the dragon
}

Another very interesting series of advertisements from the same period was for different forms of chemical pesticides, insecticides and fertilizers. These advertisements are set in different countries and on different continents and all follow the same polyphonic format. This series adds yet another dimension to the notion of speaking voice and I will refer to this role here as the narrator. By this, I mean a voice that is positioned within the frame of the advertisement and which narrates a story about the company and its accomplishments. In this series, which I will call the "Shell ${ }^{30}$ and the Dragon " series, the reader is cast into the role of narratee, or following Hillis Miller's classification of the minimal personages necessary for a narrative, the "witness who learns" (in Lentricchia \& McClaughlin, 1995:75). Each advertisement has a title which connects to the story that the advertisement narrates. The example that I will discuss, just like the one above, is for aldrin and appeared in The Economist in December 1958. The "dragon" which the crusading company must slay takes the form of different pests and insects and is always shown as a visual element of the advertisement and is always depicted in a frame to connote how the work of Shell is removing it from the world. Moreover, it is proportionately much larger than its surroundings.

\section{Image removed due to copyright.}

Figure 8:38 Part of a small miracle sense of wistful longing for a better, far-way world. The world that Shell constructs is a world ${ }^{30}$ I consider that Shell cast themselves in the role of St. George, fighting different "dragons" for the good of
Britain and mankind.
${ }^{31}$ See, for example, McQuarrie \& Mick (2003) on the impact of poetics in general and metaphor in particular, in
advertising or Zinkhan (1994) and Stern et al (1998) for discussions of the role of poetics in persuasion. ${ }^{30}$ I consider that Shell cast themselves in the role of St. George, fighting different "dragons" for the good of
Britain and mankind.
${ }^{31}$ See, for example, McQuarrie \& Mick (2003) on the impact of poetics in general and metaphor in particular, in
advertising or Zinkhan (1994) and Stern et al (1998) for discussions of the role of poetics in persuasion. ${ }^{30}$ I consider that Shell cast themselves in the role of St. George, fighting different "dragons" for the good of
Britain and mankind.
${ }^{31}$ See, for example, McQuarrie \& Mick (2003) on the impact of poetics in general and metaphor in particular, in
advertising or Zinkhan (1994) and Stern et al (1998) for discussions of the role of poetics in persuasion. ${ }^{30}$ I consider that Shell cast themselves in the role of St. George, fighting different "dragons" for the good of
Britain and mankind.
${ }^{31}$ See, for example, McQuarrie \& Mick (2003) on the impact of poetics in general and metaphor in particular, in
advertising or Zinkhan (1994) and Stern et al (1998) for discussions of the role of poetics in persuasion.

The advertisements in this series all follow the same structure and this structure clearly fulfills what Hillis Miller claims are the basic demands of any narrative. After the title, which in the example that I will describe is "Small part of a miracle," (figure 8:38), the poetic narrator opens with a description that draws the reader into a world of romantic beauty; a "Once upon a time" sequence. This is the initial situation.

\begin{abstract}
"Pink snowflakes, floating from the wind-stirred cherry tree: willow fingers wet with spring rains noisy on bright umbrellas. A landscape washed with soft and glowing colour, of new leaf and flower and bud. Spring in Japan - a time for loveliness."
\end{abstract}

For Burke, language is symbolic action and its poetic use is therefore grounded in purpose. As Jerome Bruner (2004:695) points out, "language constructs what it narrates, not only semantically but also pragmatically and stylistically" and the alliterations, rhythms and metaphors ${ }^{31}$ of the opening sequence introduce the reader to a fairy tale world of beauty and harmony, and induce a 
of "Once upon a Time" an idealized situation, and is a necessary contrast to the element of menace that the first story-teller then introduces: "And for the farmer, worry". The villain is about to be introduced into the fairy tale with a mixture of alliteration and the repetition of the word "awakening", first as a positive adjective and then, at the end of the sentence and section, as a verb filled with foreboding.

"And for the farmer, worry. For in the awakening world, pests both below and above soil are also awakening."

The dragon, the villain of the tale, in this case, the onion fly, is then introduced, abruptly breaking and reversing the dream-like quality of the opening sequence. A second, more factual narrative voice then introduces the geographical context and explains the background to the problem. Typically, this second narrator participant provides figures which emphasize the importance of the staving off potential attack and for destroying the enemy and which add weight and authority to his contribution.

"In Japan, rocky and mountainous and desperately short of arable land, some 90 million people are crammed into only 142,800 square miles - of which under $20 \%$ will bear crops.

Yet, despite often violent climatic conditions and a not naturally very fertile soil, Japanese farmers manage, by some of the most intensive cultivation in the world, to provide from 80 to $85 \%$ of the nation's food supply - a miracle of production calling for immense efforts of care and attention and protection against loss. For every ounce of food is priceless."

A third narrative voice, the biologist, provides expert information about the villain, and names it. Its methods of attacking the innocent plants and its life cycle are then described. As Propp (1968) has shown, the dramatis personae of the classic folktale fulfill a function in the plot, but do not drive it, or as Amelie Rorty has argued, (in Bruner 2004) agency is given to figures rather than to characters.

"Among pests which attack the vegetable crops on the terraced hillsides, the onion fly (Hylemyia antiqua Meig.) - which also attacks leeks and shallots - is of considerable importance, not only because of the severe damage it causes but because of its rapid breeding cycle. Eggs laid on Sunday will by Wednesday be larvae which will feed, destructively, on the crop for three weeks before pupating. Seventeen days later a new generation of adult flies will be on the wing."

This voice is then substituted by a fourth narrative voice, that of the Shell spokesman, that tells the poor suffering victims what arms they need to obtain to fight the villain and provides detailed instructions for how to destroy its powers. In this sequence of reversal, Shell is the hero that will come to their rescue and restore peace and prosperity to the blighted land, overturning evil and allowing life to revert to normal. One interesting aspect of the position taken by this voice is that it extends the benefits of the products to far beyond the borders of the focal, fairy tale land, and that the alternative measurement systems given greatly enlarges the cast of potential addressees.

"To control this prolific pest, known in many countries, farmers in Japan are now employing the same sure remedies as those who crop vaster fields in other lands: aldrin and dieldrin, the powerful insecticides developed by Shell. Aldrin, either as dust or spray, broadcast before planting at 2-3 lbs. per acre (2.2-3.3kg. per hectare) or used as a row treatment during growth using $1 / 2-1 \mathrm{lb}$. per acre $(0.6-1 \mathrm{~kg}$. per hectare), will give effective and lasting control."

A final, fifth narrative voice then reverts to the more poetic language of the opening of the narration to end on a rallying, rhetorical note. Often, this connects directly to the title of the story, but in the example described above, requires a little more thought on the part of the reader who must interpret the miracle as Japan's agricultural success. 
And not only of the ubiquitous onion fly, but of many other threatening pests of the soil. In any language, aldrin means destruction - to those which themselves seek to destroy."

This voice of "they all lived happily ever after" uses a "form" (Levinson 1988) which is much more emotive than the informative preceding section. The global nature of the product is again implied by the comment that "aldrin means destruction" in any language, and the recycling of the notion of destruction first as a noun and then as a verb in positions of emphasis as the last words of the two final clauses, leaves the narratee with a very strong impression of the effectiveness of the product. Contact information is then provided in the base-line.; an unadulterated company voice. This is where the needy can go to retain the services of the hero who can help rid them of their own particular dragons.

Thus, although the series might at first appear to be quite simple, a closer reading of the advertising text shows a polyphonic text with six different participant voices all playing a different role in communicating the message and each representing a different facet of the Shell company Ego. These range from the poet who awakes empathy, to the practical, instructive voice of the company spokesman. Moreover, the two images presented in the advertisement reflect different voices and serve different purposes: to illustrate the "Once upon a time," and to portray the villain. The advertisement too is formulated as a cleverly constructed narrative with all the ingredients of a folktale in which Shell participates in two roles; both with the agency of the dragon-slaying and objectified as the magic potion that will rid the fairy tale world of its pests and bring about the happy ending. Shell is both an actant providing the weapons, and is the "Other" around which much of the drama develops and is also the topic of discussion.

\section{Shell in America}

Shell produced a series that was published in Scientific American that same year. Although this series too is for Shell Chemicals, the advertisements of which it comprises are very different in both style and content to those intended for the British or European readers. These differences are evident not only in the fact that the American advertisements are in full colour, but also in the way in which Shell presents itself and altercasts its audience.

In the first example, (figure8:39) the Shell Ego is projected by means of a tableau that is representative of a romanticized, American macho life-style. ${ }^{32}$ The heading and the image create a pun that is based on the notion of brand in an advertising and business context and as part of the work of the cowboy in the image. This is reinforced by the positioning of the Shell logo on a flayed cow hide ${ }^{33}$. The second example (figure 8:40) also projects Shell as a hero, fighting the "crimes" committed by insects and pests of the soil.

The advertisements feature no speaking agent, but like the Shell and the Dragon series, the company voice is projected through a narrator. In one example, the narrator is a voice that knows and understands the reader, "( $t$ )he man with a taste for thick, juicy steaks - or the rancher [whose] brand and reputation" depend on the quality of the cows he "ships to market." He then explains to the reader how Shell chemicals are providing fertilizers to improve the growth of the grass and clover that the cattle eat and consequently, the fattening

\footnotetext{
${ }^{32}$ See for example O’Barr (2006) or Høngmark Knudsen (2012) for what constitutes the masculine and macho.

${ }^{33}$ As has been suggested by for example, W.D. Redfern (1982) McQuarrie \& Mick (1992), Abel (1994) James Leigh, (1994), and Djafarova (2008) appreciation and understanding of a play on words increases both reader attention and retention of the advertising message. Bonhomme \& Lugrin (2008) have suggested that visual tropes not only contribute to pleasure but also make concepts more concrete which can result in better retention.
} 
of the cattle. This speaker insists on the increased profitability that can be achieved by using these chemicals, suggesting that the reader is a rancher. However, the final paragraph reopens the addresseeship again with a direct address to the individual man who likes his steaks. "Next time you sink your teeth into an unusually tasty steak, remember that this may have come about because Shell helped Nature to do her job better." The text comes full circle in a kind of chiasmus. Shell is presented as friendly, knowledgeable, with a sense of humour and a deep understanding of what a rancher and a "real man" as represented by the life-style depicted in the image, wants and needs.

\section{Image removed due to copyright. Image removed due to copyright.}

The company logo, placed on a cow hide, moves into the frame of the advertisement to participate more actively as the company voice, and emphasizes the play on words which runs through the advertisement. In the informative statement at the bottom of the page the voice becomes less that of a soul-mate and more businesslike to proclaim that the Shell Chemical Corporation is "Chemical Partner of Industry and Agriculture".

The second example, (figure 8:40) from the same series is a parody ${ }^{34}$ of a stereotypical view of America shown in films. Again, there is a play on words which links the image of the robbers coming out of the soil and the recycled colloquialism of the heading, "Nips crime at the roots" instead of the standard form to "nip in the bud". Humour is achieved by the visual showing the criminal insects carrying away their roots rather than fruits of their crime and by the personification of the gangster insects. The masked leader of the gangsters is looking towards the reader, checking if they have been spotted. Again, a narrator explains what Shell is doing to help protect the crops, and introduces an interesting new participant role: "we" the nation. "For years, the insect underworld raided the nation's cornfields"... "our most valuable crop". Shell first projects itself as the new "policeman" guarding the nation's interests, and then as a humble servant:

\footnotetext{
${ }^{34}$ See for example Zinkhan (1994), who extended the concept of humour in advertising to include parody.
} 
"Protecting vital crops against the costly ravages of root-destroying soil insects is another of the many ways Shell Chemicals serves the farmer." Finally, the advertisement introduces Shell in its third participant role as the "Chemical Partner of Industry and Agriculture".

The participant role chosen by the company seems to be that of a partner helping to preserve "our" American way of life.

As these examples illustrate, the audience design (Allan Bell 1984) that Shell used for its American advertisements was very different to that intended for Britain and Europe. I will return to this in the following section.

\section{Mobil}

Before leaving the $1950 \mathrm{~s}$, one more advertising series deserves particular attention. The example shown in figure 8: 41 appeared in Scientific America and advertises the American company, Mobil. Not only do the advertisements in this series feature colour photographs but they are also double spreads, concepts which came to British print advertisements almost two decades later. The advertisements show how Mobil lubricating products help companies to become more efficient and thereby save money. The advertisements typically feature a colour photograph on the left and four smaller black and white photos showing different parts of the company's processes on the right and the work of the men photographed is explained in the texts below. In the example in figure 8:41, for example, the dramatic colour photo attracts our attention. We learn that thanks to Mobil's lubrication, 43,907 machine production hours have been saved over a three year period by the Rockwell Standard Corporation as Mobil helped them to cut downtime by over $36 \%$. The text under each photograph tells the reader how much money was saved by each of the processes illustrated

\section{Image removed due to copyright.}

. Figure 8:41 Mobil Correct Lubrication 
The advertisement ends with a slogan in the bottom tight corner: "Another reason You're Miles Ahead with Mobil!" This is a direct address to the reader which brings him into the group categorised as Mobil users. Moreover, the opening words of the slogan state that the information that the advertisement has just been imparted is yet another reason in an already known and probably extensive list. The combination of alliteration and assonance "Miles and Mobil" is typical of slogans (Leigh 1994) and supports retention. Shell made use of this with "You can be Sure of Shell" and Esso were to follow suit with "Put a Tiger in your Tank".

However, while in their advertisements, BP, for example, talk of the money they could save Britain, Mobil talk about the savings for individual companies. American Caltex advertising in The Economist explain how they are "partners in progress" all over the world and are working to improve the situation of different groups of people. While Shell's advertisements in The Economist discuss the benefits of its chemical industry for potential investors or job seekers in Britain and explain how they help to improve people's life styles and how their petrochemicals eradicate disease and pests in faraway countries, their American advertisements, like those of Mobil, focus much more on the advantages for individual users and on cost savings for individual farmers.

Differences in the ways that companies advertised in Britain and the United States are evident even in the decades that followed. However, before investigating these advertisements, let us take a look at the very special phenomenon of the Shell Valentine.

\section{Shell Valentines}

The extremely popular Shell Valentine series spans a period from 1938 to the 1970s and can be considered as an extension and development of the corporate gift first introduced by Gulf (Russell 2007) and contributed to the forging of a brand family that is discussed by Sherry (2005).

These cards expanded the role of the reader. Although it had become common for readers to actively interpret the puns and metaphors of the advertisements, this series required them to become complicit in the deception of the drama being performed, perform the role of the "Valentine" and to actively complete the text. This is a supreme example of the idea that communication is a creative activity in which both the sender and the recipient contribute to the resulting meaning, (Lindholm, 2007: 52).

The cards are designed in a traditional, romantic style with flowers and shells as motifs. The speaking voice, or agent, is that of the "lover" who professes his love through multiple references to his car and to the pleasures of motoring with the addressee who is cast in the role of the beloved who shares this passion. The Shell Valentines "recontextualize" traditional Valentine cards with humour, and puns, as well as intertextualities including allusions to Shell, its products and its previous advertisements, abound. The addressed reader is expected to understand and interpret these allusions and to finally complete the last line of the poem: "You can be sure of ..." to attribute Shell with the qualities of a steadfast and trusted lover.

The participant roles are therefore layered, the company joking with the addressee, playing the part of the lover, or the motorist who has succeeded in obtaining a Valentine and giving it to his beloved. In fact, Shell gave these cards away to customers. ${ }^{35}$ The recipient of the card has also a number of roles as on one level, he or she realizes that the card is an advertisement

\footnotetext{
${ }^{35}$ The Valentines were sent to lady customers and became so popular complaints were received from lady drivers who did not receive a card (BP Archives)
} 
and not a true declaration of love, but on another, is cast into the role of Valentine, and finally, has to complete the card.

In the example shown in figure 8:42 the actants or, following Burke (1945) the Agents, are Cupid, in the bottom left hand corner, who has been cast in the role of service station attendant, the spirit of the air with the oil can in the top right, and the lovers driving in the oldfashioned car towards Cupid who will provide them with the means to escape. The Scene is a romanticised country road along which the lovers are driving and the Purpose of the drama is to remind the public about Shell and its products as well as to create good-will for the company.

Disproportionately large Shells both frame the picture and dominate the foreground, and humour is added by the shells on the milestone by which Cupid is waiting ready to service the vehicle. Ribbon-bedecked hearts float like clouds above in the blue sky above

Ribbon-bedecked hearts float like clouds above in the blue sky above

The Valentine rhyme reads:

When cupid fills the petrol tank

And wipes the windscreen clear

We'll soon

my leap-year Valentine

Be far enough from here.

The road is straight, the signposts wait

\section{Image removed due to copyright.}

All garlanded with flowers

For winter gloom will soon be gone

And "better spirits" ours.

So fly with me and certain be, Should things go ill or well, I'm always at your service; for You can be sure of .....

Figure 8: 42 Shell Valentine

The concept of Shell Spirit from the 1910s is recycled in the rhyme as a word play on the better quality of Shell products and the notion that the lovers will feel happier when the winter gloom has gone.

\section{The years of turmoil}

After the wanton desire of the 1950s, followed the turmoil of the 1960s and 70s, characterized by increasing awareness about the dangers of pesticides, and when problems such as the Iraqi revolution, the rising tide of Arab nationalism and OPEC with the subsequent embargos, and a failing pound sterling made business operations extremely difficult for the companies. Moreover, despite massive new finds in Africa, wars broke out there leading to the disruption of supplies and to negative publicity for the oil industry. As a consequence of these circumstances, the European oil companies were very restricted and restrictive in their 
advertising and published mostly in general newspapers or in specialist magazines. ${ }^{36}$ Although advertising was not actually banned in Britain as it was in France, product advertisements were extremely rare and instead, Shell and BP advertised together as ShellMex and B.P. Ltd. These advertisements, like the ADWords series from the 60s which appeared in newspapers demonstrate how the companies are helping Britain.

The first example of the ADWords (figure 8: 43) depicts a scene where two actants are leaning over a bridge. The first speaker, to the left, states that "Shell-Mex and B.P.Ltd. are the main suppliers of oil, fuel and lubricants for both the Forth Bridge and the New Severn Bridge." The other man responds with the quip "No wonder it's called contract bridge", punning on the concept of work contracts and on the card game. In the second example (figure 8:44), the farmer driving his tractor across the word farming" asks "How you gonna keep them fuelled on the farm?" and the supplier's representative tells him: "Whatever you can use, we can supply it faster" and goes on to say how "farmers glow with bucolic pleasure when they think of the service they get". It is significant that the advertisement is not for pesticides but that instead, it echoes the advertisements of 1958 where the companies talked about securing food supplies for the nation.

\section{Image removed due to copyright. Image removed due to copyright.}

The joint Shell-Mex \& BP Ltd joint logo features in these advertisements.

Another joint campaign from the two companies was from the end of the 1960s and again, the advertisements explained how they were helping Britain to build and to meet the future. These advertisements were published in The Economist in 1968. Each advertisement describes some new invention or improvement to the infrastructure in which the companies are involved.

In each case, a visual joke is created by a pictorial element in one letter of the typography. In the example in figure 8:45, a lifebuoy replaces the second "o" in overboard while in figure $8: 46$, the " $m$ " in Jumbo has the shape of an elephant.

Figure 8:45 opens with the pompously significant words "As a servant of the island race Shell-Mex and BP is appropriately fond of the sea. It has its own coastal fleet plying between refineries and coastal terminals. It also has its own bunkering vessels to whose number a rather strange-looking newcomer has been add on Thames and Mersey." The companies are positioning themselves as patriots and as servants to the nation. Moreover, they are stressing the centrality of the sea in British history. The advertisement goes on to explain how this will

\footnotetext{
${ }^{36}$ This was also the period when television commercials appeared and Shell in particular did advertise with these.
} 
improve the service that they can provide and how they always "throw overboard any old method when they can introduce a new one" that provides better results. The text echoes and anchors the visual and explains the unexpected heading that hails the reader: "Throw that ship overboard rather than "Man overboard".

\section{Image removed due to copyright. Image removed due to copyright.}

Figure 8:46 refers to the advent of the "new giant jets", the jumbo jets that are "going to be thirsty" and explains how Shell-Mex and BP Ltd will be ready and waiting with fuels and fuelling methods that will allow the minimum turn-around time. The question that hails the reader plays with the concept of "Jumbo the elephant" and the jumbo jet. It positions the companies on the cutting edge of technology and as partners in technological development.

Each advertisement ends by explaining that Shell-Mex and B.P. Ltd distribute the petroleum products of both BP and Shell in the United Kingdom, and then ends with a comment specific to the particular advertisement and how their work helps Britain.

Advertisements also appeared in The Times, Guardian and Financial Times both from these series and from others that publicized the work that Shell-Mex and B.P. Ltd. was doing to help Britain and its development. One particularly interesting example comes from a series that made up of discussions between two cartoon characters and is from 1961, two years after the first cross Channel hover. The advertisement explains the role of the company in the development of this new form of transport and ends with the following words:

"Two things worth remembering: (1) The fuel and lubricants for the prototype Hovercraft SNR1 were supplied by Shell-Mex \& B.P.Ltd. (2) We have always looked after, fussed over, and generally mothered the pioneers of air transport."

The words that are particularly interesting here are "always" and the three verbs, which are not those normally associated with cutting edge technology. The companies are positioning 
themselves not only as an integral part of avionics since its incipience, but as something more than a partner. Shell and BP have nurtured the development of air transport.

Other advertisements show how they are "using fewer of everything to market more" and provide the reader with facts and figures for new larger road tankers, rail tankers and new, bigger faster turn-around terminals which result in "[e]ver crisper, more efficient service to customers [and] Higher productivity - in the national interest."

During this time of trouble, although the companies did not directly advertise their products, they did work to maintain a presence and this was frequently done by engaging the public in some form of activity, as actant participants in their different publicity campaigns.

In addition to the examples described above, one of the more interesting ways in which this was done was through a "literary" competition which ran throughout the mid-sixties and which was published in The Economist, Punch ${ }^{37}$ and The New Statesman. This competition expanded the notion of the reader as actant, engaging in a game of wits, but also reminded the reader about the companies' activities in the service of the nation and positioned them as intellectually and culturally aware, and hence, contributed to their social and cultural forms of capital. The first competition was to help commemorate the opening of the Forth Bridge, for which they had supplied oil fuel and lubricants (figure 8:44) thus reinforcing the earlier advertisement, and other examples included suggesting an "all British" name for a "new supersonic airliner and a case for the choice as written by The Duke of Wellington, Oscar Wilde or Rudyard Kipling”.

A second competition which also engaged the public in a real, dialogical situation, was a road safety competition which aimed to find and implement a "new, imaginative idea" to make communities safer for children and young people. In this case too, the companies were engaged in a form of public relations whereby the competition functioned as a means for them not only to do good, but also to be seen doing good (Waeraas \& Ihlen 2009).

In general, the focus of the advertisements that appeared in Britain during the 1960s was how the oil companies were helping improve standards of living on both the national and the local community level by working towards improved transport efficiency and safety.

\footnotetext{
${ }^{37}$ Punch is a satirical weekly magazine from 1841 . It is intellectually challenging and presupposes a reader with a good knowledge of current affairs as well as a high level of general education.
} 


\section{Advertising in America}

Although Europe was in a state of crisis and economic depression, the situation was different in the United States. While America too faced problems with energy supplies and prices and the oil companies faced antitrust indictments, the American economy was solid, partly thanks to the Marshall Plan and its oil for dollars, and the oil companies continued to advertise.

However, the general growing mistrust in the companies and suspicion that the succession of oil crises were staged to increase profits, in combination with the Santa Barbara Spill and the findings of the Club of Rome in 1972, resulted in a change in advertising strategy even there. Companies do not exist in a vacuum but must operate in the social context of which they are a part, and I have already mentioned the innovative approach to advertising that was adopted by Mobil in 1970 in response to this reality (Porter \& Kramer 2006). As Mobil's proactive advertising methods have been the subject of a number of studies (Crabble \& Vibbert 1983, 1985, Smith \& Heath 1990, Brown et al 2001, Brown \& Waltzer 2005), I will not discuss them further here but will turn instead to the more traditional forms of advertising practiced by the other companies in the oil business as the age of awareness slowly began to dawn.

\section{Shell in America}

First I would like to discuss two Shell advertisements that appeared in Scientific American in 1970. These are particularly interesting for a number of reasons. One is in relation to Shell's participant roles and the pragmatic triad and the other is that the visual element of these advertisements is a photograph (Rampley 2005). Although BP had used commonly photographs in their advertising during the1950s, the visuals in Shell's advertisements had been drawings. Moreover, the photographs were in full colour.

A photograph requires a photographer and thus a person who has seen with his own eyes in situ, the phenomenon photographed. Thus, the rhetorical power of a photograph is stronger than that of a drawing which does not make

Image removed due to copyright.

\section{Figure 8: 47 The fawn} the same claims on reality. The Camera never lies! (David Freedberg 1982).

The first of these featured a large colour photograph ${ }^{38}$ of a young deer lying peacefully in the grass (figure 8:47). The fawn is in the centre of the photograph and is the focal point of the page. Underneath are the words "In three weeks he may be dead" and in the bottom righthand corner is the traditional read and yellow Shell logo.

The cruel contrast between the photograph and the headline below engages the interest of the reader.

Rhetorically, this image is very strong and makes use of the technique of pathos. The helpless fawn with its big brown eyes is lying in a seemingly idyllic place, unaware of the imminent

\footnotetext{
${ }^{38}$ Shell did in fact publish one series of advertisements in The Economist at the very end of the 60s into the early $70 \mathrm{~s}$. These were photographs, rather than the drawings that had illustrated their earlier advertisements with one single element in colour against the monochrome of the background of the visual. Colour was otherwise still extremely rare in the British periodicals.
} 
danger that is threatening his life (Holbrook \& Batra 1987, Hansen \& Riis Christensen 2007, Söderlund 2003). This technique is continued in the opening section of the written text. Like the "Shell and the Dragon" series from 1958, the opening sequence provides a fairy tale atmosphere to the narrative "In the beautiful woods and valleys of eastern Ohio" (Scott 1994b) which is quickly broken and we are told that "time is running out". The reason for this is ticks, "crab-like pests" that attack not only the young deer but also "virtually any land animal or bird they can get hold of".

Again, Shell provides the solution to the problem, this time, working in a team with the Oklahoma Department of Wildlife Conservation and Oklahoma State University. These partners bestow upon Shell authority and legitimacy as part of a team of experts and scientists working towards saving the lives and lessening the suffering of helpless young creatures.

In rhetorical terms, these participants provide the Ethos which supports the Pathos of the photograph and the claims made by Shell. Moreover, they become the active participants in the narrative, "using Shell's Gardona" insecticide as the weapon of choice ${ }^{39}$ in the battle that they are fighting. Shell is then described as an active member of the team; "Shell has also funded a grant to Oklahoma State University's Department of Entomology for more intensive study on the control of ticks".

The narrative voice then changes from that of an outsider relating the facts to become that of Shell speaking as a group, "we". "Shell's concern with wildlife is only part of an all-out program to help save our environment. So far we've backed our commitment with millions of dollars a year in the war against pollution. And we're moving as fast as we can. Because like the fawn, we're all running short on time."

Two points are particularly interesting here. First, is that the shifting meaning of the first person pronoun. The "we" of the Ego Shell becomes an inclusive "our" common environment and the final pronoun extends beyond the "we" of the company to include us all as participants in the narrative. The second point is that Shell talks of its "concern with wildlife". In the advertisements of the 1950s, any concern with wildlife was to control it in order increase yields or to protect human life but by the late 1960s, attitudes had changed and environmental organisations had begun to make their voices heard, thanks to Rachel Carson (1962). Companies began to point out that only the specific pest that was targeted suffered and that other creatures were not harmed by their products.

The second advertisement is from October 1970 and was a double spread (figure 8: 48). This advertisement provides a particularly stark example of how text and photograph (Freedberg 1989, Rampley 2005) are intricately interwoven to create and to strengthen participant roles.

The focal point of the advertisement is the head of a young black man, photographed standing in front of the Lincoln Memorial. The gaze of the statue of Abraham Lincoln, with the words "is enshrined" above its head, stares into the distance slightly over our right shoulder, but the gaze of the young man is fixed on us. The symbolic contrast between Lincoln and his fight for the freedom of each individual on the "given" left of the spread and the words of the heading is striking (Mick \& Buhl 1992). Not only do the fundamental rights proclaimed in the American Constitution seem to be questioned, but the words also draw upon some of the most famous in the Gospels, "Man cannot live by bread alone"40 As Barthes has pointed out (1977:16) a photograph always communicates with the text, title or caption that

\footnotetext{
${ }^{39}$ Weapon was a term that also appeared in various combinations and guises in the "Shell and the Dragon" series.

${ }^{40}$ Matthew, 4.4.
} 
accompanies it; it is both "objective" and "invested" (ibid: 20) and the visual image that Shell present seems to be at odds with the text (McQuarrie \& Mick 1996, 1999). Moreover, as a photograph is a result of "being there" of "having seen" it represents something that is or has been. This makes the young man's plight more tangible and less abstract; he really exists, and makes his gaze more compelling.

As Kress and van Leeuwen point out, (1996:122) when represented participants look directly at us, this establishes a connection and creates a visual form of address. The reader or viewer is addressed explicitly with a "visual 'you'" constituting an "image act" which demands something of the addressee. Moreover, the photograph has been taken from a relatively close personal distance, (ibid:130) and this increases the addressee's sense that the young man is demanding responsivity.

The second thing that I would like to point out about the visual appearance of the advertisement concerns the lay-out of the actual text. Until the last three paragraphs, when the way in which Shell is working with bank loans and their reasons for doing this are explained, the text is organized sentence by sentence on the page and each new sentence is indented. This makes it relatively easy to read. Moreover, the sentences that make up the first part of the text and set the scene, lack articulated subjects. Is this a stylistic representation of the relatively low educational levels of the boys that the text brings to the attention of the addressee or is it a way to entice the public to begin to read the lengthy text?

The text opens by stating "Twenty million free Americans are locked in slums." This opposition between the words "free" and "locked" underline the confusion that has been engendered by the image and heading and tempt the addressee to read on. We learn that they are "Living in misery"; "Idling their lives away on front stoops"; "Because they don't have training to get and hold decent jobs."

Is the young man demanding our attention asking for us help?

\section{Image removed due to copyright.}


The text goes on to tell the addressee that "for some of them there is hope" because "[g]overnment and industry are working together to train the unskilled." There is then an interesting change of tense from the narrative present used to set the scene, to the historic past, as the role of Shell as the "Other", is expounded. "Back in January '68 Shell introduced an automotive tune-up course in a New York high school where there was a dropout problem." The voice of the informant goes on to explain how this successful project has developed and that in "a low-income area of Trenton, New Jersey, Shell has opened a modern packaging plant"; "The objective is to make it a business that is owned-and-operated by people of different minority groups"; "Business is solicited on a competitive basis, not as a "give-us-the-work-and-you'll be-helping-the-underdog" plea." The informant then explains how "Shell has made special deposits of nearly one million dollars in banks mostly owned and operated by businessmen of different ethnic minorities" to help them facilitate minority business loans.

The advertisement ends with a new participant informant, the voice of Shell.

"Shell feels that money for all these programs is well spent. Our goal is to help provide the increased capability America needs. And, of greater importance, to help more Americans share in the tangible rewards of living in this country. Because without these rewards, freedom has a hollow ring".

The reference to the heading in the closing statement is typical of Shell advertising rhetoric of the mid and late twentieth century. In the bottom right hand corner is the Shell logo which symbolizes the new thinking that Shell represents.

The participant roles in this advertisement are very interesting. Visually, the participants are the stone Lincoln, upraised in the background overseeing the world he helped to create but not looking at the young man of flesh and blood who demands the addressee's engagement and response. Shell too is made visually present by its logotype. The third element of the dialogical situation, the very strong cultural anchoring of this advertisement, is also visually present in the large heading which takes up one third of the page. The participant informant, or the narrator of this "rags to riches" story (Booker 2004) is represented by two distinct voices; first an observer who recounts the state of affairs and then the voice of Shell explaining the company's philosophy. Neither Lincoln nor the young man are active participants in the narrative, but act as symbols of the dream and of the reality and show how Shell is working to reconcile the two. Thus, the participants in the narrative include young men like the one whose gaze insists on our response, the school system, the government, industry, minority groups, banks and Shell, who is claiming partnership with these and leading them and the country from rags to riches.

This advertisement is particularly rich in rhetorical devices of both visual and textual nature (Booth 2004, Olsen et al 2006, Borghini et al 2010) and is filled with symbolic and intertextual references.

\section{The American Companies}

While Shell published a few advertisements in Scientific America during this period, the American companies advertised heavily. One of the most frequent contributors was the Standard Oil Company of New Jersey. They ran an extensive series of double-page advertisements that all followed the format of a large colour photograph spread across the pages to illustrate the accompanying long text.

The advertisement "Education on the move" shown in figure 8:49 is from November 1969 and shows a group of teenagers running after a truck. 
Like the example in figure 8:48, this advertisement explains how an oil company, in this case, Standard Oil, is working to help young drop-outs to get a better future. However, whereas the Shell advertisement demanded the reader's personal engagement and response, here, the young people are in the distance, running en masse towards some sort of vehicle. The reader is positioned as a detached observer whose interest in the scene being played out is purely one of curiosity. The focal point of the advertisement is not the actual individuals but the work that the company is doing to better their general situation.

The rather lengthy text, which is typical of the series, opens in a casual, chatty manner. "That truck in our picture causes quite a stir as it rolls from town to town. Some kids think it is a traveling circus. Ah well."

\section{Image removed due to copyright.}

\section{Figure 8:49 Education on the move}

In combination with the opening words and the pronoun "our", the choice of the familiar "kids" and the colloquialism "to cause a stir" positions the reader as a partner in an on-going dialogue with an informant from the company who explains that despite its appearances, the truck is a classroom with all the latest "gadgets [which] have a single purpose. To bury the old lecture-and-listen teaching methods under the ivy. And substitute involvement."

The concept of involvement is ambiguous as it refers on the one hand, to the students becoming more actively involved in their own education. This is metaphorically anchored by the image which shows them actively pursuing this new and innovative source of education, instead of passively listening. On the other hand, it obliquely refers to the company's involvement in education and society, a position which the informant evolves at some length, explaining how

"[s]ome of these experiments are already silver linings in a thundery sky. Harlem Prep School ${ }^{41}$ is one. Nearly all of its students are dropouts from the public school system. Thirty entered college last year. Seventy-five have

\footnotetext{
${ }^{41}$ In April 1970, Standard Oil of New Jersey published a second advertisement featuring Harlem Prep. The advertisement explains that the school "is less than three years old. It has its home in an old supermarket. There is no other independent school in America quite like it". The advertisement talks about the success that the school has had and is illustrated by a row of thirteen people standing with their arms round each other. Of the
} 
been admitted this year. Another program has come up with some answers to the psychological problems of bright students who mysteriously flunk out of college."

Again, the photograph with the grey, cloudy sky conspires with the speaker's language and use of the saying "every cloud has a silver lining" to suggest that the situation for these young people, and by extension, for the country, is serious. The sky is not merely cloudy but is thundery due to the flunking rate in the public school system. ${ }^{42}$ However, Standard's commitment to education does not stop with this, but they are also backing "a lively new magazine called "Change" [which] is dedicated to exploring new directions in higher education and hopes to find sensible solutions to the problems that underlie student unrest."

An interesting aspect of this advertisement involves the references that it makes to the specific American context in which it is set. These include the comment that the truck does not use the traditional methods found "under the ivy", the privileged world of the academic elite of the "Ivy League" and an implication that while these methods are based on distance, Standard's methods are based on the involvement of all concerned.

The advertisement closes with the informant suddenly introducing another voice; that of an expert in the field, the editor of the new magazine, with the words: "Listen to the editor." The editor's words are then reproduced within speech marks. "We intend to be an irreverent foe of all that is arcane and irrelevant in higher education. We intend to help return to higher education that long lost art - the plain English sentence."

The advertisement ends with a return of the speaker's voice. "Knowledge keeps no better than fish. The plain English sentence should speed its delivery enormously."

A number of interesting points arise here. Firstly, this is an interesting example of what Adelswärd (2000) has called a "virtual" participant voice. ${ }^{43}$ Secondly, the "we" of the editor must incorporate both the writers of the magazine and the Esso Educational Foundation which is supporting it. In other words, Standard is positioning itself as a champion of what they see as the basics of education, one element of which is the ability to communicate successfully in simple English. Thirdly, on a lexical level, the language of the actual quoted sentence is not an example of everyday, modern English, but a parody of the language of the well-educated. The editor expresses his plea for a move away from the arcane towards the plain English sentence with a rhetorical style and a vocabulary that is more adapted to that of a British public school teacher of the previous century.

The informant then returns to the more mundane with the fish metaphor. However, the underlying message is that knowledge must constantly be developed and up-dated, if it is to be of any value; something which is in line with the work of the oil companies. Knowledge will be more accessible and have a greater impact on more people more quickly if it can be delivered in plain English. This advertising text is an exceptionally rich example of both polyphony and heteroglossia.

thirteen, three are female and one, probably the headmaster, Ed Carpenter, is white. Jersey Standard express their pride in having provided some of the support that has been necessary for this project to succeed.

${ }^{42}$ The concept of public school in the U.S.A. must not be confused with the public school in the U.K. In the U.S.A. the public system is the state system while in Britain, public schools are elitist, extremely expensive and especially at the time when this advertisement appeared, typically the reserve of the aristocracy and upper classes.

${ }^{43}$ Anward (2002:140) discusses the complexity of the relationship between a "real" speaker and a "virtual" speaker. In the case of an advertisement such as this one, where the "real" speaker is already the fictional voice of a collective of animators (Goffman), the situation becomes even more complex. 
The oil company is making a strong plea for education and is projecting itself as a supporter and benefactor of new ways of encouraging and teaching students. It casts itself in the roles of benefactor, educator and innovator, and makes no mention at all of its business. In other words, this is a clear example of corporate social responsibility and PR. ${ }^{44}$

Just like Shell, Standard Oil also began to display a concern not only for social issues but also for the environment in their advertisements at this time. The socio-political mood of the day required that the oil companies began to display a concern with the environment and to counter accusations that their work was detrimental to nature. The advertisements in the series included a description of a dynamite substitute, the "popper" that does not harm aquatic life during seismographic explorations, and of the company's environmental stewardship. The example shown in figure 8: 50 provides an interesting example of the how Standard Oil presented itself as stewards of the environment.

That the world of oil is a world that is at one with the stereotypical view of America as the land of the cowboy, manliness and the great outdoors, is made explicit in the photograph and is anchored in the title "Coexistence on the King Ranch" (Mick \& Buhl 1992, Scott \& Vargas 2007). The theme of the advertisement is the coexistence of nature with the oil industry on the King Ranch, "a hunk of pure Americana under the huge Texas sky." In the text that accompanies the photograph, the company states that there are "thirty thousand cattle and twenty-eight oil and gas fields; two thousand miles of fencing and on thousand miles of buried pipeline; over three hundred windmills and the world's largest natural gas plant."

\section{Image removed due to copyright.}

\section{Figure 8:50 Coexistence on the King Ranch}

They list the wild birds that have elected "to stay and multiply by the thousand" on this ranch where 500 cowboys work as an argument against those who claim that oil is a "noisy, messy

\footnotetext{
${ }^{44}$ Notice the similarity of the ambitions that Standard Oil declare here with the Shell "Lincoln" advertisement.
} 
business" and refer to the water that is returned to the ponds and creeks after being used for cooling purposes where deer, nigail, javelinas and the valuable cattle "guzzle it". ${ }^{4}$

In this example, the reader is projected as an objective observer of life on the ranch. The cowboys are moving away towards the refinery and are viewed from behind, demanding no engagement or relationship. This can be compared with the strong emotive aspects of the Shell advertisement (figure 8: 47).

Another advertisement by Standard Oil for its environmental stewardship "The enchanted oil refinery" shows "Esso's Fawley refinery on England's south coast". Kress \& van Leeuwen (1996: 45) have argued that "pictorial structures have deeply important semantic dimensions" and that soft focus and soft colours act as modality markers (ibid: 164). The wildlife represented in the foreground of this advertisement is in sharp focus and thus connotes what "is", while the soft, blurry contours of the refinery lower its modality and are suggestive of what might be; a visual metaphor for the "enchanted refinery". Although the animals are foregrounded, none gaze directly at the camera and therefore do not engage with the reader. The choice of creatures represented, rabbit and a bird happily unconcerned by the presence of a watching fox, is another metaphor for the enchantment of the refinery. The expert voice of the advertisement is provided by Major Oliver Kite ${ }^{46}$, a prominent British naturalist, who lends legitimacy to the project, and confirming and endorsing the remarkable Standard's "remarkable example of wildlife conservation" and praising their planting of twenty-six thousand trees and shrubs which screen the refinery from the road and provide a suitable habitat for wildlife.

Standard Oil New Jersey was not alone in discovering and proclaiming its stewardship,

\section{Image removed due to copyright.}

Figure 8: 51 Texaco's good news is not just a call to prevent the however, and other American companies, like Texaco also began to recognize the problem of environmental degradation. In the example, (figure 8:51), Texaco explain to the public how they are working to counteract pollution. Their efforts include a new department for environmental pollution "made up of Texaco people who are dedicated to finding ways to protect the earth, the air, and the water".

The advertisement from 1972 (figure 8:51) shows a little girl with pigtails, carrying a white duck and surrounded by a motley and extremely unlikely group of animals, such as sheep, a donkey, a turkey, a wild cat and a bear. This pollution of "the most faraway forests" but is a visual

\footnotetext{
${ }^{45}$ The people and organisations making these claims include for example, Greenpeace, which has proven a thorn in the side of the oil industry on numerous occasions. It was founded in Canada in 1971 as a response to planned underwater nuclear testing off the coast of Alaska in an area which was the home of 3,000 endangered sea otters as well as peregrine falcons and other species of wildlife. http://www.greenpeace.org/usa/en/campaigns/history/ ${ }^{46}$ Welshman, Oliver Kite was a master fly fisherman as well as a popular television nature programme personality of the 1960 s.
} 
metaphor for Utopia (Scott 1994a), where just as in the world of the "enchanted refinery", every creature lives in harmony and natural enemies are a thing of the past.

The child and the animals that would be most expected to be at risk from the others are looking towards the camera demanding the response of the reader. The two animals that are foregrounded are the wild cat on the left side of the picture who is looking towards the left, into the past and the bad old days, and the woolly lamb in the at the bottom centre right who is facing the right and the "good news" of the utopian future that Texaco are offering.

The 1970s and 80s were decades when a number of "incidents," among which the Amoco Cadiz disaster of 1978 and the Exxon Valdez spill of 1989 received the most publicity. The Gulf War and Saddam Hussein's burning of the oil fields in the early 1990s in combination with further spills of the coast of Europe deepened the public's concern with the negative environmental impact of the oil industry and deepened the legitimacy problems that it faced, particularly in Europe. Other problems facing the industry included the situation in Nigeria and the role that Shell played there (Livesey 2001), and the attempted disposal of the Brent Spa platform which, fueled by the rhetoric of Greenpeace, (Mitvis 2000) caused public outcry. The first report of the IPCC which was published in 1990 and the Kyoto Protocal on Climate Change from 1997 put further pressure on the oil companies whose activities were singled out as the major drivers of climate change.

During this period the companies maintained a low profile and print advertising was at a minimum, especially in Europe. This situation began to change at the end of the $90 \mathrm{~s}$ and a series of mergers took place. BP led the way and merged with Amoco at the end of 1998, Mobil and Exxon merged in 1999, the French and Belgian companies began to merge in 2000 to eventually become Total, and Texaco merged with Chevron in 2001. Shell was the only company that did not enter into a new partnership or merger. This development resulted in new advertising campaigns that typically converged with the concepts of PR and characteristically stressed the companies' social responsibility (Livesey \& Kearins 2002, Cook 2008, Ries \& Ries 2004, Koller 2008, Ihlen 2006, 2007, 2008).

\section{The turn of the century}

\section{"For all our Tomorrows"}

One of the last campaigns that BP ran before its merger with Amoco was also one of its most successful; ${ }^{47}$ It titled "For all our Tomorrows," and like the advertisements of Shell and Standard Oil some twenty years earlier, the focus of this series is the ways in which the company is working to improve the environment and the situation of the young and underprivileged by facilitating their education. The campaign, which dates from the beginning of the 1990s, ran on TV both in Britain and internationally as well as in international business publications, and was intended partly as an answer to critics of the oil industry for its greed and lack of concern for the future. In other words, it was a form of image repair strategy (Benoit 1997, Stutts \& Barker 1999, Svensson 2009).

The campaign also introduced BP's move into the world of solar energy as figure 8:52 shows.

\footnotetext{
"Colin lives in a remote African village. He has no light to study by at home so after a full day of classes he remains at school to finish his homework.

You may wonder where he gets the energy from. Actually it comes in the form of electricity generated by solar modules.
}

\footnotetext{
${ }^{47}$ The campaign won the Worldaware Award for Effective Communication in 1992.
} 
Since 1981 we've supplied solar-powered vaccine refrigerators and water pumps to clinics, and lighting systems to schools throughout the African continent. Solar technology may never eclipse conventional power sources.

But it already promises the children of Africa a brighter future.

Solar technology may never eclipse conventional power

sources. But it already promises the children of Africa a

brighter future.

Supplying solar power to remote parts of the world is one of the things BP is doing today, for all our tomorrows.

\section{Image removed due to copyright.}

Figure 8:52 BP Solar energy the linguistic complexity builds up to include puns (eclipse) and the play on words in the last two sentences.

BP is bringing enlightenment, metaphorically represented by Colin, who is portrayed bathing in a golden light surrounded by darkness, in a manner which is reminiscent of some of the paintings of the Dutch classical period (Berger 1972, Scott 1974a, Marchand 1985, Pointon 1997). In this way, the contrast between the dark and the light that is provided by BP is made starkly visible. Colin is portrayed at a distance, looking into his books and not trying to make contact with the reader. This allows the reader to take stance which is objective as well as empathic. Colin is a young boy whose educational ambitions mean that he must study alone, away from his family and he would be quite in the dark, both literally and metaphorically if it wasn't for BP's solar power. In this way, BP portrays themselves as the bringer of light, both intellectual, through facilitating education to provide children like Colin with "a brighter future" and also physical, by taming the power of the sun. ${ }^{48}$

As Burke (1950/62:46) has pointed out, all communication is "addressed" and involves "consubstantiality" or persuasion and identity. A speaker draws on identification to establish rapport and to persuade the audience to identify with the speaker's interest. Burke extends the pathos principle beyond its traditional, pragmatic range to account for psychological response and sociological context as factors which predispose audience response (Nan Johnson, 1988:156). In other words, Augustine's observation about "moving the minds of listeners" comes into play.

\footnotetext{
48 Some ten years later, BP adopted the metaphor presented in this advertisement as their logo when they changed from the yellow letters on a green background to their Helios symbol, thereby equating themselves with the mythological figure of Helios and with his powers. I will return to this in the following chapter.
} 
Significantly, the title of the BP campaign and its recurring slogan was "For all our tomorrows". These four apparently simple words are pregnant with multiple meanings. First of all, "tomorrows" is unusual in the plural. It implies on the one hand a sense of continuity, of progress and on the other, that this future belongs to every individual, to "all" of us. At the same time, "all" can refer either to each and every one of us, or to every day in the future, tomorrow and the next day and every day after that that we live and experience. "For" can simply be a destination but can also be the reason why BP is doing what they are doing. Finally, "our" embraces the reader and the whole of humanity in a sense of fellowship and oneness. The future of the world concerns and unites us all.

To exemplify this further, one of BP's most successful advertisements from the series stars a ladybird. This advertisement was hailed as the best remembered in the Wall Street Journal (Philip Nelson 1974).

At first sight, this advertisement (figure 8:53) has little to do with oil. Instead, the visual element comprises a large photograph of a beautiful ladybird, an insect that is recognised as both harmless and useful and that is moreover a favourite among children (Holbrook \& Batra 1987). The ladybird has been photographed lying on its back, its legs in the air, apparently dead, and the surprising words "Weedkillers needn't be ladykillers" call out to the reader.

First, it should be pointed out that the headline

Figure 8:54 Ladykillers

"Weedkillers needn't be ladykillers" is filled with connotations.

One of these is its reference to a popular film of 1955, The Ladykillers ${ }^{49}$ while the others are rather more complex. During Lyndon Johnson's presidency (1963-69) social rights became an important issue in the United States and amongst the issues addressed by his Great Society Program were aid to education, the beautification of the urban environment and conservation. These are the issues (Catrin Johansson 2007) raised in BP's campaign series.

A further point of relevance is that President Johnson's wife was commonly known as Ladybird.

Under the striking and simple photograph of the dead or dying ladybird, we can read:

(i) As any conservationist will tell you, weeds aren't the only things that weedkillers kill.

(ii) Because more often than not, weedkillers are made of a concentrate which has to be mixed with water.

(iii) And the resulting mixture has a nasty habit of getting washed into lakes and streams.

(iv) Or of being blown off target onto innocent victims like birds and insects.

(v) The sad result is a lot of dead wildlife, much of which would have done a great deal to improve the environment.

(vi) Ladybirds for example are a major consumer of aphids throughout the world.

(vii) For literally millions of harmless living things therefore, a new oil which BP has developed is a lifesaver.

(viii) Added to existing products at formulation stage, it ensures that weedkillers can be sprayed more accurately. And it makes certain that once sprayed, they stick only to the intended victim

${ }^{49}$ The Ladykillers starred Alex Guiness, Peter Sellers and Cecil Park and is considered a classic. 
(ix) All of which means that the ladybird can go on ridding us of aphids in exactly the way that nature intended.

(x) Whilst weedkillers will only destroy the things they were designed to destroy.

(xi) Helping to conserve nature is one of the things BP is doing today, for all our tomorrows

The first rhetorical tactic that is used is to draw the reader into the congregation of conservationists, a role which becomes part of his "corporate we's." BP is taking a stance, something that John Du Bois (2010:25) defines as "a public act by a social actor, achieved dialogically through overt communicative means, of simultaneously evaluating objects, positioning subjects (self and others) and aligning with other subjects, with respect to any salient dimension of sociocultural life". At issue are the conflicting needs of unnamed farmers and gardeners and of conservation. BP is projecting itself as well aware of these problems and that it is working to solve them. Another point worthy of observation is the word "victim" which is repeated in paragraphs (iv) and (xiii). In other words, pathos is used as a strategic function to "move the minds" of the readers and predispose them to respond favourably. These "innocent victims" which become "dead wildlife" are contrasted with the "intended victims." BP's new oil is a "lifesaver" for "millions of harmless living things" (vii) and the company and its products are equated with nature, conservation and the future of all of us; with "all our tomorrows".

\section{Profits or Principles}

The next major campaign (Koller 2008) was produced by Shell at the end of the decade and was in direct response to the criticism that it personally had been subject to for a number of issues such as acid-rain (Hajer 1995) the Niger Delta scandals (Boele et al 2000, Wheeler et al 2000, Livesey 2001, Michael Peel 2005), and the public response fired by the accusations of Greenpeace (Anabela Carvalho 2007), to their intended disposal of the Brent Spar platform (Dickson \& McCulloch 1996, Mirvis 2000, Johan Graafland 2002, Vian Bakir 2006 ), as well as an increasing public awareness of the environmental problems that were surfacing and a general mistrust of the industry as a whole. In 1998, Peter Knight produced "The Shell Report, Profits and Principles - does there have to be a choice?" and the campaign was developed from this (Livesey \& Kearns 2002, Coupland \& Brown 2004).

Peter Knight's report opens with an introduction to its purpose.

"We care about what you think of us.

We want you to know more about how we work and how we strive to live up to our principles.

This report is part of a dialogue, and we will continue to seek your views."

These words fill the centre of the first page of the actual report and have been produced in a font that resembles handwriting. Typefaces are not merely vehicles for transferring messages but are means for communicating personality and are filled with connotations. They can be enlisted to indicate the relationship that exists, or that the sender would like to encourage, between himself and the receiver (e.g. van Leeuwen 2005, 2006, Nørgaard, 2009, Stöckl, 2005). However, the strong relationship-building discourse of the report goes far beyond the choice of a typeface which connotes personal correspondence. Among the 43 words that comprise this introduction, the pronoun "we" is used five times and "us" and "our" once each. "You" features twice and "your" on one occasion. Moreover, the typeface used is rounded, a quality that is associated with femininity, gentleness, the natural and the organic (Kress \& van Leeuwen 1996, van Leeuwen 2005); characteristics with which a multinational corporation, and perhaps particularly an oil giant, are not normally attributed. 


\section{Image removed due to copyright.}

Figure 8:54 Why green is good
One of the first advertisements in this series (figure 8:54) was entitled, "Why green is good," and appeared both as a double-page spread (Pollay 1985) and as a single page advertisement in a variety of publications including The Economist, New Statesman and Scientific American. This advertisement presents the thesis that is central to the Knight Report, namely, that profits and principles are not mutually exclusive. The visual comprised a selection of green bank notes of different denominations and from different currencies. An American dollar on which enough of the motto "In God We Trust" is visible for the addressee to easily recognize has a prominent position among the pile. The bank notes in the visual are all green and provide a visual and textual wordplay associating the green of money and American greenbacks or dollars, with the green of the environmental movement. The text that accompanies these green notes is generally organized as a list of sentences. ${ }^{50}$ This is particularly clear in the double-page version where the text is not in columns. The example shown in figure 8:54 is the single-page version.

The voice is that of Shell, the company, and it is Shell that "we" refers to here. The reader is the direct participant addressee and the topic of the address is Shell, the company as a successful and ethical business. The closing words (line 14) address the reader directly as an individual, "thou" and offer an opportunity to invest and become a shareholder and partner.

1 Somebody once said that a principle isn't a principle until it costs you money.

2 So where does this leave all those companies which have embraced a more responsible social and environmental attitude?

3 Does this make them a risky investment? Or an investment you can't risk ignoring?

4 Let's look at a few facts.

5 Over the last three years, we've outperformed the Morgan Stanley Capital World Index by several percentage points per year.

6. We have one of the strongest balance sheets of any company in any industry. Our dividends have grown each year.

7. We're investing $\$ 12$ billion year on year in projects creating long-term value for shareholders.

8. We are one of the top performers in the energy sector of the Global Dow Jones Sustainability Index and included in the UK's FTSE4 Good Index from its inception in 2001.

9. And the highest quality talents continue to make their way towards us, as they look for a company whose corporate values match their own personal ones.

10. All of which suggests two things.

11. A company which cares as much about how it makes money, as how much money it makes, will make money. For its shareholders, its investors and its employees.

12. And whoever coined the phrase about principles was living in the past.

13. A past which grows dimmer and more distant by the day.

14. If you'd like to know more, a visit to www.shell.com could prove profitable

The advertisements in this series were generally in the form of a double spread with the majority of the text on the right page. A particularly interesting example from this series was "The real price of oil", a double spread which showed a picture of the Brent Charlie oil rig in

\footnotetext{
${ }^{50}$ This technique became frequent after the "Freedom" advertisement from the late 60s (figure 8:49).
} 
a grey and stormy North Sea with a page-long text on the right, a clear reference and response to the Brent Spar crisis. The text accompanying the photograph reads:

1.We're all involved in the oil business.

2.Every time we start our cars, turn on our lights, cook a meal or heat our homes, we're relying on some form of fuel to make it happen.

3.Up to now, it's inevitably been a fossil fuel, part of the carbon chain.

4. And, just as inevitably, that will have to change.

5.Long before we decide to stop using fossil fuels, costs will have already made the decision for us.

6.Not just the monetary cost, but human cost, the cultural cost, the environmental cost.

7.We will, quite rightly, demand that our future energy is both sustainable and renewable.

8. We will expect a lot from the likes of solar power, wind power, geothermal power and hydrogen fuel cells.

9.And it will take time.

10.Various estimates suggest that by 2050 , nearly one third of the world's energy needs could come from just such sources.

11. Which leaves the other two thirds to come from conventional fuels, such as oil and gas.

12.To make this happen, we have to strike a balance.

13.Between the need to protect people's way of life and their environment and the need to provide them with affordable energy.

14.Between the cost of developing new technology to extract the utmost from current fuels and the cost of developing new power sources.

15.This is what Shell does every day, all over the world.

16.This is why we need to hear from and listen to, everyone who has an interest in the world.

18.17. Which is pretty much everyone in the world.

19.This is the real price of energy and it's worth it, if only to make sure our children have the chance to buy it.

20.And a world worth buying it in.

21.A platform for all points of view is at www.shell.com

The advertisement ends with the new slogan, "Profits. Principles. Or both?" followed by the red and yellow Shell logo which provides the only splash of colour on the spread.

A comparison between the texts of these two advertisements is extremely interesting. In this latter advertisement, the company has changed the participant roles that prevailed in their earlier advertisements in general, and in "Why green is good", in particular. The participant voice of "Why green is good" is that of the company expressing their standpoint and the "we" of the "énonciateur" "51 is the voice of Shell the company that informs the reader "you" of their views and work and offering an opportunity to find out more and even profit from Shell's business philosophy.

The advertisement described above, "We're all involved in the oil business", shifts the focus from "we and you", to a much more inclusive "we and us". The opening statement (1) begins with an all including "we", underlined by "all" and the verb "involved" and immediately forms a relational bond between the participant addresser and the participant addressee, in this case, the intended addressee. No intermediary actant is introduced and the words are addressed directly to the reader. In all, the pronoun "we" occurs eight times during the text, "our" four times and "us" once. In the first eight sentences, the pronoun "we" occurs six times in an including sense and "our" three times. These sentences present the problem and underline the fact that we are all involved and that together we are responsible for the future.

\footnotetext{
${ }^{51}$ I use the term "énonciateur" here as in this series displays a high level of heterglossia and the different stands taken by the company voice changes from énoncé to énoncé and is very much involved in orienting the reader to the specific referential values of the particular advertisement (Johansson \& Suomela-Salmi 2011:88 discussing Culioli's understanding of enunciation).
} 
Repetition and the paralleling of lexical and structural items, including the strong "We will" $(7,8)$ which is echoed in line 9 , create immediacy and intensity.

The text has three distinct moods. The first is that of the opening sequence, "We're all involved in the oil business" (1-8) which is emotive and presents the need for change and for our common involvement. In this section, the fact that our everyday lives are based on the use of energy is made salient and the idea that this involves costs is stressed. The need for discovering new environmentally friendly sources of sustainable and renewable energy such as solar power, wind power, geothermal power and hydrogen fuel cells is introduced. Repetition and parallel structures are among the rhetorical devices that give this section its emotive quality. Line 9, "And it will take time" provides the transition to a more factual tone where Shell explains that change will take time and that we cannot dispense with fossil fuels in the foreseeable future. The repetition of the word "cost" helps to create a link between the two parts. This section ends with Shell presenting itself as the indefatigable hero working to find solutions to our problems of balancing our needs with their costs "every day, all over the world".

The last sequence, (lines 16-21) is a call to involvement and Shell is offering and encouraging the reader to participate in a dialogue. It is in line 16, the last time that the pronoun "we" occurs that it is not inclusive but refers exclusively to Shell, the company, who requires "everyone" to respond. In line 12, it is ambiguous and could be understood to refer either to everyone or to the company. Shell cast themselves in the role of a heroic "one of us" helping to save the world for "our" children, a rhetorical return to pathos and an echo of the BP campaign.

The more usual advertisements in the series typically comprised two-page spreads with a photograph expressing a negative state of affairs on the left with an empty Shell logo in its centre, and a positive one on the right with the complete logo. Issues taken up in these advertisements include alternative energy sources, such as in the advertisement "Wish upon a star or make a dream come true?" global warming, "Cloud the issue or Clear the air?" "Exploit or Explore?" which discussing ensuring that biodiversity is respected during oil and gas explorations, and in the example below, human rights, "None of our business? or the Heart of our Business?" Typically, the two statements are common expressions and in this way, constitute a recycling of the concept of the "Some phrases seldom ring true" advertisements of the 1930s (figure 8:24). Another interesting feature of this series is that on both sides, the body copy is ragged on the left hand side and justified on the right, a phenomenon that is rather unusual. However, the result of this is that the texts finish below the centre of the two shell symbols and create a vector to connect the logo with the text. Moreover, the straight left-hand side of the second text leads clearly to the third textual element which is justified on the left but ragged on the right. Yet another function of this use of justification is that it helps to physically compartmentalize the different elements of the text, thereby showing the differences and incompatibility of the approaches.

Another interesting feature of the series is that in small print at the bottom of each left-hand side, the company addresses the matter of identity and tries to clarify their use of the first person plural pronouns. They write: "Each Shell company is a separate and distinct entity. In this advertisement, the words "Shell", "we" "us" and "our" refer, in some places, to the Royal Dutch /Shell Group as a whole, and in others to an individual Shell company or companies, where no useful purpose is served by identifying the specific company or companies." In the "Wish upon a Star" advertisement they further specify that the reference to "Shell International Renewables" refers specifically to "those Shell companies which are 
individually engaged in the Renewables business". Similarly, in a rather larger font size and using the upper case to facilitate the addressee's reading of the text, Shell write: "We welcome your input", inviting a true dialogue and go on to provide a web page, an e-mail address and a physical address in London in order to make contact easy. Across the spread, to the left of the empty logo-shape are the words "Profits \& Principles" and on the right, "Is there a choice? These are followed by the red and yellow logo. In these advertisements, Shell first engage the reader in the issue and then communicate by means of the lay-out that they are bringing hope and a solution to the problem that has been introduced. Typically, the issue is presented in white on a dark background, like a photographic negative, while Shell's stance is presented in black on white. Kress \& van Leeuwen (215) suggest that a white text against a dark background suggests a negative stance.

The issue, the old, known facts, presented in the example shown in figure 8:55 is that of Human Rights and on the left side of the spread, the voice of Shell addresses the reader directly to state the generally accepted view: "Human Rights. It's not the usual business priority. And for multinational companies operating in developing countries, it could be tempting to dismiss it; to call it a socio-political issue rather than a business one, and hope it just goes away." Shell identifies itself as a multinational company operating in developing areas and then suggests that their attitude to the matter is not the usual one. The topic is Human Rights and this is related to business (figure 8:55). The new is that:

1. At Shell, we are committed to support fundamental human rights and have made this commitment in our

2. published Statement of General Business Principles. It begins with our own people, respecting their rights as

3. employees wherever they work in the world. We invest in the communities around us to create new

4. opportunities and growth. And we've also spoken out on the rights of individuals - even if the situation has

5. been beyond our control. It's part of our commitment to sustainable development, balancing economic

6. progress with environmental care and social responsibility. In today's business environment, we don't pretend

7. there are any easy answers, but we continue to stay involved. Because making a living begins with respecting life.

\section{Image removed due to copyright.}


Shell, the company, is the "énonciateur" that addresses the general public who are cast in the role of participant addressee. The verbs that Shell uses to describe its activities all display a positive, proactive stance: "We are committed", "We invest", "We have spoken out" "We don't pretend", We continue". Shell presents itself as a positive, active, dynamic company with a strong social agenda which extends beyond the needs of their own employees to embrace communities everywhere (Keyishian 1996). The impressive list of achievements suggests to the recipient that he too could and should be a conscientious citizen of the world (Bostdorff \& Vibbert 1994) and the contact information provides him with the opportunity to contribute and become part of Shell's achievements, in other words, to become part of the inclusive "we" of Shell and feel good about himself.

What is particularly interesting in these advertisements is the lack of the pronoun "you". Although it features at the end of the "Cloud the Issue or Clear the Air?" advertisement, the pronoun is not directed towards the reader, but is used in the general sense of "people" or "one": "Solutions to the future won't come easily, particularly in today's business climate, but you can't find them if you don't keep looking". In this series, Shell plays the roles both of narrator and protagonist, and is indeed, explaining "about how we work"

From the introduction to the report and the first examples, it could be assumed that all the advertisements in this series would be characterized by direct forms of recipient address, but Shell use these advertisements as a forum for presenting their socio-political stance and is an example of values advocacy (Bostdorff \& Vibbert 1994, Keyishian 1996, Livesey 2001, 2002, Coupland \& Brown 2004, Cook 2008) and the role of the addressee is to listen and learn. Active participation on the part of the addressee is limited to an opportunity to respond to the invitation to contact Shell that is extended at the bottom of the right-hand page.

\section{Towards a new beginning}

\section{British Petroleum}

The new century brought with it a series of major mergers. The first of these was the merger of BP with Amoco at the end of 1998.

\section{Image removed due to copyright. Image removed due to copyright.}


The majority of the advertisements that BP Amoco produced together centred on their work to support the arts and to publicise their performance in the environmental and social spheres.

The example in figure 8:56 was published in the New Statesman in 1999 and ostensibly advertises the Cardiff Singer of the World competition which they ran jointly with BBC Cymru Wales. There is no mention whatsoever of the new company's business and it merely features humorously in the play on words where "supporting company" replaces the "supporting cast" which could be expected. However, the new company name is prominent (Rossling 2001) and BPAmoco casts itself as a patron of the fine arts (Bourdieu, 1984 1986, Stallabrass 2004) and as a philanthropic organisation (Harry Keyishian 1996, Sen \& Bhattacharya 2001).

The example in figure 8:57 from May 1999, explains how besides reporting their financial results, the new company "account[s] publicly for [its] performance in the environment and society" and how this report "tells you honestly of our performance in meeting stringent targets of controlling pollution and reducing our effect on the environment." The report (Matteo Fuoli 2012) also covers the company's goals of ethic responsibility wherever they have a presence (Kotler 1986, Sen \& Bhattacharya 2001, Koller 2008). The advertisement explains that four cases are featured, one of which concerns Eygpt, where they "have a significant programme of support for education benefitting children like the two featured" and advises the reader how they can obtain the report. The two boys look up at the reader, smiling and happy. The close shot and their direct gaze demands our response and the angle both reinforces their size and also their dependence (Kress \& van Leeuwen 1996) upon the outside world, represented by BPAmoco, for a secure future. This is the only instance in my corpus of a BP advertisement which shows people in close up facing the camera demanding response. Generally, people are portrayed as types, often with their backs to the camera as representatives of a group. Even in the case of Colin (figure 8:52), we are distanced from the boy who does not seek contact. Later advertisements centre round the company's work with museums and educational exhibitions for children in the U.K.

\section{Beyond Petroleum}

However, the joint name was short-lived and by the end of 2000, the company was simply BP and the helios ${ }^{52}$ logo (Flosch 1995, Rampley 2005, Scott \& Vargas 2007) as well as the new concept of "Beyond Petroleum" were born, as the example in figure 8: 58 from the Christmas 2000 issue of the New Statesman shows.

The visual shows a calm, blue ocean with a clump of trees replacing the oil rig that might otherwise be expected under the letters BP and four white boxes of white text act as clouds running across the clear blue sky from the corner of the BP box to the top right-hand corner, the place of dreams and visions. The sentences in the boxes all connect back to BP and read: "BP means being a global leader in producing the cleanest burning fossil fuel. Natural Gas; means being the largest producer of solar energy in the world; means being the first company to introduce cleaner burning fuels to many of the world's polluted cities: means starting a journey that will take the world's expectations of energy beyond what anyone can see today."

The white flash of light which runs across the pages reinforces the purity symbolised by the colour palette (Kress \& van Leeuwen 2002, van Leeuwen 2011) and compounds the mystique of the image.

\footnotetext{
${ }^{52}$ Helios was the sun god and this is discussed in more detail in Chapter 9. BP was the first company to work seriously with solar energy, (figure 8: 52) and thus, the choice of logo is perhaps not surprising
} 


\section{Image removed due to copyright.}

Figure 8:58 BP and the helios

Later advertisements used the helios symbol and also the slogan Beyond Petroleum.

By the mid-1990s, the focus of BP's advertisements was the need for energy diversity. Two series carried this message. The message communicated in the first one consisted of a statement which was often based on a common saying or currently discussed phenomenon such as "It's time to go on a low carbon diet" an allusion to diet fashions and a play on the words carbon and carbohydrate. This series attracted the reader's attention by combining a statement which jars in some way with what might be expected and the bold yellow that highlighted the key words. The example in figure 8:59 plays on the expression "to think outside the box" and hails the reader with the statement that "It's time to think outside the barrel". This of course refers to the notion of oil which is sold in barrels and suggests that we must look to new, alternative sources of energy. In this example, each of the text boxes takes up one of the issues, highlighted in yellow, that are important to BP. The first is the Environment, and BP states that: "In 1997, we became the first major energy company to acknowledge the need to take precautionary steps against climate change by reducing greenhouse emissions" and goes on to say that it is ahead of target in this area. The other issues are communities and working with self-help programmes while the third is education as they recognise its impact on both society and businesses. In this advertisement, BP explains how it is working with both the WWF and the Chinese Education Ministry to introduce the concept of sustainable development among 200 million Chinese children.

The example in figure 8:59 is one which appeared in the New Statesman and therefore targets a British audience (Perelman \& Olbrechts-Tyteca, 1958, Burke 1945, Weinstein and Deutschberger 1963, Sacks et al 1974, Scott, 1994, Alan Gross 1999, Bolduc \& Frank, 2010). 
Image removed due to copyright. Image removed due to copyright.

As in the case of BP advertisements in the late 1950s, the references that are made are exclusively British and the reader is expected to be familiar with places like Hull. BP identifies with the needs of the U.K with statements like; "It's going to take a menu of energy sources to ensure that we have supplies that we can rely on," and facts like the company is "on target globally to generate wind electricity to the annual needs of some 700,000 average UK households." BP is presenting the face that is preferred by the British public.

One thing that is particularly interesting with this campaign is that the company ran a similar one in the United States, but while the advertisements in the British series proclaimed that the aim was to secure energy supplies through diversity, the American advertisements focused on biofuels. In this series, the frame of reference was purely American, with for example, frequent references to Dupont, a large U.S company with which BP was working "to develop an advanced generation of biofuels". Other statements made in this series include "Sugar beet, corn, wheat. Our recipe for renewable fuel," or "local, homegrown ingredients," with its connotations of homeliness, good nutrition values, healthiness and security in the bosom of your family. Moreover, while the economic benefits of these new biofuels are suggested, it is only for farmers. When bio fuels were mentioned in the European advertisements, BP were careful to point out that the bio fuels used did not impact upon food supplies whereas in the U.S. advertisements, this aspect was completely ignored (Fairclough 1995, Martin \& White 2005). Another interesting comparison between the two series is that while the UK advertisements were for ways to secure energy supplies, those aimed at the US public centred on "gasoline" and also insisted; "we're investing \$15 billion over ten years to find and produce new energy supplies in the Gulf. In fact, BP is the largest investor in U.S. energy development, investing \$30 billion over the last five years." These two versions of BP's alternative energy advertising discourse reveals clearly their understanding of the importance of identifying with the audience and also the differences that the company perceived between their various European and American stakeholders.

The second series appeared not only in the press but also as posters, for example, outside Heathrow's Terminal 4 and also stresses the importance of energy diversity. The example 
shown in figure 8:60 can be considered to be the prototype as others in the series built on this. One advertisement, for example, reads "The answer to energy security: all of the above" and the five alternatives hang from power lines running above the text while another example stares: "There's strength in numbers, and security in having a number of energy sources" and goes on to explain they are working towards "a more dependable energy future" for Britain and invites the reader to "Learn more at bp.com."

However, the focus of the majority of BP's advertisements was its work with and support of the arts. The advertisement in figure 8:61 from the New Statesman 2001 tells the reader "How BP helps to change the face of arts in London" a visual and textual metaphor which attracts attention and interest (Redfern 1982, McQuarrie \& Mick 1992 Abel 1994, Leigh 1994, Djafarova 2008). Each quadrant of the face represents one of the institutions that they support and also explains from where they have been taken. The top left quadrant represents the Tate Britain which is illustrated by Sir Joshua Reynolds Self Portrait as a Deaf Man from 1775, which is part of their extensive collection of British art, while to the right, the British Museum is illustrated by a cast gold mask from Colombia and dated 600-1100 AD. The lower quadrants represent the Royal Opera House, illustrated by a Singer, and the lower right quadrant the National Portrait Gallery, where the company sponsor an annual portrait painting competition. The text tells the reader how "BP seeks to help the arts to continue to provide fresh experiences for people in London" and insists on the importance of public support for the different events, such as Regent's Park Open Air Theatre, is vital.

\section{Image removed due to copyright. Image removed due to copyright.}

The advertisement in figure 8:62 from the British Museum was published in the New Statesman at Christmas 2010 and was the first advertisement that I found from after the Deep Water Horizon disaster that occurred in the Gulf of Mexico in April that year and which resulted not only in terrible environmental damage, but also in the loss of human life. The advertisement invites the reader to visit the special exhibition of the Book of the Dead ${ }^{53}$ at the British Museum which is sponsored by BP.

\footnotetext{
${ }^{53}$ Whether or not the choice of the word "afterlife" in the headline is a conscious attempt at humour on the part of $\mathrm{BP}$ is a matter of speculation.
} 


\section{ExxonMobil: Taking on the world's toughest challenges}

ExxonMobil, which is the direct descendant of Rockefeller's Standard Oil, came into being in November 1999 when Exxon and Mobil merged to become the largest of the Super Majors. The corporation was ranked number 5 globally in the Forbes Global 2000 in 2013. ${ }^{54}$

Although they too advertised their promotion of the arts, among other things, their sponsorship of an exhibition of Pisanello's paintings at the National Gallery, ${ }^{55}$ two campaigns with the slogan "Taking on the world's toughest energy challenges" have dominated their advertising.

\section{Image removed due to copyright. Image removed due to copyright.}

The first of these consisted of a series of advertisements that built upon Exxon's television commercials from their "Human Driver" campaign from the late 1990s. The print advertisements that ExxonMobil produced featured a motorist or other individual being transported in a motor vehicle. Structurally, the most salient elements of the advertisements are a series of circles of different sizes that are connected by fine lines. The meaning of the circles is rather ambivalent and they can be interpreted as thought bubbles emanating from the "driver" or "driven" participant and as also as glimpses of their peripheral vision. The circles contain either text, or photographs taken from the actant participant's perspective.

In the example in figure 8:63 which is from 2007 the text in the topmost circle reads "today, an energy company and a leading university". This is linked to the smallest circle by a line and the text reads "share a common goal." This circle, which is the largest and is in the centre of the page is the focal point and contains the passenger and the words "the common good." The other circles contain a glimpse of the driver and there are two other connected circles

\footnotetext{
${ }^{54}$ It is the world's third largest company by revenue and its largest shareholder is the Gates Foundation .

55 These advertisements appeared in The New Statesman 5 times during the winter of 2001.
} 
with the words "today, an energy company and a leading university" in the largest and "share a common goal" in the smaller. This leads back to the passenger and "the common good". The company voice then anchors the visual by explaining to the reader how

“[a]long with other industry leaders, we've helped establish a research centre at Stanford University in California, dedicated to finding new technologies that meet the world's growing energy needs, whilst dramatically reducing greenhouse gas emissions." The company goes on to explain how this Global Climate and Energy Project, which is a pioneer in the field of low greenhouse gas energy research, provides research awards in four European countries and is "challenging the world's best minds to develop new thinking and new energy solutions. Which is good news for all of us."

From the specific "we" of the company, the voice moves to the inclusive "all of us" to show how the work of ExxonMobil is essential to everyone, to "the common good".

By 2008, the circles of the first "Taking on the world's toughest energy challenges" had developed into the atom formation that is seen in the bottom right corner of figure 8:64. The first two advertisements to use this were double-page spreads that portrayed ExxonMobil experts of different kinds. Each advertisement showed two named experts; one portrayed two male experts and the other, two women. They were photographed half body, a social distance, to suggest a fairly personal relationship with the reader, standing slightly one behind the other, smiling and gazing at or towards the camera in a way which implies involvement (Kress \& van Leeuwen 1996). Each makes a brief statement about the importance of their specific area of work. For example, one of the men, the lithium battery specialist explains how the innovation of a "new separator film" which is "one recent innovation", thereby implying that there are many, will make batteries safer and more reliable, and thereby lead to lower emissions. This is done in a sentence which matches three strong, comparative adjectives, "safer", "more powerful" and "more reliable" with three potential results, "more hybrid and electric vehicles on the road faster, boosting fuel economy and dramatically reducing emissions." The close shot, his name and his title within the company suggest reliability and inspire confidence.

Like the example in figure 8:63, the advertisement closes with the company voice and an inclusive comment or question. The blue-grey elements of the atom formation are filled with chemical formulae and equations. The colour and the atomic formations connote technology (Kress \& van Leeuwen 1996:88). Moreover, like the earlier series, the statements made as the headings are written without capital letters. However, an internet contact address is provided.

After a run of these two advertisements during 2008 and into 2009, ExxonMobil developed the concept further (figure 8:64). The atom structure still features in each advertisement, but more people are portrayed and moreover, they are portrayed in different combinations at full length, and thus socially more distant. The example shown here, "Many parts working together - the only way to solve the world's energy challenges" is illustrated by a group of four individuals of different ages, ethnic backgrounds and gender, all looking with friendly confidence towards the reader. The concept of different parts working together is further illustrated by the metaphoric cogs on the wall behind the experts. However, this campaign has two particularly interesting features and can be divided into two series. The first series follows the format shown in figure 8:64, and although the individuals portrayed differ from advertisement to advertisement, the anchoring, explanatory text remains the same.

"By 2030 we expect energy demand to be 35 percent higher than it was in the year 2005, driven largely by people in the developing world seeking higher standards of living. Meeting this growing long-term demand requires that we develop all economic sources of energy - oil, natural gas, coal, nuclear and alternatives. 
This global energy demand is matched by a global environmental challenge - curbing greenhouse gas emissions and addressing the risks of climate change. No single energy technology available today solves this dual challenge, and it is very likely no single energy technology will solve it tomorrow.

We need an integrated set of solutions, powered by technology and innovation - ranging from producing energy more effectively ... to using it more efficiently ... to developing new options.

ExxonMobil is working to help meet the world's energy challenges - investing billions in additional supplies, developing technology options to improve vehicle efficiency and testing new carbon capture technologies that could reduce emissions significantly. Because only by integrating all of our energy options - new sources and new technologies - will we solve our dual energy and environmental challenges."

The rhetoric of ExxonMobil is based on logos and the company presents facts and assumptions. The pronoun "we" occurs four times; on the first occasion, it refers to the company and to their assessment of the situation while in the following cases it is somewhat less clear and could refer to a generalised "all of us". However, two things are very clear. One of these is that ExxonMobil take for granted the fact that demand will increase while the other is that this is recognised to be a problem. However, rather than using this rather uncomfortable word, ExxonMobil prefer the rather euphemistic term "challenge" and talk of the dual challenge of energy supplies and environmental degradation that we are facing.

The second series in this campaign is based on the individual characters portrayed in the first. In this second series, individual experts are introduced by name and the work in which they are engaged is presented (figure 9:28). ${ }^{56}$

\section{The World of Chevron}

Chevron $^{57}$ too came into being at the turn of the century and was formed in 2001 by the merger of what was then Chevron and Texaco. As in the case of the BP merger with Amoco, during the first years the newly formed corporation used both names, ChevronTexaco, but by 2005, was simply Chevron.

Among the first Chevron advertisements that appeared in The Economist in 2005 is one that I choose to call "from Dave" (figure 8:65). The headline of the advertisement forms a banner over the letter below, which is from David J. O'Reilly, the Chairman and CEO of the Chevron Corporation to an unspecified addressee. This lack of addressee implies that the letter is to everyone. The inclusive use of the pronoun "we" and the direct address to an unspecified "you" substantiates this implication. "It took us 125 years to use the first trillion barrels of oil. We'll use the next in 30 . So why should you care?

The text ends with the hand-written signature, "Dave" and a small note, seemingly stuck to the bottom of the letter that asks the question "willyoujoinus" but which in reality, is a website. The letter is on a wooden surface covered with maps, graphs and oil-related pictures in a manner which is characteristic of the series and which shows different aspects of the oil business while at the same time suggesting that the writer is busy, has many different things to deal with and has a good overview of the situation from the figures generated to the individual people involved.

This is a very interesting advertisement. It "leaks" the genre into a new dimension (Opacki 1987, Todorov 1990) and it takes the idea of inclusivity one step further. The company voice

\footnotetext{
${ }^{56}$ An example from this group of advertisements will be discussed in the following chapter.

${ }^{57}$ Chevron was born out of Standard Oil California which was formed in 1911 as a result of the Sherman Antitrust Act which forced Standard Oil to split (Yergin 2008) and it merged with Gulf Oil in 1984 and took the name Chevron Corporation.
} 
becomes much more than the voice of a multinational corporation addressing its stakeholders (Bhatia 2002, Koller 2008) and instead, the "énonciateur" is cast as the company CEO, who after a presenting the situation that we are facing and explaining the alternative courses of action that we can choose, signs off as a friend, as someone we know, as "Dave".

\section{Image removed due to copyright.}

Figure 8: 65 Dave

1. Energy will be one of the defining issues of this century. One thing is clear:

2. The era of easy oil is over. What we all do next will determine how well we

3. meet the energy needs of the entire world in this century and beyond.

4. Demand is soaring like never before. As populations grow and economies

5. take off, millions in the developing world are enjoying the benefits of a lifestyle

6. that requires increasing amounts of energy. In fact, some say that in 20 years

7. the world will consume $40 \%$ more oil than it does today. At the same time,

8. many of the world's oil and gas fields are maturing. And new energy discoveries

9. are occurring in places where resources are difficult to extract.,

10. physically, economically and even politically. When growing demand meets

11. tighter supplies, the result is more competition for the same resource.

12. We can wait until a crisis forces us to do something. Or we can commit to

13. working together and start by asking the tough questions: How do we

14. meet the energy needs of the developing world and those of the industrialized

15. nations? What role will renewables and alternative energies play? What is

16. the best way to protect our environment? How do we accelerate our conservation

17. efforts? Whatever actions we take, we must not just look to next year, but to

18. the next 50years.

19. At Chevron, we believe that innovation, collaboration and conservation are

20. the cornerstones on which to build this new world. We cannot do this alone.

21. Corporations, governments and every citizen of this planet must be part of

22. the solution as surely as they are part of the problem. We call upon scientists

23. and educators, politicians and policy-makers, environmentalists, leaders of

24. industry and each of you to be part of reshaping the next era of energy.

After the initial statement of fact with which the text opens, "we" the addressees, are cast into the role of actant participants: "What we all do next" (line 2) and given responsibility for the 
future. Interestingly, Dave states that "there is no easy oil" 58 a statement that automatically generates a certain sympathy and respect for the company's endeavours. This is followed up in lines 9 and 10, where the circumstances that surround the extraction of oil are pointed out. It also suggests that the difficulty of the operation should also allow them a certain level of understanding in the extraordinary case of failure. In other words, it is a disclaimer. The pronoun "we" occurs eleven times, including twice in line 2, and "our" occurs twice in the twenty-four lines of the text. Additionally, both words feature once in the headline. The "we" changes character in the last paragraph (lines 19, 20 and 22) to become the "we" of Chevron, the company. Chevron then addresses the reader directly, "each of you" in line 24, before asking the question will you join us? However, from line 12, the identity of "we" is less clear. Does it refer to Chevron or to a responsible collective? In line 19 it is clear that "we" is Chevron.

The rhetorical structure of the advertisement is interesting. In the first half, Dave describes the situation to the readers of his letter, and then in the third paragraph, presents the alternative courses of action that we can take together (line 12). These alternatives are presented as waiting or as being proactive. Assuming that we choose to act, Dave then poses four questions that need to be addressed: growing energy demand, the role of renewables and alternative sources of energy, the environment and conservation. He insists that we must take a long-term perspective $(17,18)$. It is not until the final paragraph (line 19), after the situation and the possible alternatives have been detailed, that Chevron is mentioned and becomes a participant and agent of reform and development. This part of the text abounds with alliteration and assonance (lines 19, 20, 21 in particular). The use of parallel structures, again with alliteration as a stylistic device, (lines 21,22) adds to the intensity of the appeal. Moreover, Chevron make three statements about their stance on the situation, "we believe", (19), "we cannot" (20) and "we call upon" (22); each of which raises the intensity of the exhortation to help. This is partly brought about by the use of alliteration in the latter two, particularly as that of line 22 recalls the earlier alliterations of the paragraph. The tripling of elements (solutions in line 19 and potential participants in 21) helps to build up to the final call which includes "each of you" (24). This advertisement is a very interesting example of the phenomenon concerning the effect of words penned by the CEO that is identified and discussed by Ken Hyland (1998).

Chevron launched a very interesting advertising series in September 2007, called willyoujoinus. This series appeared regularly throughout 2008 and was part of a campaign that included an on-line computer game, rather like The Simms. The advertising campaign began with a single page advertisement showing a modern city skyline silhouetted against a dull, grey-white evening sky. The buildings, which were predominantly skyscrapers, were completely in the dark. The text, in dark grey letters against the milky sky simply read: "This is your city" (figure 8:66). The following week showed the same city, but the words read: "Your city is waiting" (figure 8:67).

\footnotetext{
${ }^{58}$ This is a position that the companies return to in their advertisements. One reason for this could be to gain sympathy for their endeavours and another could be to underline the risks and problems involved.
} 


\section{Image removed due to copyright. Image removed due to copyright.}

Finally, at the end of September, The Economist included a cleverly constructed fold out twopage spread advertisement (figure 8:68) which opened up to show an illuminated city against a blue evening sky, with a "plane flying overhead and a red, lit-up parking sign at the bottom right hand corner. The text read: "This is your city. How will you power it?"

\section{Image removed due to copyright.}

\section{Figure 8:68 Energyville}

The full text explained: "Chevron presents: Energyville an energy game developed by The Economist Group." This was followed by a series of questions. "How do we meet growing global demand? What new kinds of fuels and power sources should we develop? And how do we safeguard the environment at the same time?" The reader was then asked to join in the development work and play the online, interactive game, Eneryville where each individual's theories could be put into practiced and the results shared and discussed, "Because only when 
we come to understand and discuss the energy problems our planet faces, can we find the inspiration and know-how needed to solve them together." The addressee was then encouraged to "Play it. Power it. Discuss it" and provided with the "willyoujoinus" address.

After initially involving the reader though the direct address of the two opening statements, "This is your city. How will you power it?" he is asked three questions. "How do we meet growing global demand? What new kinds of fuels and power sources should we develop? And how do we safeguard the environment at the same time?"

The repeated use of the first person plural and the direct address creates a sense of escalating urgency but also directly involves the reader. The first person plural pronoun is ambiguous as it could refer to the company or to the company together with the reader or even to mankind. The following sentences imply that the problem is general and not company specific; "These are the questions facing us all. And together, we can find the answers."

The second paragraph explains how "Chevron brings you Energyville, an online, interactive game that puts you in charge of meeting the energy demands of your city" and explains how the game is to be played. The reader is invited to "put your theories into practice" and told that the idea is to choose "from a portfolio of energy sources to power your city today, and through to 2030." The role and participation of the reader is stressed by the recurring use of "you" and "your" and the paragraph ends with the statement "Every decision you make will affect the environment, the economy, and your city's security" which delegates responsibility to the reader-as-participant. The city, blazing with lights and the transports clearly illustrated on the right side of the picture represent the unquestioned growing demand for energy, and consequently, the need for new energy sources, environment, economy and security that are all established as important elements for the world and implicitly, are matters which Chevron are working to solve.

The language of the text is factual and places the reader firmly in the centre of both the problem and the solution. The implication is that the reader is aware of the problems and has spent some time thinking about them and about possible solutions and is encouraged or instructed in the third paragraph to "share your results and challenge others." This, according to Chevron is "Because only when we come to understand and discuss the energy problems our planet faces, can we find the inspiration and know-how needed to solve them together." (My underlining). Chevron positions themselves as a partner in an inclusive community of humanity (Pennycook, 1994a) that must work together to solve our common problems.

When the advertisement appeared in full in The Economist in the fourth week of September, it was followed a few pages later by a second advertisement, headed "Who is going to help meet a global energy demand that is expected to grow about $50 \%$ by 2030 ?" which referred directly back to Energyville. Below the question, written in white against a mustard yellow background, is the answer; "Join us, and you will" (figure 8:69). Again, Chevron addresses the reader directly as a potential partner. The question and answer fill the upper quarter of the single page, and below is a blue folder, with a mobile phone on it to the right and a sheet of paper with a message and the Chevron logo and the slogan "Human energy" lying over the phone. The text of the advertisement functions as a job advertisement and invites people to apply to Chevron for careers opportunities.

"At Chevron, delivering energy begins with our global business team. From developing innovative strategies to managing our financial practices throughout the process, you'll be a part of an extraordinary group of individuals helping to meet the world's growing energy needs. Find out where your skills and talents can take you. Visit us online today." 


\section{Image removed due to copyright. Image removed due to copyright.}

The visual elements of the advertisement portray people at work and the young woman in the foreground illustrates the idea that Chevron is a company for everyone, young and old, male and female. This attitude is confirmed by the photograph behind her. The young woman has been photographed at a social distance, at eye-level and at a frontal angle to suggest equality and involvement. She is looking at the reader demanding interaction and encouraging response (Kress \& van Leeuwen, 1996:154). The pen angled downwards leads the reader's eye to the Chevron logo. The pen does not merely function as a pointer but also as a symbol of communication, referring back to the personally signed letter from "Dave" the CEO.

An example of the third type of advertisement that Chevron produced at this time is shown in figure 8:70 and emphasises the inclusivity of Chevron, not just as a potential employer but as a company that works for as well as with everyone. These advertisements often appeared as double-page spreads. The example above sometimes appeared as a double-spread where the right hand page is the blue colour of the Chevron logo and all that is on it are the words "The world is growing by more than 70 million people a year" across the top, and below, in a smaller font, the question "So is that a problem or a solution?" Again, in this example there is a pen pointing at the Chevron logo to the right of the page and this is lying on a letter which is placed on top photographs of very different people in very different situations, ranging from a mother bathing with a young baby to a competitor in the Paralympics or a football game in the desert. The insistence on letter-writing in these advertisements adds another layer to the inclusiveness of the company's communication. Everybody is welcome to participate, not just people with access to the internet and who can log onto the willyoujoinus site, for example.

The text of the advertisement begins by stating the problem. "With our planet's population continuing to increase, and the quality of life for millions in the developing world improving daily, our demand for energy is also growing." The continuous tense indicates agency and dynamism and the traditional rhetorical device of a list of three is used to introduce the background to the problem, to qualify it positively and to state the consequences; namely, "that to meet everyone's needs from now may take 50\% more energy than we use today." The 
challenge is introduced in a new paragraph and "could be one of the greatest ...our generation will face" and is defined as "(f)inding and developing all the fuel and power we need for our homes, businesses and vehicles, while protecting the environment". Again, the informant, or writer of this text employs lists of three for the needs and elements of challenge.

The writer then goes on to explain how the challenges can be overcome: "The key to ensuring success is found in the same place that created this need: humanity itself." The colon marks a rhetorical pause before the solution is named as well as "the unique spirit we all possess." "We" as members of "mankind" are accredited with the ability to "take on, and overcome, any issue" if only this spirit "is allowed to flourish". There follows a list of five positive qualities with which this spirit is accredited; "hard work, ingenuity, drive, courage and no small measure of commitment. To success, to each other, to the planet."

These advertisements reflect the company's mission statement: "At the heart of Chevron is our Vision to be the global energy company most admired for its people, partnership and performance" (Ries \& Ries 2004).

From about 2010, Chevron introduced a new advertising campaign "We Agree" which builds on the idea of partnership, joint responsibility and action.

This campaign consists of a series of television commercials which take up those issues that they believe are important in the places where they are active, and propose ways in which oil

\section{Image removed due to copyright.} companies should work to improve the social and environmental situation of those living in these areas. Print advertisements then appear in major periodicals, for example, which summarise the commercials.

\section{Figure 8: 73 We Agree}

The individuals portrayed represent the work with corporate responsibility in which Chevron is engaged (figures 7:3 and 11:5)., and are almost exclusively female and are from developing countries. The example in figure 8:73 is one of the earlier advertisements, and is also one of the very few in which the women portrayed are smiling. Although the photographs have been taken close-up, at an intimate distance, the women are not directly involved with the reader. The woman to the right has her gaze firmly fixed on a bright future, as the direction of her gaze implies. When we follow her gaze we are directed to the reason for her optimism, namely that oil companies should support local communities, and we are led to infer that this is exactly what Chevron has done and that she has been granted a micro-loan with which she can build a future for herself, her family and her community (Livesey \& Kearins 2002, Koller 2008). The second woman is depicted as a kind of reactor, looking at the happy actant who is looking outside the photograph (Kress \& an Leeuwen 1996) and also functioning both as a vector to lead the focus of our attention to the first woman and also to compound the happiness expressed by the first. 


\section{Total: Our energy is your energy}

The present day French corporation, Total, also came into being in its present form during this period after Total's takeover of Belgian Petrofina in 1999 and then of Elf Aquitaine, and finally the name Total was adopted in $2003 .{ }^{59}$

The original Total had advertised occasionally in the British press, mostly to advise that they were expanding their presence in the U.K. However, after 2003, the new company began to advertise more frequently and advertisements appeared regularly in The Economist, for example with the slogan "Our energy is your energy."

The first series of advertisements was composed of two photographs linked by a common colour palette. The example shown in figure 8:72 is typical of the series (see also figure 9:24). The top photograph makes a statement which is completed by the second in a contrasting colour. In figure 8:72, the words in white that accompany the top photograph

\section{Image removed due to copyright.} "Looking after a scarce resource" are completed by the words "To secure the future of energy" and the smaller text explains how Total is searching for new sources of oil and of energy to secure supplies in the future and for ways to reduce the use of oil which is a "valuable resource". Their contention is that "extending the life of oil" means to reduce its use in industry, and like the other majors, state that demand will increase.

The visual shows a Total oilman in silhouette

Figure 8: 72 Our energy is your energy against the beautiful, dawn sky. His work secures the energy future of the child whose toy aeroplane mirrors the real aeroplane that is silhouetted in the sky and is a metaphor for future energy needs. As Total tell the reader, the energy that they produce is for us; they are working to secure our energy future because "[their] energy is our energy".

In August 2007, Total announced a more energy efficient and more environmentally friendly fuel, and in January 2008, the company was required to pay compensation to the victims of the pollution caused by the sinking in 1999 of the Erika. ${ }^{60}$ The advertisements in the second series are a response to these events.

Each advertisement of the series has a heading, the first word of which begins with the letters $\mathrm{CO}$, reminding the reader of the problems of $\mathrm{CO} 2$ and showing how Total plans to combat this major threat to the environment. "Commitment to discovery", "Common interests", "Complementary, naturally", "Contributing to our future" and "Consumer benefits" are some examples of the topics addressed by the advertisements in this series. The letters $\mathrm{CO}$ are in a

\footnotetext{
${ }^{59}$ After various different company names, the Elf was completely removed, probably to disassociate the company from the Elf Aquitaine scandal, discussed in Shaxon (2011).

${ }^{60}$ The Maltese registered tanker broke up and sank off the Brittany coast in 1999 leaving a fifteen kilometre-long slick of heavy oil. Total appealed against the verdict which was upheld by the French Courts on September $25^{\text {th }}$ 2012 requiring them to pay compensation.
} 
different colour, for example, blue in the case of Common interests and pink in Consumer benefits, while the rest of the heading is in white or black. Below each heading is an unpunctuated sentence beginning with a capital letter and the words "Imagine if".

Structurally and artistically, the "Co" series builds on the earlier advertisement (figures 8:72, 9:24) that comprise two half-page photographs, placed one on top of the other, a "harder" one showing the work of the company and another "softer" photograph with a strong, dreamy, human element (Kress \& van Leeuwen, 1996). The slogan "Our energy is your energy" and the colourful Total logo are at the bottom and in the bottom right corner of the page. While in the earlier series the photographs are both the correct way up, this series turns the lower photograph upside-down and the silhouettes and darker colours of the earlier series haveoften been replaced by a lighter colours, often gentle pastels.

\section{Image removed due to copyright. Image removed due to copyright.}

The first of the advertisements shown here, (figure 8:73), "Commitment to discovery" is followed by the words "Imagine if a sustainable energy future also depended on the discovery of new oil resources" printed in black against the summer sky dotted with cumulous clouds that fills the upper part of the page. Below the sky, a calm blue-grey sea disappears into the distance beyond an empty beach of clean white sand. In the distance, a plane is flying out of the top right of the page and to the right of the centre, two strong male arms, clad in a blue shirt with rolled-up sleeves, is holding aloft a young boy, flying like the aeroplane. The boy is also dressed in a blue shirt, is wearing jeans and is bare foot. The boy bares a strong resemblance to the child silhouetted in the 2007 series. At first sight, the bottom half of the photograph seems to be a reflection of this in a pool of clear still water left by the tide. However, closer inspection shows that it is an upside-down khaki-clad engineer talking into a walkie-talkie, a measuring instrument of sorts on a stand in front of him, pointing towards a drilling rig in the distance. At first sight, his legs seem to merge with the arms holding the child aloft and the grey-blue of the lower part of the page seems to reflect the clouds above. 
When the page is turned upside-down, the details emerge and the engineer, or perhaps geophysicist is in a desert and the sandy beach with its hollows is a landscape of sparsely vegetated sand dunes, prospecting for oil. The pool of water is the cloudless sky.

The four-line text, in a small black font at the bottom of the page describes the work depicted in the lower part of the double photograph. The factual, objectivity of the text which is reinforced by the portrayal of Total as the third person topic is in stark contrast with the soft, dreamy nature of the visual.

"Although oil resources are still plentiful, to satisfy growing demand both now and in the future Total continues to make significant discoveries. Relentlessly seeking to increase the productivity of oil field reserves, we innovate to exploit new sources of fossil fuel. But because oil is precious, it will be vital to focus its usage in those areas where it is hardest to replace: in transportation and petrochemicals. $w$ ww.total.com".

These words echo those of the example in figure 8:72.

"Contributing to our future" continues the desert theme. The upper part shows a desert landscape with a row of what seem to be sections of a huge oil pipeline stretching far into the distance towards the barren hills on the horizon while the "reflected" upside-down photograph shows a calm, grey ocean with a red boat, a tanker, which follows the trajectory of the pipe line towards the right of the page. In the distance are dark heavily vegetated hills and mountains forming bays and coves and which echo the hills of the desert in the image above. The main theme of these two advertisements is that Total is working globally to ensure energy supplies worldwide.

The theme of the example shown in figure 8:74, "Common interests" is climate change and environmental protection. In this advertisement, "Imagine if confronting climate change and solving energy needs were inseparable" the problem of global warming which is suggested by the icebergs is contrasted with our need for energy, exemplified by the illuminated modern city which is reflected as the shadow of the icebergs. The text that accompanies the images states:

"For Total, satisfying energy needs sustainably and controlling the environmental impact of our activities are our top priorities. In our search for new sources of fossil and renewable energy (such as solar and biomass), the Group is working hard to achieve greater energy efficiency and optimise processes to cut greenhouse gas emissions. With a pilot project to capture and store CO2 in France's Lacq basin, Total is developing innovative technology to confront global warming."

Again, while the visual elements of the advertisements are pleasurable, poetic, attention attracting "dreamwork" (Davidson 1978) which require interpretive input from the reader (Stern 1990, Bonhomme \& Lugrin 2008), the text is factual. The website address is provided for further information.-

The need for more energy while minimising the impact on the environment is the theme of Total's advertisements just as it is for those of ExxonMobil, the Chevron advertisements prior to 2010 and the energy diversity campaigns from BP.

\section{Shell in the twenty first century.}

I end this diachronic survey and analysis of the print advertisements published by the oil companies just as I began; with Shell. In 2002, the company stared a new campaign called "People, planet and profits". This was based on based on the Shell Report from 2002 and featured real people who worked with the company and included North Sea fishermen (figure 
$7: 2$ ). The company explained how by listening to these experts in other fields and working with them, they could achieve better results.

In 2005 they announced a new partnership with WPG (the World Press Group) comprising BusinessWeek, The Economist, Fortune, International Herald Tribune, National Geographic, Newsweek and Time and with this, a new communication strategy. The new campaign, "Real People", dates from September 2005 (figures 7:4, 9:36).

In the advertisement that announced their new advertising strategy they wrote "WPG provides the business credibility, commercial flexibility and international delivery we sought for our new global communication strategy". They then listed the different elements of the campaign, which aimed to "break new ground". Their "Creative concept", for example, was to use "real people and real stories to create greater impact and better understanding of Shell's tangible response to the global energy challenge". They also stated that their media strategy was to "switch focus from advertisement exposure to real engagement via media partnerships and events".

The series built on the ideas of the 2002 advertisements but moved beyond the direct sphere of the company to incorporate a much wider variety of professions and to demonstrate the farreaching impact of Shell on our daily lives. The new series consisted of head and shoulders studies of individuals from different backgrounds, gazing into the camera and therefore looking directly at the reader and seeking response. This "breast pocket shot" is typically used to connote expertise and reliability, (Kress \& van Leeuwen, 1996); a quality which is compounded by the naming of the individuals portrayed. The photographs were framed with a question at the top and with the answer of the actant or agent, photographed below. Thus, the individuals in the photograph participate as themselves, as representatives of a profession and as a voice attributable to Shell and which endorses Shell.

This participant role is shared by individuals from very diverse businesses, and includes Matsatejo Sokiaw, who is the Plant Manager of an LNG joint venture between Mitsubishi, Shell and the government of Brunei, and Rick Scott, (7: 4) an American who together with his team "has already opened the world's first hydrogen filling station in Washington DC". As these examples indicate, the individual behind the voice is named. Participants come from all over the world and demonstrate the scope of Shell's activities.

Each advertisement ends with an individual e-mail address that includes the name of the actant participant, or endorser. This individualizes the advertisement and implies a personal relationship between the endorser and the addressee who is encouraged to contact this participant directly. In this way, the company seemingly removes the role of themselves as middleman or conduit between the two depicted participants, the endorser, and their potential partner in dialogue, thereby fostering a sense of direct communication between individuals. The example in figure 8:77 shows how Shell are involved in the Japanese food industry and also underlines the global nature of their business. The participant voices are those of Shell, who first asks the question and then reports the answer of the represented participant and provides the explanation to the answer. In each case, the red and yellow Shell logo is prominent at the bottom right-hand corner, showing that Shell is cast in a participant role.

In the example shown in figure 8: 75, the chain of reliance upon Shell for the Japanese noodle manufacturer is stressed in the first two sentences. Shell present themselves as an important cog in the machinery of everyday life and provide the addressee with an angle that would not usually be considered. Moreover, the global implications of Shell's work are illustrated and underlined by the references to places as far apart as Japan and Australia. In line 5, Shell 
changes from figuring as the third element of the living tripartite unity (Bakhtin 1981) to becoming the Ego of the narrative; "our" business, "we're providing energy". The addressee is invited to take a more active participant role "by visiting" the web-site. Here, Shell too, assert that demand will increase (line 4).

\section{Image removed due to copyright. Image removed due to copyright.}

1 "Restaurants and schools throughout Tokyo rely on Takefumi Suzuki for their daily supply of fresh noodles.

2 To keep his factory running smoothly, he relies on energy generated from natural gas, liquefied by Shell in

3 Australia and shipped to Japan. Liquified Natural Gas (LNG) is one of the key energy sources for the future 4 and Shell is the world's leading private supplier. With global demand set to treble in the next twenty years, 5 what's good for Mr Suzuki's business is also good for ours. Find out how we're providing energy for people 6 now and in the future, by visiting shell.com/takefumi"

Shell produced two more series shortly after this.

The first of these, "Real Energy" can be divided into two strands, one called "Start from a different place", while inspired by Wittgenstein, I choose to refer to the other as "Aspect Dawning" . This series dominated Shell's advertising during 2008, but also featured in the years both before and after.

The tic-tac game shown in figure 8:76 "Start from a different place", appeared in a number of forms, the version with the male hands shown below, a version with female hands and the buttons in different positions, some with no anchoring text and some with a few words. There is also a version with the words on the tic-tac game in the correct order that is accompanied by a longer text of some 700 words which expresses the opinion that "Humans were made to be mobile" and traces our nomadic roots during which "[w]e learnt to explore the vast horizons of our planet, and built a trading system that today powers a global economy" and eventually settled in villages and then cities. It insists that "Mobility - for travel, trade and

\footnotetext{
${ }^{61}$ This refers to the issue of "seeing as" exemplified by the duck/rabbit in the 15th lecture of Wittgenstein's Philosophical Investigations, from 1953.
} 
tourism - enriches all our lives. It fuels economic growth, is essential for poverty reduction, and allows us to broaden our experience of the world, family and friends." The company explains how they are working to facilitate this mobility and all the benefits that it brings by researching into a variety of energy solutions and ends by stating: "Starting from a different place means we are making progress on a cost effective development path to cleaner transport. The puzzle continues, but solutions are under way."

One very interesting aspect of the longer version of this advertisement is that it appeared in both The Economist and Scientific American but with slightly different content. This can be compared with the differences in the BP advertisements destined for an American or British public. The Shell advertisement includes more information about hydrogen fuel in the American version, perhaps what is most interesting is the discussion of biofuels.

The American version states:

"We also work on lower carbon fuels. Shell is already one of the world's largest distributors of first generation biofuels. Now we are working with partners to develop second generation biofuels that could have around $90 \%$ lower emissions than gasoline, using feedstocks like straw or wood chips".

However, just like BP, the information written for The Economist and the British and European public is quite different to that intended for the American public.

"We also work on lower carbon fuels. Shell is one of the world's largest distributors of ethanol and biodiesel made from food crops. The rapid growth in food-based biofuels poses dilemmas and risks - higher food prices and issues over biodiversity, land use and human rights. Moreover, the $\mathrm{CO} 2$ benefit is variable.

So we are working with partners to develop non-food biofuels that could have around $90 \%$ lower emissions than gasoline, using feedstocks like straw or wood chips. We are seeking very tight quality controls and appropriate measures and assurance systems for sustainability, land use and $\mathrm{CO} 2$ production."

I have underlined the differences between the two versions to facilitate comparison. It is immediately evident that there is a great deal less concern in the United States for the impact of biofuels on food supplies, biodiversity and sustainability. These two versions of what is basically the same advertisement are a very good example of how Shell seeks to identify with its audience and to apply arguments that will resound with the different publics (Perelman \& Olbrechts-Tyteca, 1958, Burke 1945, Weinstein and Deutschberger 1963, Scott, 1994, Alan Gross 1999, Bolduc \& Frank, 2010) to present the face that will be best appreciated and accepted (Goffman 1959, 1967).

An example of the "Aspect Dawning" part of the series is provided below in figure 8:77 (see also figures 7:6, 7:7, 7: 8). The headline and the image, which on closer inspection is a key, are metaphorical (Cohen 1978, Davidson 1978, Booth 1978, Biasko \& Mokwa 1986, Zaltman \& Coulter 1995, Ang \& Lim 2006) and together, create a play on words; "In the New Energy Future, We'll have to unlock what's locked away". (Abel 1994, McQuarrie \& Mick 1992, Djafarova 2008). This advertisement is framed at the by coniferous trees, which are potential sources of energy and which play a part in the $\mathrm{CO} 2$ cycle. The key holds the world in its grooves, with pure snow-topped mountains and blue oceans and the bright yellow ridge suggests the sun. The inference is that by unlocking what is locked away, perhaps at the bottom of these oceans, we will be able to prevent global warming. Again, the words of the text that accompany the image anchor, confirm and exemplify the aspects of the new energy future that we can illicit through a study of the image and the accompanying headline.

1.As the global population grows and energy demand increases we need innovation to make the most of the

2. world's energy resources, however difficult the conditions. 
3. Like developing the technology to release oil locked deep beneath the ocean in the Gulf of Mexico. And 4. helping create one of the world's largest oil and gas projects in the remote and challenging conditions of

5. Russia's Sakhalin Island.

6. In addition, our Enhanced Oil Recovery techniques access previously unreachable oil from existing wells.

7. And while unlocking the energy the world needs, we continue to develop technologies to manage $\mathrm{CO} 2$ emissions.

8. To find out how Shell is helping prepare for the new energy future visit www.shell.com

\section{Image removed due to copyright. Image removed due to copyright.}

Again, the assumption is that demand will grow and participant voice is that of the company presenting facts about the situation in the world and informing him of Shell's work to improve this. The first "we" is inclusive and encompasses mankind, while afterwards, it refers exclusively to Shell. References to on-going projects as well as the continued development of strategies for managing CO2 display the global nature of Shell's activities as well as underlining the extent and variety of their work. Here again, the reader is invited and encouraged to find out more and to become a more active participant in the communicative

The "Let's Go" series postdates the Real Energy series and generally features a young person $^{62}$ or young people from different parts of the world involved in some activity. Again, the image dominates, but in this case, comprises a photograph. The example in figure 8:78 above, for example, shows two young boys from Brazil. The young people do not seek contact with the reader but are involved in their activity and in their own lives. Each advertisement begins with a direct, inclusive address to the reader to elicit joint action for some cause. This action is future- oriented. The red "Let's Go" suggests a sense of urgency and leads the eye towards the red of the logo, showing that the partnership in the action is Shell and also helps to balance the banner heading.

2008 was a year when the climate came into focus and Shell, presenting itself as "a business operating worldwide that's been around for more than a century, and aims to be successful

\footnotetext{
${ }^{62}$ A commonly recurring advertisement from the series features a special car and a competition sponsored by Shell to see how far it is possible to go on one litre of fuel.
} 
long into the future," and that thinks "about tomorrow every single day - and in every aspect of our decision-making," published four individual advertisements in The Economist. ${ }^{63}$ that are a hybrid of advertisement and advertorial (Brown et al. 2001, Brown \& Waltzer 2005, Porter \& Kramer 2006, Fairclough 2009, Tynyanov 1977, Opacki 1987, Todorov 1990). While one presents Shell's work with education and arts for the young, the other three explain to the people in power how they should act ${ }^{64}$ and what Shell is doing to meet "challenges and deliver progress to our customers", in the "complex environment" in which they operate "where demand for energy is accelerating while supplies of responsible and sustainable energy are becoming increasingly difficult to secure"

One of these, "A Climate plan for the G8 leaders" provides a good example of these and appeared shortly before the G8 meeting took place that summer.

The visual element of the advertisement comprised an empty table with a white surface around which were placed eight blue chairs, all of the same colour, but varying slightly in form to indicate the different countries and interests of the participants at the meeting. In the centre of the table, written in the same blue as the chairs, was the climate plan.

"Imagine a power plant that captures and buries its $\mathrm{CO} 2$. That then as a by-product makes clean hydrogen for transport fuel, and by also combusting biomass generates negative $\mathrm{CO} 2$ emissions (as biomass absorbs $\mathrm{CO} 2$ while it grows).

This is not science fiction. It could be reality if we work together to make it happen and if enough governments starting with the G8 Leaders' Hokkaido Summit in July - agree a long-range global policy framework with the right mix of regulations and stable incentives.

The world's ecosystems and climate have reached a saturation point. The Intergovernmental Panel on Climate Change (IPCC) says we have 10-20 years at best to stabilise greenhouse gas emissions then reduce them sharply to prevent climate change shocks. The IPCC estimates that CO2 capture and storage (CCS) could provide up to $55 \%$ of the emission reduction needed to avoid the worst effects of climate change.

The idea is simple: capture $\mathrm{CO} 2$ from heavy industry including refineries and power plants, and then inject it deep underground where it can be trapped for thousands of years. While some technical challenges remain, the underlying CCs technologies are mostly proven and similar to techniques used to improve oil recovery in mature fields.

We welcome the call by the G8 Energy Ministers for the launch of 20 large-scale CCS projects globally by 2010. Many energy companies including Shell are already developing CCS demonstration projects, working with government agencies and research institutes. In our view of the future, CO2 could be captured and stored at $90 \%$ of all coal- and gas-fired power plants in developed countries by 2050 , and at least $50 \%$ of plants in developing countries. Today, none use CCS because it adds extra cost, uses more energy, and because permit requirements and liability for the $\mathrm{CO} 2$ are not yet clear.

To meet this major undertaking, a helpful international policy framework would include:

- $\quad$ 'Cap and trade' or emissions trading systems to put a price on emitting CO2

- Credits for CCS in the Clean Development Mechanism and existing systems such as the EU's Emissions Trading System

- A global clean technology fund (for which CCS is eligible)

- Transition funding for a flagship demonstration programme to validate the technology, establish costs and identify pathways to cost reduction.

\footnotetext{
${ }^{63}$ Porter \& Kramer (2006) discuss the importance of the social context in which companies operate and which must guide their business strategies.

${ }^{64}$ These hybrid forms can be compared with Mobil's advertorials which also sought to influence public policy.

65 This quotation is taken from "Creative thinking is one of the most precious resources we have" a PR piece that explains how "Inspiring creative thinking is fundamental to Shell's success as an energy company".
} 
There is no time to lose, especially as more energy will come from more carbon-intensive types of fossil fuels. Consider Canada's vast reserves of oil sands. It's technically challenging to convert heavy bitumen into clean burning fuel, so $\mathrm{CO} 2$ emissions are higher than conventional petrol - about 15 percent more. Yet the world needs this oil to meet rising demand. To produce this fuel without adding to climate stress, we're focusing on solutions to reduce these emissions. CCS could be an effective way of mitigating these higher emissions.

With the right framework for CCS, cleaner energy could be a reality sooner - helping to secure a responsible energy future. To learn more about Shell's approach to CO2 management, please visit www.shell.com/climate"

Shell begin by presenting a vision of a power plant that is $\mathrm{CO} 2$ neutral and claim that this vision can become a real possibility "if we work together to make it happen and if enough governments - starting with the G8 Leaders' Hokkaido Summit in July - agree a long-range global policy framework". They then endorse and summarise some of the main findings of the IPCC, a body which they also use to legitimise their standpoint, before going on to explain their plan in more detail. They admit in passing that $\mathrm{CO} 2$ is emitted from industry, including refineries and power plants, but do not specifically mention the word oil. They then list the requirements of a "helpful international policy framework" applied to the CCS (capture and storage) technologies that they are advocating. These include carbon trading and financial support for research. The text ends with a call to action and an invitation to visit the Shell website to find out more.

The first of the other two, "Creative thinking is one of the most precious resources we have," takes issue with energy security and the matter of terrorist threats, and was based on the global forum set up by Shell in London, New York and Kuala Lumpur to discuss the challenge of global energy security. The other, based on the Shell Sustainability Report for 2007 addressed the question: "Can the world meet the fuel challenge of our age: to secure more energy but with less CO2?" Again, Shell provided very specific solutions and recommendations to those in positions of power, including Obama.

\section{Presentations and re-Presentations}

The advertisements produced by the oil companies are many and varied. Although some of the changes in their advertising are a result of new technology and changes in advertising regulations, the many of the themes that dominate the discourse have also changed over the some hundred years that the companies have been producing print advertisements. These changes are related to contemporary socio-political conditions which have required the companies to reinvent themselves to be able to continually present new and different "faces" that are in accord with the changing socio-political situation and which represent the preferences of their publics.

However, a number of themes are recurrent, and merely reappear in slightly new and more modern guises, and it is these that are the subject of the following chapter. 


\section{Chapter 9}

\section{The Myth of Oil}

A close study of the advertisements of the oil companies reveals two recurring inter-related themes; the mythical nature of oil and the mythical qualities of those who bring this magic liquid to us. In the following chapters, I will examine these themes to show the ways in which oil and the work of the oil industry are mythologised, ${ }^{1}$ and uncover and discuss the different symbols that populate the mythological world of oil.

\section{A World of Myth and Adventure}

The world of black gold is a world of myth and adventure. I have already noted that the first century BC historian, Diodorus of Sicily, claimed it as one of the greatest miracles of Babylon, and have explained how Pliny the Elder enumerated its many uses. I have discussed at some length Frye's Myth of Romance and shown how it applies to the world of the oil industry and to advertising of the oil companies. However, the mythos of oil is not limited to the heroic quest for the magic liquid that, when brought to the deprived community that is awaiting the hero, will restore life to an edenic state. Neither does the dragon-slaying theme of the Romance complete the mythical themes of oil. While these are very important elements in the adventure of oil and in the search for the magic liquid, they are in themselves only one part of the mythical world of oil.

\section{The Bringer of Life}

Among the many uses of oil that Pliny the Elder described, pharmaceutical applications abounded. Oil, in the form of bitumen, was used for salves and ungents and was known to have restoring properties. Thus, it it perhaps not surprising to find that oil companies have played on this theme and associated their products with water and the sun, the two natural resources that are most central to life.

The Magic Liquid

Image removed due to copyright.

\section{Figure 9:1 Britannia at the well} that first catches the liquid is a shell. Cast in the role of participating actant, Britannia in all her glory is collecting this liquid into a Grecian-type urn which she carries together with her usual accoutrements, the trident, helmet and sword. The red of the urn symbolises the red of the Shell oil cans. What could be interpreted as being the sword of the legendary King Arthur, Excalibur, seems to be plunged into the ground by her side and the splashing waters of the fountain merge with the waves of the ocean in the background.

\footnotetext{
${ }^{1}$ The oil industry is not alone to mythologise its products. See for example Sullenberger (1974) who discusses folklore and myth in marketing. However, in the case of the oil industry, myth is central to both the companies and their products.
} 
The reader is hailed by a voice that can be attributed to the company and which proclaims: "Shell distributes more petrol refined from crude oils produced within the British Empire than all other petrol distributing companies in Great Britain combined." Colour and typography foreground the words "Shell produced within the British Empire" and the red of this lettering repeats the colour of urn borne by Britannia. The underlying message communicated by the structure of the advertisement is that the British Lion is now being helped by the purely British company, Shell to provide for Britain and make it strong. The ocean in the background connotes the important role that oil, and Shell, played in the First World War, which was won largely because Marcus Samuel was instrumental in persuading Churchill to fuel the Royal Navy's ships with oil rather than with coal, and in assuring sufficient supplies.

This advertisement appeared in other, slightly different forms in newspapers, and one later version for newspaper publication specified at the bottom

\section{"The British lion yields \\ The power Britannia wields.}

Another aspect of the special qualities attributed to oil is illustrated in the advertisement shown in figure 9:2. This is one of the early postcard advertisements and has a number of interesting features. The first of these is to be found in the actual name of the product. The word "Spirit" has a number of meanings and these include a conceptualization of energy which permeates people and places. Thus, Shell is the provider of energy. However, "spirit" also has a religious connotation and the gift of the "Holy Spirit" enables people to accomplish amazing feats which would otherwise be impossible. Finally, if this picture seems in some way familiar, it is because it is a pastiche of Botticelli's Birth of Venus. ${ }^{2}$

Instead of Venus rising naked from her scallop shell and trying to protect her nakedness with her long, curling hair, with the sea behind her, we are shown an innocent, fully-dressed little girl, whose curly hair is pushed into a lacey cap. The child symbolizes the purity that the slogan, "It's perfect purity - that's the point," proclaims. However, the angle of the child's head echoes that of Venus and this lends yet another level of symbolism to the image. The child is a symbol the future and also of life.

Throughout antiquity, the scallop, or the Shell of Saint James, has symbolized the feminine, from the outside, the protective and nurturing Image removed due to copyright. principle and from the inside, the life force. Thus, by connotation, Shell Motor Spirit is a pure life force imbued with the mythical powers of Venus, the goddess of fertility and prosperity, and Venus, the planet nearest to the Earth and also known as the Morning Star or the Evening Star. On a practical level,

Figure 9:2 It's perfect purity the boats bobbing on the water behind the child suggest one of the uses to which the product can be put.

The mythical qualities of Shell Motoring Spirit are also illustrated by the be-winged female creature, part angel and part spirit, in Greco-Roman dress depicted in the example below

\footnotetext{
${ }^{2}$ This is an example of the way in which advertisers used art to cultivate an image of respectability (e.g. Marchand, 1985). In Britain, Shell was one of the first companies to use art to confer a reputation for good taste (e.g. Hewitt 1992) onto the brand.
} 
(figure 9:3). Sitting on a British Petroleum certificate, she is holding a red Shell can and lighting the huge oil lamp above her head with ease using only one hand. The light from the lamp glows golden onto the top of the certificate like the sun whose powers it is challenging. The creature's elegantly pointed foot creates a vector which draws the reader's eyes from the lamp down towards the scrolled text which reads "The Light and Power of the Age" while the red background colour echoes the can and lends cohesion to the whole. Oil is depicted as a powerful, magical liquid that is bringing light and life to the world. Oil is depicted as no ordinary substance, but is as liquid with very special, mythical and magical qualities ${ }^{3}$ in these advertisements.

\section{Image removed due to copyright. Image removed due to copyright.}

Figure 9:3 Lamp oil
Figure 9:4 the Shell sun

\section{The Sun and the Stars}

The sun is the Earth's source of light, warmth and power. It is therefore not surprising that it has been used by the oil companies to symbolise both the properties and the qualities of their products. Without the warming rays of the sun and the light that these bring almost nothing grows and little survives.

The example in figure 9:4 is from 1925 and featured on the cover of the Swedish Tourist Association's annual magazine (in Wilson 2012). The Shell logo has replaced the setting sun which has broken through the clouds and bathes the world in a powerful light. This occurs at the same time as the two lady motorists have stopped by a Shell service sign.

The concept of the Shell logo as the sun was repeated in the "Profits and Principles" campaign that resulted from the 1998 Knight report. One of the advertisements in this series, "Cloud the issue or Clear the air?" takes up the issue of global warming. The left page of the double-spread shows a cloudy sky with a Shell silhouette trying to peer through the clouds while the right has a cloudless sky where a bright Shell logo is the focal point and where the text underneath explains that Shell is not only going to meet the agreed Kyoto targets but to exceed them in theirefforts to balance "economic progress with environmental care and social responsibility".

\footnotetext{
${ }^{3}$ It should be recalled that the oil distributed by Shell originated in the mysterious "Land of Fire" and that the Nobels named their first tankers after fire worshippers.
} 
Therefore it is not by chance that BP adopted its new "helios" logo in 2001 (figure 9:5). ${ }^{4}$

Helios, the Sun god, is often portrayed with a halo of light around his head, and this attribute is depicted in the logo. The colours of the logo are also symbolic. The white centre connotes purity as well as the intense heat and energy of the centre of the sun while the yellow represents its rays. Finally, the green that constitutes the rim of the image symbolises growth and fertility and connotes the clean energy "beyond petroleum" that the company is providing. The logo symbolises dynamic energy in all its forms and the intricate petal-like links represent interconnectedness.

\section{Image removed due to copyright.}

Figure 9:5 BP Helios logo

\section{Image removed due to copyright.}

One of the best-known stories associated with Helios concerns his son, Phaeton, who in his foolhardy bravery tried to drive his father's chariot but lost control of it and set the earth on fire. Phaeton's intrepidity can be seen as a metaphor for the daring of both the men who search for oil and of those who use it to go further and faster. In this way, the helios logo is also a natural continuation of the early advertisements of the god-like creatures driving a chariot pulled by two strong and uncontrollable horses. This is discussed in the next section.

Texaco too, looked at the heavens to find a suitable symbol for their products, and the advertisement from 1941 (figure 9:6) shows the Texaco logo shining in the night to guide and comfort weary motorists travelling through a hostile nocturnal landscape. This advertisement sybmolises not only the energy of the stars that light our way when the sun disappears, but also suggests the star that guided the Three Wise Men to the shelter that Mary and Joseph had found.

These examples illustrate how the oil companies have taken recourse to the power of nature and its life giving qualities to formulate the mythology of their products and of their brands.

Figure 9: 6 Texaco's star from Wilson 2012:42.

\section{Horse Power}

The mythical nature of oil is also implied in figure 9:7. In this advertisement, the chariot of the mythical warrior queen, Boadicea, who led a rebellion against the Romans in what is now the south of England, is being serviced by a mythical figure that resembles a Grecian god but that could be a Roman soldier, reduced to submission.

\footnotetext{
${ }^{4}$ During the 1990s, BP became interested in solar energy and this association was a natural choice. BP had adopted the "green shield" in 1968. This is a green shield with the letters BP in yellow. Until the 1930s, there was no particular colour scheme was associated with the company, but lorries were often red and green.

Although blue and white tended to dominate the shields, by the 1930s, green and yellow began to become more common. The early, red petrol pumps were thought to spoil the countryside and were re-painted green to better blend into the landscape.
} 
He is kneeling by her chariot to oil its wheels with Shell's superior, modern British product and by connotation, oiling the wheels of the anticipated war effort.

\section{Image removed due to copyright. Image removed due to copyright.}

This advertisement is also interesting because of the horses, the chariot and the caped figure in Greco-Romano dress. These are frequent in Shell's early advertisements. When they introduced their "Quick-starting Pair" campaign, one of the earliest themes was that of two horses pulling a chariot driven by a mythical creature in Greco-Romano dress (figures 8:2, 8:12). Typically, as shown in figure 9: 8, the S.E. Scott poster depicting two powerful horses, the horses are of different colours. The front of the chariot is in the form of a red Shell logo. Often, they were depicted leaping into the air as they performed their "flying" start. The advertisements symbolized the speed and power of the products, and of course, played with the concept of "horse power", the term that was used to measure the power of an engine.

Jean $\mathrm{D}^{\prime}$ Ylen ${ }^{5}$ developed this idea and created the mechanical horse as a metaphor for the car, and this is a more mythical creature than the ones depicted in figure 9: 8. In Jean D'Ylen's posters, the mechanical horses are of different colours and the people that are trying to hold them are typically quite young boys. The example here (figure 9:9) is of the horse being fed with Shell from one of the new sealed cabinets. Shell petrol, a magic potion, with the result that the two young boys who are one on each side of him are having great trouble restraining him.

The colour-scheme used by D'Ylen involves further symbolism. The mechanical horse is green while the boys are dressed in red. Since the first traffic lights were installed in London in 1868, red has been the code for stop and green for go. This

Image removed due to copyright.

\section{Figure 9: 9 Horse power} action makes the visual metaphor even clearer and the brief written text, the slogan-like "For the utmost horse power" simply complements the image, a firmly anchoring its meaning and creating a visual pun on the idea of the horseless carriage.

In addition, the magic liquid that spouts from the cabinet is not black, the normal colour of oil but is golden in colour. This symbolizes its precious and magical qualities. The Shell colours of red and gold frame the image and underline the message that it is Shell that has such an amazing effect.

\footnotetext{
${ }^{5}$ Jean D' Ylen was the pseudonym of Jean Beguin, (1886-1938) the well-known French artist who became famous for his work with advertisements.
} 
While Shell advertised their "Quick-Starting Pair", one particular innovation that BP stressed concerned the additives that it used to "stop knocking" or "banish pinking". The advertisements that it ran for this, BP Ethyl, were also among the most innovative of the company's advertisements and build on the Shell horses. BP used the concept of the horse in a number of their advertisements, but the one shown in figure 9:10 is particularly interesting and supports my contention that myth plays an important role in the advertising of the oil companies. In 1933, McKnight Kaufffer was commissioned to design a lorry bill for BP. This advertisement has been claimed to be the best poster he ever designed. ${ }^{7}$

As Kress \& van Leeuwen (1996:53) have pointed out, we associate angularity with the inorganic, the crystalline and with technology, and the strong angles in this advertisement

\section{Image removed due to copyright.}

\section{Figure 9: 10 BP Ethyl controls horse-power} promote the idea that BP ethyl is an innovative, new and technologically superior product.

However, there is another level to this advertisement. Here, Jean D'Ylen's mechanical horse has become a magnificent, white full-blood with a flying mane and tail, and the man who is restraining him is a naked male athlete with rippling muscles.

The image is also packed with direct references to the story of Pegasus, the untamed, divine stallion of Greek mythology who was charged by Zeus to bring lightning and thunder from Mount Olympus, being captured by the Greek hero, Bellerophon, the slayer of monsters. Traditionally, as here, Pegasus is depicted as white, and the man's physique, together with the quiver over his shoulder, indicate that he is a hero and a hunter. These two superb physical specimens, man/god and horse/god, their powerful muscles rippling, are joined together and resemble a classical Greek statue. It is an iconic image that resounds in the European cultural consciousness from both actual statues and pictures of statues that we have encountered over the years.

The left and centre of the advertisement is dominated by a flash of lightening, whose two vertices lead the eye upwards towards the words BP and then ethyl. The lightning, which has a clear white core and a grey-blue surround, echoes the colours of the product name. The letters $\mathrm{B}$ and $\mathrm{P}$ have a thin yellow shadow to the left and while the upper part of these letters is blue, the lower part is white and together with the word ethyl, builds a block of solid colour above the thin yellow frame that runs down from the yellow shadow of the P. This frame is open on the right where the heavily shaded words "anti-knock" can be distinguished leading from the upper edge of the frame down to the horse's tail. The bottom edge of the frame is supported by the words "horse-power" written in the same blue-grey shade as the upper part of the letters B and P and act as a restraint to the horse. The word "controls" is written

\footnotetext{
${ }^{6}$ This is something that occurs when combustion of the mixture of air and fuel in the cylinder starts off correctly in response to ignition by the spark plug but one or more pockets of air/fuel mixture explode outside the envelope of the normal combustion front. The fuel-air charge is meant to be ignited by the spark plug only, and at a precise time in the piston's stroke cycle. Knock occurs when the peak of the combustion process no longer occurs at the optimum moment for the cycle. The shock wave creates the characteristic metallic "pinging" sound, and cylinder pressure increases dramatically.

${ }^{7}$ The first 25 years: History as Mirrored in the Advertising of Shell-Mex and B.P. Ltd.1932-1957 p.13 (Archive reference 24670) B.P. Archives, Warwick University
} 
through the bottom of the left part of the frame. Outside the frame is the first syllable in white, while within the frame the verb is completed by the second syllable in yellow, a pure colour associated with action. ${ }^{8}$ This is later echoed in the yellow ethyl sign in the bottom right of the picture, to which the frame line leads.

At the bottom, the verb and the man and horse lead the eye upwards towards the product name, BP Ethyl. The shades of blue-grey which move through to white, stand out against the black background like the flash of lightening which unites the different elements of the advertisement. The colour palette of the product name is echoed in the man and the horse. The yellow of the verb, which is echoed in product logo, and the horse and the man form two saliences which balance each other and which are connected. This is emphasized by the vector from the verb which leads the eye towards the man and the horse. The textual function of this arrangement reinforces the notion that "BP Ethyl controls horsepower". The strength and power of the mythological creatures is metaphorically exported to the product.

Technology and the natural world are dramatically framed together to demonstrate their cojoining and it is BP that provides the power for man to dominate nature. The somewhat angular typeface with the be-winged $\mathrm{B}$ and $\mathrm{P}$ connote technology and also symbolise the mythological nature of the product (Van Leeuwen, 2005, 2006, Nørgaard, 2009). The statuelike man and horse give the product a symbolic attribute of classicism and tradition, showing how BP combines cutting-edge technology with timeless values and attributes.

Mobil also recurred to the myth of Pegasus and used a red winged horse in their logo (figure 9:11). The shape of the horse here ressembles that of the constellation and thus goes beyond the myth to also connote the natural power that the product possesses.

The example for their "Continually New Mobilgas Special" (figure
Image removed due to 9:12) provides a double mythological metaphor, as the company are not content to merely imply the qualities of the product in the copyright. logo but explicitly express them in the image and text of the advertisement where they state:

Figure 9: 11 Mobil logo

'It's true, literally true. We've made 17 different improvements in gasoline quality just since the end of the

Image removed due to copyright. war - improvements that make Mobilgas Special continuously new..." Among these seventeen improvements are "maximum power" and "quick sure starts".

The written text that anchors the metaphoric horse image is foregrounded by size and position between the horse's wings, and the innovative aspects of the product are stressed Figure 9: 12 Flying Horsepower by the typography which follows the contours of the hill over which the horse is flying.

The Mobil horse untamed by any man but flies alone and free over the car that parallels its progress down below, climbing the steep hill with apparent ease.

\footnotetext{
${ }^{8}$ Van Leeuwen (2011)
} 
Thus, like Shell and BP, the American company equates Pegasus with power and uses this well-known mythical creature to illustrate the qualities of its products and to portray itself as an innovator. ${ }^{9}$

\section{Fire}

However, it is not only with Pegasus, the mythical horse that the oil companies identify but also with the phoenix, a fire spirit which never dies and always leads the way. In many cultures its tail plumage is thought to be gold and red, and in the example, the birds' tailplumage is echoed in

Image removed due to copyright. the Shell tanks below (figure 9:13). The bird symbolises not only the origins of the oil in Azerbaijan, the Land of Fire, but also the power and endurance of Shell and the way in which it is at the forefront of technological development.

Figure 9:13 the Phoenix

The advertisement from the B.P. "Magic of Persia" series (figure 9:14) underlines the mythical importance of fire as well as its role in the oil industry.

The photograph shows the ancient temple of Maidan-iNaftun in the Valley of Oil and opens with the dramatic statement:

"Thousands of years ago, Persians bowed before altars whose leaping flames were to them the symbol of the supreme powers of nature."

Image removed due to copyright.
Now, through one of the "miracles of modern British industry", B.P now has its chief source of supply near the ruins of one of the temples of the ancient Fire Worshippers and "the British motorist has fallen heir across the centuries to the treasures of mineral oil once held sacred by the Fire Worshippers of Ancient Persia."

Oil is sacred, and in its manifestation as fire has been worshipped over the centuries; first by the Ancient Persians and now by the modern motorist.

Figure 9:14 Temple of the Fire Worshippers

\section{Modern Myths}

The theme of man taming the horse, or controlling horse power, was taken up in an article in The Economist (October 25, 1958, pp. 24-25) entitled "The Driver as Hero" which discusses and compares "petrol gladiators" such as Stirling Moss, with their ultra light vehicles, and the earlier generation of "gladiators" who needed to be stronger to be capable of "taming" and

\footnotetext{
${ }^{9}$ Horses, and particularly race horses, appear frequently in different ways in oil industry advertising, especially during the first half of the $20^{\text {th }}$ century.
} 
turning the monster cars "into race-winning machines". The author of the article describes how the early racing drivers were usually amateurs wanting to break speed records and who "possessed none of the unique allure of the sportsman-cum-entertainer of the racing driver today" and discusses the changes in attitude, financial reward, prestige and skill between the modern-day racing drivers and those of the early years of the sport. It is interesting to note that in the early BP advertisements, the company specifically state that the "special dope" that is used in racing cars cannot be bought at the pump. The passion for speed and power that is implicit in the Pegasus-inspired advertisements much have touched a chord among many aspiring "horse-tamers". The relationship between the motor vehicle and its equine counterpart is both implicit and explicit in the article, and the the driver is a hero.

\section{Superman}

In 1954, B.P. began a new advertising theme, the BP Superman series (figure 9: 15) based on the popular character from the late $1930 \mathrm{~s} .{ }^{10}$ This theme built on the pre-war "plus a little something" series. BP Super was in this way attributed with the magical qualities of kryptonite and the man who used it would be become endowed with the mythical qualities of a super hero if he used this substance of modern myth.

The first B.P. Superman was the racing driver, Stirling Moss, for being "plus a little something in so many races" but everybody had the chance to become a superman simply by using BP Super. From Stirling Moss, a true motoring hero in the tradition of oil company endorsers, the series went on to encompass a wide range of men who would not normally be

\section{Image removed due to copyright.} considered in this category. The connotation is that every man has the possibility to be a Superman and that BP will provide him with all that he needs to become a hero. This is demonstrated by the faceless motorist who appears sometimes in his own right and sometimes as a part of other advertisements for the product.

There is no general format to this series which also shows supermen ranging from racing stars to well-known comedians to family fathers. However, common themes include the Figure 9: 15 BP Superman economic advantages of using this product which banishes pinking, giving better performance, easier starting and smoother acceleration, and the notion that innovative BP researchers have been busy behind the scenes.

\section{Einstein's Brain}

In his essay on Einstein, Barthes (1957: 85-87) points out how Einstein is commonly portrayed photographically writing complex formulae on a blackboard, and that this designates how, without any apparent effort or preparation, the "magic formula of the world" $\mathrm{E}=\mathrm{mc}^{2}$ was found.

Shell ran two advertisements that depicted school children writing on a blackboard, in one a boy and in the other, a girl. These advertisements are particularly interesting for their iconicity (figure 9:16).

\footnotetext{
${ }^{10}$ The Superman character has a strong sense of morality and always overcomes both problems and evil. The connotation is that BP has these characteristics and that Energol is their equivalent to kryptonite.
} 
The seemingly disorganised writing on the blackboard that is attributal to the children ranges from three-dimensional figures to cogs, a bird, an envelope and a musical quaver note as well as the unanswered question "Isn't it high time someone got negativity about negativity?" This lack of order suggests how the magic formula was reached through unconventional thinking and implies that Shell too are going find to the magic formula to solve the world's problems by keeping an open mind, which like that of a child, does not think along the standard paths.

\section{Image removed due to copyright.}

The advertisement is not framed and so the girl and the blackboard are not contained. This implies that the reader is also included in the search for ways to say "yes". The writing on the board begins slightly outside the picture to the left, but extends towards and beyond the right and the future.

Barthes (1957) also points out how Einstein's actual physical brain became mythologised by his donating it to research. Shell devloped this theme with two other advertisements in their "new energy future" series which ran parallel with the "real energy solutions" series from about 2007.

Like the example I have just described (figure 9: 16), the concept that underlies the "new energy future" series is the importance of radically different thinking, and the story-lines all incorportae a problem-solving motif where the company is cast in the role of the

Figure 9:16 Say no to No m. Two of the advertisements in the series are created protagonist who has to solve this problem. Two of the advertion
around a human head in profile looking towards the right.

The one depicted in figure 9:17 shows a brain with different energy solutions. The metaphoric visual which fills the lower half of the page is a stylised head with a colourful brain divided into different compartments, each holding a different energy solution, such as fuel from straw, fuel from woodchips and a wind farm. The Shell logo is positioned where the mouth would be and above the head the text reads; "Tackling climate change and providing fuel for a growing population seems like an impossible problem, but at Shell we try to think creatively." Having acknowledged the problem, Shell explains how they are working to solve it. "In addition to our growing oil and gas businesses, we're investing in energy sources like wind, and also investigating innovative new engine fuels made from unexpected sources like gas, hydrogen, straw, waste woodchips and marine algae". ${ }^{12}$ The other "Einstein -inspired" advertisement (figure 7:7) comprises a pink head with a single thought in the brain: "What does it take to discover something new every day?" The answer is provided in small print underneath the chin: "To tackle the world's energy challenges, from oil and gas power to biofuel power, just takes brain power."

\footnotetext{
${ }^{11}$ As Kress and van Leeuwen (1996) have pointed out, the right side of the page typically indicates the new and thus the format of the image acts to underline the innovation of Shell's work.

${ }^{12}$ It is interesting to note that of the seven sections depicted in the brain, three show biofuels, one wind power and of the three largest, one represents hydrogen fuels while the other two involve gas. Oil does not feature. It is also interesting to notice that Shell point out that their traditional businesses are growing and that oil is the first to be mentioned.
} 
The suggestion underlying these advertisements that the ingenuity and brilliance of Shell and the company engineers can be compared and perhaps equated with that of Einstein.

\section{Image removed due to copyright. Image removed due to copyright.}

Shell is not the only oil company to use the metaphor of the human brain to illustrate their work, however, and Esso too (perhaps the best known brand of ExxonMobil) has used this image in their advertisements for more energy with lower emissions (figure 9:18). The reader is hailed with the question "More energy and lower emissions?" and immediately provided with the answer: "Only one kind of power can deliver them both." The glowing hot brain underneath metaphorically completes the answer: Esso's brain power. This is why "for decades, Esso has constantly led the energy industry in research and technology."

Moreover, although they do not physically depict a brain, BP too used the concept in a series from 2005 with headlines built on word plays like "When it comes to green matters we develop grey matter" or "It's time to think outside the barrel" (figure 8:59).

\section{The Myth of the Hero}

I have discussed the ways in which the oil companies depict their products in mythological terms and now go on to show how they portray themselves and their workers. First I will discuss the roles that are assigned to the male participants in the advertisements and then, as the hero of the myth of romance must have a heroine, the role ascribed to his "lady".

In chapter 2, I described some of the challenges and dangers that the pioneers of the oil industry overcame in their endeavours to find and then extract the precious liquid. The quest is filled with dangers. These include the different and extreme terrains that have to be traversed and explored, and threats from warring political factions in the lands where the oil is found and that can jeopardise the safety not only of the operations but also of the oil men. However, the challenges that the oilman faces do not end with the discovery of the magic substance and many dragons must be fought and slain not only to reach the liquid, but also to bring it safely back to those waiting impatiently at home for the comfort and convenience that it can give. The precious liquid itself is dangerous and must be treated with great care and respect during its extraction and transportation and even when it is used. Thus, to fulfil his quest, the hero must not only compete with rivals who are seeking precious substance, but also collaborate with others (Asa Berger 1996) to bring the home and transform it into an elixir that will confer light, speed and ease on the waiting community. 
To succeed in this quest and bring energy to the waiting world, the hero needs not only bravery, strength and endurance but also exceptional intelligence to be able to solve the riddles that are strewn along the way. How can the sources of life-giving energy be extracted, and how can this be done without damaging the environment and driving the chariot into the earth? There is no easy answer for the supermen of the oil companies who must continuously seek for new sources of the precious liquid that will save a world that is never satisfied but increasingly demands more.

Thus, the companies of the oil industry depict their heroes in a number of guises. These can most simply be broadly categorized as the adventurers whose task it is to find the liquid, and the alchemists who transform it to delight and please.

\section{The Adventurer}

I have already stated that Mick (1987: 252) has suggested that Propp's work is a source of inspiration for what he refers to as story grammars in advertisements, and I have already mentioned that I consider Northorp Frye's "theory of myths" and especially his "mythos of summer" to be a central concept in my analysis of the advertisements produced by the oil companies. The "mythos of summer" is the term that Frye uses for the genre of Romance, whose essential element is adventure. The adventure of Romance typically centres on a Quest, ${ }^{13}$ the search for a magic substance that will save or empower. It is this quest that is implicit in many of the oil company advertisements.

First, the hero must travel to distant lands where both the terrain and the climate are often hostile. The hostility of the landscape is clear from in the advertisements shown in figures 9: 19 and 9:20. In the first, three oil men $^{14}$, pioneers and adventurers, fight their way along a shallow waterway through a rocky section of the South American jungle. Petroleum tells how the search for oil in Columbia was often made even more difficult by the thick jungle and that the only way was through small streams and other waterways. Moss clad rocks like the ones depicted made progress even more difficult. These were of course, not the only dangers (Wilson, 2012:148). The solid boots and tropical helmets of two of the men, as well as the equipment that they are carrying denotes some of the problems facing these adventurers. Further, Kress \& van Leeuwen point (1996:144) that although the back view is complex and ambivalent, one of the things that the exposure of the back can connote is vulnerabilty. To be in the jungle, miles from anywhere,especially in the days before easy comminications, was certainly to be in a position of extreme vulnerability.

A differently hostile landscape is depicted in the BP advertsement from 1959 (figure 9:20) . The text simply states: "Dynamite for shot-firing being carried across the country by camel train" and explains how the company is exploring six areas in their search for oil. Not only is the terrain hostile, but the transportation of dynamite under such primitive and unpredictable circumstances is another challenge for the oil heros in their quest to bring us the magic liquid that we need for our welfare and survival today. Here, the terrain is dry and exposure to the extreme temperatures of the hot and sunny day and chill of the night is a hardship. Moreover, not only is the transportation of the dynamite that is needed to blast the rock dangerous, but the magic substance itself is unpredictable. The extraction of the oil itself can result in disaster and the production of petroleum requires great care as it is a product that is highly explosive.

\footnotetext{
${ }^{13}$ See for example the writings of Vladimir Propp (1968 and 1971), Arthur Asa Berger (1996) and Christopher Booker, (2004) for further discussions.

${ }^{14}$ The fact that there are three adventurers is also significant as the number three has many mystical and spiritual connotations and features frequently in folktales.
} 


\section{Image removed due to copyright. Image removed due to copyright.}

Figure 9: 19 Taken from Esso's Petroleum magazine cited in Wilson (2012:148)
Figure 9: 20 Across the Lybian desert

While historically, oil was known for its healing properties, inhaling petroleum or coming into physical contact with it is known to be injurious to health. Many have given up their lives to the extraction and exploitation of this magic substance, ${ }^{15}$ which if treated with the slightest disrespect has a tendency to retaliate and burst into flames. Thus, the men who search to bring us this magic liquid are romantic heros in Frye's sense. They are strong and fearless and readily face dangers and discomfort for the sake of their communities.

The beautifully illustrated series of twelve advertiements that BP produced in 1925 to which I have already refered (9:14) which I refer to as "The Magic of Persia" provide yet more evidence of this. One of the themes is how through innovations brought about by the company, life in both Britain and Persia has improved. The advertisements in this series are all full-page and were produced on glossy paper. In each case, the top half of the page is filled by a square-shaped illustration which is "From an original drawing by Christopher Clark, R.I." Clark was a well-known artist of the time whose work was exhibited at the Royal Academy, for example, and who generally favoured military themes. The words "BP" and underneath in smaller lettering "The British Petrol" catch the eye at the bottom of the page and the address of the Distributing Organisation of the Anglo-Persian Oil Co. Ltd. is provided across the bottom, underlined by what seems to be a garlanded pipe. Each of the advertisements begins with a picturesque description of what is illustrated by the drawing and relates to times and traditions long gone by in the history of Persia. These traditions are all based on or involve the many uses of petroleum. The narratives are all very informative, and open in a style reminiscent either of a tourist guide book or of a school text book.

In the example shown in figure 9: 21 , the author of the text describes the hostile countryside which the men had to cross with only mules to help them. Further, the mythical qualities of the difficulties that the country offered are subtly underlined by them being three; desert plains, deep gorges and mountains.

\footnotetext{
${ }^{15}$ See Chapter 2.
} 
He stresses problems that these men faced and refers to them as pioneers, ascribing them with the qualities of endurance and indefatigability.

I provide the full text of this advertisement here as it describes the difficulties facing these brave adventurers very clearly.

\section{Image removed due to copyright.}

\section{Figure 9: 21 Pipe Line in Persia}

The opening sets the scene in the manner of a fairy tale. The inversion, "difficulties innumerable were encountered at the end of the opening sentence lends weight to these and also resonates with the voice of a traditional fairy tale.

"In the days before the War, ${ }^{16}$ when the first pipe line of the AngloPersian Oil Company was laid, difficulties innumerable were encountered.

One hundred and fifty miles of barren country lay between the then recently discovered oil fields and the coast. Desert plains, deep gorges and mountain passes had to be traversed. The small body of British pioneers who carruied out the work were faced with privation and hardship, and often serious danger."

In the second section of the text, the frontal positioning of the distance increases the sense of its length. The groups of three elements of the terrain that had to be traversed at the beginning of the second sentence, with the three problems encountered listed in an order of increasing difficulty and positioned at the end of the achievement add to the fairy tale quality of the narrative.

The slow, heavy work, and the determinaton of the men involved is expressed by the repetions, "mule by mule" and "step by step" and by the otherwise superfluous "at last".

"But the work went on. Mule after mule laden with pipe found its sure-footed way step by step further inland, until at last the vein of steel was complete, and the first of the rich crude oil of Persia flowed to the coast en route to England.

The original pipeline has since been duplicated to meet the ever-growing demand for the Company's products, notable among which is "BP" the British petrol.

Refined at Llandarcy, South Wales, the crude oil of Persia, "BP" can be relied on to give maximum power, speed and mileage per gallon. And the demand for it grows daily greater as motorists in increasing numbers come to realise that it is both best and British."

The heroes have succeeded in bringing the precious life-giving liquid to Britain, but more is needed and the brave adventurers will have to repeat their arduous task and repeat their mission to bring yet more of the magic liquid home to Britain to try to satiate demand. The metaphoric reference to the pipe line as a vein of steel and to the oil that is pumped through this pipe line being ascribed the quality of life blood, circulating from Persian to England and bringing benefit to both nations, confers upon oil the status of the bringer of life that I have previously discussed (figure 9:1).

\footnotetext{
${ }^{16}$ The War referred to is of course WW1.
} 
The tradition of portraying men engaged in the discovery of oil as adventurers is still found in the advertisements of the oil companies today.

\section{Image removed due to copyright.}

\section{Figure 9:22 She looked for trouble and learned a lot}

The Standard Oil New Jersey advertisement from 1970 (figure 9:21) shows two men standing at the prow of an icebreaker. In the far distance, there is a dog team. These pioneers are miles from civilisation in a cold and dangerous environment where they have been looking "for trouble". Their mission was to "reduce the Arctic from a forbidding mystery to a set of identifiable problems" and "to test the feasibility of a year-round sea-route between the oil discovery in Alaska and the Atlantic coast". ${ }^{17}$

Two more recent examples include the Chevron advertisement from the first decade of the century (figure 9:23) This photograph is one element of a much larger advertisement and shows two men sitting in a hot and barren landscape miles from civilisation, seemingly discussing how they can help to supply the glovbal demand for oil.

\section{Image removed due to copyright.}

Figure 9:23 Chevron willyoujoinus to the text, has interested Total since the late 1980s.
Similarly, the advertisement from Total from 2006 (figure 9:24) depicts two solitary adventurers, far from the comforts of civilisation.

One man is a diver "reviewing the oil issue in depth" to bring "new solutions to the surface" while the second man gazes out over the sea at the sun, a source of energy that according

\footnotetext{
${ }^{17}$ Esso, as the Standard Oil Company of New Jersey, positioned an eight-page article-type advertisement in Scientific American (1968) entitled "The New Adventurers" where they discussed the questions of why these men search for gas and oil offshore in dangerous environments, the risks that they take and finally, if they pollute the coastal waters.
} 


\section{Image removed due to copyright.}

The advertisement involves a double visual and verbal metaphor and pun. The first is the statement "Reviewing the oil issue in depth" which is illustrated by the solitary diver with his bright lamp in the depths of the ocean, while the second is the second man, gazing out over the quiet surface of the ocean whose surface is illuminated by the light of the sun. However, the diver is floating above the earth and seems at first to be in the sky, "bringing new solutions to the surface".

Following Kress \& Van Leeuwen (1996), this implies the possible, while the man gazing at the sun in the bottom right hand corner just above the company logo is reality. ${ }^{18}$

\section{Figure 9:24 Total bringing new solutions}

Another aspect of the adventure of petroleum, whether in aeroplanes, cars or boats, was embodied in the endorsers that populated many of the earlier advertisements.

The majority of these were aviation pioneers, such as Amy Johnson, venturing out into the very new world afforded by the magic of oil and competing with Phaeton in their attempts to fly further, faster and higher, or motor racing heroes, trying to break speed records. Other, later, motoring heroes that have advertised the oil companies through receiving sponsorship and providing endorsement, include racing drivers like Sterling Moss and also Donald Campbell, ${ }^{19}$ who appeared extensively in BP advertisements during the 1950s and early 1960s and who lost his life trying to break his own speed record on Coniston Water.

As Erdogan (1999) has pointed out, such endorsers can trigger the aspirations of others ${ }^{20}$ be like the the hero. Certainly, a number of early

Image removed due to copyright.

Figure 9:25 with Scott in the Antarctic advertisements refer to races and portray seemingly ordinary upper-class gentlemen who have competed.

Other endorsers included explorers that the companies had sponsored. One well-known early example from Shell was Captain Scott's

\footnotetext{
${ }^{18}$ The advertisements in both the series in their "Our energy is your energy" campaign challenge the reader's sense of reality and require that he thinks about what he is seeing, a technique that for example Bonhomme \& Lugrin (2008) suggest results in better retention while Cohen (1978) for example, believes that the transactional aspect of interpreting such metaphors leads to a closer relationship between the two parties involved.

${ }^{19}$ Campbell was the son of Malcolm Campbell who held speed records during the 1920s and 30s. Donald held a total of 13 records, including both the land and water records which he set in 1964. He is the only person to have done this. He died on Coniston in 1967 in an attempt to break his own record.

${ }^{20}$ Certainly a number of early Shell advertisements depict gentleman who are engaged in motor racing and in their 1930s series "snappy engines", BP pointed out that although "No livelier petrol can be obtained from any pump [, the] special dopes used for speed records are both unobtainable and unsuitable for ordinary motoring."
} 
exploration of the Antartctic, (figure 9:25) ${ }^{21}$ while BP sponsored Fuchs, ${ }^{22}$ almost 50 years later. $^{23}$

These endorsers are examples of real heroes and adventurers who illustrate the heroic aspects of the quest for oil with its incumbent dangers and discomforts.

The romantic hero of the quest for oil is very much a man but there has been a shift in the way in which these heroes are portrayed as figures 9:26 and 9: 27 show.

Høngmark Knudsen (2012) points out that meanings of "the moving target of masculinity" (9) are rooted in discourses from the past and which are generally current today. These include the notion that masculinity involves sports and athleticism and an element of "roughness". Her findings are in line with those of O'Barr (2006), who identified power, strength, virility, athleticism and competitiveness among the attributes of masculinity. Tuncay Zayer (2010) contends that there eight representative themes of ideal masculinity: the Adventurer, the Athlete, the Attractive Man, the Daredevil, the Family Man, the Goal-Driven Man, the Individual and the Strong Man. Typically, the men engaged in prospecting and drilling for oil are portrayed as Adventurers, Daredevils, Athletic and Goal-Driven, as well as being physically strong.

\section{Image removed due to copyright. Image removed due to copyright.}

Figure 9:26 is an advertisement published by Texaco in the 1970s. The text explains how "Texaco drilling crews understand the language of oil. They speak it in 125 territories". The company then explains how they employ men in the countries where they work.

\footnotetext{
${ }^{21}$ Robert Falcon Scott led two expeditions to the South Pole. The first was the successful "Discovery Expedition" of 1901-1904 and later he led the ill-fated Terra Nova Expedition (1910-1913) where Scott and four companions died from a combination of cold and exhaustion on the return journey.

${ }^{22}$ Vivian Ernest Fuchs (1908-1999) is best known for leading the Commonwealth Trans-Antarctic Expedition, the first overland crossing of Antarctica. He received a knighthood in 1958 after the team returned.

${ }^{23}$ Fuchs actually sent the chairman of BP a telegram from the Shackleton Base thanking the company for their support.
} 
The men pictured are very different and come from different ethnic and racial backgrounds, but not only is the oil world portrayed as exclusively male, the masculinity of the oil business is underscored by the perspective from which the photograph has been taken which foregrounds the blatantly sexual stance of the figure at the centre right. The gaze of the men is focused on the camera and they exude confidence. While the man whose pose is blatantly sexual looks at the reader in a way that is almost confrontational, some of the others appear nonchalant and secure in their skills and camaraderie. The man portrayed at the far right is standing somewhat in front of the others and seems to be looking down at the reader. These men are adventurers and daredevils and display the "roughness" that Høngmark Knudsen (2012) mentions. They exude raw masculinity.

The picture to the right (figure 9:27) is part of an advertisement published by ChevronTexaco in the 1990s. It is the second page of a double spread which shows an oil rig, viewed through the screen of an aeroplane or helicopter, in the middle of an empty blue ocean with the words "What's coming into view is a better partner for you", recycling the words of their 1950s series "Partners in Progress" described in Chapter 8. The photograph shows four men, dressed in the typical clothes of a building worker or engineer and who all look relaxed in each other's company and comfortable on their small platform high above the water, miles from civilisation. However, while the men from the 1970s are depicted as a strong, sexualised male gang, these men are intellectualised. The view from above brings into focus their pristine white helmets contrasting with the more mixed headgear and physical display of the Texaco men and their stance is relaxed. These men are in deep discussion with each other and have no need to display themselves to the public. The modern oil man is more intellectual, a scientist rather than a man of physical action. As Chevron is a company that prides itself on its international impact ${ }^{24}$, the men featured are also of different nationalities. However, I claimed earlier that myth plays an important role in the advertising of the oil companies and it is clearly evidenced in this depiction of masculinity.

\section{The Alchemist}

I have already stated that the roles assigned to the romantic heroes of the world of oil can be classified as either that of an adventurer, the man who journeys to find the precious liquid or of an alchemist, the man with the magic powers to transform it.

One of the advertisements in the "I'll tell you something else about Shell" series from 1958 refers directly to this notion. The advertisement features two university students discussing their future careers and one says to the other: "Do you realise that the petroleum chemist is the modern alchemist".

There is a magical quality about the alchemist, who traditionally turned base metals into gold, and the implication is that Shell is magically turning petroleum into something with a much greater value. The speaking actant in the advertisement goes on to explain how the petroleum chemist is creating both "well-known chemicals, but also ...completely new substances. It is his work which provides the new materials to complement the age of nuclear power."

\footnotetext{
${ }^{24}$ Chevron has developed from Caltex, whose "International Panorama of Progress" series from the 1950s ended with the words "partner in progress" in "over 70 countries in Europe, Asia, Australia and New Zealand." Notice too that their advertisements from the first decade of the $21^{\text {st }}$ century feature individuals of different races and from different continents.
} 
An advertisement in the "BP Maps the Future" series of the same year communicates a similar message. The visual depicts a pair of hands holding some delicate instrument and the reader is asked: "How will these hands shape tomorrow's motoring?" This direct question compels the response of reading further to find out that the hands are those of a BP chemist at their Sunbury-on-Thames research station. The company then states that the work of these almost one thousand workers is "to conjure more and better products from one single substance - crude petroleum." The petroleum chemist is a magician.

Another example from the same period goes under the heading "Shell meets the challenge; Within the Lethal Zone". In this advertisement the reader is informed how the company is an innovator: "Here is Shell "Leadership in Lubrication" in action - anticipating a need, undertaking fundamental research, and finally developing the products to solve a problem of world-wider importance." What is particularly interesting is that the heading of the advertisement stresses the dangers involved and that this is compounded by the human figure that illustrates it. At first sight this figure seems to be floating in space rather like one of the astronauts who were the new heroes of the age but is in reality a man dressed to enter the "lethal zone" of a nuclear plant where there is radioactivity. The dangers inherent in the work of the company and of the alchemists are implicit in these words.

It is interesting to note that in the first years of the $21^{\text {st }}$ century, the companies began to name the real individuals who began to appear as actants in their advertisements and who therefore become more than mere representants or types (Wetzel 2011, Morgan 2012). ${ }^{25}$

In their advertisements, ExxonMobil, for example, now discuss the innovative work of their engineers and name both them and other experts and innovators. Jurgen Schwenger, portrayed in figure 9:28, for example, is involved with "an ingenious new technology that has transformed the scale on which natural gas be be safely and efficiently be liquefied and transported with a new class of ships that can hold $80 \%$ more liquefied natural gas and are a remarkable $40 \%$ more energy efficient". This will diversify Europe's energy resources and help to provide the whole continent with energy security.

\section{Image removed due to copyright.}

Figure 9:28, an ExxonMobil alchemist
Schwenger is portrayed as an individual innovator, a token rather than a type, who by connotation, is representative of the innovative character of the entire corporation. He looks directly at the reader, open and friendly, confident in his standing and demanding contact and response. The amazing nature of his achievement, "Designing ships that transport $80 \%$ more natural liquified gas is no easy feat, but that didn't stop our engineers" is underlined by the visual metaphor of the ant carrying the leaf which is much bigger than itself.

\footnotetext{
${ }^{25}$ In Chapter 7, figure 7:8, I showed the snake drill that was inspired by a bendy straw and it is one of the extremely rare occasions when Shell name an inventor, Jaap van Ballegooijen, whose other way of thinking was inspired by watching his son drinking a milkshake.
} 
Unlike the adventurers portrayed in the advertisements I discussed in the previous section, the alchemist is not portrayed as a member of a team, but rather as a goal-driven individual who does not rest until he has found a solution to any problem that may arise to transform the substance that the advernturer brings him into something of even greater value to the community.

\section{The Cast of Participants Expands}

However, expression of the myth of oil is not limited to those who are cast in the typical roles of hero and alchemist and other characters make up a supporting cast and with whom the heroes cooperate in different ways. As I mentioned earlier, Arthur Asa Berger (1997), developing the work of Vladimir Propp, identified a number of the most common basic actions in a fairy tale and found that these do not only consist of searching and suffering but also include cooperation.

One of these roles is the alchemist's apprentice, a character who takes the achievements of the master and extends their use beyond the actual transformation to incorporate ways in which the transformed substance can be shared with other members of the community. Another is the story teller who recounts the heroic deeds of the adventurers and describes the magic performed by the alchemists to the spellbound public. Consequently, the mythical heroes of the advertisements are sometimes joined by a secondary group of participants, entrepreneurs, experts and educators, whose contributions to the development of society are directly dependent upon the work of the principal characters.

\section{The Entrepreneur}

The Mobil advertisement that incorporates the Endicott Johnson Company (figure 9:29) is a good example of how the alchemist works with the entrepreneur and the expert and how their combined heroic achievements are for the common good.

\section{Image removed due to copyright.}

Figure 9:29 You're Miles Ahead with Mobil 
The text describes how the "Leading shoe manufacturer cuts downtime and maintenance ... increases production....all though Mobil's lubrication program!" and explains how "Mobil engineers, in close cooperation with plant personnel, analyzed lubricant application methods" and together, created a way to save time and costs. The plant personnel are examples of experts while the company is an example of business entrepreneurship at its best.

Entrepreneurs ${ }^{26}$ feature frequently among cast of participants that populates the of myth of oil. Often, the oil companies are portrayed as entrepreneurial organisations in their own right, and at the same time, as sponsors or benefactors that help other, individual entrepreneurs or small groups and communities. A glance at Shell's "Real People" series shows men involved with their businesses and expanding and developing these, and at the same time benefitting the community, with the help of Shell and its expertise. Rick Scott's hydrogen filling station in Washington DC (figure 7: 4) discussed in chapter 7 is one example, and Ian Hazlewood, who features in the BP advertisement (figure 7:5), provides another.

A particularly interesting example is from an advertisement in the Standard Oil New Jersey and Esso series from the early 1970s. The advertisement follows the pattern of others in the series (figures 8: 49, 8:50, 9:22) and consists of a double-spread photograph of a group of Tyonek Indians moving en masse towards the camera, carrying the tools of their newly acquired trades against the background of a grey, unfriendly landscape, which suggests the hardships that the oilmen experienced in their quest for the magic liquid. The text informs the reader that it is thanks to the "several million dollars that [one of the company affiliates] paid for the right to explore for oil on their land" that new prosperity has come to this Alaskan community. After describing the new opportunities that this investment has brought to the area and the entrepreneurship that it has generated, the company point out that despite the large sum of money paid out for the prospecting rights, no oil was discovered. They also state that this is not unusual as "only one out of every fifty exporatory wells drilled in the U.S. actually results in the discovery of oil in commercial quantities."

The company is not only suggesting that the men who search for oil are heroes, but is underlining the uncertainty of their success, and consequently, the altruism and social heroism of Standard Oil whose enterprises involve such risk, both with regards to physical discomfort and to the uncertainty of financial gain.

This advertisement not only illustrates how the work of the company is supporting and encouraging entrepreneurship and bringing better living standards to all types of communities, but is also a display of the way in which companies promote a desired image through CSR, as discussed for example by Livesey \& Kearins (2002), Ihlen (2008) and particularly by Sen \& Bhattacharya (2001). seems to be the youngest

\section{The Expert}

Another role that the oil companies both play themselves and cooperate with is that of the expert, a role that I conflate to include the educator. This conflation of the two roles can perhaps be compared with de Certeau's discussion (1984) on the nature of the expert and the philosopher and the changing concept of expertise. The example shown in figure 9: 30, is an early example from about 1910 of the expert sharing his knowledge with those who are less well informed.

\footnotetext{
${ }^{26}$ Both Merriam-Webster and dictionary.reference.com include the aspect of risk in their definitions of an entrepreneur.
} 
"This, gentlemen, is the famous Motor Spirit known as "Shell," which attained premier position immediately on its introduction six years ago and has since been unfailingly successful; it has now extended its supremacy to the realms of flight". The stance is confident and the expert informant is gazing directly at the audience, but the angle suggests that he is looking down slightly, as though he was standing on a slightly raised podium. This automatically implies a position of authority. This is compounded by the clothing of the expert, which in conjunction with the form of address that he uses positions him as a member of the leisured classes. Notice too, the use of superlatives, in this short eulogy to Shell. ${ }^{27}$

Image removed due to copyright. Image removed due to copyright.

The second example (figure 9:31) is from about 1919, and the expert is a Shell service station worker in his neat uniform (Rossling 2001) proudly showing off the company's new sealed cabinets. This is an early example of expertise in action, a phenomenon that is illustrated in the 1958 advertisement published by Mobil (figure 9:32)

\section{Image removed due to copyright.}

Figure 9:32 His skilled hands

\footnotetext{
${ }^{27}$ The use of superlatives in advertising is discussed in Chapter 4 and is a development attributed by Jackson Lears (1994) to Phineas Barnum.
} 
Not only does the headline take up the skilled hands ${ }^{28}$ of the specialist mechanic, but the opening words of the first two of the three paragraphs below the headline emphasise expertise, which is then illustrated in the photographs below. "Expert training is important" is illustrated by such a training session, while "Your Mobil dealer has special skills" is illustrated by the dealer demonstrating one of these skills. These words are written in bold font to make them stand out. The third photograph and paragraph refers to their products which are "tops," and the male dealer here shows a female customer a product (García-Muñoz \& Martínez 2009) that the company's research experts have developed. The earliest forms of expertise demonstrated simply concerned the superiority of a brand of petroleum products, but by the 1950 s, this expertise incorporated not only the chemical components that are included in the specific brand and that for example, make it start better in the summer or that prevent knocking, but also the development of nuclear energy and agricultural solutions.

Later, this expertise grew to include improving issues concerning social welfare and economic development as well as answers to environmental problems.

\section{The Educator}

Educational expertise is a recurrent theme of the advertising of the oil companies and this finds expression in a variety of forms. The materials that Shell provided for schools and which included posters about flowers and wild life exemplify this. $\mathrm{BP}^{29}$ too has always shown showed an interest in education. One example is their "Khan" exhibition at Wembley in 1925. This was built up to show every phase of their work to bring oil products to motorists in Britain, and another is their beautifully illustrated series of twelve advertisements showing and explaining traditional life in Persia ${ }^{30}$ and describing how the company is improving life for both Persians and the British. Their 15-step detailed cartoon overview of the "The story of oil" from that period ${ }^{31}$ is yet another example of the way in which the company wanted to teach people about their business as is their strip cartoon "Tony Strikes Oil" from 1953.

Today, oil companies are involved in a number of educational projects of different kinds. In 1958, for example, in their "BP marks the Future" series, the company advertised one of their major achievements as the establishment of a school in West Australia where the children of the people involved in their new refinery could be educated. Another project is the Folger Shakespeare Research Library on Capitol Hill, Washington, established by Standard Oil of New York President Henry Clay Folger in the early 1930s, while in the 1970s the company supported a new form of schooling, "Education on the Move" which is discussed in the previous chapter, to counteract dropping out. ${ }^{32}$ Shell too have supported education in different forms and more recently, have supported and sponsored a number of projects such as the Launchpad project at the London Science Museum or the Questacon Science Circus to help schoolchildren in remote parts of Australia.

\footnotetext{
${ }^{28}$ The advertisement from BP in 1958 that was discussed earlier (also uses the concept of skilled hands. Similarly, a series of Shell advertisements in the "Real Energy" series from the first decade of the $21^{\text {st }}$ century is illustrated by a pair of male hands engaged with a tic-tac game and trying to "Start from another place".

${ }^{29}$ During the years that BP was partly state owned, part of fits profits contributed to the welfare state, and in the 1950 s and 60s the corporation paid for the children of staff to go to school and university (Simms \& Boyle 2010:246).

${ }^{30}$ See figure 9:21 for example

${ }^{31}$ In this way, BP anticipated the findings of George Gallup on the impact of cartoons.

${ }^{32}$ See for example figure 8:50, which is the first of several advertisements that have this theme and discuss this school form.
} 
While the earlier advertisements tended to emphasise the adventurous nature of the hero on his quest, today it is more as protectors of the planet and defenders of a life style that the companies' heroic tendencies are proffered for display.

However, the heroes of the mythical world of oil are all men and if semiotically, the masculine is irrevocably connected with and opposed to the feminine (Schroeder \& Zwick 2004), the male hero must have a female counterpart; a heroine or a "lady".

\section{The Myth of the Lady}

The beautiful Chéret posters from the end of the $19^{\text {th }}$ century advertising a safe, new illuminant depict women as "ladies of the lamp". These women are independent, elegant creatures and are typically portrayed in graceful, almost ballet dancer-like poses lighting their lamps. The example in figure 9:33 is from 1894, and the woman's posture, clothing and the apparent simplicity of the act connnate the cleanness of the new illuminant and the ease with which it can be used. Although it can be argued that the home is tradidionally female territory, these women are still portrayed alone, independent and capable.

\section{Image removed due to copyright. Image removed due to copyright.}

Figure 9:33 Chéret: lamp oil

This is underlined in an early postcard advertisement where a man in motoring gear is used to show Shell Motor Spirit while a woman dressed as a maid holds up a lamp to show the advantages of Royal Standard Lamp Oil.

Other advertisements confirm this tendency to portray women as homemakers and concerned only with their families (e.g. Coutney \& Lockeretz, 1971, Gaye Tuchman 1979, Sullivan \& O’Connor, 1988, Elliot et al 1992).

Tim Russell (2007) has reported how oil companies in the United States provided rest rooms to encourage customers. Gulf was the first of the companies to do this in the early 1930s and Texaco and also Shell quickly followed the trend to use the provision of rest rooms as a weapon in their advertising armoury. All of these advertisements featured women and children as the assumption was clean rest rooms would be a female priority in the choice of petrol. The headline "Something we ladies appreciate!" (figure 9:34) underlines this belief. 
This Texaco advertisement from the early 1950s (figure 9:34) shows an elegant young mother driving an open-top car with three happy, neat and well-dressed little girls. The young woman's hat and pearl earrings connote respectability and a comfortable economy. All four are smiling and despite the open top, they do not have a hair out-of-place. The bonnet of the car creates a vector which points towards the large Rest Room sign, whose position in the top right of the image indicates that it is not only a new concept but also source of comfort and satisfaction (Kress \& van Leeuwen 1996). The connotation is that they are happy and tidy because they have just visited the Texaco rest room and are about to drive away. Although the copy states that the rest room is "Another Texaco dealer service appreciated by motoring families", in this example, as in all the others, only the female members of these exclusively white, middle- class motoring families are depicted. The "we" of the headline, which is attributable to the immaculately and conservatively dressed mother, can be interpreted as a general reference to what women like, or as an acknowledgement of inclusion and sisterhood with a female reader.

Similarly, in the very few advertisements which they published and which featured women in The Economist from 1958, Shell and Caltex both advertised how their petroleum-based products made life easier for women and stressed in particular the new fabrics that had come on the market thanks to their innovations. A decade later, Amoco ran a number of advertisements for their new fabrics in Scientific American.

The example shown in figure 9:35 for their "durable press polyester fabrics" is headed "Freedom FromThe Press" and portrays a group of four women sitting around an ironing board to play cards and drink coffee. The women are elegantly dressed and coiffed, and the text opens with the words. "Ironing day in the housewife's week isn't what it used to be" and explains how thanks to "Amoco's contribution to durable press polyester fabrics ... [t]roublesome shirts, suits, dresses, playclothes, and bed linen come with a free press. Stay wrinkle free, care free."

Instead of a basket full of ironing, there is a large bag full of grocery shopping next to one of the women, who also has a black and white dog tied up to the chair on which she is sitting to play her hand. The implication is that instead of being at home ironing, thanks to Amoco, she can go shopping and drop in to visit other

\section{9:35 Freedom From The Press} housewives for leisure purposes.

The connotation is that a woman's place is very much in the home to take care of her husband's as well as the household laundry, but that Amoco is freeing them. Another connotation is that the lack of stress and work involved in having to do the ironing as well as everything else will help to keep not only her fabrics, but also her face, wrinkle-free. ${ }^{33}$ Again, the advertisement uses a pun to make its point and also recycles the notion of "Freedom from

\footnotetext{
${ }^{33}$ It should be remembered that oil had a long tradition of being a major ingredient in cosmetics and that the petrochemical industry developed this further.
} 
the Pressgangs" that had taken men to work long, hard hours on board ships and in a more contemporary context, the concept of "freedom of the press" "34.

One of the most interesting aspects of these advertisements is perhaps is that they postdate both The Feminine Mystique by Betty Friedan (1963) which marked the reawakening of American women to an awareness of the pervasive societal pressures to conform to the traditional female role ${ }^{35}$ and to the writings of Simone de Beauvoir. ${ }^{36}$ By suggesting that Amoco is helping women in their daily lives, these advertisements are acknowledging the movement to free women from the burden of household chores.

However, the trend to portray women as homemakers is still strong today (see figure 9:36), and just as the Amoco advertisements associated women with fabrics and the home and men with work and industry, the Shell "Real People" series from about 2005 did the same.

\section{Image removed due to copyright.}

Figure 9:36 This Dutch windsurfer has pointed out, there seems to be cultural lag between the stereotypes portrayed in advertisements and social reality.

These examples show how the magic liquid that the heroic oil companies bring back from their quest make life easier for the female population. Like the heroes of Romance, they bring treasures to their Ladies.

\footnotetext{
${ }^{34}$ This pun was particularly relevant at the time, as in 1964, the Supreme Court had ruled that journalists could not be prosecuted for publishing material about public officials unless actual malice could be proved. The origins concerned an Alabama segregationalist who had published attacks on Martin Luther King Jr.

http://civilliberty.about.com/od/freespeech/tp/Freedom-Press-History-United-States-Timeline.htm (May 62013 ). ${ }^{35}$ Demarest \& Garner (1992:363) point out that articles by both Betty Friedman and Simone de Beauvoir were the central focus of a number of specific issues of both Ladies Home Journal and Good Housekeeping during the late $60 \mathrm{~s}$ and early $70 \mathrm{~s}$., but their impact upon general advertising does not seem to have been very great. In fact, according to these authors, it is only" in times of national economic peril" such as the two world wars, that women have been portrayed as strong and independent (358).

${ }^{36}$ Simone de Beauvoir's Le deuxième sexe appeared in 1949 and was translated into English, The Second Sex, in 1953. This translation has been subject to a great deal of criticism as among other things, it was selective about what content was in fact translated.
} 
Power is characteristic of all relationships and at all levels. Power is often founded on the presumption that one partner in the relationship "knows" and that the other will take the knower's advice (Foss et al. 2002:352). In the advertisements of the oil industry, male actants are regularly portrayed as experts, they are given agency and their expertise can be communicated directly to the reader, man to man as exemplified in figures $3: 6,8: 37$ or in the first photograph of figure 9:31. Alternatively, it can be demonstrated through the intermediary of a less knowing woman. In the advertisements that make up my corpus, the female is a vehicle for demonstrating both the quality of the products and the superior knowledge and expertise of the expert. She listens eagerly while the expert tells her about the advantages of the product, as the examples from Shell (figure 9:31) and the last photograph in the Mobil advertisement shown in figure 9:32 illustrate. In figure 9:32, men are portrayed as members of a group who "know" and understand and do, while the only woman ${ }^{37}$ who appears in the narrative is depicted as someone who is outside this group and to whom the product in its can is proudly displayed for her inspection. The hero is offering the lady a physical example of the treasure.

However, women are not only portrayed as less knowledgeable but there are also numerous examples where the female acolyte is depicted as stereotypically ignorant.

One instance of this can be found in the series from ShellMex and BP that appeared in Motor in the mid-1950s for Snowflake anti-freeze. The male characters might have "a problem" or in the case of Mr. Blackwell, who "operates a fleet of vehicles" take "no chances" while the female

\section{Image removed due to copyright.} character portrayed in the series, Miss Hilcot, (figure 9:37) "needs help". She is a damsel in distress waiting for a knight in shining armour to appear on the scene and rescue her, in this case, the Shell-Mex \& BP Ltd. hero with a can of the right anti-freeze. Moreover, while the male characters are introduced first through their professions and then perhaps, their family responsibilities, the female is defined by her appearance. "Betty Hilcot, 28, brown-haired and pretty as you can see" simply lives in a flat in Kensington and is merely attributed with good looks.

\section{Figure 9:37 Miss Hilcot needs help}

Another interesting aspect of this advertisement is what Goffman referred to as "gender display". Betty Hilcot is stereotypically portrayed with her head slightly tilted in a rather gamine fashion, not looking straight into the camera, but towards it, and touching herself; in other words, clearly demonstrating what Goffman refers to as "the feminine touch". ${ }^{38}$ Moreover, she seems to have little or no relationship with the motor vehicle depicted behind her.

A very interesting example of expertise being demonstrated through the medium of female ignorance is the Enjay ${ }^{39}$ advertisement "To line a ditch or hold a hitch, call on Enjay skills"

\footnotetext{
${ }^{37}$ See for example Umiker-Sebeok (1996) or Elliot et al (1992) for a discussion of how men are not only shown in positions of authority but also dominate the spatio-temporal resources of advertisements.

${ }^{38}$ This posture is one which can be associated with photographs of the ultra-feminine Marilyn Monroe.

${ }^{39}$ Enjay Chemical Company was a division of Humble Oil \& Refining and became incorporated into what is today ExxonMobil.
} 
published in Scientific American in 1963. The advertisement comprises two photographs; one of a group of men working in the desert with heavy machinery and cranes, and who, from the headline can be understood to be lining a ditch, and the other showing a boat being moored with a strong rope. The advertisement opens with the words of the informant: "When a new secretary asked her Enjay boss what technical service meant, he didn't know where to start".

Woman is not depicted as a "maker of meaning" (Laura Mulvey:1975) but as a vessel through which man can impose his view of the world, and in this case, describe the work of the company's "2900 highly trained technical experts, many of whom are nationally recognised authorities."

The advertisements of Shell, and to a lesser extent, BP in the 1930s made frequent recourse to this technique and to allow the expert to show off his knowledge, and often portrayed women as frivolous sex objects.

\section{Image removed due to copyright. Image removed due to copyright.}

While the elegant, sophisticated, upper class lady driver depicted in the BP advertisement from 1934 acknowldges her problem, namely that she does nor seem to be getting the best from her car and asks for the expert advice of the male, ${ }^{40}$ the Shell advertisement with the popular slogan "You can be sure of Shell" goes much further. ${ }^{41}$ When the girl rather innocuosly asks "Do you like this Shell advertising" it subtly suggests that the couple are engaged in a conversation about Shell. ${ }^{42}$ Although the girl is mainly interested in the advertisements, the male protagonist replies that "it's not as good as their petrol which really is the best". Moreover, the typical Shell slogan has been preceded by the words "everybody knows" which implies that the girl who questions any aspect Shell is rather silly and uninformed. Not only does the man act as an expert on Shell advertisements and products, but he also physically lifts and supports supporting the scantily clad girl, thereby showing his ability and willingness to protect and defend those who are weaker. He is not only her intellectual, but also her physical superior, and his strength and the ease and confidence with

\footnotetext{
${ }^{40}$ See for example Klassen et al (1993) for a study of the ways in which male-female relationships are portrayed.

${ }^{41} \mathrm{It}$ is one of a number of such advertisements. In one, the male expert balances two scantily clad girls on a pole

${ }^{42}$ This is a strategy that the company returns to in the 1950 s.
} 
which he lifts her high in the air functions as a metaphor for the reliability and superiority of Shell. This is in line with O'Barr's (2006) observations.

\section{Summary}

Ellis \& Stam (2010: 428) have postulated that the "narrative self is born into a world of practices from which it must choose projects and life plans that can give its life narrative unity," and a company too must create a corporate identity which can provide it with a clear and unambiguous image which finds resonance with its different stakeholders. The way in which this is done is frequently through myth (Levy, 1959, 1974, Stern 1995, Martin Green, 1996, McWhinney \& Batista 1988, and Goia et al 2000).

The roots of the myth go back some 5,000 years and the story-line of the tales that the oil companies recount revolves around the quest for oil, the magical liquid that can "calm our sufferings and assuage our woes"43 It is this that the hero of the epic seeks to bring home to solve the problems and ease the lot of the waiting community. The principle heroic characters involved in the quest are the adventurer, who faces great dangers and discomfort to find the liquid, and the alchemist whose expertise allows him to transform the raw substance into a multitude of products that improve the lives of others. However, other secondary characters, who are allied with the hero, include the entrepreneur and expert whose skills and knowledge allow the work of the alchemist to come to the best possible use, and help to distribute the magic substance in its varius forms to the people. The role of the educator is to spread the message and raise awareness of the wonders of oil. As a Romantic hero must have a Lady to whom he devotes his enterprise, both gifts that will make life easier, more comfortable and more beautiful are offered to the lady, and also knowledge. Generally, this is done through the mediation of an expert.

The oil companies describe their activities in terms of Frye's Myth of Summer and portray themselves as true heros through their "protection" or "defence" of those who are weaker, the courage they show in their never-ending quest for more oil and their sacrifice of both personal comfort and profits for the greater good. The latter is demonstrated by the advertisements which explain their various social programmes including education and the support of entrepreneurs. These are the superior and noble qualities with which the companies attribute themselves through their advertisements.

In his investigations into the narrative structure of commercial communications, ${ }^{44}$ Jean-Marie Flosch (1995) not only situated the role of semiotics in branding, but also developed the morphology of Vladimir Propp. ${ }^{45}$ From Propp's original functions, three major tests can be identified. These are a qualifying test through which the subject (the hero) becomes competent and qualified to perform a task, for example, through examinations or initiation rituals. The second test is the decisive test in which the hero is fulfilled by completing a number of actions, and finally, the third test is the glorifying test where he is recognised for what he has done or has become. Flosch then went on to discuss competence and performance. Like Goffman (1959), Flosch sees "Performance [as] the notion of 'doingbeing', while he considers competence as what makes 'being' or 'being-able-to'" (52).

\footnotetext{
${ }^{43}$ From the advertisement for Seneca Oil cited in Yergin (2008:4).

${ }^{44}$ The study which I am referring to here is Flosch's analysis of Crédit du Nord and its merger with the Banque de $1^{\prime}$ Union Parisienne in 1984. The original text can be found on pages 49-82 of his work from 1990, but I will refer to the English translation by Robin Orr Bodkin, which appeared in 2001. The specific chapter, chapter 3, is called "A Star is Born: Defining Visual Recognition for Crédit du Nord".

${ }^{45}$ According to Flosch (2001:49) Propp's 31 functions provided the first definition of narrative as an ordered sequence of interrelated or 'interdefined' formal episodes. Semiotics subsequently reduced this series.
} 
Through their advertisements, the oil companies portray themselves as competent and qualified and show how they go out into an often hostile world to do what "a man has to do". They display the characteristic actions identified by Asa Berger (1996). The first of these is the pursuit of their goal, namely to search for the Grail, sources of energy. In the pursuit they suffer, but cooperate with others along the way and finally, having successfully completed the Quest, they are able to help and protect those who are weaker and defenseless against the difficulties and discomforts that ensue from a life without the magic liquid, oil. Finally, their remarkable achievements are presented.

Through their advertisements the oil companies display themselves as both "doing-being" heroes and "being" competent experts. It is these aspects of their work that they bring into their dialogical encounters with the reader and with which they aspire to touch a chord of recognition. 


\section{Chapter 10}

Doing Being the Good Guys

I stated in the first chapter that the oil business is extremely capital intensive and referred to Bourdieu's (1986) claim that economic capital is connected to cultural and social forms of capital and have described the general trajectory of the industry as well as the sometimes circuitous paths followed by some of the companies to achieve their ultimate goal; the protection and healthy growth of the capital that they have invested. ${ }^{1}$

In "The Forms of Capital" (1986), Bourdieu described social capital as a 'credential', a form of group membership and recognition, and by 1992, had developed this definition to encompass "the sum of resources, actual or virtual, that accrue to an individual or a group by virtue of possessing a durable network of more or less institutionalized relationships of mutual acquaintance and recognition" (119). The reproduction of social capital requires the continuous affirmation and reaffirmation of positive recognition, and for a business, this is achieved through advertising and being seen to act as a responsible corporate citizen whose interests are in line with those of its stakeholders and whose undertakings are for the common good. Indeed, Pollay \& Gallagher (1990:359) have underlined the important contribution made by advertising for economic success. Therefore the advertisements of the oil companies can be understood to be a part of the "unceasing effort of sociability [and] series of exchanges" (Bourdieu 1986:250) that present the desirable "face" which contributes to the healthy maintenance of the social capital that they have worked to acquire over the years.

Oil has long been imbued with mythical qualities as a source of mysterious fires and as a salve to sooth and even cure illness, and the oil companies have made use of these qualities in their advertisements and connected its attributes with mythological characters. Similarly, the oil man has commonly been portrayed as a heroic adventurer who goes out into the unknown on a quest to find and bring home a magical substance. It is my contention that much of the social capital which the oil companies have built up is founded on this concept of heroism and the different "lines of action" that Arthur Asa Berger (1996) developed from Propp. The group identity created by the companies in the oil industry portrays the oil man as a romantic hero and adventurer and the advertisements encourage the reader to identify in different ways with these heroes who appear under a number of guises. The objective of these heroes who symbolise the oil companies, is to improve the lives of the communities of which they are a part by their "lines of action" and to extend the benefits attributable to their endeavours to others who are less fortunate and who need their help to succeed and in some cases, even to survive. In other words, the advertisements portray the oil companies as social actors intent upon increasing our collective life quality; they show the companies "doing being" the good guys.

While "doing being" the good guys is common to the identity that all the companies strive to communicate, it can take a number of different forms and the "good guys" depicted in my corpus range from pioneers and adventurers such as Captain Scott and Captain Eyston to educators and various forms of experts and innovators. However, as I have previously pointed

\footnotetext{
${ }^{1}$ The company reports show that despite the political and environmental problems that they have faced over the years their economic capital is strong. Data for January $31^{\text {st }} 2014$ for example, showed that BP had paid $\$ 12,874,338,575$ in settlements after the 2010 Deepwater Horizon accident but that they reported a profit of $\$ 18$ $905 \mathrm{~m}$ for the first half of 2013, some $\$ 14000$ up on the previous year. My intention here is to show how the companies work to maintain and develop their economic capital by working to improve their capital in its other forms.
} 
out, companies need to create and to present a specific image or brand personality, especially when the products that are offered are largely interchangeable. This is in line with Klein's (2000) contention that brand has become an allegorical embodiment of particular combinations of virtues or admirable characteristics. Thus, although the companies all depict oil, their magic substance, as the fount of all good and themselves in the role of romantic heroes, they have needed to create a particular heroic identity for themselves and by extension, for their brand.

I have been able to identify five different heroic types that correspond to the brand personalities of the five major oil companies. I have also been able to observe that the five dimensions of brand personality suggested by Aaker (1997), namely sincerity, excitement, competence, sophistication and ruggedness, are displayed to varying degrees by the different companies. I do not believe that these types are the result of any conscious marketing strategy but that instead, they evolved over time as a consequence of the different companies' origins, history and particular circumstances. In fact it should be remembered that Marcus Samuel chose a shell as logo merely to honour his father's business and that this was first a mussel. Moreover, the colour red was chosen simply because Standard Oil was using blue for its cans. However, it must be admitted that the current BP logo, the helios, was the result of careful thought. In the following, I will describe the different faces or heroic social identities which the companies present to the public to help to maintain and protect their capital. Unlike the American giants or French Total, Shell and BP have a long history as companies in their own right and have not resulted in their current forms from a series of mergers and acquisitions. Therefore these two companies can, as usual, be considered to be over-represented in my material.

\section{Shell the Crusader}

Among the various attributes of a crusader provided by a number of different dictionaries, we can read "a vigorous campaigner for social and political change" (Oxford), while a crusade includes "enterprises undertaken with zeal and enthusiasm" (MerriamWebster) and "any venturesome outcome, especially one with an uncertain outcome" (Farlex). A glance at the early history of the Shell Company and the determination exhibited by its founder, Marcus Samuel, to pursue his dreams and achieve his ends, both with regard to his business and later to his social ambitions, substantiate my claim that Shell does indeed play the part of a crusader. The main dimensions of brand personality that the company shows are excitement, competence and sincerity.

Shell developed from an existing a business which added the distribution of oil to its activities after its founder had perceived the business opportunity that this would bring. It has never watched from the side-lines, but has always led the field. Its early advertisements provided social commentary and voiced opinion on technical and social developments, ranging from sealed cabins to make filling a car with petrol safer and the role that the company should play in fuelling the navy, to votes for women. Later, Shell anticipated WWII in its advertisements, then supported and joined its name to nuclear power and even to space exploration. As well as crusading for technological advancement, Shell's advertisements stress the need to help people whose conditions for farming are less benevolent than those found in Britain and the United States, for example, to a more direct call for corporate social responsibility towards the end of the 1960s. This call was developed in the "Profits and Principles" campaign (figures $8: 54,8: 55)$ which challenged businesses to consider the social and environmental consequences of their actions and preached that profits and principles were not mutually exclusive. Their crusading, rather besserwisser attitude, was clearly seen again in 2008, for 
example, when in an advertorial-like advertisement published in The Economist, they told the G8 how to solve the problems of climate change, and their more recent campaigns insist that there are ways to successfully tackle the problems of climate change while maintaining and increasing secure supplies of energy (figure 8:78).

The advertisement from 1909 showing a Joan of Arc figure seated on a superb white steed with a castle in the distance (figure 8:4) symbolises the company. Like the founder of Shell, Joan was of relatively humble origins but was determined and fired by her convictions. She feared no one and was prepared to tell people with power what to do and how to act to achieve what she believed was best for the country and its people. Today, this crusading spirit can be seen in the advertisements where the company proclaim that they know how things should be done and that everybody should follow their advice. A brief glance at the Shell word cloud from 2008 in the next chapter, illustrates the issues that the company insists are central and for which we should fight. It is interesting to note that the words energy, fuel and world have more prominence than the company name and their crusade is for these, together with cleaner emissions.

Shell also worked to add cultural capital to its credentials. On a personal level, by 1902, Marcus Samuel had succeeded in attaining the prestigious position of Lord Mayor of London and had also been knighted. In addition to this form of more institutionalised cultural capital, the company acquired over time cultural capital in its embodied state through its policy of encouraging and promoting promising artists to create their advertising posters. Many of these artists, for example Paul Nash, (figures 8:16, 8:17) became well-known as painters in their own right and not simply for their work for Shell, and the company began to hold successful exhibitions of the artwork that it had commissioned as advertisements. Shell also began to produce a series of books to promote tourism and these were written and illustrated by wellknown writers and artists. In fact John Betjeman, the future poet laureate, was a regular contributor and wrote not only sections of the books but also some of the advertisements, such as the series for White May and Pink Aladdin paraffin. Bing Crosby also promoted Shell adding the weight of his name and popularity to their social and cultural capital. Today, although Shell still has an interest in the arts and sponsors both a drama series at the National Theatre and a concert series at the Festival Hall, the focus of the company's cultural work is to sponsor and promote museums where people can learn about geology and the oil industry, for example, and where children can learn about science. This is a continuation of their earlier work to provide schools with teaching materials for science and nature studies.

In this way, Shell can be considered to be working to maintain and develop their different forms of capital and also to be striving to influence society and champion those ideas that they believe will lead to a better world. Underlying these crusades is, of course, the need to be considered a responsible company and to be seen to be working for the public good. This involves endeavours to mitigate the problems of climate change and environmental degradation to which our enthusiastic and previously unquestioning use of the products that they developed has given rise. In other words, Shell's advertisements present them as "the good guys" and the spokesmen and champions of a better, and now, greener, world. In the words of one of their 2008 advertorial-type advertisements:

"For us, there is no debate about climate change. It's real. It needs to be addressed in a serious way and there is no time to lose. The longer action is delayed, the harder it will get. We are working to help secure a responsible energy future that delivers more energy to meet growing needs but with lower greenhouse gas emissions." 


\section{BP the Missionary}

Unlike Shell, BP, or Anglo-Persian as it was first known, came into existence as a company that prospected for oil and as a producer. Its founder was a relatively wealthy upper-class pioneer who possessed a certain cultural capital and who received government backing fairly early. As the company was based where the oil was and its legitimacy was acknowledged through the backing of people whose Britishness and repute were unquestioned, its advertising and heroic nature developed in a way which is different to that of Shell.

BP tried to create a kind of little Britain wherever it was established and to impose British ideas and values. In Persia, it became a kind of colonising power and advertised how its work was helping the indigenous people to modernise and improve their lifestyles while at the same time, it was providing Britain with much needed oil. This is clearly seen in the "Magic of Persia" series. Oilmen were portrayed as intrepid adventurers overcoming personal danger and discomfort to help the indigenous people and to bring the precious liquid home to Britain. Moreover, they built schools and institutions in the places where the settled to advance British ideas and bring the benefits of British technology to the communities. This is in line with the concept that the work of a missionary is to improve education, literacy, health care, social justice and economic development and to convince others of the need to adhere to a specific set of principles, or that a missionary is very enthusiastic and eager about doing a job or supporting a cause (Merriam-Webster).

Advertisements from the 1950s show this missionary tendency, for example in the "BP Maps the Future" series (figure 8: 36) where they talk about the school that the company has caused to be built in Australia or the training of African "local talent" to work as petrol pump operators. The BP advertisement for their work to benefit children in Egypt (figure 8: 57) and especially the solar energy advertisement from the "For all our tomorrows" campaign and to which I have already referred in another context, (figure 8:52) provide clear illustrations of this missionary tendency.

The visual in figure 8:52 shows a young, lone, African boy working hard with his education. However, the light in which he is bathed and which put the books in focus not only shows the way in which the company is bringing solar energy to Africa but is also a metaphor for the enlightenment that they are bringing to the "Dark Continent", as it was known. It is characteristic of the ways in which the work of Christian missionaries was often depicted: as a light in the darkness. The text anchors and expands upon the visual to explain how BP is striving to improve the educational and economic situation of the "children of Africa" as well as ensuring that health services will be better. The advertisement positions BP as a missionary, a hero going out into the less developed areas of the world to bring both physical and intellectual enlightenment.

BP advertisements are also characterised by patriotism, (figure 8:26) in the sense that earlier, they insisted on the way in which they were striving to make life better in Britain (figures $8: 27,8: 36)$ and the colonies while today, they encourage and sponsor British art and culture (figures 8:56, 8:61. 8:62) . This characteristic is witnessed by Gareth Jones (1977) who has reported how as long ago as 1914 , BP, then APOC, published notices in the newspapers about how they were working together with Shell, for the good of the nation. In fact the single word that dominates their advertising in 1958 is British which occurs 32 times. Much of the company's later advertising is also characterised by a missionary zeal. For example, during the second half of the 1990s, one series not only showed how BP supported different 
educational programmes ${ }^{2}$ that aimed to develop interest in science and engineering in schools, or how BP employees acted a mentors for undergraduate students but also a how they helped and sponsored people who have a mission. These missions included collecting money for cancer research, bringing better business opportunities to a deprived area, helping the British Red Cross and supporting Riding for the Disabled. In the $21^{\text {st }}$ century, much of their advertising has focused on how the company bring the work of the great British cultural institutions such as The Royal Ballet and The Royal Opera to people who would not normally be able to experience such performances. BP also advertise their support of major exhibitions in different museums and are very active in promoting and sponsoring British art. For example, they not only own an extensive collection of British art which is displayed free of charge to the public at the Tate but also provide expert guides to talk about different paintings. BP also sponsors an annual Portrait Award and the resulting paintings are also exhibited free of charge.

I maintain that this desire to provide the general public with access to British culture and to encourage people to learn is another form of missionary zeal. As is evidenced by its name, the insistence upon all that is British has permeated the company and its advertising and is a means of maintaining social capital in the circles where these advertisements are found: today, BP advertisements are most frequently found in The New Statesman, a very British periodical that was founded in 1913, is published in London and has its origins in the Fabian Society ${ }^{3}$. It is also a way in which the company acquires cultural capital in its objectified state as pieces of art, for example, but in its institutionalised state, the cultural capital that BP put on display adds to its social capital. The dimensions of brand personality that dominate the advertisements are sincerity and sophistication.

\section{Total, the Visionary}

As I have already explained, Total is the result of a fusion of Belgian Petrofina and the scandal-surrounded Elf Aquitaine. The name was finalised in 2003 and the company had to find a new identity to repair the damage done by the fraud charges in which Elf Aquitaine was involved. As I am only considering English language advertising, it is not until quite late that the company appears in my corpus and then it is to briefly introduce its entry into the UK.

It is the advertisements that appeared after 2003 that are interesting and that reveal the company's new identity as a visionary and dreamer. Typically, the advertisements have a double lay-out with one picture placed above the other, and the colours are soft to connote dreaminess. In one of the sections, we see the visionary or the vision and in the other, the work of the people who make the vision a reality (figures 8:72, 9:24). Later advertisements, from about 2008 in the "CO series" invert these two images so that one is reflected as a distorted shadow of the other (figures 8:73, 8:74) After the headline, which explains the role of Total, for example "Commitment to discovery", the reader is asked to "Image if....." and the ideal or dream-world that Total is working to achieve is described. Again, the company or the oil man is presented as a hero, but the Total hero is a solitary man with imagination and vision. Total's advertisements show a brand that is sincere.

\footnotetext{
${ }^{2}$ I have already mentioned in Chapter 9 that BP also supported the education of their staff's children during the 1950 s and 60s.

${ }^{3}$ The Fabian Society was politically left of centre and included writers such as George Bernard Shaw and the economist, John Maynard Keynes was also an influential member of the Board. The magazine states that it is committed to "development, human rights and the environment, global issues the mainstream press often ignores".
} 


\section{Chevron, the Partner}

Caltex, one of the companies that have made up Chevron, proclaimed in the 1950s that it was "Partner in Progress" (figure 8:35) and I contend that this very same characteristic permeates the advertising of the company today. Chevron grew out of a number of oil companies, particularly Gulf Oil and Texaco that had to cooperate to fight Rockefeller's Standard Oil, and the collaboration and partnership that the companies shared with each other spilled over into their view of business and of a service-partnership with their customers. The very name Caltex is made up of the combination of Standard Oil of California and Texaco.

For example, Gulf and then Texaco pioneered the provision of rest rooms at filling stations (figure 9:34). Advertisements by Texaco from the 1930s, for example, stress how this service is "appreciated by motoring families". The companies have entered a kind of partnership on the journey and their role is to provide comfort. Olle Wilson (2012) has also stressed the importance of the service and help that these stations offered the traveller, and I claim that the different services as well as the road maps pioneered by Gulf were a way for the companies to form a relationship with the customer and to "be there" for them.

However, the companies that came to make up Chevron did not limit their innovations to rest rooms and maps to help motorists, but also worked to make life easier for people all over the world and in many different occupations. While Caltex advertisements of the 1950s showed how the company was working towards development on different continents as a "partner in progress", by the 1970s, Texaco was advertising the many different nationalities of its drilling crews (figure 9:26) and in the 1990s, ChevronTexaco continued to communicate the same message actually stating in one advertisement "What's coming into view is a better partner for you" (figure 9:27).

A central theme in is the need for everyone to work together and to help each other across nations and professional roles. For example, in 1968, Texaco advertised that it was coming to Europe listing the countries where it was setting up operations and insisting on its responsibilities to the countries, large towns and small villages where it would be establishing business. The series also asked the reader to Texaco to find out more about the way they do business. This desire for personal contact with the public and the suggestion that cooperation is desirable is a major characteristic of Chevron advertisements today. By the mid-2000s, Chevron's advertisements were portraying people of very different ages and with different ethnic backgrounds and their "willyoujoinus" campaign encouraged people to share their ideas and feel part of the future of energy as well as to apply to work for them. In the only advertisement in my corpus that specifically portrays a female engineer and which dates from 2007, the company explains how "[a]t Chevron, you can be part of a team of engineers that thrives on solving the toughest problems. With a work environment that is as big as the world and with challenges to match, you'll have the resources and support you need to succeed." The Chevron "We Agree" campaign from 2010 also centred round partnership. One advertisement, for example, announces: "Oil companies should support the communities they're part of" (figure 8:73) while another states that "Protecting the Planet is everyone's Job" (figure 11:5). Chevron is an advocate of solidarity and a team spirit.

In this way, Chevron projects a corporate identity which is inclusive and which exhorts the reader to join them. The heroic stance that they take is that of an intrepid, outspoken leader who is prepared to act as the world's social conscience and who encourages the public to join them in a partnership which will improve the world for everyone everywhere. While the 
dimension of brand personality that the company shows today is sincerity, before it merged to become Chevron ruggedness characterised many of the advertisements.

\section{ExxonMobil, the Expert}

While Chevron grew out of the efforts and enterprise of intrepid adventurers and pioneers like Patillo Higgins and Captain Lucas, ExxonMobil resulted from the business strategies of Standard Oil and Rockefeller. This is reflected in their advertisements and in the identity which these portray. Rockefeller had pioneered market research to discover what potential customers might potentially like and these desires had to be translated into finished products. The advertising of ExxonMobil, whether as Standard Oil New Jersey through the 1970s, for example, or through its various stages and subsidiaries like Esso, is characterised by its focus on engineering and on scientific development. Esso's early "Put a Tiger in your Tank" series, (figure 11:4) for example, did not rely on the cute tiger, but focused on the superior technology that went into the "tank" going to great lengths to describe the innovations introduced to the petrol and explain how these will improve performance and protect the engine. When the cute tiger was replaced by a real specimen, the message was the power and smoothness that could be obtained by using the products.

The heroic role undertaken by ExxonMobil is that of the expert engineer, the bringer of the latest cutting edge engineering science that will improve both the motoring experience and reduce the negative impact on the environment. The scientific bias of the company advertisements is evidenced for example in the campaign "Taking on the world's toughest challenges" with its characteristic blue-grey atom symbol (figure 8:64) which, following Kress \& Van Leeuwen (1996) is considered to represent power, knowledge and energy while the steely blue-grey colour scheme of the series connotes metal and technology. The focus of the advertisements in this series is centred round the technological innovations that the company is making and the individual experts who are responsible for these. In other words, the identity that ExxonMobil present is that of an expert, a scientist whose heroism consists of doggedly striving to achieve feats of engineering that have previously been considered impossible. The image of a tiny ant carrying a leaf that is some ten times its own size and which is the focus of an advertisement (figure 9:28) that describes one of these engineering feats, a new technology that allows more natural gas to be safely transported, for example, illustrates the heroic nature of ExxonMobil in its drive to improve our world. Competence and technical sophistication are the dominant dimensions of ExxonMobil's brand personality.

\section{The Damsel in Distress}

The analyses have shown how the five major oil companies work to maintain and reproduce their different forms of capital and how they each identify with a different heroic role. Schroeder \& Zwick (2004:23) have pointed out that semiotically, masculinity is irrevocably connected with and opposed to femininity. As the oil business is determinedly masculine, logically, the roles in which female characters are cast should be stereotypically feminine. What emerges from my analyses is that the roles to which women are assigned have changed very little over the last 80 years or so (Ford et al 1991, Elliot et al 1992,) and are typically feminine but that perhaps surprisingly, this has not always been the case.

Although the achievement of the romantic hero who fulfils his quest traditionally benefits a whole community, it is often to a specific lady that he brings the magical substance and it can generally be said that the roles played by the relatively few women who feature in the advertisements are characterised by passivity and subordination, (Kang 1997, García Muñoz \& Martínez 2009, Mager \& Helgeson 2010). They are the recipients of the benefits that the 
efforts of the heroes bring. Particularly interesting, however, is the way in which these recipients have changed over time and also the actual "tokens" which the victorious heroes offer.

The earliest advertisements were for oil as an illuminant and typically depicted a woman lighting a lamp with ease (figure 9:33). Shell's early postcards and lorry bills also showed women driving motor cars, (figures 8:7, 9:4) demanding the right to vote, (figure 8:3) and in line with the mythical nature of oil that I have already demonstrated, as spirit-like creatures or goddesses holding up cans of the magic liquid (figures 8:2, 9:3). Shell also sponsored female aviators, particularly Amy Johnson, or Mrs Mollison (figure 3:5) as they tended to refer to her, and commonly used her name and picture to endorse their products, together with the names of other, male pioneers of motorised travel in its different forms.

However, by 1929, this view of women as independent equals in the world of oil had undergone a change. A series of print advertisements from then, "Shell petrol is different" compared the qualities of Shell petrol with women by portraying two very similar women side by side, one of whom was "perfect" and likened to Shell, and the other with a "flaw" such as overweight, (figure 8:33) and likened to other petrols. By the 1930s, the women that appeared in the Shell advertisements were figures of fun. Older women, like the chars in one example from the "Some phrases seldom ring true" series (figure 8:24) or the old lady who warns her husband to be careful of "those quick-starting shells" in an example from one of the "Quick Starting Pair" series (figure 8:19) are caricatures of a specific type, while younger women are portrayed scantily and saucily clad and are the object of not only the male gaze but also of male instruction. The strong, athletic men (O' Barr 2006) often depicted in the "Everybody knows ....Y You can be sure of Shell" series of advertisements were bringing information to the girls who were ignorant of the qualities of Shell and who did not have the intellectual qualities to understand the "clever" advertisements without their help. Moreover, the women here were often portrayed in a position of total physical as well as intellectual dependency as the men were holding them aloft (figure 9:39). The "token" that these heroic men are bringing to the lady is knowledge and information about the magic liquid. BP too portrayed women either as in need of male help and advice or as sex objects, for example in their "Ethyl" series. Men were still instructing helpless "brown-haired and pretty" women (figure 9:37) with their problems in the 1950s and were cast in the role of their protectors and teachers, and instructing them to buy Snowflake anti-freeze.

Through the application of further magic, the spoils that the hero brought home from the quest could be transformed into physical gifts for the lady. These gifts included products that would make her house spotlessly and effortlessly clean, fabrics for both her home and her body, and cosmetics of different types to enhance her looks and increase her desirability. Confirming the observations made by William O' Barr (2006) my corpus shows how even in the mid and late 2000s, as exemplified in the "Real People" (figure 9:36) and "Let's Go" series (7:1). Shell typically portrays women in relation to appearance, to their homes and their families (figures 9:34, 9:35, 9:36) and little girls are passive while boys are active. Women are "damsels in distress" who need the help that chivalrous Shell can bring them to manage their daily lives, while men use Shell at work.

While Total do not relegate the world of women to the home, the only female in their "Imagine if" series is young and elegantly coiffed, working indoors in a pristine laboratory as part of a team, while men in the series are shown out of doors and typically alone in hostile environments. Chevron, too, show women at work, but again, they function as part of a team, whether as engineers or as young administrators (figure 8:69) learning from older, paternal 
men. This is in line with the findings of Mary Gilly (1988) ${ }^{4}$, Artz \& Venkatesh (1991) and O'Barr (2006) for example. While the team aspect of the advertisements could be consistent with the company's insistence on partnership, in every case, the women portrayed in the team or partnership, are in a subordinate role. This confirms Gilly's (1988:83) observation that the men portrayed in her corpus were likely to be depicted as independent whereas the women were depicted in roles relative to others. Moreover, the individuals portrayed in the "We Agree" campaign where Chevron proclaim their social engagement are all in need of help and are almost exclusively quite young and female. One of the exceptions is a very old man holding a very young girl child and the other is a wallaby (figure 11:15).

Since their rather sexist advertisements of the 1920s and 30s, women have rarely featured in BP advertisements other than as figures in crowd scenes. The exceptions are the advertisements in The New Statesman for the company's cultural engagement in society and where women are shown in paintings or artistic performance such as a ballet or exceptionally, is their London Olympics campaign. I have previously pointed out that BP sponsored British athletes who appeared in the UK advertisements and American ones who appeared in the States $^{5}$. However, the British athletes who featured in the advertisements were Lizzie Armistead, a female cyclist and most often, Stef Reid, competing in the Paralympics. Both women were portrayed bursting through the helios, the former on a bicycle and the latter, running on blades and moving towards the right into a promising future. BP, like the other majors, use women in their advertisements to portray them as the grateful recipients of the benefits of the magic liquid brought back from the quest.

The advertisements ExxonMobil reveal the least sexist attitude to women although it is men who dominate the earlier advertisements and who are portrayed by Standard Oil of New York as the pioneers and experts of the second part of the twentieth century. More recently, the company produced a series around a gender neutral driver through whose eyes the reader saw the advertising message, and this developed into the atom formation that is found in their advertising today. In their series "Taking on the world's greatest challenges", both men and women are depicted as experts and are portrayed both working together, and in parallel advertisements. However, it must be mentioned that men still dominate numerically (figure 8:64) and that it is men who are portrayed individually and as the pioneers in the field, while women tend to be shown in positions that are less specific to the world of oil and engineering.

\section{Summary}

Through their advertisements, the major oil companies work to maintain and reproduce their capital. Moreover, they commonly build on the notion of the mythical qualities of oil and of the oil man as a hero of Romance to generate a view of their "doing being" the good guys. As what is considered "good" is not constant over time but is dependent upon the social and political climate, the ways in which the companies try to present themselves as working for the common good and the strategies that they have employed to project a positive face to the public have varied greatly.

Despite their common point of departure, namely the heroic nature of the oil man, they have developed rather different heroic characters which lend themselves to some brand

\footnotetext{
${ }^{4}$ Although Gilly (1988) has investigated television commercials, her findings are similar to those of scholars who have looked at print advertisements. It is interesting that she sees very little difference between the United States and the more traditional Mexico, while Australian commercials seem to be rather less gender stereotypical.

${ }^{5}$ According to the official home page, BP "supported 60 outstanding athletes from nine countries".
} 
differentiation. These characters have their origins in the history of the companies and in their founders and have generally emerged rather than resulted from conscious efforts and decisions. I maintain that even specific and expensive campaigns like Shell's "Profits and Principles" or BP's "For all our tomorrows" which both came into being as a response to negative public feeling, were based on the heroic brand personality that had inadvertently emerged over time.

An interesting observation is that the companies clearly display the national tendencies described by Biswas et al (1992). As these scholars observed, the European companies often use pathos in their advertising communication while the American companies prefer rational arguments and facts. However, Chevron's latest campaign falls outside of this norm. A comparison of the ExxonMobil advertisement (figure 8:26) portraying the innovation of Jurgen Schwenger and those of the other "alchemist" introduced in this series with that of Shell's snake drill innovator (figure 7:8) who was inspired by watching his son drink a milkshake clearly illustrated this tendency. Another telling example from about 1970 can be found in the advertisements by Standard Oil and Shell for their involvement in improving the schooling of young underprivileged Americans that were published in Scientific American. (figures 8:49 and 8: 50). While Standard Oil portrays its actants en masse and in the distance, Shell portrays one individual close up gazing directly at the reader and demanding response.

However, from my analysis of the advertisements, it emerges that the ways in which women have been depicted by the oil companies has changed in a way which is rather unexpected. From being independent individuals and even highly respected pioneers in the early days of motoring, women became damsels in distress because of their ignorance of motoring matters or sexualised and figures of fun for their appearance or behaviour. They were then relegated to the home and to become the grateful recipients of both household and beauty products.

A working woman is still typically portrayed in a position that is subordinate to that of her male colleagues. Moreover, women are frequently used as what I call representantes or female semiotic types whose only role is to provide the company with a face that shows the way in which they are heroically "doing being" the good guys.

\section{Image removed due to copyright.}

Figure 11: 1 Glamour from an oil well
The Shell advertisement taken from The Advertising Archives (figure 11:1) provides a fairly accurate summary of the way in which the oil companies have portrayed the respective roles of women and men. For the woman, what is important is "Glamour from an oil well" and the female actant is depicted applying a bright red lip stick which has the same shade as the Shell logo. It is also highly probable that other less obvious contributions of the industry, such as the shampoo which gives her hair sheen ${ }^{6}$ and her eye shadow, are also based on oil and its derivatives; all thanks to the unceasing efforts of the heroic oil men.

\footnotetext{
${ }^{6}$ The only advertisements for Shell (or any other oil company) that I found in The Economist during and immediately after the war years were for shampoo to give hair sheen or to give fabrics a wonderful feel.
} 
The man, on the other hand, is portrayed as an expert with a fuelling "Service Tip" to interest male readers who take motoring and getting the best out of their vehicle seriously. The company itself is characterized as innovative alchemists who "cracked" the secrets of petroleum" to get the new Shell fuel".

The Romance of the Quest for Oil infuses a multitude of the advertisements of the oil companies, and the common cause of each heroic adventurer is to improve the lives of those who are in some way weaker by bringing to them the benefits of the magic liquid in one or more of its multiple guises. As García-Muñoz \& Martínez (2009) have noted, women are over-represented in advertisements as consumers and housewives. 



\section{Chapter 11}

Advertising: a Mirror of Society?

My purpose has been to investigate what the major companies of the oil industry communicate in their advertisements, how they do this and to whom they address their messages. In the previous chapter, I discussed the ways in which the companies work to present an identity ${ }^{1}$ that is acceptable to their publics and which allows them to protect their different forms of capital and unveiled the different "personalities" that the companies have developed to create some form of differentiation.

Questions that now need to be addressed are how the messages that they communicate have changed over time and how they reflect and relate to the prevailing socio-political conditions.

The preceding analyses clearly demonstrate how the advertising of the oil companies is so much a "mirror" of society but rather a prism which can disperse reality as well as reflect it. Repetition leads to sedimentation and in this way the myth becomes a collective version of reality. The advertisements do not only reflect the contemporary political situation and the social trends and preferences among their intended publics, but also serve to project and refract those trends and outcomes that the companies consider desirable. In the following, I shall disentangle and discuss the major trends that can be observed.

\section{A Mirror of Innovation and Technical Progress}

The advertising of the oil companies captures and mirrors the innovation and technical progress that characterises the twentieth century and which was largely fuelled by the oil industry. Many of the very first advertisements were for oil as an illuminant and as a better, safer and cheaper alternative to those previously available. However, at the beginning of the twentieth century, oil as a means of propulsion rather than as an illuminant or a general lubricant became their focus. The mythical qualities that had been attributed to oil since the Antique found new expression in advertisements for oil as a magical substance that could power different types of motorised vehicles and enable man not only to travel farther and faster than ever before, but even to finally conquer his nature and realise what had previously been an unachievable dream; to fly. The Shell advertisements for Motor Spirit exemplify this tendency. Not only are the products perfect on both land and sea, but the be-winged creatures, part Antique god or goddess and part spirit, holding their laurel-wreathed red cans for all to see, connote the winning, mythical properties of the magical substances contained therein.

One of the ways in which the different oil companies advertised the superiority of their products was through the sponsorship and subsequent endorsement of aviation and motoring pioneers and record breakers. Charles Lindbergh used Mobiloil in the Spirit of St. Louis on the first solo flight across the Atlantic in 1927, while the following year, Amelia Earhart used Mobiloil to protect Friendship on her historic flight across the Atlantic. In Britain, Shell and BP advertisements attributed the success of national heroes like Amy Johnson and Captain Eyston in the 1930s and Donald Campbell and Stirling Moss in the 1950s and 60s to their latest innovations in motor oils and fuels, while the Polar expeditions of both Captain Scott and Dr Vivian Fuchs were shown to have been dependent upon BP's support and the quality of the products with which they sponsored the adventurers. In the United States, the presentday ExxonMobil supplied the fuel and lubricants for the Wright brothers' historic flight at

\footnotetext{
${ }^{1}$ I use identity here in the sense defined by Helena Kantanen (2012).
} 
Kitty Hawk and in 1915, Mobil provided the products for Ralph De Palma's success in the Indianapolis 500 race. $^{2}$

After WWII, mobility became increasingly important and more and more people owned a motor vehicle, not simply for pleasure but out of everyday necessity and the oil companies worked to improve and create better petrols and lubricants. The concept of Summer Shell and Winter Shell became outdated, for example, and the same product could be used throughout the year. One of the most successful advertising campaigns of the late 1950s was Esso's "Put a Tiger in Your Tank" for their "New Power-formula" which incorporated cleaning power, firing power and octane power. "New" was one of the most common adjectives in the industry advertisements and was always equated with positive progress.

It should not be forgotten that the American oil industry was the cradle of modern market research. Consequently, when oil and its derivatives became the basis of a plethora of new materials, the advertisements reflected this, bringing these new products to public notice and showing how they made the world around us more beautiful and efficient and life simpler and more pleasant ${ }^{3}$. Oil, and also oil-based products became essential ingredients of modern life. The petrochemical industry provided households with new materials which made life more comfortable, the reduction in the use of coal for heating was helping to make cities cleaner while farmers were helped by pesticides developed by the oil companies. After WWII, advertisements for different types of fabrics, plastics and building materials as well as for pesticides and fertilisers, which were depicted as being the magical answer to all the farmers' problems, joined and gradually replaced many of the companies' more traditional advertisements for fuel and lubricants and began to appear in respected periodicals and business magazines. These products were all developed from petrochemicals, the building bricks of modern life, and the impact of the oil industry on all our lives was incontestable. Oil had not only become "the lifeblood" of the economies of the industrialised world (Yergin, 2008:526), but its effects also trickled out to impact upon almost every other country in the world.

As I stated earlier, nuclear power was developed in part as a means to combat and diminish dependency upon the increasingly unreliable oil producing nations of the Middle East. However, the oil companies could not simply accept the competition from this new source of energy which had been hailed as both cheaper and more efficient, but had to respond to its potential challenge and threat. This response was typically proactive. For example, in 1958, Shell produced advertisements that showed how they were able to provide the "new thinking" that would master the "new problems" that the "rich promise" of nuclear power in "a world hungry for energy" would entail. In this way, rather than risk being supplanted by nuclear power, the oil companies demonstrated that their contributions were necessary to the success of this new industry and that they operated on the cutting edge of scientific invention and technological progress.

A particularly telling example of this trend is from 1962 and celebrates Glenn John, who in February of that year became the first American to orbit the Earth. The advertisement was humorous in nature and under a simple, comic sketch of a man being shot into space was a short humorous rhyme which acclaimed both "Glenn and the men who put him in orbit so well". The advertisement plays on the concept of the early postcard advertisements which showed people stopping for Shell in the most unexpected of places, including the North Pole

\footnotetext{
${ }^{2}$ About us http://corporate.exxonmobil.com/en/company/about-us/history/overview (02.25.2014)

${ }^{3}$ For example, Standard Oil New Jersey produced the first commercial petrochemical, isopropyl alcohol, which is still used as a solvent and a cleaner in 1920 .
} 
(e.g. figure 8: 8) and the Egypt of the Pharaohs to state that one day we will all "stop at the Moon for Shell". This intertextuality, together with the popular slogan "Go Well, Go Shell" that follows, draws Shell into this technological breakthrough. Although the company do not specifically state that they have played any part in this extraordinary scientific achievement, the reader is led to form an association between Glenn John and Shell, and consequently attribute the company with the very latest technological progress.

However, with the disturbing realisation of the 1960s that oil was not perhaps only the bringer of all good things and that the benefits that it afforded the western world came at a price that was much higher than anybody had been able to anticipate, the oil companies had to adapt their advertisements to these new insights and work to counter negative publicity. Just as they had previously proclaimed themselves as the leaders and facilitators of progress and development based on oil, the companies began to investigate new approaches to solving the problems that had been seen to emerge. Their advertisements began to change the angle of reflection to emphasise their innovative solutions to these problems and at the same time, absolve the industry of any blame. Although the companies never lost sight of the centrality of energy to our lives and continued to insist that our energy needs are growing and that it is they, with their cutting edge technology that can fulfil these needs, the focus of the companies' advertising began to shift.

This shift took two directions. The first was to present an industry that was working to deliver more of the safer, cleaner energy that the public had come to believe was essential, and the second was to show how the companies themselves were working to reduce the impact of using their products. During the late sixties and early to mid-seventies, for example, Standard Oil advertised their cooperation with other companies to find new and improved ways to lubricate submarines underwater, reduce emissions and to safely access new sources of oil without harming wildlife. Indeed, the insistence that their activities and products were harmless or even beneficial to the surrounding wildlife became, and has remained, a major theme in the advertising of the industry. By 1981, BP was involved solar power and the oil companies began to investigate alternative sources of energy such as wind, geothermal and biofuels as well as natural gas. The new "green" technologies are the avenue of approach used by one strand of these advertisements and demonstrate how the companies are still striving for "the common good" (ExxonMobil, 2007) both to deliver more and cleaner energy and to improve energy efficiency. The focus of the second strand is rather more traditional. Acknowledging and insisting that mobility is more important than ever, these advertisements present the ways in which the industry is addressing the problem of emissions and pollution that this lifestyle brings. The advertisement "Let's Go Further on One Litre of Fuel" from Shell's "Let's Go" series from about 2008 design competition is one good example of this, while the ExxonMobil series depicting for example, the work of Jurgen Schwenger (figure 8: 28) and his colleagues who are involved in creating better energy efficiency, shows another approach to the problem.

\section{Oil Company Advertising as Social Comment}

The advertising of the oil industry both reflects and also projects innovation and technical progress and how this innovation and progress are anchored in a historical reality. However, a successful advertisement should touch the heartstrings of the reader, and for this emotive exchange to take place requires that the advertiser or sender of the message to be communicated can create the sense of identification with the audience that Kenneth Burke insists is central to persuasion. To persuade, it is necessary not only to speak the same language but also to use common images and show common attitudes, in other words, to 
adapt the message to the lifeworld and the values of its audience. Thus, as Roland Barthes (1977) has pointed out, to fully understand an advertising message requires both linguistic and cultural knowledge. Although these are closely inter-related, I will treat them as far as possible as separate entities.

\section{Cultural Knowledge and the Lifeworld}

First, I will address the matter of cultural knowledge which is specific to the lifeworlds of both a particular group of people and to a particular time. This phenomenon is clearly illustrated by my analyses of the print advertisements of the oil companies. The early advertisements are heavy with contemporary references and allusions. Because of the nature of my corpus and the rather different histories and advertising strategies of the British and American companies, my early examples will be taken from the British companies.

Shell's early postcards have cultural references ranging from popular English nursery rhyme characters to the celebration of the beatification of Joan of Arc in 1909, the fascination with Egyptology that was fired by Lord Carnarvon's funding of Howard Carter's excavations of the Valley of Kings in 1907 and the implied comment of the 1913 Nelson's Column parody with its implicit attack on APOC and reference to the role Shell should play in the future of Britain. ${ }^{4}$ Later advertisements also rely on the reader's knowledge and understanding of the social and political situation, and include the Suffragette Movement ${ }^{5}$ (1927) and Achnacarry Castle, where in 1928, the "As-Is" Agreement was reached by the major British and American oil companies in order to establish a uniform selling price and allocate market quotas. The castle features in one of Shell's advertisements from that year in their "See Britain" series. An advertisement from 1929 demands that the reader recognises the three leaders of the three British political parties and also to understand the multiple meanings of the words party and spirit in the play on words, "The Non-Party Spirit," used in the advertisement. This is an example of the way in which culture and language work together to create meaning.

These advertisements firmly position Shell as a player that not only comments the social situation but also contributes to the development of society. I have already described in some detail the Glenn John advertisement from 1962 to illustrate this point and demonstrate how Shell linked its name to technological progress. Although Shell led the way in linking their name with contemporary events that were not only connected to the achievements of racing heroes and pioneers who travel further and faster in their advertisements, BP followed suit. One particular example is a lorry bill that proposed a visit to Whipsnade Park Zoo which opened in May 1931. Situated in the Chiltern Hills, some 30 miles (48 kilometres) north of London, it was the first open zoo in Europe to be easily accessible to the visiting public, especially to motorists and was an immediate success. BP use this popular new destination to encourage members of the public to drive there on their products, and in so doing, connect the company's name with this particularly British achievement.

\footnotetext{
${ }^{4}$ Charles Greenway, who had become the head of APOC (later BP) in 1909, had recognised the business opportunities offered by a contract to supply the Royal Navy and insisted that this should be done by a "truly British company" rather than the "Shell menace" which was a monopoly in the hands of foreigners.

${ }^{5}$ Although in some parts of the United States women over 21 had the right to vote as early as 1869 or 70 , and Australian women were given the vote in 1894, women in the UK were first given the vote in 1918 if they were over 30 and met certain property qualifications, and in 1928 suffrage was extended to all women over the age of 21.

${ }^{6}$ The play on words refers to the fact that Shell Motor Spirit is approved by all three political parties, the Conservative, the Liberal and the new Labour party and plays with the concept "party spirit". On one level to level this means to be in the mood for fun and on a second, spirit can also refer to the alcoholic spirit that might feature as an element of the party.
} 
Both companies also made use of popular sportsman and specific, sporting events in the contemporary sporting scene in their advertisements. One example from Shell's "QuickStarting Pair" series (figure 8: 18) requires the reader to understand the reference to cricket and to be able to recognise and associate the excellence of the "pair" portrayed in the advertisement with the products while to fully understand an example from BP's Ethyl series from 1935, (figure 8:30), the reader must not only understand the word game that is played in the advertisement, but also know that the answer to the puzzle is a race horse that is a strong contender for the coming Derby. In other words, to fully understand these advertising messages, very specific linguistic and cultural knowledge were essential.

Typically, the advertisements had an element of humour. This changed in 1939 with the short Shell "Fore" series by Thomas Derrick from 1939 (figure 8:34) and which was the final campaign before the war clamped down on the British oil companies. The contemporary social and political circumstances underline the pun and give it deeper implications.

Later advertisements from both Shell and BP hailed the return to normal after the war and celebrated the end of petrol rationing. They also joined forces to congratulate Elisabeth II on her coronation in 1953 in a

Image removed due to copyright.

Figure 11:1 The Coronation upon the benefits that their work had brought and would continue to bring to the nation, a feature of their joint advertising well into the 1960s.

\section{Socio-Political Conditions}

As a result of WWII, the importance of oil and its secure supply had become evident and demand was greater than ever. Unfortunately, Europe had been devastated by the war and in 1947, the European Recovery Programme, or the Marshall Plan was initiated to help reconstruct Britain and Europe and to combat the growing power of Communism. Oil, both to provide Europe with the energy necessary for recovery and to fuel the American economy, was essential to this Plan. However, trading in dollars was generally detrimental to the economies of Europe and one way for the Europeans to save dollars was to expand their refining. The Suez Crisis exacerbated the problem and increased the need felt by the oil companies to become less reliant on others for their supplies.

The oil company advertisements of the 1950s reflect this situation. On the one hand, they celebrate the possibilities that oil and its derivatives bring and the opportunities that the industry affords both investors and potential employees, and on the other, insist on the importance of independence. While Shell advertisements discuss the advantages that their products bring to agriculture, reflecting the negative consequences of the food rationing that could still be felt and show how they can improve world heath and world economies, the focus of BP is on securing oil supplies and minimising the use of dollars. References to 
specific places and refineries in these BP advertisements assume that the reader has a good knowledge of British geography.

It was during this period that British and American oil companies began to advertise not only in newspapers and specialist magazines but also in quality periodicals, such as The Economist in Britain and Scientific American in the United States. Moreover, the companies gradually began to place advertisements in each other's publications and to adapt their messages and styles to the culture of the country of publication. The advertisements that Shell placed for Shell Chemicals in these periodicals, for example, clearly demonstrate the way in which the company addresses the different lifeworlds that prevail among their different stakeholders on the two continents provide an early example of "glocal" advertising, or adapting the language and content of an advertisement to the context and encyclopaedic of the intended reader. Similarly, advertising in The Economist, American Caltex adopted the approach of "helping the world" that both Shell and BP tended to favour in the advertisements that they published in that periodical.

The problems that the oil companies began to encounter during the 1960 s were of different kinds and impacted upon their advertising. To the growing insight that pesticides were not a simple panacea but that they also had serious side-effects, were joined the ecological disasters that followed two major oil spills, one off the coast of Britain and the other of the coast of California. While earlier accidents had occurred in faraway places out of the line of vision of the general public, these two spills brought the dangers inherent in the oil business suddenly into full view. A number of environmental movements emerged from these disasters, such as Get Out Oil (GOO), a direct response to the Santa Barbara spill, and Earth Day. For Shell and BP, who shared a Nigerian operation, the situation was worsened by the war in Biafra where not only was the situation for their workers extremely dangerous, but where oil output was only a fraction of what had been planned and supplies became limited.

It should be remembered that in France, there was a ban on any form of advertising that could be considered to encourage and increase oil consumption and British companies also reacted to the various oil crises by greatly reducing their advertising during this period. In their print advertisements, Shell and BP focused on shared specifically British endeavours which involved providing the fuels and lubricants needed for major engineering projects such as the new Forth Bridge (figure 8:45) and the Severn Bridge or providing farmers with fuel for their tractors (figure 8:46) rather than with different kinds of chemicals to increase their yields. Sparked by the writings of Rachel Carson in 1962, pesticides had become a controversial issue and were excluded from the advertisements. Moreover, the British-based companies also refrained from publishing in periodicals with a wider, more international readership. Instead, they focused on a more domestic public and their message centred round what they could do and were doing to help Britain through the succession of oil-related crises that characterised the 1960s and 70s. To remind the public of their presence and goodwill, they also organised various competitions including one for traffic safety. However, American companies like Phillips Petroleum and Texaco took advantage of the situation to advertise their arrival into Britain and Europe in The Economist.

Although advertisements in major British periodicals are extremely rare during this period, when the companies gradually began to advertise the range of their products again in the U.S.A. during the $1970 \mathrm{~s}$, there is a clear shift towards emphasizing how safe these are. For example, Shell's advertisement for the Gardona insecticide (figure 8:47) from Scientific American in 1970 stresses how the company is working with conservation experts to "help save our environment". Other advertisements for pesticides after this period, such as those by 
Standard Oil, all stress that the product will only harm the pest that it targets and that the company is working to protect and conserve wildlife and the environment and the concept of stewardship is introduced. This is clearly demonstrated by the advertisements in my corpus.

Companies have to operate in a social world and present an image that is in harmony with the values and interests of their stakeholders and a second trend that can be seen as a result of the change in public opinion was the insistence that the oil industry was working towards cleaner and safer extraction and transportation processes. In the United States, Standard Oil of New Jersey led the way with a large series of double-spread advertisements that asked questions like "What kind of world will we leave them" with a photograph of two young children on an almost empty beach, or "Co-existence on the King Ranch" (figure 8:50) that explains how an oil refinery and nature can live together. The advertising message that the companies tried to communicate was that they understood, respected and shared the implicit anxieties of the public and were able to provide solutions. Life could continue as usual but thanks to their commitment and expertise, there would be no more unfortunate repercussions. In fact, the pre-emptive campaign started by Mobil in its Op-Eds and Observations in 1970 aimed to show how the company had answers to all the problems that both decision-makers and grassroots citizens experienced, sometimes even before these issues had become part of the public debate. These series provide a very clear example of an oil company not only reflecting trends but also driving opinion through the prism of their views and values.

Another consequence of the events of the 1960s and the decades that followed was that the oil companies began to focus less on product advertising and more on their public and social welfare programmes. An increasing number of voices, such as that of the play-write Eugene O'Neill and the economist E.F. Schumacher, were raised in criticism of the greed and lack of concern for human life that the companies were seen to display. This negative perception of the industry was not redeemed by the Elf Aquitaine Scandal of the mid-1990s. This scandal, which implicated the leaders of the French government, did nothing to enhance the image of the oil industry, but instead showed it as being deeply embroiled in political and economic power games. This change in the way in which the industry was perceived required a strong and proactive response.

Although displays of corporate responsibility were not new to the advertising of the companies and could be seen in campaign series such as "BP Maps the Future" from the 1950 s or the British Shell pesticide advertisements from the same period, social welfare and corporate responsibility began to dominate the print advertisements on both sides of the Atlantic. Shell's 1970 U.S. advertisement "Man cannot live by Freedom Alone" (figure 8:48) provides a particularly good illustration of the way in which the company incorporated the notion of corporate responsibility with a specific social, political and cultural context. Published after the assassination of Martin Luther King in 1968, the advertisement draws on the reader understanding the changes that were taking place in the United States and the basic principles of the American Constitution as well as Biblical references. However, as my analyses show, the target of such corporate support has gradually extended from the local and specific to the global. One likely reason for this is that the audiences targeted by the advertisements are increasingly international, and another is that it is a proactive response to bad publicity that the industry has faced as a result of more major oil spills and from Human Rights groups monitoring the impact of the oil business on indigenous communities in the areas where they operate.

The 1990s saw the advent of a new era in oil-company advertising. This was hailed by an article published in The Economist on October $15^{\text {th }} 1988$ entitled "Changing colour". Opening 
with the words "Green is the world's new political colour" the article summarises the situation and mood of the time, describing how pollution has finally become an issue and that "in the rich countries, people increasingly tell opinion pollsters that they are unhappy about the environment: about noise and filth, but also about the possibility that they are doing lasting harm to the fabric of the world their children will inherit."

BP's "For All Our Tomorrows" campaign from the beginning of the 1990s is a response to this criticism and explains how the company is investing in solar energy and what it is doing to support African communities and to protect the environment. In this campaign, BP take issue not only with the environment but also describe how they are working to combat social injustice and to improve the lives of people in less wealthy parts of the world. Shell's "Profits and Principles" series from the late 1990s is another good example of a reaction to the swing in public opinion. Shell had received extremely bad press for the impact of their activities in the Niger Delta during the early 1990s and the campaign raises issues of corporate responsibility both for the environment and to protect human rights. The series includes an advertisement that is analysed in Chapter 8 and which is clearly a direct response to Greenpeace's damaging allegations about the dangers of Shell's planned disposal of the Brent Spar Platform in 1995, (discussed by Dickson \& McCulloch 1996) and is yet another, particularly significant, example of Shell making use of current events in their advertisements. The image used in the double spread, a photograph of the Brent Charlie rig in a grey and stormy North Sea lends extra impact to the message that the company communicate and the closing line "A platform for all points of view" compounds the allusion. To fully appreciate this advertisement therefore requires both knowledge of the recent events and the linguistic skill that is needed to understand the verbal and visual pun on the word "platform". Another example of the move towards advertisements as declarations of corporate responsibility and of values advocacy is Chevron's "We Agree" campaign from about 2010. As well as touching upon the common theme of environmental protection, this series insists that businesses in developing countries should be helped with microloans and that it is our common responsibility to eliminate AIDS. According to one of their advertisements calling for an end to AIDS, this particular cry to corporate responsibility was a result of involvement in Africa where the tragic plight of their workers was brought to the company's attention.

I argue that the oil companies demonstrate a strong awareness of the attitudes that are prevalent in the societies in which they operate and that they adapt their advertisements to meet and respond to these attitudes and to the various interests shared by different stakeholders. ${ }^{7}$ In short, the companies identify with their different publics and adapt the messages that they communicate to these audiences.

As the publics addressed by the advertisements have become increasingly global, the more specific cultural references that were frequent in local and national advertisements have disappeared to be replaced by a rhetoric which an international audience can understand and identify. This much narrower international repertoire of shared experience and encyclopaedic knowledge limits the possibilities of explicit cultural reference and intertextuality which advertisers previously enjoyed. In the case of the oil companies, the environment and the continued need for energy supplies are global concerns and concepts that can be understood and identified with by international publics and frequently feature in their advertising rhetoric.

\footnotetext{
${ }^{7}$ The cultural differences in attitudes between Americans and Europeans discussed by Rowlands (2000), Skodin \& Skaerseth (2001), Kolk \& Levy (2004) and Newell \& Paterson (2010) as well as the research of Biswas et al. are confirmed by my findings. Jain (1989) has also discussed the strategies of MCNs when they run global campaigns or adapt their advertising to more local communities.
} 
To underline this point, although my study shows that the oil companies no longer tend to sponsor and endorse specific sporting events in their print advertisements, BP did sponsor the 2012 London Olympic Games. These Games are of international interest and are something to which everybody can relate and in which the majority of people have some interest. What is most significant, however, is that the company sponsored a number of individual athletes and as BP, like the other majors, now has headquarters and major interests on both sides of the Atlantic, American as well as British athletes received sponsorship. However, all the athletes who featured in British periodicals and on British billboards were British. This is a clear example "glocalisation" and of how the company has worked to identify with a specific audience and to adapt to the cultural values of that public. Other examples include the advertisements that BP places in The New Statesman to announce exhibitions in different museums, or concerts and events by well-known national companies, such as the Royal Ballet, that they are sponsoring, while a particularly striking example from 1998 is for their Portrait Award. The advertisement consists of the painting and its name, "Jude", the middle name of the artist, and the headline calls out to the reader "There's nothing obscure about the BP Portrait Award winner". This requires the reader to make the connection between the painting and the novel by Thomas Hardy, Jude the Obscure, written in 1895. To underline this connection, the body copy ends with the words "Thanks to BP, entry is free so hardy souls can visit as often as they wish."

\section{Language}

The impact of language in its different forms on advertising has been the object of a great deal of research, and the consensus of opinion is that even if humour can be international, communication is closely tied to cultural norms and wordplay and intertextuality are generally socio-culturally specific. The general trends among my corpus substantiate these claims.

As the earliest advertisements that make up my corpus are posters or postcards, it is the image rather than the verbal text that is central. However, with the publication of advertisements in newspapers, magazines and specialist journals giving the addressee more time to reflect and to read the advertisement, language, both as a source of information and of the intellectual stimulus and pleasure that attracts attention and encourages retention, became increasingly important.

One of the most popular campaigns from the 1930s onwards was the Shell place names series (figures 8:22, 23). This series usually appeared in newspapers and required the reader to have some understanding of British places and place names and to be able to connect these with the play-on-words involving Shell. The example, "Wormwood Scrubs but Shell sweeps the board" provides a good example of the extensive cultural and linguistic knowledge that are necessary to fully understand the message and humour of the communication. The visual comprises a piece of wood riddled with worms all armed with buckets and mops washing the wooden boards of a rather strange building through the holes. The worms are dressed in the striped outfits typically associated with prisoners. As Wormwood Scrubs is a well-known London prison, the allusion becomes clear. The building's high walls and lack of windows together with one wall with doors close together on three levels represents the prison. The image indeed shows the worms sweeping or washing the floorboards, but the colloquial expression "to sweep the board" means to win everything. In other words, Shell is superior to any other petrol. Similarly, Shell's "Some phrases seldom ring true" series (figure 8:24) requires the reader to understand the common colloquial phrases and to be able to find the humour that the combination of the phrase and the visual together produce. The BP proverbs series from the late 1920s (figure 8:28) is another example of complicated word play and 
requires the reader to know and understand the proverb used in the headline and to relate this to the slightly changed proverb that comments on the first and relates this to the visual. For example, the saying "The proof of the pudding is in the eating" is changed to "The proof of the petrol is in the using" and the follow-up "Fill up with BP, the spirit that is always up to proof" alludes to the alcohol that is commonly added to an English pudding.

The Shell Chemical advertisements published in Scientific American in the 1950s also make extensive use of word play to connect the written text to the visual (McQuarrie \& Mick 1992). The advertisement showing the cowboys branding cattle, with the headline "How to make a brand weigh more" (figure 8: 39) is a good example not only of this, but also underlines the culture-specific nature of the advertisements.

BP made use of puns in the "For all our tomorrows" series from the 1990s, including what I will call an "extended pun" built around the concepts of solar power and energy to create a metaphor for the way in which the company was driving development in Africa (figure 8: 52). During the mid and late 2000s, BP ran an advertising campaign that also involved word play, but this did not require the depth of cultural knowledge of earlier series. Headlines stating "It's time to think outside the barrel" (8:59) or "It's time to turn up the heat on global climate change" and "It's time to go on a low-carbon diet", which also alludes to the Western obsession with dieting and the popularity of the low-carbohydrate diet, do introduce an element of linguistic surprise and playfulness, but for readers who do not grasp the language game, the message is clearly stated in the text below.

However, it is not only through the humorous use of puns that the language of the advertisements has changed.

Advertisements of the 1950s and even 1970s frequently alluded to literature and to other, often currently popular, cultural phenomena. I have already touched on this with reference to the intertextuality of the Shell advertisement from 1968, "Man cannot live by Freedom Alone" (figure 8: 48) but there are other examples. One of these can be gleaned from a Caltex "Partners in Progress" Figure 8:35) advertisement from 1958 that was published in The Economist and therefore targeted a primarily British audience. The woman standing gazing at her reflection in the full-length, ornate mirror is reminiscent of Cinderella as portrayed in the popular Disney cartoon film while the dark, cathedral-like factory buildings on the canal-side in the background arouse associations with the English textile industry and the "dark, satanic mills" of William Blake's poem, "Jerusalem". Now, thanks to Caltex, Cinderella will go to the ball.

Two particular series, both from Shell, are particularly worth commenting upon. The first of these is the long-running Valentines series which assumes that the reader is familiar with the genre of Valentine cards and can apply and adapt this knowledge to the advertisements to make sense of the visual elements of the advertisement, understand the language games that the company is playing and fill in the final gap in the rhyme. The second is exemplified in the series that I have called "Shell and the Dragon" (figure 8:38) This series requires that the reader is conversant with the "once upon a time" format of a fairy tale and also, in a large number of the advertisements that make up the series, is aware of the literary or popular cultural references. One particularly striking example is from March 1958. Not only does the headline of the advertisement, "Arise, Sir Watkin" parody the words famously ascribed to Queen Elisabeth I when she knighted Walter Raleigh, but the body of the text borrows from William Wordsworth's possibly best-known poem, "The Daffodils." Other examples include "Pirates of Magdalena" which echoes the literary genre of pirate story eternalised in Robert Louis Stevenson's "Treasure Island" and expects readers to recognise and appreciate 
references to Creosus and Jiménez de Quesada. "Time of the Weevil" echoes the title of the 1951 science fiction success, "Day of the Triffids" while the headline of another advertisement, "Island in a Living Tide" lends itself to associations with a song by Harry Belafonte that was very popular at the time, "Island in the Sun". The advertisement from October 1958, "Of great and small" triggers both a clear lexical connection to a popular English children's hymn as well as a structural echo of Longfellow's poem, "The Song of Hiawatha" that also formed part of every child's education.

Although the examples above could perhaps be considered to make cultural rather than directly linguistic demands upon the reader, another interesting aspect of this particular series that can be identified and attributed to the use of language is the idea of "the foreign" and the attitude towards this that the advertisements suggest. I contend that the advertisements in this series make use of specific vocabulary of the country or place that is central to the advertisement to promote a sense of the exotic. Words like pampa, estancieros, tucuras and criollos and ombú, in "Island in a Living Tide" or bieticultori, a term found in "Time of the Weevil" or bundu and royiwa from "Not Marked on the Map", also tend to imbue the reader with a sense of distance and even of superiority, of "we and them". This tendency can also be seen in BP's "Magic of Persia" advertisements.

One more feature of these particular series and which can also be found in other advertisements up until the 1960s is a rather detrimental attitude towards people who are not British or American. In "Not Marked on the Map" we read: "This ground is royiwa, observed the boys sombrely." The term "boy" to refer to a black African worker would no longer be considered acceptable. BP's advertisement in their "BP Maps the World" series from the same year and same periodical in which they refer to the indigenous people that they are training as "local talent" is another example of language use which today is unacceptable and which taken in conjunction with the visual elements of the advertisements, implies Western superiority. Shell Chemical's American advertisement featuring a "Mayan dandy" also from 1958 is a particularly good example of a derogatory view of indigenous peoples and of how language was used to suggest the distance and superiority of the oil companies and their western stakeholders to the other peoples of the world who they were helping and introducing to an oil-based form of civilisation. However, with the gradual decolonisation of Africa during the 1960s as well as the efforts of Martin Luther King in the U.S., such tendencies disappeared.

Other changes can also be seen in the language of the advertisements. First, if we continue to examine the lexical changes that have occurred, my corpus shows that the vocabulary of the advertisements published in The Economist and Scientific American has become simpler and more restricted. Examples from The Economist include for example, includes words like pupating, ubiquitous, prolific, fronds, voracious and eradication, while BP uses words like expatriate, conventional, and exceed and Caltex talks about convenience and prosperity, and refers to how the laborious work of beasts of burden has been supplanted by petroleum power. If we fast-forward to Scientific American in the early 1970s, Standard Oil uses terms like irreverent foe and arcane, as well as colloquialisms such as cause a stir, and flunk. With increasing globalisation and a more international intended reader, vocabulary has become simpler and more repetitive. Words like emissions, environment and energy populate the pages of the advertisements of the $21^{\text {st }}$ century.

Another trend is that not only the language, but also the complexity of the language has undergone a shift. Adjectives and adverbs abound in the print advertisements from the 1950s through to the 1970s, decreasing in number through the 1990s. In 1958, Shell, for example, 1 
offers us "deep-clefted, luxuriant valleys", "often violent climatic conditions and a not naturally very fertile soil", "a strange inexplicable decline", "clogging deposits" and "the sterner demands of modern engines" as well as "effectively and economically" and "voraciously attacking" roots, while over a decade later Standard Oil talks about "a hunk of pure Americana under the huge Texan sky" and of reducing "a forbidding mystery to a set of identifiable problems", and our "tiny, fragile, vulnerable planet" as well as "beautifully simple" and "precisely as planned".

Moreover, the sentences have become shorter and simpler with fewer clauses, and often comprise only one main clause, with a typically standard word-order. For example, Shell's opening sentences from a 1958 advertisement "To a world hungry for energy, nuclear power holds out rich promise. With it, inescapably, come complex new problems which can be mastered only by new thinking," can be compared with their 2008 conclusion, "To tackle the world's energy challenges, from oil and gas power to biofuel power, just takes brain power". Similarly, referring to the hands that are shown in one of its advertisements from 1958, BP writes that they belong to "One of nearly a thousand research workers whose main task is to conjure more and better products from one single substance - crude petroleum" can be compared with Shell's simple "The world needs to tackle $\mathrm{CO} 2$ emissions" fifty years later. This pair of sentences not only exemplifies the change in the structural and lexical complexity of the language but also the shift from product to environment. Shell's simple exhortations to "Start from a different place", or BP's "Think outside the barrel" also from 2008 clearly demonstrate these changes.

Not only has the language of the advertisements become simpler and more standardised to suit the demands of a more heterogeneous, international public, but as the last examples above indicate, a second trend that can clearly be seen is that the length of the body copy texts in the print advertisements has decreased. In The Economist, Shell advertisements from 1958 averaged about 280 words and those of BP ranged from 166 to 341 with the majority being around 200. In 2008, advertisements from the major companies in the same periodical averaged about 80 for Total, 100 for ExxonMobil and for Shell, about 50, although this varied greatly from 5 to about $100 .^{8} \mathrm{BP}$, advertising in The New Statesman, also averaged 80 words in each advertisement.

In general, my corpus shows that while the visual elements of earlier advertisements illustrated the text, today, the written text anchors the visual.

\section{The Changing Face of Oil}

The language of the oil advertisements not only shows the effects of globalisation and an increasingly international public on the oil industry but also reveals changes in the social and political climate. I have already pointed out that events of the 1960 s led to an increasing general awareness of the negative aspects of oil, both with regard to its pursuit and its use, and the oil companies were compelled to change their approach and to present a new face to the world. A list of the most common slogans that the companies have used provides a very clear overview of the major changes. Two main phenomena characterise these changes. The first can be seen though the change in the pronouns used in the advertisements which reflect the changing relationship between the advertiser and the addressee, in other words, a change in the participant roles, while the second can be observed by what is actually advertised.

\footnotetext{
${ }^{8}$ Exceptions are the Shell advertorials, such as the G8 example and their long version of their Start from a Different Place.
} 


\section{Changing Participant Roles}

The changing participant roles can most clearly be summarised by reflecting on the different slogans that have populated the advertising of the companies over the decades and the slogans listed in the table clearly show the changes in the advertising of the oil companies. These changes seem to represent four different stages and are elaborated below.

\section{Table 1: slogans showing the changing face of oil}

\begin{tabular}{|l|l|l|}
\hline The quick-starting pair & Shell & 1926 \\
Shell petrol is different & Shell & 1928 \\
That's Shell ...that was & Shell & 1930 \\
You can be sure of Shell & Shell & 1931 \\
Plus a little something & BP & $1930 \mathrm{~s}$ \\
BP Ethyl for 'Snappy Engines' & BP & \\
Banish Pinking with BP Ethyl & BP & \\
Times change so does Shell & Shell & $1950 \mathrm{~s}$ \\
Are you a BP Superman? & BP \\
Partners in Progress & Caltex & \\
BP maps the future & BP & \\
You're Miles Ahead with Mobil & Mobil & \\
Put a Tiger in your Tank & Esso & 1959 \\
For all our tomorrows & BP \\
Profits and Principles & Shell & 1992 \\
Beyond Petroleum & BP \\
Taking on the world's toughest challenges & ExxonMobil & 1998 \\
Human Energy & Chevron \\
willyoujoinus & Chevron \\
Our energy is your energy & Total \\
Let's go & Shell \\
Real Energy & Shell \\
\hline
\end{tabular}

\section{From Paternalism to Partnership}

As the slogans indicate, there has been a move from a situation where the oil companies take charge and work towards what they consider to be the common good, to them seemingly demanding more active participation on the part of the public. The advertisement below from Gulf in 1934, can be compared with the first of the Chevron "from Dave" series to clearly show this change in attitude and in participant roles. In order to show this, I deem it necessary to reproduce here the Gulf ${ }^{9}$ advertisement, which was published in Fortune. ${ }^{10}$

The company director, one of the "Men who live for tomorrow" is at his window looking out over the smoking refinery. He is standing above, looking down on the world outside which he is contemplating. He is turned away from the addressee, remote and isolated, wondering what he can do for the future well-being of the city below and its inhabitants.

The text that accompanies the image merges the role of the executive with that of a scientist.

\footnotetext{
${ }^{9}$ Gulf, one of the Seven Sisters, ceased to exist in 1985 when it merged with SOCAL (Standard Oil of California), later to become Chevron.

${ }^{10}$ From Marchand (1985:234).
} 
1. For certain scientists of the Gulf Refining Company, the present does not exist. Their eyes are on the

2. future - for their duty is to foresee tomorrow's motoring needs.

3. These men bring to their task a gift for scientific prophecy and a genius for perseverance. Theirs is

4. task in which science must live happily mated with imagination.

5. Will changing engine design call for a radically different motor fuel? These men must develop and

6. perfect it. Will tomorrow's streamlined cars call for an oil able to resist airplane speeds? These men

7. must make such oil a fact.

8. Already the results of their foresight have been notable. For out of the Gulf Research Laboratories came

9. the Alclor process of refining motor oil - probably the most significant single achievement in the

10. history of lubrication.

11. From these laboratories came Gulf's process for retarding gasoline deterioration. From them, too, came

12. a process which cut the cost ten times over of an essential industrial chemical.

13. Gulf products could be kept abreast of the times without the Gulf Research Laboratories. But in any

14. contest for leadership, the laurels must go to the organization that walks with eyes fixed ahead.

\section{Image removed due to copyright.}

Figure 11:2 Gulf Refining Company 1934

The distance and lack of reciprocity between the company, represented by this example of a man "who live[s] for tomorrow" and the addressee or potential consumer of his unselfish endeavours, is inscribed in the use of the third person. However, there is no glass in the window to separate him from the reality of the world outside and thus, he is part of this this world upon which he muses. The aeroplane in the sky symbolises the future and illustrates the question in line 6 which remains unanswered; "Will tomorrow's streamlined cars call for an oil able to resist airplane speeds?"

The language of the copy is filled with modality. In the second sentence (2) the noun "duty" is underlined by the modal form "must" (lines 4, 5,7 and 14) and two of these are ascribed to the men, who attributed with the qualities of "scientific prophecy and a genius for perseverance" (3) "must develop" and "must make" the oil of the future. The rhetoric of the text includes parallelism of the modal question and answer structures of lines 5 and 6 as well as line 11, and a striking use of metaphor. For example, in line 4, science is personalised and 
metaphorically paired with imagination as a partner in a long-term familiar relationship, "happily mated with imagination", an abstraction which is also humanised. The organisation, implicitly the Gulf Refining Company, is also metaphorically attributed with human qualities such as walking and eyes (14). Further, engine design and the tomorrow's cars are given agency and the ability to "call for" various products that they will need $(5,6)$.

Although my main purpose here is to show the shift in the way in which the companies portrayed their relationship with their various publics, the Gulf advertisement is also interesting in that it centres on the products that the company produces and anticipates developing. These aspects of the company's business, as well as concepts such as the future, imagination and the perseverance needed to achieve results, are issues which find an echo in the advertising of the other companies.

\section{From Present to Future}

Until the late 1950s, oil companies tended to live in the present, with the exception of the Gulf advertisement above and Shell advising motorists about the immediate practical necessity of changing from summer to winter products. The 1958 advertisements are the first that typically look towards the future, and BP is the first to specifically state this in a slogan, "BP Maps the Future". In fact, as the list of slogans shows, the concept of the future becomes common in later BP campaigns, such as "For all our tomorrows" from the early 1990s. This trend, however, is also apparent in individual advertisements from different companies. The Caltex series with its slogan "Partners in Progress" also suggests this in the visuals where the characters are portrayed stepping outside the frame into the future. The textual elements that make up advertisements also clearly substantiate this trend, as exemplified not only by Shell's John Glenn advertisement but on a more serious note by their advertisements from 1958 when they discuss the ways in which the company "will be producing the 'goods to make goods"' . Similarly, in the 1970s Standard Oil explains in one advertisement how with their expertise "the world's seaways will be just that much safer" and in another, shows a photograph of two small boys on an almost empty beach and asks, "What kind of world will we leave them?" The future tense has taken over the advertisements and with this, the notion that we are the custodians of the Earth and must pass it on to future generations begins to permeate the advertisements of the oil companies.

\section{From Product to Presence}

The first group of advertisements, which stretches until the end of the 1950s, has a clear product orientation.

Tony, the famous Esso tiger from $1959{ }^{11}$ with the "Put a Tiger in Your Tank" campaign (figure 11:4) clearly demonstrates the importance of the particular product, New Esso Extra, and is the last advertising campaign that centred round an actual product that was addressed to the general public. The tiger is shown with the well-known characters from Aesop's fable, and the "real" reason for the tortoise's success in the race against the hare is explained in the visual where Tony is filling him up with New Esso Extra.

\footnotetext{
${ }^{11}$ In the U.S.A., the Esso brand (together with Humble and with Enco, which is an abbreviation of Energy Company ) was replaced by the name Exxon on January $1^{\text {st }} 1973$. The name Enco was considered but dismissed as it is too similar to the Japanese for "stalled car". These companies all formed part of Standard Oil of New Jersey group. The Esso Tiger had originated in Norway early in the twentieth century but was rediscovered and revitalised by Emery Smith, a young copywriter who had been charged with boosting Esso's sales in 1959.
} 
This advertisement is interesting for a number of reasons. First of all, it introduces a cartoon character. Tony was to become extremely popular as the face of Esso, and Shell also created a cartoon character (Mr. Shell) to represent their company products (Till \& Shrimp $1998^{12}$ ) and the use of real celebrity endorsers became less common among the oil companies.

This advertisement is also interesting as it is one of the last examples of the linguistic shifts that took place. The reader is addressed directly and is told what the product, New Esso Extra, can do for him. The pronoun "your" which is underlined in red in the headline is repeated in every column further personalising the text: "your very first tankful"; "your engine;" and "finally "your tank," while in the last sentence of the third column, the reader is directly addressed as "you". It is one of the last times that the oil companies directly address the reader in this way. The words under the tortoise tell the reader to "Watch the Esso Report" on television Moreover, the reader is assumed to have some knowledge of engines and of their workings as well as understand the reference to the well-known fable to which the words of the tiger, "The real story of the tortoise and the hare" give a humorous twist. Finally, the slogan is particularly interesting as this is one of the last to refer to the matter of petrol and motoring.

1. Cleaning power! Dirt can clog even a new carburettor in a few months of normal operation causing hard starting and rough idling. Your very first

\section{Image removed due to copyright.} tankful of New Esso Extra will start to clear away these deposits -in new engines or old.

2 Firing power! Spark plug and cylinder deposits can cause misfiring, pre-ignition and hot spots. New Esso Extra neutralizes these harmful deposits - to help your engine fire smoothly, to help preserve the power of new cars and restore lost power to many old cars.

3. Octane power! New Esso Extra has the high octane that most cars now need for full smooth performance without knocking. You'll get all these extras with New Power-formula Esso Extra gasoline - it puts a tiger in your tank! Happy Motoring!

\section{Figure 11:4 the classic Esso slogan}

Another other interesting feature of this series is that it is a clear example of the American preference for logos, or a strongly informational content in the advertisement.

On a purely lexical level, my corpus shows that words like starting, idling, pre-ignition, knocking, deposits, performance, tank, engine and gasoline or petrol which all occur in this advertisement vanished from the industry's vocabulary with the troubles of the 1960s. The terms motoring and cost which feature in the Gulf advertisement were also commonly found

\footnotetext{
${ }^{12}$ Till \& Shrimp contend that the advantage of cartoon characters is that they are immune to negative publicity, and while I can accept the validity of their claim, I suggest that in the case of oil company advertisements, this shift away from celebrity endorsement might be a result of the negative publicity surrounding the companies which resulted in celebrities being less willing to lend their names to the companies and their products.
} 
in the product advertisements which abounded until the end of the 1950s. Other common concepts during this period are those of the increased comfort and ease that these products afford us. After this, expressions that incorporate environment, cutting emissions, efficiency, nature, wildlife, health, safety, green, pure, energy needs, commitment, innovation, future, challenges, reliable, secure and togetherness come to dominate the advertising lexis. The companies ceased advertising their products, and instead began to focus on their endeavours to fulfil the needs and demands that they attributed to the public and on how they were working to improve our world.

The Chevron advertisement from 2010 (figure 11:5) and the BP advertisement (figure 11: 6) from 2010 exemplify this shift.

The wallaby (figure 11:5) stares fearlessly at the reader demanding response and on the right side of the page is the statement "Protecting the Planet is everyone's job". Followed by the simple affirmation, "We agree" and through this affirmation are the names and signatures of an Australian Naturalist and a Chevron Environmental Executive placed side by side. This placement reinforces the close relationship between the company and environmental work and is a development of the personal commitment of the company leadership that the "willyoujoinus" series signed by "Dave" the company CEO introduced to the advertisements. The red lines which divide the different sections of the statement help to reinforce the message and find an echo in the red lettering of "We Agree" and it is this colour, which is an element of the Chevron logo, which lends cohesion to the page. The positioning of the wallaby as the given and the statement as the new emphasises the message and its revolutionary nature. The wallaby is not a mere illustration but is the given, driving force behind the message.

The white text underneath the Chevron logo connotes that these words are indeed attributable to the company and express its beliefs and are not something which they simply endorse.

\section{Image removed due to copyright. Image removed due to copyright.}


The example shown in figure 11:6 is one of the first times that BP used their new Helios $\log o^{13}$, which was launched in 2000 and is one of the occasions when the "Beyond petroleum" slogan was used. The headline, in the white box on the left plays with this concept, "How BP in Australia helps get water beyond clean." The Ego of the advertisement is distanced by the third person, which implies objectivity. The photographs show a team from the University of Queensland who are monitoring the new wetland that BP has created, while on the right is the new Bulwer Island wetland at dawn. The new logo, the Helios and an internet address are in the bottom right hand corner under the main text where I have underlined the words that have come to dominate the discourse of the oil companies. The text reads:

1.BP actively promotes innovative ways to improve health, safety and the environment. For instance at our

2.Bulwer Island Refinery in Australia there is a project for purifying waste water that actually benefits the

3.environment.

4. Using only simple, natural processes, BP helped create a brand new wetland which naturally purifies and

5. returns waste water to be used again.

6. It's an example of science, engineering and natural processes working together. What's more, the new wetland

7. is a very popular attraction. For local schools it's ideal for science lessons - and for 98 species of birds it's an

8. ideal home. “

In contrast to the Esso "Put a Tiger in Your Tank", there is no overt product placement or recommendation in either advertisement. Instead, in the case of the Chevron example, the reader is first hailed by a statement of fact in a way that leaves no room for questions or disagreement and to which the gaze of the wallaby adds urgency and acquiescence. The reader is drawn into complicity as a member of the community through the pronominal "everyone" and the affirmation "We Agree" challenges him to refute the statement and thereby forfeit the right to be a member of the inclusive community denoted by "we" and instead, become one of the outsiders, one of them.

In the copy of the advertisement, the company refers to itself as "we" to indicate personal involvement and a sense of group identity. The environmental concerns of the company are emphasized by the use of the term "extraordinary lengths" which places Chevron on a level which is far above the normal and also implies that their endeavours have not been without difficulties while the verb "remains" suggests that Chevron's work in area has had no impact on the area. The final statement implies that Chevron is a company that has the "right management" for industry and the environment to co-exist in harmony.

Similarly, in the BP example, there is no mention of any product in this advertisement and any tenuous connection with their actual business can only be inferred in the reference to their refinery (2). Instead, what BP discusses are their "innovative ways" to better our everyday lives (1) and leisure opportunities (7). The text promotes them as a responsible, conscientious corporate citizen working to improve education and provide wildlife with new habitat (8). The international aspects of the business are made manifest in the setting, Australia, (2) and line 6 provides a telling example of the way in which nature, and the company, are linked together like the interlocking elements of the Helios logo. The purpose of this advertisement is not to promote a product, but to ensure that the enlightened, global presence of the company and the social aspects of their commitment to establishing this presence around the world become firmly anchored in the reader's consciousness. The reader is not directly addressed, but is simply informed, like a potential participant from the local schools, about BP's innovation.

\footnotetext{
${ }^{13}$ The logo was designed after the company merged with Amoco and is named after the Greek god of the sun, which it represents. According to the company, the colours reflect heat, light and nature, and the interlocking shapes are a metaphor for different parts working and acting as one.
} 
The purpose of these advertisements is not to directly promote a product, but to ensure that the enlightened, global presence of the company and the social aspects of their commitment to establishing this presence around the world become firmly anchored in the reader's consciousness.

\section{Changing Participant Roles and Shared Responsibility}

A comparison between the advertisements in the Caltex "Partners in Progress" series from 1958 and the Chevron willyoujoinus campaign from 2007 illustrates this change in direction. As I have already mentioned, typically, the pen-and-ink drawings that illustrate the 1958 series break out of their frames to show how Caltex is moving beyond the bounds of the present. An insistence on the power of petroleum and other derivatives of oil to bring prosperity and a better life to the peoples of the world that permeates this series. One of the most interesting aspects of the International Panorama of Progress series is that it represents a hybrid between the earlier advertisements which offer a product, and later ones which offer some sort of partnership or participation. The collaboration which Caltex is offering, however, is one whereby they provide the products which make it easier for their prospective "partner in progress" to move forward and do a good job better and more easily. The willyoujoinus campaign was introduced in The Economist during the month of September and each week, the reader was provided with more intriguing information. The campaign started with a sigle page advertisement showing the silhouette of a darkened city against the evening sky, and the simple information "This is your city". The following week the reader was asked how he would power his city and finally, a complicated four-page spread introduced the whole problem with the city lit up and the reader was asked to join Chevron in planning how best to provide the energy to power "his" city and to work with the question of how to meet growing energy demands and power a city. This could also be done on an interactive web-site organised like a computer game.

These two series clearly illustrate how the roles of the dialogical participants in the advertising of the oil companies have changed. The advertisements no longer show what the company can do for the individual or the public, but instead, discuss what the company can do for the public, the nation and the world. Although the BP advertisement which I have used as an example (figure 11: 6) does not reflect this, there has also been a move from a third person reference to the company, as in the Gulf advertisement, to a more inclusive "we". "We" is the pronoun of solidarity (Brown \& Gilman 1960) and has the potential to encode group membership both inclusively and exclusively. This shift from an exclusive "we" referring to the company towards a more inclusive "we" is particularly evident after the turn of the century.

This shift can also be shown by a comparison of two campaigns from the Shell advertising repertoire. The "Shell and the Dragon" series from the 1950s and the "Let's Go" campaign from the years in the middle of the first decade of the twenty-first century clearly exemplifies the changes in advertising orientation and discourse trajectories from product and expertise to service, social commitment and expertise. These series show how the advertising of the company has moved from a clear, product orientation to one of service and expertise.

These examples also demonstrate how the advertising of the oil companies has shifted from selling their products, often on a local level, to reminding the public of their global presence. 


\section{From Oil to Energy}

The advertisements show that the companies' involvement in the oil business is no longer central to their business, but that they have become energy companies. A glance at the slogans listed in table 11:1 after BP's "Beyond Petroleum" campaign reveals how the oil industry has indeed moved beyond petroleum to focus its attention on the much wider concept of energy.

As the changing pronouns demonstrate, the companies no longer paternalistically provide the public with goods, but have moved into a partnership in which they provide the expertise which we need to solve "our" common problems; energy supplies and the environment.

This change in the discourse of the oil industry is clearly shown by the word clouds which follow and which illustrate the shift that the companies have made over time, both with regard to the vocabulary that they use and the attitudes that they display. The size of the individual words represents the frequency with which they appeared in the advertisements while the size of the company names in the two clouds is relative to the number of advertisements that the respective companies placed as well as to how often the company name appeared in the different textual elements of the advertisements.

The first example is from 1958 and provides a summary of the advertisements that were published in The Economist that year. This was a year when the oil companies advertised extensively, when enthusiasm for oil and all the benefits that it could bring was high and when the effects of the Suez crisis meant that Britain was anxious about securing future supplies.

In the first of the word clouds the company names dominate and common words are oil, petrol, engine, power, product, production, company and British. The adjectives new and modern also occur very frequently and product names are evident and specific countries and regions are named. The second example is from 2008 which was also a year when companies advertised quite extensively.

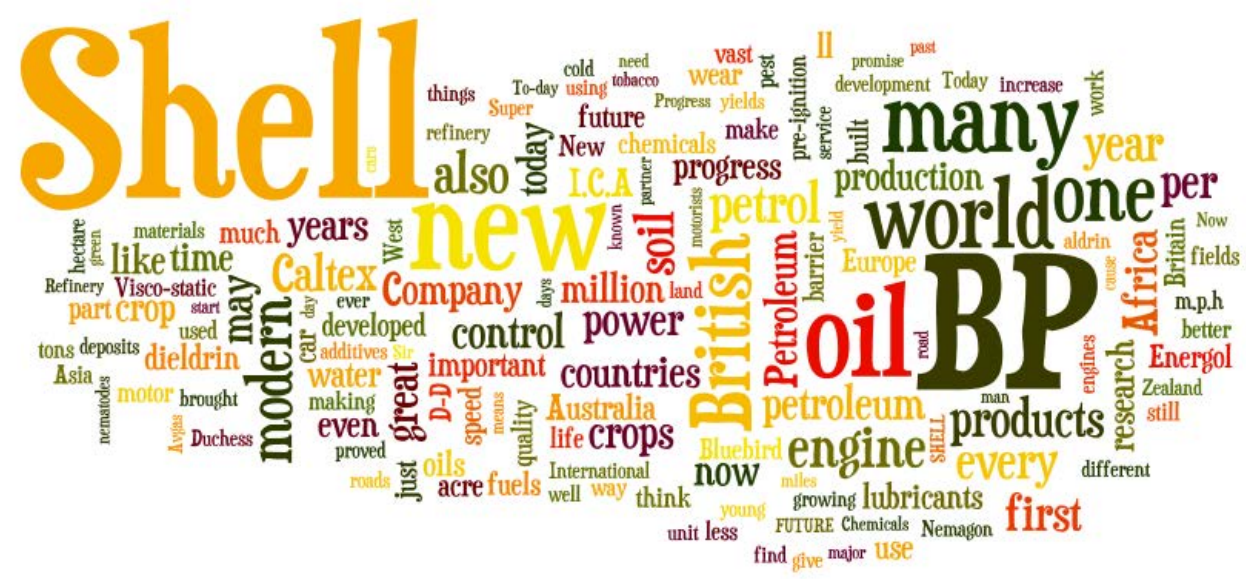

Figure 11: 7 Lexical overview of oil-company advertising 1958. 
By 2008, awareness of the environmental impact of oil had reached new heights and the issue of climate change was on the agenda for the G8 meeting in the summer of that year. However, while the advertisements from 1958 are all taken from The Economist and feature the three companies Shell, BP and Caltex, which later became part of Chevron, those from 2008 include other sources such as Newsweek and The New Statesman. This is because BP no longer placed advertisements in The Economist where Shell and Chevron dominate, but where even ExxonMobil and Total advertised.

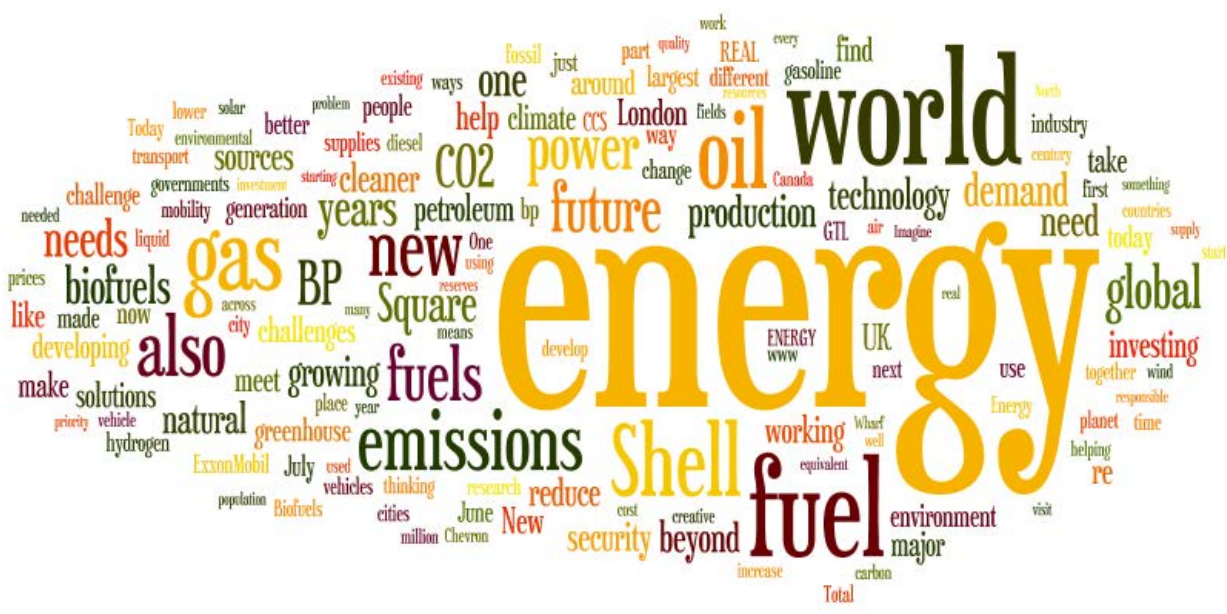

Figure 11:8 Lexical overview of oil-company advertising 2008

This cloud clearly shows the move from oil to energy and away from the concept of products. Company names have become much less important and while the adjectives new and future are still important, security, natural, climate, biofuels, gas, cleaner, reduce and CO2 are central. From presenting the benefits of their products to specific geographical areas, the companies have made a shift towards discussing the situation of the world, the second most frequently occurring word after energy.

Moreover, a word count shows that in 1958, the pronoun you, occurred a total of 39 times while we appeared on only 6 occasions. In 2008, this had changed dramatically. You featured a total of 7 times while $u$ s and our each occurred 5 times and we appeared no fewer than 72 times in Shell's advertisements. A similar count for BP in 1958 gives a total of 14 you and 6 your while we and us occur once and twice respectively. In 2008, this had changed to 7 times for you and 14 and 5 for we and our respectively.

This change in pronominal use underlines the changing relationships between the oil companies and their customers who have now become partners in the drive to create a safer, cleaner world with an endless supply of green energy that will satisfy all our demands.

Two clouds from 1958 and 2008 respectively, and that represent only the advertisements that Shell placed in The Economist, make this shift in oil industry discourse even more evident. 


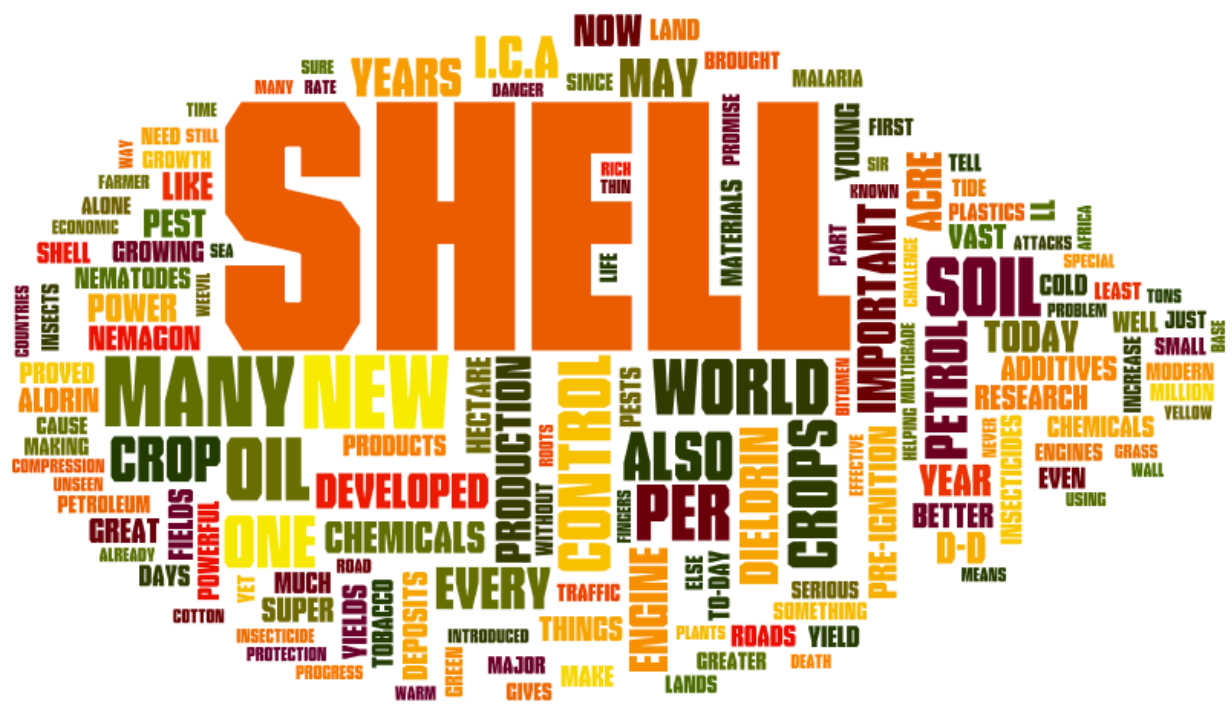

Figure 11:9 Shell word cloud The Economist 1958

In 2008, the products and chemicals that dominate the cloud from 1958 have given way to energy, fuels, the world, emissions, cleaner, power, climate and government.

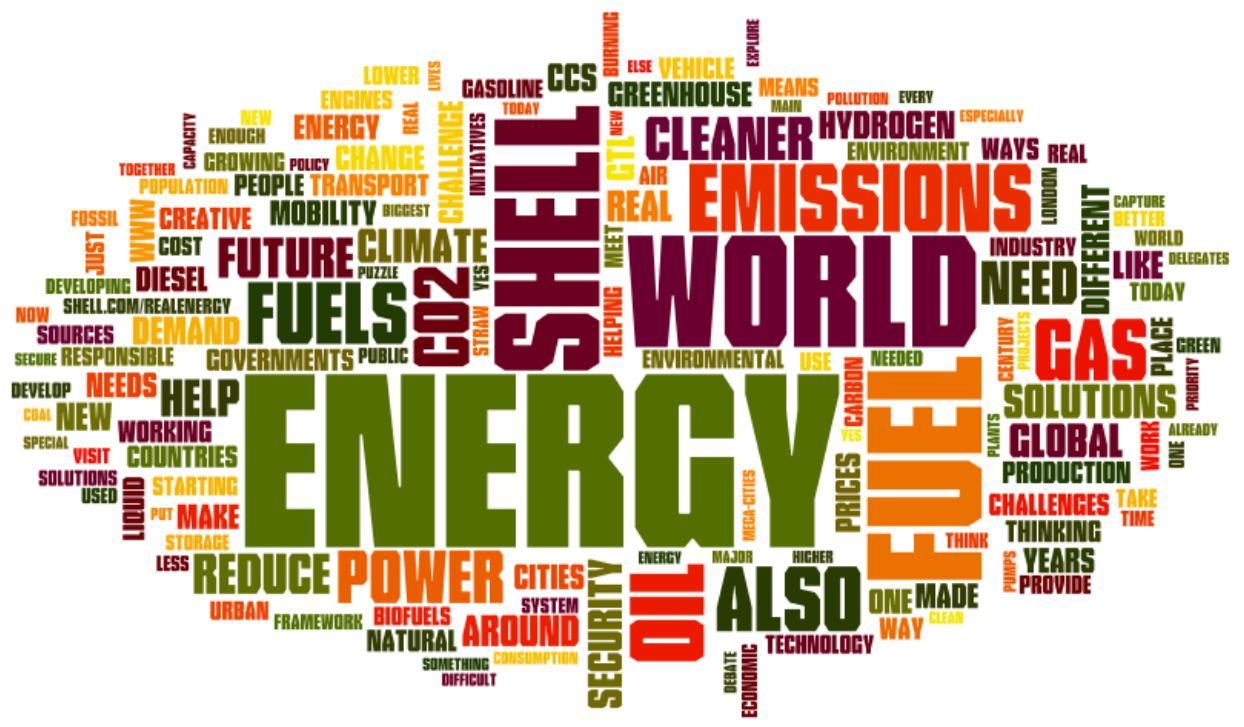

Figure 11:10 Shell word cloud The Economist 2008

The opening words of ExxonMobil's annual report from 2012 aptly summarise the way in which the oil companies now present themselves and substantiate the evidence of the 2008 word cloud. I have underlined the words which occur with particular frequency in oil industry advertisements and that are shown in the word clouds. 
"Energy is the lifeblood of prosperity.

It supports higher living standards and enables people around the world to live, work, and achieve as never before. As we look to the future and the energy challenges ahead, one thing is certain: Even with growing efficiency, the world is going to need more energy. Billions of people alive today, and yet to be born, will need affordable and reliable supplies of energy to realize their hopes and aspirations.

Meeting this challenge requires technological innovation and disciplined investment focused on long-term value creation. It requires a commitment to integrity and protecting the environment."

\section{Summary}

This chapter describes how the major companies involved in the oil industry have adapted their advertising messages to contemporary socio-political situations and how displays of corporate responsibility, values advocacy and also issues management have become increasingly commonly tools in the advertisers' communications kit. Increasing globalisation has impacted upon the ways in which they communicate with their publics and this is made manifest both in terms of the culture-specific elements of the advertisements and also by the different linguistic resources that the companies bring into play. It also shows how the oil industry has been "relexicalized" and how the "preconstructeds", (Fairclough 1992) the "givens" of the company discourses have changed. The trajectory that has emerged is one where the companies move from paternalism to partnership, product to presence, and in particular, from oil to energy. 

The advertising of the oil industry has a long history and its impact on our lives goes far beyond the actual products that we buy. In the United States, for example, the oil company logos that came to populate the roadsides to advertise both their service stations and their products changed the face of the country, while in Britain lorry bills brought works of art to the nation. Through their sponsorship of different motoring pioneers and sporting events the companies introduced the concept of endorsement and they were early to understand the importance of service and of building customer relationships in ways that included free gifts, loyalty awards and even staff uniforms. Even market research has its origins in the work of the oil industry to find potential new products and consumers. Today we accept these innovative, oil-company-driven, marketing ploys as a self-evident aspect of our everyday lives. The oil companies have played a major part in the development of the genre of advertising in its many forms.

However, the impact of the oil companies on our everyday lives extends far beyond club cards and loyalty points on things that we buy. As I have pointed out, oil and products made from its derivatives are now central to modern society and generally make our lives easier. We walk along pavements, use plastic bags, dress in fabrics and buy exotic foods without giving a thought to the fact that it is thanks to the efforts of the oil industry that this is possible. Unfortunately for the companies, we have also begun to realise that oil is not merely the fount of all goodness, but that even in this case, good is countered by its antithesis, evil.

Michel de Certeau (1984) has insisted that it is essential to begin with the phenomenon and then consider how this is represented, and the phenomenon that I have addressed here is the advertising of the major companies involved in the oil industry. More specifically, I have investigated what the companies advertise, how they do this and to whom they seem to communicate, and in the spirit of Clifford Geertz (1973:21) I have tried to "get from a collection of ethnographic miniatures (...) wall-sized culturescapes".

It is now time to return to the questions that were raised in Chapter 1, and summarise my findings.

1. What do the oil companies communicate in their advertisements, how do they do this and to whom do they communicate?

2. How have the messages that they communicate changed over time, and in what way they relate to or reflect prevailing socio-political conditions and public opinion?

3. How do the companies differentiate and profile themselves?

My analyses show that common to all the advertisements of all the oil companies, whether these be a wayside sign advertising different types of service facilities or a print advertisement for a newspaper, periodical or poster of some kind which are the focus of my research, is the insistence that they are working for us and to make our lives better and more comfortable. The advertisements present the oil companies "doing being" the good guys who are there for us.

The dialogical approach which I have used positions an advertisement as a part of a whole and not as a solitary entity. An advertisement is not a one-sided message communicated from the advertiser to the potential consumer, but is intricately and irrevocably situated in a time, a place, a social situation and in addressivity. As I have shown, an advertisement is a response to a particular situation and as such, can either look back to what has gone before or look forward to introduce what is to come. A dialogical approach insists on context, an aspect which is central to answering the question, "why?" and which is ignored or neglected in much 
other research into advertising. Such an approach lends itself particularly well to a diachronic study as it takes into account not only the actual historical context but also the multiplicity of other voices that are echoed in an advertisement.

\section{The Diachronic Analysis}

The diachronic analysis shows how the early advertisements present products; first basic illuminants, and then oils and spirits for motor engines. Petrol and lubricants for the motorist dominated the oil company advertisements until the 1950s when products made from various petrochemical derivatives began to appear. Many of these were fertilizers and pesticides which were hailed as the farmer's dream and the elixir of life. Other products that were advertised included plastics, fabrics and building materials, and delight in the comforts with which the oil industry was filling our lives and our rapidly increasing dependency upon petrochemicals and of more and faster travel, seemed to know no bounds. However, a growing insight into the negative impacts of the oil industry on the environment during the 1960s forced the oil companies to change their advertising strategies, and a clear shift from advertising products to advertising presence can be observed. Instead of discussing the superior qualities of their lubricants, for example, the companies began to describe their social engagement and the different educational projects which they sponsored or in which they were involved. Advertisements from the turn of the century continue to stress company presence, social commitment and corporate responsibility and increasingly, ways in which the companies are working towards a greener, cleaner environment and to guarantee energy security and fulfil our projected ever-increasing energy demands.

The diachronic analysis oil industry advertising reveals three general periods characterised by particular attitudes. The first of these is the age of use and abuse during which individual, as well as national dependency upon oil took firm root. During the 1950s, oil was considered to be a means by which man could tame and control nature, a view which proliferated until a number of wake-up calls began to indicate that nature could not without impunity be treated in this way. The impact of our use of petrochemicals and of the production and transporting of oil began to make its presence increasingly felt. The third stage that can be identified is the age of stewardship and protection which began as a form of image repair (e.g. Benoit 1997, Stutt \& Barker 1999) or direct response to the increasing number of critical voices that could be heard. However, in line with the observations of I.H. Rowlands (2000), for example, the advertising of the different companies reveals the importance of national beliefs and ideology on these responses.

\section{The Semiotic Analysis}

The semiotic analysis shows how not only what the companies advertise but also the ways and means with which they communicate respond to changing circumstances. The earliest advertisements were in the form of postcards or posters which in Britain, were often fixed to the sides of lorries. Many of the posters were created by artists who already were, or who became, well-known and are of a very high artistic standard. The message to be communicated needed to be clear and colourful to attract attention and to be quickly and easily understood. The image dominated and texts were simply anchors which named the product, often in the form of a slogan. The advertisements were intended for a purely British public and assumed that those seeing them had a shared cultural background. Many of the advertisements also encouraged tourism within the British Isles and fostered a sense of national pride and awareness of the sights and scenery that Britain could offer. 
When the companies began to advertise in newspapers, magazines and periodicals, they were able to direct their advertising messages to specific groups and focus on aspects of their products that were of particular interest to these people. The new advertising forum also meant that people had more time to read and study the messages and the visual element of the advertisements began to function as an illustration of the increasingly important text or copy. Moreover, the more specific target groups meant that the companies could assume a greater level of common knowledge or of shared interests and attitudes than had previously been possible. As a result, the advertisements began to adopt a more intimate tone, speaking to the reader as one of the initiated rather than one of the masses that do not appreciate the advantages that the finer qualities of the products bring. Another consequence of the assumption that the reader and the advertiser had a common background was that specific, often highly current, cultural references as well as wordplay became regular feature of the advertisements. The companies could adapt both the content and the language of their advertisements to the specific publics with whom they were communicating.

However, increasing globalisation has meant that the audiences with which companies must communicate are much less homogenous. This has meant on the one hand that the oil companies can no longer assume that the individuals who read their advertisements understand culturally specific references and on the other, that the linguistic resources at their disposal are more limited. The advertisements that I have studied are all in English, and whereas the earlier examples are often intended for a well-educated, native English speaking audience, this is no longer the case. Periodicals like The Economist are now available almost everywhere are read by people from a wide variety of countries and cultures and whose mother tongue is not English. Thus, the oil companies have tended to revert to the early technique of presenting a striking visual image which is anchored or explained by a text. Moreover, as the intended reader can no longer be assumed to share the same values and have the same attitudes, the companies can no longer poke fun and make some of the rather outrageous statements that have featured in their older advertisements. In the same way, the characters now portrayed in the advertisements better illustrate the diversity of the reading public as well as the global reach of the oil companies.

\section{The Intended Reader}

Kenneth Burke (1945) has insisted on the importance of identification in the act of persuasion and contended that the persuasive aspect of rhetoric is actually the ability to identify your cause with the interests of your audience and then to employ those rhetorical devices whose interplay will best persuade and manipulate this audience. He has suggested that identification is a communicative and cooperative response on two levels. The first is an individual response whereby a person acts to identify and associate with some target group and to think of himself as "belonging" to this group. The various associations which the individual can adopt then result in a variety of "corporate identities" or what Goffman referred to as the "so-called 'I' [which] is merely a unique combination of partially conflicting corporate "we's" (Cheney 1983:143). One consequence of these split selves is that individuals carry with them identifying "baggage" in the forms of values and interests, and another is that their corporate identity is a means of enhancing the "self" and granting it status and prestige (ibid:146).

For an advertiser, it is important to "foresee a model of a possible reader" (Eco 1984:7) and then leads him towards a meaning of the text that accords with the message that is to be communicated. My analyses show that the companies do indeed identify their intended addressees. This is done partly through their selection of periodicals and newspapers in which they publish their advertisements and the careful adaptation of their message according to 
their different readerships. Moreover, they identify not only with the target audience but are also to extremely sensitive to prevailing socio-political moods and conditions. This identification is demonstrated through the different elements of Burke's Pentad that come into play in the advertisements, for example through the choice of scene and agents and the through the language and other semiotic devices that are used. The earlier advertisements typically depict well-to-do agents in situations which are related to motoring and the implication is that the addressee is wealthy and has the leisure and the spirit of adventure to enjoy the pleasures of motoring. Women too are portrayed and the advertisements would find resonance among the "new" independent and adventurous women of the day. However, the advertisements of the 1930s begin to show a male world in which women are often depicted as a source of amusement, and the addressee is a man who understands motor cars and engines.

By the 1950s, however, many of the advertisements began to appear in quality periodicals whose readership is middle-class, well-educated, often relatively well-to-do and in a position to make decisions. Instead of trying to sell a particular product, these advertisements increasingly suggest that the oil business is a good investment and by providing contact information, offer the reader a chance to respond and become an active participant in the dialogue initiated by the company. As Perelman \& Olbrechts-Tyteca (1969) observed, any change in the audience must lead to a change in the way that argumentation is formed if its intention is to affect and influence. Thus, since the gradual dawning of awareness that began in the 1970s, the themes of many of the advertisements have increasingly become an appeal to a shared commitment to protect our environment while simultaneously protecting our right to unlimited energy supplies.

This invitation to respond and to join the companies in dialogue has become increasingly common, particularly with the advent of the internet. At the same time, the reader is not as commonly addressed directly as "you" but instead is wrapped into a collective "we-ness" which demands participation and collaboration, not only in dialogue, but in action. In the later advertisements, the addressee is frequently drawn into the dialogical situation through the gaze of an actant, an agent whose gaze demands response. The first response is normally to read the text to find out more about the scene and to understand the purpose of the advertiser. Again, the apparent purpose of these advertisements is not to sell products, but is rather to win the addressee over to the viewpoint of the company and to join them. In some cases, this invitation is a literal invitation to apply for a position with the company, and then the addressee is a potential employee, most probably a graduate, and in others, it is an exhortation to share the company's world view, support the company's endeavours and by extension, to favour their products.

\section{Research Questions Answered}

In short, the information communicated in the advertisements of the oil companies no longer centres on products but instead on presence and on corporate social responsibility in various forms, whether this is for the improving the quality of life for one individual or one community or to providing every person with a greener and more comfortable lifestyle while ensuring the safety and well-being of the planet. The nature of addressees to whom the companies direct their advertisements has also undergone a shift. While the earlier advertisements demanded that you should buy this product, today, the companies communicate a sense of collectivity; that we have to work to achieve a better world together. 
Instead of the man-in-the-street who needs to buy some petrol, the addressee has become a businessman or governmental agency who can invest or change the course of events. Rather than advertising a way to gain personal advantage, the companies are advertising a way to show empathy and become a good person. This is in line with the prevailing socio-political situation and with public preferences, and my diachronic analysis shows that the companies have always listened and responded to these. Similarly, the oil companies now better reflect the multi-national and multi-ethnic world in which we live, both in the choice of the actants and representants that populate their advertisements and also by the simpler language that is now used, the lack of specific cultural references and by the dominance of the visual.

One thing that the oil companies have in common is that they endeavour to present themselves in a positive light in accordance with the seven themes identified by Kerr $(2005)^{1}$. Further, considering the vast costs and dangers involved in the quest for the magic liquid, oil, they have mythologised the origins of the industry and cast themselves in the powerful mythic role of intrepid hero, a role in which they altercast their readers.

Since the very early days when they first began to change our world and make it possible for us to see to work late into the night, to travel further, faster and more comfortably, and to have access to new materials to simplify and enrich our everyday, they have considered themselves as benefactors.

However, as a result of increased public understanding of the way in which extracting oil and developing different petroleum-based products is detrimental to the health of both people and the planet, the oil industry has become identified with the anti-hero. Consequently, while the companies still insist that their business is to improve our lives and lifestyles, more recently, they have added the task of working to combat environmental degradation and global warming to their agendas. Concurrently, they are constantly striving to fulfill mankind's everincreasing demand for energy. In other words, their advertisements show that despite all the problems that they face, the companies are still "doing being" the good guys.

A further problem encountered by the oil industry is that to the vast majority of the population, the products that derive from petroleum are interchangeable. To return once again to the advice which Bruce Barton, the first guru of marketing, gave the oil companies, (Marchand 1985: 194); fuel is an unavoidable expense and no particular pleasure is derived from the selection of one brand rather than another. Similarly, few individuals worry about whether the plastic work surfaces in their kitchen or the material that paves the roads upon which they drive originate in the research laboratories of a particular oil company. Moreover, because of agreements going back to 1928 when the companies determined to curtail destructive competition and because of the structure of the whole industry, they cannot compete or differentiate on price to the consumer. In addition, many of the oil companies have merged, so how then do they create and maintain any sense of identity and differentiate themselves?

My analyses indicate that they do this by adopting rather different heroic roles and that these have emerged and evolved over time and are rooted in the origins of the company. Shell has taken on the mantle of crusader, while BP has taken on the role of a missionary. Chevron is everyone's partner and ExxonMobil has cast itself as the expert engineer and scientist, while

\footnotetext{
${ }^{1}$ These seven themes are the responsible citizen, a democratic partner, civic engagement, societal concern, a civilizing force, an expert and the voice of reason.
} 
Total, which finally came into being in its current form as recently as 2003 , is the visionary looking for inspiration in nature.

\section{A mirror of society?}

The advertising of the oil companies does indeed reflect society and the advertisements that they have produced show the social, political and even cultural trends and preferences that dominate. However, I do not believe that this is an adequate assessment of the role that their advertising plays. The oil industry is not a follower of trends, but since its incipience has been a leader and has shaped the society and even the world in which we now live. Changes in discourse can and do contribute to changes in beliefs and actions (Fairclough 2005: 932), something of which the oil industry has long been aware. As I pointed out in Chapter 2, in the first decades of the $20^{\text {th }}$ century, the oil companies got people into motor vehicles and very quickly changed the face of the United States (Yergin 2008: 191-193). Although this process was slower in Europe, the impact of the motor car on our lifestyles and on the countryside has been enormous. This influence has not only been on a physical, practical level, but the oil companies have also been influential in deciding public policy. It was Shell, followed by BP that drove the move from coal to oil-driven ships before WWI while in the 1970s Mobil asserted their right to have a public voice (Kerr 2005) and championed the use of advertorials to shape public opinion and try to influence national policy. In 2008, Shell adopted the strategy and produced a climate plan for the G8 leaders.

Advertising in its various forms is a powerful tool and exposes its publics to frequently repeated messages which often depict an ideal and even unreal world. Repetition leads to acceptance and legitimisation, and exposure to advertisements and particularly to the catchy slogans that often accompany them, results in what they are proclaiming becoming part of our everyday (Certeau 1984). We know, for example, that we "can be sure of Shell" and that Profits and Principles can happily co-exist.

It is through discourse that we construct the objects of which we speak, (Foucault 1969) and the discourse of the advertisements produced by the oil companies is still working to convince us, among other things, that we need to be able to travel freely and without limits, that we will need increasing amounts of energy and that this can be realised without further damage to the planet. That we will need more and more energy is something that the oil companies have been insisting for decades and something that they continue to insist despite the environmental problems that we are experiencing. By repeating and recycling their arguments "with différance" (Anward 2004) as well as by the formulaic use of slogans, the oil companies help to create and produce the world which we inhabit. Their contentions become sedimented into the collective reality and go largely unquestioned and undisputed. ExxonMobil announced in their annual report from 2012 that "between 2010 and 2040, global energy demand is expected to grow by 35 percent, which will require the responsible development of new energy resources". In other words, they are repeating the claims that the industry has been specifically making since the 1950s. They are insisting that we cannot survive without more of what is already destroying the planet. However, the companies will come to the rescue because they can and will fulfil our demands safely, by means of "responsible development".

It is my contention that advertising of the oil companies is not so much a mirror, but rather a prism through which they can frame, reflect, and distort reality and bend it in ways which better project the image that they wish to us to see. It shows them "doing being good guys". 


\section{References}

Aaker, Jennifer L. (1997) "Dimensions of Brand Personality” Journal of Marketing Research 34, 347-356

Abel, Farough (1994) "Visual Puns as Interactive Illustrations: Their Effects on Recognition Memory" Metaphor and Symbolic Activity 9 (1) 45-60

Achard, Pierre (1986) "Discours et sociologie du langage" Langage et société, 37, 5-60

Achard, Pierre (1995) "Formation discursive, dialogisme et sociologie" Langages, 29, 117, $82-95$

Adelswärd, Viveka (2000)'“Who is talking?" Some thoughts on speakers, voices and virtual participants' in Creative Crossroads - Electronic Honorary Publication Dedicated to Yvonne Waern on Her Retirement

Ahearn, Laura (2001) "Language and Agency" Annual Review of Anthropology, 30, 109-137

Amnesty International (2011) "UN confirms massive oil pollution in Niger Delta" Annual Report 2011 hppt://www.amnesty.org/en/news-and-updates

Anderson, Alison, G. (2002) "The Media Politics of Oil Spills” Spill Science and Technology Bulletin. Vol.7, Nos 1-2, pp.7-15.

Ang, Swee Hoon \& Elison Ai Ching Lim (2006) "The influence of metaphors and product type on brand personality perceptions and attitudes" Journal of Advertising, Vol. 35, No.2 (June) pp. 39-53

Anscombre, Jean-Claude (2009) "La comédie de la polyphonie et ses personnages" Langue Française 164, December, 11-33, Birkelund et al. (eds).

Anward, Jan (2002) "Other voice, other sources" in Per Linell \& Karin Aronsson (eds.): Jagen och rösterna: Goffman, Viveka och samtalet/Selves and Voices: Goffman, Viveka, and Dialogue. Linköping, 127-148.

Anward, Jan (2004) "Lexeme Recycled. How Categories Emerge From Interaction" Logos and Language, Journal of General Linguistics and Language Theory, 2 (Ed. Klaas Willems)

Aristotle (2004) Rhetoric, (W. Rhys Roberts, translator) Dover Thrift Editions New York Arndt, Robert (1975) "Suez: The reopening" Saudi Aramco World September/October Artz, Nancy \& Alladi Venkatesh (1991) "Gender Representation in Advertising", Advances in Consumer Research, 18 , 618-623.

Asa Berger, Arthur (1996) Narratives in Popular Culture, Media and Everyday Life, Sage Publications

Assman, Jan (1995) Collective Memory and Cultural Identity New German Critique, 65, Cultural History/Cultural Studies (Spring - Summer) 125-133

Austin, J.L. (1962) How to Do Things with Words (second edition) Harvard University Press Cambridge Mass.

Backer, Lise (2008) "Narrating organisational identities by way of evolutionary tales: taking Shell from an oil to an energy company" Scandinavian Journal of Management, 24, $1,33-43$

Backer, Lise (2009) "When Oil and Wind Turbine Companies Make Green Sense Together" Business Strategy and the Environment 18, 43-52

Backer, Lise \& Timothy S. Clark (2008) "Eco-Effective Greening Decisions and Rationalizations: The Case of Shell Renewbles" Organization Environment, 21, 227-244

Bakhtin, M.M. (1981) The dialogical imagination: Four essays (translated and edited by C. Emerson). Minneapolis: University of Minnesota Press

Bakhtin, M.M. (1984) Problems of Dostoyevsky's Poetics (edited and translated by Caryl 
Emerson, Introduction by Wayne Booth) Theory and History of Literature, Volume 8, Manchester University Press

Bakhtin, M.M. (1986) Speech genres and other late essays (Translated by V. McGee, edited by C. Emerson \& M. Holquist) Austin: University of Texas Press

Bakir, Vian (2006) "Policy Agenda Setting and Risk Communication: Greenpeace, Shell, and Issues of Trust" The Harvard International Journal of Press/Politics 11, 67-88

Balmer, John M.T. (2001) "Corporate identity, corporate branding and corporate marketing: Seeing through the fog" European Journal of Marketing 35, 3, 4, 248-291

Bamberg, J.H. (1994) The History of the Britiish Petroleum Company, Volume 2 The AngloIranian Years, 1928-1954 Cambridge, The Press Syndicate of the University of Cambridge

Banfield, Ann (1982) Unspeakable Sentences London, Routledge \& Kegan Paul.

Barad, Karen (2003) "Posthumanist Performativity: Toward an Understanding of How Matter Comes to Matter" Signs: Journal of Women in Culture and Society 28, 31, 801-828

Barkham, Patrick (2010) "Oil spills: Legacy of the Torrey Canyon" The Guardian, June 24

Barnham, Chris (2008) "Instantiation Reframing brand communication" International Journal of Market Research, 50, 2, 203-220.

Barsky, Robert R. (1995) "The Construction of the Other and the Deconstruction of Self: The Case of Convention Hearings" pp.79-102 in Encountering the Other(s): Studies in Literature, History, and Culture Gisela Brinker-Gabler (ed).State University of New York Press, Albany

Barthes, Roland (1957) Mythologies Editions du Seuil

Barthes, Roland (1966) "Introduction à l'analyse structural des récits" Recherches sémiologiques : l'analyse structurale du récit. Communications, 8, 1-27.

Barthes, Roland (1967) Elements of Semiology (translated by Annette Lavers \& Colin Smith) Hill and Wang, New York

Barthes, Roland (1977) Image, Music, Text (Translated by Stephen Heath) Fontana Press London

Barthes, Roland (1994) The Semiotic Challenge (translated by Richard Howe 1988) University of California Press

Bates, Leonard, J. (1955) "The Teapot Dome Scandal and the Election of 1924" The American Historical Review, 60, 2, 303-322

Beaton, Kendall (1955), "Dr. Gesner's Kerosene. The Start of American Oil Refining” The Business History Review, 29, 1, 28-53

Belk, Russell W. \& Richard W. Pollay (1985) "Images of Ourselves: The Good Life in Twentieth Century Advertising” Journal of Consumer Research 11, 4, 887-897

Belkaoui, Ahmed \& Janice M. Belkaoui (1976) "A Comparative analysis of the Roles Portrayed by Women in Print Advertisements: 1958, 1970, 1972” Journal of Marketing Research 13, 2 168-172

Bell, Allan (1984) "Language Style as Audience Design" Language in Society, 13, 2 $145-204$

Bell, Philip \& Marko Milic (2002) “Goffman's Gender Advertisements revisited: combining content analysis with semiotic analysis" Visual Communication 1, 203-222

Benoit, William, L. (1997) "Image repair discourse and crisis communication" Public Relations Review 23, 177-186

Benveniste, Emile (1966) Problèmes de linguistique générale 1 Editions Gallimard Benveniste, Emile (1974) Problèmes de linguistique générale II Editions Gallimard Berger, John (1972) Ways of Seeing, Clays Ltd. St. Ives, plc, Penguin Modern Classics Bergström, Bo (2003) Bild \& Budskap: Ett triangeldrama om bildkommunikation, Carlssons Bernstein, David (1983) “That's Shell - that is!” An Exhibition Of Shell Advertising Art 


\section{Barbican Art Gallery and Shell UK}

Bhatia, Vijay K. (1993) Analysing Genre: Language Use in Professional Settings Harlow, Longman

Bhatia, Vijay K. (2002) “Applied genre analysis: a multi-perspective model” Ibérica, 4, 3-19

Biasko, Vincent J. \& Michael P. Mokwa (1986) "Creativity in Advertising: A Janusian

Perspective" Journal of Advertising 15, 4, 43-72

Birkelund, Merete, Nølke, Henning \& Rita Therkelsen (2009) "La polyphonie linguistique"

Langue Française 164, December

Biswas, Abhijit, Olsen, Janeen \& Valerie Carlet (1992) “A Comparison of Print

Advertisements from the United States and France" Journal of Advertising, 21, 4, 73-81

Blackden, Richard (2012) "Gulf of Mexico oil spill: BP wins victory over US government as trial is postponed until 2013" The Telegraph, May $3^{\text {rd }}$

Boele, Richard, Fabig, Heike \& David Wheeler (2001) "Shell, Nigeria and the Ogoni. A

Study in Unsustainable Development: II. Corporate Social Responsibility and

'Stakeholder Management' versus a Rights-based Approach to sustainable

Development" Sustainable Development 9, 121-135

Boje, David M. (1995) "Stories of the Story-telling Organization: A Postmodern Analysis of

Disney as "Tamara- Land" The Academy of Management Journal 38, 4, 997-1035

Bolduc, Michelle K. \& David A. Frank (2010) "Chaïm Perelman and Lucie Olbrechts-

Tyteca's "On Temporality as a Characteristic of Argumentation": Commentary and

Translation" Philosophy and Rhetoric, 43, 4, 308-315

Bonhomme, Marc \& Gilles Lugrin (2008) "Interprétation et effets des figures visuelles dans

la communication publicitaire: le cas de la métonymie et de la métaphore" Studies

in Communication Sciences 8, 1, 237-258

Booker, Christopher (2004) The Seven Basic Plots : Why we tell stories Continuum

International Publishing Group

Booth, Wayne (1978) "Metaphor as Rhetoric: The Problem of Evaluation" Critical Inquiry 5, 1, (Special Issue on Metaphor) 49-72

Booth, Wayne (2004) The Rhetoric of Rhetoric The Quest for Effective Communication Blackwell Publishing

Borghini, Stefania, Visconti, Luca Massimiliano, Anderson, Laura and John F. Sherry, Jr. (2010) "Symbiotic Postures of Commercial Advertising and Street Art" Journal of Advertising 39, 3 113-126

Bostdorff, D.M \& Vibbert S.L. (1994) "Values advocacy: Enhancing organizational images, deflecting public criticism, and grounding future arguments" Public Relations Review, 20, 141-158

Bourdieu, Pierre (1982) Ce que parler veut dire Librairie Arthème Fayard

Bourdieu, Pierre (1984) Distinction: A Social Critique of the Judgement of Taste (Richard Nice translator) Routledge Kegan \&Paul

Bourdieu, Pierre (1986) "The forms of capital” In J. Richardson (Ed.) Handbook of Theory and Research for the Sociology of Education (New York, Greenwood), 241-258. (Richard Nice translator)

Bourdieu, Pierre (1987) Choses dites Les Editions de Minuit, Paris

Bourdieu, Pierre (1991) Language and Symbolic Power (John B. Thompson, ed. translated by Raymond Gino and Matthew Adamson) Cambridge, Polity Press,

Bourdieu, Pierre (1998) Practical Reason: On the Theory of Action Stanford University Press

Bourdieu, Pierre (2005) The Social Structures of the Economy (translated by Chris Turner) Cambridge, UK Polity Press

Bourdieu, Pierre \& Loïc J.D. Wacquant (1992) An Invitation to Reflexive Sociology Oxford, 
Polity Press and Blackwell Publishers

Boyce, Mary E. (1996) “Organizational story and storytelling: a critical review” Journal of Organizational Change Management 9, 5 5-26

Boyle, David \& Andrew Simms (2010) Eminent Corporations The rise and fall of the great British Corporation, Londin, Constable

Breton, Philippe (2003, $3^{\text {rd }}$ ed.) L'argumentation dans la communication Paris

Éditions La Découverte,

Briggs, Charles L. \& Richard Bauman (1992) "Genre, Intertextulity, and Social Power" Journal of Linguistic Anthropology, 2, 2, 131-172

Brinson, Susan L. \& William L. Benoit (1999) “The Tarnished Star: Restoring Texaco's Damaged Public Image" Management Communication Quarterly, 12, 4, 483-510

Brown, Clyde, Waltzer, Herber \& Miriam B. Waltzer (2001) "Daring to Be Heard:

Advertorials by Organized Interests on the Op-Ed Page of The New York Times, 1985-1998" Political Communication, 18:1, 23-50

Brown, Clyde \& Herbert Waltzer (2005) "Every Thursday: advertorials by Mobil Oil on the op-ed page of The New York Times" Public Relations Review 31, 197-208

Bruner, Jerome (2004) “Life as Narrative" Social Research, 71, 3, 691-710

Brunyé, Tad, Ditman, Tali, Mahoney, Caroline, Augustyn, Jason and Holly Taylor (2009) "When you and I share perspectives: Pronouns modulate perspective taking during narrative" Psychological Science 20, 27-32.

Burke, Kenneth (1945) A Grammar of Motives (1969 paperback edition) University of California Press,

Burke, Kenneth (1950) (California edition1969) A Rhetoric of Motives University of California Press,

Burke, Kenneth (1966) Language Symbolic Action: Essays on Life, Literature, and Method University of California Press,

Burkitt, Ian (1998) The Death and Rebirth of the Author:The Bakhtin Circle and Bourdieu on Individuality, Language and Revolution" in Bakhtin and the Human Sciences: No Last Words Michael E. Gardiner \& Michael Mayerfeld Bell (eds.) Sage Publications

Campbell, Joseph with Bill Moyers (1988) The Power of Myth Doubleday

Carson, Rachel (1962) Silent Spring Fortieth Anniversary Edition, First Mariner books, New York, Houghton Mifflin Company

Carvalho, Anabela (2007) "Ideological cultures and media discourses on scientific knowledge: re-reading news on climate change" Public Understanding of Science $16,2223-243$

De Certeau, Michel (1984) The Practice of Everday Life (Steven Rendall translator) University of California Press

Chandler, Daniel (1997) An Introduction to Genre Theory

http: / / faculty. washington.edu/farkas/HCDE510Fall2012/Chandler genre theoryDFAnn.pdf

Chandler, Geoffrey (1977) "The Innocence of the Oil Companies," Foreign Policy, 27 (Summer) 52-70)

Cheney, George (1983) "The Rhetoric of Identification and the Study of Organizational Communication" Quarterly Journal of Speech 69, 143-158

Cheskin, Louis \& L. B. Ward (1948) "Indirect Approach to Market Reactions" Harvard Business Review, 26, 5, 572-580

Chilcote, Ryan (2003) "Kuwait still recovering from Gulf War" for CNN, January 3

Church, Frank (1977) “The Impotence of Oil Companies" Foreign Policy, 27 (Summer), 27-51

Cioffi, Frank L. (1988) "The Audience within the Object: The Implied Teacher in Composition Textbook Advertisements" Written Communication 5, 277-305 
Cohen, Ted (1978) "Metaphor and the Cultivation of Intimacy" Critical Inquiry 5,

1, (Special Issue on Metaphor) 3-12

Confessore, Nicholas, (2005) "An Old Oil Spill Divides a Brooklyn Neighborhood” The New York Times November $1^{\text {st }}$

Cook, Guy (1992) The Discourse of Advertising King's Lynn Routledge

Cook, Guy (2001) The Discourse of Advertising (Second Edition) King's Lynn Routledge

Cook, Guy (2008) “Advertisements and Public Relations" pp. 113-130 in Handbook of Communication in the Public Sphere (Ruth Wodak \& Veronika Koller, eds) Mouton de Gruyer

Coupland, Christine \& Andrew D. Brown (2004) "Constructing Organizational Identities on the Web: A Case Study of Royal Dutch/Shell” Journal of Management Studies 41, $8,1325-1347$

Courtney, Alice E. \& Sarah Wernick Lockeretz (1971) “A Woman's Place: An Analysis of the Roles Portrayed by Women in Magazine advertisements" Journal of Marketing Research 8, 1 92-95

Crable, Richard, E. \& Steven L. Vibbert (1983) "Mobil's Epideictic Advocacy: "Observations" of Prometheus-Bound" Communication Monographs, 50, (December) 380-394

Crosswhite, James (2010) “The New Rhetoric Project” Philosophy and Rhetoric, 43, 4, 301-307

Culler, Jonathan (1981) The pursuit of signs: semiotics, literature, deconstruction, Ithaca N.Y. Cornell University Press

Daly, Ann \& Len Unsworth (2011) "Analysis and comprehension of multimodal texts" Australian Journal of Language and Literacy 34, 1, 61-80

Danow, David (1991) The Thought of Mikhail Bakthin from Word to Culture Palgrave Macmillan

Davidson, Donald (1978) "What Metaphors Mean” Critical Inquiry 5, 1, (Special Issue on Metaphor) 31-47

Dawson, Leslie, M. (1971) "Marketing Science in the Age of Aquarius" Journal of Marketing, 35, 66-72

De Fina, Anna (1995) "Pronominal choice, identity, and solidarity in political discourse" Text 15, 3 379-410

Demarest, Jack \& Garner Jeanette (1992) “The Representation of Women's Roles in Women's Magazines Over the Past 30 Years" The Journal of Psychology, 126, 4, 357-369

Derrida, Jacques (1980) "The Law of Genre" Critical Inquiry 7, 1, 55-81

Dickson, Lisa \& Alistair McCullogh (1996) "Shell, the Brent Spar and Greenpeace: A Doomed Tryst?" Environmental Politics 5, 1, 122-129

van Dijk, Teun A. (2008) Discourse and Context, A Sociocognitive Approach Cambridge University Press

DiMaggio, Paul J. \& Walter W. Powell (1983) “The Iron Cage Revisited: Institutional Isomorphism and Collective Rationality in Organizational Fields" American Sociological Review, 48, 2, 147-160

Djafarova, Elmira (2008) "Why Do Advertisers Use Puns? A Linguistic Perspective" Journal of Advertising Research, June 267- 275

Douglas, Mary (1970) Natural Symbols, Penguin Education, Penguin Books, Aylesbury, Great Britain

Drucker, Peter F. (1984) "The new meaning of corporate social responsibility", California Management Review, 26, 2.

Du, Shuili, Bhattacharya, C.B. \& Sankar Sen (2007) "Reaping relational rewards from 
corporate social responsibility: The role of competitive positioning" International Journal of Research in Marketing, 24, 224-241

DuBois, Shelley (2010) “Update: BP's advertising budget during the spill neared $\$ 100$ million" http://money.cnn.com/2010/09/01/news/companies/BP spill advertising

Du Bois, John (2010) "The Stance Triangle," in R. Englebretson (ed.), Stancetaking in discourse: Subjectivity, evaluation, interaction. Amsterdam: Benjamins.

Ducrot, Oswald (1980) “Analyses pragmatiques" Communications, 32, Les actes de discours, $11-60$

Duff, David (ed.) (2000) Modern Genre Theory Longman, Pearson Education Limited

Eco, Umberto (1972) La Structure Absente; Introduction à la recherche sémiotique Mercure de France

Eco, Umberto (1979) A Theory of Semiotics, Indiana University Press, Bloomington

Eco, Umberto (1984) The Role of the Reader: Explorations in the Semiotics of Texts Indiana University Press, Bloomington

Eco, Umberto (1990) The Limits of Interpretation Indianan University Press, Bloomington and Indianapolis

Edell, Julie, A. \& Richard Staelin (1983) "The Information Processing of Pictures in Print Advertisements", Journal of Consumer Research. 10, June, 45- 61

Elliott, Richard, Eccles, Susan \& Michelle Hodgson (1992) "Re-coding gender representations: Women, cleaning products, and advertising's "New Man" International Journal of Research in Marketing 10, 311-324

Elliott, Richard \& Christine Elliot (2005) "Idealised images of the male body in advertising: a reader-response exploration" Journal of Marketing Communications, 11, 1, 3-19

Ellis, Basia D. \& Henderikus J. Stam (2010) "Addressing the Other in Dialogue: Ricoeur and the Ethical Dimensions of the Dialogical Self" Theory Psychology, 20, 420-435

Ergodan, Zafer (1999) “Celebrity Endorsement: A Literature Review” Journal of Marketing Management, 15, 4, 291-314

Fairclough, Norman (1992) Discourse and Social Change Cambridge, Polity Press

Fairclough, Norman (1995) Media Discourse London: Edward Arnold

Fairclough, Norman (2005) "Peripheral Vision: Discourse Analysis in Organization Studies: The Case for Critical Realism" Organization Studies, 26, pp. 915-939

Fairclough, Norman (2010) Critical Discourse Analysis, The Critical Study of Language $\left(2^{\text {nd }}\right.$ edition) Pearson Education Limited

Farmer, Richard, N. "Would You Want Your Daughter to Marry a Marketing Man?” Journal of Marketing, 31, 1, 1-3

Ferrier, Ronald W. (1982) The history of the British Petroleum Company, Volume 1: The developing years 1901-1932 Cambridge, Cambridge University Press

Fill, Alwin F. (1986) “'Divided illocution' in conversational and other situations and some of its implications" International Review of Applied Linguistics 24:27-34

Firat, A. Fuat \& Alladi Venkatesh (1993) "Postmodernity: The age of marketing" International Journal of Research in Marketing 10, 227-249

Fish, Stanley (1980) Is There a Text in This Class, The Authority of Interpretive Communities Cambridge MA, Harvard University Press

Flory, Marja \& Oriol Iglesias, (2010) "Once upon a time: The role of rhetoric and narrative in management research and practice" Journal of Organizational Change Management 23, 2 113-119

Flosch, Jean-Marie (1985) Petites Mythologie de l'œil et de l'esprit pour une sémiotique plastique Éditions Hadès-Benjamins

Flosch, Jean-Marie (2001) $2^{\text {nd }}$ edition Semiotics, Marketing and Communication: Beneath the Signs, the Strategies (Robin Orr Bodkin, translator) Palgrave 
Forceville, Charles (1994) "Pictorial Metaphor In Advertisements" Metaphor and Symbolic Activity 9, 1 1-29

Forceville, Charles (1995) "IBM is a tuning fork: Degrees of freedom in the interpretation of metaphors" Poetics 23, 189-218

Ford, John B., LaTour, Michael S. \& William J. Lundstrom (1991) “Contemporary Women's Evaluation of Female Role Portrayals in Advertising" The Journal of Consumer Marketing 8, 1, 15-28

Foss, Sonja K. Foss, Karen A. \& Robert Trapp (2002) Contemporary Perspectives on Rhetoric (third edition) Waveland Press, Inc. Illinois

Foucault, Michel (1969) The Archaeology of Knowledge and the Discourse on Language (Translated by A.M. Sheridan Smith) Vintage Books, A Division of Random House, Inc. New York

Foucault, Michel (1970) The Order of Things An archaeology of human sciences Tavistock Routledge Classics

Fowler, Alistair (1979) "Genre and the Literary Canon" New Literary History, 11, 1, Anniversary Issue: II 97-119

Fowler, Alistair (1982) Kinds of literature: An introduction to the theory of genres and modes Harvard University Press

Fowler, Roger (1996) Linguistic Criticism (second edition) Opus, Oxford University Press

Franco de Oliveira, Neil Armstrong (2012) "O Conceito de Campo em Bakhtin e Bourdieu para a Abordagem dos Gêneros Jornalísticos na Escola” Revista Educação e Linguagens, Campo Mourão, 1, 1, 2012

Frank, David A. (2010) "Book Reviews: After the New Rhetoric" Quarterly Journal of Speech, 89, 3, 253-266

Freedberg, David (1989) The power of images Chicago, University of Chicago Press

Friedman, Milton (1970) "The Social Responsibility of Business is to increase its profits" The New York Times Magazine, September 13, 1970

Frye, Northrop (1957) The Anatomy of Criticism Third Essay: Archetypal Criticism: Theory of Myths http://northropfrye-theanatomyofcriticism.blogspot.se/2009/02/third-essay-

Fuoli, Matteo (2012) "Assessing social responsibility: A quantitative analysis of Appraisal in BP's ad IKEA's social reports" Discourse \& Communication 6, 1, 55-81

Galpern, Stephen, G. (2009) Money, Oil and Empire in the Middle East,, Sterling and Postwar Imperialism 1944-1971 Cambridge, Cambridge University Press

Gamson, William, A. \& Andre Modigliani (1989) "Media Discourse and Public Opinion on Nuclear Power: A Constructionist Approach" American Journal of Sociology $95,1,1-37$

García-Muñoz, Núria \& Luisa Martínez (2009) “El consumo femenino de la mujer en la publicidad. El sexismo en las campañas publicitarias rechazadas por la audiencia" Trípodos 24, 149-160

Gareth Jones, G. (1977) "The British Government and the Oil Companies 1912-1924: The Search for an Oil Policy" The Historical Journal, 20, 3 647- 672

Garrett, Jason \& Rajesh Iyer (2013) "International Advertising Research: A Literature Review" International Journal of Management 30, 1, 143-159

Geertz, Clifford (1973) The Interpretation of Cultures, Basic Books, Inc. New York

Genette, Gérard (1992) "The Architext”, (translated by Jane E. Lewin) pp.210-218 in Duff, David (ed.) (2000) Modern Genre Theory Longman, Pearson Education Limited

Gilly, Mary C. (1988) "Sex Roles in Advertising: A Comparison of Television Advertisements in Australia, Mexico, and the United States" Journal of Marketing, $52,2,75-85$

Gioia, Dennis A. Schultz, Majken \& Kevin G. Corley (2000)"Organizational Identity, Image 
and Adaptive Instability" The Academy of Management Review 25, 1, 63-81

Goffman, Erving (1959) The Presentation of Self in Everday Life Doubleday Ancor Books

Goffman, Erving (1967) Interaction Ritual: Essays on Face-to-Face Behavior, Pantheon Books New York

Goffman, Erving (1974) Frame Analysis An Essay on the Organization of Experience Boston, Northeastern University Press

Goffman, Erving (1976) (1979 with Introduction by Vivian Gornick) Gender Advertisements Harvard University Press Cambridge Massachusetts

Goffman, Erving (1977) "The arrangement between the sexes" Theory and Society 4, 3, 301-331.

Goffman, Erving (1981) Forms of Talk University of Pennsylvania Press Philadelphia

Goldberg, Victor P. (1994) "Recovery for Economic Loss Following the Exxon Valdez Oil Spill" The Journal of Legal Studies 23, 1, 1-39.

Gordon, Wendy (2006) "Out with the new, in with the old" International Journal of Market Research 48, 1, 7-26

Gordon, Wendy (2011) "Behavioural economics and qualitative research - a marriage made in heaven?" International Journal of Market Research 53, 2, 1-15

Görlach, Manfred (2002) “A linguistic history of advertising 1700-1890" in Sounds, Words, Texts and Change, selected papers from the $11^{\text {th }}$ International Conference on English Historical Linguistics, Santiago de Compostela, Sept 7-11, 2000, John Benjamins

Graafland, Johan J. (2002) "Profits and Principles: Four Perspectives" Journal of Business Ethics 35, 293-305

Green, Martin (1996) "Some Versions of the Pastoral: Myth in Advertising: Advertising as Myth" pp. 29-47 in Advertising and Culture: Theoretical Perspectives (Mary Cross, ed) Westport, Praeger Publishers

Gregory, James, R. with Jack W. Wiechmann (1991) Marketing Corporate Image, The Company As Your Number One Product NTC Business Books Lincolnwood, Illinois, NTC Publishing Group

Griffenhagen, George B. and James Harvey Young (1959) Old English Patent Medicines in America (EBook \#30162] Contributions from the Museum of History and Technology, United States National Museum Bulletin 218 Smithsonian Institution, Washington D.C

Grigalunas, Thomas A. Anderson, Robert, C., Brown, Gardner, M. Jr., Congar, Richard, Meade, Norman F. and Philip E. Sorensen "Estimating the Cost of Oil Spills: Lessons from the Amoco Cadiz Incident" Marine Resource Economics, 2, 3, 239-262

Gross, Alan (1999) "A theory of the rhetorical audience: Reflections on Chaïm Perelman" Quarterly Journal of Speech, 85, 2, 203-211

Grunig, James E. (ed) (1992) Excellence in Public Communications and Communication Management New Jersey, Lawrence Erlbaum Associates, Publishers

Günthner, Susanne (1998) "Polyphony and the "Layering of Voices" in Reported Dialogues. An Analysis of the Use of Prosodic Devices in Everyday Reported Speech" Interaction and Linguistic Structures, 3, 4-25

Hagan, Susan M. (2007) "Visual/Verbal Collaboration in Print: Complementary Differences, Necessary Ties, and an Untapped Rhetorical Opportunity" Written Communication 24, 49-83

Hajer, Maarten A. (1995) The Politics of Environmental Discourse Ecological Modernization and the Policy Process, Clarendon Press Oxford 
Hanks, William, F. (1987) "Discourse genres in a theory of practice" American Ethnologist, $14,4,668-692$

Hanks, William F. (1996) Language and Communicative Practices University of Chicago Press

Hansen, Flemming \& Sverre Riis Christensen (2007) Emotions, Advertising and Consumer Choice Copenhagen Business School Press, Universitetsforlaget Liber

den Hartog, C. \& R.P.W.M. Jacobs (1980) 'Effects of the 'Amoco Cadiz' oil spill on an eelgrass community at Roscoff (France) with special reference to the mobile benthic fauna" Helgoländer Meeresunters, 33, 182-191

Harvey, Fiona (2011) "North sea oil spill worst for a decade'" The Guardian, Monday, 15 August

Harvie, B.A. (2011) Historical Review paper: The Shale Oil Industry in Scotland 1858-1962 II: Oil-shale quality, resources and technological advances Oil Shale2011, 28, $1,78-84$

Hausman, Carl M. (1989) Metaphor and Art: Interactionism and Reference in the Verbal and Nonverbal Arts Cambridge University Press

Heath, R.L. (2002) "Issues management: its past, present and future" Journal of Public Affairs, 2, 4, 209-214

Heath, R. L. \& K. R. Cousino, (1990) "Issues management: End of first decade Progress report" Public Relations Review, 16, 1, 7-18.

Helsloot, Niels \& Tony Hak (2007) "Pêcheux's Contribution to Discourse Analysis" Forum Qualitative Sozialforschung /Forum: Qualitative Social Research 8, 2, Art 1.

Hendon, Donald, W. and William F. Muhs (1986) "Origin and Early Development of Outdoor Advertising in the United States" Emerald Backfiles

Hermans, Hubert (1996) "Voicing the Self: from Information Processing to Dialogical Interchange" Psychological Bulletin, 1, 31-50

Hermans, Hubert (2001) "The Dialogical Self: Toward a Theory of Personal and Cultural Positioning" Culture Psychology 7, 243-281

Hermans, Hubert \& Giancarlo Dimaggio (2007) "Self, Identity, and Globalization in Times of Uncertainty: A Dialogical Analysis" Review of General Psychology, 11, 1, 3161

Hewitt, John (1992) “The 'Nature'and 'Art'of Shell Advertising in the Early 1930s” Journal of Design History, 5, 2, 121-139

Hidy, Ralph W. \& Muriel E. Hidy (1955) Pioneering in Big Business 1882-1911 History of Standard Oil Company New Jersey, New York Harper \& Brothers

Hillis Miller, J. (1990) "Narrative" Chapter 5, 66-79, in Lentriccha, Frank \& Thomas McLaughlin eds. (1995, second edition) Critical Terms for Literary Study University of Chicago Press

Hirsch, Afua \& John Vidal (2012) "Shell spending millions of dollars on security in Nigeria, leaked data shows" The Guardian August 19th

Hirschmann, Elizabeth, C. (1986) "The Creation of Product Symbolism" Advances in Consumer Research 13, 327-331

Hirschman, Elizabeth C. Scott, Linda \& William B. Wells (1998) "A Model of Product Discourse: Linking Consumer Practice to Cultural Texts" Journal of Advertising 27, $134-50$

Hodge, Robert \& Gunther Kress (1988) Social Semiotics Polity Press in association with Basil Blackwell Ltd. Padstow

Holbrook, Morris, B. (1987a) "What is Consumer Research?” Journal of Consumer Research $14,1,128-132$

Holbrook, Morris B. (1987b) “The Study of Signs in Consumer Esthetics: An Egocentric 
Review" pp. 73-122 in Marketing and Semiotics New Directions in the Study of Signs for Sale Jean Umiker-Sebeok, (ed.) Berlin, Mouton de Gruyter

Holbrook, Morris B. \& Rajeev Batra (1987) "Assessing the Role of Emotions as Mediators of Consumer Responses to Advertising" Journal of Consumer Research 14, 3, 404-420

Holmgren Caicedo, Mikael (2009) Retorik, Lund, Liber

Holt, Douglas B. (2003) "What Becomes an Icon Most?" Harvard Businesss Review March

Hong, J.W., Muderrisoglu, A. \& Zinkhan, G.M. (1987) "Cultural differences and advertising expression: a comparative content analysis of Japanese and US magazine advertising" Journal of Advertising, 16, 1,.55-62

Høngsmark Knudsen, Gry (2012) "Man’s last stand! Polysemy and dialogue in advertising reception" Advertising and Society Review, 13, 2.

Hunt, Tristram (2006) "England and the Octopus" History Today, July, 56, 7, 34-40

Hyland, Ken (1998) "Exploring corporate rhetoric: Metadiscourse in the CEO's letter" Journal of Business Communication, 35, 2, 224-244

Hymes, Dell (1972) "Models of the interaction of language and social life" in J. Gumpertz \& D. Hymes (eds) Directions in Sociolinguistics: The Ethnography of Communication New York, Holt

Ignatius, David, (2002) “True Crime: The Scent of French Society” Legal Affairs

http://www.legalaffairs.org/issues/May-June2002/story ignatius maayjune2002.html (April 29th 2013)

Ihlen, Oyvind (2006) "The oxymoron of 'sustainable oil production': the case of the Norwegian oil industry" in Business Strategy and the Environment 18, 1, 5363, January 2009 Published online 21 November 2006 in Wiley InterScience (www.interscience.wiley.com) DOI: 10.1002/bse.563

Ihlen, Oyvind (2007) "Klimaendringene og olieindustriens retoriske utfordring" Rhetorica Scandinavica 43, höst 18-38

Ihlen, Oyvind (2008) "Mapping the environment for corporate social responsibility: Stakeholders, the publics and the public sphere" Corporate

Communications An International Journal 13, 2, 135-146

Iser, Wolfgang (1974) The Implied Reader, Patterns of Communication in Prose Fiction from Bunyan to Beckett The John Hopkins University Press

Iser, Wolfgang (1978) The Act of Reading: A Theory of Aesthetic Response The John Hopkins University Press

Jacobs Geert (1998) "Projected discourse: An analysis of receiver roles in press releases" Text $18,4,505-523$

Jakobson, Roman (1960) "Closing Statement: Linguistics and Poetics" 350- 377 in Style in Language, Thomas A. Sebeok (ed.) New York, Jointly, Technology Press of Massachusetts Institute of Technology and John Wiley \& Sons, Inc.

Jain, Subhash C. (1989) "Standardization of International Marketing Strategy: Some Research Hypotheses" Journal of Marketing 53, 1 70-79

Jarré, Renée (2007) Louis Althusser: Hailing, Interpellation, and the Subject of Mass Media http://ezinearticles.com/ (May $7^{\text {th }} 2013$ )

Jauss, Hans Robert (1982) Toward an Aesthetic of Reception Translation from German by Timothy

Baht, Introduction by Paul de Man Theory and History of Literature, Volume 2

University of Minnesota PressMinneapolis

Javalgi, Rajshekhar G. Traylor, Mark B, Gross, Andrew C. \& Edward Lampman (1994)

"Awareness of Sponsorship and Corporate Image: An Empirical

Investigation" Journal of Advertising 23, 4, 47-58

Jensen, J.W. (1968) "The Importance of Energy in the First and Second World Wars" The 
Historical Journal, 11, 3, 538-554

Johansson, Catrin (2007) “Goffman's sociology: An inspiring resource for developing public relations theory" Public Relations Review 33, 275-280

Johansson, Marjut \& Eija Suomela-Salmi (2011) "Énonciation, French pragmatic approaches" pp.71-101 in Discursive Pragmatics edited by Jan Zienkowski, Jan-Ola Östman \& Jef Verschueren, John Benjamins Publishing Company

Johnson, Nan (1988) "Reader-Response and the Pathos Principle" Rhetoric Review, 6, 2, $152-166$

Jones, Alan (2012) "Shell oil protestors climb National Gallery" The Independent, 21 February

Jones, Brian, D.G. \& David D. Monieson (1990) “The Early Development of the Philosophy of Marketing Thought" Journal of Marketing 54 (January) 102-113

Joy, Annamma, Sherry, John F. Jr \& Jonathan Deschenes (2009) "Conceptual blending in advertising" Journal of Business Research 62, 39-49

Kabay, M.E. (2011) "The BP case: Online reputation" Network World August $11^{\text {th }}$

Kang, Mee-Eun (1997) “The Portrayal of Women's Images in Magazine Advertisements: Goffman's Gender Analysis Revisited” Sex Roles 37, 11/12 979-996

Kantanen, Helena (2012) "Image, identitet and stakeholder dialogue" Corporate Communications International Journal, 17, 1 56-72

Kaufman, Burton, I. (1977) "The Oil Cartel Case and the Cold War" The Business History Review, 51, 1, 35-56

Keating, Michael, (2012) "Nigeria's oil disasters are met by silence” The Guardian, Monday January 12

Kelly, William, J. \& Tsuneo Kano (1977) "Crude Oil Production in the Russian Empire 18181919” Journal of European Economic History Fall/6:307-338

Kelley, William, T. (1956) "The Development of Early Thought in Marketing and Promotion" The Journal of Marketing, July pp.62-67.

Kerin, Roger, A. (1996) "In Pursuit of an Ideal: The Editorial and Literary History of the Journal of Marketing" The Journal of Marketing, 60, January,1-13

Kerr, Robert (2005) The Rights of Corporate Speech: Mobil Oil and the Development of the Voice of Big Business New York: LFB Scholarly Publishing, reviewed by Philip A. Dynia (2006) in Law \& Courts, 16, 3, 238-241

Ketola, Tarja (1993) "The Seven Sisters: Snow Whites, Dwarfs or Evil Queens? A Comparison of the Official Environmental Policies of the Largest Oil Corporations in the World" Business Strategy and the Environment, 2, 3 22-33

Keyishian, Harry (1996) '"We Bring Good Things to Life"/"We're Always There"; The AdWorld of GE"' pp. 29- 47 in Advertising and Culture: Theoretical

Perspectives (Mary Cross, ed) Westport, Praeger Publishers

Klassen, Michael L., Jasper, Cynthia R. \& Anne M. Schwartz (1993) "Men and Women: Images of their Relationships in Magazine Advertisements" Journal of Advertising Research March/April 30-39

Klein, Naomi (2000) No Logo St.Ives, Harper Perennial Kloepfer, Rolf (1987) "SYMPRAXIS- Semiotics, Aesthetics, and Consumer Participation" pp. 123-150 in Marketing and Semiotics New Directions in the Study of Signs for Sale Jean Umiker-Sebeok,(ed) Berlin, Mouton de Gruyter

Kloepfer, Rolf (1987) "SYMPRAXIS- Semiotics, Aesthetics, and Consumer Participation" pp. 123-150 in Marketing and Semiotics; New Directions in the Study of Signs for Sale Jean Umiker-Seboek (ed). Berlin, Mouton de Gruyter

Knight, Peter (1998) Profits and Principles - does there have to be a choice? (The Shell Report) Charterhouse Printing 
Kolk, Ans \& David Levy (2004) "Multinationals and Global Climate Change" in Multinationals, environment and global competition 171-193

Koller, Veronika (2008) "Identity, image, impression: corporate self-promotion and public relations," pp.155-180 in Handbook of Communiaction in the Public Sphere (Eds. Wodak, Ruth \& Veronika Koller) Mouton de Gruyter

Koller, Veronika (2012) "How to Analyse Collective Identity in Discourse - Textual and Contextual Parameters" Critical Approaches to Discourse Analysis across Disciplines 5, 2, 19-38

Kotler, Philip and Sidney J. Levy (1969) "Broadening the Concept of Marketing” Journal of Marketing 33 (January), 10-15

Kotler, Philip and Sidney J. Levy (1971) "Social Marketing: An Approach to Planned Social Change" Journal of Marketing 33 (July) 3-12

Kotler, Phillip \& Sidney J. Levy (1971) "Demarketing, yes, demarketing” Harvard Business Review, (November- December) 74- 80

Kotler, Philip \& Gerald Zaltman (1971) "Social Marketing: An Approach to Planned Social Change" Journal of Marketing, 35 (July) 3-12.

Kotler, Philip (1972) “A Generic Concept of Marketing” Journal of Marketing, 36 (April), 46-54

Kotler, Philip (1986) “Megamarketing” Harvard Business Review (March-April) 117-124

Kotler, Philip, Wong, Veronica, Saunders, John and Gary Armstrong (2005) Principles of Marketing (Fourth European Edition) Harlow, Pearson Education Limited

Kress, Günther (1990) "Critical Discourse Analysis" Annual Review of Applied Linguistics, $11,84-99$

Kress, Günther \& Theo van Leeuwen (1996) Reading Images: The Grammar of Visual Design Trowbridge, Routledge

Kress, Günther \& Theo van Leeuwen (2002) "Colour as semiotic mode: notes for a grammar of colour" Visual Communication 1, 343-368

Kress, Günther (2010) Multimodality: A social semiotic approach to contemporary communication, Padstow, Routledge

Kristeva, Julia (1969) Recherches pour une sémanalyse Éditions du Seuil

Kristeva, Julia (1986) The Kristeva Reader (Toril Moi editor) New York, Columbia University Press

Kuna, David, P. (1976) "The concept of suggestion in the early history of advertising psychology" Journal of the History of the Behavioral Sciences, 12, 4 347-353

Langford, Martin, (2005)“Smelling of roses or drowning in crude oil? A point of view on managing environmental crises" Journal of Communication Management 9, 3 365-374

Langholz-Leymore, Varda (1987) "The Structure is the Message: The Case of Advertising" pp. 319-335 in Marketing and Semiotics; New Directions in the Study of Signs for Sale Jean Umiker-Seboek (ed). Berlin, Mouton de Gruyter

Lannon, Judie \& Peter Cooper (1983) "Humanistic Advertising: A Holistic Cultural Perspective" International Journal of Advertising, 2, 3, 195-213

Lears, Jackson (1994) Fables of Abundance: A cultural history of advertising in America Basic Books, The Perseus Books Group

LeClercq-Vandelannoitte, Aurélie (2011) "Organizations as Discursive Constructions: A Foucauldian Approach" Organization Studies 32, 9, 1247-1271

Leech, Geoffrey (1983) Principles of Pragmatics Longman

van Leeuwen, Theo, (1996) "The representation of social actors" pp 32-70 in Texts and Practices: Readings in Critical Discourse Analysis Carmen Rosa Caldas- 
Coulthard and Malcolm Coulthard (eds). Routledge

van Leeuwen, Theo, (2003) "A multimodal perspective on composition" in Framing and Perspectivising in Discourse, pp. 23-62 (Titus Ensink and Christoph Sauer, editors) John Benjamins Publishing Company

van Leeuwen, Theo, (2005) "Typographic meaning" Visual Communication 4, 137-142 van Leeuwen, Theo, (2006) "Towards a semiotics of typography" Information Design Journal and Document Design 14, 2 139-155

van Leeuwen, Theo, (2008) "New forms of writing, new visual competencies" Visual Studies, $23,2,130-135$

van Leeuwen, Theo (2011) The Language of Colour: An introduction, Padstow, Routledge Leigh, James H. (1994) “The Use of Figures of Speech in Print Ad Headlines" Journal of Advertising 22, 2, 17-33

Lerougetel, Antoine (2003) "France: Elf verdicts reveal state corruption at highest levels" World Socialist Web Site http://www.wsws.org/en/articles/2003/11/elff-n25.html (April 29th 2013)

Levinson, Stephen C. (1988) "Putting Linguistics on a Proper Footing: Explorations in Goffman's Concepts of Participation" pp. 161-227 in P. Drew, \& A. Wootton (Eds.), Goffman: Exploring the interaction order Oxford, Polity Press.

Levy, Sidney J. (1959) "Symbols for Sale" Harvard Business Review (July-August) 117-124

Levy, Sidney, J. (1987) "Semiotician Ordinaire" in Marketing and Semiotics; New Directions in the Study of Signs for Sale Jean Umiker-Seboek (ed). Berlin, Mouton de Gruyter

Linell, Per (2009) Rethinking Language, mind, and world Dialogically; Interactional and Contextual Theories of Human-Sense Making Charlotte, Information Age Publishing

Linke, Angelika (2007) "Communicative genres as categories in a socio-cultural history of communication” Germanic Histories from 'Below'(1700-2000) Elspaß, Nils Langer, Joachim Scharloth \& Wim Vandenbussche editors) Studia Linguistica Germanica

Livesey, Sharon M. (2001) "Eco-Identity as Discursive Struggle: Royal Dutch/Shell, Brent Spar, and Nigeria" The Journal of Business Communication, 38,1, 58-91.

Livesey, Sharon M. (2002) Global Warming Wars: Rhetorical and Discourse Analytic Approaches to Exxonmobil's Corporate Public Discourse" Journal of Business Communication; 39, 117-146

Livesey, Sharon M. \& Kate Kearins (2002) "Transparent and Caring Corporations?: A Study of Sustainability Reports by the Body Shop and Royal Dutch /Shell" Organization Environment, 5, 233-258

Lorenz, Susan, Rabinsky, Mark \& Jen Wurtzel (2008) “Exxon Mobile and British Petroleum: A tale of two companies or just business as usual?" Natural Resources and Environment 501; Climate Change - A Move to Action

Lovelock, James (2006) The Revenge of Gaia London, Penguin Books,

Lucaites, John Louis, Condit, Celeste Michelle \& Sally Caudil (eds) (1999) Contemporary Rhetorical Theory: A Reader The Guilford Press

Lundmark, Carita (2006) "The Creative Use of Idioms in Advertising” Nordic Journal of English Studies, 5, 1 71-98

Lysonski, Steven (1985) "Role Portrayals in British Magazine Advertisement" European Journal of Marketing, 19, 7, 37-55

Madden, Thomas J. \& Marc C. Weinberger (1982) "The Effects of Humor on Attention in Magazine Advertising" Journal of Marketing, 11, 3, 8-14

Magel, Nick (2010) "Chevron's New Ad Campaign Hijacked by Truth ... and the Yes Men" 
October 18 http://itsgettinghotin here.org

Mager, John \& James G. Helgeson (2010) "Fifty Years of Advertising Images: Some

Changing Perspectives on Role Portrayals Along with Enduring Consistencies" Sex Roles 63, 238-252

Maillat, Didier \& Steve Oswald (2009) "Defining Manipulative Dicourse: The Pragmatics of

Cognitive Illusions" International Review of Pragmatics 1 348-370

Marchand, Roland (1985) Advertising the American Dream Making way for Modernity, 1920-1940 London, University of California Press (1986 edition)

Marková, Ivana (2003) Dialogicality and social representations, The Dynamics of Mind Cambridge, Cambridge University Press

Markus, Hazel \& Paula Nurius. 1986 "Possible selves" American Psychologist, 41, 9, 954-969.

Martin, James R. \& Peter R.R. White (2005) The Language of Evaluation Appraisal in English, Palgrave Macmillan

Mawson, Chris (2010) A History of the Shell County Guides http://home.btconnect.com/eyebookshop/SCG/newhistory.htm

McCawley, James D. (1999) "Participant Roles, Frames, and Speech Acts" Linguistics and Philosophy 22, 595-619

McCloskey, D.N. (1996) “Other Things Equal: Keynes was a Sophist, and a Good Thing, Too" Eastern Economic Journal 22, 2 231-234

McCloskey, D.N. (2009) "Rhetoric Matters Ethical Standards in a Humanistic Science of Economics" Challenge 52, 4, 25-31

McQuarrie, Edward F. \& David Glen Mick (1992) "On Resonance: A Critical Pluralistic Inquiry into Advertising Language" Journal of Consumer Research, 19, (Sept) 180-197

McQuarrie, Edward F. \& David Glen Mick (1996) "Figures of Rhetoric in Advertising: TextInterpretive, Experimental, and Reader-Response Analysis" Journal of Consumer Research 26, (June) 37-54

McQuarrie, Edward F. \& David Glen Mick (1999) "Visual Rhetoric in Advertising Language" Journal of Consumer Research 22, (March), 424-438

McQuarrie, Edward F. \& David Glen Mick (2003a) "Visual and Verbal Rhetorical Figures under Directed Processing versus Incidental Exposure to Advertising" Journal of Consumer Research 29 (March), 579-587

McQuarrie, Edward F. \& David Glen Mick (2003b) "The Contribution of Semiotic and Rhetorical Perspectives to the Explanation of Visual Persuasion in Adverting" (Chapter 11, 191-221) in Persuasive Imagery A Consumer Response Perspective, (Scott, Linda M. and Rajeev Batra, eds.)Mahwah, New Jersey, Lawrence Erbaum Associates, Publishers

McQuarrie, Edward F. \& Barbara Phillips (2005) "Indirect Persuasion in Advertising. How Consumers Process Metaphors Presented in Pictures and Words" Journal of Advertising 34, 2 7-20

McWhinnney, Will \& José Batista (1988) "How Remythologizing Can Revitalize Organizations" Organizational Dynamics 17, 2, 46-58

Meira, Liliana \& Tiago Ferreira (2008) "Narrative and Image: Metaphors of the Dialogical Self and the Problem of Spatiality (commentary on Ruck \& Sluneko)" International Journal for Dialogical Studies 3, 1, 291-300

Merleau-Ponty, Maurice (1948) The World of Perception (translated by Oliver Davis, 2004), Padstow, Routledge

Mendez de Oliveira, Angela Francisca (2011) "Diálogos Possíveis - Mikhail Bakhtin e Pierre Bourdieu: A Natureza Social de Lingugem” Web-Revista Sociodialeto 
Bach.,Linc. , Mestrado-Letras-UEMS/ Campo Grande 1, 5, novembro

Mick, David Glen (1986) "Consumer Research and Semiotics: Exploring the Morphology of Signs, Symbols, and significance" Journal of Consumer Research 13, 196-213

Mick, David Glen (1987) "Toward a Semiotic of Advertising Story Grammars" pp. 249-278 in Marketing and Semiotics New Directions in the Study of Signs for Sale, Jean Umiker-Sebeok, (ed) Berlin, Mouton de Gruyter

Mick, David Glen \& Claus Buhl (1992) “A Meaning-Based Model of Advertising Experiences" Journal of Consumer Research, 19, 3, 317-338

Miller, Carolyn R. "Genre as Social Action” (1984) Quarterly Journal of Speech 70, 151-167

Mirvis, Philip, H. (2000) "Transformation at Shell: Commerce and Citizenship" Business and Society Review 105:1 63-84

Moffitt, Mary Anne (1994) 'Collapsing and Integrating Concepts of 'Public' and 'Image' into a New Theory" Public Relations Review, 20, 2, 159-170

Morgan, Katalin (2012) "Stereotypes, prejudices, self and 'the other' in history textbooks" Yesterday \& Today 7, 85-100

Morgan, Susan E. \& Tom Reichert (1999) "The message is the metaphor: Assessing the comprehension of metaphors and analogies in advertisements" Journal of Advertising 28, 1-12

Mossberg, Lena \& Erik Nissen Johansen (2006) Marknadsföring i upplevelseindustrin Lund, Studentlitteratur

Mulvey, Laura (1975) "Visual Pleasure and narrative Cinema" Screen 16,3, 6-18 http://www.jahsonic.com/VPNC.htnl

Murphy, John M. (2001) "Mikhail Bakhtin and the Rhetorical Tradition" Quarterly Journal of Speech, 87, 3, 259-277

Muttitt, Greg (2011) Fuel on the Fire: Oil and Politics in Occupied Iraq, London, Bodley Head

Myles, John F. (2013) "Instrumentalizing Voice: Applying Bakhtin and Bourdieu to Analyze Interactive Voice Response Services" Journal of Communication Inquiry http://jcj.sagepub.com/content/early/2013/06/09/0196859913491765 (29/08/13)

Needham, Alex (2011) "Tate may not renew BP sponsorship deal after environmental protests" The Guardian, December $13^{\text {th }}$

Neely, Matthew (2006) “The Suez Crisis” matthew.neely@bodleian.ox.ac.uk

Nelson, Phillip (1974) “Advertising as Information” The Journal of Political Economy, $82,4,729-754$

Nevett, Terry (1981) "The Scapa society: The first organised reaction against advertising" Media Culture Society April, 3, 2, 179-187

Newell, Peter (2008) "Civil Society, Corporate Accountability and the Politics of Climate Change" Global Environmental Politics 8, 3, 122-153

Newell, Peter \& Matthew Paterson (2010) Climate Capitalism, Global Warming and the Transformation of the Global Economy, Cambridge University Press

Newton, Tim \& George Harte (1997) “Green Business: Technicist Kitsch?” Journal of Management Studies 34, 1, 75- 98

Nølke, Henning, Fløttum, Kjersti \& Coco Norén (2004) ScaPoLine: La théorie scandinave de la polyphonie linguistique Editions Kimé

Nørgaard, Nina (2009) "The Semiotics of Typography in Literary Texts : A Multimodal Approach" Orbis Litterarum 64, 2, 141-160

Nossiter, Adam (2010) "Far From Gulf, a Spill Scourge 5 Decades Old" The New York Times June 16

Nöth, Winfried (1987) “Advertising: The Frame Message” pp. 279-294, in Marketing and Semiotics; New Directions in the Study of Signs for Sale, Jean Umiker-Seboek 
(ed). Berlin, Mouton de Gruyter

Nöth, Winfried (1990) Handbook of Semiotics Indiana University Press Bloomington

O' Barr, William (2006) "Representations of Masculinity and Femininity in Advertisements" Advertising and Society Review 7, 2, Advertising Educational Foundation

O' Halloran, Kay L. (2008) "Systemic functional-multimodal discourse analysis (SF-MDA): constructing ideational meaning using language and visual imagery" Visual Communication 7, 4, 443-475

Ogilvie, Madeleine \& Katherine Mizerski (2011) "Using semiotics in consumer research to understand eveyday phenomena" International Journal of Market Research 53, $5,651-668$

Ogilvy, David (1963) Confessions of an Advertising Man (2004 edition), London, Southbank Publishing

Ojea, Antonio (2007) "Un estudio detecta problemas de salud entre los voluntarios del 'Prestige'" elnortedecastilla October 2

Olsen, G. Douglas, Pracejus, John W. \& Thomas C. O’Guinn (2006) "How Nothing Became Something: White Space, Rhetoric, History, and Meaning" Journal of Consumer Research, 33, 82-90

Olsen, G. Douglas, Pracejus, John W. \& Thomas C. O'Guinn (2012) "Print advertising: White Space" Journal of Business Research 65, 855-860

Onkvist, Sak \& John J. Shaw (1999) "Standardized International Advertising: Some Research Issues and Implications" Journal of Advertising Research Nov/Dec 19-24

Opacki, Ireneusz (1987) "Royal Genres" pp. 118-127 in Modern Genre Theory, Davis Duff ed. (2000) Longman

Orsato, Renato (2006) "Competitive Environmental Strategies. When does it pay to be green?" California Management Review, 48, 2, 127-143

Orwell, George (1936) Keep the Aspidistra Flying, Bungay, Suffolk, Penguin Books

Oswald, Steve (2013) Humour et inattendu : aspects linguistiques et cognitifs www.steveoswald.tk (29.06.2013)

Overington, Michael A. (1977) "Kenneth Burke and the Method of Dramatism" Theory and Society, 4, 131-156

Packard, Vance (1957) The Hidden Persuaders a Pelican Book, Penguin

Packard, Vance (1963) The Waste Makers, New York, Giant Cardinal

Painter, David, S. (1984) "Oil and the Marshall Plan" The Business History Review, 58, 3 359-383

Patterson, Maurice \& Richard Elliot (2002) "Negotiating Masculinities: Advertising and the Inversion of the Male Gaze" Consumption, Markets and Culture, 5, 3, 231-246

Paul, James A. (2003) Oil Companies in Iraq: A Century of Rivalry and War Global Policy Forum. Conference in Berlin on Corporate Accountability, November 25-26.

Pêcheux, Michel (1981) “L'étrange miroir de l'analyse du discours" Langages, 62, 5-8

Peel, Michael (2005) "Crisis in the Niger Delta: How Failures of Transparency and Accountability are Destroying the Region" Chatham House Africa Programme Armed Non-state Actors Project AFD BP 05/02

Pennycook, Alistair (1994a) "The politics of pronouns" ELT Journal 48, 2, 173-178

Pennycook, Alistair (1994b) "Incommensurable Discourses?” Applied Linguistics, 15, 2, 115-138

Perelman, Chaim and Lucie Olbrechts-Tyteca (1969) The New Rhetoric: A Treatise on Argumentation, Notre Dame Press

Perelman, Chaïm (1977) L'Empire Rhétorique Paris, Vrin,

Pettenger, Mary \& Emily Plec (2010) "Selling Green: How Green is ExxonMobil's Framing 
of Alternative Energy?" International Studies Association Annual Convention 17-21 February 2010

Phillips, Barbara J. (1997) “Thinking Into It: Consumer Interpretation of Complex Advertising Images" Journal of Advertising 26, 2, 77-87

Phillips, Barbara J. (2000) "The Impact of Verbal Anchoring on Consumer Response to Image Ads" Journal of Advertising, 29, 1, 15-24

Phillips, Barbara J. \& Edward F. McQuarrie (2002) "The Development, Change, and Transformation of Rhetorical Style in Magazine Advertisements 1954-1999" Journal of Advertising, 31, 4, (Winter) 1-13)

Phillips, Barbara J. \& Edward F. McQuarrie (2004) "Beyond visual metaphor: A new typology of visual rhetoric in advertising" Marketing Theory 4, 1/2, 113-136

Plinius, Caius Secundus Om Bildkonsten Naturalis historia XXXIII-XXXVII translated by Bengt Ellenberg, (1997) Jonsered Paul Åströms förlag,

Pointon, Marcia (1997, $4^{\text {th }}$ edition) History of Art. A Students' Handbook Routledge

Pollay, Richard, W. (1983)"Measuring the Cultural values Manifest in Advertising" Current Issues and Research in Advertising 71-92

Pollay, Richard, W. (1985) "The Subsidizing Sizzle: A Descriptive History of Print Advertising, 1900-1980" Journal of Marketing, 49, (summer) 24-37

Pollay, Richard W. (1986) "The Distorted Mirror: Reflections on the Unintended Consequences of Advertising" Journal of Marketing 50 (April) 18-36

Pollay, Richard W. and Katherine Gallagher (1990), “Advertising and Cultural Values: Reflections in the Distorted Mirror" International Journal of Advertising, 9, 361-374.

Porter, Michael, E. \& Mark R. Kramer (1999) "Philanthropy's New Agenda: Creating Value" Harvard Business Review, November-December 121-130

Porter, Michael, E. \& Mark R. Kramer (2006) "Strategy and Society: The Link Between Competitive Advantage and Corporate Social Responsibility" Harvard Business Review, December 1-14

Postone, Noishe, LiPuma, Edward \& Craig Calhoun (eds) (1993) Bourdieu: Critical Perspectives The University of Chicago Press

Pracejus, John W., Olsen, G. Douglas \& Thomas C. O'Guinn (2006) "How nothing became something: White Space, Rhetoric, History and Meaning" Journal of Consumer Research, 33, June, 82-90

Prasad, Ajnesh \& Ingo Holzinger (2008) “The Ethics of Marketing Social Responsibility: A Critical Management Perspective" presented at the Critical Management Studies Pre-Conference Workshop, Academy of Management, Los Angeles, California, August.

Prasad, Anshuman \& Raza Mir (2002) "Digging Deep for Meaning: A Critical Hermeneutic Analysis of CEO Letters to Shareholders in the Oil Industry" Journal of Business Communication, 39, 92, .92-116

Pratt, Joseph, A. (1980) "The Petroleum Industry in Transition: Antitrust and the Decline of Monopoly Control in Oil”, The Journal of Economic History, 40, 4, 815-837

Preston, Ivan, L. (1975) The Great American Blow-Up: Puffery in Advertising and Selling, (revised edition, 1996) The University of Wisconsin Press

Propp, Vladimir (1968) Morphology of the Folktale ( $2^{\text {nd }}$ edition) University of Texas Press, Austin

Propp, Vladimir (1971) "Fairy Tale Transformations" (1928,) translated by C.H. Severens, pp. 50-67 in Duff, David (ed.) (2000) Modern Genre Theory, Longman, Pearson Education Limited

Qvarsell, Roger \& Ulrika Torell eds. (2005) Reklam och Hälsa: Levnadsideal, skönhet och 
hälsa I den svenska reklamens historia Carlssons

Raggatt, Peter T.F. (2007) "Forms of Positioning in the Dialogical Self: A System of Classification and the Strange Case of Dame Edna Everage" Theory \& Psychology, 17, 3, 355-382.

Rampley, Matthew (2005) ed. Exploring Visual Culture: Definitions, Concepts, Contexts, Edinburg University Press

Redfern, W.D. (1982) "Guano of the Mind: Puns in Advertising” Language \& Communication, 2, 3, 269-276

Richards, Jef. I. \& Catharine M. Curran (2002) “Oracles on "Advertising”: Searching for a Definition" Journal of Advertising 31, 2, 63-77

Ricoeur, Paul (1975) La métaphore vive Éditions du Seuil

Ricoeur, Paul (1978) "The Metaphorical Process as Cognition, Imagination, and Feeling"

Critical Inquiry 5, 1, (Special Issue on Metaphor) 143-159

Ries, Al \& Laura Ries (2002) The Fall of Advertising and the Rise of PR, Harper Business (2004 edition)

Robinson, G.D (1995) "Paul Ricoeur and the Hermeneutocs of Suspicion: A Brief Overview and Critique" Premise, 2, 8, 12-24

Romaine, Suzanne (1999) Communicating Gender New Jersey, Lawrence Erlbaum Associates, Inc. Publishers,

Rossling, Göran (in collaboration with Lars Hinn) (2001) Instant Recognition and World Class Brands Bokförlaget Arena

Roulet, Eddy (2011) "Polyphony" (208-222) in Discursive Pragmatics, edited by Jan Zienkowski, Jan-Ola Östman \& Jef Verschueren, John Benjamins Publishing Company

Rowlands, Ian H. (2000) "Beauty and the beast? BP's and Exxon's positions on global climate change" Environment and Planning C: Government and Policy $18,339-354$

Royce, Terry D. (1998) Visual-Verbal Intersemiotic Complementarity in the Economist Magazine PhD Dissertation, The University of Reading Centre for Applied Language Studies in the faculty of Arts and social Sciences

Royce, Terry D. (2007) "Intersemiotic Complementarity: A Framework for Multimodal Discourse Analysis" 63-109 in Royce, T and Wendy Bowcher eds. (2007) New Directions in the Analysis of Multimodal Discourse New Jersey, Lawrence Erlbaum Associates, Inc. Publishers,

Russell, Tim (2007) Fill 'er Up! The Great American Gas Station, Voyageur Press

Sacks, H., E.A. Schegloff, \& G. Jefferson (1974) "A Simplest Systematics for the Organization of Turn-Taking for Conversation" Language, 50, 696- 735

Saiia, David, H. Carroll, Archie B. \& Ann K. Buchholtz (2003) "Philanthropy as Strategy: When Corporate Charity "Begins at Home" Business and Society,.42, June, 169-201

Savitt, Ronald (1980) "Historical Research in Marketing” Journal of Marketing 44, (Fall) $52-58$

Schofield, Hugh (2003) "Elf trial reveals moral vacuum" BBC News

http://news.bbc.co.uk/2/hi/europe/2973267.stm (April 29th 2013)

Schroeder, Jonathan E. \& Detlev Zwick 82004) "Mirrors of Masculinity: Representations and identity in Advertising Images" Consumption, Markets and Culture, 7, 1, 21-52

Schumacher, E.F. (1973) Small is Beautiful a study of economics as if people mattered, London, HarperPerennial

Scott, Linda M. (1994a) "Images in Advertising: The Need for a Theory of Visual Rhetoric" Journal of Consumer Research, 21 (September), 252- 273 
Scott, Linda M. (1994b) “The Bridge from Text to Mind: Adapting Reader-Response Theory To Consumer Research" Journal of Consumer Research, 21 (December) 461480

Scott, Linda M. \& Patrick Vargas (2007) "Writing with Pictures: Toward a Unifying Theory of Consumer Response to Images" The Journal of Consumer Research 34, (Oct) 341-356

Segal, Robert A. (2004) Myth: A Very Short Introduction Oxford University Press

Sen, Sankar \& C.B. Bhattacharya (2001) "Does Doing Good Always Lead to Doing Better? Consumer Reactions to Corporate Social Responsibility" Journal of Marketing Research 28 (May) 225-243

Shaxon, Nicholas (2011) Treasure Islands: Tax Havens and the Men who Stole the World London, Bodley Head,

Sherry, John F. (1983) "Gift Giving in Anthropological Perspective" The Journal of Consumer Research 10, (Sept), 157-168

Sherry, John, F. Jr. (1987) "Advertising as a Cultural System" in Marketing and Semiotics, New Directions in the Study of Signs for Sale, Umiker-Sebeok (ed) Mouton de Gruyter

Sherry, John F. Jr. (2005) "Brand Meaning" in Kellogg on Branding, The Marketing Faculty of the Kellogg School of Management (Alica M. Tybout \& Tim Calkins eds.) New Jersey, John Wiley \& Sons, Inc.

Sherry, John F. Jr \& John W. Schrouten (2002) "A Role for Poetry in Consumer Research" Journal of Consumer Research, 29, 218-234

Shusterman, Richard (ed) (1999) Bourdieu; A Critical Reader Oxford, Blackwell

Skaerseth, Jon Birger \& Tora Skodvin (2001) "Climate Change and the Oil Industry: Common Problems, Different Strategies" Global Environmental Politics, 1, 4, 43-64.

Skulstad, Aud Solbjorg (2008) "Creating a "green" image in the public sphere:

Corporate environmental reports in a genre perspective" pp.181-201 in Handbook of Communiaction in the Public Sphere (Eds. Wodak, Ruth \& Veronika Koller) Mouton de Gruyter

Slembrouck, Stef (2011) "Intertextuality" (156-175) in Discursive Pragmatics edited by Jan Zienkowski, Jan-Ola Östman \& Jef Verschueren John Benjamins Publishing Company

Simms, Andrew \& David Boyle (2010) Eminent Corporations: The rise and fall of the great British Corporation London, Constable \& Robinson Ltd.

Simons, Herbert W. \& Trevor Melia eds. (1989) The Legacy of Kenneth Burke University of Wisconsin Press

Smith, Gerri, L. \& Robert L. Heath (1990) "Moral Appeals in Mobil Oil's Op-Ed Campaign" Public Relations Review, 16, 4, 48-54

Söderlund, Magnus (2003) Emotionsladdad marknadsföring Malmö, Liber,

Sonesson, Göran (1992) Bildbetydelser : Inledning till bildsemiotiken som vetenskap Studentlitteratur, Lund

Sonesson, Göran (1998) "Denotation and Connotation." Encyclopedia of Semiotics 187-89.

Sonesson, Göran (2005) "De la métaphore à 1'allegorie dans la sémiotique écologique" Protée, 33, 1, 77-90.

Sparling, Samuel (1906) Introduction to Business Organization New York, Library, the MacMillan Company

Spitzmüller, Jürgen \& Ingo H. Warnke (2011) 'Discourse as a 'linguistic object': methodical and methodological delimitations Critical Discourse Studies, 8. 2, 75-94 
Spotts, Harlan E. Weinberger, Marc G. \& Amy L. Parsons (1997) "Assessing the Use and Impact of Humor on Advertising Effectiveness: A Contingency Approach" Journal of Advertising 26, 3 17-32

Stallabrass, Julian (2004) Contemporary Art: A Very Short Introduction, Oxford University Press

Stanford Encyclopedia of Philosophy Peirce's Theory of Signs, http://plato.stanford.edu/entries/peirce-semiotics/ $\left(14^{\text {th }}\right.$ February 2013).

Stern, Barbara B. (1990) "Beauty and Joy in Metaphorical Advertising: The Poetic Dimension" Advances in Consumer Research 17, 71-77

Stern, Barbara B. (1993) "Feminist Literary Criticism and the Deconstruction of Ads: A Postmodern View of Advertising and Consumer Responses" Journal of Consumer Research 19, 556-566

Stern, Barbara B. (1995) "Consumer Myths: Frye's Taxonomy and the Structural Analysis of Consumption Text" Journal of Consumer Research 22, 2, 165-185

Stern, Barbara B. (ed) (1998) Representing Consumers, voices views and visions Routledge Stern, Barbara, B. with Zinkhan, George, M. \& John F. Sherry Jr. (1998) "Poetry and Representation in consumer research; the art of science" Chapter 10, pp. 290307 Representing Consumers: Voices, Views and Visions (Barbara Stern ed.) Routledge

Sternthal, Brian \& C. Samuel Craig (1973) "Humor in Advertising” Journal of Marketing, 37 (October) 12-18

Stevens, Karen Lee (2009) "1969 Santa Barbara oil spill: from crisis to change" Santa Barbara Pet Examiner, January 28

Stöckl, Hartmut (2009) "Typography: body and dress of a text - a signing mode between language and image" Visual Communication 8, 247-262

Stutts, Nancy B. \& Randolph T. Barker (1999) "The Use of Narrative Paradigm Theory in Assessing Audience Value Conflict in Image Advertising" Management Communication Quarterly 13, 209-244

Sullenberger, Tom E. (1974) "Ajax Meets the Jolly Green Giant: Some Observations on the use of Folkore and Myth in American mass marketing" The Journal of American Folklore, 87, 343, 53-65

Sullivan, Gary L. and P.J. O'Connor (1988) "Women’s Role Portrayals in Magazine Advertising: 1958-1983” Sex Roles, 18, 3 /4, 181-188

Svensson, Peter (2009) "Embracing Left and Right: Image Repair and Crisis Communication in a Polarized Ideological Milieu” Management Communication Quarterly 22, $555-576$

Swales, John (1990) Genre Analysis: English in Academic and Research Settings Cambridge University Press

Swales, J.M \& Priscilla Rogers (1995) "Discourse and the Projection of Corporate Culture: The Mission Statement" Discourse \& Society 6, 223-242

Tanaka, Keiko (1992) "The pun in advertising: A pragmatic approach" Lingua 87 91-102

Tarbell, Ida M. (1904) The History of the Standard Oil Company McClure, Phillips and Co.

Taylor, Charles R (2002) "What is Wrong with International Advertising Research?" Journal of Advertising Research 42, 6, 48-54

Thébaud, Olivier, Bailly, Denis, Hay, Julien and José Pérez “The cost of oil pollution at sea: an analysis of the process of damage evaluation and compensation following spills" otvm.uvigo.es/.../Prestige_Hayetal.pdf January 252012

Till, Brian D. \& Terence A. Shimp (1998) "Endorsers in Advertising: The Case of Negative Celebrity Information" Journal of Advertising, 27, 1, 67-82

Todorov, Tzvetan (1970) "Problèmes de l'énonciation" Langages, 5, 17, 1970, 3-11. 
Todorov, Tzvetan (1990) “The Origin of Genres" (1978) translated by Catherine Porter, pp. 193-217 in Duff, David (ed.) (2000) Modern Genre Theory, Longman, Pearson Education Limited

Tolf, Robert, W. (1976) The Russian Rockefellers: the saga of the Nobel Family and the Russian Oil, Hoover Institution Publications

Tom, Gail \& Anmarie Eyes (1999) "The Use of Rhetorical Devices in Advertising” Journal of Advertising Research August 39-43

Topdahl, Rolv Christian (2012) "Strasbourg hearing heartens North Sea divers" Aftenbladet September $19^{\text {th }}$

Trifonas, Peter Pericles (2001) Barthes and the Empire of Signs, Cambridge, Icon Books

Trosborg Anna (ed. 1997) Text Typology and Translation John Benjamins

Tuchman, Gaye (1979) "Women's Depiction by the Mass Media" Signs, 4, 3 528-542

Tuncay Zayer, Linda (2010) "A Typology of Men's Conceptualizations of Ideal Masculinity in Advertising" Advertising \& Social Review, 11, 1,

Turner, Louis (1976) "The Oil Majors in World Politics" International Affairs (Royal Institute of International Affairs 1944-) 52, 3, 368-380

Tynyanov, Yury (1977) “The Literary Fact” (1924,) translated by Ann Shukman, in Duff,

David (ed.) (2000) Modern Genre Theory 29-47, Longman, Pearson Education

Limited

Umiker-Seboek Jean (1987) (ed). Marketing and Semiotics; New Directions in the Study of Signs for Sale Berlin, Mouton de Gruyter

Umiker-Seboek Jean (1996) "Power and the Construction of Gendered Spaces" International Review of Sociology 6, 3, 389-403

Unger, Lynette, S. (1995) "Observations: A Cross-Cultural Study on the Affect-Based Model of Humor in Advertising" Journal of Advertising Research January/February

Vakratsas, Demetrios \& Tim Ambler (1999) "How Advertsing Works: What Do We Really Know?" Journal of Marketing, 63, (January).26-43

Venkatesan, M. \& Jean Losco (1975) "Women in Magazine Ads: 1959-71" Journal of Advertising Research 15, 5, 49-54

Vidal, John (2010) "Nigeria's agony dwarfs the Gulf oil spill. The US and Europe ignore it" The Observer, Sunday, May 30

Vieira de Camargo Grillo, Sheila (2007) "Epistémologie et genres du discours dans le cercle de Bakhtin" LINX Nanterre 56, 19-36

Volosinov, L.S. (1986) Marxism and the Philosophy of Language (Ladislav Matejka \& I.R. Titunik, translators) Harvard University Press

Waeraas A. \& Oyvind Ihlen (2009) "Green Legitimation; The construction of environmental ethos" International Journal of Organizational Analysis 17, 2, 84-102

Waern,Yvonne, Pettersson, Rune \& Gary Svensson (2004) Bild och föreställning - om visuell retorik Studentlitteratur

Wagner, Louis C. \& Janis B. Banos (1973) “A Woman's Place: A Follow-up Analysis of the Roles Portrayed by Women in Magazine Advertisements" Journal of Marketing Research 10, 2 213-214

Walker, John, A. (1994) Art in the Age of Mass Media (revised second edition) Chipping Norton, Pluto Press

Walker, Mary, Langmeyer, Lynn \& Daniel Langmeyer (1992) “Celebrity Endorsers Do You Get What You Pay For?” Journal of Services Marketing 6, 4, 35-42

Wall, Anthony (2001) "On bringing Mikhail Bakhtin into the social sciences" Semiotica 133, $1,4,169-201$

Wallop, Harry (2012) "BP trial: in numbers" The Telegraph, February $26^{\text {th }}$

Wang, Alex (2007) "Priming, Framing, and Position on Corporate Social Responsibility" 
Journal of Public Relations Research, 19 (2) pp.123-145

Ward, Graham (2000) editor The Certeau Reader Blackwell Publishers

Ward, James \& William Giadis (1990) "Metaphor in Promotional Communication: A Review of Research on Metaphor Comprehension and Quality" Advances in Consumer Research 17, 636-642

Ward, John O. (2007) "Preface" to What is the New Rhetoric? (Susan E. Thomas, ed.)

Newcastle, Cambridge Scholars Publishing

Waters, Judith \& George Ellis (1996) "The Selling of Gender identity" pp. 113-124 in Advertising and Culture: Theoretical Perspectives (Mary Cross ed.) Westport, Praeger Publishers

Weinberger, Marc G. \& Charles S. Gulas (1992) “The Impact of Humor in Advertising: A Review" Journal of Advertising 21, 4, 35-59

Weinstein, Eugene A. \& Paul Deutschberger (1963) "Some Dimensions of Altercasting" Sociometry, 26, 4, 454-466

Wertsch, James V. (1991) Voices of the Mind: Sociocultural Approach to Mediated Action Harvard University Press

Wetzel, Linda, "Types and Tokens", The Stanford Encyclopedia of Philosophy (Spring 2011 Edition), Edward N. Zalta (ed.), http://plato.stanford.edu/archives/spr2011/entries/types-tokens/.

Wheeler, David, Rechtman, René, Fabig, Heike Boele and Richard Boele, (2001) "Shell, Nigeria and the Ogoni. Analysis and Implications of Royal Dutch/Shell Group Stategy" Sustainable Development 9, 177-196

Wikman, Christine (2005) L' imagine pubblicitaria dell' olio d' olive, della pasta e del caffè: Uno studio comparative sulla ricezione Etudes Romanes de Lund 76 Romanska institutionen Lunds Universitet ( $\mathrm{PhD}$ dissertation)

Williams, Glyn (1999) French Discourse Analysis The Method of Post-Structuralism Routledge

Williams, Raymond (1980) "Advertising: The magic system" in Problems in Materialism and Culture, London Verso, 170-195

Wilson, Olle (2012) Raffinerade rum: Bensinstationer och precisionskultur I Sverige 19261956, Stockholm, Nordiska museets förlag

Wittgenstein, Ludwig (1953) Philosophical Investigations (translated by G.E.M. Anscombe) Basil Blackwell

Wodak, Ruth \& Michael Meyer (2009) "Critical Discourse Analysis: History, Agenda, Theory, and methodology" Chapter 1 pp.1-33 in Methods of Critical Discourse (second edition, Wodak \& Meyers, eds.) Sage Publications

Wolin, Lori D. (2003) "Gender Issues in Advertising - An Oversight Synthesis of Research: 1970-2002” Journal of Advertising Research 111-129

World Nuclear Association (2001) Three Mile Island Accident http://www.worldnuclear.org/info/inf36.html

Worthern, W.B. (2010) Drama: Between Poetry and Performance John Wiley \& Sons

Wright Mills, C. (1940) "Situated Actions and Vocabularies of Motives" American Sociological Review, 5, 6, 904-913

Yergin, Daniel (2008) The Prize: the epic quest of oil, money and power Free Press, a Division of Simon \& Schuster, Inc. New York

Zaltman, Gerald \& Robin Higie Coulter (1995) "Seeing the Voice of the Customer: Metaphor-Based Advertising Research," Journal of Advertising Research, 35 (July/August) pp. 35-51

Zienkowski, Jan (2011) "Discursive pragmatics; a platform for the pragmatic study of discourse" pp.1-13, in Discursive Pragmatics edited by Jan Zienkowski, 
Jan-Ola Östman \& Jef Verschueren John Benjamins Publishing Company Zinkhan, George M. (1994) "Poetry in Advertising" Journal of Marketing Research Zinkhan, George M. \& Betty D. Gelb (1987) "Humor and Advertising Effectiveness Reexamined" Journal of Advertising 16, 1 66-68 